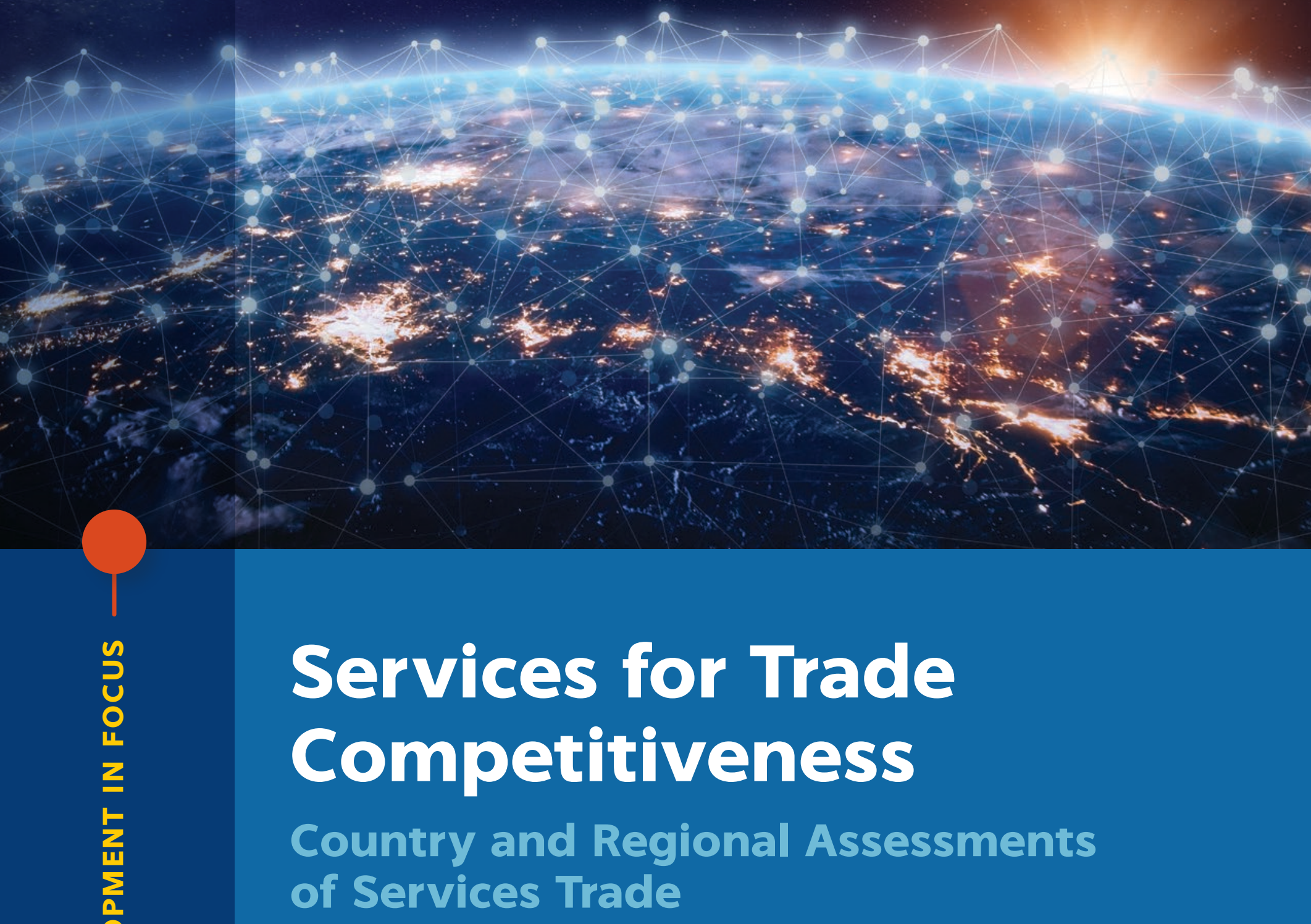

Claire H. Hollweg and Sebastián Sáez, Editors

(4) WORLD BANK GROUP 

INTERNATIONAL DEVELOPMENT IN FOCUS

\section{Services for Trade Competitiveness \\ Country and Regional Assessments of Services Trade}

Claire H. Hollweg and Sebastián Sáez, Editors 
(C) 2019 International Bank for Reconstruction and Development / The World Bank

1818 H Street NW, Washington, DC 20433

Telephone: 202-473-1000; Internet: www.worldbank.org

Some rights reserved

123422212019

Books in this series are published to communicate the results of Bank research, analysis, and operational experience with the least possible delay. The extent of language editing varies from book to book.

This work is a product of the staff of The World Bank with external contributions. The findings, interpretations, and conclusions expressed in this work do not necessarily reflect the views of The World Bank, its Board of Executive Directors, or the governments they represent. The World Bank does not guarantee the accuracy of the data included in this work. The boundaries, colors, denominations, and other information shown on any map in this work do not imply any judgment on the part of The World Bank concerning the legal status of any territory or the endorsement or acceptance of such boundaries.

Nothing herein shall constitute or be considered to be a limitation upon or waiver of the privileges and immunities of The World Bank, all of which are specifically reserved.

Rights and Permissions

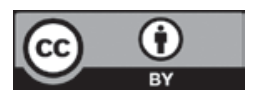

This work is available under the Creative Commons Attribution 3.0 IGO license (CC BY 3.0 IGO) http:// creativecommons.org/licenses/by/3.0/igo. Under the Creative Commons Attribution license, you are free to copy, distribute, transmit, and adapt this work, including for commercial purposes, under the following conditions:

Attribution-Please cite the work as follows: Hollweg, Claire H. and Sebastián Sáez, eds. 2019. Services for Trade Competitiveness: Country and Regional Assessments of Services Trade. International Development in Focus. Washington, DC: World Bank. doi:10.1596/978-1-4648-1406-8 License: Creative Commons Attribution CC BY 3.0 IGO

Translations-If you create a translation of this work, please add the following disclaimer along with the attribution: This translation was not created by The World Bank and should not be considered an official World Bank translation. The World Bank shall not be liable for any content or error in this translation.

Adaptations-If you create an adaptation of this work, please add the following disclaimer along with the attribution: This is an adaptation of an original work by The World Bank. Views and opinions expressed in the adaptation are the sole responsibility of the author or authors of the adaptation and are not endorsed by The World Bank.

Third-party content-The World Bank does not necessarily own each component of the content contained within the work. The World Bank therefore does not warrant that the use of any third-partyowned individual component or part contained in the work will not infringe on the rights of those third parties. The risk of claims resulting from such infringement rests solely with you. If you wish to re-use a component of the work, it is your responsibility to determine whether permission is needed for that re-use and to obtain permission from the copyright owner. Examples of components can include, but are not limited to, tables, figures, or images.

All queries on rights and licenses should be addressed to World Bank Publications, The World Bank Group, 1818 H Street NW, Washington, DC 20433, USA; e-mail: pubrights@worldbank.org.

ISBN: 978-1-4648-1406-8

DOI:10.1596/978-1-4648-1406-8

Cover photo: NicoElNino/iStock by Getty Images. Used with the permission of iStock by Getty Images; further permission required for reuse.

Cover design: Debra Naylor / Naylor Design Inc. 


\title{
Contents
}

\author{
Foreword $x i$ \\ Acknowledgments xiii \\ About the Editors $\quad x v$ \\ Contributors $x v i i$ \\ Executive Summary $\quad$ xix \\ Abbreviations $\quad x x v$
}

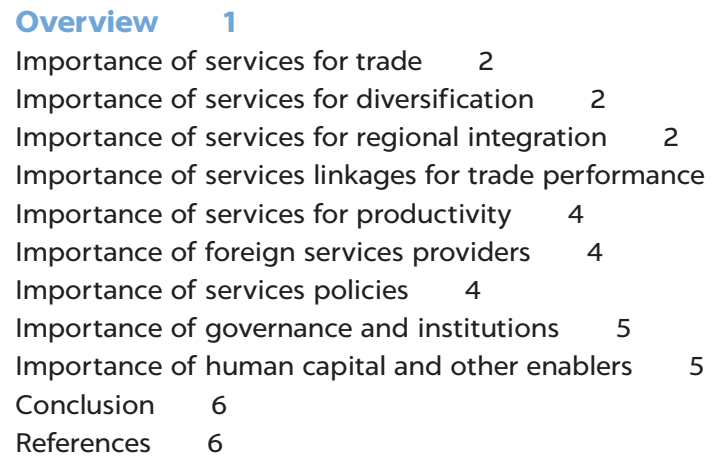

PART 1: $\quad$ EAST ASIA AND PACIFIC 7

CHAPTER 1: Linkages between Services and Manufacturing: An Empirical Analysis of the Lao People's Democratic Republic 9

Claire H. Hollweg, Laura Gomez-Mera, and Gonzalo Varela

Services-manufacturing linkages 9

Economywide effects of services performance $\quad 14$

Subjective and objective measures of the performance of the services sector 17

Effects of services on firm performance $\quad 24$

Policy implications 28

Notes 29

References 30

CHAPTER 2: The Services Trade Policy and Regulatory Framework in Myanmar 33

Martín Molinuevo, Sjamsu Rahardja, and Sebastián Sáez

The policy and regulatory framework for services trade and investment $\quad 34$ 
Policy-making framework and institutions

Subsectoral policies and practices 44

Conclusion 52

Notes 53

References 53

\section{PART 2: $\quad$ EUROPE AND CENTRAL ASIA 55}

CHAPTER 3: The Contribution of Services to Competitiveness in the Russian Federation $\quad 57$

Birgit Hansl, Sebastián Sáez, and Erik van der Marel

Services in the domestic economy 57

Valuing trade in services 58

Services and regional development 64

Trade diagnostics for the Russian Federation $\quad 66$

Policy recommendations $\quad 71$

Notes 72

References 72

\section{PART 3: $\quad$ LATIN AMERICA AND THE CARIBBEAN 75}

CHAPTER 4: Performance and Productivity of Services Trade in Peru: A Competitiveness Analysis

Sebastián Sáez and Erik van der Marel

Peru's trade in services 78

Productivity and trade in services 81

Contribution of services to economic performance $\quad 87$

Effect of regulation, the rule of law, human capital, and use of information and communications technology on exports

$$
\text { of services } 91
$$

Conclusion 96

Notes 96

References 97

PART 4: MIDDLE EAST AND NORTH AFRICA 99

CHAPTER 5: Economic Complementarities in Services in the Mashreq and Turkey

101

Claire H. Hollweg and Daria Taglioni

The role of services in the domestic economy 102

Services trade with the world 102

Bilateral services exports 104

Indicators of services exports 106

Value added of services 116

Conclusion 117

Notes 118

References 118

PART 5: $\quad$ SOUTH ASIA 119

CHAPTER 6: Diversifying Nepal's Economy by Creating a Dynamic Services Sector

121

Claire H. Hollweg

Assessing the potential of services exports 
Linkages between services and manufacturing

The regulatory environment for services 135

Challenges in specific services subsectors 136

Policy implications 140

Notes 140

References 141

CHAPTER 7: Services Trade Performance in Pakistan

Erik van der Marel and Sebastián Sáez

Value added of services in the domestic economy

Valuing services in trade 146

Determinants of services trade 151

Policy recommendations 156

References 157

PART 6: $\quad$ SUB-SAHARAN AFRICA 159

CHAPTER 8: Valuing Services Trade within Africa 161

Barak Hoffman, Miles McKenna, and Sebastián Sáez

Services go global 162

Assessing the value added of services in trade 163

Exports of services from Africa $\quad 167$

Conclusion 175

Notes 176

References 177

CHAPTER 9: Integration of Services and Manufacturing

in Ethiopia 179

Claire H. Hollweg, Esteban Rojas, and Gonzalo Varela

Contribution of services to changes in GDP, employment, and poverty reduction $\quad 180$

Services exports 185

Linkages between services and manufacturing 188

Services inputs and the productivity of manufacturing

Concluding remarks 200

Notes 201

References 202

CHAPTER 10: The Regulatory Environment for Trade in Services in Liberia 203

Claire H. Hollweg, Martín Molinuevo, and Sebastián Sáez

Performance of services trade: Constraints and determinants 204

Horizontal measures affecting services 208

Governance and institutional setting 212

Sectoral services policies and governance $\quad 215$

Conclusion and recommendations 221

Notes 222

References 223

Appendix A: Definitions and Methodology 225

Appendix B: Sectoral Classification of Services Trade

Boxes

ES.1 Construction of the World Bank Export of Value Added Database xxii

1.1 Using exports to diversify into more sophisticated activities in Uruguay

1.2 Correlation between subjective and objective measures of electricity in Lao PDR 19

2.1 Policy-making benefits of effective intragovernmental coordination 36 
2.2 Adopting a transparent, objective procedure for licensing foreign telecom providers in Myanmar $\quad 47$

5.1 Statistical limitations in capturing foreign direct investment and developments in Islamic finance $\quad 110$

6.1 Top 10 legal and regulatory issues constraining investment in hotels in Nepal 131

6.2 Challenges in Nepal's transport sector 136

6.3 Diaspora networks to encourage trade in services 138

8.1 The gender dimensions of trade in services in Africa 163

8.2 Effects of restrictiveness on trade in professional services in East Africa 176

9.1 Premature deindustrialization 180

Figures

1.1 Composition of manufacturing value added (backward linkages) in selected Asian countries, $2011 \quad 10$

1.2 Composition of domestic services inputs in manufacturing exports in selected countries, $2011 \quad 11$

1.3 Sectoral composition of services value added in domestic production and exports of Lao PDR, $2011 \quad 12$

1.4 Sectoral composition of services exports by selected countries, $2013 \quad 12$

1.5 Percentage of firms identifying finance, electricity, and transportation as major obstacles to doing business 18

1.6 Share of firms in Lao PDR, East Asia and Pacific, and all countries that use email or have their own websites, 2009 and $2012 \quad 23$

2.1 Services Trade Restrictiveness Index (STRI) in Association of Southeast Asian Nations (ASEAN) member states, by subsector, $2012 \quad 34$

2.2 Government institutions relevant to the formulation of services trade policy in Myanmar 37

2.3 Perceptions of the rule of law, regulatory quality, and government effectiveness in selected countries in East Asia, 2003-12 39

2.4 Telecommunication indicators in selected countries in East Asia, 2004-13 46

2.5 Readiness indicators for information technology outsourcing services in selected East Asian countries 50

2.6 Tourist arrivals and revenues in Myanmar, 1996-2012 51

2.7 Myanmar Travel and Tourism Competitiveness Index, $2015 \quad 52$

3.1 Employment in agriculture, industry, and services in the BRICS, 2000 and $2017 \quad 58$

3.2 Relationship between services value added and per capita GDP, $2013 \quad 59$

3.3 Contribution to value added of agriculture, industry, and services in selected countries, 2000-13 59

3.4 Gross exports and value-added shares of machinery and business services in selected countries, 2011 61

3.5 Share of services exports in total exports in selected countries, by type of service, $2011 \quad 61$

3.6 Share of services exports in total exports in selected country groups and countries, $2011 \quad 62$

3.7 Relationship between gross services exports, direct value added of services to other exports, and total value added of services exports and per capita GDP, $2011 \quad 64$

3.8 Relationship between services exports and per capita GDP, 2011-13 67

3.9 Relationship between the Services Trade Restrictiveness Index (STRI) and per capita GDP and services value added, $2013 \quad 68$

3.10 Relationship between the Services Trade Restrictiveness Index (STRI) and regulatory quality, $2012 \quad 69$

3.11 Barriers to direct investment in services and cross-border services trade, 201270

3.12 Correlation between services trade and human capital index and number of Internet users, $2013 \quad 70$

4.1 Correlation between diversification of services exports and per capita GDP, $2009 \quad 80$ 
4.2 Correlation between Services Trade Restrictiveness Index (STRI) and per capita imports and exports of services, $2012 \quad 81$

4.3 Correlation between Services Trade Restrictiveness Index (STRI) and value added of services exports, $2011 \quad 81$

4.4 Value added of services exporters and total factor productivity in Peru, by type of ownership and subsector, $2012 \quad 83$

4.5 Gross, direct, and total shares of services in exports in selected country groups and countries, 201190

4.6 Importance of "other business services" as inputs in exports in selected countries, $2011 \quad 91$

4.7 Correlation between services exports and per capita GDP, 201192

4.8 Correlation between Services Trade Restrictiveness Index (STRI) and per capita GDP and share of value added of services in GDP, 201393

4.9 Correlation between mode 3 restrictions and mode 1 trade, 201093

4.10 Correlation between regulatory quality and the Services Trade Restrictiveness Index (STRI), $2013 \quad 94$

4.11 Correlation between the complexity of services and the rule of law, $2010 \quad 95$

4.12 Correlation between services trade and human capital and Internet use, $2013 \quad 95$

5.1 Relationship between value added of services as percent of GDP and per capita GDP, 2000-02 and 2008-10 102

5.2 Index of exports of services by selected economies, 2000-10 103

5.3 Bilateral services flows between Turkey and other countries in the region, 2000-11 104

5.4 Turkey's imports and exports of services, by subsector, 2005105

5.5 Residuals versus fitted values estimated with GDP and fixed effects, 2005-09 107

5.6 Gravity model of trade in services for Turkey and selected countries in the Middle East and North Africa, 2005-09 109

5.7 Trade complementarity index for Turkey and selected countries in the Middle East and North Africa, 2004-10 110

5.8 Trade intensity index for Turkey and selected countries in the Middle East and North Africa, 2005-09 112

5.9 Revealed comparative advantage index for Turkey and selected countries in the Middle East and North Africa, 2000, 2005, and 2009113

5.10 Relationship between sophistication of services exports and per capita GDP in Turkey and selected countries in the Middle East and North Africa, 2001 and $2009 \quad 114$

5.11 Sophistication of services exports of Turkey and selected countries in the Middle East and North Africa, 2001-09 115

5.12 Herfindahl-Hirschman Index of concentration for Turkey and selected countries in the Middle East and North Africa, 2000 and $2010 \quad 115$

6.1 Sectoral contributions to growth in Nepal, 2005-14 122

6.2 Correlation between direct value added in services exports and per capita GDP, 2011

6.3 Growth of services exports in Nepal versus growth of world imports of services 124

6.4 Herfindahl-Hirschman Index of export concentration in selected countries, 2005 and $2013 \quad 125$

6.5 Direct and total value added of Nepal's exports, by subsector, $2011 \quad 126$

6.6 Correlation between services exports as share of GDP and per capita GDP, $2013 \quad 127$

6.7 Subsectors of revealed comparative advantage of selected countries, 2005 and $2013 \quad 128$

6.8 Gravity model of tourism in Nepal, $2012 \quad 130$

6.9 Composition of manufacturing value added (backward linkages) in Nepal, $2011 \quad 134$

6.10 Composition of domestic services inputs in Nepal's manufacturing exports, $2011 \quad 134$

6.11 Percent of firms identifying provision of services as major or severe obstacles 135 
6.12 Correlation between Services Trade Restrictiveness Index (STRI) and gross services exports and services inputs, $2007 \quad 137$

7.1 Employment shares of agriculture, industry, and services in selected countries, 2000 and $2017 \quad 144$

7.2 Cross-country correlation between value added of services and level of development, 2011-13 144

7.3 Value added of agriculture, industry, and services in selected countries, 1990 and $2013 \quad 145$

7.4 Rate of growth of value added of agriculture, industry, and services in selected countries 2000-13 145

7.5 Shares of gross exports and value added of exports in goods and services in selected countries, $2011 \quad 148$

7.6 Share of various types of services in the value added of exports in selected countries, $2011 \quad 150$

7.7 Cross-country correlation between the share of services exports in total exports and per capita GDP, 2011

7.8 Cross-country correlation between Services Trade Restrictiveness Index (STRI) and per capita GDP and value added of services, 2013 152

7.9 Cross-country correlation between direct and total value added of services exports and Services Trade Restrictiveness Index (STRI), $2009 \quad 153$

7.10 Services Trade Restrictiveness Index (STRI) for modes 1 and 3 in selected countries, $2009 \quad 153$

7.11 Cross-country correlation between services exports (mode 1) as percent of GDP and Services Trade Restrictiveness Index (STRI) for mode 3, $2010 \quad 154$

7.12 Gap to the frontier in terms of governance effectiveness, regulatory quality, and the rule of law in selected countries $\quad 155$

7.13 Cross-country correlation between regulatory quality and Services Trade Restrictiveness Index (STRI), $2013 \quad 155$

7.14 Gap to the frontier in terms of number of Internet servers, number of broadband subscriptions, and human capital quality in selected countries 156

7.15 Cross-country correlation between services trade as percent of GDP and human capital and Internet use, $2013 \quad 157$

8.1 Share of services exports in total exports in selected countries in Africa, $2011 \quad 165$

8.2 Services linkages to other economic activities and to exports in selected countries in Africa, $2011 \quad 166$

8.3 Services linkages to other economic activities and to exports in the Arabic Republic of Egypt, Morocco, and Tunisia, $2011 \quad 167$

8.4 Structure of services exports in selected least developed countries in Africa, $2011 \quad 168$

8.5 Structure of services exports in selected other countries in Africa, 2011

8.6 Cross-country correlation between share of services in total exports and per capita GDP, $2011 \quad 169$

8.7 Cross-country correlation between value added of services exports (as a share of total value added of exports) and per capita GDP, by sector, 2011

8.8 Relationship of Services Trade Restrictiveness Index (STRI) and services exports 173

8.9 Cross-country correlation between regulatory quality and Services Trade Restrictiveness Index (STRI) 174

9.1 Annual contributions of agriculture, industry, and services to GDP growth in Ethiopia, 2000-16 181

9.2 Value-added of agriculture, industry, and services in selected countries, 1990, 2000, 2010, and $2016 \quad 182$

9.3 Changes in employment in the services sector in Ethiopia, by subsector, 1990-2011 183

9.4 Ratio of labor productivity in services to average labor productivity in selected countries, $2011 \quad 183$

9.5 Labor productivity in Ethiopia, by sector, 1990-2011 184

9.6 Average annual growth in employment, value added, and labor productivity in Ethiopia, 1990-2011 
9.7 Share of services in total exports in selected countries, 2003 and 2015

9.8 Relationship between traditional and modern services exports and per capita GDP, 2010-12 187

9.9 Composition of services exports by selected countries, $2013 \quad 187$

9.10 Inputs into and from productive sectors in Ethiopia, 2011 189

9.11 Composition of Ethiopia's domestic and exported manufacturing value added, by subsector, 2011

9.12 Composition of services value added (forward linkages) in selected countries, $2011 \quad 192$

9.13 Composition of manufacturing value added (backward linkages) in selected countries, $2011 \quad 193$

9.14 Composition of domestic value added in Ethiopia by manufacturing subsector, $2011 \quad 193$

9.15 Composition of services inputs in manufacturing in selected countries, $2011 \quad 194$

9.16 Relationship between services inputs in manufacturing and level of development, by subsector, 2011

9.17 Services Trade Restrictiveness Index (STRI) in selected countries, by subsector and mode, 2008198

10.1 Cross-country correlation between share of value added of services in GDP and per capita GDP, 2005-07 and 2010-12 204

10.2 Cross-country correlation between share of exports and imports of commercial services in GDP and per capita GDP, 2005-07 and 2010-12 205

10.3 Human Development Index in West Africa, by country, 1980-2012 207

10.4 Liberia's Doing Business ranking, 2013208

10.5 Governance indicators in selected countries in West Africa, 2012212

10.6 Governance indicators in Liberia, 2003-12 213

10.7 Sectoral restrictions on investment in services subsectors in Liberia 216

Tables

1.1 Access to finance in Lao PDR, East Asia and Pacific, and all countries 18

B1.2.1 Subjective and objective measures of electricity use in Lao PDR, East Asia and Pacific, and all countries 19

1.2 Mean and median indicators of electricity, telecommunication, and water services in Lao PDR, East Asia and Pacific, and all countries 20

1.3 Trade volumes, distances, and cost for major trade corridors, 2011

1.4 ICT development index and price basket for selected countries in East Asia 22

1.5 Access to Internet services in East Asian countries, $2013 \quad 23$

1.6 Estimated effects of quality of selected services on firm performance in Lao PDR and East Asia and Pacific 27

2.1 State-owned enterprises in Myanmar's services sector 42

2.2 Regional mutual recognition arrangements on professional services signed by Myanmar 49

3.1 Total value added of sectors and services subsectors in selected countries, $2011 \quad 63$

3.2 Export revenues as a percent of total revenue in the Russian Federation, by region and services subsector 65

4.1 Composition of exports of "other commercial services" in selected countries, 2005-06 and 2012-13 79

4.2 Correlation between exporting and productivity in the modern services subsector of Peru 82

4.3 Correlation between use of software and exporting of services in Peru, 201382

4.4 Correlation between productivity and foreign and domestic private capital shares in Peru, $2012 \quad 84$

4.5 Correlation between productivity and foreign and domestic private capital (dummy) in Peru, $2012 \quad 85$

4.6 Correlation between downstream productivity and services reform in Peru, 2008-13 85 
4.7 Correlation between downstream productivity growth (1-year lag) and services reform in Peru, 2008-13 86

4.8 Sectoral composition of value added of Peru's domestic economy, 2011 (percent of total domestic value added) 87

4.9 Sectoral composition of the value added of Peru's exports, 2011 (percent of total value added of exports) 88

4.10 Sectoral contributions to value added in selected countries, 2011 (percent of total) 89

5.1 Gravity model of trade in services, 2005-09 107

5.2 Direct and forward linkages of selected services in Turkey and selected countries in the Middle East and North Africa (percent) 116

6.1 Contribution of tourism to GDP and employment in selected countries, $2014 \quad 129$

7.1 Sectoral composition of Pakistan's domestic economy, 2011 (percent of GDP) 146

7.2 Share of services in value added of Pakistan's exports, 2011 (percent of total) 147

7.3 Value added of services subsectors in selected countries, 2011 (percent of total) 149

9.1 Major obstacles perceived by manufacturing firms in Ethiopia (percent of respondents, except when otherwise indicated)

9.2 Determinants of labor productivity, based on perception of services' performance 200

10.1 Governance ratings of countries of West Africa, $2012 \quad 208$

10.2 Formal horizontal restrictions/requirements to services trade in Liberia

10.3 Impact of horizontal administrative practices on services trade in Liberia

A.1 Modes of supply of trade in services 226

A.2 Balance of payments classification of services trade 226

B.1 WTO sectoral classification of services trade 233 


\section{Foreword}

Developing countries' participation in the global economy has become more complex. In the past, integration was mainly about buying and selling goods internationally. To perform these activities countries needed to manage exchange rate policies, reduce tariffs, and eliminate non-tariff barriers. Trade liberalization, technological change, and production fragmentation have significantly transformed the required policy mix to integrate domestic production in international supply chains. In this new context, modern trade policy is multidimensional; it requires the coordination of a large set of policies, which include FDI attraction, services trade policies, movements of people, institutional arrangements such as protection of intellectual property rights and investor protections, and more recently, policies to foster the digital economy.

Among the salient characteristics of this shifting landscape, the growing tradability of services offers new opportunities for developing countries to participate in the global economy. Cross-border services trade accounted for 23 percent of global trade in 2017; developing countries accounted for 21 percent of it, up from 15 percent in the mid-1990s. Also, and more importantly, services play a critical role as determinants of agricultural and manufacturing value chains. In summary, access to high-quality/low-cost services plays a significant role in countries' capabilities to compete in the global economy.

Services for Trade Competitiveness: Country and Regional Assessments of Services Trade presents select case studies on the role of services for trade. The book shows the types of barriers that affect services trade, their potential impact, the role of services determinants, including regulations, the role of services linkages for other economic activities, and policy choices to foster the role of services in developing economies.

The book builds on the World Bank's extensive applied research on services trade policy and performance. The Trade and Regional Integration (TRI) Unit at the Macroeconomics, Trade and Investment Global Practice has developed several analytical tools to help countries map their relative position in the global competitiveness space and to support informed policy decisions to seize the benefits and opportunities provided by services trade. The case studies included in 
the book cover low- and middle-income countries using a range of methodologies and datasets. The book illustrates how new methodologies developed by the World Bank can help policy makers, academics, and experts to assess the competitiveness of the services sector. It helps to answer pressing questions on services competitiveness, on trade diversification, how to create a more conducive regulatory environment to promote service sectors, and how to support countries' participation in trade agreements.

While there are countries that have taken advantage of the new opportunities that services trade offers, there is untapped potential and scope for significant improvements. Notably, trade liberalization in services' policies remains a priority for many developing countries. In addition, in those countries where the policy regime is relatively open, policy reform should be complemented by institutional arrangements to strengthen governance and investment in skills upgrading and services-trade-specific infrastructure to fully reap the potential. There are also efforts needed by countries to invest in collecting services trade relevant data, including firm-level data, to improve their understanding of services trade performance.

This book is intended to help policy makers to better design services policies and reforms and to encourage governments to view services trade in the multidimensional trade policy landscape.

\section{Caroline Freund}

Director

Macroeconomics, Trade and Investment Global Practice

The World Bank 


\section{Acknowledgments}

Services for Trade Competitiveness: Country and Regional Assessments of Services Trade is a product of the Trade and Regional Integration Unit of the Macroeconomics, Trade and Investment Global Practice of the World Bank. Edited by Claire H. Hollweg and Sebastián Sáez, it is based on a compilation of studies on services trade undertaken by staff and consultants of the Trade and Regional Integration Unit since 2013 to support World Bank country teams and their clients.

The editors would like to thank Michael Ferrantino, Gaurav Nayyar, and Nadia Rocha, who peer-reviewed the manuscript and provided value suggestions. Tanya Cubbins and Shiny Jaison helped format the volume. We are grateful to Barbara Karni for editing the book and to Cindy Fisher and Stefanie Heim from the World Bank's Publishing Program for overseeing publication and dissemination. The book would not have been possible without the guidance and support of the staff of the Trade and Regional Integration Unit and its management team, including Manuela Francisco (practice manager), Caroline Freund (director), Anabel Gonzalez (senior director), Esperanza Lasagabaster (practice manager), Antonio Nucifora (practice manager), Jose Reis (practice manager), Klaus Tilmes (director), as well as the financial support of the Umbrella Facility for Trade Trust Fund. Finally, we acknowledge the collaborative effort of a large team of people who supported and helped deliver the chapters, but we leave these acknowledgments to the contributing authors' respective chapters. 



\section{About the Editors}

Claire H. Hollweg is a senior economist with the Macroeconomics, Trade and Investment Global Practice of the World Bank. Before studying economics, she worked as a journalist. She has worked with the government of South Australia and the Pacific Economic Cooperation Council in Singapore. Her research interests include development economics, with a focus on the nexus between trade, labor markets, servicification of manufacturing, and upgrading in global value chains. She holds a PhD and an MA in economics from the University of Adelaide.

Sebastián Sáez is a lead economist with the Macroeconomics, Trade and Investment Global Practice of the World Bank. He served as an adviser to the Chilean minister of finance during the Uruguay Round negotiations of the General Agreement on Tariffs and Trade (GATT). He subsequently served as deputy permanent representative in the Chilean Mission to the World Trade Organization and as head of the Free Trade Agreement of the Americas Department in the Chilean Ministry of Foreign Affairs. Beginning in 2001, he headed the Chilean Department of Foreign Trade, Ministry of Economy, where he participated in trade negotiations with the European Union, the Republic of Korea, and the United States. Before joining the World Bank in 2009, he worked in the International Trade and Integration Division of the United Nations Economic Commission for Latin America and the Caribbean (UN-ECLAC). He holds an MA in economics from Catholic University of Rio de Janeiro, Brazil. 



\section{Contributors}

Laura Gomez-Mera, associate professor, University of Miami

Birgit Hansl, program leader, World Bank Group

Barak Hoffman, consultant, World Bank Group

Miles McKenna, analyst, World Bank Group

Martín Molinuevo, senior private sector specialist, World Bank Group

Sjamsu Rahardja, senior economist, World Bank Group

Esteban Rojas, consultant, World Bank Group

Daria Taglioni, lead economist, World Bank Group

Erik van der Marel, senior economist, European Center for International Political Economy, and associate professor, Université Libre de Bruxelles

Gonzalo Varela, senior economist, World Bank Group 



\section{Executive Summary}

\section{WHY TRADE IN SERVICES MATTERS}

Services trade is growing in importance for developed and developing countries alike. For developing countries in particular, services offer an increasingly important avenue for integrating into global markets. Cross-border services trade accounted for 23 percent of global trade in 2017; developing countries accounted for 21 percent of it, up from 15 percent in 1995 (World Bank 2018). The explosion of services trade-and services more generally-in the global economy reflects falling trade and investment barriers as well as new digital technologies that have reduced the costs of delivering services across borders.

Services support developing countries' trade through their dual role as a source of competitiveness as inputs into manufacturing and agriculture exports and a means of diversifying trade. Many developing countries have benefitted from the expanding opportunities offered by new technologies to become strong exporters of modern services activities. Their experiences show that such countries can join the club of services exporters and benefit from opening of the services market.

Services have also become increasingly important for trade as production internationalizes. The global value chain revolution has been accompanied by key changes in the services sector, underscoring the importance of the goods-services nexus. For example, managing the complexity of the value chain and preserving productions throughout the chain require strong coordination that relies on efficient service providers such as auditors, lawyers, and managers.

Boosting trade competitiveness through domestic services and services trade matters for growth, economic development, and poverty reduction. Services trade can be used as an engine for economic growth, as enhancing the competitiveness of the domestic services sector can drive performance of other sectors. 


\section{OBJECTIVE OF THIS VOLUME}

Recognizing that services affect the ability of countries and their firms to compete on international markets, the Trade and Regional Integration (TRI) Unit of the World Bank has developed an extensive work program to promote the performance of countries' domestic services sectors as well as their competitiveness, including in services trade. The unit assesses the competitiveness of services trade and the regulatory environment, drawing on its databases of services and services trade. Its assessments are designed for a wide audience, including policy makers in developing countries and development practitioners in international organizations, policy-making institutions, and academia. The purpose of these assessments is to help developing countries make informed policy choices to increase their chances of benefiting from the increasing prominence of services in international trade. This work represents only part of a broader World Bank effort to support services trade in client countries. For example, the Research Department's Trade and Integration Unit (DECTI) also produces strong services trade products, including the Services Trade Restrictions Database (Borchert, Gootiiz, and Mattoo 2012).

This volume presents selected applications of the methodologies developed by the TRI Unit in order to showcase how other countries could adopt these new methodologies to assess the competitiveness of their services sector, understand the types of barriers to services, and learn from the resulting policy implications. The chapters are based on new diagnostics tool for assessing services and services trade developed by the TRI Unit in 2012-15. Although these assessments were produced several years ago, their novel methodologies, findings, and policy implications remain valid today.

\section{ASSESSMENT TOOLS}

Valuing Services in Trade: A Toolkit for Competitiveness Diagnostics (Sáez and others 2014) provides a framework, guidance, and practical tools for analyzing a country's services sector. It identifies the specific enabling factors that can improve competitiveness, highlights constraints that affect services trade, and suggests policy responses for addressing them. The toolkit helps policy makers in developing countries integrate services into their overall trade strategies and facilitate integration into global markets.

A Services Trade Competitiveness Diagnostic (STCD) consists of four modules:

- Module 1 produces measures of outcomes in trade in services.

- Module 2 assesses the existence and importance of a domestic services sector.

- Module 3 assesses countries' potential for expanding trade in services.

- Module 4 examines broad policy areas and options for addressing the constraints identified in Modules 1, 2, and 3. It distinguishes between sectoral policies that can be implemented in the short to medium term and horizontal measures and strategies related to the domestic economy and institutions that can be implemented over a longer time horizon.

An STCD includes a desk-based assessment of trade outcomes to formulate hypotheses on failures and policy areas to address in detail; in-country field 
research, to obtain input from a wide variety of stakeholders, including government officials and the private sector; and analysis of issues that emerge during the field research.

Services trade and investment flows face a wide range of regulations-at and behind the border-that can severely distort trade. The Regulatory Assessment Toolkit:A Practical Methodology for AssessingRegulation and Trade and Investment in Services (Molinuevo and Sáez 2014) helps policy makers identify inefficient regulations as well as alternative regulatory approaches that do not distort trade but help modernize the services trade regulatory framework. It looks at horizontal policies that affect all sectors as well as sector-specific policies.

The development of new databases of services trade by the World Bank (as well as other organizations) has greatly facilitated the development and application of these methodologies to developing countries. Collecting data on cross-border trade in services is notoriously difficult, in large part because of the intangible nature of services but also because of the extensive efforts needed to record such data. The World Bank Trade in Services Database provides information primarily on annual bilateral services trade flows in Mode 1 (cross-border trade) and Mode 2 (consumption abroad) for 199 countries across a multitude of sectors and years starting in 1985. It tries to fill the gap on trade statistics for developing countries by consolidating multiple sources of bilateral trade data in services, including data from the Organisation for Economic Co-operation and Development (OECD), Eurostat, the United Nations (UN), and the International Monetary Fund (IMF).

New measures of trade in terms of value added help make explicit the direct value-added contribution of the services sector to domestic production as well as exports, as well as the linkages the services sector provides to all other sectors of the economy in terms of value added. Many databases do not include many developing countries, however.

The Export of Value Added Database developed by the TRI Unit of the World Bank (Francois, Manchin, and Tomberger 2013) measures trade on a value-added basis based on national input-output tables from the Global Trade Analysis Project (GTAP) (box E.S.1) for 1992, 1995, 1997, 2001, 2004, 2007, and 2011. It also measures both the direct contribution of services to total exports in terms of value added and the indirect contribution of services through linkages. It provides information on 118 countries across 27 sectors, including 14 manufacturing, 9 commercial services, and 3 primary sectors.

The World Bank Services Trade Restrictions Database provides information on the regulatory regime for the international provision of services in 103 countries (Borchert, Gootiiz, and Mattoo 2012). It covers information on five services sectors: financial services, telecommunications, retail distribution, transportation, and professional services. Regulations are classified on the basis of the mode of supply to which they apply: the provision of services through cross-border trade (Mode 1), the establishment of a commercial presence (Mode 3), and the movement of natural persons (Mode 4). Most of the information was gathered from country surveys conducted over 2008-11, based on common questionnaires, thereby ensuring comparability across countries. Using a system of scores and weights, the qualitative information on countries' policy measures was translated into restrictiveness indexes ranging from 0 to 100 (the more restrictive a regulatory regime, the higher the index value). The information in the database was gathered primarily on the basis of whether policies discriminate against foreign services providers. For the most part, it therefore does not cover domestic services regulations that affect domestic and foreign services providers equally. 


\section{BOX ES.1}

\section{Construction of the World Bank Export of Value Added Database}

The World Bank Export of Value Added Database provides data on how value-added structures and services linkages to trade have evolved over time. It is built using a panel of global input-output data (a set of global social accounting matrices) spanning intermittent years from 1992 to 2011 from the Global Trade Analysis Project (GTAP). It covers both key OECD economies and developing countries.

The GTAP database is produced by a consortium that includes the World Bank, the U.S. International Trade Commission (ITC), the World Trade Organization (WTO), the Organisation for Economic Co-operation and Development (OECD), the United Nations Conference on Trade and Development (UNCTAD), the Food and Agriculture Organization of the UN (FAO), and a number of universities and research institutes, based at Purdue University. It represents a massive combined effort to produce a shared public good-a database of national input-output tables, organized as social accounting data and linked to one another through trade and investment flows.
It serves as a critical, open source input to applied policy modeling.

The GTAP database represents the most comprehensive, convenient, and internationally comparable source of sector-specific data across countries. Of the 129 regions in its eighth release, 112 represent individual countries and 17 represent composite regions. In the case of individual countries, the social accounting matrix (SAM) for each country relies on the most recent input-output data available from national sources for each country (see Aguiar and Walmsley 2012). These data are harmonized to a standard 57-sector format for ease of comparison.

Limitations of the GTAP data include infrequency of updates (the most recent one takes the data only to 2014) and the fact that some input-output data may be adjusted to provide consistency with merchandise trade and macroeconomic data also used in the SAM. Therefore, results should be interpreted cautiously and should be seen as a first attempt to understand trade performance in developing countries.

\section{WORLD BANK APPLICATIONS OF THESE NEW TOOLS}

These toolkits and databases have been applied to a range of contexts. A common application has been supporting countries' engagements at the WTO, including joining the institution and implementing commitments made within it. They have also been used as part of other required processes. In Myanmar, for example, a Regulatory Assessment of Services Trade and Investment (RASTI) was conducted to inform the Diagnostic Trade Integration Study (DTIS). In Liberia a RASTI was conducted as part of the WTO negotiation process.

These tools have also been applied to assess the scope for enhanced services trade integration through greater or more diversified services exports. Analytical work in Nepal assessed its trade potential in services and identified actionable policy measures needed to achieve this potential. The work was conducted in support of Nepal's Trade Integration Strategy, which identified three services sectors with potential to drive the country's export growth: tourism (leisure, business, education medicals); labor services (semi-skilled and skilled human resources); and information technology and business processing outsourcing services.

Other analyses have focused on how services can support enhanced manufacturing trade competitiveness, by assessing the linkages between services and other sectors of the economy. In the Lao People's Democratic Republic (PDR), a priority is implementing reforms and commitments in a way that benefits the private sector, including leveraging its WTO accession for economic integration 
as a driver for improving the business and investment regime while simultaneously expanding supply-side capacity. The services sector played an important role in the growth process of Lao PDR during the last decade. The World Bank's report looked at the extent to which the services sector contributed to better integrating Lao PDR in the global marketplace-directly, by facilitating diversification and upgrading, and indirectly, by providing inputs to other sectors in the economy. It recommended some policies to increase competition in the services sector, reduce distortive regulations and open up to foreign participation, build skills at the individual and firm level, and invest in hard and soft infrastructure to promote the development of the sector.

\section{STRUCTURE OF THIS VOLUME}

The volume consists of 10 chapters, each showcasing a streamlined version of a larger country or regional assessment undertaken by World Bank staff. The chapters focus on the methodological aspects of the studies, specifically how the TRI Unit's toolkits in services trade were applied to country work around the world, in a variety of contexts. The chapters are organized alphabetically by World Bank regions.

Services trade differs from goods trade in a variety of important ways. For this reason, some basic concepts relevant to services trade are needed to understand the analyses presented in the volume. These concepts include how services can be traded, the ways services trade is measured (including gross transactions versus value-added measures), the institutions that collect data on services trade, the types of services measured in trade statistics, and the ways services trade can be regulated. To avoid duplication across chapters, the appendix provides definitions and methodological explanations.

\section{REFERENCES}

Aguiar, A. H., and T. L. Walmsley. 2012. "Regional Input-Output Data." In Global Trade, Assistance, and Production: The GTAP 8 Data Base, edited by Narayanan G., B., A. Aguiar, and R. McDougall, Chapter 7. Center for Global Trade Analysis, Purdue University.

Borchert, I., B. Gootiiz, and A. Mattoo. 2012. "Guide to the Services Trade Restrictions Database." Policy Research Working Paper 6108, World Bank, Washington, DC.

Francois, J., M. Manchin, and P. Tomberger. (2013). "Services Linkages and the Value Added Content of Trade.” Policy Research Working Paper 6432, World Bank, Washington, DC.

Molinuevo, M., and S. Sáez. 2014. Regulatory Assessment Toolkit: A Practical Methodology for Assessing Regulation on Trade and Investment in Services. Washington, DC: World Bank. doi: 10.1596/978-1-4648-0057-3.

Sáez, S., D. Taglioni, E. van der Marel, C. H. Hollweg, and V. Zavacka. 2014. Valuing Services in Trade: A Toolkit for Competitiveness Diagnostics. Washington, DC: World Bank. doi:10.1596/978-1-4648-0155-6.

World Bank. 2018. World Development Indicators (database), Washington, DC, http:// wdi.worldbank.org. 



\section{Abbreviations}

\begin{tabular}{|c|c|}
\hline AEM & ASEAN Economic Ministers \\
\hline AFAS & ASEAN Framework Agreement on Services \\
\hline ASEAN & Association of Southeast Asian Nations \\
\hline ATM & automated teller machine \\
\hline BPO & business process outsourcing \\
\hline BRICS & Brazil, Russia, India, China, South Africa \\
\hline CBM & Central Bank of Myanmar \\
\hline CPA & certified public accountant \\
\hline DICA & Directorate of Investment and Company Administration \\
\hline DTIS & Diagnostic Trade Integration Study \\
\hline EAP & East Asia and Pacific \\
\hline ECOWAS & Economic Community of West African States \\
\hline FAO & Food and Agriculture Organization of the UN \\
\hline FDI & foreign direct investment \\
\hline GATS & General Agreement on Trade in Services \\
\hline GDP & gross domestic product \\
\hline GTAP & Global Trade Analysis Project \\
\hline HHI & Herfindahl-Hirschman Index \\
\hline IBSB & Insurance Business Supervisory Board \\
\hline IDI & ICT Development Index \\
\hline $\mathrm{ICT}$ & information and communications technology \\
\hline IFRS & International Financial Reporting Standards \\
\hline IMF & International Monetary Fund \\
\hline ISIC & $\begin{array}{l}\text { International Standard Industrial Classification of } \\
\text { All Economic Activities }\end{array}$ \\
\hline IT & information technology \\
\hline ITES & information technology-enabled services \\
\hline ITT & invitation to tender \\
\hline Lao PDR & Lao People's Democratic Republic \\
\hline LDC & least developed country \\
\hline MAC & Myanmar Accountancy Council \\
\hline MEB & Myanma Economic Bank \\
\hline MFTB & Myanma Foreign Trade Bank \\
\hline MIC & Myanmar Investment Commission \\
\hline
\end{tabular}




$\begin{array}{ll}\text { MoCT } & \text { Ministry of Communication and Transport } \\ \text { MoHT } & \text { Ministry of Hotel and Tourism } \\ \text { MoPF } & \text { Ministry of Planning and Finance } \\ \text { MRA } & \text { mutual recognition agreement } \\ \text { n.e.c. } & \text { not elsewhere classified } \\ \text { NTIS } & \text { Nepal Trade Integration Strategy } \\ \text { OECD } & \text { Organisation for Economic Co-operation and Development } \\ \text { R\&D } & \text { research and development } \\ \text { RASTI } & \text { Regulatory Assessment of Services Trade and Investment } \\ \text { RCA } & \text { revealed comparative advantage } \\ \text { SAM } & \text { social accounting matrix } \\ \text { SME } & \text { small and medium enterprise } \\ \text { STCD } & \text { Services Trade Competitiveness Diagnostic } \\ \text { STRD } & \text { Services Trade Restrictions Database } \\ \text { STRI } & \text { Services Trade Restrictiveness Index } \\ \text { TCI } & \text { trade complementarity index } \\ \text { TFP } & \text { total factor productivity } \\ \text { TFP-R } & \text { total factor productivity-deflated } \\ \text { TII } & \text { trade intensity index } \\ \text { TRI } & \text { Trade and Regional Integration } \\ \text { UNCTAD } & \text { United Nations Conference on Trade and Development } \\ \text { UNDP } & \text { United Nations Development Programme } \\ \text { WTO } & \text { World Trade Organization }\end{array}$




\section{Overview}

The last quarter of the 20th century witnessed significant changes in trade patterns. Among the most important for developing countries were the rise of global value chains and the increasing tradability of services.

Services have become critical for countries' trade, including participation and upgrading in global value chains. They play a dual role-as inputs into manufacturing value chains and as value chains of their own. Some studies estimate that services account for 40 percent of the value added of world trade (Lanz and Maurer 2015). Much of the value of manufactured goods comes from inputs of services industries, which determine countries' relative position in global value chains as well as their ability to upgrade and densify such chains. Services inputs includes a wide variety of activities, including design, marketing, distribution, and customer support.

The interdependence of goods and services markets means that an integrated approach to trade policy design is needed that recognizes the unintended consequences of trade and regulatory policies (Hallward-Driemeier and Nayyar 2018; Sáez and others 2014).

The case studies in this book seek to help policy makers, experts, and private sector players understand where particular countries are located in the services competitiveness space and assess how policies can increase the role of services in their economies. They address seven policy questions:

- How important are services for trade and diversification?

- How important are services for regional integration?

- How important are the linkages between services and other traded sectors?

- How important is the performance of services for productivity?

- How important are foreign providers for services performance?

- What determines the performances of services trade, and what is the relative importance of these determinants for different services? 


\section{IMPORTANCE OF SERVICES FOR TRADE}

Over the last few decades, the falling costs of travel, improvements in information and communications technology (ICT), and the development of electronic infrastructure greatly enhanced the ability of services to be produced in one location and consumed in another. As a result, trade of services picked up for all income groups.

African countries are adding their names to the growing list of developing countries that trade services both regionally and farther abroad to major markets (chapter 8). Kenya, Mauritius, Senegal, and South Africa provide services as far away as Europe (Cattaneo and others 2010; Goswami and others 2012). Transport, distribution, trade, and other business services are Africa's main services exports. Measured in terms of value added, excluding intermediate inputs, services trade is much more significant for African countries than previously thought. Nevertheless, Africa lags dramatically in terms of its share of global services trade; in most countries in the region, the share of direct services exports is below what would be expected based on their level of development.

\section{IMPORTANCE OF SERVICES FOR DIVERSIFICATION}

Services support the diversification of economic activities. Many developing countries are seizing new export opportunities for services, developing value chains or integrating them into services activities, usually by developing traditional activities, such as tourism and transport. In Ethiopia (chapter 9), exports of traditional services reached 6 percent of GDP in 2010-12, significantly overperforming many comparator countries. Modern services exports represented just 2 percent of GDP, however.

The importance of traditional services in a country's trade has policy implications. In Nepal, for example, the largest constraint to the tourism sector is inadequate infrastructure, in particular airports and roads. Given that three-quarters of tourists arrive by air, addressing this constraint may offer one of the greatest potential boosts to growth. Inadequate tourism accommodation infrastructure is also a big constraint.

Given a propitious business environment and appropriate policy support, developing countries can participate in modern services, such as information technology (IT) and IT-enabling export activities-as the experiences of Costa Rica, India, and the Philippines have shown.

The case study of Nepal (chapter 6) illustrates that the business environment is not helping foster exports of IT-enabling services. It recommends that Nepal implement policies that support domestic software and ICT-enabled services firms through a range of activities, including targeted capacity building, the provision of risk capital, expansion of partnering assistance through incubators and accelerators, and formalization opportunities.

\section{IMPORTANCE OF SERVICES FOR REGIONAL INTEGRATION}

Economic integration is a key avenue through which countries can benefit from regional opportunities; many of the potential welfare gains of enhanced economic integration accrue from increased trade and investment flows. 
Identifying untapped potential for deeper and wider trade integration can help identify policies that can unleash these potentials for mutual benefit.

Chapter 5 evaluates potential bilateral economic linkages and complementarities in services trade between Turkey and the Mashreq countries of Jordan, Lebanon, the Syrian Arab Republic, and Iraq, as well as other countries in the region. Services trade in the region is low, and the potential for further integration seems limited by similar specialization profiles. A more diversified and sophisticated services sector could enhance regional integration in both services and manufacturing. A priority for policy makers should be diversification, in particular toward modern and more sophisticated services. Eliminating domestic impediments that may be holding back the development of such services could spur growth and regional integration not only in services but also in manufacturing, thanks to the forward linkages of services in most countries in the region.

\section{IMPORTANCE OF SERVICES LINKAGES FOR TRADE PERFORMANCE}

The case studies show that services play a significant role as inputs to other economic activities, including agriculture, extractive industries, and manufacturing. Services help these sectors reach the global market and compete with imports in the domestic market. They affect the competitiveness of activities that are the most important trade for developing countries.

New trade data that measure trade transactions on the basis of value added reveal the importance of services to other sectors. Services are an important supplier of inputs into Ethiopia's domestic economy, in which the services and manufacturing sectors are more intensely linked than in most countries in the world. They account for 38 percent of the economy's value-added linkages (excluding a sector's value added that is consumed directly rather than used as an input). But manufacturing firms report that services are obstacles to production. The structure of manufacturing helps explain the strong interconnectedness of services and manufacturing in Ethiopia, but it may also be a constraining factor for manufacturing where services can be important value-added inputs. For example, Ethiopia's manufacturing sector adds little value directly. At the same time, the linkages between financial services and manufacturing are particularly weak, where access to finance is a serious constraint in Ethiopia.

In Nepal the lack of availability of services inputs-including transport, finance, electricity, and water supply-seems to be holding back the manufacturing and agriculture sectors. The structure of Nepal's domestic services sector may be constraining the development of higher-value-added manufacturing: 78 percent of domestic services inputs into manufacturing exports are for distribution and transport (in China and India, this figure is less than 40 percent).

The Peru case study (chapter 4) tells a slightly different story. Services in Peru are mainly a direct export activity to end-consumers rather than an input into other export activities. Forward linkages in services (the inputs services provide to other sectors) represent about 20 percent of total exports. This finding may mean that domestic services are still relatively expensive for Peruvian manufacturing firms. Competitive services inputs are essential for any economy; ensuring that firms have access to low-cost, high-quality services should be a priority for any diversification and competitiveness strategy in Peru. 


\section{IMPORTANCE OF SERVICES FOR PRODUCTIVITY}

In the Lao People's Democratic Republic (PDR) (chapter 1), the linkages between services and manufacturing are weaker than in comparator countries. Services inputs represent only about 10 percent of the total value added of manufacturing-much less than the world average of about a third. The case study shows that difficulties procuring services inputs affects the performance of firms in Lao PDR, where the inadequate quality of services appears to be a stronger constraint than in other countries in the region. The quality of transportation services appears to have the strongest effect on firm productivity, followed by quality of electricity. Improvements in the quality of both services would have the largest effect on performance: A one standard deviation increase in firms' subjective rating of the quality of transportation is associated with a 15 percent increase in performance (measured as total factor productivity), and a one standard deviation decrease in the number of power outages experienced by a firm in a typical month would result in a 13 percent improvement in performance levels.

\section{IMPORTANCE OF FOREIGN SERVICES PROVIDERS}

The case study of Peru illustrates the role foreign providers may play as services exporters. Peru's experience shows that increasing foreign firm participation and enhancing competition in services markets have economywide effects on firms. Three-quarters of the firms in Peru that export services are owned by private foreign firms; they have above-average levels of productivity. The largest difference in productivity between foreign and domestic firms is in the professional services subsectors. Firms that receive more foreign investment (as well as firms that receive more domestic private capital) are more productive than firms that receive public capital. Firms that are exporters and have larger foreign capital shares are significantly more productive than average.

\section{IMPORTANCE OF SERVICES POLICIES}

Policies on services are restrictive in many developing countries. Such policies increase the cost of imported services, reducing the competitiveness and productivity of the many activities that rely on services. Case studies reveal that high regulatory restrictiveness is associated with a smaller direct value-added contribution of services to production. Considering the use of services as inputs by other sectors, including manufacturing, the relationship with the regulatory environment becomes significantly negative: Countries with burdensome regulations in services use fewer services as inputs to manufacturing sectors.

The empirical literature confirms that liberalization of services has a large positive impact on productivity (Arnold, Javorcik, and Mattoo 2011; Arnold, Mattoo, and Narciso 2008; Fernandes and Paunov 2012). Simulation of the impact of policy reforms on productivity in Ethiopia suggests that if finance were as accessible as it was in Rwanda, firms' labor productivity would increase by 4.3 percent. If electricity conditions were to match conditions in Rwanda, labor productivity would rise by almost 2.2 percent. Matching China's transportation services would increase productivity by about 4.2 percent. 


\section{IMPORTANCE OF GOVERNANCE AND INSTITUTIONS}

Reducing restrictiveness is a necessary condition to create a thriving services sector-but it is not sufficient. Without adopting a sound regulatory environment, the benefits of liberalization may be limited. In Peru (chapter 4) and Pakistan (chapter 7), for example, barriers to services trade are relatively low, but regulatory governance structures are weaker than in countries that share similar levels of restrictiveness.

In Myanmar (chapter 2), the policy challenge is to complement the market opening that has taken place with a regulatory framework that fosters transparency, provides clarity about laws and regulations affecting access to and operations of services markets, protect consumers, and ensures competition. Myanmar's institutional framework for services trade policy is spread across multiple ministries and agencies with overlapping mandates. The problem creates inconsistent policies, especially in negotiating trade agreements, and weakens the monitoring of implementation. In addition, many agencies have limited understanding of services trade policy and negotiations. A coordination mechanism needs to be put in place to ensure policy coherence.

Weak governance and administrative practices represent the main limitations to trade and investment in services in Liberia (chapter 10). The government has reduced regulatory barriers to services trade and investment, but the institutional framework remains weak. The main governance limitations relate to access to clear regulatory guidelines-which is a challenge even for government officials directly involved in their implementation. Regulatory measures are communicated informally to the public and between government agencies, increasing discretion in the application of regulatory measures and leaving room for unwarranted restrictions to trade and investment. The gradual establishment of simple, clear, and binding governmentwide regulatory procedures and the improvement of access to existing business regulations, especially licensing procedures, would improve governance. Greater public access to legal instruments is necessary to increase the transparency and predictability of business regulation.

The case studies confirm one of the most important findings of the empirical literature on services trade: institutions matter. They show that weak rule of law is usually associated with low levels of modern services exports. For optimal exploitation of trade in these services, the rule of law must be strong enough to enforce the multiple contracts that are involved in modern services.

Despite policy reforms, trade performance in most of the countries studied is below what would be expected given their level of development. Services exports remain concentrated in traditional services exports instead of more dynamic, high-valued-added modern service exports. The problem may reflect the lack of strong governance and institutional structure to ensure that reforms promote competition, imports of services, and access to new foreign and private sector operators.

\section{IMPORTANCE OF HUMAN CAPITAL AND OTHER ENABLERS}

Many services sectors are significantly more skill-intensive than goods industries. Endowments of human capital are thus a critical determinant of exports of modern services. 
The low levels of critical enablers of services exports hold back the sector. Electronic infrastructure also has a positive effect on services exports; telecommunication infrastructure, broadband access, and the digital economy more broadly are among the most powerful drivers of the modern services sector.

The Nepal case study suggests that the government should support IT infrastructure, power supply, transport, and auxiliary services. Capacity building should be enhanced by forging stronger linkages between industry and educational institutions. Skills upgrading should include foreign language skills, managerial skills, and technical training programs.

\section{CONCLUSION}

To participate and upgrade in global value chains, developing countries need to adopt a holistic approach, taking action in many areas. They need to improve telecom and digital infrastructure, incentivize investment, improve the business environment and reduce informality, protect intellectual property rights, and support international good practices to facilitate trade. These policy efforts need to be complemented by strong collaboration by the public and private sectors and the establishment of programs that help build firms' innovative and managerial capabilities. This volume addresses many of these areas.

\section{REFERENCES}

Arnold, J., B. Javorcik, and A. Mattoo. 2011. "Does Services Liberalization Benefit Manufacturing Firms? Evidence from the Czech Republic.” Journal of International Economics 85 (1): 136-46.

Arnold, J., A. Mattoo, and G. Narciso. 2008. "Services Inputs and Firm Productivity in SSA: Evidence from Firm-Level Data.” Journal of African Economies 17 (4): 578-99.

Cattaneo, O., M. Engman, S. Sáez, and R. M. Stern, eds. 2010. International Trade in Services: New Trends and Opportunities for Developing Countries. Washington, DC: World Bank.

Fernandes, A. M., and C. Paunov. 2012. "Foreign Direct Investment in Services and Manufacturing Productivity: Evidence for Chile.” Journal of Development Economics 97 (2): 305-21.

Goswami, A. G., P. Gupta, A. Mattoo, and S. Sáez. 2012. "Services Exports: Are the Drivers Different for Developing Countries?” In Exporting Services: A Developing Country Perspective, edited by A. G. Goswami, A. Mattoo, and S. Sáez, 25-79. Washington, DC: World Bank.

Hallward-Driemeier, M., and G. Nayyar. 2018. Trouble in the Making? The Future of Manufacturing-Led Development. Washington, DC: World Bank.

Lanz, R., and A. Maurer. 2015. "Services and Global Value Chains: Some Evidence on Servicification of Manufacturing and Services Networks.” WTO Staff Working Paper ERSD2015-03, World Trade Organization (WTO), Economic Research and Statistics Division, Geneva.

Sáez, S., D. Taglioni, E. van der Marel, C. H. Hollweg, and V. Zavacka. 2014. Valuing Services in Trade: A Toolkit for Competitiveness Diagnostics. Washington, DC: World Bank. 



\title{
Linkages between Services and Manufacturing: An Empirical Analysis of the Lao People's Democratic Republic
}

\author{
CLAIRE H. HOLLWEG, LAURA GOMEZ-MERA, AND GONZALO VARELA
}

This chapter sheds light on the ways in which the services sector has contributed to competitiveness and integration into the global marketplace in the Lao People's Democratic Republic (PDR). In focuses on the role of services for manufacturing competitiveness. The analysis contributes to an evidence-based discussion of the challenges faced by Lao PDR as it seeks to maximize gains from trade and integration.

The ability of Lao PDR to integrate into the global economy, achieve exportled growth in noncommodity exports, and reap the benefits that such growth has on labor markets and poverty will depend on achieving international competitiveness in nontraditional export sectors. Services support export diversification directly and are also an important factor in the competitiveness of manufacturing and agricultural exports. Exploring the linkages between services and these sectors, and whether services are constraining productivity, will provide analytical support to the government in implementing policies to improving the efficiency of the services sector.

\section{SERVICES-MANUFACTURING LINKAGES}

Lao PDR's services sector has contributed considerably to economic growth. The size of the services sector (41 percent of GDP in 2014) is smaller than in other countries at similar levels of development, however.

Services exports, which represented 6.9 percent of total services production in 2013, grew alongside expansion of the sector. However, traditional services dominate services exports. Heavy reliance on a few traditional segments makes Lao PDR's export basket the most concentrated among comparator countries, adding to the economy's vulnerability to sector-specific shocks.

Although services continue to be important inputs in other sectors in the economy, the linkages between services and manufacturing are weaker than in comparator countries. ${ }^{1}$ Services contribute almost a quarter of the economy's inputs measured in terms of value added, a small share by international standards. 
Together, agriculture, energy, and minerals contributed 68 percent of domestically supplied inputs; manufacturing contributed only 6 percent. Compared with other countries, both the direct value added that the services sector generates and the inputs it provides are low.

Lao PDR's manufacturing sector relies less on services inputs than comparator countries in both domestic production and export-oriented activities (figure 1.1). $\underline{2}$ Services inputs represent about 10 percent of the total value added of manufacturing output. This figure is much lower than the world average of about one-third. It is also much lower than in comparator countries except Vietnam. In Bangladesh, for example, services represented 31 percent of manufacturing domestic value added; the figure for all other countries ranged from 17 percent to 22 percent. Services represented about 21 percent of manufacturing exports, suggesting that they are better used as inputs by export activities in Lao PDR than sectors focused only on the domestic market and that a competitive services sector is needed to increase manufacturing exports.

Manufacturing production in Lao PDR is heavily reliant on inputs from energy and the extractive sectors (mainly related to minerals) and to a lesser extent agriculture. About half (51 percent) of manufacturing value added is made up of inputs from the primary sector. This figure is much larger than in all comparator countries (Mongolia, at 48 percent, is the closest comparator). Bangladesh, Cambodia, Nepal, Thailand, and Vietnam all have stronger linkages to their agricultural and manufacturing sectors.

Most service activities in Lao PDR are traditional ones, such as distribution/ trade and transportation (figure 1.2). On average, almost 90 percent of the services inputs used by manufacturers are distribution and transport; modern services contribute little to manufacturing value added. Moderns services are less

FIGURE 1.1

Composition of manufacturing value added (backward linkages) in selected Asian countries, 2011

a. Domestic production

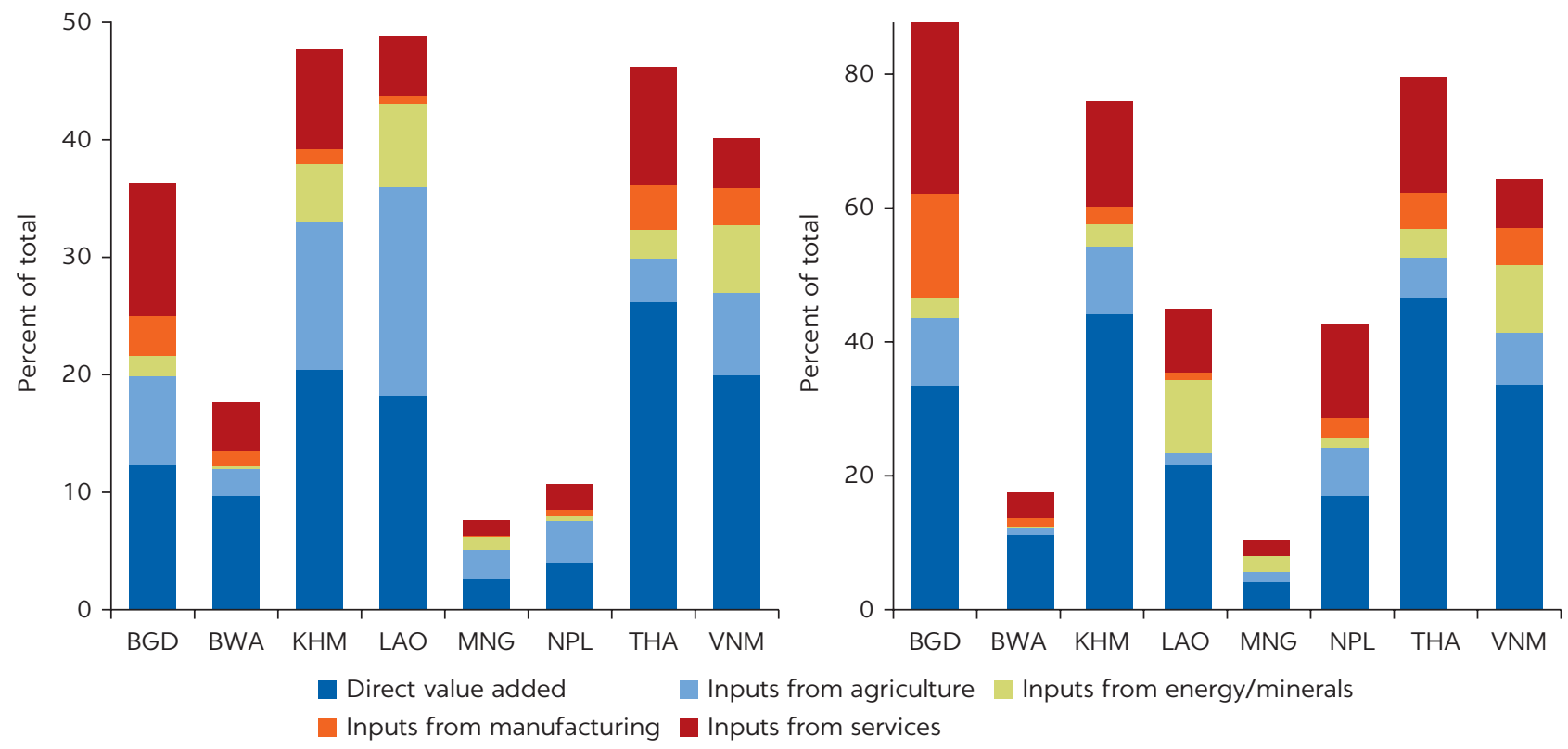

Source: World Bank Export of Value Added Database.

Note: $\mathrm{BGD}=$ Bangladesh; BWA = Botswana; $\mathrm{KHM}=$ Cambodia; $\mathrm{LAO}=$ Lao PDR; MNG = Mongolia; NPL = Nepal; THA = Thailand; VNM = Vietnam. 
FIGURE 1.2

\section{Composition of domestic services inputs in manufacturing exports in selected countries, 2011}

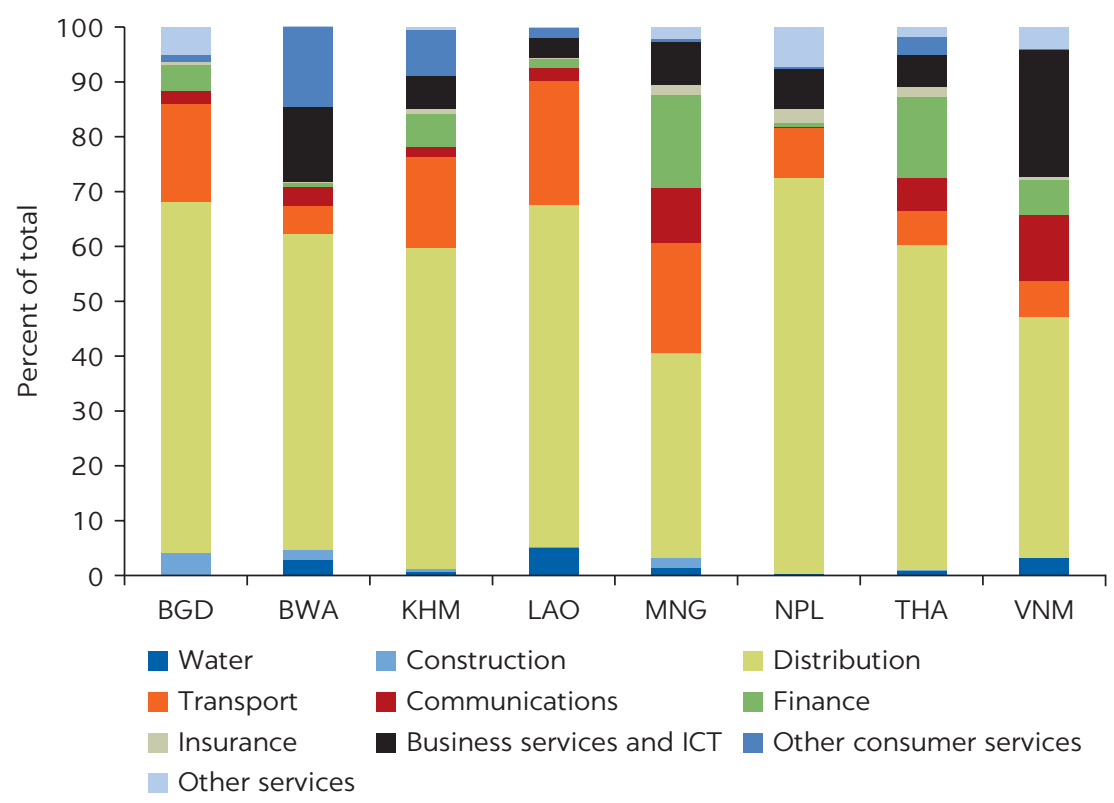

Source: World Bank Export of Value Added Database.

Note: $\mathrm{BGD}=$ Bangladesh; BWA = Botswana; $\mathrm{KHM}=$ Cambodia; $\mathrm{LAO}=\mathrm{Lao}$ PDR;

MNG = Mongolia; NPL = Nepal; THA = Thailand; VNM = Vietnam. ICT = information and

communications technology.

important than they are in peer countries, although other economies' manufacturing production and exports rely heavily on wholesale and retail trade as well as transportation. Inadequate access to financial and communication services, which represent only 3 percent of total services inputs into manufacturing, may be preventing manufacturing firms from moving into higher value-added activities.

The low use of financial services as inputs in production and export is consistent across manufacturing subsectors. The structure of services inputs into manufacturing is fairly similar across export sectors (figure 1.3). Energy/ minerals, metals, primary agriculture, and other primary products rely more heavily on services inputs, as well as inputs from the utility sector, than other products. Communication services appear to be more important for other primary (energy/minerals) production.

This pattern is consistent with the country's export profile. Services exports are heavily concentrated in traditional as opposed to modern activities. Exports account for about 6 percent of GDP-about average for countries at the same level of income. Transportation services generally play a more important role in landlocked countries than in countries with access to the sea. Although Lao PDR is landlocked, the share of transportation services in services is low, and performance is driven largely by travel services. At 2 percent of GDP, modern services exports are lower than among comparators except Bhutan; they are significantly below countries at similar levels of development outside the region.

Modern services exports are also less diversified than most comparator countries (exceptions are Bhutan and Vietnam) (figure 1.4). Lao PDR's services export 
FIGURE 1.3

Sectoral composition of services value added in domestic production and exports of Lao PDR, 2011

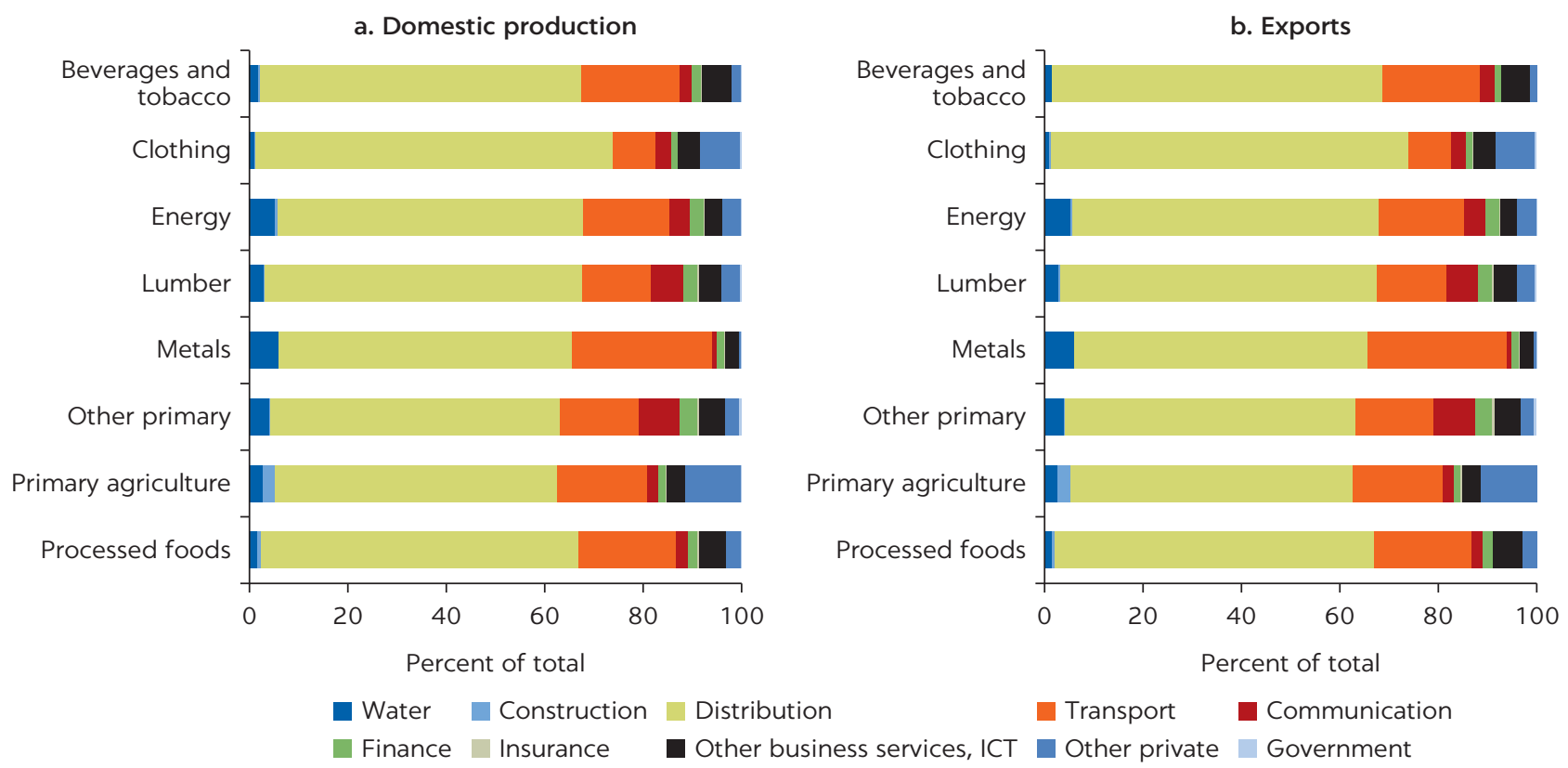

Source: World Bank Export of Value Added Database.

Note: ICT = information and communications technology.

\section{FIGURE 1.4}

\section{Sectoral composition of services exports by selected countries, 2013}

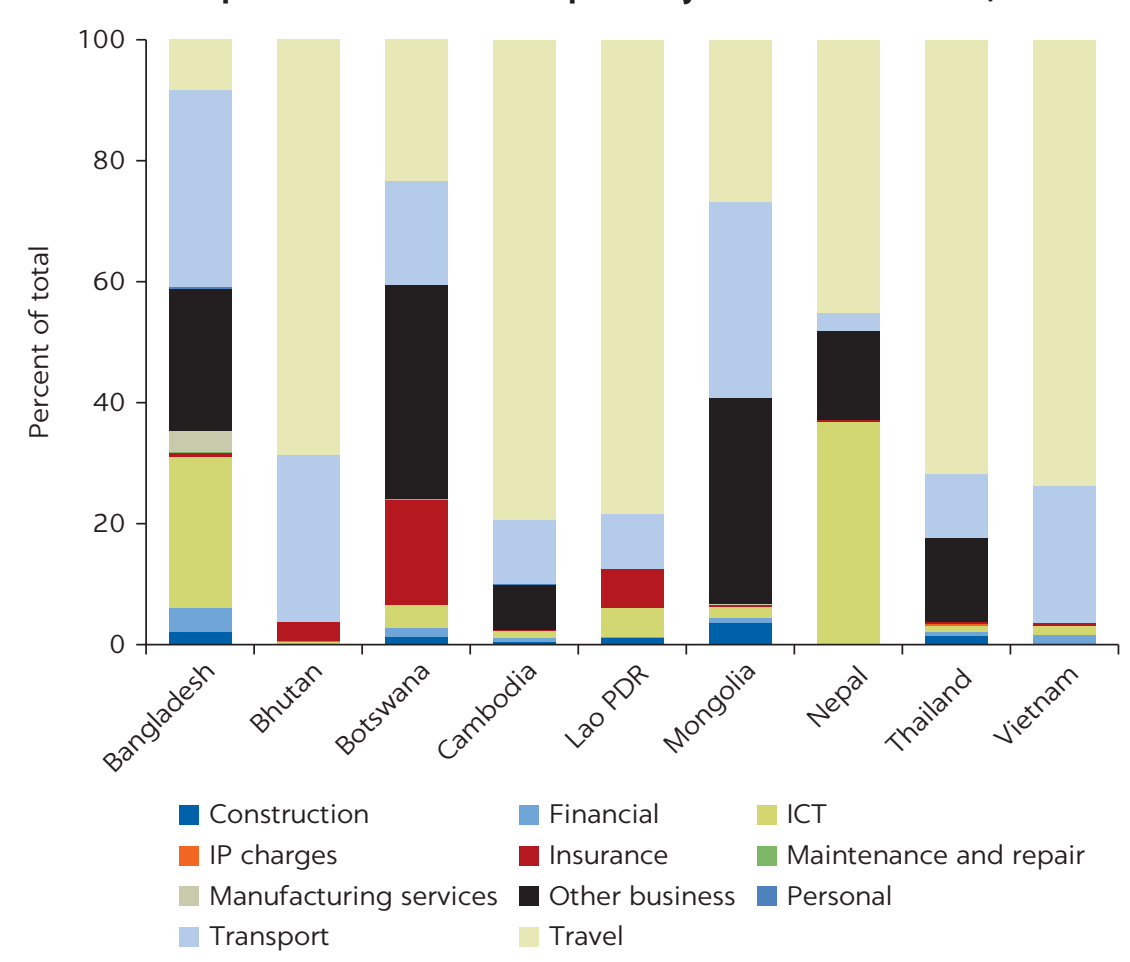

Source: UNCTADstat.

Note: ICT = information and communications technology; IP = intellectual property. 
structure is most similar to that of Cambodia and Vietnam. Outside the region, in Bangladesh and Botswana, for example, modern services represent more than 60 percent of the export basket; in Lao PDR they represent just 12 percent. Bangladesh, Botswana, Mongolia, Nepal, and Thailand have all been more successful in exporting other business services. The concentration of the services sector in traditional services may constrain the diversification and upgrading of manufacturing.

Key to diversification of export and production structures is diversification of the country's assets, which include natural resources, physical and human capital, and public institutions (Gill and others 2014). Lao PDR has substantial room to improve its human capital. Lack of education and skills is a key constraint. Other factors include macroeconomic instability and a business climate that is not fully conducive to investment and innovation.

Improving the quality of services provision is crucial to achieving economywide gains in terms of productivity and competitiveness. Inefficient supply of services inputs acts as a tax on production of goods that use these services intensively.

Many countries have developed services to both diversify and upgrade exports. Lao PDR can learn from their experiences. Uruguay, for example, used services both to diversify its export offerings and to add sophistication to its natural resource-intensive export products (box 1.1).

\section{BOX 1.1}

\section{Using exports to diversify into more sophisticated activities in Uruguay}

Like Lao PDR, Uruguay is remote and small, with a population of 3 million. It is abundant in natural resources (fertile land), with an export basket that has been highly concentrated in natural resourceintensive products (leather, beef, wool, and more recently soybeans and wheat), since the incorporation of cattle by Spanish colonizers in the early 1600s. This concentration has spurred debate over how to diversify the export basket and increase its sophistication.

Services, particularly services related to information and communications technology (ICT), have been crucial in reducing Uruguay's dependence on natural resource-intensive exports. Between 2002 and 2013, services exports increased more than fourfold, from $\$ 745$ million to $\$ 3,158$ million. Within services, ICT-related exports increased from \$14 million in 2002 to $\$ 180$ billion in 2013 , when they accounted for almost 6 percent of services exports. ICT and other business services are the third-most important services sector in Uruguay, after travel and transport, according to trade data from UNCTADstat.
The internationalization of modern services firms in Uruguay has been crucial for development. Remoteness and scale-two important constraints for exporters of merchandise-are less likely to constrain scaling up in these activities than they are in other activities. The sector, made up of about 350 firms producing and selling products and services to 55 markets in 2008 (Betarte, Cancela, and Moleri 2008), briefly became the largest software exporting cluster in Latin America; accounting for 2.2 percent of the country's GDP in 2016. ${ }^{a}$ For the first time in Uruguay's history, knowledge accumulation at the national level has generated significant exports that are not based on natural resources. The dynamic sector has provided know-how for the sophistication of natural resourceintensive exports.

Uruguay illustrates the importance of services for diversification and upgrading in its dual role as a direct supplier of final goods and as inputs to other sectors. Knowledge-intensive services subsectors have provided key inputs for resource-intensive export 
BOX 1.1, continued

products, such as boneless beef. The software industry played a key role in the implementation of the bovine full traceability system. The system, which identifies calves from birth to the meatpacker, allows Uruguayan beef to secure high prices in high-end international markets.

Several factors policies and market conditions contributed to the development of the ICT sector in Uruguay:

- Uruguay was a successful first mover that quickly scaled up, internationalized and showed potential entrants that the business was profitable (decreasing "discovery costs") (Snoeck and Pittaluga 2012).

- Although the cluster received no specific public support or incentives, it benefited from the patronage of the public sector.

- Tax exemption incentives after the export take-off period and the setting up of Special
Economic Zones, where export-oriented firms could operate under beneficial tax conditions, helped create a geographical cluster.

- Well-qualified professionals combined a high level of technical education with in-depth knowledge of specific sectors, putting them in an excellent position to tap into the growing market for sector-specific software applications and services (Kesidou and Romijn 2008).

- The private and public sectors coordinated with skill providers to adapt school curricula to the needs of the sector.

The public sector-including Uruguay XXI, the export promotion agency-provided support for the internationalization of firms, co-financing the search for information about foreign markets and potential clients, for example, and helping firms develop global business plans.

a. Uruguayan Chamber of Information Technologies (CUTI), https://www.cuti.org.uy/.

\section{ECONOMYWIDE EFFECTS OF SERVICES PERFORMANCE}

Can openness to trade and investment in the services sector improve domestic services and hence firms' productivity $?^{2}$ Is access to good-quality and reliable services important for productivity upgrading in Lao PDR?

The rest of this chapter addresses the first question by reviewing the literature and the second question using firm-level data for a cross-section of countries in East Asia and Pacific (EAP) and other regions as well as a Lao PDR panel..4 It examines data on the quality of services provision in Lao PDR and in regional comparators, presents data on firms' perceptions as well as the actual difficulties faced by firms in procuring services, and investigates the extent to which inadequate provision of services affects the performance of firms in Lao PDR and other countries in EAP. $\underline{5}$ The findings largely confirm that inadequate provision of backbone services, particularly weak transport services and infrastructure, hinders firm performance in Lao PDR.

\section{Openness to trade and investment in services and firm-level productivity}

Liberalization of services trade differs from liberalization of goods trade in its effects on domestic activity in the import-competing sector. Liberalization of services leads to increased scale of domestic activity in import-competing sectors, as Mattoo, Rathindran, and Subramanian (2006) note, because foreign factors tend to locate domestically (as foreign provision requires the mobility of capital or 
workers and cross-border trade is not feasible for many services) or domestic competition increases as a result of more effective regulation. These dynamics of competition will lead to better and more reliable provision of existing services, new varieties of services, and competitive pricing of services. Liberalization is also expected to increase productivity, trade, and output in the services sector and improve economywide performance through links with productive sectors.

A vast body of literature documents the links between services sector reform and economic performance. Research linking services sector reform and performance focuses on four channels:

- services reform and economywide gains

- services reform and services sector performance

- services reform and manufacturing export competitiveness

- services reform and manufacturing productivity.

The following sections examine each channel.

\section{Services reform and economywide gains}

Mattoo, Rathindran, and Subramanian (2006) study 60 countries over the period 1990-99 to determine whether the impact of liberalization of services on growth differs from that of liberalization of trade in goods. They find that countries with open financial and telecom sectors grew faster than other countries. This cross-country evidence confirms the intuition that emerges from various case studies. For example, Hodge (1998) reports that in South Africa, foreign entrants across all segments of the financial market played an important part in turning the country into a regional financial center. Foreign entry improved the competitiveness of the financial services market by reducing prices, increasing product variety, and improving service delivery.

Reforms are not related only to the liberalization of the sector but also to improvements in the quality of regulations. Eschenbach and Hoekman (2006) use an index of quality of policy for various services subsectors in 20 transition economies. They find that policy improvements attract foreign direct investment (FDI) and are associated with the post-1990 growth performance in these economies.

\section{Services reform and performance of the services sector}

The sequence of reforms in the services sector affects sector performance. Using data for 86 developing countries over the period 1985-99, Fink, Mattoo, and Rathindran (2003) find that privatization and competition improved performance. They argue that comprehensive reforms yield the largest gains and that the sequence of reforms matters. Their results suggest that competition policies should be incorporated simultaneously with privatization, to prevent liberalization for leading to themeresubstitution ofdomestic (usuallystate-controlled) monopolies for foreign monopolies.

\section{Services reform and export competitiveness}

Telecommunications' infrastructure is key to exporters' competitiveness. Fink, Mattoo, and Neagu (2005) and Francois, Manchin, and Pelkmans Balaoing (2009) examine the effects of services sector reform on manufacturers' export 
competitiveness, looking in particular at the communications-related sectors. Using bilateral data on communication costs and trade flows for 107 countries, Fink, Mattoo, and Neagu (2005) find that costs negatively affect trade flows, with the effect larger for differentiated goods. Using a panel of Asian economies, Francois, Manchin, and Pelkmans Balaoing (2009) find that variations in communications-related infrastructure affected export performance.

Bas (2013) examines the impact of services reform in energy, telecommunications, and transportation services in India in the mid-1990s. She finds a nonnegligible positive effect on the probability of exporting and on the export sales shares of firms producing in downstream manufacturing industries.

Evidence from case studies sheds light on the underlying mechanisms in the identified result. In telecommunications, foreign entry and increased competition led to substantial cost reductions and the introduction of new services in Chile (Wellenius 2002) and the Philippines (APEC 1998). Expansion of Internet services in the early 2000s improved communications within Africa and between Africa and the rest of the world.

\section{Services reform and manufacturing productivity}

Not all services sector reforms are equal in terms of their effect on the productivity of firms operating in downstream activities, and not all firms benefit equally. Arnold, Javorcik, and Mattoo (2011) combine firm-level data for manufacturers in the Czech Republic with several indicators of services sector reform. They find sizable effects on productivity. Allowing foreign entry into services industry (through the reduction of regulatory barriers to the operation of foreign affiliates in the sector) is the key channel through which services sector reform affects manufacturing productivity. Foreign acquisitions resulted in dramatic changes in the productivity and sales of acquired firms.

Arnold, Mattoo, and Narciso (2008) use data from 1,000 firms in 10 countries in Sub-Saharan Africa for the period 2001-05. They find that better performance of communications, electricity, and financial services increased manufacturing total factor productivity (TFP).

Fernandes and Paunov (2012) use firm-level data on Chilean manufacturers combined with FDI stocks in the services sector to examine the impact of the stocks on manufacturing firms' productivity. They find a positive and significant effect. The largest improvements in productivity were in manufacturing firms farthest from the technology frontier.

Arnold and others (2010) use data from Indian manufacturing firms to construct indicators of services sector reform in India. They find that potential productivity gains appear to be greatest in services subsectors most closely related to trade: transportation, communications, and finance. They also find that the effects are stronger on foreign than domestic firms.

Duggan, Rahardja, and Varela (2013) look at Indonesian data for the period 1997-2009. They find that reductions in services restrictiveness toward FDI were systematically associated with productivity gains for manufacturing firms operating in downstream sectors. Reforms in the transportation, electricity, gas, and water sectors were particularly relevant for manufacturing performance. Foreign equity limits, screening, prior approval requirements, and other restrictions on the operations of foreign firms mattered more for downstream productivity than relaxing restrictions on hiring foreign personnel. 


\section{SUBJECTIVE AND OBJECTIVE MEASURES OF THE PERFORMANCE OF THE SERVICES SECTOR}

The World Bank's Enterprise Surveys provide subjective and objective measures of the quality of provision of key services inputs to firms in downstream sectors. Subjective measures are based on firms' perceptions (on a scale of $0-4$ ) of how great a constraint they consider electricity, water services, transportation, and access to finance for their businesses. Objective indicators are derived from questions about the difficulties and incidents firms confront with their electric and water supplies. Both types of indicators are available for the financial sector and electricity services; only subjective information is available for transportation services. The surveys cover 127 countries, including Lao PDR, for which data are available for 2009 and 2012.

\section{Finance}

Access to finance appears to be a major constraint for firms in Lao PDR. In 2009 almost 21 percent of firms identified access to finance as the main obstacle to the success of their operations. When asked to rate the degree of severity posed by access to finance, 19 percent of firms indicated that inadequate access was at least a major obstacle.

More recent data point to an improvement in firms' satisfaction with access to finance. In 2012 only 10 percent of firms reported it as the leading obstacle to their operations. This figure is lower than the average for both EAP (18 percent) and a larger cross-regional sample (14 percent). Only 11 percent of firms rated access to finance as a major or severe obstacle in 2012. This figure is on par with the regional average of 11 percent and substantially below the cross-country average of 26 percent (figure 1.5, panel a). Access to finance in Lao PDR compares favorably with other countries, including regional peer Vietnam, where more than 15 percent of firms identified it as a major or severe obstacle to their performance (figure 1.5, panel b).

Perceptions of the quality of access to finance also appear to vary across regions, although the differences are not statistically significant. Firms in the capital city, Vientiane, and in Savannakhet, where almost 70 percent of all surveyed firms are located, have the most negative perceptions of the quality of access to finance. On average, 19 percent of firms in the capital identified finance as at least a major constraint. By contrast, only 4 percent of firms in Champasak and no firms in Luang Namtha complained about access to finance in 2012.

Are these perceptions consistent with the actual quality of services firms receive? Lao PDR firms appear to confront difficulties when trying to obtain financing. In Lao PDR, on average 84 percent of a firm's investments are financed internally. The figure is 76 percent in EAP and 67 percent for the average firm in the sample (table 1.1). Among firms in Vientiane, where half of the firms interviewed are located, the proportion of investments financed internally is 91 percent. For working capital, the relevance of internal funds increases to 88 percent in Lao PDR, a higher figure than the regional average of 82 percent and the cross-country average of 71 . Less than 7 percent of investments in Lao PDR were financed by loans and lines of credit from banks, a lower figure than the 10 percent for the average firm in EAP and 17 percent for firms in the larger sample. 
FIGURE 1.5

\section{Percentage of firms identifying finance, electricity, and transportation as major obstacles to} doing business

a. Lao PDR, East Asia and Pacific, and all countries

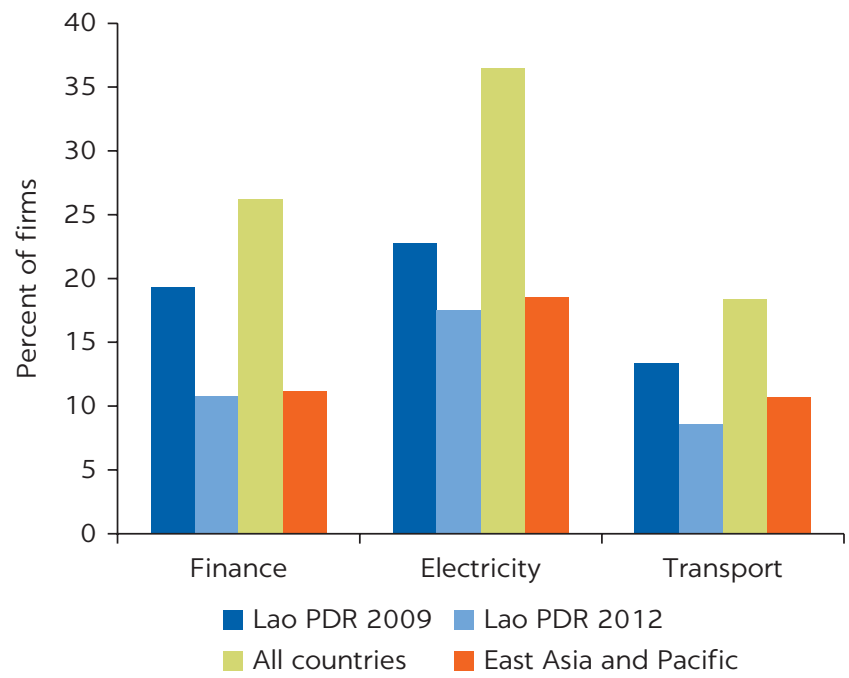

b. Lao PDR and comparators

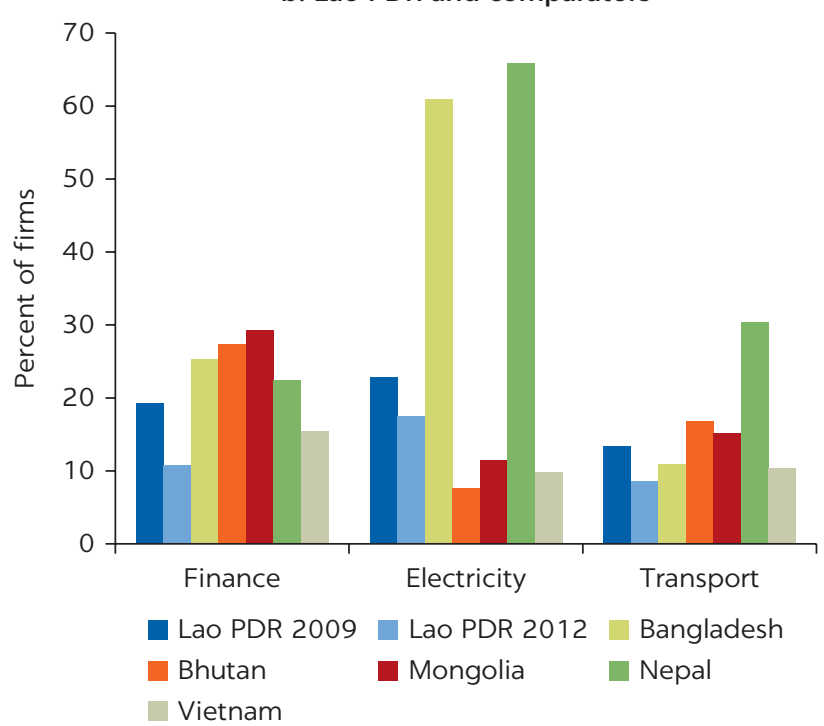

Source: World Bank Enterprise Surveys.

Note: Data for all countries and for East Asia and Pacific are the averages of responses over one or several years between 2006 and 2014. Data for Bangladesh are average of responses in 2007 and 2013. Data for Nepal and Mongolia are average of responses in 2009 and 2013. Data for Bhutan and Vietnam are for 2009.

TABLE 1.1 Access to finance in Lao PDR, East Asia and Pacific, and all countries

\begin{tabular}{lccc}
\hline PROPORTION OF & LAO PDR & EAST ASIA AND PACIFIC & ALL COUNTRIES \\
\hline Investments financed internally & 84.3 & 80.1 & 66.9 \\
\hline Investments financed by banks & 60.8 & 10.1 & 16.8 \\
\hline Investments financed by supplier credit & 20.6 & 2.0 & 5.1 \\
\hline Investments financed by equity or stock sales & 40.3 & 4.8 & 4.2 \\
\hline Working capital financed internally & 87.6 & 82.2 & 71.3 \\
\hline Working capital financed by banks & 80.0 & 11.0 & 13.3 \\
\hline Working capital financed by supplier credit & 20.9 & 4.0 & 11.5 \\
\hline
\end{tabular}

Source: World Bank Enterprise Surveys.

Note: Figures are averages for Lao PDR firms interviewed in 2009 and 2012. Figures represent the average proportion of a firm's investments (purchases of fixed assets) or working capital that was financed by different instruments.

\section{Electricity}

Poor-quality electricity services is an important obstacle to doing business in Lao PDR. In 2009 almost 23 percent of firms identified inadequate electricity as a major or severe obstacle to their operations. This proportion decreased to 17 percent in 2012. These performance valuations are on par with the average for EAP of 18.5 percent but substantially below the cross-country average of 36.5 percent. Indeed, as panel $\mathrm{b}$ of figure 1.5 shows, the quality of electricity services appears to be better in Lao PDR than in other Asian countries, such as Bangladesh and Nepal. The poor quality of electricity is an obstacle to both upgrading productivity in existing industries and diversifying the production structure in Lao PDR. 
Perceptions of the quality of electricity services vary within Lao PDR. Electricity appears to be a greater constraint for firms in Vientiane, Champasak, and Luang Namtha than elsewhere. More than 28 percent of firms in Vientiane viewed electricity as a major obstacle in 2009. This proportion decreased to about 19 percent in 2012, but electricity still remained the main obstacle, according to firms in Vientiane. The proportion of firms that expressed concerns with the quality of electricity was even higher in Luang Namtha (25 percent). Perceptions of the quality of electricity improved in some cities (Vientiane and Champasak) and deteriorated in others (Savannakhet and Luang Prabang).

These perceptions reflect actual inadequacies in electric power provision (box 1.2). On average, firms in Lao PDR wait 20 days to obtain an electric connection, with a median wait time of 16 days, compared with a median of 10 days for the EAP region and 12 for all countries in the sample (table 1.2). On average, firms in Lao PDR experience 2.5 power outages a month. This figure is below the regional average (6.8) and much lower than the cross-country average (17.9).

\section{BOX 1.2}

\section{Correlation between subjective and objective measures of electricity in Lao PDR}

The association between the number of monthly power outages a firm in Lao PDR faces and the extent to which it ranks electricity as an obstacle to its operations are strongly correlated (table B1.2.1). Each additional power outage results in an increase of 0.1 in the obstacle score firms give to electricity. This effect appears to be substantively larger for firms in Lao PDR than for firms in other EAP countries and in the larger cross-regional sample. There is also a significant correlation between the number of days firms have to wait to get an electric connection and the extent to which they identify electricity as an obstacle.

TABLE B1.2.1 Subjective and objective measures of electricity use in Lao PDR, East Asia and Pacific, and all countries

\begin{tabular}{lcccc}
\hline VARIABLE & LAO PDR & LAO PDR & $\begin{array}{c}\text { EAST ASIA AND } \\
\text { PACIFIC }\end{array}$ & ALL COUNTRIES \\
\hline Power outages & $0.0938^{* * *}$ & $0.111^{* * *}$ & $0.0398^{* * *}$ & $0.004704^{* *}$ \\
\cline { 2 - 5 } & $(0.0233)$ & $(0.0378)$ & $(0.0039)$ & $(0.001556)$ \\
\hline Electric connection & & 0.00527 & 0.0013 & $0.00086^{* * *}$ \\
\hline Length of power outages & & $(0.00513)$ & $(0.0009)$ & $(0.000192)$ \\
\cline { 2 - 5 } & & & & $0.00955^{* * *}$ \\
\hline Constant & $1.294^{* * *}$ & $1.388^{* * *}$ & $1.33^{* * *}$ & $(0.001721)$ \\
\hline Number of observations & $(0.0901)$ & $(0.226)$ & $(0.051)$ & 8,267 \\
\hline$R$-squared & 239 & 41 & 575 & 0.031 \\
\hline Estimation & 0.087 & 0.176 & 0.095 & OLS \\
\hline
\end{tabular}

Source: World Bank Enterprise Surveys.

Note: Robust standard errors are in parentheses. Data for Lao PDR are for 2009 and 2012. Data for East Asia and Pacific and all countries cover all years available. OLS $=$ ordinary least squares.

${ }^{* * *} p<0.01, * * p<0.05, * p<0.1$. 
TABLE 1.2 Mean and median indicators of electricity, telecommunication, and water services in Lao PDR, East Asia and Pacific, and all countries

\begin{tabular}{|c|c|c|c|c|c|c|c|c|c|c|c|}
\hline \multirow[b]{2}{*}{ ITEM } & \multicolumn{2}{|c|}{$\begin{array}{l}\text { NUMBER OF DAYS TO } \\
\text { OBTAIN PHONE } \\
\text { CONNECTION }\end{array}$} & \multicolumn{2}{|c|}{$\begin{array}{l}\text { NUMBER OF POWER } \\
\text { OUTAGES IN TYPICAL } \\
\text { MONTH }\end{array}$} & \multicolumn{2}{|c|}{$\begin{array}{l}\text { NUMBER OF DAYS TO } \\
\text { OBTAIN ELECTRICITY } \\
\text { CONNECTION }\end{array}$} & \multicolumn{2}{|c|}{$\begin{array}{l}\text { NUMBER OF DAYS TO } \\
\text { OBTAIN A WATER } \\
\text { CONNECTION }\end{array}$} & \multicolumn{2}{|c|}{$\begin{array}{l}\text { NUMBER OF WATER } \\
\text { SUPPLY INCIDENTS IN } \\
\text { TYPICAL MONTH }\end{array}$} & \multirow[t]{2}{*}{$\begin{array}{l}\text { PERCENTAG } \\
\text { OF FIRMS } \\
\text { OWNING A } \\
\text { GENERATOR }\end{array}$} \\
\hline & MEAN & MEDIAN & MEAN & MEDIAN & MEAN & MEDIAN & MEAN & MEDIAN & MEAN & MEDIAN & \\
\hline $\begin{array}{l}\text { Lao PDR } \\
2009\end{array}$ & 4 & 3 & 1 & 0 & 16 & 16 & 73 & 100 & 2 & 0 & 10 \\
\hline $\begin{array}{l}\text { Lao PDR } \\
2012\end{array}$ & n.a. & n.a. & 3 & 2 & 23 & 15 & 19 & 14 & 7 & 1 & 15 \\
\hline $\begin{array}{l}\text { East Asia } \\
\text { and } \\
\text { Pacific }\end{array}$ & 9 & 4 & 7 & 1 & 24 & 10 & 19 & 7 & 3 & 0 & 32 \\
\hline $\begin{array}{l}\text { All } \\
\text { coun- } \\
\text { tries }\end{array}$ & 22 & 7 & 18 & 4 & 35 & 12 & 34 & 10 & 10 & 3 & 36 \\
\hline
\end{tabular}

Source: World Bank Enterprise Surveys.

Note: Data for East Asia and Pacific and all countries cover all years available.

n.a. $=$ Not available.

However, median values are far worse than in regional counterparts. Indeed, 90 percent of firms in Lao PDR experienced a power outage within a month of being surveyed (Enterprise Survey for Lao PDR 2012). Smaller cities seem to have more frequent power outages than larger ones.

\section{Water}

Firms in Lao PDR waited twice as long as firms in other countries in the region in 2012 to obtain a water connection (a median of 14 versus 7 days). On average, firms in Lao PDR face twice as many water outages as firms in other EAP countries. The average (and median) number of water supply incidents that firms in Lao PDR experience in a typical month is below the average (and median) for the larger sample of all countries, however.

\section{Transportation}

Being a landlocked country and lacking a railway system, Lao PDR depends primarily on road and, to a lesser extent, river and air transportation. Roads account for 80 percent of all passenger and goods movement. The road network reaches all parts of the country. Its density is highest in the central and southern regions (OECD 2013). Road density is lower in Lao PDR than in other countries in the region. Less than 15 percent of the road network is paved, with paved stretches serving primarily urban areas.

Despite significant improvements in transportation and connectivity, the quality and availability of transportation services continue to be problems for a large proportion of firms (see, for example, Trade and Transport Facilitation Assessment, World Bank 2014). Almost 14 percent of firms in Lao PDR identified poor quality of transportation services as a major or severe obstacle. This figure is higher than with the regional average of 11 percent. In 2012 almost 8 percent of firms in Lao PDR said transportation was the number one 
constraint to their operations. In contrast, only 5 percent of firms in EAP and less than 3 percent of firms in the larger sample of countries ranked transportation as the top obstacle.

Firms perceive transportation services as less of a problem in Lao PDR than in other Asian countries, such as Nepal and Bhutan, where 30 percent and 17 percent of firms, respectively, identified transportation as a major or severe obstacle (see panel b of figure 1.5). Firms' valuations vary across Lao PDR. Firms located along the country's main trading routes, which connect Vientiane, Savannakhet, and Pakse with the Bangkok and Laem Chabang seaports in Thailand, tend to have more favorable assessments of the quality of transportation services. This finding is not surprising, given the lower costs in trucking services since restrictions to the cross-border movement of trucks were lifted in 2004. As a result, larger, better-organized Thai trucking firms provide most cross-border transportation services.

Lao PDR trucking companies still face challenges in the market. These companies are smaller than Thai companies and use older equipment; they serve primarily short-distance domestic movements, transporting goods to and from the border. Loading and unloading goods at the border adds to the total cost of land transportation. Factors discouraging Lao PDR operators from providing cross-border services include the failure of their trucks to meet Thai safety standards; language differences, which expose drivers to harassment; and the fact that vehicles are driven on different sides of the road.

The cost of transporting cargo within Lao PDR is high (table 1.3), particularly compared with other developing countries, mainly because of the distance to ports and the large proportion of empty containers moving from the port for loading or returning to the port after unloading (World Bank 2014).

International transportation firms need licenses to operate in Lao PDR. They are issued for a period of five years. The number of transportation firms with licenses to operate between Thailand and Lao PDR increased from 3 in 2000 to 111 in 2011. Nevertheless, anecdotal evidence suggests that the system of licenses may be posing a constraint to some local firms. Firm representatives mentioned that some firms were unable to obtain licenses and had to rely instead on established firms.

Restrictions associated with licensing prevent firms from integrating vertically and developing their own transportation services. Anecdotal evidence suggests that this problem affects many companies that export energy and minerals. Because of the high intensity with which they use transportation inputs, they prefer to integrate this activity into their core operations. ${ }^{6}$

TABLE 1.3 Trade volumes, distances, and cost for major trade corridors, 2011

\begin{tabular}{lcccc}
\hline CORRIDOR & $\begin{array}{c}\text { DISTANCE } \\
\text { (KILOMETERS) }\end{array}$ & $\begin{array}{c}\text { TRAVEL TIME } \\
\text { (HOURS) }\end{array}$ & $\begin{array}{c}\text { TRADE VOLUME } \\
\text { (PERCENT OF } \\
\text { TOTAL) }\end{array}$ & $\begin{array}{c}\text { COST } \\
\text { (\$ PER } \\
\text { CONTAINER) }\end{array}$ \\
\hline Vientiane-Bangkok & 620 & 12 & 40 & 1,200 \\
\hline Savannakhet-Bangkok & 645 & 12 & 19 & 1,100 \\
\hline Pakse-Bangkok & 750 & 13 & 9 & 1,300 \\
\hline Source: World Bank 2014 & & & &
\end{tabular}

Source: World Bank 2014. 


\section{Telecommunications}

Despite significant progress in updating and improving telecommunication services, Lao PDR still lags its comparators. In 2012 it ranked 123rd out of 157 countries on the ICT Development Index, which is based on a range of internationally agreed upon ICT indicators, with an index of 2.1 (table 1.4). Although its score increased since 2010, it remains one of the lowest-ranked countries in the region, ranking well below the developing country average of 3.4.

ICT services in Lao PDR are among the world's most expensive. In 2011 Lao PDR ranked144th of 166 countries in terms of the ICT price basket, which represents an average of fixed telephone, mobile cellular, and fixed broadband prices. The low performance of ICT affordability highlights the need for further liberalization and for progress in the removal of restrictive and anticompetitive practices. Respondents from the private sector complained about anticompetitive practices toward foreign providers. Lao PDR Telecom (the public provider) set the minimum prices in Lao PDR five or six times higher than prices in Thailand or Vietnam, preventing foreign providers from competing through price reductions. It also limits promotions or special offers to running for a maximum of 2 weeks with prior approval. The government created a Lao gateway, through which all international traffic needs to pass. Its creation raised the costs of calls into Lao PDR rose from $\$ 0.030$ to $\$ 0.065$. ?

Lao PDR also lags its regional comparators in terms of access to ICT. In 2013, for example, the number of fixed telephone subscriptions per 100 people was 1.8-far fewer than the 11.4 in Vietnam or the 4.0 in Cambodia (table 1.5). Lao PDR also underperformed in terms of mobile subscriptions per 100 people, with 101.9, compared with 149.4 in Vietnam, 132.0 in Cambodia, and 106.8 in the Philippines. The share of households with Internet access in Lao PDR

TABLE 1.4 ICT development index and price basket for selected countries in East Asia

\begin{tabular}{|c|c|c|c|c|c|c|}
\hline \multirow[b]{3}{*}{ COUNTRY } & \multicolumn{4}{|c|}{ ICT DEVELOPMENT INDEX } & \multicolumn{2}{|c|}{$\begin{array}{l}\text { ICT PRICE BASKET } \\
\text { (PERCENT OF PER CAPITA } \\
\text { GROSS NATIONAL INCOME) }\end{array}$} \\
\hline & \multicolumn{2}{|c|}{ SCORE } & \multicolumn{2}{|c|}{ RANKING } & \multirow{2}{*}{$\begin{array}{c}\text { SCORE } \\
2012\end{array}$} & \multirow{2}{*}{$\begin{array}{c}\text { RANKING } \\
2012\end{array}$} \\
\hline & 2010 & 2012 & 2010 & 2012 & & \\
\hline Brunei Darussalam & 4.85 & 5.06 & 52 & 58 & 1.0 & 26 \\
\hline Cambodia & 1.88 & 2.30 & 119 & 120 & 24.3 & 130 \\
\hline Indonesia & 3.01 & 3.43 & 97 & 97 & 5.5 & 104 \\
\hline Lao PDR & 1.84 & 2.10 & 120 & 123 & 37.4 & 144 \\
\hline Malaysia & 4.63 & 5.04 & 57 & 59 & 1.8 & 51 \\
\hline Myanmar & 1.65 & 1.74 & 129 & 134 & n.a. & n.a. \\
\hline Philippines & 3.04 & 3.34 & 94 & 98 & 9.0 & 113 \\
\hline Singapore & 7.47 & 7.65 & 10 & 15 & 0.4 & 3 \\
\hline Thailand & 3.29 & 3.54 & 89 & 95 & 3.4 & 78 \\
\hline Vietnam & 3.41 & 3.80 & 86 & 88 & 6.0 & 106 \\
\hline World (average) & & 4.35 & & & & \\
\hline $\begin{array}{l}\text { Developing } \\
\text { countries (average) }\end{array}$ & & 3.44 & & & & \\
\hline
\end{tabular}

Source: ITU 2012, 2013.

Note: ICT = information and communications technology; n.a. = not available. 
TABLE 1.5 Access to Internet services in East Asian countries, 2013

\begin{tabular}{lcccc}
\hline & $\begin{array}{c}\text { FIXED-TELEPHONE } \\
\text { SUBSCRIPTIONS PER } \\
\text { 100 PEOPLE }\end{array}$ & $\begin{array}{c}\text { MOBILE } \\
\text { SUUSCRIPTIONS PER } \\
\text { 100 PEOPLE }\end{array}$ & $\begin{array}{c}\text { PERCENT OF } \\
\text { HOUSEHOLDS WITH } \\
\text { A PERSONAL } \\
\text { COMPUTER }\end{array}$ & $\begin{array}{c}\text { PERCENT OF } \\
\text { HOUSEHOLDS WITH } \\
\text { INTERNET ACCESS }\end{array}$ \\
\hline $\begin{array}{l}\text { Brunei } \\
\text { Darussalam }\end{array}$ & 17.2 & 113.8 & 86.9 & 72.4 \\
\hline Cambodia & 4.0 & 132.0 & 5.4 & 3.9 \\
\hline Indonesia & 15.5 & 115.2 & 15.1 & 6.5 \\
\hline Lao PDR & 1.8 & 101.9 & 8.7 & 5.1 \\
\hline Malaysia & 15.7 & 140.9 & 66.9 & 64.7 \\
\hline Myanmar & 1.1 & 11.2 & 2.3 & 1.8 \\
\hline Philippines & 4.1 & 106.8 & 16.9 & 18.9 \\
\hline Singapore & 37.8 & 153.4 & 87.7 & 87.7 \\
\hline Thailand & 9.1 & 120.3 & 26.9 & 18.4 \\
\hline Vietnam & 11.4 & 149.4 & 17.5 & 15.6 \\
\hline Source: ITU & & & &
\end{tabular}

Source: ITU 2013.

FIGURE 1.6

Share of firms in Lao PDR, East Asia and Pacific, and all countries that use email or have their own websites, 2009 and 2012

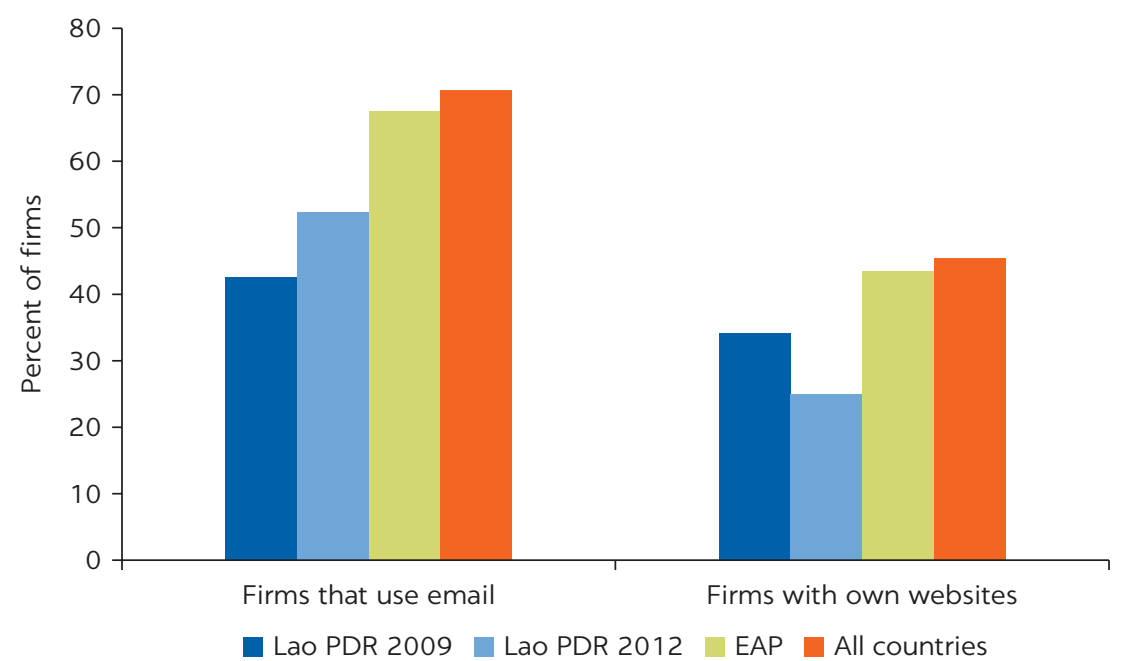

Source: World Bank Enterprise Surveys.

Note: $\mathrm{EAP}=$ East Asia and Pacific.

(5.1 percent) is lower than in all other countries in the Association of Southeast Asian Nations (ASEAN) except Cambodia (3.9 percent) and Myanmar (1.8 percent).

Data from World Bank Enterprise Surveys suggest that firms in Lao PDR have more limited access to Internet services than businesses in other countries. Less than 47 percent of firms rely on email for communications, compared with 67.5 percent for other EAP countries and 71 percent for the cross-regional sample. Only 30 percent of firms have their own websites, compared with 43 percent of firms in EAP and 45 of firms in the larger sample (figure 1.6). These results could reflect demand factors, such as whether clients and other business partners rely 
on these means of communications, rather than supply. However, evidence from interviews confirmed the inadequacy of Internet services, in addition to its high cost. Internet is considered a luxury good in the tax system and is hence taxed at 10 percent, increasing costs for a service that is crucial for innovation.

Access to high-quality ICT is crucial to improve the competitive edge of Lao PDR in tourism and increase the daily expenditures of tourists. It plays a role in the pre-travel, travel, and post-travel phases of tourism. In the pre-travel phase, it provides tools that facilitate information search, planning, and reservations. During the travel phase, it helps provide real-time information about the destination (maps of cities or regions, information about events and places of interest, and so forth). In the post-travel phase, it allows tourists to share their travel experience with others, an important platform for promoting tourism (Balandin and Laizane 2013).

\section{Determinants of cross-firm variation in perceptions}

Perceptions of the quality of services vary across types of firms. After controlling for differences in firm characteristics, the share of firms in Lao PDR that perceive access to finance as a constraint is 20 percent higher than the average for EAP and 12 percent lower than the average firm across all countries considered. Foreign firms operating in Lao PDR are less vulnerable to constraints in accessing finance than domestic firms the same size in the same sector. Controlling for differences in firm characteristics, manufacturing firms appear to be more constrained by access to finance than firms in other sectors in all three samples. Size does not seem to affect firms' valuation of financial services in Lao PDR. In contrast, in EAP and the broader sample, size is negatively associated with perceptions of access.

Exporters and firms in the manufacturing sector tend to have less favorable perceptions of the quality of electric services than nonexporters and firms in other sectors in all three samples. More experienced firms seem to be less constrained by inadequate electricity provision.

Exporters in Lao PDR and in EAP are also more constrained than nonexporters by inadequacies in transportation services. Foreign firms operating in Lao PDR and in EAP countries have more positive perceptions of the quality of transportation services. All else equal, the share of respondents perceiving transportation services favorably was 20 percentage points higher among foreign firms than among domestic firms. By contrast, in the larger cross-country sample, foreign firms have a more negative assessment of the constraints posed by transportation services.

\section{EFFECTS OF SERVICES ON FIRM PERFORMANCE}

This section investigates the extent to which difficulties procuring services inputs affects the performance of firms in Lao PDR (see appendix A for the empirical methodology). .9

Productivity performance is heterogeneous across firms. In general, firms that are more integrated in the global marketplace are typical more productive than firms in the same country, same sector, and comparable size that are not as well integrated. 
In Lao PDR, TFP of exporters is almost 40 percent higher than TFP of nonexporters, but this premium is lower than it is in EAP region or in the larger cross-regional sample. Exporters from Lao PDR are less productive than their counterparts in EAP and the larger sample. 10

In general, foreign-owned firms are substantially more productive than domestic firms. They are much more productive than domestic firms in Lao PDR.

Firm size also matters. In all of the samples studied, larger firms are slightly more productive than smaller ones. This premium is slightly larger for firms in Lao PDR than for the average firm in the EAP region and in the sample of 133 countries.

How do different types of services affect firm productivity? To avoid potential problems of endogeneity between firms' perceptions of services provision and performance, we aggregate firm-level responses into regional averages. We then regress firm TFP and labor productivity on subjective measures (regional averages) and objective indicators of service performance, using the firm characteristics mentioned above (exporter status, foreign ownership, size, and age) as additional covariates, controlling for sectors, countries, and years.

The results show that the quality of financial, electricity, transportation, and telecommunications services provided to downstream firms, measured both through subjective and objective indicators, is systematically and significantly associated with firm performance. The findings are relatively robust to alternative measures of performance (labor productivity or TFP). They are consistent with the view that services matter for the performance of firms across all sectors of the economy.

\section{Finance}

There is a negative association between perceptions of access to finance and firm productivity, although the statistical significance of this relationship is less robust for Lao PDR than for the other countries in the sample. For the larger sample of countries, there is a negative association between firms' perceptions of poor access to finance and TFP and labor productivity. The negative relationship between finance performance ratings and labor productivity is also evident when considering EAP countries. All else equal, firms in Lao PDR that complain about the poor quality of financial services appear to be more, not less, productive than those that do not. This finding may reflect the fact that more sophisticated firms with more complex financial needs place greater emphasis on an efficient and well-functioning financial market.

Firms that have greater access to bank financing tend to be more productive. The links between objective indicators of access to finance and productivity. For EAP and the sample of all countries, there is a negative association between higher reliance on internal funding for investments in fixed assets and in working capital and TFP. In addition, the results show that the greater the percentage of investment that firms finance with bank loans, the higher their TFP, suggesting that firms that have greater access to bank financing are more productive. In Lao PDR, only the extent of reliance on internal funds for working capital appears to have a statistically significant (and negative) effect on TFP.를 Reliance on bank financing for working capital investments is associated with higher levels of productivity. $\underline{12}$ 


\section{Electricity and water}

Inadequate access to electricity constrains firms' productivity. Negative perceptions of the quality of electricity are associated with lower levels of TFP, for both the cross-regional sample and, more clearly, firms in EAP. The estimated coefficient on the obstacle perception is also negative for Lao PDR, although the effect is not significant, very likely because of the small size of the sample. These regressions include controls for the fact that some firms have their own generators, which may affect their perceptions of the quality and availability of electricity. $\underline{13}^{\underline{1}}$

These results are robust to alternative measures of productivity. The estimated coefficient for the electricity obstacle is negative and significant in both the Lao PDR and the EAP models. If the average perceptions rating for electricity in Lao PDR (1.35) rose to Chinese levels (0.48), the labor productivity of Lao PDR firms would increase by 4 percent.

The productivity losses associated with unreliable electricity services are also evident when considering objective indicators. The results show a significant negative relationship between the number of outages a firm experiences in a typical month and its productivity. For firms in EAP, each additional power outage is associated with a 1 percent decrease in TFP. This effect seems to be much stronger for firms in Lao PDR. Reducing the median number of monthly power outages from two to one (the median in EAP) would increase productivity by 9 percent. For the larger cross-country sample, the effect of power outages on productivity is substantially weaker (negative and significant at the 1 percent level). For the larger sample, there is a statistically significant association between the average duration of an outage and firm performance.

The availability and continuity of water provision is also associated with firm productivity. For firms in Lao PDR and for the larger sample of EAP countries, the number of water supply interruptions experienced by a firm in a typical month is associated with lower TFP. For firms in Lao PDR, one additional water supply interruption results in a productivity loss of 3 percent, compared with less than 0.5 percent for the average EAP firm. For firms in EAP, the duration of water outages also appears to be negatively and significantly associated with productivity.

\section{Transportation}

Perceptions of poor quality in transportation services are associated with a productivity loss of more than 50 percent for firms in EAP-and the association is even greater in Lao PDR. If perceptions of transportation services as an obstacle in Lao PDR (0.98) were to match Indonesia's (0.83), TFP would increase by 31 percent. For labor productivity, the estimated coefficient of transportation obstacle is also negative and significant but smaller. If perceptions of transportation quality in Lao PDR rose to Indonesian levels, the labor productivity of local firms would grow by 1.3 percent.

\section{Telecommunications}

Access to Internet connectivity is associated with higher productivity of firms in Lao PDR. Data on subjective measures are not available. The analysis therefore focuses on two objective indicators of Internet access: whether a firm uses 
emails in communications with clients and suppliers and whether it has its own website.

Firms in Lao PDR that rely on emails for their communications are more than 110 percent more productive (in terms of TFP) than those that do not. Firms that use their own websites to communicate with potential clients and suppliers have 40 percent higher TFP than firms that do not. The productivity premium from using email seems to be stronger for the average firm in EAP and slightly lower for the average firm in the cross-regional sample..$^{14}$

For firms in Lao PDR, use of email is associated with lower, not higher, labor productivity. In contrast, for the other two samples, email use has a smaller effect on labor productivity than on TFP but remains positive.

\section{Summary}

These findings confirm the links between the quality of backbone services and firm productivity in Lao PDR. They indicate that the quality of transportation and electricity affects firms' productivity; the evidence on access to finance is less conclusive. The quality of transportation services appears to have the strongest effect on firm productivity (measured in terms TFP and labor productivity).

Table 1.6 summarizes the results. It reports standardized coefficients, which measure changes in the dependent variable associated with a one standard deviation change in the explanatory variable. These results indicate that inadequate quality of services appears to be a stronger constraint in Lao PDR than in other countries in EAP. Changes in the quality of transportation and electricity services would have the largest effect on performance. A one standard deviation

TABLE 1.6 Estimated effects of quality of selected services on firm performance in Lao PDR and East Asia and Pacific

\begin{tabular}{|c|c|c|c|c|}
\hline \multirow[b]{2}{*}{ TYPE OF SERVICE } & \multirow[b]{2}{*}{ INDICATOR } & \multirow{2}{*}{$\begin{array}{l}\text { ESTIMATED EFFECT ON } \\
\text { TOTAL FACTOR } \\
\text { PRODUCTIVITY }\end{array}$} & \multicolumn{2}{|c|}{ ESTIMATED EFFECT ON TOTAL FACTOR PRODUCTIVITY } \\
\hline & & & LAO PDR & $\begin{array}{l}\text { EAST ASIA AND PACIFIC } \\
\text { REGION }\end{array}$ \\
\hline \multirow[t]{5}{*}{ Access to finance } & Subjective & & & \\
\hline & Perceptions of obstacle & Negative & $0.23^{*}$ & 0.22 \\
\hline & Objective & & & \\
\hline & $\begin{array}{l}\text { Reliance on internal } \\
\text { funds }\end{array}$ & Negative & $-0.15^{*}$ & $-0.08^{*}$ \\
\hline & Reliance on bank finance & Positive & 0.15 & $0.11^{*}$ \\
\hline \multirow[t]{4}{*}{ Electricity } & Subjective & & & \\
\hline & Perceptions of obstacle & Negative & -0.01 & $-0.02^{*}$ \\
\hline & Objective & & & \\
\hline & Power outages & Negative & $-0.13^{*}$ & $-0.05^{*}$ \\
\hline \multirow[t]{2}{*}{ Transportation } & Subjective & & & \\
\hline & Perceptions of obstacle & Negative & $-0.15^{*}$ & $-0.06^{*}$ \\
\hline \multirow[t]{3}{*}{ Telecommunications } & Objective & & & \\
\hline & Email use & Positive & $0.39 *$ & $0.25^{*}$ \\
\hline & Company website & Positive & $0.30 *$ & $0.17^{*}$ \\
\hline
\end{tabular}

Source: World Bank Enterprise Surveys.

Note: Standardized coefficients from regression models available from authors upon request. Objective measures are not available for transportation.

Subjective measures are not available for telecommunications.

$* p<0.1$. 
increase in firms' subjective rating of the quality of transportation is associated with a 15 percent increase in performance (measured as TFP-R). A one standard deviation decrease in the number of power outages experienced by a firm in a typical month would result in a 13 percent improvement in performance levels.

\section{POLICY IMPLICATIONS}

Several policy recommendations emerge from this analysis:

1. Move forward with World Trade Organization (WTO) and ASEAN Framework Agreement on Services (AFAS) commitments to ensure a liberal trade and investment regime for services. Openness in the services sector is a critical component of a comprehensive growth-enhancing trade policy. Yet Lao PDR's commitments under the General Agreement on Trade in Services (GATS) feature relatively low sectoral coverage and shallow obligations. It is important that Lao PDR move ahead with the commitments in the financial and telecommunications sectors and consider options for opening up distribution and retail. Restrictions to foreign firm entry into several tourismrelated activities, such as guesthouses, are still in place and should be removed. In transportation, adding flexibility to licensing procedures would help firms that may want to integrate the activity into their core business.

2. Make regional liberalization commitments compatible with multilateral ones. Regional integration in services could potentially be a platform for wider integration with the global marketplace. It is important that multilateral (with GATS/WTO) and regional commitments (with AFAS) be made compatible. Lao PDR has made greater progress toward liberalization at the regional than at the multilateral level. Some inconsistencies suggest that trade negotiation strategies would be more effective if centralized and there were a strong mechanism for consultation and coordination across line ministries. $\underline{15}$

3. Complement openness with sound regulatory reforms, to help realize the gains. To gain from openness to trade and investment, it is necessary to create an enabling, transparent, and predictable regulatory environment. Lao PDR has ambitiously committed to regulatory reforms in the telecommunications sector. It is crucial that it draft a telecom reference paper that sets out principles and institutional requirements needed for the regulation of the sector, including rules on access and use of telecom infrastructure, the independence of the regulatory body, and anticompetitive behavior.

4. Empower relevant agencies with adequate financial resources and skilled staff. Sound and transparent regulatory frameworks yield little if the capacity of institutions is weak. Limited staff and budgets limit agencies' capacity to respond to regulatory challenges. User-friendly guidelines on the main horizontal laws for officials and the public could help support transparent implementation.

5. Support diversification of the economy by building up the stock of human capital. Skills development is key to upgrading into more sophisticated services and manufacturing production. Lack of skilled workers is a top constraint for firms in Lao PDR. Targeted, long-term policies to strengthen basic education, reform curricula to meet market demand, and align vocational training to private sector needs are crucial. In the short term, facilitating the entry of foreigners with relevant skills could alleviate some constraints.

6. Encourage exports of services through export promotion interventions aligned with international good practices. A more liberal services trade regime implies 
increased opportunities for Lao PDR firms to start exporting. To support them in the process, policy makers should take stock of international good practices. Evidence suggest that export promotion activities focusing on reducing costs associated with information search have a positive effect on export diversification. In contrast, support for participation in trade fairs and trade missions has weak effects on export growth (Cadot and others 2011).

7. Invest in hard and soft infrastructure, particularly in transportation, electricity, water, and Internet connectivity. Development of the road network is important to reduce transportation costs. Energy infrastructure needs to be strengthened-by, for example, increasing the capacity of conductors that transmit electricity over long distances, which would help boost energy exports during high season and allow importing to satisfy domestic demand in low season. It is important to level the playing field between domestic and foreign providers of Internet services, in order to increase competition and improve performance. Eliminating the luxury tax on Internet makes sense.

\section{NOTES}

1. The analysis of services value added dynamics and of services and manufacturing linkages relies on data from Lao PDR's most recent update of its input-output table in the Global Trade Analysis Project (GTAP), which dates from 2002, and more recent data for comparable countries.

2. Eight countries were chosen as comparators for Lao PDR. Regional peers include Cambodia, Thailand, and Vietnam. Bhutan, Botswana, Mongolia, and Nepal were included because they are landlocked countries. Bangladesh was chosen because it is an important exporter of garments.

3. This chapter analyzes linkages between manufacturing and services in the formal sector. The informal economy is likely sizable, but data on it were not available.

4. The first question could not be studied empirically because of data constraints (mainly the lack of substantial variation in restrictions on services trade and direct investment in the services sectors).

5. This section uses the terms performance and totalfactor productivity (TFP) interchangeably. The two terms are not equivalent. TFP is associated with the efficiency with which firms combine inputs to obtain output; it is technical in nature. Improvements in TFP take place when firms produce the same output using fewer inputs. Measures of TFP should capture this technical dimension by looking at physical relationships between inputs and outputs (in the literature, these measures are often referred as TFP-Q). Productivity measures typically rely on relationships between values produced and input bills that are deflated at some sectoral level, depending on the granularity of the deflator data (these measures are often referred to in the literature as $T F P-R$ ). Within a sector, an increase in an input price that is used more intensively by a firm (or a reduction in output prices) will make that firm appear as having lost TFP, even if the quantity of inputs required to produce a given amount of output remains unchanged. The term performance is vaguer than TFP. It is highly associated with TFP but also covers profitability. In this section, the term performance is used as a synonym of TFP when measured in value terms. Ratios of output values to labor costs (labor productivity) are also used as indicators of performance.

6. For exports of metals, for example, transportation accounts for 8 percent of total inputs. It is the third-most important input after metals themselves and distribution-related inputs.

7. The information was gathered from interviews with private telecom providers in Vientiane during fieldwork in 2015.

8. Information on firms' inputs and outputs from World Bank Enterprises Surveys was used to calculate two measures of firm productivity: labor productivity and total factor productivity (TFP). TFP was estimated as a residual of a Cobb-Douglas production function, with real output as a function of capital, labor, and intermediate inputs. 
9. The Enterprise Surveys also contain data for a panel of firms from Lao PDR that were interviewed in 2009 and again in 2012. A panel fixed-effects model was used to assess the impact of services quality on firms' performance. This information is very useful, because it reveals how changes in the perceptions of the quality of services provision are associated with productivity at each firm. The same empirical strategy was used (regressing measures of productivity on measure of the performance of services, controlling for observable firm characteristics and unobservable characteristics that are fixed over time [captured by the firm-level fixed effect], as well as for sector and year fixed effects). Data on firm-level perceptions of each type of service were used instead of regional averages, as in the previous specification. The results show a negative association between firms' perceptions of the quality of services provision and TFP. However, the estimated coefficients for the finance and electricity obstacle variables are not statistically significant. In contrast, perceptions of the quality of transportation services appear to have a significant and negative impact on firm productivity. The results also reveal a statistically significant positive association between access to the Internet and reliance on ICT services and productivity.

10. When the interaction of Lao PDR and exporter is added to the models, the estimated coefficient for the term is significant and negative.

11. These estimated relationships are not robust to alternative measures of productivity. In Lao PDR, higher reliance on internal funds for investment is associated with higher levels of labor productivity.

12. For EAP and the whole sample, bank financing for both working capital and fixed assets investments is associated with higher productivity (the estimated coefficients are positive and significant). In Lao PDR, only bank financing for working capital has a statistically significant (positive) effect on TFP.

13. The more negative the perceptions of the quality of electricity services, the more likely a firm in Lao PDR (and EAP) is to get its own generator.

14. These results do not imply that Internet connectivity causes productivity to be 110 percent higher. Although Internet connectivity is likely to have a positive impact on productivity, it is also the case that more sophisticated firms, which may also happen to be more productive, use the Internet more intensively.

15. For example, approval is required regionally but not at the multilateral level; minimum foreign ownership requirements exist at the regional but not the multilateral level.

\section{REFERENCES}

APEC (Asia-Pacific Economic Cooperation). 1998. The Impact of Liberalisation: Telecommunications Industry in the Philippines. Singapore: APEC Secretariat.

Arnold, J., B. Javorcik, M. Lipscomb, and A. Mattoo. 2010. "Services Reform and Manufacturing Performance: Evidence from India.” CEPR Discussion Paper, 8011, Centre for Economic Policy Research, London.

Arnold, J., B. Javorcik, and A. Mattoo. 2011. "Does Services Liberalization Benefit Manufacturing Firms? Evidence from the Czech Republic.” Journal of International Economics 85 (1): $136-46$.

Arnold, J., A. Mattoo, and G. Narciso. 2008. "Services Inputs and Firm Productivity in SubSaharan Africa: Evidence from Firm-Level Data." Journal of A frican Economies 17 (4): 578-99.

Balandin, S., and S. Laizane. 2013. “e-Tourism: The Role of ICT in Tourism Industry.” Proceedings of the 13th Conference of the Fruct Association, 184-85.

Bas, M. 2013. "Does Services Liberalization Affect Manufacturing Firms' Export Performance? Evidence from India.” CEPII Working Paper, Centre d'Études Prospectives et d'Informations Internationales, Paris.

Betarte, C., H. Cancela, and J. Moleri. 2008. "Informe Final de la consultoría sobre tecnologías de la información y comunicación en el marco del plan estratégico nacional en ciencia, tecnología e innovación.” Mimeo, Montevideo, Uruguay.

Cadot, O., A. M. Fernandes, J. Gourdon, and A. Mattoo. 2011. Where to Spend the Next Million? Applying impact evaluation to trade assistance. Washington, DC: World Bank. 
Duggan, V., S. Rahardja, and G. Varela. 2013. "Service Sector Reform and Manufacturing Productivity: Evidence from Indonesia.” Policy Research Working Paper 6349, World Bank, Washington, DC.

Eschenbach, F., and B. Hoekman. 2006. "Services Policy Reform and Economic Growth in Transition Economies." Review of World Economics/Weltwirtschaftliches Archiv 142 (4): 746-64.

Fernandes, A., and C. Paunov. 2012. "Foreign Direct Investment in Services and Manufacturing Productivity: Evidence for Chile.” Journal of Development Economics 97 (2): 305-21.

Fink, C., A. Mattoo, and I. C. Neagu. 2005. "Assessing the Impact of Communication Costs on International Trade.” Journal of International Economics 67 (2): 428-45.

Fink, C., A. Mattoo, and R. Rathindran. 2003. "An Assessment of Telecommunications Reform in Developing Countries." Information Economics and Policy 15 (4): 443-66.

Francois, J., M. Manchin, and A. Pelkmans Balaoing. 2009. "Regional Integration in Asia: The Role of Infrastructure." In Pan-Asian Integration: Linking East and South Asia, edited by J. Rancois, P. B. Rana, and G. Wignaraja, 439-86. London: Palgrave Macmillan.

Gill, I., I. Izvorski, W. van Eeghen, and D. De Rosa. 2014. Diversified Development: Making the Most of Natural Resources in Eurasia. Washington, DC: World Bank.

Hodge, J. 1998. "Developing a Trade and Industry Policy Agenda for Service Sectors in South Africa.” Working Paper, Trade and Industrial Policy Strategies, Pretoria.

ITU (International Telecommunication Union). 2012. Measuring the Information Society Report 2012. Geneva: ITU.

—. 2013. Measuring the Information Society Report 2013. Geneva: ITU.

Kesidou, E., and H. Romijn. 2008. "Do Local Knowledge Spillovers Matter for Development? An Empirical Study of Uruguay's Software Cluster.” World Development 36 (10): 2004-28.

Mattoo, A., R. Rathindran, and A. Subramanian. 2006. "Measuring Services Trade Liberalization and Its Impact on Economic Growth: An Illustration.” Journal of Economic Integration 21 (1): 64-98.

OECD (Organisation for Economic Co-operation and Development). 2013. "Structural Policy Country Notes: Lao PDR." Country note in "Economic Outlook for Southeast Asia, China and India 2014: Beyond the Middle-Income Trap. Paris: OECD Publishing.

Snoeck, M., and L. Pittaluga. 2012. "Software Discovery in Uruguay. Public-Private Solutions to Coordination Failures.” In Export Pioneers in Latin America, edited by C. Sabel, E. FernándezArias, R. Hausmann, A. Rodriguez-Clare, and E. Stein, 239-270. Washington, DC: InterAmerican Development Bank.

UNCTADstat (database). UNCTAD (United Nations Conference on Trade and Development), Geneva, https://unctadstat.unctad.org.

Wellenius, B. 2002. "Closing the Gap in Access to Rural Communications Chile: 1995-2002." Discussion Paper 430, World Bank, Washington, DC.

World Bank. 2014. Lao PDR: Trade and Transport Facilitation Assessment. Washington, DC: World Bank.

World Bank Enterprise Survey for Lao PDR. 2012. Washington, DC, https://datacatalog .worldbank.org/dataset/lao-pdr-enterprise-survey-2012.

World Bank Enterprise Surveys (database), Washington, DC, http://www.enterprisesurveys.org.

World Bank Export of Value Added Database, Washington, DC, https://datacatalog.worldbank .org/dataset/export-value-added-database. 



\section{The Services Trade Policy and Regulatory Framework in Myanmar*}

MARTÍN MOLINUEVO, SJAMSU RAHARDJA, AND SEBASTIÁN SÁEZ

Trade and investment in the services sector are central elements of Myanmar's growing economy. They drive the economy in two ways.

First, services are a key input for other export activities, such as minerals, textiles, and agriculture. Services trade can help overcome supply-side constraints such as limited access to finance, lengthy and costly transport, and poor telecommunications infrastructure.

Second, services exports can provide an opportunity for diversification. Empirical analysis shows that although services as inputs into other economic activities will remain the main determinant of economic performance in developing countries, these countries can potentially join the club of services exporters and benefit from opening of the services market, if adequate and comprehensive regulatory reform is adopted (Mattoo and Payton 2007). Indeed, the trade strategies of some developing countries, such as Cambodia, include a pillar on the export of services, especially tourism (World Bank 2014).

An open trade and investment regime, supported by a transparent and effective regulatory framework, is key to developing the services sector. Trade in services is governed mainly by domestic regulation that limits foreign participation in the domestic market or aims to correct market failures (such as imperfect and asymmetric information, lack of competition, and natural barriers to entry).

In less than decade, Myanmar has taken steps to engage in the global economy and promote private initiative in the domestic market. In the services sector, it has relaxed or removed important hurdles to private and foreign ownership of services firms.

This chapter seeks to increase the understanding of trade in services in Myanmar in order to promote transparency and efficiency in the regulation of services trade. It reviews the legal and regulatory framework governing trade and investment in services, which may act as a constraint to the expansion of services. It focuses on telecommunications, business services, distribution, and tourism, because of their value as inputs in the production of goods and other services or their export potential.

* The editors are grateful to Ellen Goldstein, Ricardo Habalian and the Myanmar CMU for authorization to publish. 
The chapter is organized as follows. The first section describes the main policies, laws, and regulations on services and the general institutional setting and rule-making capacity for services trade policy, including trade negotiations. The second section looks at how these laws, regulations, and institutions apply to specific services. The third section summarizes the chapter's main findings and offers recommendations for policies to promote the expansion and heighten the competitiveness of the services sector.

\section{THE POLICY AND REGULATORY FRAMEWORK FOR SERVICES TRADE AND INVESTMENT}

In less than a decade, Myanmar has taken important steps to engage in the global economy and promote private initiative in the domestic market. As in other transition economies, reform seeks to shift the driving force of the economy from the state to the private sector. Policy and regulatory reformulation in the services subsectors has removed hurdles to private and foreign ownership of services firms. This section examines Myanmar's services regulatory regime on the basis of information in the World Bank Services Trade Restrictions Database (Borchert, Gootiiz, and Mattoo 2012).

Myanmar has a relatively open services trade regime, as indicated by its Services Trade Restrictiveness Index (STRI), which captures the impact of domestic regulations (services trade policies) on imports of services and services providers (figure 2.1). Telecommunications services, for example, are formally open to foreign providers. ${ }^{1}$

Myanmar does not allow cross-border transactions of deposits or loans or automobile, life, or reinsurance services. Foreign firms can enter the air

FIGURE 2.1

Services Trade Restrictiveness Index (STRI) in Association of Southeast Asian Nations (ASEAN) member states, by subsector, 2012

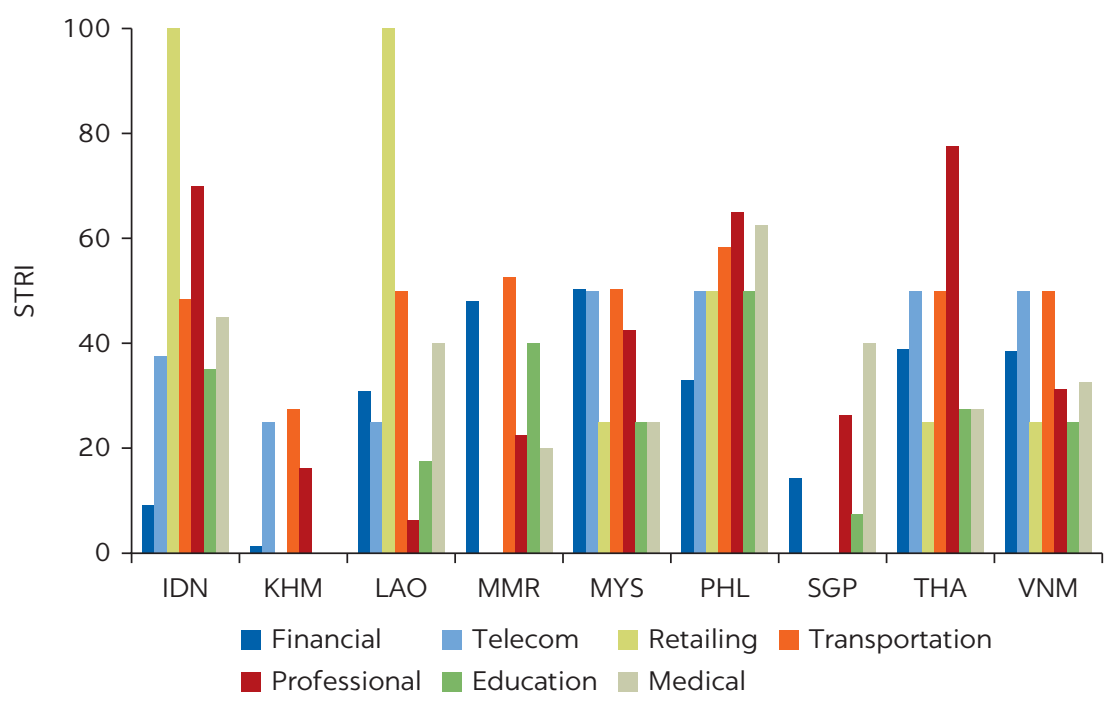

Source: Gootiiz and Mattoo 2015.

Note: STRI = Services Trade Restrictiveness Index. The STRI at the regional level is calculated as the simple average of individual countries' STRIs. The cross-border air passenger transport subsector is excluded. IDN = Indonesia; $\mathrm{KHM}=$ Cambodia; $\mathrm{LAO}=$ Lao PDR; MMR = Myanmar; MYS = Malaysia; PHL = Philippines; SGP = Singapore; $\mathrm{THA}=$ Thailand; $\mathrm{VNM}=$ Vietnam. 
transport services market only by establishing a joint venture; their equity participation is limited to 49 percent. Foreign participation is allowed in other transport services, except rail transport. There are no restrictions on maritime transport services or maritime auxiliary services, except a ban on the acquisition of an existing entity. Foreign natural persons are not permitted to provide auditing or legal services, but foreign entry in legal services is allowed through branching, the formation of a separate legal entity, or joint ventures. In accountancy, architecture, and engineering, entry through branching or full partnership is not allowed.

\section{POLICY-MAKING FRAMEWORK AND INSTITUTIONS}

Trade in services remains a new area for policy making for Myanmar institutions. As a member of the World Trade Organization (WTO) and ASEAN, Myanmar is involved in various trade negotiations that include trade and investment in the services sector. No specific agency leads the formulation of a comprehensive policy on trade in services, however. Myanmar lacks a clear strategy on trade in services, and negotiations are carried out in an ad hoc manner.

Policy formulation requires a skilled coordinator and efficient procedures for sharing information. Given the breadth of the services sector, and the highly technical regulatory skills it requires, the role of a policy maker is that of a coordinator. For trade policy to be effective, information should flow back and forth between the trade ministry and the specialized regulatory agency. Relevant regulatory agencies typically include the regulator of telecommunications services, the central bank, professional bars and associations, and relevant sectoral ministries. The ministries responsible for sectoral policies and regulatory agencies should first provide the trade ministry with a clear picture of the regulatory status quo in their sector, including laws and regulations, policy goals, and the regulatory plan. The trade ministry should then articulate a services policy, including guidelines on potential international obligations, as part of a broader national trade policy, in close consultation with the relevant authorities. The policy can be enacted through adoption of necessary changes in the regulation under the orbit of each relevant body. The trade ministry and other relevant ministries should have access to proposed new regulations at conception and at the draft stage, so that they can assess the impact on trade and compliance with international trade agreements (box 2.1).

Multiple government agencies in Myanmar share overlapping mandates on trade in services, often in a conflicting and inefficient manner. Coordinating roles between different agencies have shifted in recent years, but they remain unclear and inefficient. Figure 2.2 shows the roles and expertise of the main ministries involved in trade policy formulation with current or past broad mandates in services trade coordination. In addition to sector-specific regulatory bodies, at least four institutions are relevant to trade policy formulation in Myanmar:

- The Ministry of Commerce: The Ministry of Commerce is formally mandated with coordinating multilateral negotiations in trade in services. Although it has been the leading agency on negotiations in trade in goods, it has not been actively involved in services trade discussions. In fact, despite its substantial mandate on the issue, it has no staff devoted to services trade. 
BOX 2.1

\section{Policy-making benefits of effective intragovernmental coordination}

Given the regulatory intensity of many services activities and the range of sectors involved, coordination across various government agencies is critical. Promoting an effective process of intragovernmental coordination is likely to generate a number of positive policy-making externalities, including the following:

- Crafting unified government positions. Coordination is essential to developing negotiating positions based on complete assessment of key national priorities and ensuring that negotiators are informed of the full range of factors affecting the domestic services market.

- Generating information based on measures affecting trade in services. Policy makers need accurate information on the domestic regulatory environment affecting trade in services. Trading partners need this information during trade negotiations. Creating and updating a central inventory or focal point (such as a database) of regulatory measures can help meet such transparency obligations.

- Identifying and analyzing the effects of measures on achieving economic or social policy objectives.
Governments at all levels need to periodically review the effectiveness of domestic policies and regulations in achieving economic and social policy objectives. Doing so may involve analyzing the trade or investment effects of regulatory measures.

- Avoiding duplicating consultations with other agencies and domestic stakeholders. Given the multitude of subsectors and measures arising from services trade, officials must achieve a balance between engaging intragovernmental partners on issues of mutual concern and avoiding inundating key departments and agencies with too much information or too many requests for input. Good regular lines of communication between individuals can assist in quickly addressing issues without creating unnecessary processes.

- Contributing to an ongoing assessment of the impact of liberalizing services trade. In most countries, the national statistical agency is responsible for data used for impact analysis. Collecting such data is challenging. Recourse to anecdotal information can be useful.

- The Ministry of Communication and Transport (MoCT): Designated as the focal point for ASEAN services negotiations in 2012, MoCT is the main agency involved in services policy. It coordinates AFAS rounds as well as ASEAN+ negotiations, seeking guidance from other line ministries and agencies in specific sectoral discussions (except on transport). Being the AFAS focal point role means that MoCT monitors implementation services commitments in all services sector covered by AFAS, including those related to the ASEAN Economic Community (AEC). Coordination of actions on trade in services remains a secondary role that has to be balanced with the ministry's transport policy making and regulatory functions. The MoCT has limited capacity and understanding of trade policy beyond its sectoral expertise and has no team dedicated to such matters.

- The Ministry of Planning and Finance (MoPF): Assigned as the AFAS focal point before the appointment of the Ministry of Transport. MoPF represents Myanmar at ASEAN Economic Ministers (AEM) Meetings, which oversee, among other areas, negotiations on services trade. MoPF is responsible for implementing the AEC goals. However, direct involvement in trade in services negotiations as well as monitoring of the implementation of services commitments is under MoCT. Despite its lack of direct engagement with 


\section{Government institutions relevant to the formulation of services trade policy in Myanmar}
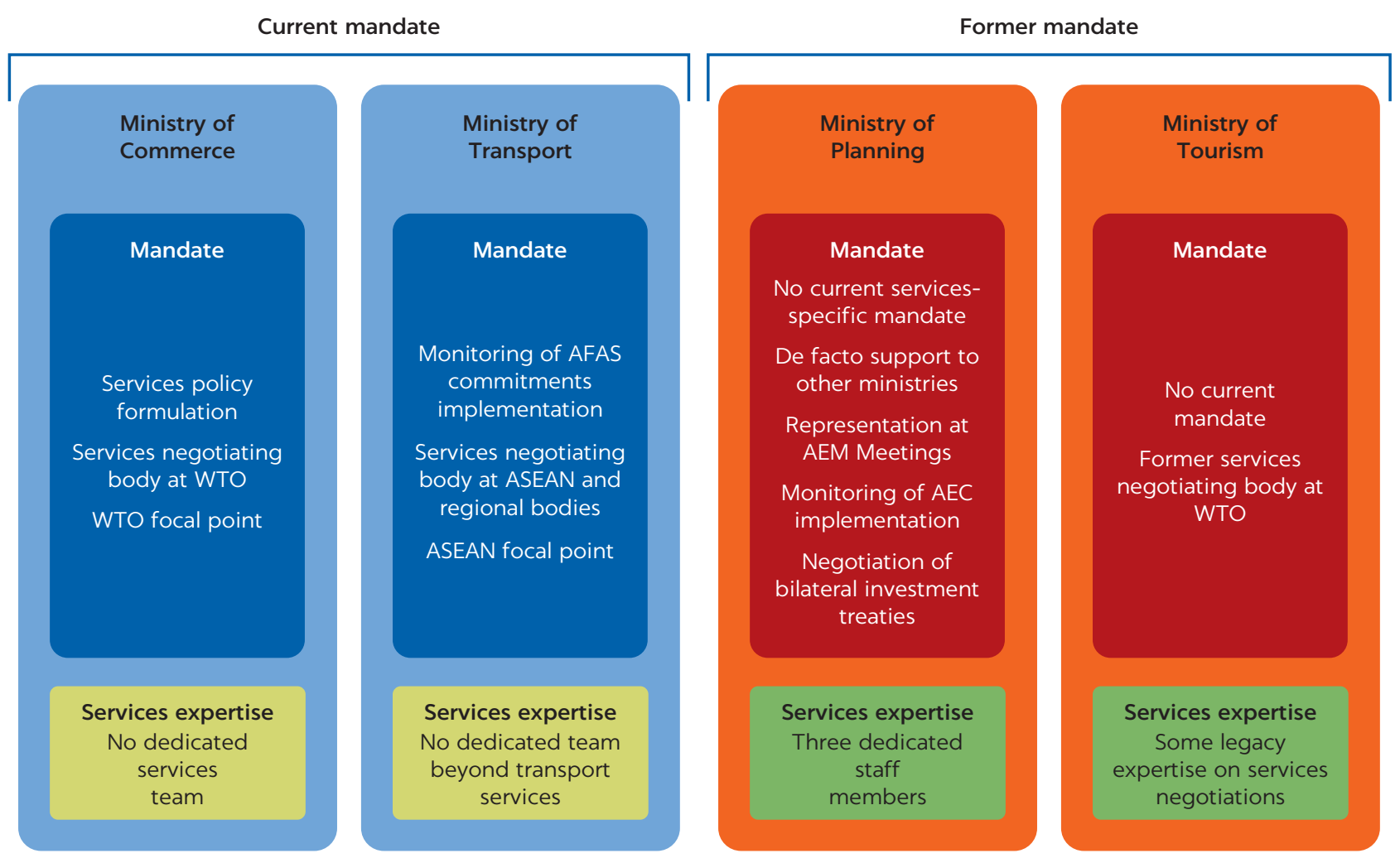

Note: AEC = ASEAN Economic Community; AEM = ASEAN Economic Ministers; AFAS = ASEAN Framework Agreement on Services; ASEAN = Association of Southeast Asian Nations; WTO = World Trade Organization.

trade in services negotiations, MoPF is the only agency with specific expertise and staff specific devoted to services negotiations, a legacy of its broader role until 2012. These staff support other ministries in conducting services negotiations. $^{2}$

- The Ministry of Hotel and Tourism (MoHT): The initial de facto services trade coordinator and negotiator before the WTO because of the strong focus of Myanmar's General Agreement on Trade in Services (GATS) commitments in the services sector, the MoHT currently holds no formal role beyond its sectoral scope. A limited understanding of services trade negotiations and policy remains within the ministry, as a legacy of its broader role.

This institutional framework creates challenges with regard to policy making. The lack of one agency clearly responsible for coordinating trade in services leads to overlapping coordination responsibilities and the inefficient use of resources. It also means that no agency is capable of aggregating interests, demands, and regulatory concerns from different services subsectors and formulating a comprehensive policy. Giving broad coordination roles to a sectoral ministry creates conflicting interests, as the agency must support policy and regulatory positions from its own services subsector while impartially negotiating commitments on a wide range of subsectors based on broader economic and trade policy goals. 


\section{HORIZONTAL POLICIES ON SERVICES TRADE AND INVESTMENT}

Myanmar's policies for services trade are increasingly open and nondiscriminatory to foreign participation. Important restrictions still remain in the governance and administrative framework, however, as well as in laws and regulations. Administrative and regulatory barriers raise the cost of operation of services firms in Myanmar, limiting the benefits of market opening.

The regulatory framework for services includes not only laws and regulations governing a particular subsector but also measures that affect a wide range of subsectors (known as horizontal measures). Regulations on buying and selling foreign currency, laws on entry and stay of foreigners, and procedures related to the establishment of firms, for example, affect many subsectors, including tourism. Examples of horizontal measures that imply restrict services supply include the following:

- Cross-border trade: Measures on transfer of funds, restrictions on access to foreign currency

- Consumption abroad: Restrictions on access to foreign currency

- Commercial presence: Limitations on land ownership, restrictions on establishment of juridical persons, and domestic employment requirements for foreign companies

- Presence of individual services suppliers: Visa requirements for foreigners, limitations on periods of stay.

Regulatory quality, the rule of law, and governance play key roles in defining the business environment. Myanmar's broader policies for private investment have greatly improved in recent years, but the broader regulatory framework and business environment have seen little progress. Regulatory quality-understood as the ability of the government to formulate and implement sound policies and regulations that permit and promote private sector development-saw some improvement between 2005 and 2010, with the adoption of policies on the business environment, but it remained stagnant between 2010 and 2012 (figure 2.3). Perceptions of the rule of law, related to adherence to rules on contract enforcement, property rights, the police, and the courts, as well as the likelihood of crime and violence, declined between 2003 and 2012. Perceptions of the quality of public services, the civil service, and its degree of its independence from political pressure in policy formulation, as captured by government effectiveness measures, remained weak stagnant. These findings lie in contrast to the progress achieved in other areas, such as liberalization of investment and the simplification of business procedures.

The main restrictions to trade and investment in services stem from administrative practices that result in unclear and unpredictable business regulations. As in other developing countries that have removed formal restrictions to services trade, the governance framework in Myanmar acts as a de facto barrier to trade and investment in services, increases risks for existing companies, and limits their competitiveness, reducing interest in investing and the quality of services. Furthermore, some sectors, such as telecommunications, professional services, and distribution, suffer from the lack of an adequate regulatory framework, which fosters an informal sector with low-quality services, especially in retail. 
FIGURE 2.3

Perceptions of the rule of law, regulatory quality, and government effectiveness in selected countries in East Asia, 2003-12

a. Rule of law

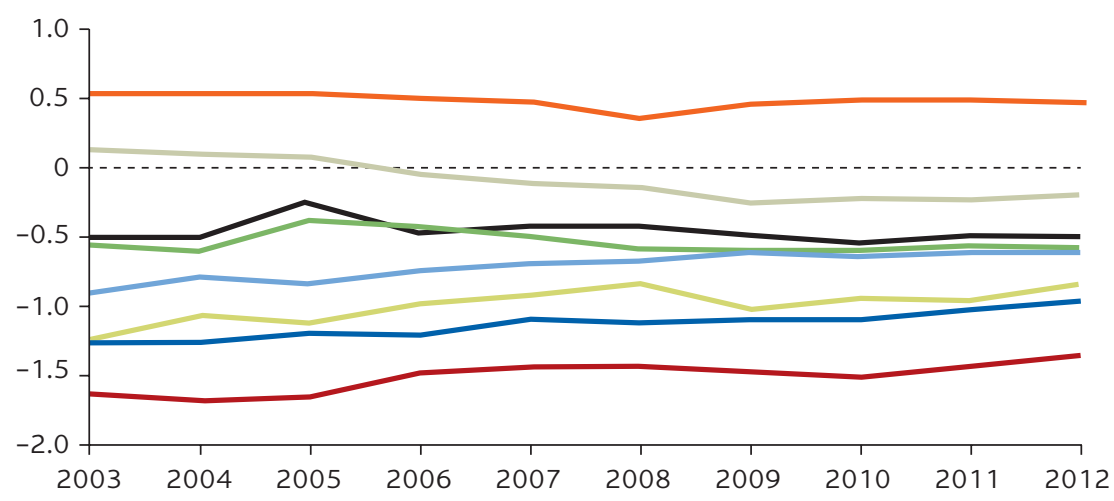

b. Regulatory quality

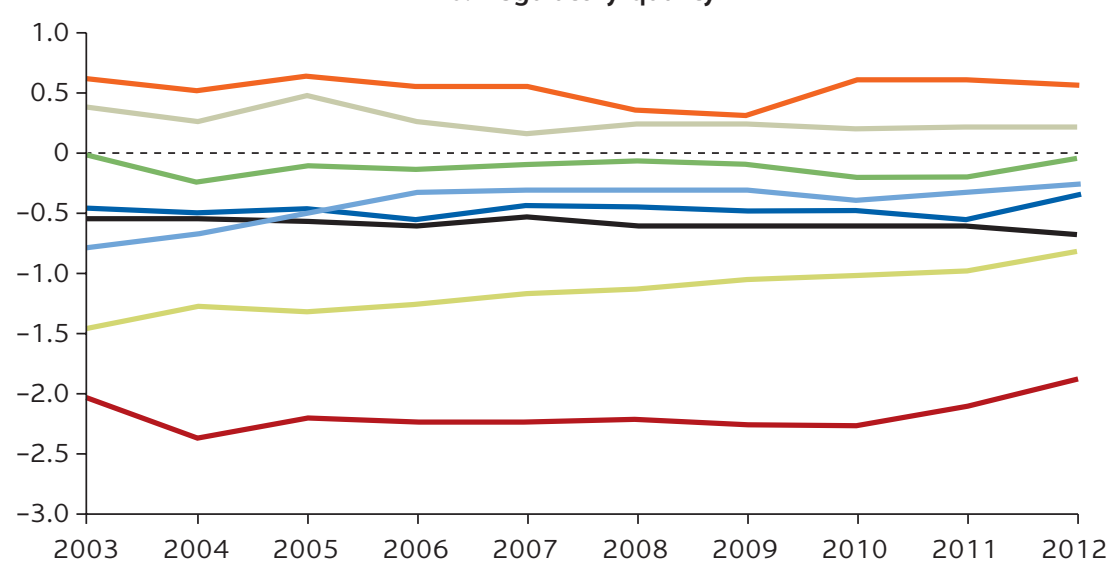

c. Government effectiveness

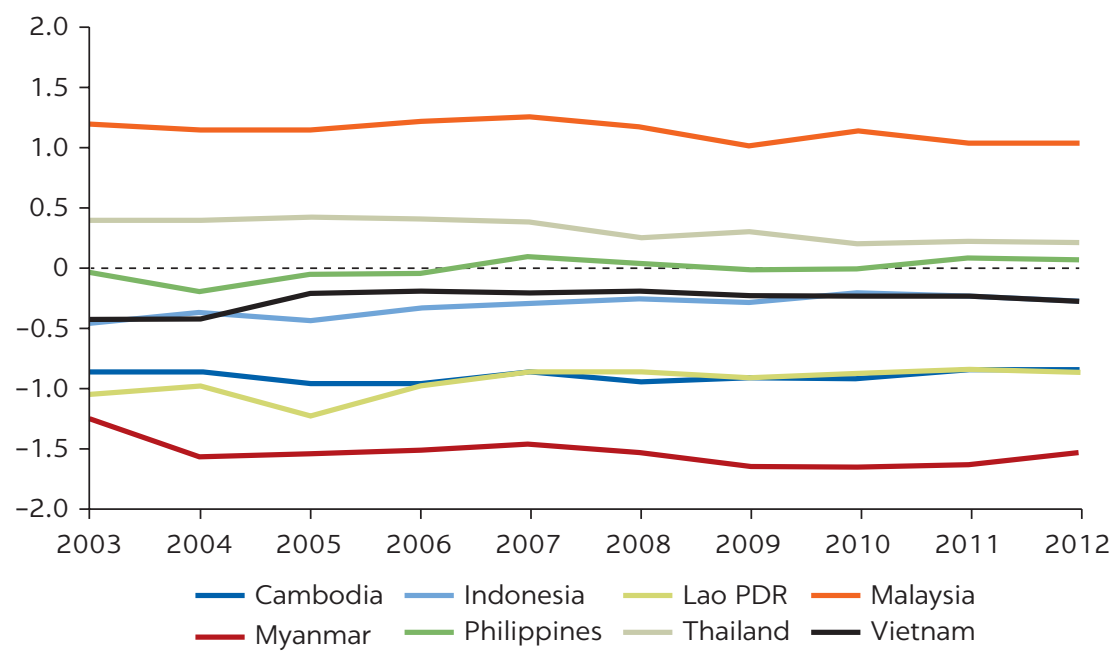

Source: World Bank Worldwide Governance Indicators. 


\section{Cross-border services}

Regulation in Myanmar does not limit the provision of cross-border services or the ability of consumers to acquire services abroad. Regulating modes of supply in which the provider is located outside the country's jurisdiction is technically challenging. In fact, no modern economy maintains across-the-board restrictions on cross-border trader. A typical restriction on this mode of supply is a requirement that the provider has representation in the country (local presence requirements), but this requirement is usually limited to specific services.

\section{Cross-border payments and transfer of funds}

The regime for international transfer of funds can restrict the ability to acquire services abroad. Restrictions on the transfer of funds can be used to prevent capital flight, support exchange rate controls, and disincentivize the purchase of goods and services abroad.

Myanmar's framework for the international transfer of funds severely limits access to cross-border services and weakens the climate for investment. Under the Foreign Investment Law, foreign investors have the right to remit foreign currency. In practice, however, transferring money in or out of Myanmar is challenging. Many international banks have been slow to update their internal prohibitions on conducting business in Myanmar following the end of U.S. and European sanctions in 2012 (U.S. Commercial Service 2014).

The transfer of funds by locally established businesses is subject to authorization by the central bank, which in turn depends on the type of license the business has received. Large foreign investments with licenses approved by the Myanmar Investment Commission (MIC) obtain broad permission for international transfers; investments registered with the Directorate of Investment and Company Administration (DICA)-typically domestic and smaller foreign investments-require individual approval for each transfer from MIC.

As a result of these limitations, as well as the past impositions of sanctions, a number of Myanmar firms still conduct foreign currency transactions through bank accounts registered in Singapore.

\section{Commercial presence}

Myanmar has taken major steps to increase private investment, including by foreign services providers, since 2011. One of the main instruments was the introduction of the new Foreign Investment Law in 2012, which opened a number of subsectors to foreign participation and provided important guarantees to foreign investors. As a result of this process, the conditions for establishment of foreign services suppliers have greatly improved. Nevertheless, laws, regulations, and, particularly, governance practices continue to restrict foreign providers, including in key services subsectors.

\section{Foreign investment laws}

The Foreign Investment Law of 2012 removed barriers to foreign capital and signaled a new economic model. To attract foreign investment, the law relaxed restrictions to foreign investment in terms of sectors and equity participation, facilitated land lease by foreign-invested forms, and widened tax and other investment incentives. 
Under the Foreign Investment Law, a foreign investment may be carried out in any of the following forms:

- investment by a foreigner with 100 percent foreign capital on the business, approved by the MIC

- a joint venture between a foreigner and a citizen or the relevant government department and organization

- any contractual arrangement that is approved by both parties.

The Foreign Investment Law and its implementing legislation identify subsectors that remain limited to domestic investment as well as subsectors in which foreign participation is permissible only in the form of joint ventures. Services subsectors reserved to Myanmar citizens include the following:

- private specialist traditional hospitals

- distribution of raw ingredients for traditional medicines

- ambulance services

- construction of health care centers for elderly people

- railway car restaurants, contracted freight-forwarding activities, railcar cleaning services, and railcar management services

- agency services

- generation of electricity under 10 megawatt

- publishing and publication of periodicals in ethnic languages, including Myanmar.

In other activities, the MIC or other line ministries consider foreign investment proposals on a case-by-case basis. Notification No. 49/2014, dated August 14, 2014, offers guidance, including details on subsectors in which foreign participation is prohibited and subsectors are subject to joint venture requirements. It lists activities in which no foreign participation is allowed, including printing and broadcasting, navigation services, and air control management. Other activities are subject to joint venture with Myanmar citizens, based on recommendation by the relevant sectoral ministry. These activities include the following:

- distribution of some food products

- packaging

- air transport services, maritime transport, and freight-forwarding services

- building and repairing of new ships at dockyard

- inland port services through container terminal and warehouse services

- private special hospitals/private special indigenous hospitals

- tourism services.

For investment in any of these areas, permission from the MIC may be granted, with the approval of the government. However, foreign equity must not exceed 80 percent. For large foreign investment projects that bring substantial benefit to public security, improve surrounding areas, or improve the living conditions of citizens, MIC will submit the application to the Union Parliament through the government for approval (WTO Secretariat 2014).

In October 2016, Myanmar passed the 2016 Investment Law, which brings together the 2012 Foreign Investment Law and the 2013 Citizens Investment Law. In addition to providing equal treatment for domestic and foreign investors, it is expected to streamline the role of MIC in approving new investment proposals. The World Bank Group provided technical support to DICA on developing implementing rules and mechanisms for the 2016 law. 


\section{State-owned enterprises}

The government of Myanmar is directly involved in several key services subsectors through state-owned enterprises. The State-Owned Economic Enterprise Law of 1989 sets out the general framework for state-owned enterprises. It lists areas that are de jure reserved to the state (banking, postal services, telecommunications, air and railway transport, and broadcasting and television services) and therefore excluded from foreign or domestic investment. Table 2.1 lists the main state-owned enterprise activities in the services sector and the relevant regulators.

\section{Administrative practices}

The actual regime for investment differs from the framework established in the legal instruments. In many cases, practices are more liberal than the legal regime, as some ministries and government bodies attempt to advance the market opening policy, even where older laws still apply. In other cases, administrative

TABLE 2.1 State-owned enterprises in Myanmar's services sector

\begin{tabular}{|c|c|}
\hline SUBSECTOR/ENTERPRISE & MINISTRY \\
\hline \multicolumn{2}{|l|}{ Media and publishing } \\
\hline Printing and publishing & Ministry of Information \\
\hline News and periodicals & Ministry of Information \\
\hline \multicolumn{2}{|l|}{ Financial institutions } \\
\hline Myanma Economic Bank & Ministry of Planning and Finance \\
\hline Myanmar Investment and Commercial Bank & Ministry of Planning and Finance \\
\hline Myanma Foreign Trade Bank & Ministry of Planning and Finance \\
\hline Myanmar insurance enterprise & Ministry of Planning and Finance \\
\hline Myanmar small loan enterprise & Ministry of Planning and Finance \\
\hline \multicolumn{2}{|l|}{ Construction services } \\
\hline $\begin{array}{l}\text { Department of Human Settlement and Housing } \\
\text { Development }\end{array}$ & Ministry of Construction \\
\hline \multicolumn{2}{|l|}{ Agriculture } \\
\hline Livestock, feedstuff, and dairy products enterprise & $\begin{array}{l}\text { Ministry of Agriculture, Livestock, } \\
\text { Fisheries and Rural Development }\end{array}$ \\
\hline \multicolumn{2}{|l|}{ Tourism sector } \\
\hline Hotels and tourism & Ministry of Hotels and Tourism \\
\hline \multicolumn{2}{|l|}{ Transport and communications } \\
\hline Posts and Telecommunications Department & $\begin{array}{l}\text { Ministry of Communications and } \\
\text { Transport }\end{array}$ \\
\hline Railways & $\begin{array}{l}\text { Ministry of Communication and } \\
\text { Transportation }\end{array}$ \\
\hline Road transport & $\begin{array}{l}\text { Ministry of Communication and } \\
\text { Transportation }\end{array}$ \\
\hline \multicolumn{2}{|l|}{ Other } \\
\hline Cooperative exports and imports & Ministry of Cooperatives \\
\hline Petroleum products & Ministry of Energy \\
\hline
\end{tabular}


practices embody restrictive policies that are well established but whose legal source remains unclear.

Notwithstanding the terms of the State-Owned Enterprise Law, the government has been taking steps to increase private sector participation in key sectors such as banking and telecommunications. These exceptional authorizations have taken the form of ad hoc licenses.

The distribution sector remains reserved to domestic firms, despite the fact that it is not listed as such in the Foreign Investment Law or other legal instruments. ${ }^{3}$ To a large extent, this regulatory gap is the result of the intense reform process undertaken by the authorities and the capacity constraints of the administration. It may be a necessary part of the policy experimentation needed in broad regulatory reform. However, a number of administrative practices, such as the ban on foreign firms in the distribution sector, directly oppose the market opening policy. The lack of consistency between the legal regime and administrative practices adds opaqueness and uncertainty to the system that weakens the market opening policy, diminishes its potential benefits, and raises entry costs.

Myanmar's general regulatory investment framework is complex and unpredictable. The numerous laws regulating the entry of investors create confusion, which affects not only applicant investors but also government officials. Foreign investors sometimes require overlapping approvals and must meet detailed and often opaque criteria for individual projects (OECD 2014). The increase in foreign investment proposals has overburdened the government, creating bottlenecks in their approval (U.S. Commercial Service 2014).

\section{Presence of individual providers}

The temporary presence of individual services providers is not restricted in Myanmar, strict visa requirements impose a burden. The government is taking steps to relax visa requirements, including by issuing on-arrival visas at major entry points. Foreign services providers can obtain business visas for up to 70 consecutive days with an invitation letter. The establishment of an e-visa service, originally intended to facilitate tourism, has been beneficial to business visitors.

A number of limitations apply to the services provided by foreign experts and the movement of intracorporate transferees. As a rule of thumb, foreign firms registered with the MIC are allowed to hire foreign experts and technicians. However, preference should be given to Myanmar citizens. (MIC 2014), and employment for jobs that do not require a particular skill is reserved to Myanmar citizens (PWC 2014). Many countries, including OECD members, maintain these types of policies, to promote domestic employment. It is important that the regimes be administered efficiently and not impose additional unnecessary burdens.

The official registration procedures for foreign services providers wishing to be employed for longer than 70 days face is cumbersome. The following procedures have to be completed (PWC 2014):

- The investor has to indicate the number of foreign experts/technicians to be employed.

- After obtaining the MIC permit, a company has to apply for an appointment and work permit. 
- With the endorsement of MIC, a company has to apply to the Directorate of Labour (in the Ministry of Labour) for a work permit and to the Immigration and National Registration Department (in the Ministry of Immigration and Population) for a stay permit and visa.

Services companies not registered with MIC face greater difficulties. They need to obtain endorsement of the relevant ministry for their activity. There are no standard rules and requirements for agencies to provide that endorsement. Foreigners employed or providing services for longer periods generally skip the registration procedures altogether and simply operate under 70-day business visas.

These employments requirements, and their practical work-arounds, impose costs on business. They are particularly onerous for domestic and small and medium-size foreign firms that are not registered with MIC, which do not receive the benefits of advocacy by a major government agency.

\section{SUBSECTORAL POLICIES AND PRACTICES}

Myanmar's next challenge is to consolidate the market opening efforts made so far and complement that liberalization effort with adequate subsector-specific regulatory and institutional frameworks that foster transparency, protect consumers, and ensure competition. Priority subsectors include telecommunications; banking and insurance; retail and distribution services; and professional services, including accounting, auditing, and legal services.

In some key subsectors, the government is already taking steps to improve institutional and regulatory conditions. With support from development partners, including the World Bank, it is implementing programs to enhance capacity and improve prudential regulations for banking services and setting up an independent regulatory for telecommunication services. It has yet to make similar progress in other important subsectors.

\section{Financial services}

Myanmar's financial sector is underdeveloped and faces restrictions on foreign participation. Basic banking indicators are weak, even compared with other low-income countries. However, the financial sector is undergoing intense transformation, as the government has identified banking services as a priority and is taking measures to improve regulatory capacity and increase the presence of foreign banks.

\section{Banking}

The Central Bank of Myanmar (CBM) is the main monitoring and regulatory body for banking services. The Central Bank of Myanmar Law enacted in July 2013 separated the CBM from the Ministry of Finance, with a view to making it an independent central bank. The main legislation regulating the sector includes the Financial Institutions Law 1990, the Foreign Exchange Management Law 2012, and the Central Bank of Myanmar Law 2013. With support from the International Monetary Fund (IMF) and the World Bank, Myanmar drafted new prudential regulations and modernized the Banking and Financial Institutions Law. The CBM's supervisory capacity is also gradually being upgraded, with support from the IMF (2014) and the World Bank (2016). 
The CBM supervises 4 state-owned banks, 23 private banks, 8 branches of foreign banks, and 10 nonbank financial institutions (such as leasing companies). The Ministry of Finance supervises microfinance institutions.

Myanmar's four state-owned banks are the Myanma Economic Bank (MEB), the Myanma Foreign Trade Bank (MFTB), the Myanmar Investment and Commercial Bank, and the Myanmar Agricultural Development Bank. The MEB, the largest bank in Myanmar, provides domestic and international banking services. The MFTB specializes in international banking. The Myanmar Investment and Commercial Bank provides banking services to private companies, including foreign joint ventures.

The CBM intends to develop the banking sector in three phases: first allowing domestic private banks to operate joint ventures with foreign banks, then allowing foreign banks to establish wholly owned locally incorporated subsidiaries, and eventually allowing foreign banks to open branches in Myanmar. Following CBM's plans for the development of the financial sector, foreign banks are currently allowed to offer services to domestic banks and foreign-invested firms.

\section{Insurance}

The Insurance Business Supervisory Board (IBSB), in the MoPF, regulates the insurance market. It was established in 1996 and underwent a major reform in 2011. It is responsible for registering new insurance providers, products, and activities. Insurers may provide life, fire, comprehensive motor, cash-in-safe, fidelity, and other insurance permitted by the Ministry of Finance.

Although foreign direct investment (FDI) in insurance is not prohibited, there have been no foreign providers of insurance services in Myanmar (WTO Secretariat 2014). Section 29 of the Insurance Business Law and Section 14-C of the Insurance Business Rules allows the entry of foreign insurance intermediaries, underwriting agencies, and insurance brokers. Although the establishment of insurance brokers is not prohibited, the IBSB has not yet decided to permit their establishment. The authorities expressed their intention to permit insurance brokers in the near future.

Under the Insurance Law, an insurer may establish itself either as a limited liability company or a wholly state-owned company. Currently, three life insurance companies are allowed to underwrite life insurance, and nine composite insurance companies are allowed to underwrite both life and nonlife insurance (WTO Secretariat 2014). A number of representative offices of foreign insurance services providers have been established in Myanmar. They offer their policies through domestic firms.

\section{Telecommunications services}

Like financial services, the market for telecommunications services in Myanmar is at a nascent stage of development. The existence of competitive telecommunication markets, especially for broadband services, and the skills of employees are among the main determinants of exports (Sudan and others 2010). Adequate telecommunications infrastructure is central to competitiveness. Recognizing this priority, the government is modernizing reducing barriers to foreign investment and improving the institutional and regulatory framework.

Decades of isolation have left Myanmar's telecommunications infrastructure in a weak state. Mobile and broadband penetration are among the lowest in the world, well below the level of its neighbors, including countries at similar levels of development (figure 2.4). Poor infrastructure, particularly in broadband and 
FIGURE 2.4

\section{Telecommunication indicators in selected countries in East Asia, 2004-13}

a. Mobile telephony

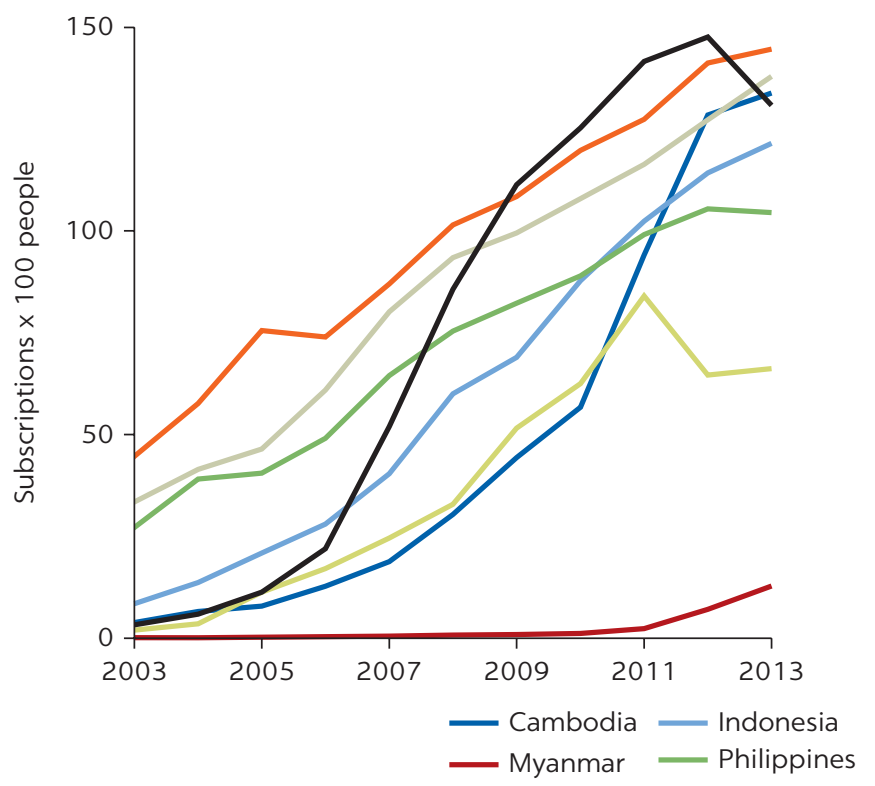

b. Broadband Internet

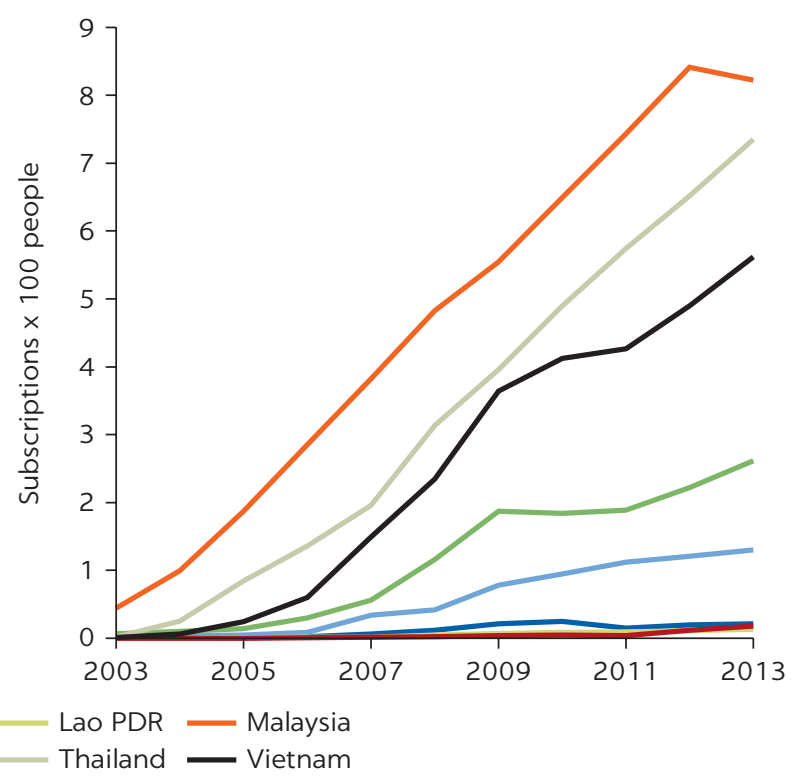

Cambodia Indonesia Lao PDR Malaysia Myanmar Philippines Thailand Vietnam

Source: World Bank World Development Indicators.

Note: The size of the circle is proportional to the number of Internet servers per million people, indicated in the legend.

Internet servers, raises costs for modern industries, reducing their competitiveness and acting as a major barrier to investment.

In 2013 Myanmar licensed its first two foreign-owned telecom services providers, breaking the monopoly of the state-owned enterprise and opening the gate to the one the world's fastest telecom mobile penetration growth rates. The licensing procedure, developed and implemented with the support of the World Bank and other international partners, was based on a tender competition that was praised for its transparency and professionalism (box 2.2).

Laws and regulations also improved. In 2013 the government enacted a new telecommunications law, meant to revamp the institutional and legal framework for the operation of telecom services. Recognizing the importance of attracting investment in the sector, it allowed domestic and foreign companies to apply for telecom licenses. The law also mandated the establishment of an independent regulatory body for the telecom market-the Myanmar Telecommunication Commission.

These legal and institutional improvements are being complemented with technical assistance and capacity building in the relevant government agencies, 


\section{BOX 2.2}

\section{Adopting a transparent, objective procedure for licensing foreign telecom providers in Myanmar}

In 2012 the government conducted a tender for the establishment of a telecommunications operator and oversaw a selection committee supported by international advisers. Its members signed a code of conduct. The committee was charged with conducting an objective and transparent process to select two operators to whom licenses would be awarded.

The committee first invited interested parties to submit Expressions of Interest (EOIs) by February 8, 2013. It received 91 EOIs.

It then invited interested parties to submit prequalification applications, in which applicants needed to demonstrate that they met objective requirements designed to show that they were qualified to deploy a nationwide public telecommunications network in Myanmar. On April 11, 2013, the committee announced that 12 of the 22 applicants had been prequalified and invited them to respond to the invitation to tender (ITT). Applicants were required to provide both a technical submission and a separate spectrum licensee fee offer.

On June 4, 2013, 11 of the prequalified applicants submitted responses to the ITT. The Vodafone-China Mobile consortium informed the government 24 hours before the deadline that it would not submit an offer. The committee disqualified one applicant, because its proposed coverage commitments fell short of the minimum requirements contained in the ITT.

The committee then assessed the technical submissions of the 10 remaining applicants. Applicants were eligible to receive up to 1,000 points, allocated as follows:
- network roll-out, infrastructure, and coverage commitment (325 points)

- $\quad$ robustness of technical plan (125 points)

- quality of marketing plan, value-added services, and distribution commitment (125 points)

- tariff commitment for mobile voice services, mobile data services, and handsets ( 75 points)

- human resources management, organization, and capabilities, including the commitment to recruit, develop, and promote citizens of Myanmar (75 points)

- quality of customer care and billing plan (50 points)

- corporate social responsibility, including commitment to contribute to the development of information and communication technology (ICT) or local inclusion development plan (50 points)

- soundness of the business plan and financing strategy (175 points).

The committee compared each of the applications on about 200 criteria. As provided in the ITT, it opened the spectrum license fee offers of the five applicants whose technical submission received scores of at least 500 points. It awarded an additional 500 points to the applicant with the highest spectrum license fee offer and a proportionate number of points to each of the other remaining applicants based on their offers. It then added those applicants' technical and financial scores. The two applicants with the highest total scores were selected. The applicant with the third-highest total score was designated as the back-up applicant.

with the support of development partners. Given the novelty and technical complexity of regulatory and monitoring functions in the telecom market, the government is giving priority to human resources. It is training government officials and linking with technical schools and engineering universities to ensure that technical capacity is being developed for the sector as a whole.

\section{Professional services}

Despite their importance, professional services in Myanmar are severely underdeveloped and capacity is limited. The biggest challenge is establishing 
an adequate governance and regulatory framework that promotes capacity development and bridges information asymmetries.

Myanmar has made progress upgrading accounting and auditing services, but formal restrictions to foreign providers remain in place. Under the Myanmar Companies Act, companies must maintain proper books of accounts, which must be kept at the registered office of the company; they must also appoint one or more auditors. The act also mandates a yearly audit, which must be performed by Myanmar auditors or firms owned by Myanmar certified public accountants (CPAs).

The Myanmar Accountancy Council (MAC) is Myanmar's main accounting body, responsible for setting accounting standards and registering auditors and accountants able to practice in Myanmar. In order to qualify as an auditor or accountant, applicant must be a CPA certified by the Myanmar Institute of Certified Accountants (MICPA) or hold an accountancy certificate or degree conferred by any foreign country recognized by the MAC. To obtain a certificate of practice, auditors must also be citizens of Myanmar and registered with the MAC.

The MAC sets out accounting standards. They are based on International Financial Reporting Standards (IFRS) standards, except the following (PWC 2014):

- IFRS 9: Financial Instruments

- IFRS 10: Consolidated Financial Statements

- IFRS 11: Joint Arrangements

- IFRS 12: Disclosure of Interests in Other Entities

- IFRS 13: Fair Value Measurement

- Interpretations from the Standing Interpretations Committee (SICs) and International Financial Chaptering Interpretations Committee (IFRICs)

The MAC prescribes the Myanmar Financial Chaptering Standards for small and medium-size enterprises (SMEs), which are adopted from the IFRS for SMEs.

Legal services do not have a regulatory framework; they remain largely unrestricted to foreign participation. The only restrictions are set out in the terms of the licenses granted to foreign-owned law firms, which require that foreign lawyers practice in association with a Myanmar lawyers, except for litigation before Myanmar courts, which is reserved to Myanmar citizens. Openness to foreign legal services, together with the flexible use of business visas, has allowed the sector to grow by attracting foreign expertise. Training, a standard curricula for education institutions, and a sound monitoring and regulatory body would be valuable to promote domestic capacity in legal services.

As a member of ASEAN, Myanmar is a party to seven mutual recognition arrangements on professional services (table 2.2).

The level of implementation of these arrangements in Myanmar is unclear. The low capacity of the bodies that regulate professional services is a hurdle to implementation of these arrangements. For accounting services, despite progress in the sector and the technical assistance projects with the regulatory bodies, no major steps have been taken toward implementing the Mutual Recognition Agreements (MRA). A comprehensive evaluation of the conditions and needs for implementation of the ASEAN MRAs would increase capacity and promote the development of professional services in Myanmar. 
TABLE 2.2 Regional mutual recognition arrangements on professional services signed by Myanmar

\begin{tabular}{lll}
\hline SUBSECTOR/AGREEMENT & SIGNING DATE & MEANS OF IMPLEMENTATION \\
\hline Engineering services & December 9, 2005 & $\begin{array}{l}\text { ASEAN registration (ASEAN Chartered Professional } \\
\text { Engineer Coordinating Committee [ACPECC]) }\end{array}$ \\
\hline Nursing services & December 8, 2006 & Bilateral registration \\
\hline Architectural services & November 19, 2007 & ASEAN registration (AAC) \\
\cline { 1 - 3 } $\begin{array}{lll}\text { ASEAN Framework Arrangement on Mutual } \\
\text { Recognition of Surveying Qualifications }\end{array}$ & & MRA \\
\hline Medical and dental services & & Bilateral registration \\
\hline Accounting services & February 26, 2009 & Bilateral registration \\
\hline
\end{tabular}

Note: ACPECC = ASEAN Chartered Professional Engineer Coordinating Committee; ASEAN = Association of Southeast Asian Nations; MRA = mutual recognition agreement.

\section{Business services}

Except for professional services, business services in Myanmar are regulated only lightly. They include computer services, real estate services, research and development, and services that encompass activities as diverse as "services related to energy distribution" and "convention services."

Thanks to rapid technological progress, information technology-enabled services (ITES) are an increasingly important area of business services. They include services directly related to information technology (IT), including software development, system integration, and web page design. They also include business services that use IT (to process insurance claims, perform desktop publishing, conduct audits, complete tax returns, and transcribe medical records, for example).

Trade in ITES still represents a small share of the total exports of most developing countries. Although several countries are enjoying gains from trade in the subsector, only a handful have developed sizable, export-oriented IT and ITES subsectors. Myanmar's large cohort of dynamic and talented youth offers a solid starting point for IT services. Anecdotal evidence suggests that a number of IT products, such as mobile apps and computer software developed in Singapore, are actually Myanmar businesses that are established or conduct operations in Singapore because of limitations and difficulties with infrastructure, the regulatory environment, and the processing of international payments in Myanmar.

Figure 2.5 shows indicators for online outsourcing readiness. It points to a comparatively strong position for Myanmar within the region in terms of the quality and availability of talent, on which it ranks above Cambodia and the Lao People's Democratic Republic, both of which have small IT services industries. Myanmar's telecommunications infrastructure and regulatory environments are weak, however.

Difficulty transferring capital is particularly harmful for IT-related businesses. International sanctions are partly to blame for this obstacle, but regulatory barriers also contribute. Banks are required to check the terms of firms' licenses before executing transfers. MIC-registered business are permitted to make most international transfers; DICA-registered companies typically require ad hoc permits for each transfer. 
FIGURE 2.5

\section{Readiness indicators for information technology outsourcing services in selected East Asian countries}

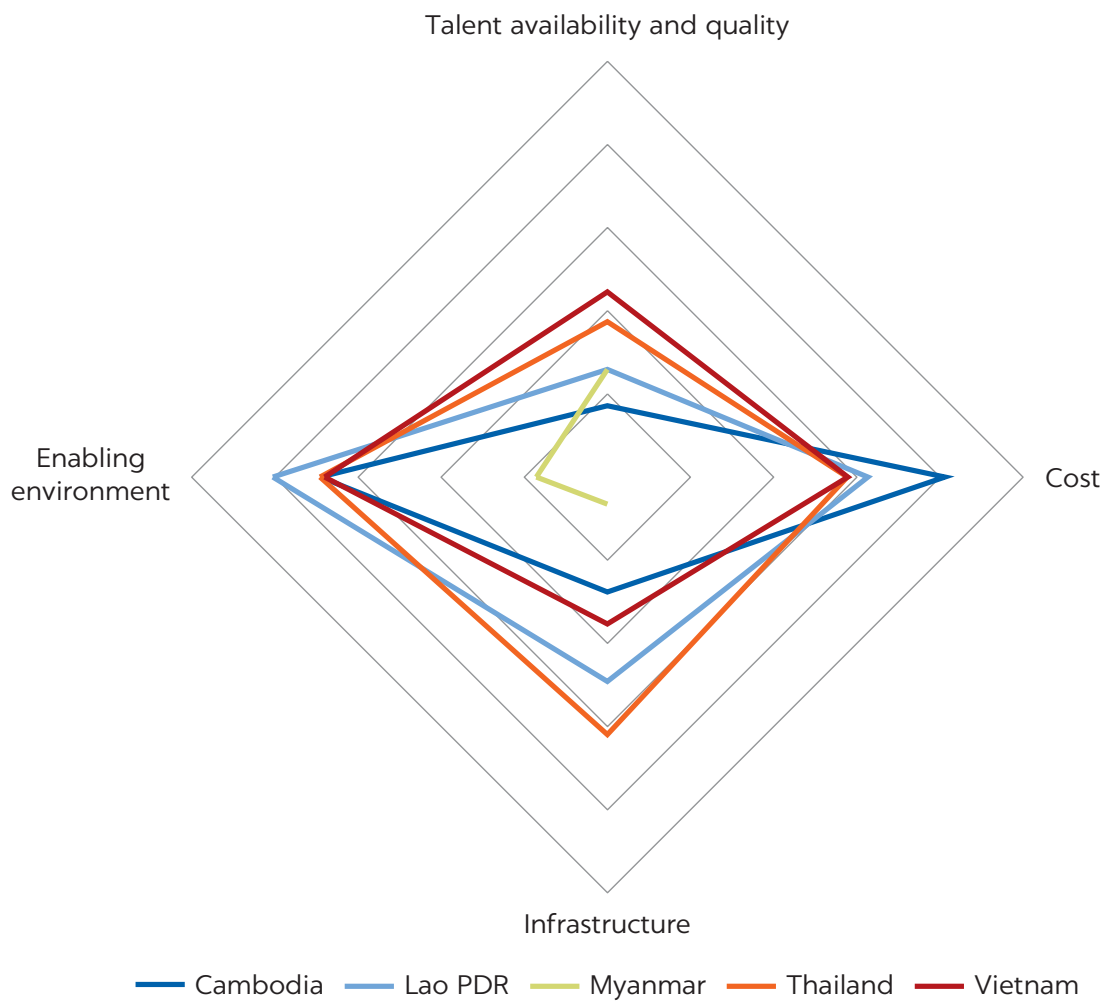

Source: Kuek and others 2015.

Note: Data on cost are not available for Myanmar.

Myanmar's IT companies are typically small or medium-size enterprises (SMEs) that are domestically owned; they are registered at DICA. However, even small start-ups in the IT sector are often reliant on international transfers, as these services typically do not require physical proximity between providers and consumers. As a result, Myanmar IT services providers, including SMEs, often locate in Singapore or Thailand, which offer easier channels for international transfers, in addition to good infrastructure and more conducive regulatory requirements.

\section{Tourism}

Myanmar's economic opening has led to a boom of foreign arrivals and revenue from tourism, doubling the number of visitors and more than tripling tourism receipts between 2007 and 2012 (figure 2.6). Although tourism in Myanmar is among the lowest in the region, the sector has one of the highest annual growth rates. The subsector is a prime candidate for services exports in the short and medium term.

Despite growth, investment in the sector and its contribution to GDP and employment are the lowest in the region. Only the contribution to total exports is comparable to other countries in the region. These findings suggest that substantial potential remains untapped. The World Travel and Tourism Council (WTTC) projects annual growth of more than 8 percent in the tourism subsector 
FIGURE 2.6

\section{Tourist arrivals and revenues in Myanmar, 1996-2012}

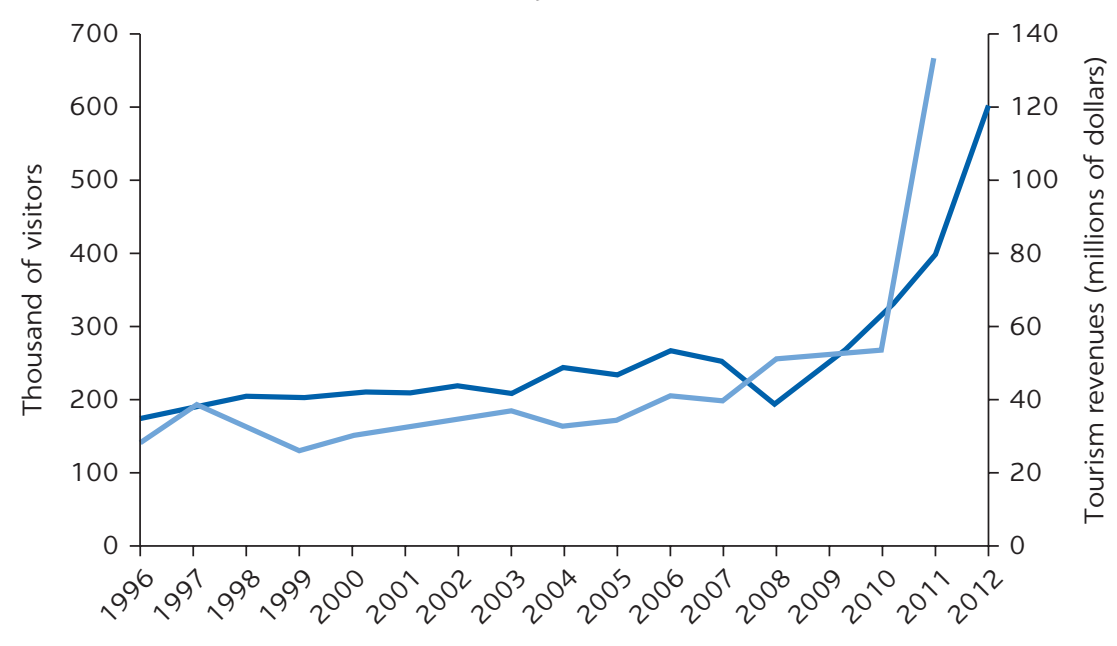

— Tourist arrival _ Tourism receipts

Source: World Bank World Development Indicators.

in Myanmar in the next decade. By 2025, the subsector will account for almost 15 percent of the country's exports, according to the WTTC.

Myanmar's tourism subsector suffers from important limitations. The World Economic Forum Travel and Tourism Competitiveness Index ranks Myanmar 134th out of 141 economies. The main challenges relate to infrastructure, both air and ground transport, and ICT. Limited entertainment, convention center, and other business-oriented offerings are also a constraint (figure 2.7).

The Ministry of Hotels and Tourism oversees tourism policies, in collaboration with the Myanmar Tourism Federation, a federation of 11 associations of tourism-related services providers. Main laws and regulations governing the sector include the Myanmar Hotel and Tourism Law 1993 and Government Notification No. 14/93(1993). Operating a hotel or lodging house requires prior permission from the Ministry of Hotels and Tourism. After obtaining ministerial permission and completing construction, the enterprise must apply for a license. Licenses are not transferable without the permission of the authorities (WTO Secretariat 2014).

The government recognized the potential of tourism services in the Tourism Master Plan 2013-20 developed by the Ministry of Hotels and Tourism. The plan is based on six strategic pillars:

- strengthening the institutional environment

- building human resource capacity

- strengthening procedures for destination planning

- developing quality products and services

- improving connectivity and tourism-related infrastructure

- building the image and brand of tourism in Myanmar.

\section{Distribution}

Distribution services are de facto closed to foreign investment, despite the fact that they are not listed among the sectors reserved to Myanmar citizens under the Foreign Investment Law or included in the list reserved to 


\section{FIGURE 2.7}

\section{Myanmar Travel and Tourism Competitiveness Index, 2015}

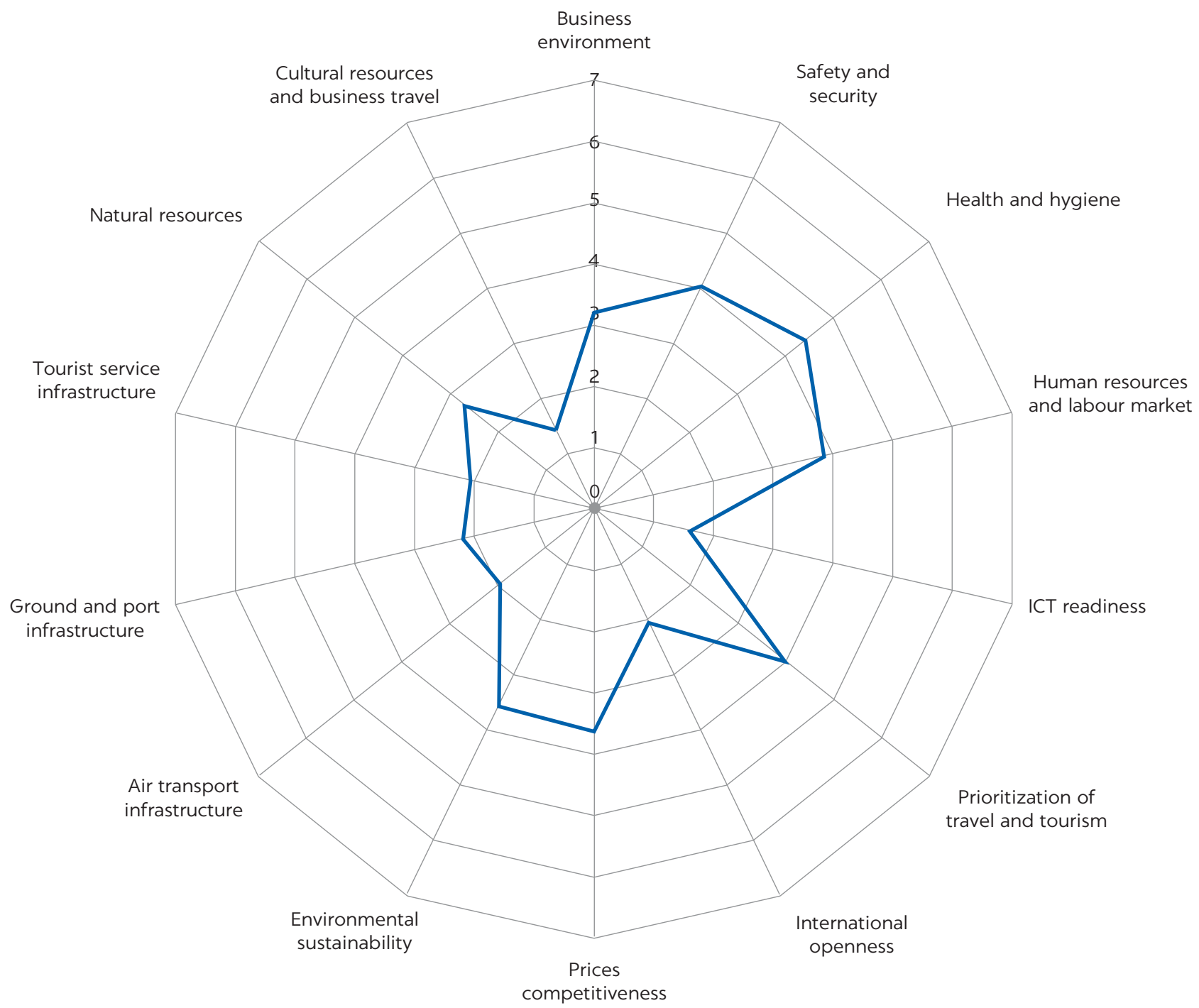

Source: World Economic Forum 2015

Note: Scores range from 1 (lowest) to 7 (highest).

state-owned enterprises. The origins of this sectoral limitations remain unclear, as no readily available law or regulation supports the exclusion of this sector from foreign investment.

In order to overcome this limitation, foreign firms need to enter into contractual arrangements with domestic companies to import and distribute products based on the international company's guidance. This mechanism results in higher costs, which are passed on to consumers, and reduces the quality of service.

\section{CONCLUSION}

The economic and regulatory reform process launched in the past decade brought about important changes in Myanmar's policy framework for trade and investment in services. Legal and regulatory amendments were aimed at 
establishing an open and nondiscriminatory framework toward foreign participation in the services sector. The framework still maintains a number of older laws, regulations, and administrative practices that do not conform to the reform and impair its progress.

Myanmar's next challenges are to complement the market opening taking place with an adequate regulatory framework that fosters transparency, provides clarity about laws and regulations affecting access and operations to services markets, protect consumers, and ensures competition. Priority subsectors in this agenda include telecommunications; banking and insurance; retail and distributions services; and professional services, including accounting, auditing, and legal services. The government is already advancing in many of these areas, together with international partners. The World Bank, for instance, is providing substantial support to improve the regulatory environment in banking and telecommunication.

Strengthening the governance framework and improving institutional capacity is also needed to support regulatory reform. Myanmar's institutional framework for services trade policy is spread across multiple ministries with overlapping mandates; similar tasks are inefficiently divided among different agencies, leading to inconsistent policies, especially when negotiating trade agreements, and weakening the monitoring of implementation. In addition, many agencies have limited understanding of services trade policy and negotiations. Capacity building in key services, as well as in the coordinating bodies related to services trade policy, should be a key priority to ensure Myanmar's ability to address the challenges of the new economic and regulatory context.

\section{NOTES}

1. Retail does not show up in the STRI or on the negative list issued by the Myanmar Investment Commission. In practice, however, foreign firms do not participate in the subsector. Foreign firms wishing to operate retail operations in Myanmar must obtain a recommendation from the Ministry of Commerce, which the ministry does not grant.

2. There have been discussions about the possible transfer of responsibility in representing Myanmar at AEM from the MoPF to the Ministry of Commerce.

3. In practice, the distribution sector also covers retailing. So far the Ministry of Commerce has not granted any recommendation for foreign investment in retail sector in Myanmar.

\section{REFERENCES}

Borchert, I., B. Gootiiz, and A. Mattoo. 2012. "Policy Barriers to International Trade in Services: Evidence from a New Database.” Policy Research Working Paper 6109, World Bank, Washington, DC.

Gootiiz, B., and A. Mattoo. 2015. Regionalism in Services: A Study of ASEAN. Policy Research Working Paper 7498, World Bank, Washington, DC. http://documents.worldbank.org /curated/en/616071467987821046/Regionalism-in-services-a-study-of-ASEAN.

IMF (International Monetary Fund). 2014. Myanmar: Staff Report for the 2014 Article IV Consultation. IMF Country Report No. 14/307, Washington, DC. https://www.imf.org/en /Publications/CR/Issues/2016/12/31/Myanmar-Staff-Report-for-the-2014-Article-IV -Consultation-42387.

Kuek, S. C., C. Paradi-Guilford, T. Fayomi, S. Imaizumi, P. Ipeirotis, P. Pina, and M. Singh. 2015. The Global Opportunity in Online Outsourcing. Washington, DC: World Bank. 
Marconini, M. and P. Sauvé. 2010. "Negotiating Trade in Services: A Practical Guide for Developing Countries.” In Trade in Services Negotiations: A Guide for Developing Countries, edited by Sebastián Sáez, 19-85. Washington, DC: World Bank. https://openknowledge .worldbank.org/handle/10986/2481.

Mattoo, A., and L. Payton, eds. 2007. Services Trade and Development: The Experience of Zambia. Washington, DC: World Bank and Palgrave Macmillan.

MIC (Myanmar Investment Commission). 2014. Myanmar Investment Guide 2014, by Myanmar Investment Commission and Directorate of Investment and Company Administration, Yangon.

OECD (Organisation for Co-operation and Development). 2002. Managing the Request-Offer Process. Paris: OECD.

—. 2014. OECD Investment Policy Reviews: Myanmar. Paris: OECD Publishing. http://dx.doi .org/10.1787/9789264206441-en.

PWC (PricewaterhouseCoopers Myanmar Co., Ltd.). 2014. Myanmar Business Guide. Yangton, Myanmar.

Sudan, R., S. Ayers, P. Dongier, A. Muente-Kunigami, and C. Zhen-Wei Qiang. 2010. The Global Opportunity in IT-Based Services: Assessing and Enhancing Country Competitiveness. Washington, DC: World Bank.

U.S. Commercial Service. 2014. Doing Business in Burma: 2014 Country Commercial Guide for U.S. Companies. Washington, DC.

World Bank. 2014. Cambodia Services Trade: Performance and Regulatory Framework Assessment. Phnom Penh.

World Bank World Development Indicators (database), Washington, DC, http://wdi .worldbank.org.

World Bank Worldwide Governance Indicators (database), Washington, DC, https://datacatalog .worldbank.org/dataset/worldwide-governance-indicators.

World Economic Forum. 2015. Travel and Tourism Competitiveness Report 2015. Geneva. https://www.weforum.org/reports/travel-and-tourism-competitiveness-report-2015.

WTO (World Trade Organization) Secretariat. 2014. Trade Policy Review. WTO Document WT/TPR/S/293, Myanmar. 



\title{
3 The Contribution of Services to Competitiveness in the Russian Federation*
}

\author{
BIRGIT HANSL, SEBASTIÁN SÁEZ, AND ERIK VAN DER MAREL
}

This chapter identifies trends in the development of services in the Russian Federation, both domestically and as exporters; assesses the potential for increasing services exports to neighboring markets; examines linkages between services and other sectors; and analyzes how the main services industries are regulated. It addresses the following questions:

- Is there untapped potential to develop the services sector in Russia?

- How do Russia's services exports perform relative to other countries?

- How close are the linkages of services to other economic activities compared with direct services exports?

- What is the trade potential for services?

- What factors lie behind the performance of services trade?

- What is the regional pattern of Russia's services trade?

The chapter is organized as follows. The first section evaluates the role of services in the domestic economy. The second section studies the performance of services trade. The third section analyzes the importance of services at the regional level. The fourth section analyzes services trade policies and performance determinants and the last section provides policy recommendations.

\section{SERVICES IN THE DOMESTIC ECONOMY}

Services employed about 60 percent of Russia's labor force in 2010. This employment share is much larger than in India and China and comparable to the shares in South Africa and Brazil (figure 3.1). $\frac{1}{}$ A large employment share for services is common in resource-rich economies. Given Russia's economic characteristics, it would be expected to have a higher services employment share than most peer countries. In fact, it has a larger share than India and China, which are much less resource rich.

* The authors thank Michael Ferrantino, Ben Shepherd and Borko Handjinski for comments and suggestions and acknowledge the support of Chanaporn Sereevoravitgul and Patrick Ibay. 


\section{FIGURE 3.1}

\section{Employment in agriculture, industry, and services in the BRICS, 2000 and 2017}

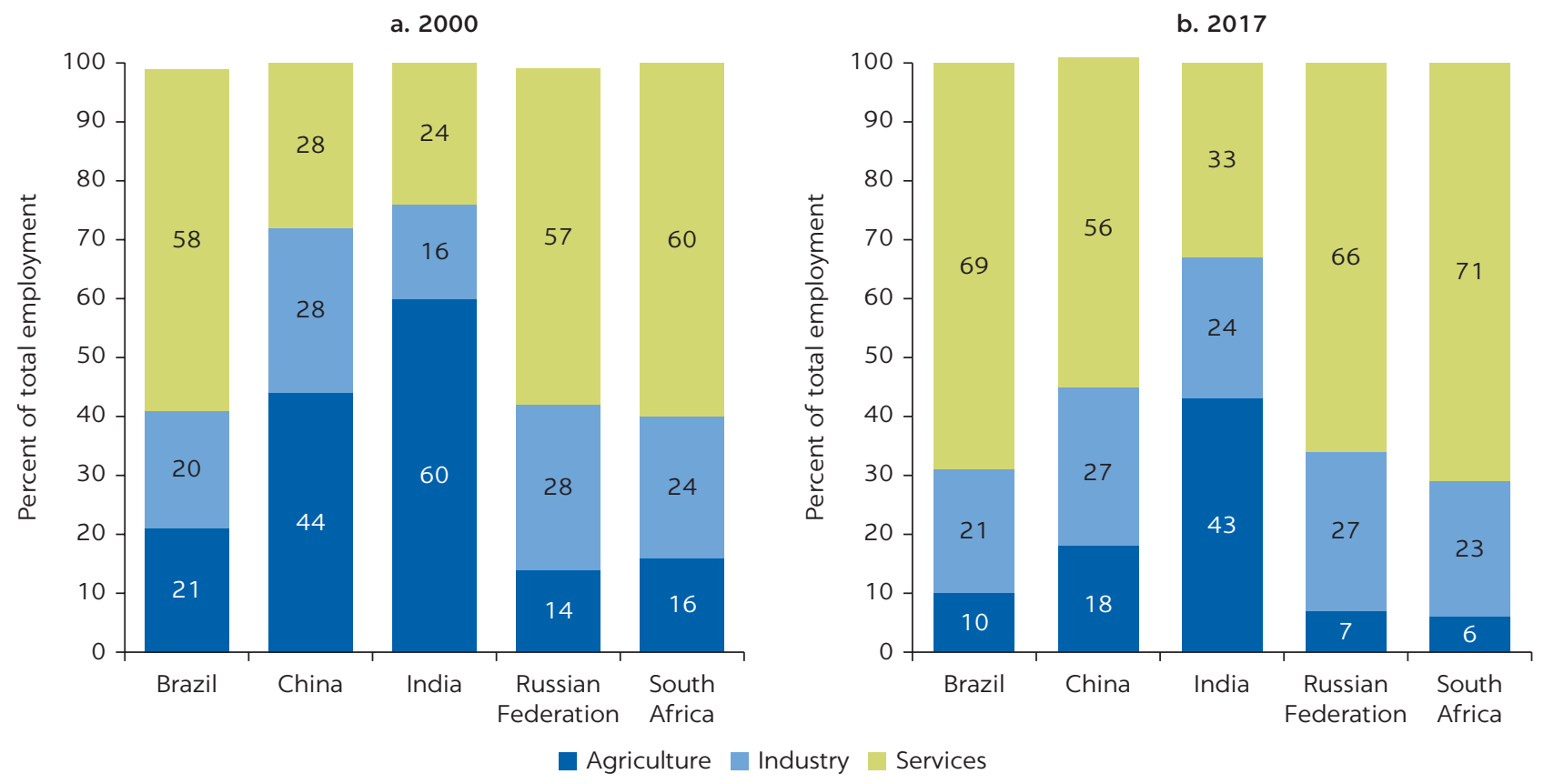

Source: World Bank World Development Indicators.

Note: Figures for Brazil and the Russian Federation are for 2009 rather than 2010.

The share of services in Russia's GDP is slightly below what would be expected for its level of development. Between 2000 and 2013, the share of services value added rose, from 56 to 60 percent. It is still smaller than in South Africa and Brazil and other countries at similar levels of development (figure 3.2). The large size of Russia's industrial sector suggests that the services sector could grow if manufacturing companies outsource services activities such as logistics and transportation that are still performed in-house and services support manufacturing activities.

Figure 3.3 illustrates the growth in value added of services in selected countries. It shows that services were the leading contributor to growth in Russia between 2000 and 2013 and that the share was higher in Russia than in Brazil and South Africa (although still lower than the share in of China and India, whose growth rates were abnormally high).

\section{VALUING TRADE IN SERVICES}

This section assesses the contribution of services to exports using various measures of their direct and indirect contribution to the value added of domestic production and exports. ${ }^{2}$ Industries with strong backward and forward linkages are central to a country's development strategy. Strong backward linkages mean that an increase in final demand for a sector's output will have major impact on industries that supply inputs for production of that output. Strong forward linkages mean that an increase in demand for the output of other sectors will have a large impact on the output of those sectors. Strong linkages of value-added 
FIGURE 3.2

Relationship between services value added and per capita GDP, 2013

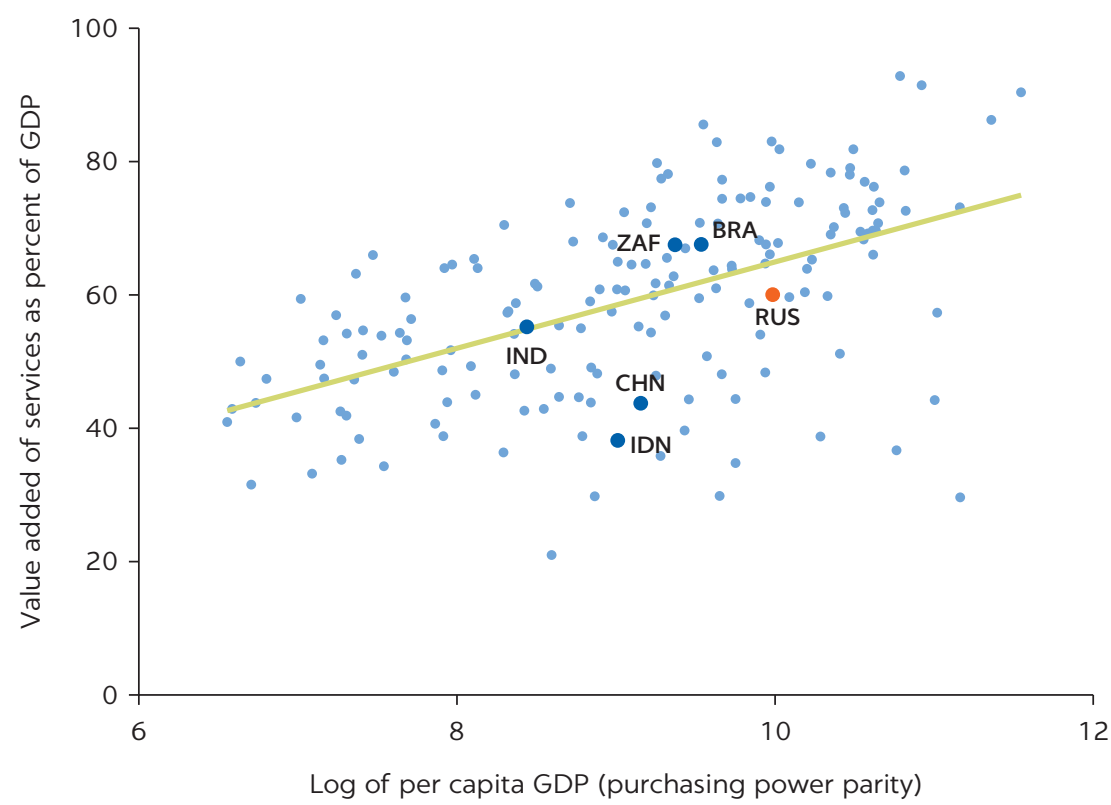

Source: World Bank World Development Indicators.

Note: GDP = gross domestic product. Dots represent countries: $\mathrm{BRA}=$ Brazil; $\mathrm{CHN}=\mathrm{China}$;

$\mathrm{IDN}=$ Indonesia; IND = India; RUS = Russian Federation; ZAF = South Africa.

FIGURE 3.3

Contribution to value added of agriculture, industry, and services in selected countries, 2000-13

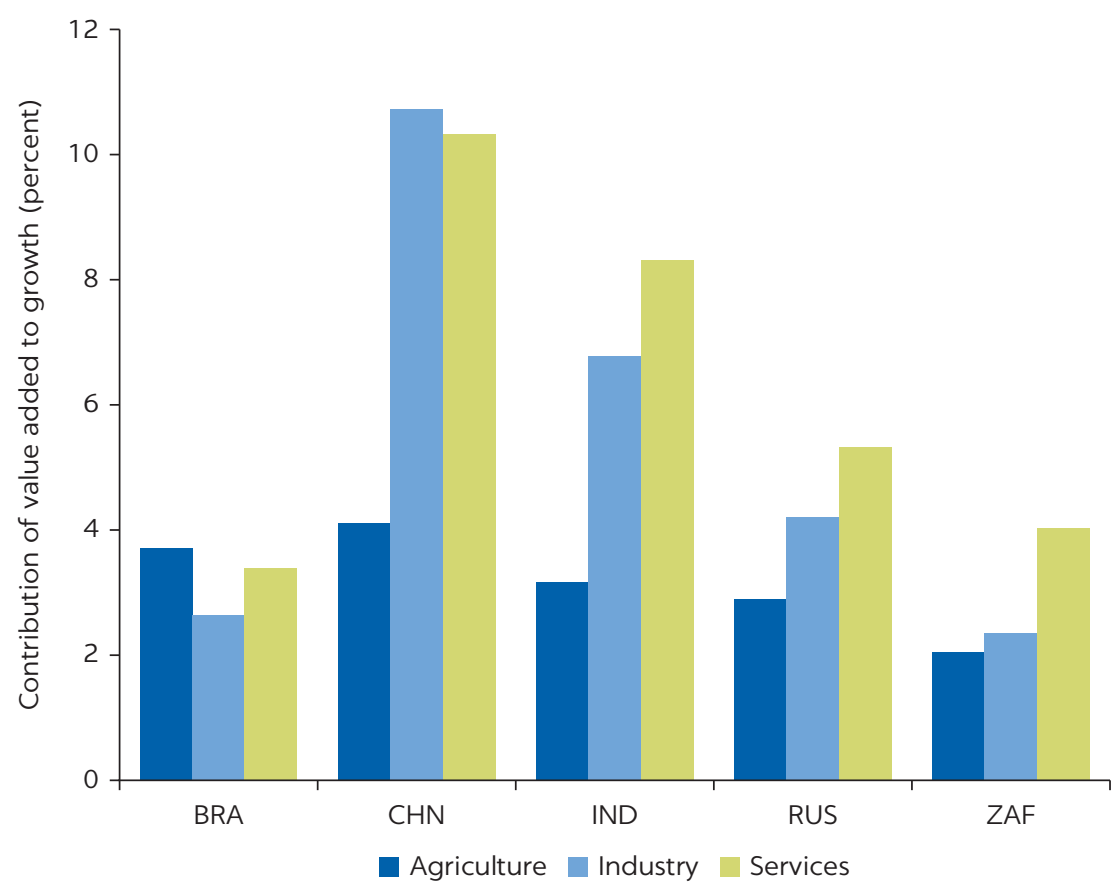

Source: World Bank World Development Indicators.

Note: $\mathrm{BRA}=$ Brazil; $\mathrm{CHN}=$ China; IND = India; RUS = Russian Federation; ZAF = South Africa. 
exports also play a role in developing export strategies. If an export strategy focuses on a sector that has a strong interlinkages with other sectors, it is likely to have a strong trickle-down effect.

In Russia most backward linkages of services are in other services sectors; linkages to the primary, energy, and manufacturing sectors are much more modest. The services sectors with the biggest backward linkages are construction, trade, distribution and hotels, which is not surprising for an emerging economy.

Russia's services sector accounted for just 9.2 percent of the total value of exports in 2011. The contribution of services to total exports rises to 34 percent when forward linkages to other export activities are considered. The increase reflects the role of services in exports of energy, which represents about half of the contribution of services to total exports (16 percent). Thus although direct services exports are low, services contribute as inputs to other export activities through forward linkages.

Trade, distribution, and hotels are the main sectors linked to energy exports. Other services demanded by the energy sector are transport (2.7 percent of total services exports, other business services (2.4 percent), and finance (1.6 percent). The second-largest consumer of services in exports is manufacturing (7.7 percent of total services exports, which uses trade and distribution (3.8 percent of total services exports), transport (1.3 percent) and business (1.1 percent) services. These results reveal that there is great scope for diversifying services to other export activities, both within the services sector and in the primary and manufacturing sectors. In peer countries, the level of services to other export sectors tends to be much higher. The high concentration of services linkages to energy also indicates the relatively low development of services as an export activity.

Backward linkages of services exports are weak in Russia; services mainly contribute to other export activities rather than being exported directly. Services backward linkages represent about 10.7 percent of total exports.

This finding has two important policy implications. First, low-cost highquality services should be a priority for any diversification and competitiveness strategy. Second, assessing and understanding barriers to services development is crucial if they are to contribute more to economic diversification and competitiveness.

Services in Russia generate higher value added than goods. Figure 3.4 breaks down gross and net measures of exports for machinery and business services (business services were chosen because it was the most dynamic services category in recent years). The share of value added is much larger for services than for goods. Gross value shares are much larger for goods than for services. The gap between gross and net value in Russia is small compared with the gap in Brazil and India, meaning that Brazil and India capture larger shares of value added from all their (gross) exports in services.

The role of services as inputs is less important for the upper-middle-income group of countries in Europe and Central Asia to which Russia belongs than it is for other income groups. ${ }^{3}$ The share of services in total exports varies across income groups (figure 3.5). It is 25 percent in high-income countries, 19 percent in European upper-middle-income countries, and 11 percent in middle-income countries (figure 3.6, panel a).

The trend is similar when the share of direct value added of services in total exports is considered excluding any forward linkages. When forward linkages are included, together with the direct measure of value added exports, the shares are similar across income groups. The gap between the direct measure and the 
FIGURE 3.4

Gross exports and value-added shares of machinery and business services in selected countries, 2011

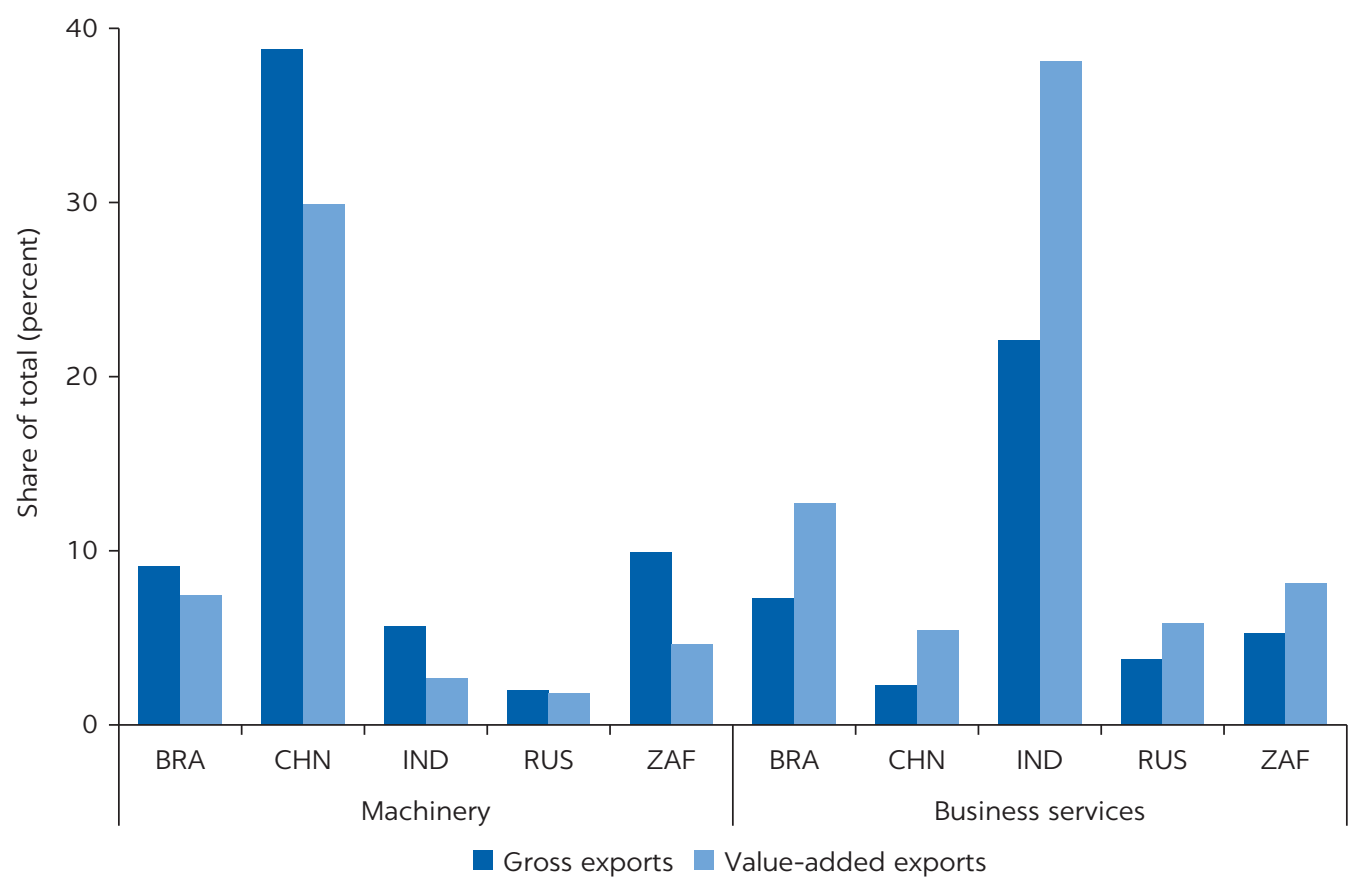

Sources: Data from World Bank Export of Value Added Database and Francois, Manchin, and Tomberger 2013. Note: $\mathrm{BRA}=$ Brazil; $\mathrm{CHN}=$ China; IND = India; RUS = Russian Federation; ZAF = South Africa.

\section{FIGURE 3.5}

Share of services exports in total exports in selected countries, by type of service, 2011

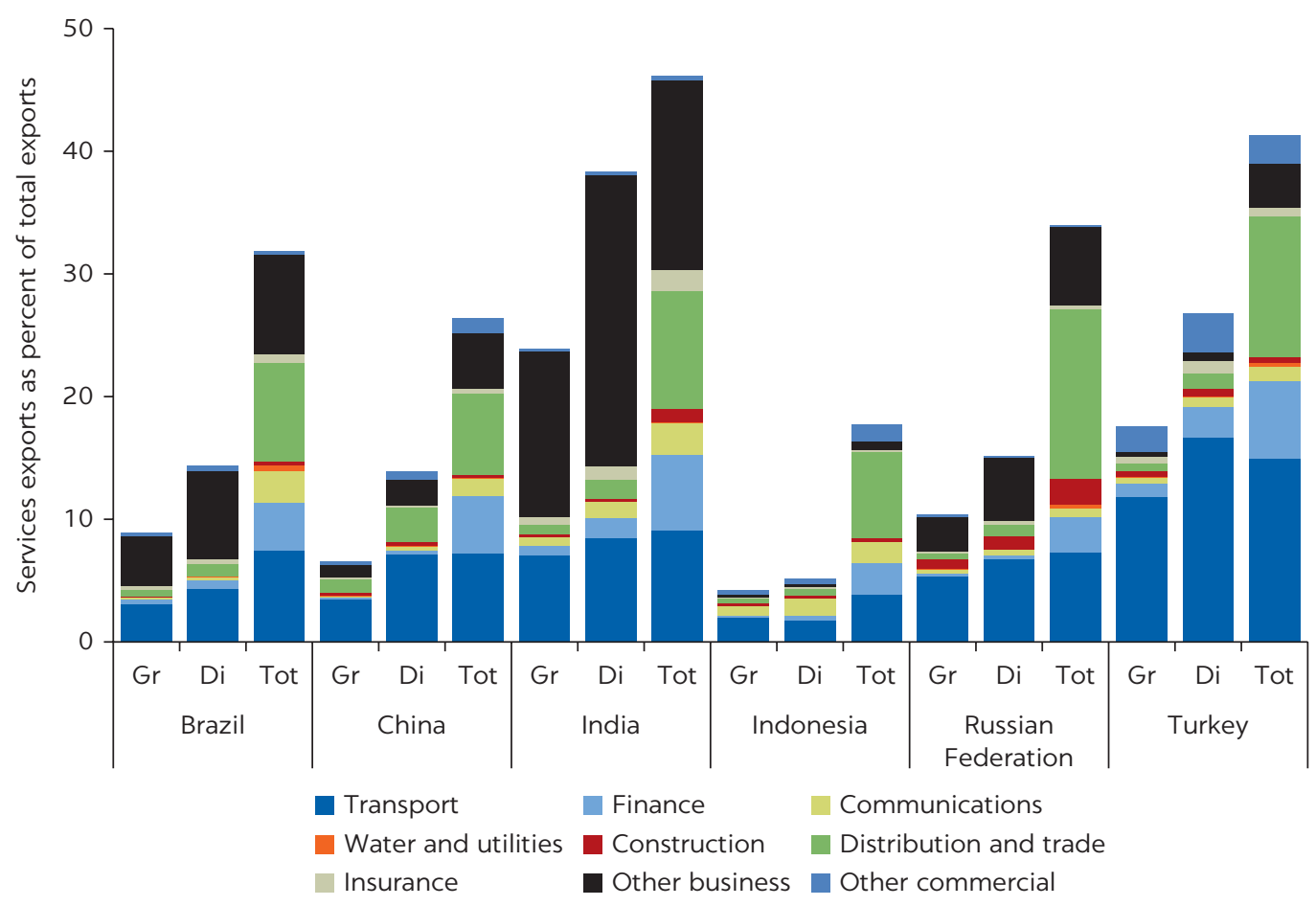


direct measure including forward linkages is greatest for upper-middle-income countries in Latin America and Asia and smallest for high-income countries generally and upper-middle-income countries in Europe.

Figures 3.5 and 3.6 show the wide variance between these two measures among the BRICS (Brazil, Russia, India, China, South Africa). These results suggest that forward linkages play an important role in Russia.

In Russia (as in the other BRICS except India), the share of services in total domestic value added (52 percent) is larger than in its share of export value added (34 percent) (table 3.1). The difference is much smaller in South Africa and even China; for India the pattern is reversed. These findings reflect the fact that many services in Russia, such as construction, are oriented toward the domestic market. They also suggests that services that are important for the domestic economy may have untapped export potential.

The distribution and hotels subsectors are outward oriented. The distribution and hotels sector contributes more than any other subsector to export value added (more than 13 percent of total exports). Other business services and transportation also make relatively large contributions to exports, although the contribution of other business services is lower in Russia than in any of its comparators (the contribution of transportation is in line with its peers). Finance is also relatively outward oriented, but its value-added contribution is smaller than in comparable countries except South Africa. The fact that the percentage of both export and domestic value added of some services is large underscores that Russia has a strong production base in these subsectors, on which it can capitalize.

\section{FIGURE 3.6}

\section{Share of services exports in total exports in selected country groups and countries, 2011}
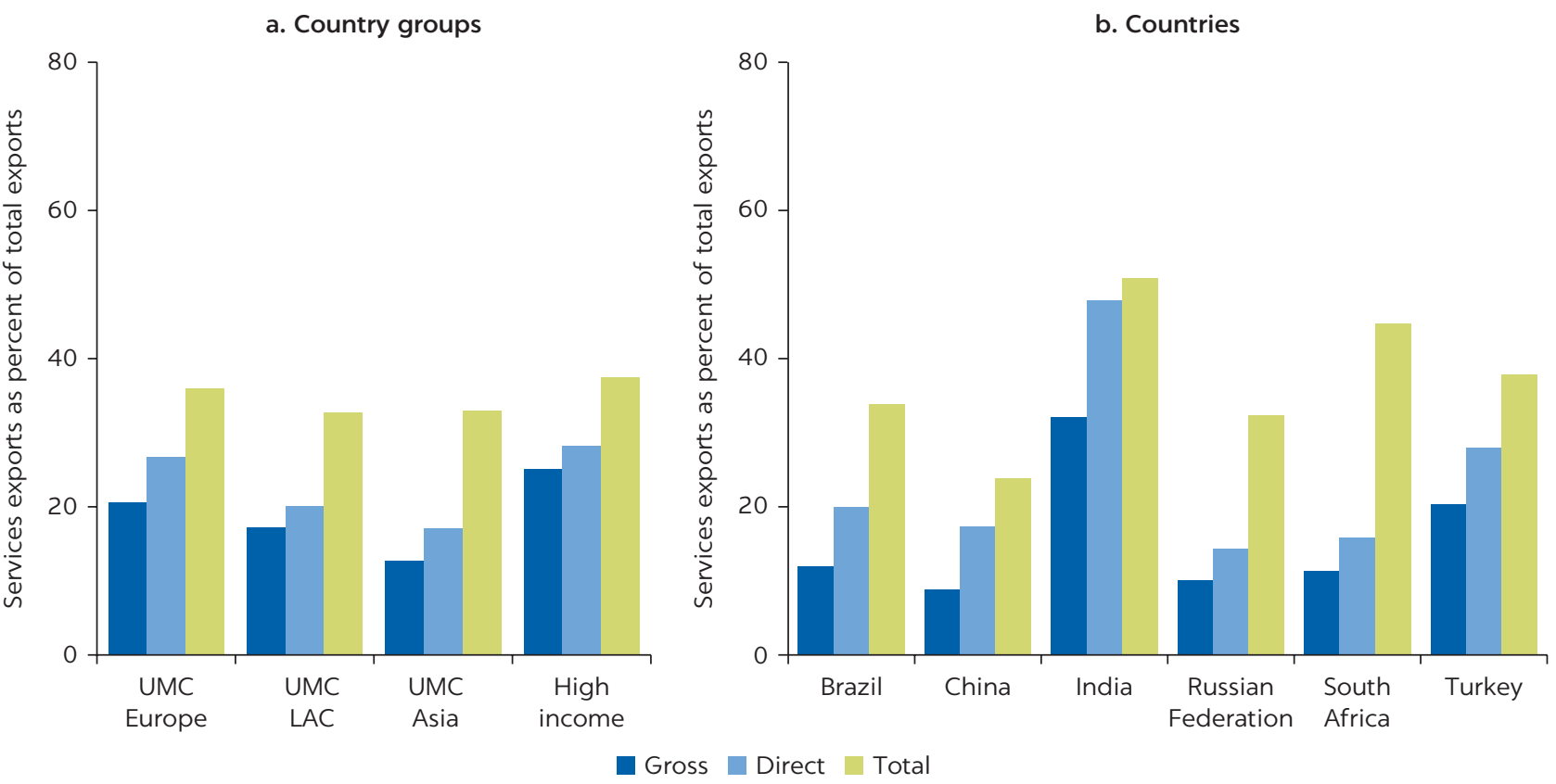

Source: World Bank Export of Value Added Database.

Note: $\mathrm{LAC}=$ Latin America and the Caribbean; UMC = upper-middle-income countries. Direct $=$ direct value-added exports; Gross = gross exports; Total $=$ direct value-added and forward linkages exports. 
TABLE 3.1 Total value added of sectors and services subsectors in selected countries, 2011

Percent of total

\begin{tabular}{|c|c|c|c|c|c|c|c|c|c|c|}
\hline \multirow[b]{2}{*}{ SECTOR } & \multicolumn{2}{|c|}{$\begin{array}{c}\text { RUSSIAN } \\
\text { FEDERATION }\end{array}$} & \multicolumn{2}{|c|}{ BRAZIL } & \multicolumn{2}{|c|}{ CHINA } & \multicolumn{2}{|c|}{ INDIA } & \multicolumn{2}{|c|}{ SOUTH AFRICA } \\
\hline & DOMESTIC & EXPORT & DOMESTIC & EXPORT & DOMESTIC & EXPORT & DOMESTIC & EXPORT & DOMESTIC & EXPORT \\
\hline \multicolumn{11}{|l|}{ Services } \\
\hline Distribution & 21.6 & 13.8 & 13.5 & 8.1 & 7.7 & 6.6 & 14.6 & 9.6 & 12.9 & 15.3 \\
\hline Transport & 6.7 & 7.3 & 5.2 & 7.5 & 6.4 & 7.2 & 7.8 & 9.1 & 3.8 & 5.7 \\
\hline $\begin{array}{l}\text { Other business } \\
\text { services }\end{array}$ & 8.0 & 6.4 & 7.7 & 8.2 & 5.2 & 4.6 & 5.1 & 15.5 & 11.2 & 8.4 \\
\hline Finance & 1.8 & 2.9 & 5.4 & 3.8 & 4.6 & 4.7 & 5.2 & 6.2 & 1.6 & 1.6 \\
\hline Construction & 9.7 & 2.2 & 5.8 & 0.3 & 7.1 & 0.2 & 7.5 & 1.1 & 3.2 & 0.5 \\
\hline Communications & 1.0 & 0.6 & 4.0 & 2.6 & 2.0 & 1.4 & 1.9 & 2.6 & 3.7 & 2.9 \\
\hline Water & 1.0 & 0.3 & 0.7 & 0.5 & 0.2 & 0.2 & 0.2 & 0.1 & 0.5 & 0.2 \\
\hline Other services & 0.5 & 0.1 & 2.3 & 0.3 & 2.3 & 1.2 & 0.3 & 0.4 & 4.2 & 3.4 \\
\hline Total services & 50.8 & 33.9 & 46.2 & 31.9 & 36.1 & 26.4 & 43.8 & 46.2 & 47.8 & 42.4 \\
\hline \multicolumn{11}{|l|}{ Other sectors } \\
\hline $\begin{array}{l}\text { Agriculture, energy, } \\
\text { and minerals }\end{array}$ & 19.9 & 51.1 & 10.1 & 36.3 & 16.3 & 17.7 & 23.2 & 23.2 & 7.3 & 18.4 \\
\hline Manufacturing & 13.3 & 14.7 & 17.8 & 31.0 & 32.6 & 54.2 & 15.8 & 29.8 & 20.8 & 37.7 \\
\hline Other & 16.0 & 0.3 & 25.9 & 0.9 & 15.0 & 1.7 & 17.3 & 0.8 & 24.2 & 1.5 \\
\hline
\end{tabular}

Sources: Data from the World Bank Export of Value Added Database and Francois, Manchin, and Tomberger 2013.

Figure 3.7 benchmarks the performance of the BRICS based on their level of development, proxied by per capita GDP in purchasing power parity terms. Russia's share of services in total exports is in line with its level of development when forward linkages are considered, but both gross and direct shares are smaller than would be expected (for gross value, direct value added, and total value added). Russia thus has scope to increase the role of services in trade, both as exports for final consumption and as inputs into exports of new goods or other services.

Russia's value-added exports stem mainly from distribution. ${ }^{4}$ Countries at Russia's level of development often specialize in subsectors such as distribution and transport services. The value added of business services in exports tends to increase as a country develops. Russia's position is below what could be expected given its national income.

Data on value added of trade reveal that Russia's services exports are performing below expectations. The analysis also illustrates the importance of services as inputs to other export activities, in particular energy. When the role of services as inputs into other economic activities is factored in, their share in total exports is consistent with Russia's level of development. This finding has three policy implications:

- Efficient, high-quality, and low-cost services are necessary to increase and maintain a country's competitiveness.

- Exports of other sectors require the support of these services as inputs through backward linkages.

- Services as final exports can be developed if supportive policies are adopted. 
FIGURE 3.7

Relationship between gross services exports, direct value added of services to other exports, and total value added of services exports and per capita GDP, 2011
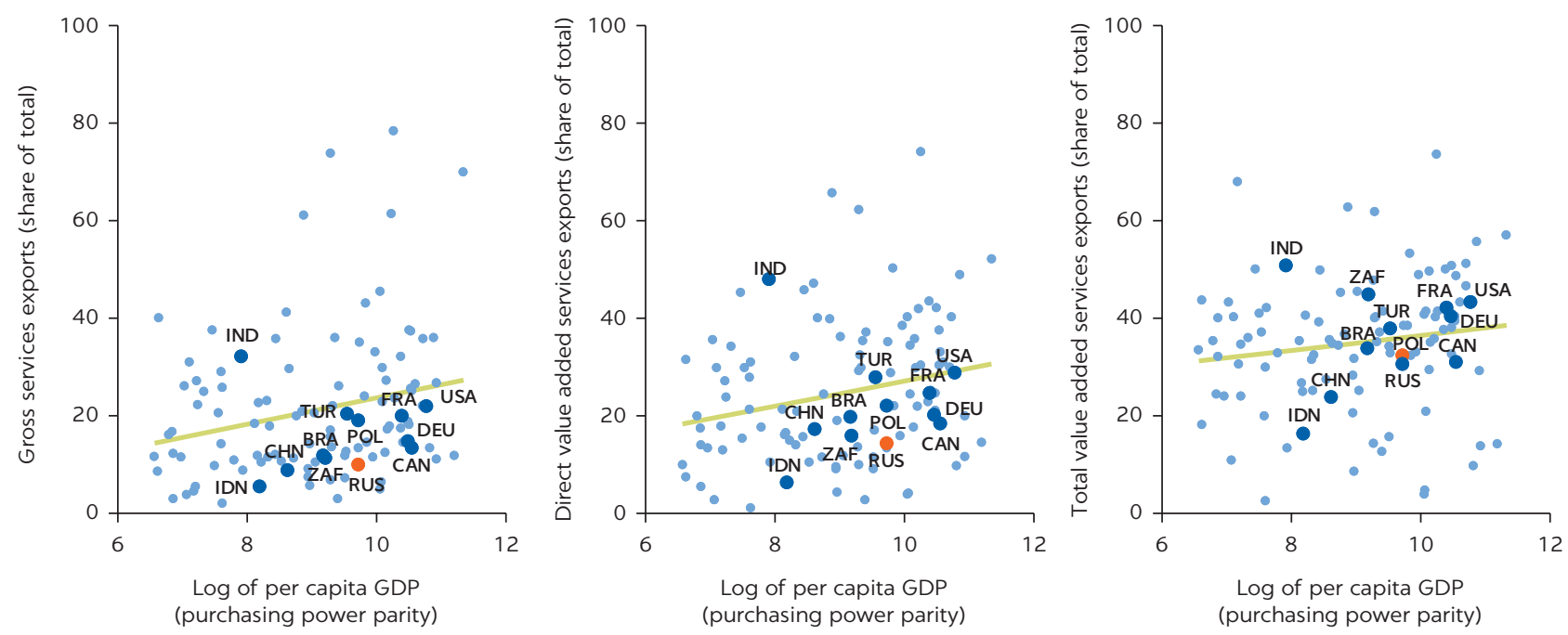

Source: World Bank Export of Value Added Database.

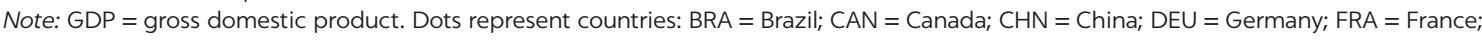

IDN = Indonesia; IND = India; POL: Poland; RUS = Russian Federation; TUR = Turkey; USA = United States of America; ZAF = South Africa.

\section{SERVICES AND REGIONAL DEVELOPMENT}

Russia is the largest country in the world. It spans nine time zones, has a complex geography and a variety of climate types, and shares borders with nine other countries. Services are critical not only for Russia's connections to the world economy but also to connect its regions with one another. This section explores the characteristics of regional services subsectors using firm-level data and assesses the extent to which internationalization of services differs by region.

Firm-level data reveal that the export revenue of firms in services, or the export propensity of firms, is low in Russia, between 1.6 (North Caucasus) and 4.5 (Far East). The average export revenue of services firms is 2.9 percent of total revenue in most regions; the large share for the Far East (12.2 percent) reflects high revenues from transportation. $\underline{5}$

Table 3.2 breaks down the average share of services exports revenue as a share of total revenue by sector. It shows that only the Central region, which is the largest region economically and includes Moscow, has export revenue in most services subsectors; the Far East, the North Caucasus, and other regions are heavily dependent on only a few sectors for export revenue. Across regions, transportation services average 6.2 percent of total revenue and professional services average 5.5 percent.

The Central region is most competitive and the South and the Volga regions least competitive. There is still much scope for services firms to become exporters, not only in the Central region but also in the Northwest, which has weak export competitiveness.

Few firms in Russia export. Of the 1,414 firms that do, 299 (21 percent) export services. Of all firms supplying services domestically, only 0.03 percent export. 
TABLE 3.2 Export revenues as a percent of total revenue in the Russian Federation, by region and services subsector

\begin{tabular}{|c|c|c|c|c|c|c|c|c|}
\hline \multirow[b]{2}{*}{ SUBSECTOR } & \multicolumn{8}{|c|}{ REGION } \\
\hline & NORTHWEST & CENTRAL & SOUTH & VOLGA & URAL & SIBERIA & FAR EAST & $\begin{array}{l}\text { NORTH } \\
\text { CAUCASUS }\end{array}$ \\
\hline $\begin{array}{l}\text { Water supply; waste } \\
\text { management }\end{array}$ & 6.8 & 0.5 & - & 0.9 & - & - & - & - \\
\hline Construction & 2.7 & 1.3 & 2.0 & 2.2 & 1.1 & 0.8 & - & 2.7 \\
\hline Distribution & 0.1 & 1.3 & 0.0 & 0.4 & 0.7 & 0.9 & 1.0 & - \\
\hline Transportation & 1.6 & 7.6 & 6.2 & 1.5 & 7.2 & 12.9 & 12.2 & 0.5 \\
\hline Tourism & - & 0.1 & - & - & 0.6 & - & - & - \\
\hline $\begin{array}{l}\text { Information and } \\
\text { telecommunications }\end{array}$ & - & 0.0 & - & - & 2.5 & - & - & - \\
\hline $\begin{array}{l}\text { Financial and } \\
\text { insurance }\end{array}$ & - & 0.0 & 0.2 & - & - & 0.5 & - & - \\
\hline Real estate & 0.1 & 0.2 & 0.1 & - & 1.0 & - & - & - \\
\hline Professional & 2.0 & 1.4 & 13.3 & 5.7 & 10.1 & 0.7 & - & - \\
\hline $\begin{array}{l}\text { Administrative } \\
\text { support }\end{array}$ & 2.7 & 0.1 & - & - & 0.0 & - & 0.4 & - \\
\hline Public administration & - & 23.1 & - & - & - & - & - & - \\
\hline Education & - & & - & - & - & - & - & - \\
\hline Health & - & 0.3 & - & - & - & - & - & - \\
\hline Arts and recreation & - & - & - & - & - & - & - & - \\
\hline $\begin{array}{l}\text { Other services } \\
\text { activities }\end{array}$ & - & - & - & 1.6 & - & - & - & - \\
\hline
\end{tabular}

Source: RUSLANA.

Note: $-=$ Not available.

Most are in the Central region (105), followed by the Volga (48), the Northwest (39), the South (36), the Ural (28), Siberia (26), the Far East (15), and the North Caucasus (2).

In the Central region, the most competitive services subsector is distribution, followed by transportation. In the Northwest, the most competitive services subsector is construction. The South's edge most competitive services subsector transportation and professional services. Most competitive services in the Ural region is transportation.

Both larger and smaller regions and districts are likely to be capable of exporting services successfully. Which are most likely to export? Competitiveness figures give only a first impression on which to base an answer. Businesses in larger markets tend to be larger than the national average, because they are able to capitalize on economies of scale and transportation costs. Hence, the larger the market, the greater the expected export revenue per firm.

This relationship is evident overall in Russia. It does not seem to hold for services, however. Both smaller and larger markets can capitalize on efficient production and export of services, probably because of technology.

Small services firms are scarce in Russia. In both the Urals and Siberia, more than 70 percent of firms are large. The share of firms with annual revenues of less than Rub 45,000 is 10 percent in the South and 9 percent in the North Caucasus. In a sample of 32 developing and developed countries, 
Freund and Pierola (2015) find that on average, the top 1 percent of firms account for 53 percent of exports. As larger firms are generally more productive and therefore more likely to export, larger Russian firms are probably responsible for most of the country's exports.

In 2010 most Russian services exports went to either Ukraine or the European Union. The North Caucasus is the most concentrated Russian region in terms of export markets (as measured by the Herfindahl-Hirschman Index); a few firms and sectors (construction and transportation) dominate its exports. The Volga region has the lowest concentration index, meaning that that the region is relatively diversified.

The Moscow subregion is the most diversified and the Arkhangelsk and Pskov subregions the least. The Nizhni Novgorod subregion is highly diversified-not surprisingly, because it adjoins the Moscow region. Subregions more distant from the capital, such as Omsk and Voronezh, also have low concentration levels

Each diversified regions has its own specialization, based on geographical endowments and development patterns. The Northwest has a comparative advantage in administrative support activities. Siberia has a comparative advantage in financial and insurance services, followed by transportation. The Central region is more productive than some other regions in health, distribution, finance, and real estate. The Ural region scores high in information and communication services. The fact that each region has its own specialization suggests that services policies will affect each region to a different degree.

Russian regions also profit from foreign direct investment (FDI) in services. FDI in Russia goes overwhelmingly to services, with only a small share invested in manufacturing. Within services, most FDI goes to the distribution sector, followed by construction services and transportation. The distribution of FDI recipients is largely similar in each region.

\section{TRADE DIAGNOSTICS FOR THE RUSSIAN FEDERATION}

\section{Traditional versus modern services exports}

Russia's exports of traditional services, such as transport and travel, are performing far better than its exports of modern services (services-such as communications, banking, insurance, business-related services, remote access services, medical records transcription, call centers, and educational services-that do not require the proximity of the buyer and supplier to be traded across borders). 6

Russia is not performing as well as some other countries at similar levels of development (figure 3.8). In 2011-13 the contribution of services exports to GDP was lower in Russia than in South Africa (although both China and Brazil performed even worse than Russia). The relationship between Russia's services trade and income level tracks that of its services value added.

Services are subject to regulatory requirements that can raise costs and restrict growth. Trade costs for services can be as much as twice as high as trade costs for goods, according to Miroudot and others (2013). Policy measures that affect only services are sometimes explicitly protectionist. Much more often, exports of services suffer from measures implemented to pursue a legitimate objective that accidentally and unnecessarily restricts trade in services. Such objectives are often pursued because services markets suffer 
FIGURE 3.8

\section{Relationship between services exports and per capita GDP, 2011-13}
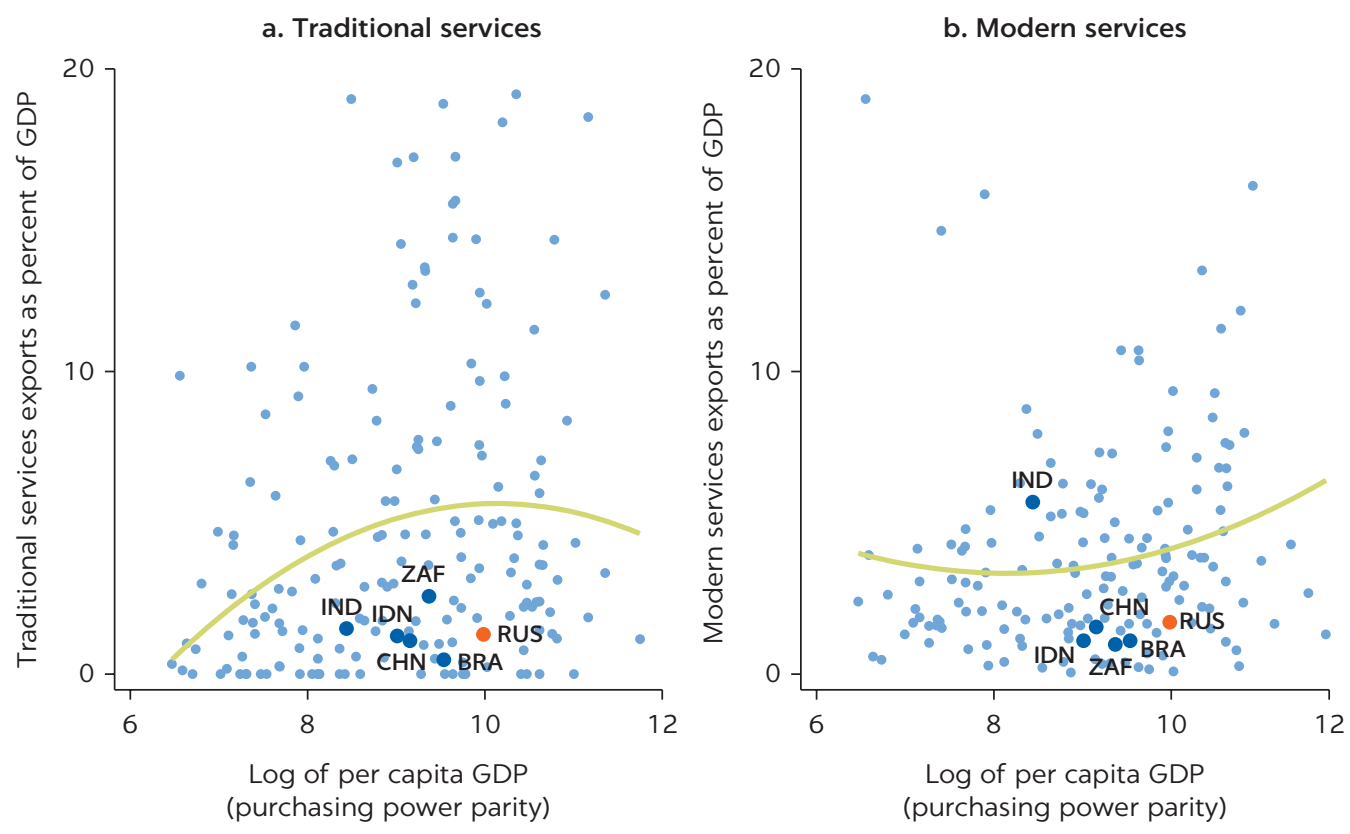

Source: World Bank World Development Indicators.

Note: Modern services are proxied using the "other commercial services category," which covers communications, construction, insurance, financial, other business, computer and information, personal recreation and cultural services and royalties. GDP = gross domestic product. Dots represent countries: $\mathrm{BRA}=\mathrm{Brazil} ; \mathrm{CHN}=\mathrm{China}$; IDN = Indonesia; IND = India; RUS = Russian Federation; ZAF = South Africa.

from market imperfections. The anti-export bias on trade in services arises if regulations are applied in ways that are economically inefficient and exacerbate costs by imposing unnecessary restrictions on free trade in services between countries. How services are regulated is critical to how well a country's trade performs.

The World Bank Services Trade Restrictiveness Index (STRI) measures the extent to which regulations are applied in ways that increase costs unnecessarily. Russia's overall STRI is in line with its level of development (figure 3.9). Russia has relatively tight regulatory restrictions in telecommunications, insurance, and financial services. These restrictions are comparable to those in India and China and more restrictive than the world average; South Africa and Brazil have less restrictive policies on these services. Professional services restrictions are tighter than in comparator countries and the world. ${ }^{7}$ Russia imposes no discriminatory restrictions on the retail sector (distribution).

Russia is somewhat protective of insurance and transport in cross-border transactions. Brazil, South Africa, and China have lower barriers in these subsectors. The main restriction in insurance is the prohibition of cross-border transactions for nonlife and life insurance); there are also limitations on the establishment of foreign insurance companies. Foreign investment in the insurance sector is capped at 25 percent of the aggregate charter capital of all insurance companies. Once this threshold is reached, no new licenses are issued to organizations that are affiliates of foreign companies (controlled by a foreign parent) or organizations in which foreign investors hold more than 49 percent of the authorized capital. 
FIGURE 3.9

\section{Relationship between the Services Trade Restrictiveness Index (STRI) and per capita GDP and services value added, 2013}

a. STRI and development

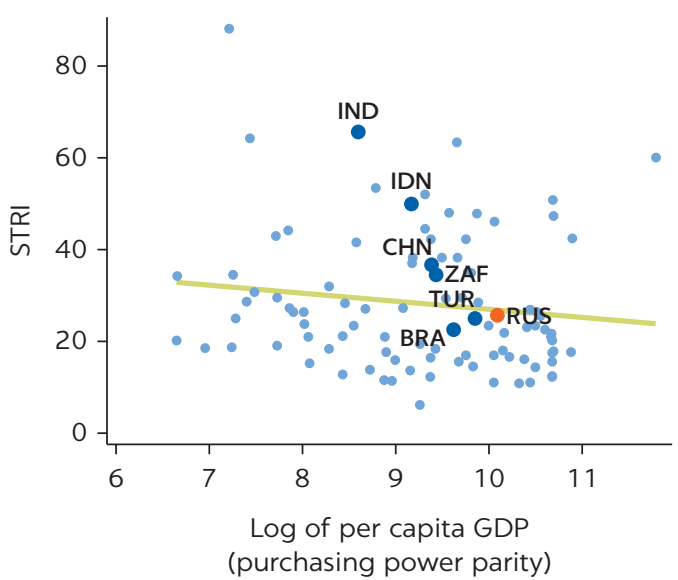

b. STRI and services value added

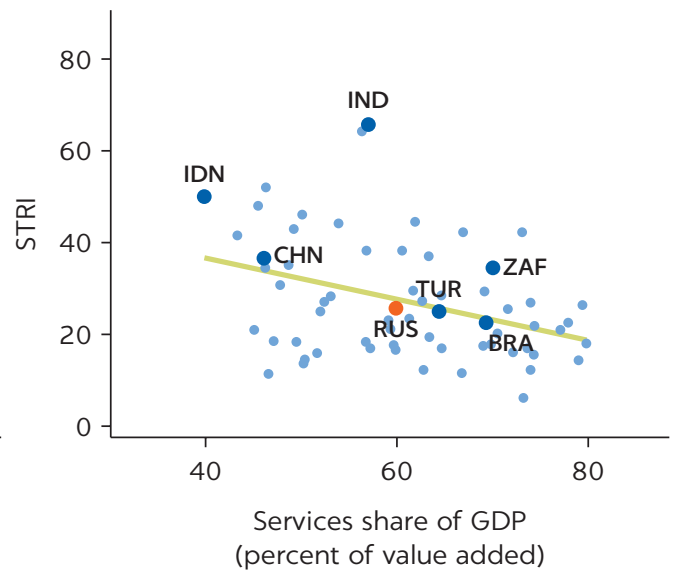

Sources: Data from World Bank World Development Indicators and Borchert, Gootiiz, and Mattoo 2012a, $2012 \mathrm{~b}$. Note: GDP = gross domestic product; PPP = purchasing power parity; STRI = Services Trade Restrictiveness Index. Dots represent countries: BRA = Brazil; $\mathrm{CHN}=$ China; IDN = Indonesia; IND = India; RUS = Russian Federation; TUR = Turkey; ZAF = South Africa.

Restrictions on direct investment or commercial presence explain the general pattern of services restrictiveness in Russia. Telecoms, professional, and to a lesser extent insurance services are more tightly regulated than the world average; restrictiveness is on a par with India. The main restrictions on telecoms relate to direct investment in both fixed and mobile networks and on insurance. Major restrictions apply to automobile, life, and reinsurance. There are also investment-related restrictions on financial services, mainly on banking. Cross-border life and auto insurance services are virtually closed, and there are major restrictions on reinsurance transactions. There are also some limited restrictions on cross-border trade in transportation services.

Domestic enabling factors (or fundamentals) also affect the performance of the services sector. They include the following:

- a country's factor endowments (such as the level of human capital, including skills and entrepreneurial ability) and natural resources (such as resources that attract tourists)

- infrastructure essential to services trade, such as a telecommunication networks that facilitate the delivery of services

- the quality of a country's rule of law or regulatory environment (Goswami, Mattoo, and Sáez 2012; van der Marel 2012).

The importance of the rule of law is related to the type of services an economy is capable of exporting. Services that are more complex tend to be more sophisticated and have higher value added. Many different contracts apply to their production. For optimal exploitation of trade in these services, the rule of law must be strong enough to enforce contracts. Russia's exports in these sectors are still extremely low, suggesting potential for increasing the role of more sophisticated and high value-added services exports. 
Figure 3.10 illustrates the negative relationship between restrictiveness and regulatory quality. The tighter the restrictions in services trade policies and direct investment in services, the lower the regulatory quality. Governments with good regulatory policies facilitate well-functioning and competitive services markets. Reducing trade restrictiveness is therefore a necessary (though not a sufficient) condition for increasing competitiveness. Domestic institutions may have a complementary role to play in creating competitive markets.

Telecoms infrastructure is a major driver of the tradability of services. Tight restrictions on investment in telecoms are likely to make it harder to raise the value of the services trade to the economy. Studies find close links between FDI and cross-border trade in services (Lennon 2009a, 2009b; Lennon, Mirza, and Nicoletti 2009). It also appears that outward FDI and services exports are complementary, as are cross-border trade and trade in direct investment services. These findings are relevant to policy, because a large proportion of services trade is facilitated through foreign affiliates.

Figure 3.11 illustrates the importance for Russia of the complementarity between cross-border trade and direct investment. Both panels show a negative relationship between restrictiveness and the share of services exports in GDP. For telecoms, Russia falls below the fitted value line, indicating much room for improvement. In finance Russia is performing below what would be predicted given the level of services trade restrictions: It has relatively tight regulatory policies in this area and relatively little trade. Relaxing regulations on investment would probably increase Russia's competitiveness in services.

Human capital is critical to the export of modern services: Countries that are better endowed with high-skilled labor and have better education export more services. They therefore usually have higher levels of services exports, as services are skill intense. Russia performs worse than expected based on these skill and education endowments (figure 3.12). It is vital that policies for the services sector recognize the importance of fully utilizing the existing potential

\section{FIGURE 3.10}

\section{Relationship between the Services Trade Restrictiveness Index (STRI) and regulatory quality, 2012}

a. Overall

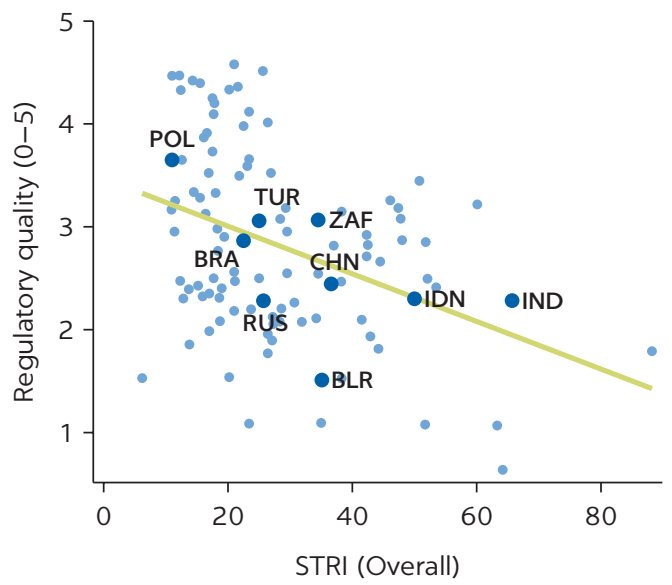

b. Financial services

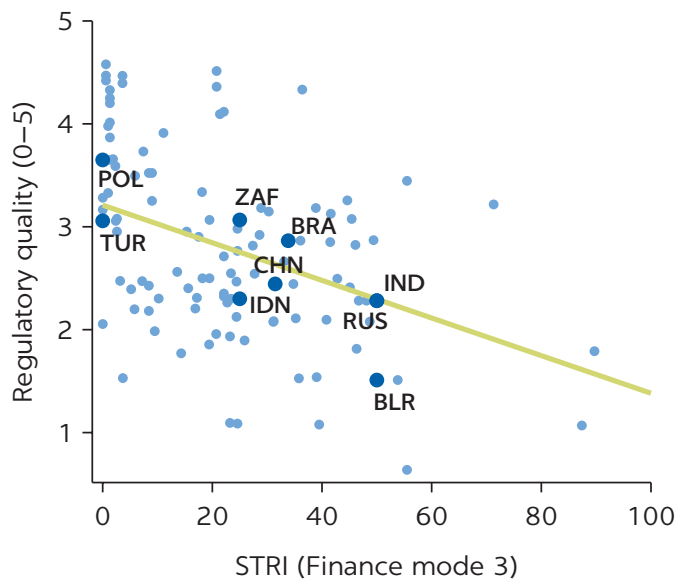

Sources: Data from the World Bank Worldwide Governance Indicators and the World Bank Services Trade Restrictiveness Index.

Note: $\mathrm{STRI}=$ Services Trade Restrictiveness Index. Dots represent countries: $\mathrm{BLR}=$ Belarus; $\mathrm{BRA}=\mathrm{Brazi} ; \mathrm{CHN}=\mathrm{China}$; IDN = Indonesia; IND = India; POL = Poland; RUS = Russian Federation; TUR = Turkey; ZAF = South Africa. 
FIGURE 3.11

Barriers to direct investment in services and cross-border services trade, 2012
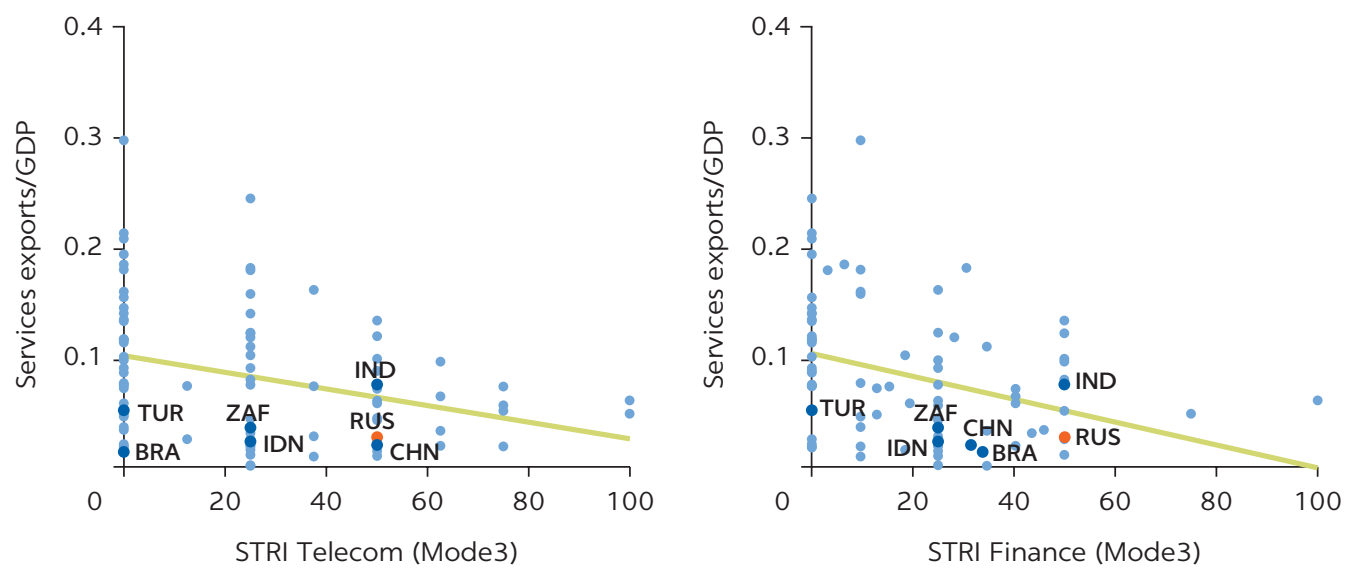

Sources: Data from World Bank Worldwide Governance Indicators and the World Bank Services Trade Restrictiveness Index.

Note: The horizontal axis shows the World Bank STRI for direct investment in telecommunications (left panel) and financial services (right panel) since Russia still shows more restrictions on direct investment for these sectors. Both vertical axes depict services trade (in logs) for cross-border trade and consumption abroad. GDP = gross domestic product; STRI = Services Trade Restrictiveness Index. Dots represent countries: BRA = Brazil; $\mathrm{CHN}=\mathrm{China}$ IDN = Indonesia; IND = India; RUS = Russian Federation; TUR = Turkey; ZAF = South Africa.

FIGURE 3.12

Correlation between services trade and human capital index and number of Internet users, 2013
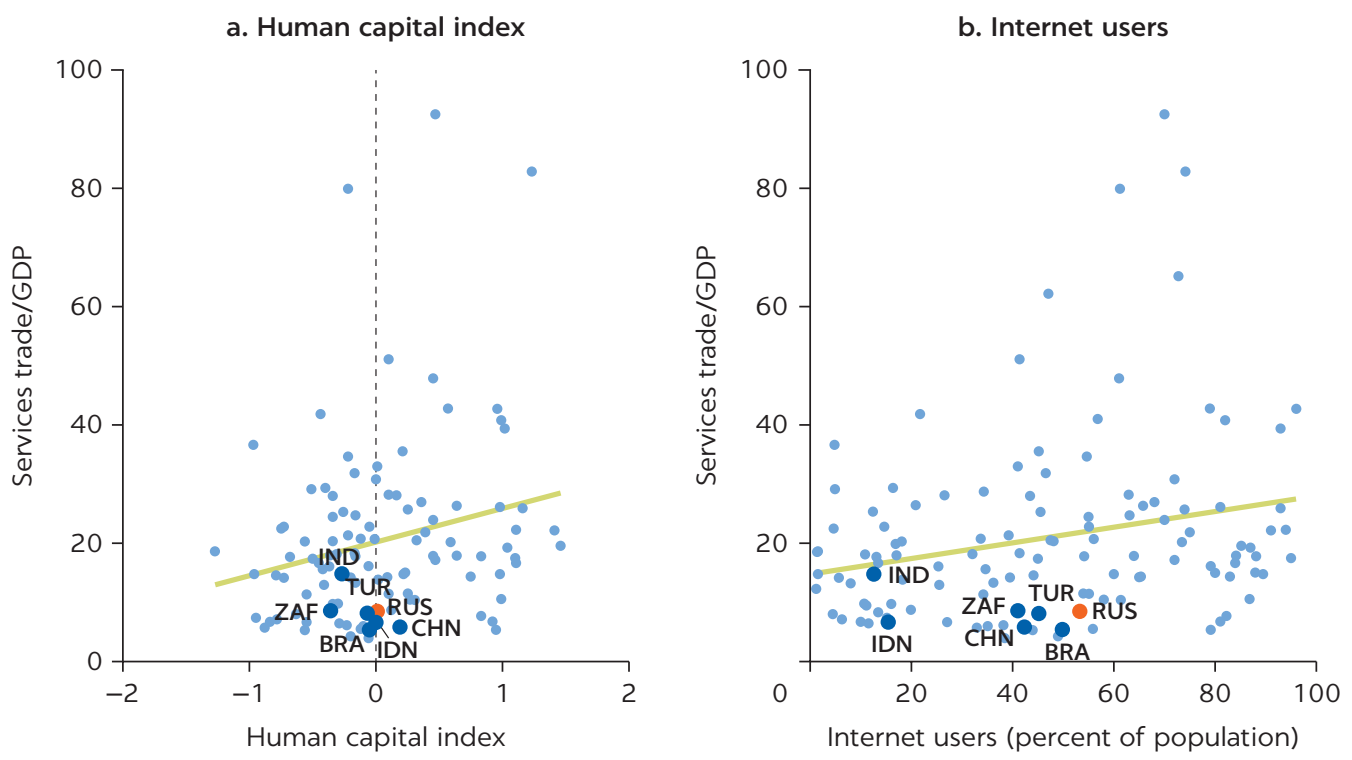

Sources: Data from World Bank World Development Indicators and the World Economic Forum 2013.

Note: GDP = gross domestic product. Dots represent countries: BRA = Brazil; $\mathrm{CHN}=\mathrm{China}$; IDN = Indonesia; IND = India; RUS = Russian Federation; TUR = Turkey; ZAF = South Africa.

given the human capital endowments and that skills are available and upgrade to take advantage of emerging services opportunities.

The growth of telecom infrastructure is the most powerful symbol of the vitality of the services sector. Electronic infrastructure has a positive effect on services exports (Freund and Weinhold 2002). Expanding Russia's services 
trade will depend critically on policies that affect telecoms infrastructure. Together with policies to make Russia more attractive to foreign investors, a strategy is needed to ensure that information and communications technology (ICT) is optimized.

\section{POLICY RECOMMENDATIONS}

Services trade can make a major contribution to Russia's development, both as inputs into other export activities and as final exports. When trade is measured in terms of value added (excluding foreign and national inputs), the contribution of services to total exports is just 8.5 percent. Services' share of total exports goes up to 32.6 percent when the contribution of services to other economic activities is considered, largely as a result of the role of services in exports of energy, which represent half of the contribution of services to total exports.

Increasing Russia's services exports will depend to a large extent on supply-side policies. Russia's regime is relatively open in terms of policies that limit or discriminate against foreign providers-and it will become even more so as the services commitments adopted on accession to the World Trade Organization (WTO) come into effect.

Russia still has onerous restrictions in some services subsectors. Jensen, Rutherford, and Tarr (2004) estimate that the largest expected gains from Russia's accession to the WTO are derived from liberalization of barriers against multinational services providers. Telecommunications, insurance, and services in general suffer from restrictions that are comparable to those of such restrictive countries as India and China and are more restrictive than the world average.

There is also scope for additional liberalization of investment measures. The FDI Regulatory Restrictiveness Index of the Organisation for Economic Co-operation and Development (OECD) shows that many activities maintain high levels of restrictiveness compared with OECD countries. Lowering the level of restrictions on FDI may benefit the emergence of new and efficient services activities by increasing competition and imports of services as well as supporting current and new exports. It will also affect enabling factors that have great influence on services-namely, institutions, governance, the rule of law, infrastructure supportive of services, and human capital.

A solid rule of law is necessary to enforce contracts, and sound governance structures are critical. The rule of law is particularly important for complex services, which tend to have higher value added.

To elevate the importance of services trade in its economy, Russia needs to enhance its human capital endowments and ICT performance. Many services subsectors are significantly more skill-intensive than goods industries, as reflected in trade patterns. Endowments of human capital are a critical determinant of exports of modern services and consequently economic output. Countries with a higher-skilled labor force and qualitatively better education export more services. Electronic infrastructure also has a positive effect on services exports. ICT has substantially expanded the scope of services trade, especially cross-border. The growth of telecommunication infrastructure is one of the most powerful symbols of the vitality of the services sector. 


\section{NOTES}

1. Certain activities that relate to both goods and services may be included in a category, as is the case in energy. The linkages between services and production activities (servicification) make this separation difficult.

2. Direct value added captures the true sector-specific value added generated within an economy, after netting out domestic and foreign inputs.

3. There are three measures of this share: the "gross" value, the "direct" measure of services in terms of value added, and the "total" contribution of services measured in terms of value added. The last measure includes the direct contribution of services to total exports, measured in terms of both their value-added content and their indirect contribution, as measured by forward linkages to other export activities. It recognizes that services are inputs in other exports of goods and services and shows which sectors contribute to the value added of final exports.

4. Distribution services include sales, maintenance, and repair of motor vehicles and motorcycles (International Standard Industrial Classification of All Economic Activities [ISIC] 50); retail sale of automotive fuel; wholesale trade and commission trade, except motor vehicles and motorcycles (ISIC 51); nonspecialized retail trade in stores (ISIC 521); retail sale of food, beverages, and tobacco in specialized stores (ISIC 522); other retail trade of new goods in specialized stores (ISIC 523); retail sale of second-hand goods in stores (ISIC 524); retail trade not in stores (ISIC 525); repair of personal and household goods (ISIC 526); and hotels and restaurants (ISIC 55).

5. The firm-level analysis applies to both Russia's eight regions (Northwest, Central, South, Volga, Ural, Siberia, Far East, and North Caucasus) and its 70 regional districts. The data allow provide only the number of exporting firms and their operational revenue in a single year, 2012; export and import data are not available in the database used.

6. The classification into traditional and modern is somewhat arbitrary, because technology is increasingly affecting the tradability of services and reducing the need for proximity. The purpose of using this classification is simply to illustrate international trends.

7. The professional services indicator refers to legal and accountancy and auditing services.

\section{REFERENCES}

Borchert, I., B. Gootiiz, and A. Mattoo. 2012a. "Guide to the Services Trade Restrictions Database.” Policy Research Working Paper 6108, World Bank, Washington, DC.

—. 2012b. "Policy Barriers to International Trade in Services: New Empirical Evidence." Policy Research Working Paper 6109, World Bank, Washington, DC.

Francois, J., M. Manchin, and P. Tomberger. 2013. "Services Linkages and the Value Added Content of Trade.” Policy Research Working Paper 6432, World Bank, Washington, DC.

Freund, C., and M. D. Pierola. 2015. "Export Superstars.” Review of Economics and Statistics 97 (5): 1023-32.

Freund, C., and D. Weinhold. 2002. "The Internet and International Trade in Services." The American Economic Review 92 (2): 236-40.

Goswami, A. G., A. Mattoo, and S. Sáez, eds. 2012. Exporting Services: A Developing Country Perspective. Washington, DC: World Bank.

Jensen, J., T. Rutherford, and D. Tarr. 2004. "The Impact of Liberalizing Barriers to Foreign Direct Investment in Services: The Case of Russian Accession to the World Trade Organization.” Policy Research Working Paper 3391, World Bank, Washington, DC.

Lennon, C. 2009a. "Trade in Services and Trade in Goods: Differences and Complementarities.” wiiw Working Paper 53, The Vienna Institute of International Economics Studies, Vienna.

—. 2009b. "Trade in Services: Cross-Border Trade vs. Commercial Presence: Evidence of Complementarity.” wiiw Working Paper 59, The Vienna Institute for International Economic Studies, Vienna. 
Lennon, C., D. Mirza, and G. Nicoletti. 2009. "Complementarity of Inputs in Services Trade." Annales d'Economie et de Statistiques 93/94 (April/June): 183-205.

Miroudot, S., J. Sauvage and B. Shepherd. 2013. "Measuring the Cost of International Trade in Services." World Trade Review, 12 (4): 719-735.

RUSLANA. (database), Bureau van Dijk, https://ruslana.bvdep.com/.

van der Marel, E. 2012. "Trade in Services and TFP: The Role of Regulation.” The World Economy 35 (11): 1530-58.

World Bank Export of Value Added Database, Washington, DC, https://datacatalog.worldbank .org/dataset/export-value-added-database.

World Bank Services Trade Restrictiveness Index (database), Washington, DC, http://iresearch .worldbank.org/servicetrade/.

World Bank World Development Indicators (database), Washington, DC, http://wdi .worldbank.org.

World Bank Worldwide Governance Indicators (database), Washington, DC, https://datacatalog .worldbank.org/dataset/worldwide-governance-indicators.

World Economic Forum. 2013. The Human Capital Report. Geneva. 



\section{Latin America and the Caribbean}





\title{
4 Performance and Productivity of Services Trade in Peru: A Competitiveness Analysis*
}

\author{
SEBASTIÁN SÁEZ AND ERIK VAN DER MAREL
}

Enhancing the competitiveness of services is particularly important as countries increasingly operate in a context of internationally fragmented models of production. This new paradigm of production is captured in the concept of global value chains, which integrate the production of goods, services, investment, and knowledge. The economic growth and development literature has established the economic benefits of exporting services (Mishra, Lundstrom, and Anand 2011; World Bank 2009).

Against this background, this chapter examines the competitiveness of Peru's services sector. It concludes that Peru has untapped potential for services exports, illustrated by the relatively low share of services exports given Peru's level of development and the fact that Peru's export structure appears to be dominated by traditional rather than modern services.

Firm-level analysis finds that most services exports in Peru take place in the district of Lima, where most services firms are located. The most productive services sector is information and communications technology (ICT) (which includes publishing, motion pictures, telecommunications, and computer services); the least productive firms are in the travel services subsector. About three-quarters of services firms that export are foreign owned. These firms have higher average value added per worker than services firms that are owned entirely by domestic private entities.

Participation by foreign services firm and increased competition in services markets increase downstream productivity: Downstream industries that are more reliant on services profit more from foreign firm participation and enhanced competition. Both foreign presence and increased competition in services have significant and positive effects on downstream productivity growth in Peru.

Peru has relatively low barriers to services trade, but its regulatory governance structures lag those of many other countries that have the same level of policy

\footnotetext{
* This chapter is based on the World Bank report Peru - Building on Success (World Bank 2015). The editors are grateful to Ekaterina Vostroknutova, Alberto Rodriguez and Pedro Rodriguez for authorization to publish.
} 
restrictiveness. Services trade accounts for much too small a share of the economy given the country's level of human capital endowments and ICT performance.

The chapter is organized as follows. The first section analyses trade in services along various dimensions, including diversification and concentration. The second section examines policies that affect firms' total factor productivity (TFP). The third section analyses the role of services in the production and exports of other economic sectors. It aims to answer the following questions: How much direct value-added in services does Peru's economy produce? How much services value added is carried forward to other sectors' production and exports? The fourth section presents the results of a trade diagnostic assessing the determinants and channels of services trade performance and evaluating the policies examined in section three in connection with "trade enablers" for services trade. The last section summarizes the chapter's main conclusions.

\section{PERU'S TRADE IN SERVICES}

\section{Exports of services}

Peru's exports of services are lower than expected given its level of development. Peru has relatively large shares of transport and travel services given its level of development: In 2012-13 the two subsectors together accounted for 88 percent of exports, the largest share among country peers (table 4.1).

"Other commercial services" (which includes professional services, finance, telecommunications, and insurance) have been growing in recent years. 1 Insurance accounted for about 8 percent of total service exports in 2012-13, a much larger share than in comparator countries. Most countries had much larger shares of other business services, such as consulting, marketing, and professional services, however.

The shares of some modern services, including finance and telecommunications, were in line with or greater than the shares in most comparator countries. Government services accounted for about 3 percent of services exports in 2012-13, a larger share than in most comparator countries. $\stackrel{2}{ }$

Peru performed poorly in terms of exports of modern services, such as ICT. It performed only marginally better in traditional services, such as transport and travel.

Figure 4.1 shows the relationship between the level of development and the level of diversification of services. It indicates that Peru's services subsectors are relatively dispersed given the country's level of development. There is nevertheless potential to increase trade (illustrated by the size of the circles) relative to the country's level of diversification. Peru's services trade is lower than peers such a Malaysia and Thailand, which have less diversified services exports.

\section{Services policies and trade performance}

Peru imports less than expected based on its level of development and services trade policies. Services imports are concentrated in the transport and ICT sectors.

Peru imports more transportation services per capita than China, Colombia, or Malaysia. Many of these services are used by downstream industries, 
TABLE 4.1 Composition of exports of "other commercial services" in selected countries, 2005-06 and 2012-13

\begin{tabular}{|c|c|c|c|c|c|c|c|c|c|c|c|c|}
\hline \multirow[b]{2}{*}{ SUBSECTOR } & \multicolumn{2}{|c|}{ PERU } & \multicolumn{2}{|c|}{ CHINA } & \multicolumn{2}{|c|}{ COLOMBIA } & \multicolumn{2}{|c|}{ MALAYSIA } & \multicolumn{2}{|c|}{ THAILAND } & \multicolumn{2}{|c|}{ SOUTH AFRICA } \\
\hline & 2005-06 & 2012-13 & 2005-06 & 2012-13 & 2005-06 & 2012-13 & 2005-06 & 2012-13 & 2005-06 & 2012-13 & 2005-06 & 2012-13 \\
\hline Travel & 66.8 & 58.3 & 31.2 & 23.6 & 51.2 & 53.2 & 47.2 & 53.1 & 51.6 & 69.9 & 66.5 & 65.6 \\
\hline Transport & 23 & 29.4 & 18 & 17.8 & 25.1 & 24.1 & 20.1 & 11.6 & 22.5 & 11.1 & 13 & 11.8 \\
\hline Other business services & 9.5 & 10.3 & 21.6 & 25.1 & 10.6 & 11.6 & 13.7 & 21.3 & 21.7 & 14.4 & 7.3 & 7.3 \\
\hline Government & 5.9 & 3.2 & 0.5 & 0.5 & 2.2 & 1.4 & 0.5 & 0.2 & 0.8 & 0.7 & 2.4 & 2.9 \\
\hline Insurance & 5.1 & 8.1 & 0.5 & 1.7 & 0 & 0.1 & 1.4 & 1.5 & 0.2 & 0.6 & 1.2 & 1.9 \\
\hline Telecom, computer & 3.5 & 3.7 & 3 & 7.7 & 7.6 & 4.7 & 5.3 & 7.2 & 1.2 & 0.9 & 2.8 & 3.2 \\
\hline Financial & 0.9 & 1.4 & 0.1 & 1.2 & 1.7 & 1.1 & 0.3 & 0.5 & 0.3 & 0.8 & 5.3 & 6 \\
\hline Intellectual property & 0.1 & 0.2 & 0.2 & 0.4 & 0.3 & 1.2 & 0.1 & 0.3 & 0.1 & 0.4 & 0.4 & 0.4 \\
\hline Maintenance and repair & 0.1 & 0 & 0.7 & 0.5 & 0 & 0.7 & 1 & 0.7 & 0 & 0 & 0 & 0 \\
\hline Personal, cultural, and recreational & 0 & 0.2 & 0.1 & 0.1 & 1.3 & 2 & 5.9 & 0.5 & 0.3 & 0.1 & 0.9 & 0.4 \\
\hline Construction & 0 & 0 & 2.6 & 5.3 & 0 & 0 & 4.4 & 3.1 & 1.3 & 1.2 & 0.3 & 0.4 \\
\hline Manufacturing services & 14.9 & 14.8 & 21.5 & 16.1 & 0 & 0 & 0 & 0 & 0 & 0 & 0 & 0 \\
\hline
\end{tabular}


FIGURE 4.1

\title{
Correlation between diversification of services exports and per capita GDP, 2009
}

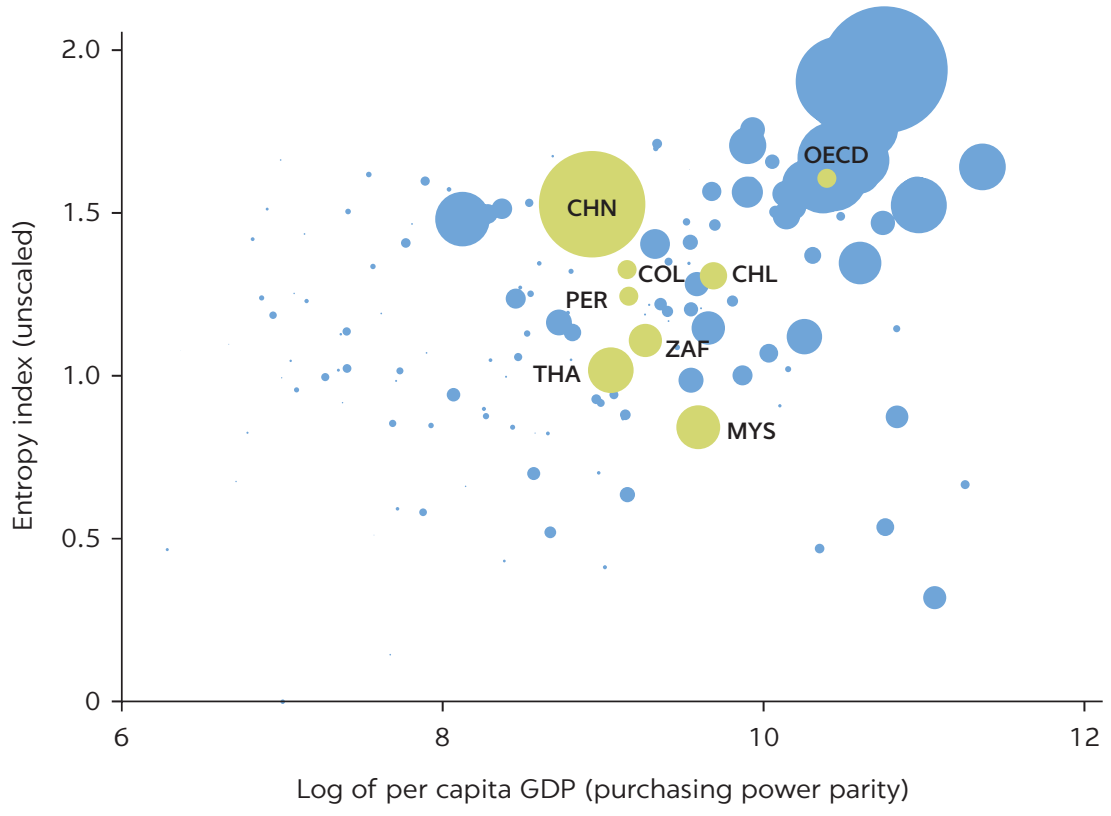

\begin{abstract}
Sources: Data from the World Bank Trade in Services Database and World Bank World Development Indicators.

Note: The Entropy Index is a measure of concentration. A higher value indicates that a country has a more diversified export portfolio. Circles represent the volume of service exports. GDP = gross domestic product; OECD = Organisation of Economic Co-operation and Development. Dots represent countries: $\mathrm{CHL}=$ Chile; $\mathrm{CHN}=$ China; $\mathrm{COL}=$ Colombia; MYS = Malaysia; PER = Peru; THA = Thailand; ZAF = South Africa.
\end{abstract}

particularly industries active in global value chains. Compared with peer countries, Peru also imports more ICT services, suggesting that these subsectors are underdeveloped domestically. Imports of financial services are also low, albeit greater than in Malaysia, South Africa, and Thailand.

Peru's imports are much lower than expected given the level of regulatory restrictions, as measured by the World Bank Services Trade Restrictiveness Index (STRI) (figure 4.2). Most countries in the Organisation for Economic Co-operation and Development (OECD) import much more per capita than Peru and have lower regulatory restrictions (figure 4.2).

Direct and forward linkages are weak in Peru. The domestic regulatory environment affects both gross exports and the exported value added of other downstream industries.

Figure 4.3 illustrates the correlation between (a) the direct value added of services exports and services policies and (b) the direct valued added of services exports plus forward linkages exported through other sectors in the economy and services policies. The correlation is stronger in panel b, suggesting that the regulatory environment may better explain the extent to which services are exported indirectly through other downstream sectors (that is, used as inputs). However, Peru is well below the fitted line in both panels, suggesting that other domestic factors explain its weak linkages. 
FIGURE 4.2

\section{Correlation between Services Trade Restrictiveness Index (STRI) and per capita} imports and exports of services, 2012

a. Correlation between STRI and imports

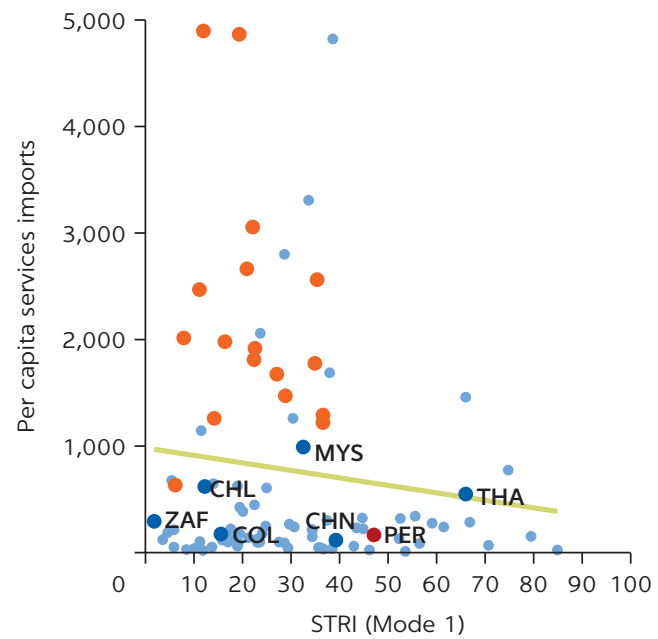

b. Correlation between STRI and exports

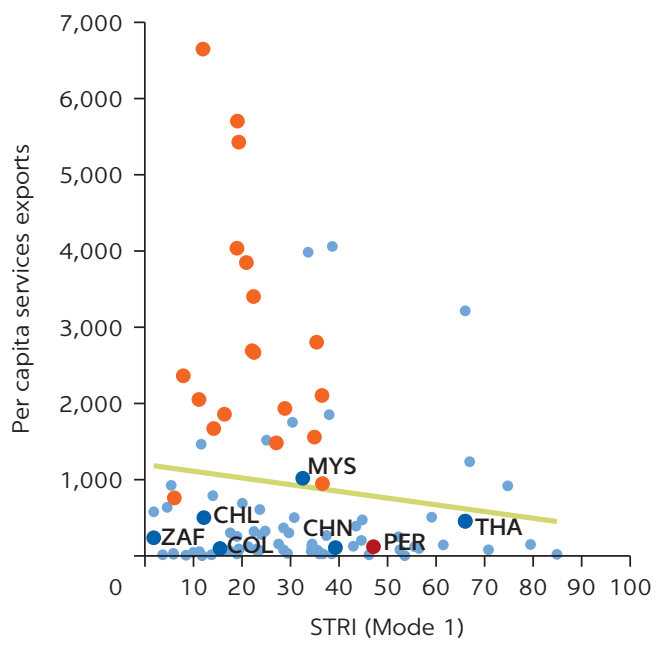

Sources: Data from World Bank World Development Indicators and Borchert, Gootiiz, and Mattoo 2012. Note: STRI = Services Trade Restrictiveness Index. Dots represent countries; red dots indicate OECD countries: $\mathrm{CHL}=$ Chile; $\mathrm{CHN}=$ China; $\mathrm{COL}=$ Colombia; $\mathrm{MYS}=$ Malaysia; $\mathrm{PER}=$ Peru; $\mathrm{THA}=$ Thailand; $\mathrm{ZAF}=$ South Africa.

FIGURE 4.3

Correlation between Services Trade Restrictiveness Index (STRI) and value added of services exports, 2011

a. Correlation between STRI and direct value added of services exports

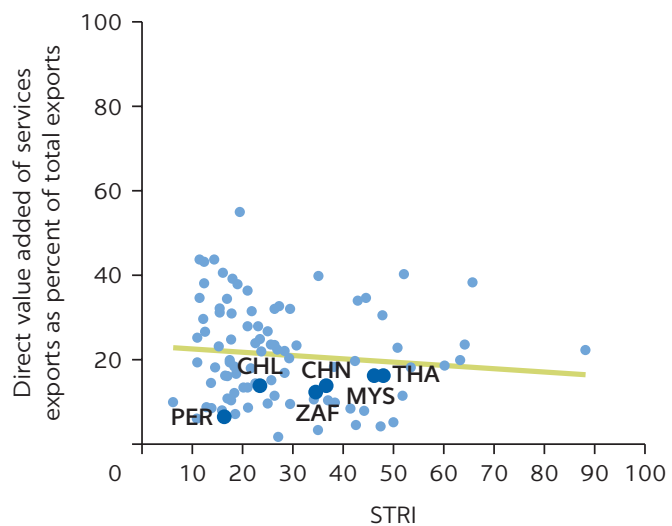

b. Correlation between STRI and total value added of services exports

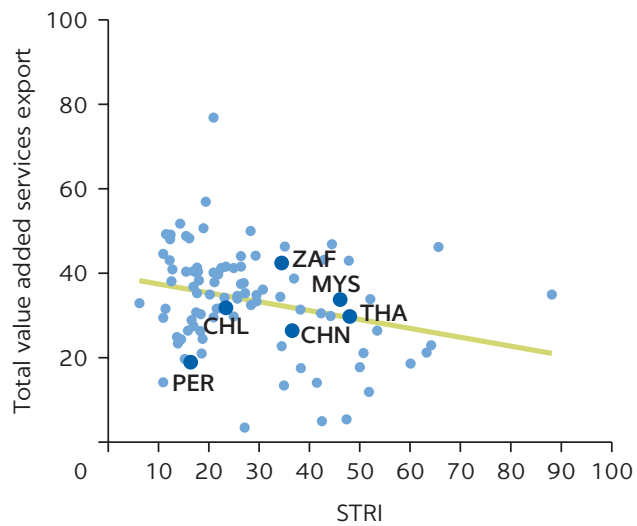

Source: Data from the World Bank Export of Value Added Database and Borchert, Gootiiz, and Mattoo 2012. Note: $\mathrm{STRI}=$ Services Trade Restrictiveness Index. Dots represent countries: $\mathrm{CHL}=\mathrm{Chile}$; $\mathrm{CHN}=\mathrm{China}$; MYS = Malaysia; PER = Peru; THA = Thailand; ZAF = South Africa.

\section{PRODUCTIVITY AND TRADE IN SERVICES}

Exporters of modern services (excluding transport, travel, and distribution) are more productive than exporters of other services (table 4.2). The empirical trade literature also finds that services exporters are more productive than nonexporters (Ariu 2016; Breinlich and Criscuolo 2011). As Peru has export densities that are relatively high in some professional services, it would be interesting to determine whether these firms are also more productive than traditional services. 
TABLE 4.2 Correlation between exporting and productivity in the modern services subsector of Peru

\begin{tabular}{|c|c|c|c|c|c|}
\hline & (1) & (2) & (3) & (4) & (5) \\
\hline ITEM & InLPQ & InLPQ_PERFORM3 & InLPV & InLPV_PERFORM3 & InTFP \\
\hline \multirow[t]{2}{*}{ exporter_ } & $0.222^{* * *}$ & $0.146^{* * *}$ & $0.523^{* * *}$ & $0.363^{* * *}$ & $0.235^{*}$ \\
\hline & $(0.0552)$ & (0.0290) & $(0.0706)$ & (0.0479) & $(0.126)$ \\
\hline \multirow{2}{*}{$\begin{array}{l}\text { exporter_- } \\
\text { exporter of } \\
\text { modern } \\
\text { services }\end{array}$} & $1.652^{* * *}$ & $1.536^{* * *}$ & $2.066^{* * *}$ & $1.841^{* * *}$ & $0.497^{* * *}$ \\
\hline & $(0.0138)$ & $(0.00724)$ & $(0.0177)$ & (0.0120) & $(8.44 \mathrm{e}-11)$ \\
\hline Observations & 4,840 & 4,840 & 4,753 & 4,753 & 3,549 \\
\hline$R$-squared & 0.519 & 0.170 & 0.264 & 0.203 & 0.266 \\
\hline $\begin{array}{l}\text { Root mean } \\
\text { square error }\end{array}$ & 0.965 & 0.652 & 0.904 & 0.644 & 1.051 \\
\hline
\end{tabular}

Source: Encuestas Economicas Anuales 2012

Note: Robust and clustered standard errors in parenthesis. Regressions are performed with ISIC three-digit fixed effects using ordinary least squares. Total factor productivity figures are from 2012, the latest year available. InLPQ = logarithm of Sales per worker; InLPV = logarithm of Value added per worker; InTFP = logarithm Total Factor Productivity.

*** $p<0.01,{ }^{* *} p<0.05, * p<0.1$.

TABLE 4.3 Correlation between use of software and exporting of services in Peru, 2013

\begin{tabular}{|c|c|c|c|c|c|c|c|}
\hline \multirow[b]{2}{*}{ ITEM } & \multicolumn{7}{|c|}{ EXPORTER (YES/NO) } \\
\hline & (1) & (2) & (3) & (4) & (5) & (6) & (7) \\
\hline \multirow[t]{2}{*}{$\ln ($ software) } & $0.411^{* * *}$ & & & & $0.336^{* * *}$ & $0.266^{*}$ & $0.543^{* *}$ \\
\hline & $(0.0319)$ & & & & $(0.0661)$ & $(0.141)$ & $(0.224)$ \\
\hline \multirow[t]{2}{*}{$\ln (R \& D)$} & & $0.289^{* * *}$ & & & 0.0754 & -0.0211 & -0.282 \\
\hline & & $(0.0235)$ & & & $(0.0565)$ & (0.159) & $(0.249)$ \\
\hline \multirow[t]{2}{*}{ In(concessions) } & & & $0.304 * * *$ & & & $0.153^{* *}$ & \\
\hline & & & $(0.0323)$ & & & $(0.0647)$ & \\
\hline \multirow[t]{2}{*}{ In(patents) } & & & & $0.211^{* * *}$ & & & $0.352^{* * *}$ \\
\hline & & & & $(0.0584)$ & & & $(0.0938)$ \\
\hline Observations & 1,161 & 1,990 & 690 & 165 & 1,161 & 272 & 103 \\
\hline Pseudo $R^{2}$ & 0.157 & 0.143 & 0.161 & 0.102 & 0.157 & 0.158 & 0.202 \\
\hline
\end{tabular}

Source: Encuestas Economicas Anuales 2012.

Note: Table reports results of logit probability regressions. Robust and clustered standard errors in parenthesis. Regressions are performed with ISIC three-digit fixed effects. R\&D = research and development.

${ }^{* * *} p<0.01,{ }^{* *} p<0.05,{ }^{*} p<0.1$.

Table 4.2 regresses various measures of productivity calculated with the firmlevel data on the export status of a firm, for all sectors and for modern services only. The results show that modern services providers are more productive than other firms.

\section{Effect of spending on software on productivity}

Spending on software is correlated with exporting services in Peru. As the Internet has expanded the scope of services trade, delivering services to external 
markets should have an effect on the exporter status of the firm. Electronic infrastructure has a positive effect on services exports (Freund and Weinhold 2002).

Using expenditures on software as a share of total research and development (R\&D) expenditures at the firm level gives a rough idea of whether ICT infrastructure helps firms reach foreign markets. Table 4.3 shows that being an exporter is highly correlated with the use of software, even after controlling for other R\&D factors (which are not correlated with how much services providers are exporting [the intensive margin of trade]).

\section{Effect of foreign and domestic capital on productivity}

Other factors may also have an effect on the extensive and intensive margin of services trade and whether an exporting firm in services is more productive. They include whether a firm is privately or publicly owned, whether it receives foreign direct investment, and the extent to which regulation is in place.

Nearly three-quarters of services exporters in Peru are foreign owned; only 22 percent are domestically privately owned. About 3 percent of exporters in Peru are of a mixed (domestic and foreign) ownership. The remaining exporting firms in Peru are also mixed but have some level of state interference (about 3 percent) or are associations (about 0.7 percent).

Value added tends to be higher in most business and professional services than in traditional services in Peru (figure 4.4, panel a). The most productive services subsector is ICT, which covers publishing, motion pictures, telecommunications, and computer services. The least productive firms are in the travel subsector. Foreign-owned firms show higher levels of value added per worker than private domestically owned firms, except in the transport sector, where domestic companies are more productive than foreign firms. The biggest difference in productivity between foreign and domestic firms is in the professional services subsectors,

FIGURE 4.4

Value added of services exporters and total factor productivity in Peru, by type of ownership and subsector, 2012

a. Value added of services by private exporters

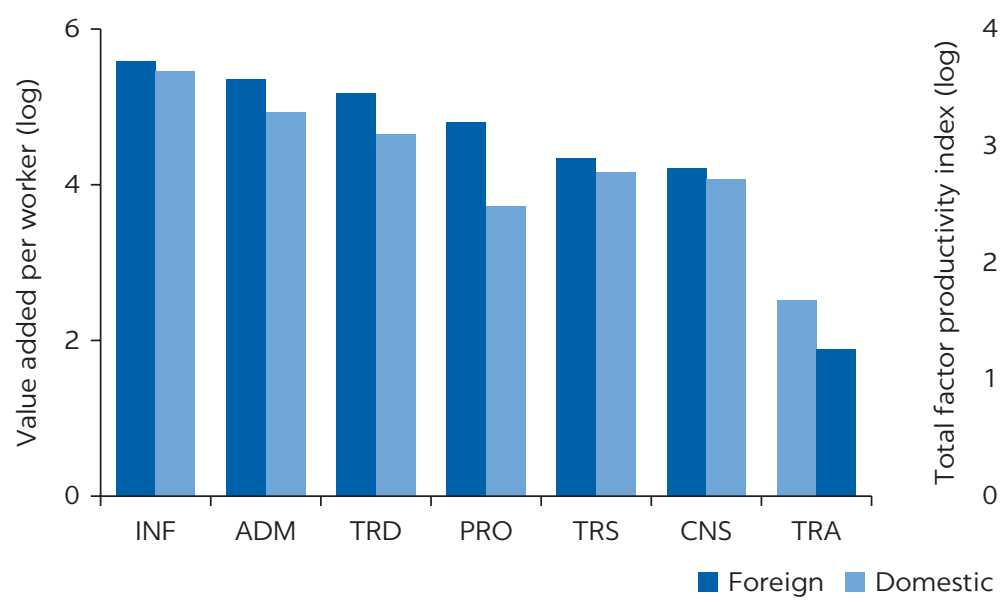

b. Total factor productivity of private services exporters

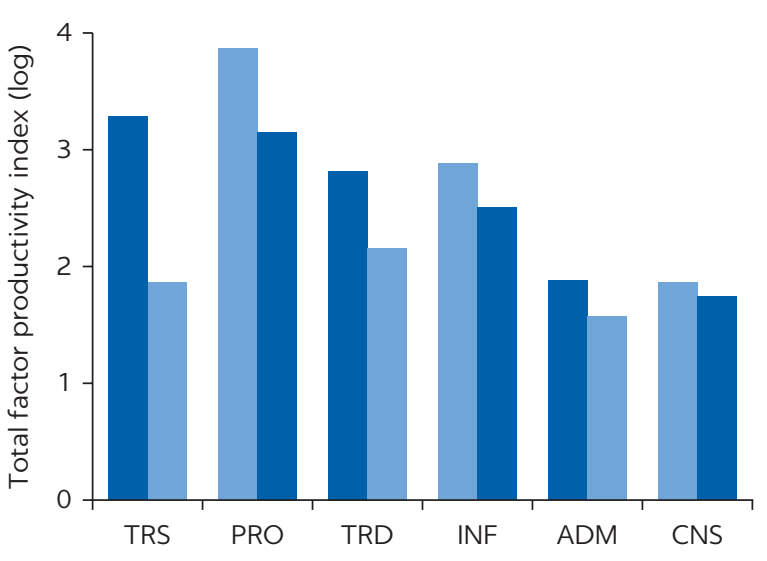

Source: Encuestas Economicas Anuales 2012.

Note: $\mathrm{ADM}=$ administrative and support services; $\mathrm{CNS}=$ construction; INF = information and communication; PRO = professional, scientific, and technical services; TRA $=$ travel services; TRD $=$ wholesale and retail; TRS $=$ transportation and storage. 
such as architectural and engineering services; R\&D; advertising market research; and other professional, scientific, and technical activities.

These results are slightly different for TFP (figure 4.4, panel b). Domestic firms providing professional services, information services, and construction services have higher TFP than foreign firms. For transport services, foreign firms have higher TFP

Foreign owned and private domestically owned firms are more productive than firms that still include some state ownership (table 4.4). In addition, the interaction terms for both variables with a dummy capturing whether a firm is an exporter reveals that only firms that are both exporters and have a large share of foreign capital are significantly more productive than other firms in terms of value added per worker. Exporters with large shares of domestic private capital do not enjoy this productivity premium.

Alternative indicators measuring foreign participation using a dummy variable confirm the importance of foreign capital in increasing productivity. The results on the role of exporters are mixed. Table 4.5 replicates table 4.4 with foreign and domestic private dummies (as opposed to shares) to verify the robustness of the results. Using these dummy variables allows TFP to be included in the regressions (columns 5-6 in table 4.4). Value added per worker is higher for exporters than nonexporters among domestic private firms but not foreign firms (column 6 in table 4.5).

\section{Effect of regulations on productivity}

Regulations are an important determinant of firms' productivity (van der Marel 2012). The STRI measures the extent to which domestic services markets are protected from foreign competition. Protection affects both imports and exports of services, because some of these barriers affect all firms in a market (Nordå and Rouzet 2015; Sáez and others 2014).

TABLE 4.4 Correlation between productivity and foreign and domestic private capital shares in Peru, 2012

\begin{tabular}{|c|c|c|c|c|c|c|}
\hline & $(1)$ & (2) & (3) & (4) & (5) & (6) \\
\hline ITEM & InLPQ & InLPQ & InLPV & InLPV & InTFP & InTFP \\
\hline \multirow[t]{2}{*}{ Foreign share } & $0.792^{* * *}$ & $0.818^{* * *}$ & $0.988^{* * *}$ & $0.880^{* * *}$ & $3.165^{* * *}$ & $3.113^{* * *}$ \\
\hline & $(0.0966)$ & $(0.120)$ & $(0.134)$ & $(0.138)$ & $(0.0955)$ & $(0.177)$ \\
\hline \multirow[t]{2}{*}{ Domestic private share } & $0.820^{* * *}$ & $0.785^{* * *}$ & $0.640^{* * *}$ & $0.785^{* * *}$ & $3.135^{* * *}$ & $3.282^{* * *}$ \\
\hline & $(0.130)$ & $(0.162)$ & $(0.181)$ & $(0.185)$ & $(0.270)$ & $(0.500)$ \\
\hline \multirow[t]{2}{*}{ Foreign share * exporter } & & 0.0448 & & $0.563^{* * *}$ & & 0.0419 \\
\hline & & $(0.161)$ & & $(0.182)$ & & $(0.257)$ \\
\hline \multirow{2}{*}{$\begin{array}{l}\text { Domestic private share } \\
\text { * exporter }\end{array}$} & & 0.448 & & 0.138 & & -0.543 \\
\hline & & $(0.334)$ & & $(0.253)$ & & $(0.523)$ \\
\hline Observations & 156 & 156 & 159 & 159 & 96 & 96 \\
\hline$R$-squared & 0.566 & 0.572 & 0.400 & 0.420 & 0.515 & 0.521 \\
\hline Root mean square error & 0.890 & 0.890 & 0.942 & 0.933 & 1.034 & 1.042 \\
\hline
\end{tabular}

Source: Encuestas Economicas Anuales 2012

Note: The variable "domestic public share of capital" is omitted and is therefore the reference group. Robust and clustered standard errors are in parenthesis. Regressions are performed with ISIC two-digit fixed effects using ordinary least squares. InLPQ: logarithm sales per worker; InLPV: logarithm value-added per worker; InTFP: logarithm total factor productivity. ${ }^{* * *} p<0.01,{ }^{* *} p<0.05,{ }^{*} p<0.1$. 
TABLE 4.5 Correlation between productivity and foreign and domestic private capital (dummy) in Peru, 2012

\begin{tabular}{|c|c|c|c|c|c|c|}
\hline & (1) & (2) & (3) & (4) & (5) & (6) \\
\hline ITEM & InLPQ & InLPQ & InLPV & InLPV & InTFP & InTFP \\
\hline \multirow[t]{2}{*}{ Foreign dummy } & $0.306^{* * *}$ & $0.240^{*}$ & $0.464^{* *}$ & $0.267^{*}$ & 0.291 & 0.228 \\
\hline & $(0.0924)$ & $(0.130)$ & $(0.181)$ & $(0.141)$ & $(0.195)$ & $(0.153)$ \\
\hline \multirow[t]{2}{*}{ Domestic private dummy } & -0.0177 & -0.0200 & $-0.144^{*}$ & $-0.190 * *$ & $-0.432^{* * *}$ & $-0.456^{* * *}$ \\
\hline & $(0.0776)$ & $(0.0803)$ & $(0.0836)$ & $(0.0719)$ & $(0.126)$ & $(0.122)$ \\
\hline \multirow[t]{2}{*}{ Foreign dummy ${ }^{*}$ exporter } & & 0.164 & & $0.510^{* * *}$ & & 0.178 \\
\hline & & $(0.139)$ & & $(0.177)$ & & $(0.171)$ \\
\hline \multirow[t]{2}{*}{ Domestic private dummy * exporter } & & 0.0255 & & $0.491^{* * *}$ & & $0.273^{* * *}$ \\
\hline & & $(0.0606)$ & & $(0.110)$ & & $(0.0605)$ \\
\hline Observations & 4,719 & 4,719 & 4,640 & 4,640 & 3,469 & 3,469 \\
\hline$R$-squared & 0.486 & 0.486 & 0.217 & 0.235 & 0.237 & 0.241 \\
\hline Root mean square error & 0.990 & 0.990 & 0.926 & 0.915 & 1.058 & 1.056 \\
\hline
\end{tabular}

Source: Encuestas Economicas Anuales 2012.

Note: The dummy variable "domestic public" was omitted and is therefore the reference group. Robust and clustered standard errors are in parenthesis. Regressions are performed with ISIC two-digit fixed effects using ordinary least squares. InLPQ = logarithm sales per worker; InLPV = logarithm valueadded per worker; InTFP = logarithm total factor productivity.

*** $p<0.01, * * p<0.05, * p<0.1$.

TABLE 4.6 Correlation between downstream productivity and services reform in Peru, 2008-13

\begin{tabular}{|c|c|c|c|c|c|c|c|c|c|}
\hline & (1) & (2) & (3) & (4) & (5) & (6) & (7) & (8) & (9) \\
\hline ITEM & InLPQ & InLPQ & InLPQ & InLPQ & InLPQ & InLPQ & InTFP & InTFP & InTFP \\
\hline \multirow[t]{2}{*}{ Foreign linkage } & $0.389 *$ & & & $0.480^{* *}$ & & & $0.358^{* *}$ & & \\
\hline & $(0.222)$ & & & $(0.216)$ & & & $(0.179)$ & & \\
\hline \multirow[t]{2}{*}{ Competition 1} & & $0.0997^{* *}$ & & & $0.0636^{*}$ & & & $0.147^{*}$ & \\
\hline & & $(0.0404)$ & & & $(0.0378)$ & & & $(0.0807)$ & \\
\hline \multirow[t]{2}{*}{ Competition 2} & & & 0.0451 & & & 0.0290 & & & $0.180^{* *}$ \\
\hline & & & $(0.0429)$ & & & $(0.0388)$ & & & $(0.0726)$ \\
\hline \multirow{2}{*}{$\begin{array}{l}\text { Foreign capital exceeds } \\
25 \text { percent }\end{array}$} & 0.0470 & $0.0999 * * *$ & $0.100^{* * *}$ & 0.0111 & 0.00573 & 0.00578 & -0.0689 & 0.0525 & 0.0537 \\
\hline & $(0.0452)$ & $(0.0243)$ & $(0.0243)$ & $(0.0486)$ & $(0.0247)$ & $(0.0247)$ & $(0.0561)$ & $(0.0341)$ & $(0.0343)$ \\
\hline Observations & 14,575 & 43,213 & 43,213 & 14,353 & 42,062 & 42,062 & 10,635 & 35,536 & 35,536 \\
\hline$R$-squared & 0.971 & 0.935 & 0.935 & 0.938 & 0.869 & 0.869 & 0.959 & 0.881 & 0.881 \\
\hline Root mean square error & 0.395 & 0.413 & 0.414 & 0.461 & 0.468 & 0.468 & 0.436 & 0.519 & 0.519 \\
\hline
\end{tabular}

Source: Encuestas Economicas Anuales 2012.

Note: Robust standard errors clustered by sector-year are in parentheses. Competition 1 includes the Herfindahl-Hirschman Index. Competition 2 covers the top five firms in terms of sales. InLPQ = logarithm sales per worker; InTFP = logarithm total factor productivity.

$* * * p<0.01, * * p<0.05, * p<0.1$

Estimates from the World Bank and the OECD measuring product market regulations for Peru yield further insight into Peru's domestic regulatory policies. These behind-the-border regulatory policies affect domestic (and possibly foreign) services firms and likely reduce the productivity of services firms in Peru.

Tables 4.6 and 4.7 report the results of firm-level analysis that regresses the productivity of all Peruvian firm in downstream industries and services linkages. This linkage is then interacted with a variable measuring services reform. These reform variables are outcome variables that encompass both policies 
TABLE 4.7 Correlation between downstream productivity growth (1-year lag) and services reform in Peru, 2008-13

\begin{tabular}{|c|c|c|c|c|c|c|c|c|c|}
\hline & (1) & (2) & (3) & (4) & (5) & (6) & (7) & (8) & (9) \\
\hline ITEM & InLPQg & InLPQg & InLPQg & InLPVg & $\operatorname{lnLPVg}$ & InLPVg & InTFPg & InTFPg & InTFPg \\
\hline \multirow[t]{2}{*}{ Foreign linkage } & $0.703^{*}$ & & & $0.944^{*}$ & & & 0.485 & & \\
\hline & $(0.423)$ & & & $(0.514)$ & & & $(0.502)$ & & \\
\hline \multirow[t]{2}{*}{ Competition 1} & & $0.216^{* * *}$ & & & 0.0568 & & & $0.257^{* *}$ & \\
\hline & & $(0.0575)$ & & & $(0.0735)$ & & & $(0.124)$ & \\
\hline \multirow[t]{2}{*}{ Competition 2} & & & $0.153^{* *}$ & & & 0.0207 & & & 0.200 \\
\hline & & & $(0.0613)$ & & & $(0.0721)$ & & & (0.134) \\
\hline \multirow{2}{*}{$\begin{array}{l}\text { Foreign capital exceeds } \\
25 \text { percent }\end{array}$} & -0.0641 & -0.0340 & -0.0333 & -0.116 & -0.0574 & -0.0574 & -0.139 & $-0.168^{* *}$ & $-0.167^{* *}$ \\
\hline & $(0.0586)$ & $(0.0316)$ & $(0.0318)$ & $(0.0723)$ & $(0.0348)$ & $(0.0348)$ & $(0.0963)$ & $(0.0685)$ & $(0.0689)$ \\
\hline Observations & 8,850 & 22,675 & 22,675 & 8,641 & 22,088 & 22,088 & 8,727 & 28,934 & 28,934 \\
\hline$R$-squared & 0.671 & 0.455 & 0.454 & 0.622 & 0.426 & 0.426 & 0.790 & 0.551 & 0.551 \\
\hline Root mean square error & 0.515 & 0.482 & 0.482 & 0.649 & 0.582 & 0.582 & 0.784 & 0.914 & 0.914 \\
\hline
\end{tabular}

Source: Encuestas Economicas Anuales 2012.

Note: Robust standard errors clustered by sector-year are in parentheses. Competition 1 includes the Herfindahl-Hirschman Index. Competition 2 covers the top five firms in terms of sales. InLPQg = logarithm growth sales per worker growth; InLPVg = logarithm growth value-added per worker; $\operatorname{lnTFPg}=$ logarithm growth total factor productivity.

${ }^{* * *} p<0.01,{ }^{* *} p<0.05, * p<0.1$

and implementation. Using them provides insight into the relative importance of various aspects of services reform.

Both participation of foreign services firms and increased competition in Peru's services markets have improved downstream productivity in Peru. In particular, the presence of foreign firms in upstream services markets had a significant effect on sales per worker (lnLPQ) in Peru's downstream industries, but so did increased competition in services, as shown in columns 2 and 3 in table 4.7. The presence of foreign firms in Peruvian upstream services markets also played a significant role in increasing downstream value added per worker (lnLPv), as shown in column 4. The size of the coefficient outcomes between the two performance variables suggests that the presence of foreign firms in Peru's services sector has a stronger impact on sales or value added per worker in downstream sectors using services. The presence of foreign firms has no meaningful impact on TFP, as shown by the insignificant result in column 7. Instead, increased competition in services has a significant impact on TFP in Peru's downstream sector.

Both foreign presence and increased competition in services have significant and positive effects on downstream productivity growth in Peru. Reforms also have a significant effect on productivity, as shown in table 4.7, in which the dependent variables of productivity used in table 4.6 are used with growth levels lagged 1 year. The results indicate that the level of increased competition has a stronger effect than foreign participation in services firm. In column 2 the first competition indicator is significant at the 1 percent level, and the coefficient is substantial. The alternative competition indicator (column 3 ) is also significant, but only at the 5 percent level. Neither competition indicator has a significant effect on value added per worker, and foreign presence has no significant effect on TFP. One of the competition indicators appears to have a significant effect on the TFP of downstream manufacturing. 


\section{CONTRIBUTION OF SERVICES TO ECONOMIC PERFORMANCE}

This section assesses the contribution of services to the value added of Peru's domestic production and exports using various measures of the direct and indirect involvement of these services..$^{\underline{3}}$ It is based on the World Bank Export of Value Added Database.

Backward and forward linkages reflect the interdependence of sectors of the economy. In a sector with strong backward linkages, an increase in demand for output has a large impact on sectors that supply it with inputs. In a sector with strong forward linkages, an increase in demand for other industries' output has a large impact on that sector.

Tables 4.8 shows the sectoral composition of the value added of Peru's domestic economy. Table 4.9 shows the sectoral composition of the value added Peru's exports. The last column in each table shows the total domestic value added and exported value added, respectively, including forward linkages. The last row in each table shows total domestic value added and exported value added, respectively, including backward linkages.

TABLE 4.8 Sectoral composition of value added of Peru's domestic economy, 2011 (percent of total domestic value added)

\begin{tabular}{|c|c|c|c|c|c|c|c|c|c|c|c|c|c|c|c|}
\hline SECTOR & $\underset{\substack{\frac{\alpha}{\alpha} \\
\frac{\alpha}{\alpha}}}{\grave{c}}$ & 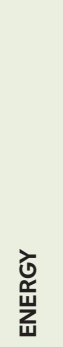 & 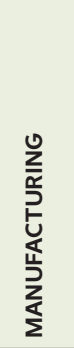 & $\sum_{\substack{\tilde{u} \\
\text { 㟧 }}}$ & 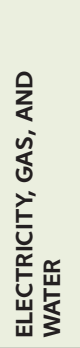 & 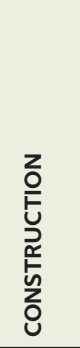 & 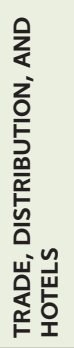 & 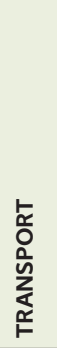 & 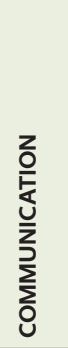 & 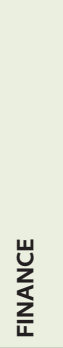 & 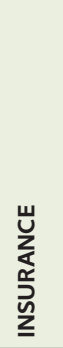 & 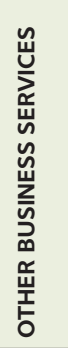 & 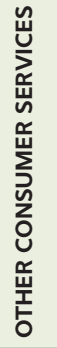 & 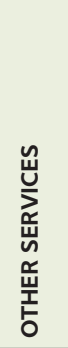 & 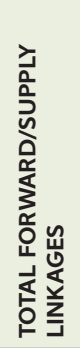 \\
\hline Primary & 10.1 & 0.0 & 5.0 & 1.0 & 0.0 & 0.2 & 0.3 & 0.1 & 0.0 & 0.0 & 0.0 & 0.0 & 0.1 & 0.2 & 16.2 \\
\hline Energy & 0.2 & 0.2 & 0.8 & 1.0 & 0.0 & 0.1 & 0.1 & 0.5 & 0.0 & 0.0 & 0.0 & 0.0 & 0.1 & 0.1 & 2.1 \\
\hline Manufacturing & 2.5 & 0.0 & 26.5 & 8.7 & 0.0 & 2.8 & 1.7 & 1.1 & 0.1 & 0.0 & 0.1 & 0.2 & 0.9 & 1.8 & 37.7 \\
\hline Services & 1.9 & 0.0 & 4.8 & 37.2 & 0.0 & 12.8 & 3.8 & 4.0 & 1.2 & 0.6 & 0.9 & 1.5 & 4.5 & 8.0 & 44.0 \\
\hline $\begin{array}{l}\text { Electricity, gas, } \\
\text { and water }\end{array}$ & 0.0 & 0.0 & 0.1 & 0.1 & 0.0 & 0.0 & 0.0 & 0.0 & 0.0 & 0.0 & 0.0 & 0.0 & 0.0 & 0.0 & 0.2 \\
\hline Construction & 0.0 & 0.0 & 0.2 & 11.0 & 0.0 & 10.7 & 0.1 & 0.0 & 0.0 & 0.0 & 0.0 & 0.0 & 0.0 & 0.1 & 11.2 \\
\hline $\begin{array}{l}\text { Trade, distribu- } \\
\text { tion, and hotels }\end{array}$ & 0.1 & 0.0 & 0.5 & 1.7 & 0.0 & 0.1 & 1.3 & 0.1 & 0.0 & 0.0 & 0.0 & 0.0 & 0.0 & 0.1 & 2.4 \\
\hline Transport & 0.2 & 0.0 & 0.4 & 2.7 & 0.0 & 0.2 & 0.2 & 2.1 & 0.0 & 0.0 & 0.0 & 0.0 & 0.0 & 0.1 & 3.3 \\
\hline Communication & 0.1 & 0.0 & 0.3 & 1.9 & 0.0 & 0.1 & 0.2 & 0.1 & 1.1 & 0.0 & 0.0 & 0.0 & 0.1 & 0.2 & 2.4 \\
\hline Finance & 0.3 & 0.0 & 0.8 & 1.9 & 0.0 & 0.3 & 0.4 & 0.3 & 0.0 & 0.5 & 0.0 & 0.0 & 0.1 & 0.2 & 3.0 \\
\hline Insurance & 0.1 & 0.0 & 0.1 & 0.9 & 0.0 & 0.1 & 0.0 & 0.1 & 0.0 & 0.0 & 0.7 & 0.0 & 0.0 & 0.0 & 1.1 \\
\hline $\begin{array}{l}\text { Other business } \\
\text { services }\end{array}$ & 0.9 & 0.0 & 2.0 & 6.0 & 0.0 & 1.2 & 1.3 & 1.1 & 0.0 & 0.0 & 0.1 & 1.4 & 0.2 & 0.6 & 8.9 \\
\hline $\begin{array}{l}\text { Other consumer } \\
\text { services }\end{array}$ & 0.1 & 0.0 & 0.2 & 4.9 & 0.0 & 0.1 & 0.1 & 0.1 & 0.0 & 0.0 & 0.0 & 0.0 & 3.9 & 0.6 & 5.2 \\
\hline Other services & 0.0 & 0.0 & 0.1 & 6.1 & 0.0 & 0.0 & 0.0 & 0.0 & 0.0 & 0.0 & 0.0 & 0.0 & 0.0 & 6.0 & 6.3 \\
\hline $\begin{array}{l}\text { Total backward/ } \\
\text { demand linkages }\end{array}$ & 14.7 & 0.3 & 37.1 & 47.9 & 0.0 & 15.9 & 6.0 & 5.7 & 1.3 & 0.6 & 1.0 & 1.7 & 5.5 & 10.1 & 100.0 \\
\hline
\end{tabular}

Source: Data from the World Bank Export of Value Added Database. 
TABLE 4.9 Sectoral composition of the value added of Peru's exports, 2011 (percent of total value added of exports)

\begin{tabular}{|c|c|c|c|c|c|c|c|c|c|c|c|c|c|c|c|}
\hline SECTOR & $\frac{\grave{c}}{\frac{\alpha}{\alpha}}$ & $\begin{array}{l}\text { J } \\
\tilde{\Psi} \\
\text { జ } \\
\end{array}$ & 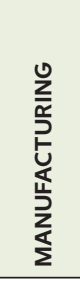 & 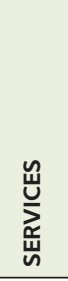 & 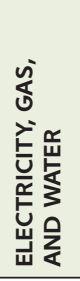 & 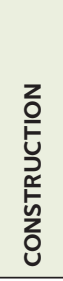 & 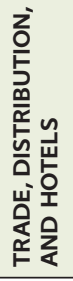 & 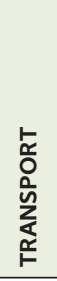 & 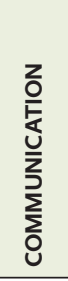 & 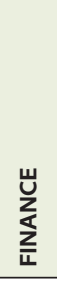 & 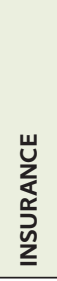 & 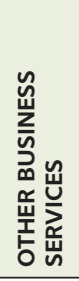 & 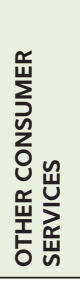 & 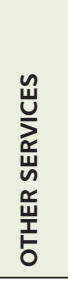 & 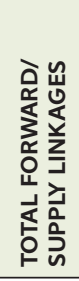 \\
\hline Primary & 23.3 & 0.0 & 8.2 & 0.1 & 0.0 & 0.0 & 0.0 & 0.1 & 0.0 & 0.0 & 0.0 & 0.0 & 0.0 & 0.0 & 31.7 \\
\hline Energy & 0.4 & 1.3 & 2.0 & 0.3 & 0.0 & 0.0 & 0.0 & 0.3 & 0.0 & 0.0 & 0.0 & 0.0 & 0.0 & 0.0 & 4.1 \\
\hline Manufacturing & 7.5 & 0.1 & 35.9 & 1.1 & 0.0 & 0.0 & 0.1 & 0.7 & 0.0 & 0.0 & 0.1 & 0.1 & 0.1 & 0.1 & 44.6 \\
\hline Services & 5.8 & 0.2 & 8.4 & 5.2 & 0.0 & 0.0 & 0.2 & 2.5 & 0.2 & 0.1 & 0.6 & 0.6 & 0.5 & 0.3 & 19.6 \\
\hline $\begin{array}{l}\text { Electricity, gas, } \\
\text { and water }\end{array}$ & 0.1 & 0.0 & 0.1 & 0.0 & 0.0 & 0.0 & 0.0 & 0.0 & 0.0 & 0.0 & 0.0 & 0.0 & 0.0 & 0.0 & 0.2 \\
\hline Construction & 0.1 & 0.0 & 0.2 & 0.1 & 0.0 & 0.0 & 0.0 & 0.0 & 0.0 & 0.0 & 0.0 & 0.0 & 0.0 & 0.0 & 0.4 \\
\hline $\begin{array}{l}\text { Trade, distribution, } \\
\text { and hotels }\end{array}$ & 0.4 & 0.0 & 1.0 & 0.1 & 0.0 & 0.0 & 0.1 & 0.1 & 0.0 & 0.0 & 0.0 & 0.0 & 0.0 & 0.0 & 1.5 \\
\hline Transport & 0.5 & 0.0 & 0.7 & 1.4 & 0.0 & 0.0 & 0.0 & 1.3 & 0.0 & 0.0 & 0.0 & 0.0 & 0.0 & 0.0 & 2.6 \\
\hline Communication & 0.3 & 0.0 & 0.5 & 0.4 & 0.0 & 0.0 & 0.0 & 0.1 & 0.2 & 0.0 & 0.0 & 0.0 & 0.0 & 0.0 & 1.2 \\
\hline Finance & 1.0 & 0.0 & 1.4 & 0.4 & 0.0 & 0.0 & 0.0 & 0.2 & 0.0 & 0.1 & 0.0 & 0.0 & 0.0 & 0.0 & 2.8 \\
\hline Insurance & 0.2 & 0.0 & 0.2 & 0.6 & 0.0 & 0.0 & 0.0 & 0.1 & 0.0 & 0.0 & 0.5 & 0.0 & 0.0 & 0.0 & 1.0 \\
\hline $\begin{array}{l}\text { Other business } \\
\text { services }\end{array}$ & 2.9 & 0.1 & 3.7 & 1.5 & 0.0 & 0.0 & 0.1 & 0.7 & 0.0 & 0.0 & 0.1 & 0.6 & 0.0 & 0.0 & 8.1 \\
\hline $\begin{array}{l}\text { Other consumer } \\
\text { services }\end{array}$ & 0.3 & 0.0 & 0.4 & 0.6 & 0.0 & 0.0 & 0.0 & 0.0 & 0.0 & 0.0 & 0.0 & 0.0 & 0.5 & 0.0 & 1.2 \\
\hline Other services & 0.1 & 0.0 & 0.3 & 0.2 & 0.0 & 0.0 & 0.0 & 0.0 & 0.0 & 0.0 & 0.0 & 0.0 & 0.0 & 0.2 & 0.6 \\
\hline $\begin{array}{l}\text { Total backward/ } \\
\text { demand linkages }\end{array}$ & 37.0 & 1.7 & 54.6 & 6.7 & 0.0 & 0.0 & 0.3 & 3.6 & 0.3 & 0.1 & 0.7 & 0.7 & 0.7 & 0.4 & 100.0 \\
\hline
\end{tabular}

Source: Data from the World Bank Export of Value Added Database.

Services' share of Peru's GDP was 44 percent in 2011. This figure was lower than the share in Colombia (73 percent), Thailand (54 percent), and Malaysia (45 percent). Construction services and trade and transport services were the subsectors with the strongest forward linkages in Peru.

Total backward services linkages contributed 48 percent of GDP in Peru, a figure that is comparable to that of most comparator countries. These linkages were mainly with other services activities, however (table 4.8). Among services, the strongest backward linkages were to construction services (11 percent of total backward linkages) and transport services ( 3 percent of total backward linkages).

Table 4.9 shows the value added of services in Peru's total exports. The contribution of services to total exports is 5.2 percent-an extremely low figure (the figure in comparator countries is 10-12 percent). Transport and travel services together with trade and distribution represent only 1.5 of total exports. Although transport and travel services sector account for the largest proportion of Peru's exports measured in terms of gross value, the value added of these services subsectors' exports for final consumption remain extremely low.

The real value added contribution of services to total exports does not increase significantly when forward linkages to other export activities 
are considered. The share of services in the value of total exports is just 20 percent. The largest contribution of services is in exports of manufactured goods (more than 8 percent of the total); another 5.8 percent moves through the primary sector. In most comparator countries, manufactured accounts account for about 20 percent of total services exports (Sáez and others 2014).

Most of the services value added exported through manufacturing sectors goes through the food-processing and metal subsectors. Trade, distribution, and hotels (together with finance and other business services) are the main sectors linked to manufacturing exports, representing 1.0 percent, 1.4 percent, and 3.7 percent of the value added of exports, respectively. These figures are low-and other activities demanded by the manufacturing sectors are even lower. In the metal industry, the main linkages are to distribution, finance, and other business services. Finance and business services are the most important services inputs carried forward in food-processing exports. The chemical sector absorbs and exports indirectly much of the value added produced in business services, finance, transport, and distribution services. Relatively little value added in insurance services is exported through other exports, suggesting that this sector functions mainly as a final service.

Value-added creation is much more important for the domestic market than for exports. This feature is evident in comparator countries as well, but the discrepancy between the two measures is greatest for Peru. Services' share of total domestic value added is larger than services' share of export value added (table 4.10). Exported value added is extremely low compared with other countries, at just 19 percent of total exports. This small share is also reflected in low domestic forward linkages. The agricultural sector provides a larger share of value added in Peru than it does in most other countries; Peru's manufacturing sector also shows large shares of exported value added.

TABLE 4.10 Sectoral contributions to value added in selected countries, 2011 (percent of total)

\begin{tabular}{|c|c|c|c|c|c|c|c|c|c|c|c|c|}
\hline \multirow[b]{2}{*}{ SECTOR/SUBSECTOR } & \multicolumn{2}{|c|}{ PERU } & \multicolumn{2}{|c|}{ CHILE } & \multicolumn{2}{|c|}{ CHINA } & \multicolumn{2}{|c|}{ COLOMBIA } & \multicolumn{2}{|c|}{ SOUTH AFRICA } & \multicolumn{2}{|c|}{ THAILAND } \\
\hline & DOM & EXP & DOM & EXP & DOM & EXP & DOM & EXP & DOM & EXP & DOM & EXP \\
\hline Transport & 3.3 & 2.6 & 6.7 & 8.9 & 6.4 & 7.2 & 5.4 & 7.4 & 3.8 & 5.7 & 4.2 & 5.2 \\
\hline Finance & 3.0 & 2.8 & 4.3 & 1.3 & 4.6 & 4.7 & 3.1 & 1.5 & 1.6 & 1.6 & 3.4 & 3.5 \\
\hline Communications & 2.4 & 1.2 & 2.2 & 0.9 & 2.0 & 1.4 & 2.8 & 1.1 & 3.7 & 2.9 & 2.0 & 1.6 \\
\hline Water & 0.2 & 0.2 & 0.6 & 0.1 & 0.2 & 0.2 & 0.7 & 0.2 & 0.5 & 0.2 & 0.4 & 0.2 \\
\hline Construction & 11.2 & 0.4 & 8.2 & 0.4 & 7.1 & 0.2 & 8.8 & 0.5 & 3.2 & 0.5 & 2.1 & 0.1 \\
\hline Distribution & 2.4 & 1.5 & 9.4 & 4.9 & 7.7 & 6.6 & 14.6 & 5.3 & 12.9 & 15.3 & 23.3 & 14.1 \\
\hline Insurance & 1.1 & 1.0 & 0.8 & 0.5 & 0.5 & 0.4 & 1.2 & 0.4 & 6.7 & 4.5 & 1.1 & 0.7 \\
\hline Other business services & 8.9 & 8.1 & 12.9 & 14 & 5.2 & 4.6 & 17.5 & 8.9 & 11.2 & 8.4 & 2.0 & 2.9 \\
\hline $\begin{array}{l}\text { Other construction } \\
\text { services }\end{array}$ & 5.2 & 1.2 & 3.0 & 0.8 & 2.3 & 1.2 & 3.0 & 1.0 & 4.2 & 3.4 & 1.5 & 1.3 \\
\hline Total services & 37.7 & 19.0 & 48.1 & 31.8 & 36.1 & 26.4 & 57.1 & 26.3 & 47.8 & 42.4 & 39.9 & 29.8 \\
\hline Agriculture & 18.3 & 35.8 & 13.7 & 32.3 & 16.3 & 17.7 & 13.8 & 49.5 & 7.3 & 18.4 & 13.4 & 15.8 \\
\hline Manufacturing & 37.7 & 44.6 & 19.3 & 35.3 & 32.6 & 54.2 & 13.6 & 23.5 & 20.8 & 37.7 & 33.1 & 53.4 \\
\hline Other & 6.3 & 0.6 & 18.9 & 0.6 & 15.0 & 1.7 & 15.5 & 0.7 & 24.2 & 1.5 & 13.6 & 1.0 \\
\hline
\end{tabular}

Source: Data from the World Bank Export of Value Added Database.

Note: DOM = domestic economy; EXP = exports. Total does not add up to 100 percent because "other services" was dropped. 
Peru's more outward-oriented services sectors in terms of value added are business services and finance; the value added of traditional services exports remains low. A common observation among developing countries and emerging economies is that sectors such as transport, distribution, and travel contribute most to export value added.

These sectoral shares remain extremely low in Peru (2.6 percent for transport and a 1.5 percent for distribution, including travel) (table 4.10). In contrast, the value-added share of exports of business services is large. Peru's insurance sector produces little value added directly and is not absorbed into its manufacturing sector's production and exports.

Forward linkages of services exports are relatively low in Peru. Services are mainly a direct export activity to end consumers rather than an input into other export activities. Weak forward linkages may reflect the fact that Peruvian services are still relatively expensive for Peruvian manufacturing firms. Lowcost, high-quality services should be a priority for any diversification and competitiveness strategy. Assessing and understanding constraints to services development is key to increasing their contribution to economic diversification and competitiveness in goods industries.

Services are important inputs in upper-middle-income countries (figure 4.5). They account for 25 percent of inputs in high-income countries and 15 percent in Latin American upper-middle-income countries. Differences across income groups are smaller when forward linkages are included. The gap between the two measures in Latin American and Asian upper-middle-income countries is large, suggesting that forward linkages play an important role in these countries. The gap between the direct and total percentage of total trade is small in Peru.

The most important forward linkages in Peru are in other business services and finance, which are more important than in other countries (figure 4.6).

FIGURE 4.5

Gross, direct, and total shares of services in exports in selected country groups and countries, 2011

a. Country groups

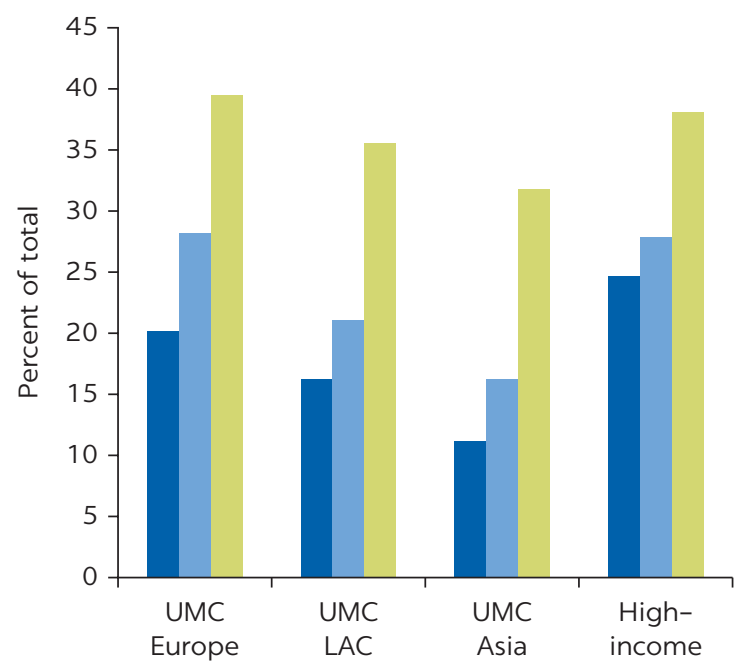

b. Countries

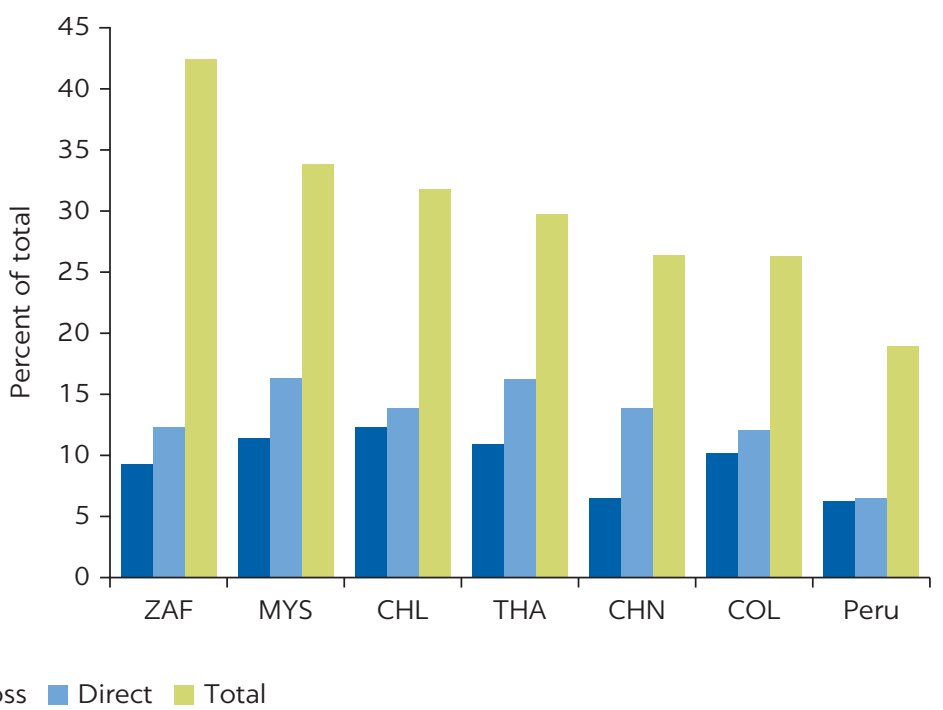

Source: Data from the World Bank Export of Value Added Database.

Note: $\mathrm{CHL}=$ Chile; $\mathrm{CHN}=$ China; $\mathrm{COL}=$ Colombia; $\mathrm{MYS}=$ Malaysia; $\mathrm{THA}=$ Thailand; $\mathrm{ZAF}=$ South Africa. $\mathrm{LAC}=\mathrm{Latin}$ America and the Caribbean; $\mathrm{UMC}=$ upper-middle-income countries. Direct = value added of services; Gross = value of services reported in the balance of payment statistics; Total $=$ value added of services including indirect contribution, as measured by sectoral forward linkages to other export activities . 
FIGURE 4.6

Importance of "other business services" as inputs in exports in selected countries, 2011

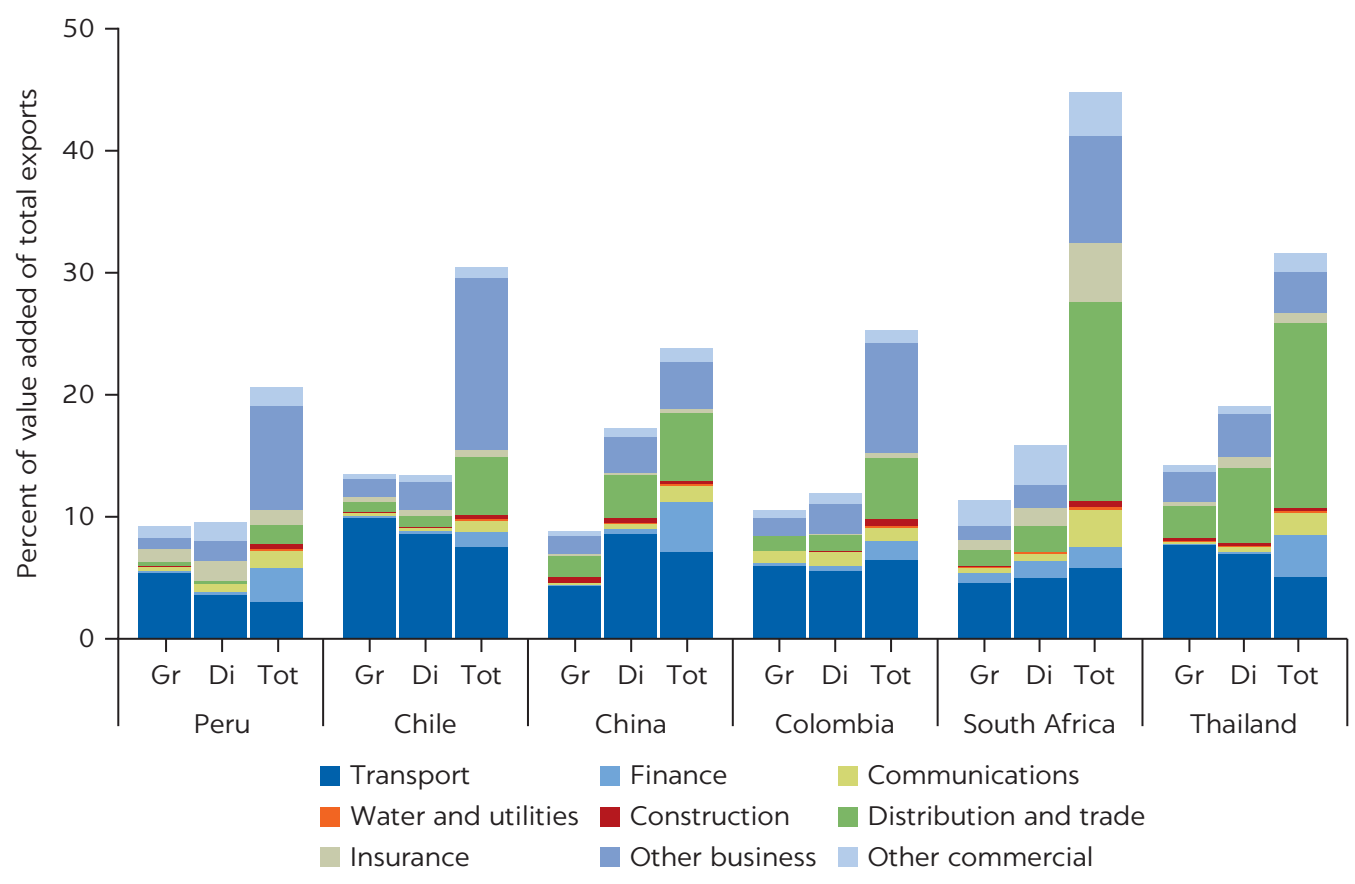

Source: Data from the World Bank Export of Value Added Database. Note: $\mathrm{Di}=$ direct; $\mathrm{Gr}=$ gross; $\mathrm{Tot}=$ total.

This pattern is surprising given that peer countries have much lower rates of forward linkages in business services and finance (except Thailand and China for finance) and higher rates for transport and distribution. Figure 4.6 compares the shares of services exports in total exports in nine subsectors in selected countries. In all peer countries, the transportation and distribution subsectors have higher rates of forward linkages than they do in Peru. Forward linkages in the two sectors are very low in Peru, probably because of the low level of development of Peru's industrial sector, which does not allow for specialization in these input services. The forward linkages of business services and finance work linkages mainly through the food-processing sector (which is closely linked to the agricultural sector) and the metal industry (which is tied to the mining and mineral sector).

Figure 4.7 shows the relationship between services exports and per capita GDP. Based on Peru's per capita GDP, one would expect higher value added for trade.

\section{EFFECT OF REGULATION, THE RULE OF LAW, HUMAN CAPITAL, AND USE OF INFORMATION AND COMMUNICATIONS TECHNOLOGY ON EXPORTS OF SERVICES}

\section{Effect of regulation}

Regulatory requirements can raise the costs of services and restrict their growth and expansion. These regulations are often implemented in the pursuit of legitimate objectives; their negative effects on services are not intentional. Domestic regulatory barriers (discriminatory or nondiscriminatory) also affect the level of a country's exports (Nordås and Rouzet 2015; Sáez and others 2014). 
FIGURE 4.7

\section{Correlation between services exports and per capita GDP, 2011}

a. Gross exports of services

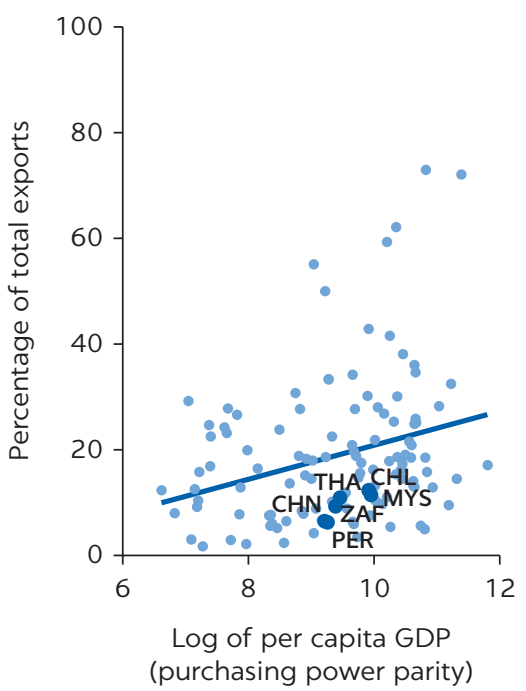

b. Direct value added of services exports

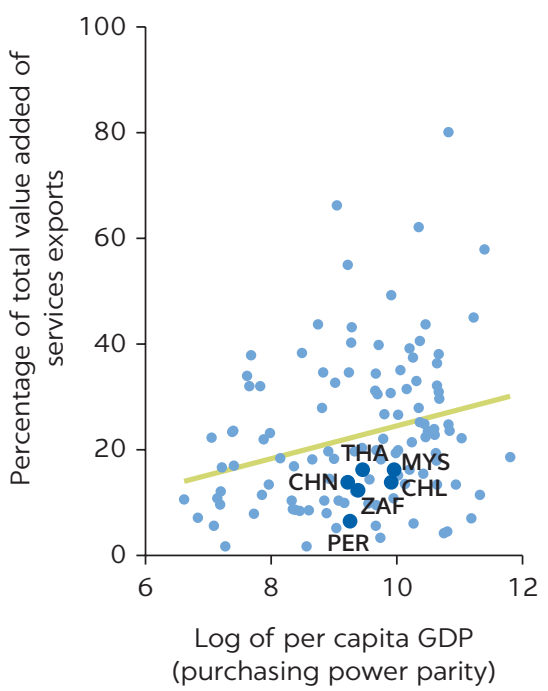

c. Total value added of services exports

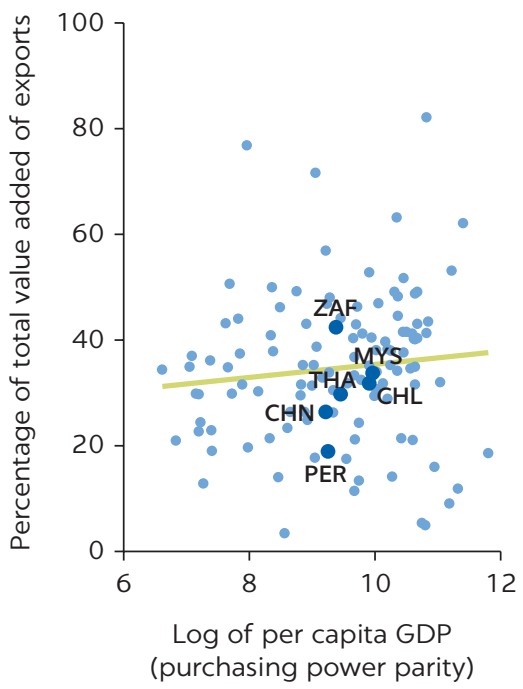

Source: Data from the World Bank Export of Value Added Database.

Note: $\mathrm{GDP}=$ gross domestic product. Dots represent countries: $\mathrm{CHL}=$ Chile; $\mathrm{CHN}=\mathrm{China}$; $\mathrm{MYS}=\mathrm{Malaysia;} \mathrm{PER}=\mathrm{Peru} ; \mathrm{THA}=\mathrm{Thailand}$; $\mathrm{ZAF}=$ South Africa.

Wealthier countries tend to have looser restrictions than poor countries (figure 4.8). Peru's STRI is lower than expected given its level of development. Comparator countries such as China, South Africa, and Thailand have much tighter restrictions.

Peru has relatively tight restrictions on insurance and financial services across all modes of supply. Professional services (which include only legal, accounting, and auditing services) are much less tightly regulated. Peru imposes no restrictions on retail and telecommunications services and only minor restrictions on transport services. Most comparator countries impose significantly tighter restrictions on these subsectors.

Insurance and finance are completely closed to cross-border (Mode 1) transactions. Mode 3 restrictions are still in place for these subsectors. Peru does not impose restrictions on Mode 1 trade in other subsectors. Professional services through Mode 3 are strict, making it difficult for foreign providers to establish affiliates in Peru.

Foreign direct investment (FDI) (a proxy for trade in Mode 3) and crossborder trade in services are strongly linked (Lennon 2009). Outward FDI and services exports are complementary, as are cross-border trade and direct investment services trade (Lennon 2009).

Figure 4.9 illustrates the importance of this complementarity between cross-border trade and direct investment for Peru. Both panels show a negative relationship between restrictiveness and the share of services exports in GDP. Peru falls below the fitted value line in both panels, indicating much room for improvement.

Many services subsectors suffer from market failures. Opening up markets to foreign firms may therefore not be sufficient to ensure competition; additional regulatory measures may be needed. 
FIGURE 4.8

Correlation between Services Trade Restrictiveness Index (STRI) and per capita GDP and share of value added of services in GDP, 2013
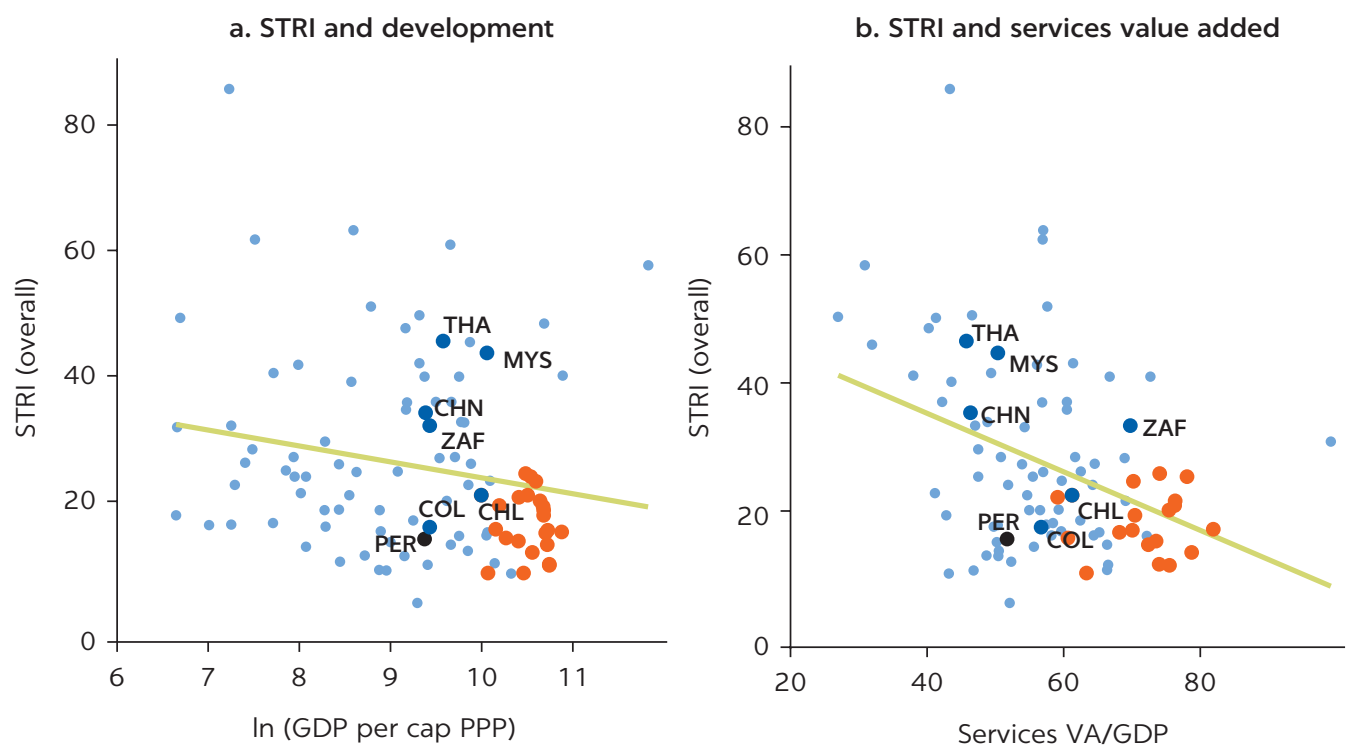

Sources: Data from World Bank Services Trade Restrictiveness Index; World Bank World Development Indicators; and Borchert, Gootiiz, and Mattoo 2012.

Note: GDP = gross domestic product; per cap PPP = per capita purchasing power parity; STRI = Services Trade Restrictiveness Index; VA = value added. Dots represent countries; dots in black are OECD countries: $\mathrm{CHL}=\mathrm{Chile}$; $\mathrm{CHN}=$ China; $\mathrm{COL}=$ Colombia; $\mathrm{MYS}=$ Malaysia; $\mathrm{PER}=\mathrm{Peru} ; \mathrm{THA}=$ Thailand; $\mathrm{ZAF}=$ South Africa .

FIGURE 4.9

Correlation between mode 3 restrictions and mode 1 trade, 2010

a. Correlation between Mode 1 exports of services and overall STRI for Mode 3

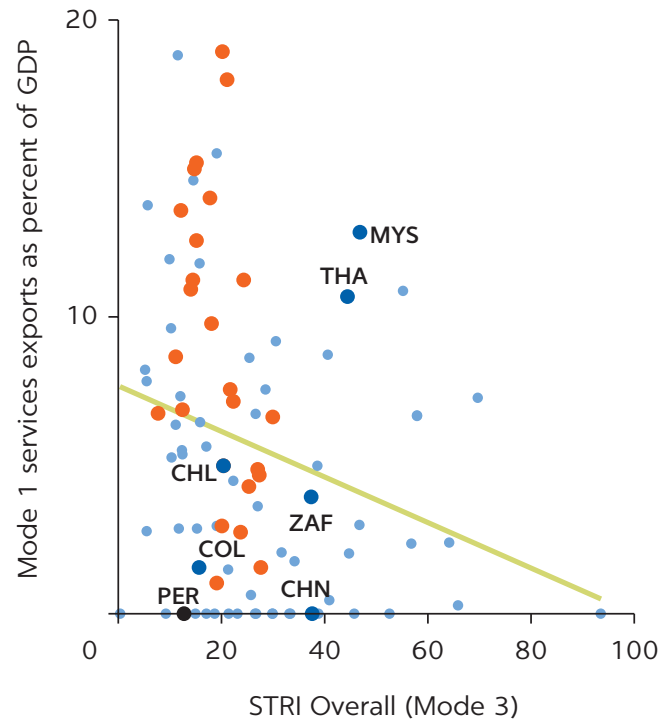

b. Correlation between Mode 1 exports of services and STRI for finance for Mode 3

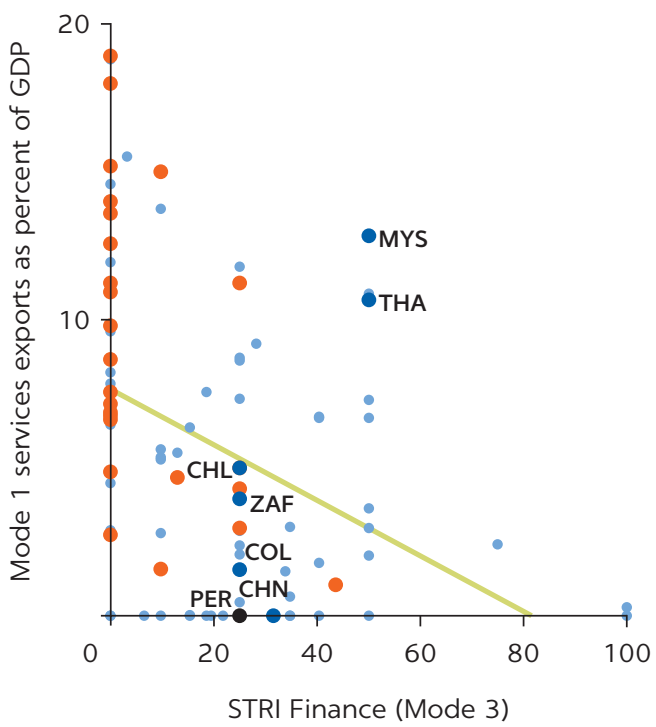

Sources: Data from the World Bank Services Trade Restrictiveness Index; the World Bank Trade in Services Database; World Bank World Development Indicators; and Borchert, Gootiiz, and Mattoo 2012. Note: GDP = gross domestic product; STRI = Services Trade Restrictiveness Index. Dots represent countries; dots in black are $\mathrm{OECD}$ coutries: $\mathrm{CHL}=$ Chile; $\mathrm{CHN}=$ China; $\mathrm{COL}=$ Colombia; $\mathrm{MYS}=$ Malaysia; $\mathrm{PER}=$ Peru; THA = Thailand; $Z A F=$ South Africa. 
Figure 4.10 depicts the negative relationship between restrictiveness and regulatory quality across countries. ${ }^{4}$ It suggest that addressing trade restrictiveness is a necessary but not sufficient condition for increasing competitiveness. Although Peru has relatively low services trade barriers, its regulatory governance structures lag those of many other countries with similar STRIs.

\section{Effect of the rule of law}

The importance of the rule of law is related to the type of services an economy exports. Modern services (sometimes proxied by "complex services") require strong domestic institutions and the rule of law, because contracting for them is often much more complicated than contracting for traditional services.

Figure 4.11 shows the relationship between the complexity of services and the strength of the rule of law. Peru is situated above the fitted line, meaning that the complexity of its service exports is greater than what would be expected given the level of rule of law.

\section{Effect of capital endowments and use of information and communications technology}

Human capital is a critical determinant of exports of modern services. Countries that are better endowed with high-skilled labor and qualitatively better education have larger shares of services exports. Peru's trade in services is much lower than predicted based on its human capital endowment (figure 4.12, panel a).

FIGURE 4.10

\section{Correlation between regulatory quality and the Services Trade Restrictiveness Index} (STRI), 2013

a.

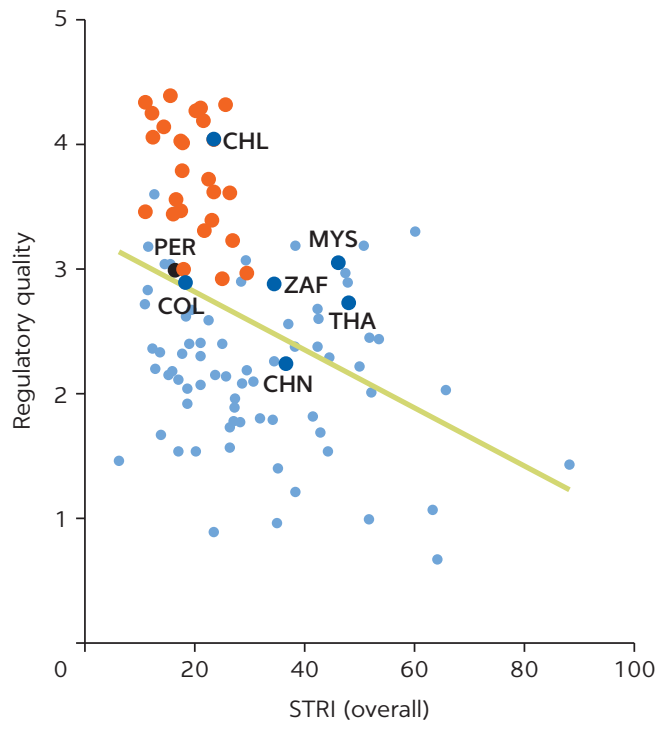

b.

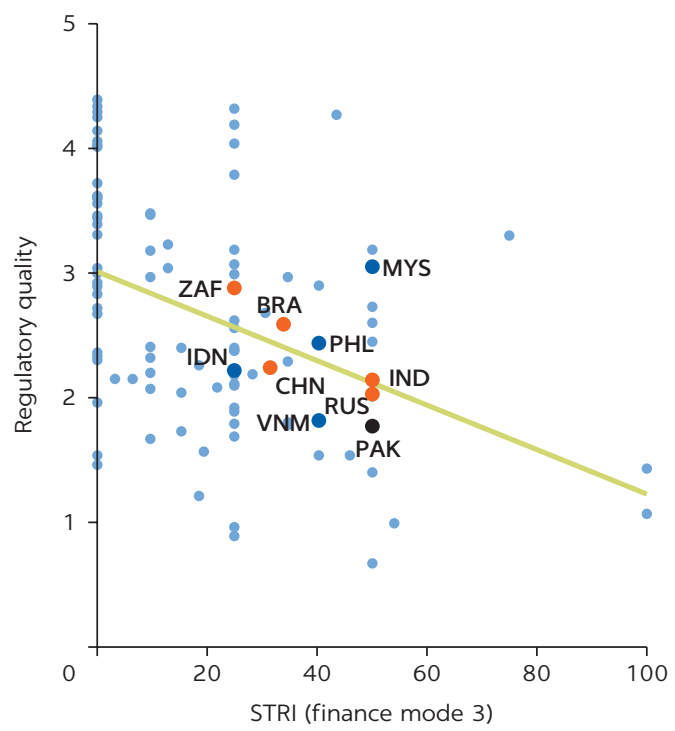

Sources: Data from the World Bank Services Trade Restrictiveness Index; World Bank Worldwide Governance Indicators; and Borchert, Gootiiz, and Mattoo 2012.

Note: STRI = Services Trade Restrictiveness Index. Dots represent countries; dots in black are OECD countries: $\mathrm{BRA}=$ Brazil; $\mathrm{CHL}=$ Chile; $\mathrm{CHN}=$ China; $\mathrm{COL}=$ Colombia; IDN = Indonesia; IND = India; MYS = Malaysia; PAK = Pakistan; $\mathrm{PER}=$ Peru; $\mathrm{PHL}=$ Philippines; RUS = Russian Federation; $\mathrm{THA}=$ Thailand; VNM = Vietnam; ZAF = South Africa. 
FIGURE 4.11

\section{Correlation between the complexity of services and the rule of} law, 2010

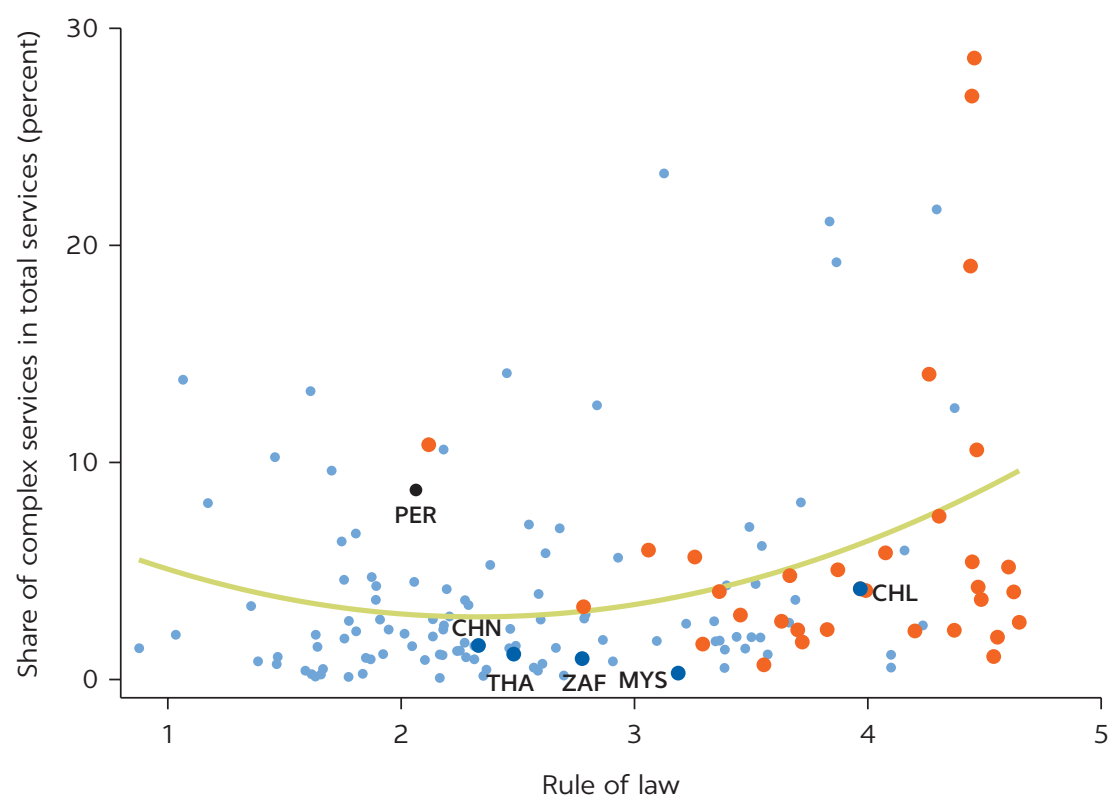

Sources: Data from World Bank World Development Indicators, the World Bank Trade in Services Database, and the World Bank Worldwide Governance Indicators. Note: Complex services include accounting and legal, finance, and insurance services. This measure is based on calculations by Costinot (2009). The rule of law comes from the World Bank Worldwide Governance Indicators. Dots represent countries; dots in black are OECD countries: $\mathrm{CHL}=$ Chile; $\mathrm{CHN}=$ China; $\mathrm{MYS}=$ Malaysia; $\mathrm{PER}=$ Peru; $\mathrm{THA}=$ Thailand $\mathrm{ZAF}=$ South Africa.

\section{Correlation between services trade and human capital and Internet use, 2013}

a. Correlation between services trade and human capital

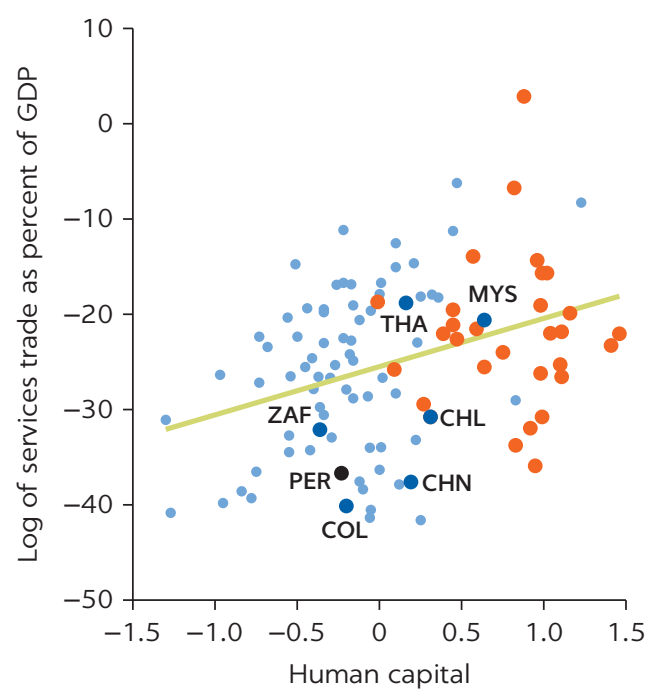

b. Correlation between services trade and Internet use

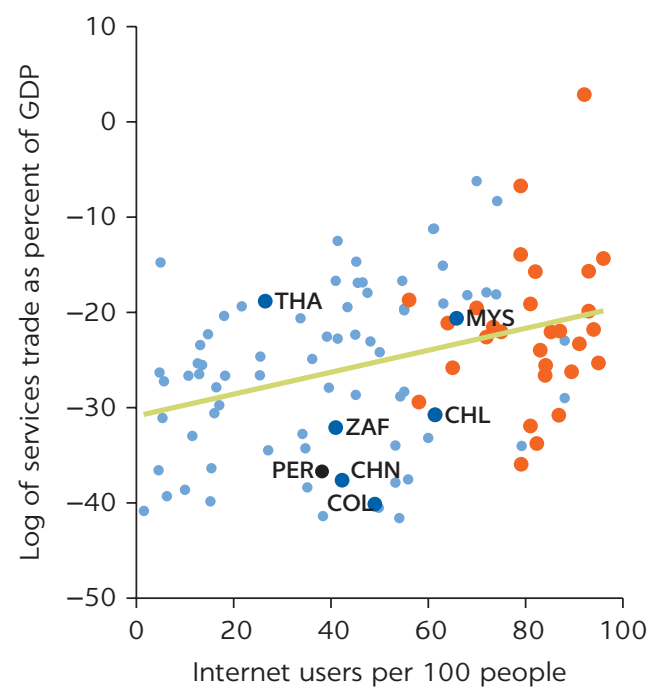

Sources: Data from World Bank World Development Indicators and the World Economic Forum 2013. Note: Human capital is measured using a scale from the World Economic Forum that ranges from -1.5 (weakest) to 1.5 (strongest). This measures captures qualitative aspects of education and the current and future workforce. $\mathrm{GDP}=$ gross domestic product. Dots represent countries; dots in black are OECD countries: $\mathrm{CHL}=\mathrm{Chile;}$ $\mathrm{CHN}=$ China; $\mathrm{COL}=$ Colombia; MYS = Malaysia; $\mathrm{PER}=$ Peru; THA = Thailand; ZAF = South Africa. 
The growth of telecommunications infrastructure is the most powerful symbol of vitality of the services sector. Peru underperforms in this area. Its share of trade in services to GDP is well below what would be expected given its level of Internet penetration (figure 4.12, panel b). Expansion of trade, particularly in ICT, will depend critically on policies affecting telecommunications and Internet infrastructure.

\section{CONCLUSION}

Several findings emerge from the analysis reported in this chapter:

- Services in Peru represent a smaller share of total exports than expected given the country's level of development. Untapped export potential exists for both traditional and modern services.

- Three-quarters of Peruvian services firms that export are owned by foreign investors. These firms have higher value added per worker than other firms. The biggest differences in productivity between foreign- and domestic-owned firms are in the professional services subsectors (architectural and engineering services, R\&D, advertising and market research, and other professional, scientific, and technical activities). Firms that receive public capital are less productive than private firms. Firms that export and have large shares of foreign capital are significantly more productive than other firms.

- Reforms that increase foreign participation and enhance competition in services markets have economywide effects. Both foreign presence and increased competition in services have significant positive effects on downstream productivity growth in Peru.

- Governance is critical to keeping markets competitive once trade is liberalized. Peru has relatively low services trade barriers, but its regulatory governance structures lag those of many other countries with similar levels of restrictions on services. Measures of the rule of law are lower than in some of its most important comparator countries.

- Services trade is very low given Peru's level of human capital endowments and Internet use. Spending on software is one of the important factors correlated with exporting services in Peru. Expansion, particularly in ICT, will depend critically on policies affecting these sectors. A strategy to develop these subsectors, together with policies that increase foreign investment, such as reductions in restrictiveness and improvements to the rule of law and regulatory quality, should be implemented.

\section{NOTES}

1. The International Monetary Fund's Balance of Payments Statistics includes three broad categories: transport, travel, and other commercial services. Commercial services includes financial services, communication services, construction services, ICT-related services, other business services, royalties and licenses fees, and personal, cultural and recreational services. This classification is different from the classification used below in the section on trade in value added.

2. Government services refer to all services (such as expenditures on embassies and consulates) associated with government or international and regional organizations.

3. Direct value added captures the sector-specific value added generated within an economy after netting out domestic and foreign inputs. 
4. Regulatory quality captures perceptions of the ability of the government to formulate and implement sound policies and regulations that permit and promote private sector development. See http://info.worldbank.org/governance/wgi/\#home.

\section{REFERENCES}

Ariu, A. 2016. "Services versus Goods Trade: A Firm-Level Comparison." Review of World Economics 152 (1): 19-41.

Borchert, I., B. Gootiiz, and A. Mattoo. 2012. "Guide to the Services Trade Restrictions Database." Policy Research Working Paper 6108, World Bank, Washington, DC.

Breinlich, H. M., and C. Criscuolo. 2011. "International Trade in Services: A Portrait of Importers and Exporters.” Journal of International Economics 84 (2): 188-206.

Costinot, A. 2009. "On the Origins of Comparative Advantage." Journal of International Economics 77 (2): 255-64.

Encuestas Economicas Anuales. 2012. Instituto Nacional de Estadística e Informática, Lima, Peru. https://www.inei.gob.pe/.

Freund, C., and D. Weinhold. 2002. "The Internet and International Trade in Services." The American Economic Review 92 (2): 236-40.

IMF (International Monetary Fund) Balance of Payments (database), Washington, DC, https:// data.imf.org/?sk=7A51304B-6426-40C0-83DD-CA473CA1FD52.

Lennon, C. 2009. "Trade in Services and Trade in Goods: Differences and Complementarities." wiiw Working Paper 53, The Vienna Institute for International Economic Studies, Vienna.

Mishra, S., S. Lundstrom, and R. Anand. 2011. "Service Export Sophistication and Economic Growth.” Working Paper 5606, World Bank, Washington, DC.

Nordås, H., and D. Rouzet. 2015. "The Impact of Services Trade Restrictiveness on Trade Flows: First Estimates.” OECD Trade Policy Paper 178, Organisation for Economic Co-operation and Development, Paris.

Sáez, S., D. Taglioni, E. van der Marel, C. Hollweg, and V. Zavacka. 2014. Valuing Services in Trade: A Toolkit for Competitiveness Diagnostics. Washington, DC: World Bank.

van der Marel, E. 2012. "Trade in Services and TFP: The Role of Regulation.” The World Economy 35 (11): $1530-58$.

World Bank. 2009. The Service Revolution in South Asia. Washington, DC: World Bank.

—. 2015. Peru - Building on Success: Boosting Productivity for Faster Growth. Report 99400, Washington, DC. https://openknowledge.worldbank.org/handle/10986/22984.

World Bank Export of Value Added Database, Washington, DC, https://datacatalog.worldbank .org/dataset/export-value-added-database.

World Bank Services Trade Restrictiveness Index (database), Washington, DC, http://iresearch .worldbank.org/servicetrade/.

World Bank Trade in Services Database, Washington, DC, https://datacatalog.worldbank.org /dataset/trade-services-database.

World Bank World Development Indicators (database), Washington, DC, http://wdi .worldbank.org.

World Bank Worldwide Governance Indicators (database), Washington, DC, https://datacatalog .worldbank.org/dataset/worldwide-governance-indicators.

World Economic Forum. 2013. The Human Capital Report. Geneva. http://reports.weforum.org /human-capital-index-2013/. 



\section{Middle East and North Africa}





\title{
5 Economic Complementarities in Services in the Mashreq and Turkey*
}

\author{
CLAIRE H. HOLLWEG AND DARIA TAGLIONI
}

Economic integration is a key avenue through which countries can benefit from regional opportunities; many of the potential welfare gains of enhanced economic integration accrue from increased trade and investment flows. Identifying untapped potential for deeper and wider trade integration can help identify policies that can unleash these potentials for mutual benefit. The centrality of services to the economic structure of many countries offers a compelling motivation for devising a cooperation agenda aimed at facilitating expanded services trade and investment.

This chapter evaluates potential bilateral economic linkages and complementarities in services trade between Turkey and the Mashreq countries of Jordan, Lebanon, the Syrian Arab Republic, and Iraq (the "core" countries of interest). It assesses the importance of services for these countries and, when data permit, reviews bilateral trade relations to determine the extent to which these countries are linked in services. It also identifies whether countries are trading to their potential and where scope exists for deeper and wider integration. 1 The chapter also considers linkages between other economies in the region, including the Arab Republic of Egypt, the Islamic Republic of Iran, Libya, Tunisia, Israel, and West Bank and Gaza (the "outer circle" countries). The analysis goes beyond the aggregate level in order to examine the scope for enhanced regional trade in various subsectors.

The chapter is organized as follows. The first section examines the importance of services in the domestic economy. The second section overviews the importance of trade in services with the world at the aggregate as well as sectoral levels. The third section focuses on bilateral linkages between the core and outer circle countries, using data from the World Bank Trade in Services Database.

\footnotetext{
* This chapter was originally prepared as a background paper to the 2014 World Bank publication Over the Horizon: A New Levant (World Bank 2014). The analysis was undertaken in 2013, using the most recent data available at that time. The authors are grateful to Sibel Kulaksiz for valuable guidance and support and Aaditya Mattoo for useful comments. The editors are grateful to Sibel Kulaksiz and Johannes Zutt for authorization to publish.
} 
The fourth section deepens this analysis by assessing the extent to which countries are reaching their potential in bilateral services trade and examining other indicators of economic complementarities. The fifth section uses the World Bank Export of Value Added Database to provide a different perspective on the importance of services exports for the economies. The last section summarizes the main findings and policy considerations.

\section{THE ROLE OF SERVICES IN THE DOMESTIC ECONOMY}

The share of a country's value added from services provides a first assessment of the existence and importance of a domestic services sector, often a precondition to developing a services export sector. The importance of services varies widely in the economies of the Mashreq (figure 5.1). Given per capita GDP levels, some countries (Syria, Egypt, Libya, and Iraq) are below their predicted share of services in value added, suggesting potential for future growth through services; other countries (Lebanon and Jordan) are above it. Turkey is at the level predicted.

\section{SERVICES TRADE WITH THE WORLD}

Many countries have impressive records of services exports. The importance of services trade identifies the current export competitiveness of the sector. Figure 5.2 shows trends in services exports. For all countries except Tunisia,

FIGURE 5.1

\section{Relationship between value added of services as percent of GDP and per capita GDP, 2000-02 and 2008-10}

a. 2000-02

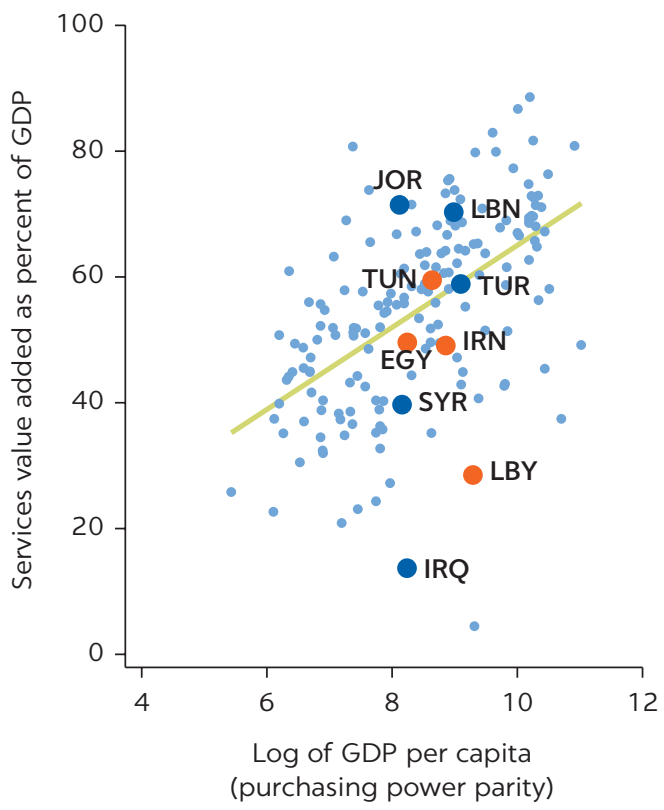

b. $2008-10$

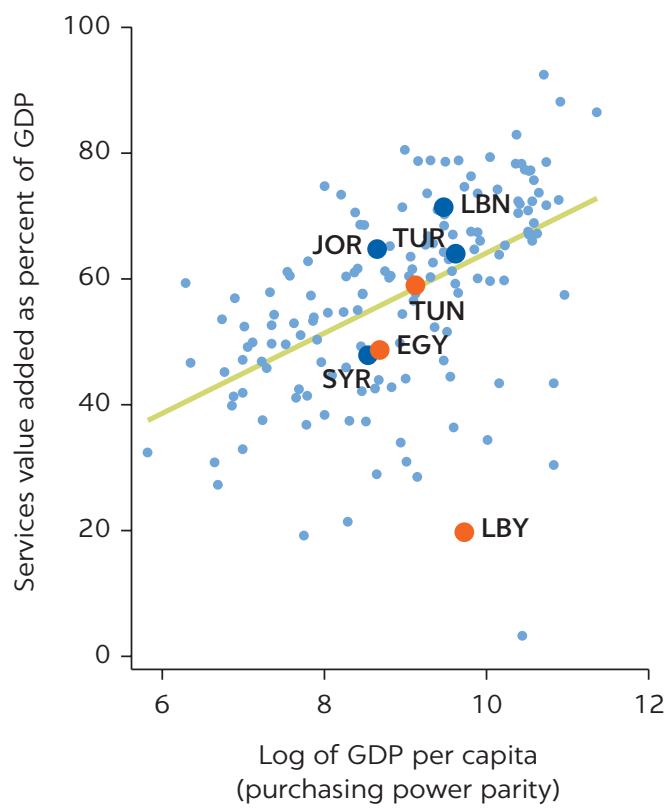

Source: World Bank World Development Indicators.

Note: GDP = gross domestic product. Dark blue dots indicate core countries of interest; orange dots indicate other economies in the region included in the analysis: EGY = Egypt, Arab Rep.; IRN = Iran, Islamic Rep.; IRQ = Iraq; JOR = Jordan; LBN = Lebanon; LBY = Libya; SYR = Syrian Arab Republic; TUN = Tunisia; TUR = Turkey. 
FIGURE 5.2

Index of exports of services by selected economies, 2000-10

a. Core countries

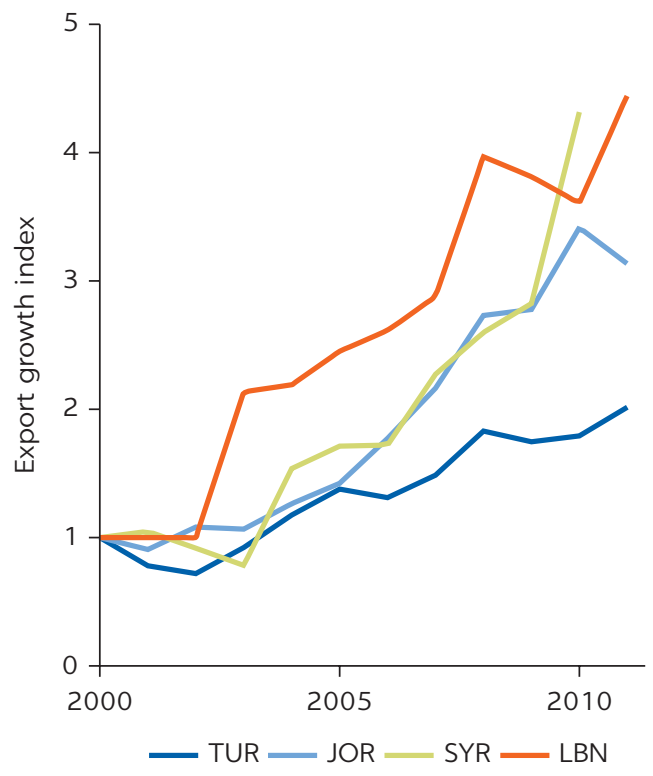

b. Outer circle countries

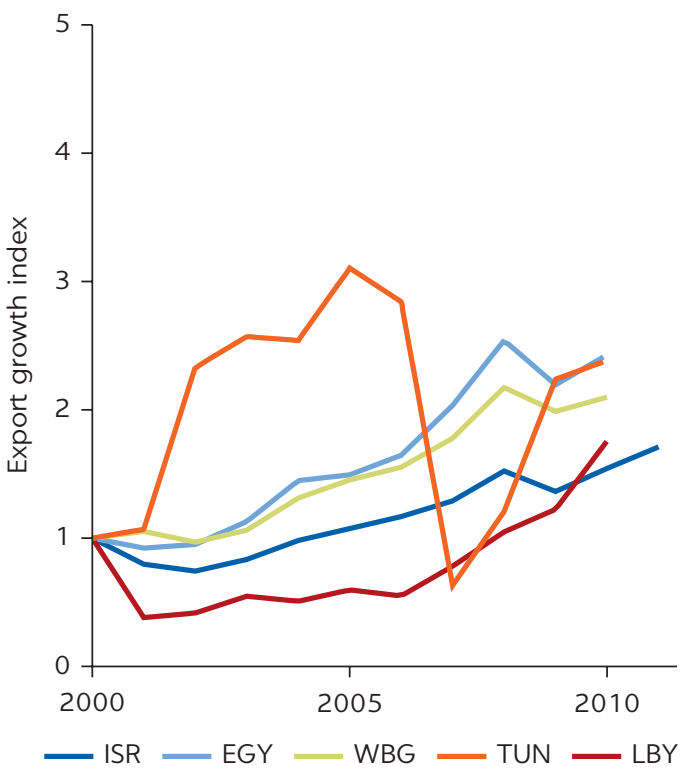

Source: World Bank World Development Indicators.

Note: The values of exports of each country are normalized to unity in 2000 to depict the growth differences across countries over the first decade of the 21st century. EGY = Egypt, Arab Rep.; ISR = Israel; JOR = Jordan; LBN = Lebanon; LBY = Libya; SYR = Syrian Arab Republic; TUN = Tunisia; TUR = Turkey; WBG = West Bank and Gaza.

services exports rose steadily during the 2000s, despite small declines during the global financial crisis of 2008-09. Tunisia experienced significant declines in exports in 2007, but its exports rebounded by 2010.

The bulk of the region's services exports are concentrated in travel services. Turkish services exports are concentrated primarily in travel services, although exports of transport services have also been increasing. The share of travel services increased to 63 percent of total services exports in 2009. Other business services accounted for less than 1 percent of Turkey's services exports in 2009. Exports of insurance, IT, post, and telecommunication services are growing very rapidly in Turkey.

The concentration of travel services exports is also evident in Egypt, Jordan, Lebanon, Syria, and Tunisia. Business services exports are also important in Lebanon and to a lesser extent Israel. The Islamic Republic of Iran and Israel are less dependent on travel services than the other countries in the region. The Islamic Republic of Iran appears to have the most diversified services exports. IT services exports are important to Israel.

Exports of services by most countries changed little through 2010. Except for Lebanon, they seem to be stuck in their initial position. Exports and imports of services are very important for Jordan and Lebanon (suggesting high external competitiveness). In many other countries, the shares of exports and imports in GDP are lower than would be predicted given their per capita GDP levels. Turkey's exports of services represent a small share of its GDP given the size of the services sector in the domestic economy. Most other countries of interest export the predicted level of services. 


\section{BILATERAL SERVICES EXPORTS}

The next step in evaluating potential bilateral economic linkages and complementarities in services trade between Turkey and the Mashreq countries is to review bilateral trade relations to determine the extent to which these countries are linked in services. This analysis goes beyond the aggregate level, evaluating regional trade in particular services subsectors. $\underline{\text { ? }}$

\section{Total services flows over time}

Figure 5.3 plots the imports and exports of a country from or to all other countries in the region. It shows that Turkey imported just $\$ 153$ million of services from Syria in 2007, 0.5 percent of Turkey's total services imports that year. Imports from the Islamic Republic of Iran and Israel reached \$264 and \$194 million, respectively.

FIGURE 5.3

Bilateral services flows between Turkey and other countries in the region, 2000-11

a. Turkish imports

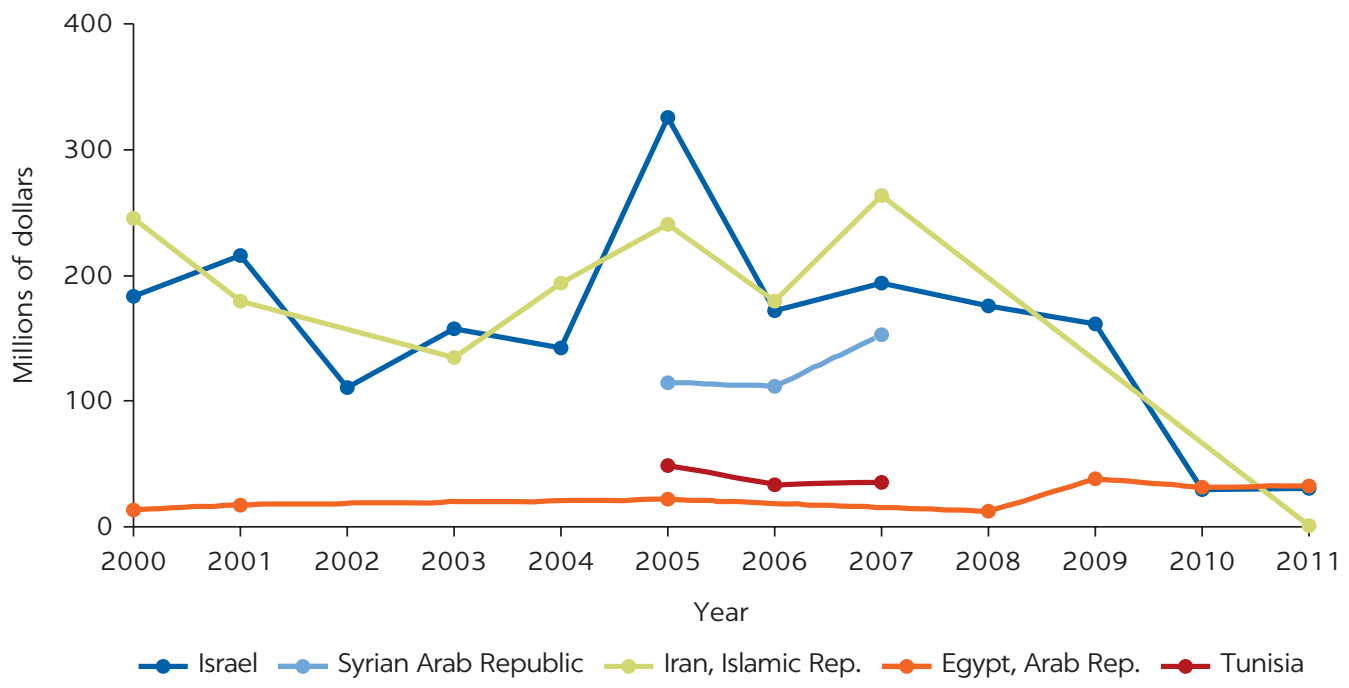

b. Turkish exports

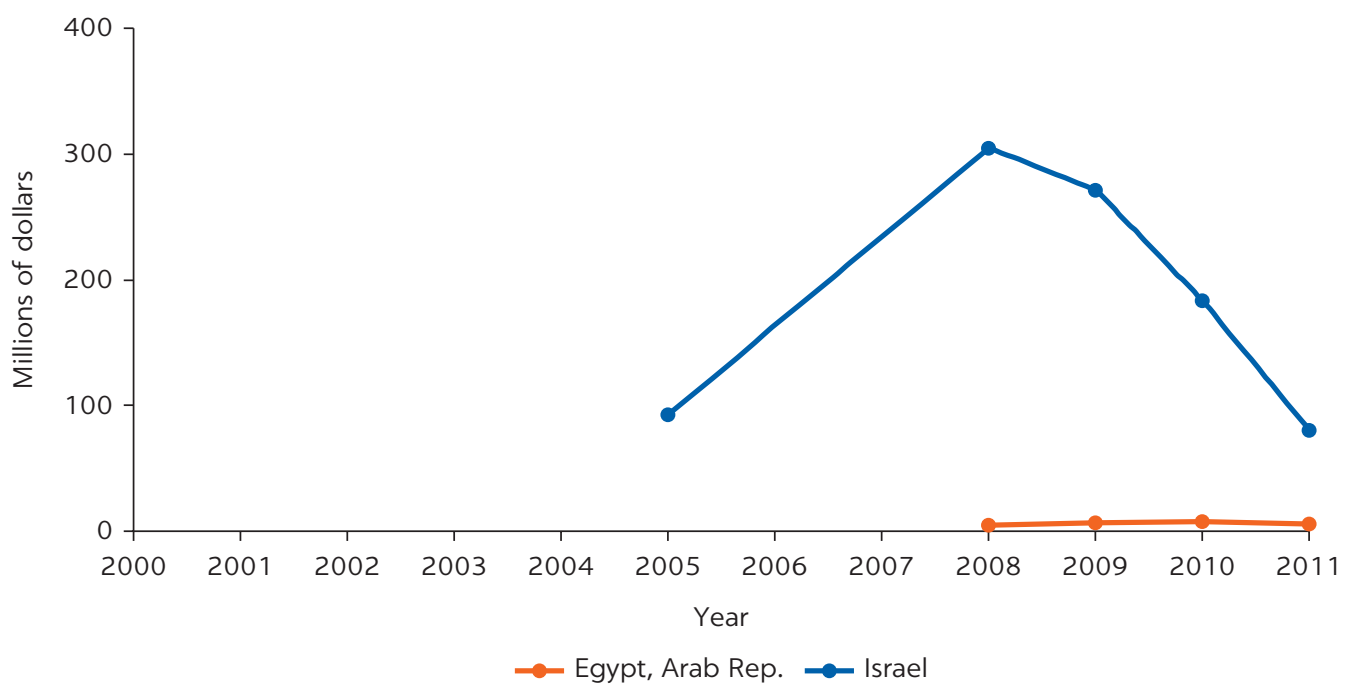


Imports from Israel dropped significantly between 2009 and 2010 and had not recovered by 2011. Imports from the Islamic Republic of Iran were also very low in 2011. Imports from the Arab Republic of Egypt and Tunisia were minimal throughout the 2000s, representing 0.2 and 0.1 percent of Turkey's services imports in 2011 and 2007, respectively. This evidence suggests that linkages through services trade between Turkey and the other countries of interest are not strong.

Turkey's total services exports to Israel reached $\$ 305$ million in 2008 but dropped to $\$ 81$ million in 2011. These flows represented only 0.6 and 0.2 percent of Turkey's total services exports and 1.4 and 0.4 percent of Israel's total services imports, respectively. Exports to Egypt were $\$ 5.8$ million in 2011 ( 0.01 percent of Turkey's total services exports and 0.04 percent of Egypt's total services imports). Exports to the Islamic Republic of Iran were \$2.9 million in 2009 (about 0.01 percent of Turkey's total services exports and 0.08 percent of the Islamic Republic of Iran's total services imports).

Libya and Tunisia have the strongest bilateral flows of services. Between 2000 and 2007, Libya's imports from Tunisia nearly tripled in value, reaching almost $\$ 300$ million in 2007, higher than any other observed bilateral flows in the region that year. They represented 14 percent of Libya's total services imports and 6 percent of Tunisia's exports in 2007. Exports to Tunisia in 2007 were $\$ 55$ million.

\section{Services flows by subsector}

Services trade is disaggregated into 11 categories as well as a residual sector: transportation, travel, communications, construction, insurance, financial, IT, royalties and licencing fees, other business, personal and cultural, and government. In 2005 imports of Turkey and the other countries of interest except Israel were composed entirely of travel services (figure 5.4). Turkey also imported other business services and personal and cultural services from Israel. Its services exports consisted primarily of business services to Israel.

\section{FIGURE 5.4}

Turkey's imports and exports of services, by subsector, 2005

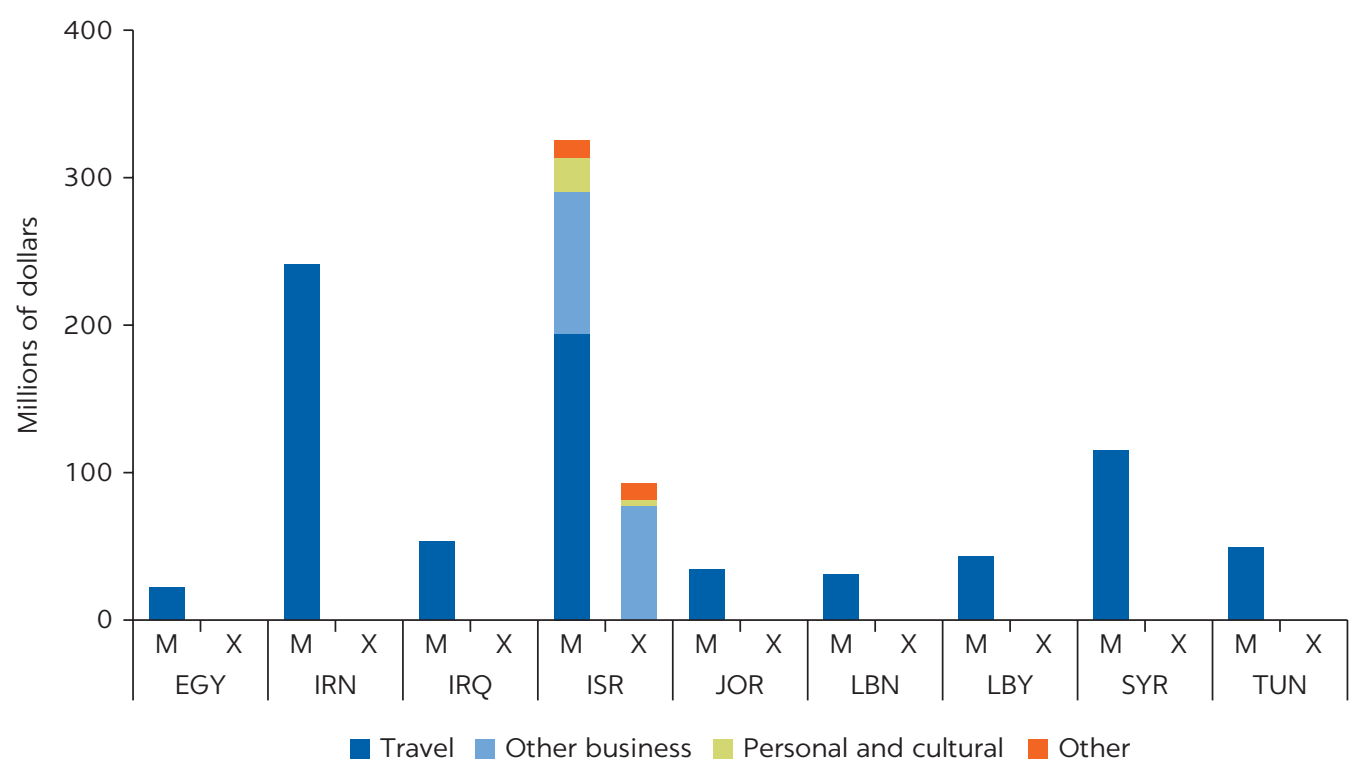

Source: World Bank Trade in Services Database.

Note: $\mathrm{M}=$ imports; $\mathrm{X}=$ exports. $\mathrm{EGY}=$ Egypt, Arab Rep.; IRN = Iran, Islamic Rep.; IRQ = Iraq; ISR = Israel; JOR = Jordan; LBN = Lebanon; LBY = Libya; SYR = Syrian Arab Republic; TUN = Tunisia. 
In 2009 Israel's imports from Turkey were primarily travel services. Its exports to Turkey included IT, business, and personal and cultural services (although other business services made up the majority). Israel imported other business services from Jordan and Egypt. Israel's minimal exports to Lebanon comprised personal and cultural services. Transportation, travel, and other business services are important for bilateral services trade between Tunisia and Libya.

Although data on bilateral flows in services are limited, they reveal that imports and exports by countries in the region represent only a small share of Turkey's total services trade and are concentrated in travel services. This evidence suggests that services trade between countries in the region may not be reaching its potential.

\section{INDICATORS OF SERVICES EXPORTS}

This section assesses whether scope exists to increase services trade integration within the region at the aggregate and sectoral levels. The analysis is based on an estimated gravity model of trade as well as trade complementarity indexes. The section also calculates and analyzes other indicators of export performance, such as revealed comparative advantage (RCA) and export sophistication. All of these indicators can help reveal what drives the structure of trade.

\section{Gravity model of trade in services}

We use a cross-country gravity model to evaluate each pair-wise export relationships between each country of interest and its trading partners. We then compare the level of bilateral trade between a pair of countries relative to their trade potential. The computation of bilateral trade potentials underlies a regression model estimating the impact of structural determinants (GDP, geographic distances, common language, and other factors) on average bilateral export values between 2005 and 2009. We use the structural determinants for each pair of countries, together with the estimated regression coefficients, to compute bilateral trade potentials. The empirical framework makes it possible to categorize bilateral exports as overtraded or undertraded, depending on the comparison between realized bilateral export values and the model's predictions.

We regress average 2005-09 bilateral exports for 189 countries on the following country-specific and bilateral characteristics: the log of distance, dummy variables for contiguity, common language, common colonial power, and the log of GDP of the exporter and importer to proxy for economic mass. We also run an alternative specification for the gravity equation in which the economic mass variable is picked up not by GDP but by importer and exporter fixed effects (referred to as a dyadic gravity equation). The results are presented in table 5.1 (the coefficients on the fixed effects are repressed to save space).

The use of exporter and importer fixed effects is suitable only if the variables of interest are dyadic (that is, exist between a pair of countries). Fixed effects control for an even wider variety of factors that affect bilateral trade flows, as they control for the omitted variables that are too difficult to measure directly. These variables include all trade policy barriers other than the right-hand side variables identified, including distance. These country-specific characteristics fall in the residual in the specification where GDP proxies economic mass. 
TABLE 5.1 Gravity model of trade in services, 2005-09

\begin{tabular}{|c|c|c|}
\hline $\begin{array}{l}\text { DEPENDENT VARIABLE: } \\
\text { LOG(EXPORT VALUE) }\end{array}$ & COEFFICIENT ESTIMATE & DYADIC COEFFICIENT ESTIMATE \\
\hline \multirow[t]{2}{*}{ log(distance) } & $-0.659^{* * *}$ & $-0.874^{* * *}$ \\
\hline & $(0.022)$ & $(0.024)$ \\
\hline \multirow[t]{2}{*}{ contiguity } & $0.776^{* * *}$ & $0.758^{* * *}$ \\
\hline & $(0.122)$ & $(0.093)$ \\
\hline \multirow[t]{2}{*}{ common language } & $1.081^{* * *}$ & $0.533^{* * *}$ \\
\hline & $(0.065)$ & $(0.053)$ \\
\hline \multirow[t]{2}{*}{ common colonial power } & -0.122 & $0.516^{* * *}$ \\
\hline & $(0.094)$ & $(0.077)$ \\
\hline \multirow[t]{2}{*}{ log(importer GDP) } & $0.727^{* * *}$ & \\
\hline & $(0.009)$ & \\
\hline \multirow[t]{2}{*}{ log(exporter GDP) } & $0.738^{* * *}$ & \\
\hline & $(0.009)$ & \\
\hline Observations & 7,817 & 8,583 \\
\hline Adjusted $R$-squared & 0.609 & 0.791 \\
\hline
\end{tabular}

Sources: World Bank World Development Indicators, World Bank Trade in Services Database, and the Centre d'Études Prospectives et d'Informations Internationales (CEPII).

Note: Robust standard errors are in parentheses. GDP $=$ gross domestic product.

${ }^{* * *} p<0.01, * * p<0.05, * p<0.1$

\section{FIGURE 5.5}

Residuals versus fitted values estimated with GDP and fixed effects, 2005-09

a. GDP

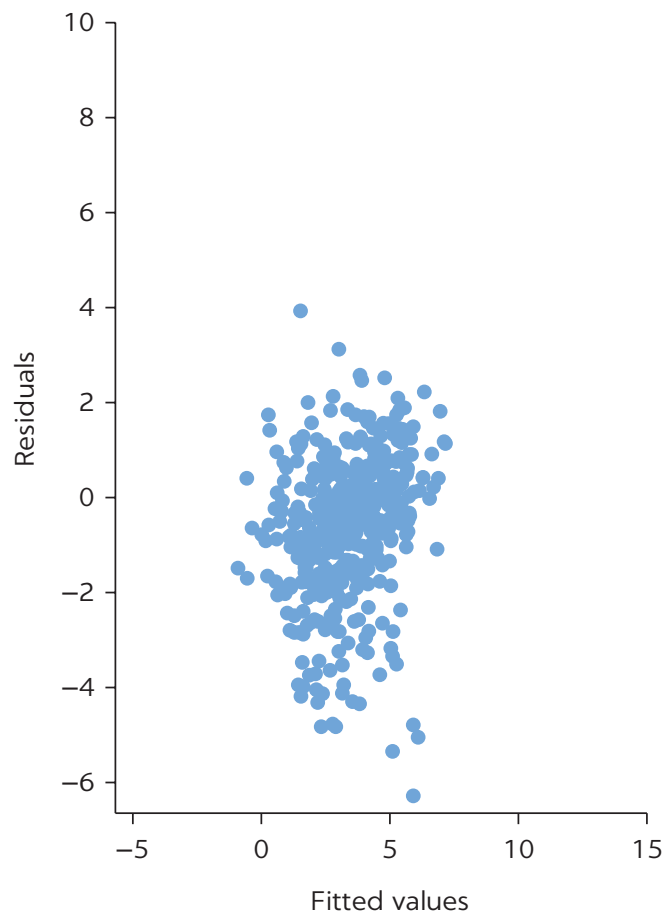

b. Fixed effects

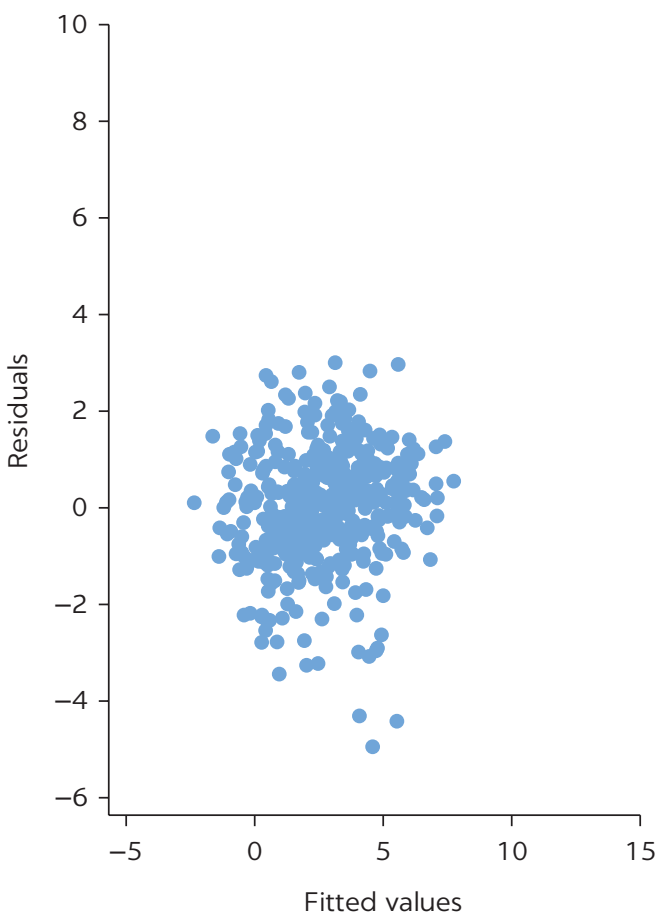

Sources: World Bank World Development Indicators, World Bank Trade in Services Database, and the Centre d'Études Prospectives et d'Informations Internationales (CEPII). Note: GDP = gross domestic product.

Figure 5.5 plots the residuals against the model's fitted values for each of the two specifications. Once properly controlling for these other obstacles in the specification with fixed effects, fitted values perform better. 
The predicted levels from the specification are lower in panel $b$ than in panel a. Lower potential trade after properly controlling for country-specific obstacles to trade suggests that these barriers are deterring services trade, both with the countries of interest and with other countries.

Figure 5.6 plots each country's actual and predicted bilateral trade relationships (given by the dyadic gravity equation). If an observation is above (below) the 45-degree line, the average observed export relationship in 2005-09 is more (less) than what the gravity model predicts, and the exporter is said to be overtrading (undertrading) with its trading partner.

Egypt underexports to Turkey, and Turkey underexports to Egypt and the Islamic Republic of Iran. Exports to Turkey by the Islamic Republic of Iran, Israel, Libya, Iraq, Jordan, and Syria are above the model's predicted levels, and exports by Tunisia and Lebanon are close to the predicted level. The gravity trade model indicates that in 2005-09, the potential export volumes between Turkey and countries in the region predicted by structural trade determinant are close to or lower than the realized intraregional trade values. This finding suggests that there may be limited scope for Turkey to increase trade integration in services in the region.

The results of the model also suggest that Turkey is overexporting to Israel and, given their strong linkages, that Libya and Tunisia are overtrading in services. Trade between Israel and other countries in the region is lower than predicted. Israel is undertrading in services with Jordan, Egypt, and Lebanon, possibly suggesting untapped potential to increase exports between these countries. However, political factors as well as data limitations may influence these results (box 5.1).

\section{Trade complementarity and trade intensity}

A trade complementarity index can help identify markets with which a country has export potential. The index measures how well the export structure of one country matches the import structure of another country. It is based on total exports and imports at the disaggregated services sectoral level, which are then aggregated into a single index for each country pair. The index number rages between 0 and 100. The higher the index number, the greater the potential for that country to export to the other market.

This index suggests that the potential for intraregional exports from Turkey to the core Mashreq countries changed little between 2004 and 2010 (figure 5.7). Trade complementarities between Syria and Lebanon with the other core countries fell; they remained steady in Jordan and the other outer circle countries. Only in Israel did the potential for intraregional exports appear to be increasing. The potential for intraregional exports from Turkey to the outer circle countries changed little between 2004 and 2010, but the level of complementarity is higher. Complementarities between Syria, Lebanon, Iraq, and the outer circle countries fell.

A trade intensity index (TII) can also be used to describe export market potential. This measure indicates a country's relative share of exports to a country compared with the rest of the world's share of exports to that country. A high (low) index number suggests that trade between a country and its partner is more (less) intense than trade with the country and the rest of the world. 
FIGURE 5.6

Gravity model of trade in services for Turkey and selected countries in the Middle East and North Africa, 2005-09
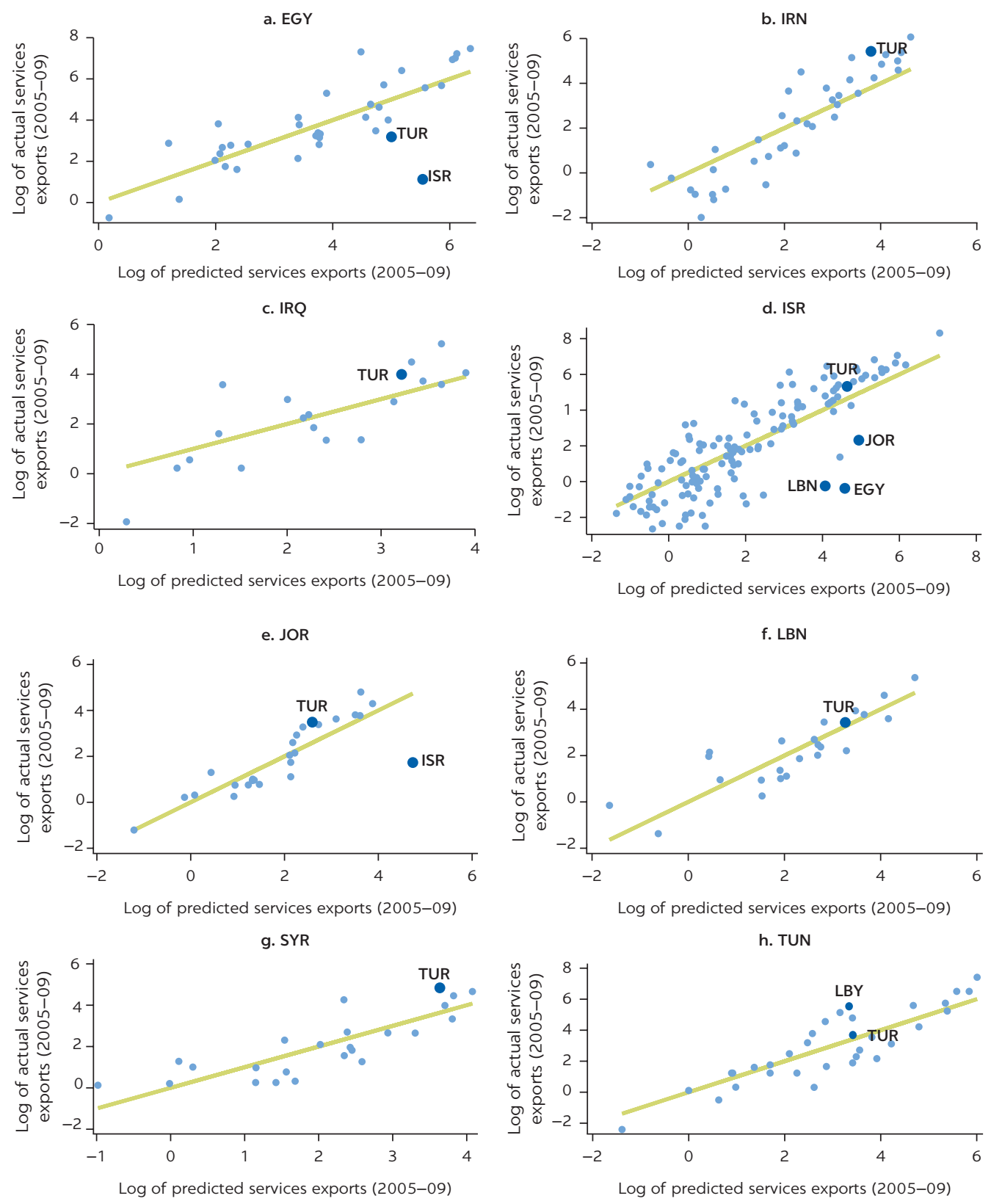

i. TUR

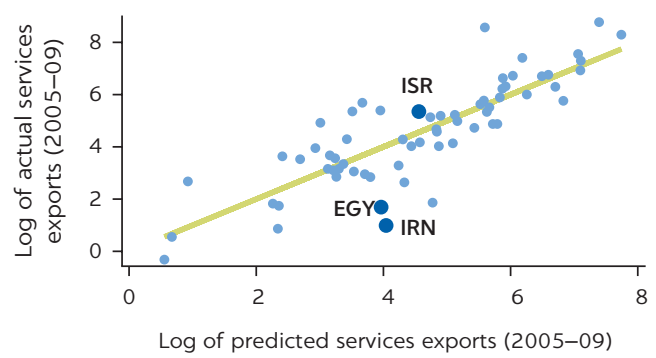

Sources: World Bank World Development Indicators, World Bank Trade in Services Database, and the Centre d'Études Prospectives et d'Informations Internationales (CEPII).

Note: Each dot in the figure represents a country observation; dark blue dots indicate countries of interest: $\mathrm{EGY}=$ Egypt, Arab Rep.; IRN = Iran, Islamic Rep.; IRQ = Iraq; ISR = Israel; JOR = Jordan; LBN = Lebanon; LBY = Libya; SYR = Syrian Arab Republic; TUN = Tunisia; TUR = Turkey. 


\section{BOX 5.1}

\section{Statistical limitations in capturing foreign direct investment and developments in Islamic finance}

Because of data limitations, only data on cross-border services trade in Modes 1 and 2 can be collected in the World Bank Trade in Services Database (they are reported in the balance of payments statistics of countries' national accounts). However, foreign direct investment (FDI) (Mode 3) remains an important channel for foreign providers to supply services. About 60 percent of the global FDI stock is in the services sector, with finance the most important subsector (Sáez and others 2014). Given the nature of services trade and the role of
FDI in the sector, the activities of affiliates include a mix of cross-border (Modes 1 and 2) and local activities (Mode 3 ).

This data constraint may be particularly relevant when considering the gravity trade potential of the countries of interest. The gravity model of trade is used to assess the bilateral gravity trade potential for these countries. However, the observed bilateral services flows are missing financial services FDI flows. Islamic banking is one obvious missing element. Inclusion of these flows is beyond the scope of this analysis.

FIGURE 5.7

Trade complementarity index for Turkey and selected countries in the Middle East and North Africa, 2004-10

a. EGY

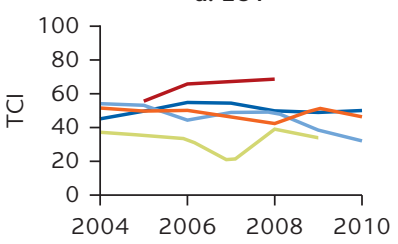

e. JOR

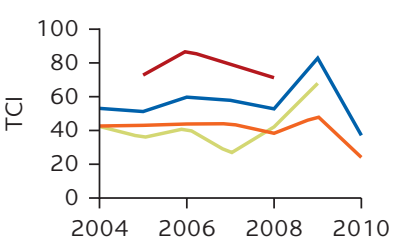

i. TUN

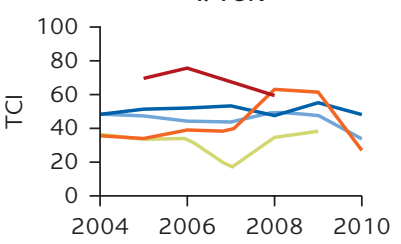

b. IRN

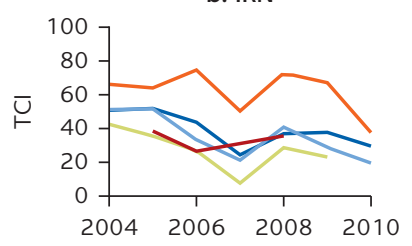

f. LBN

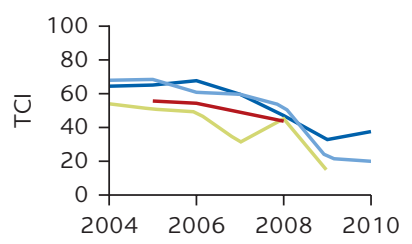

j. TUR

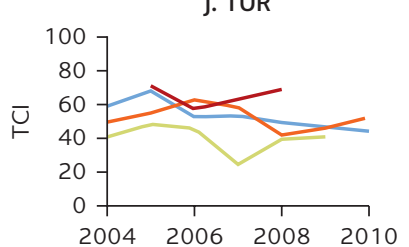

c. IRQ

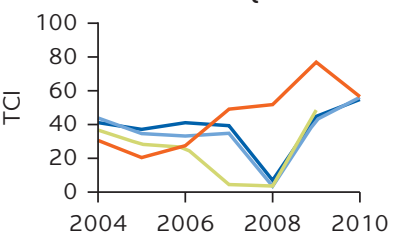

g. LBY

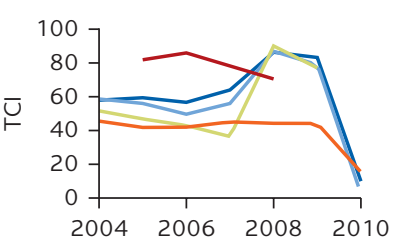

d. ISR

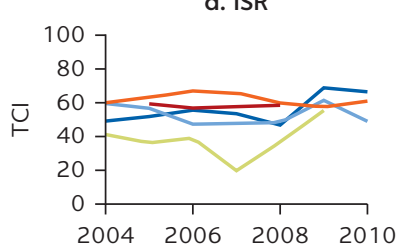

h. SYR

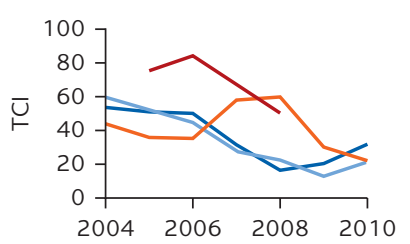

- TUR JOR - SYR LBN - IRQ

figure continued on next page 
a. EGY

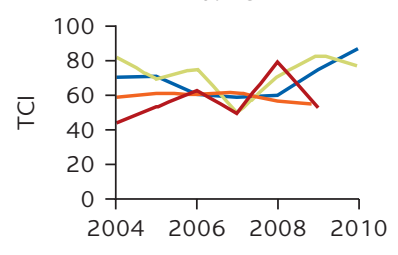

e. JOR

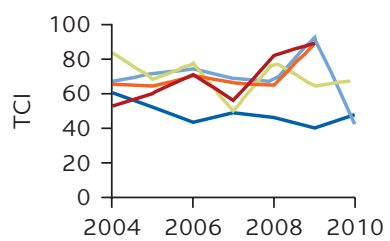

i. TUN

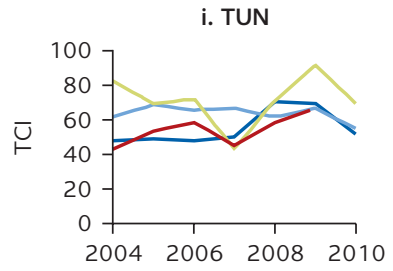

b. IRN

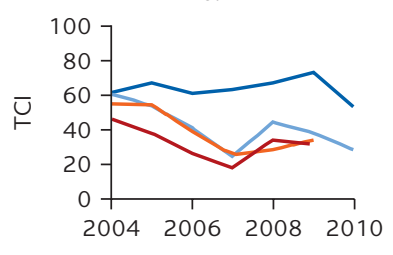

f. LBN
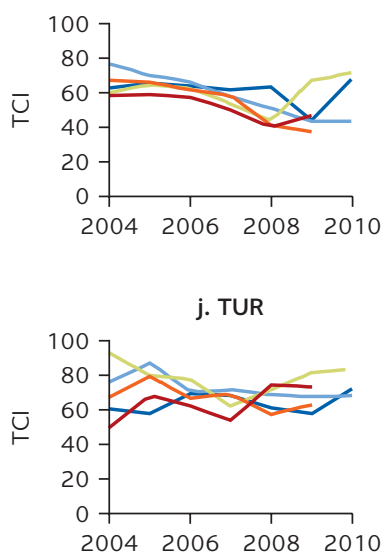

c. IRQ

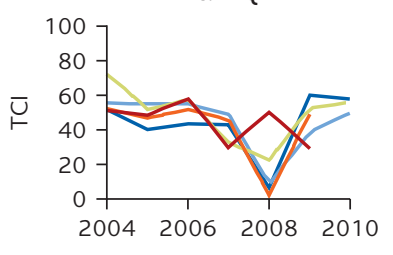

g. LBY

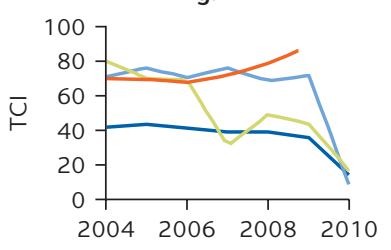

d. ISR

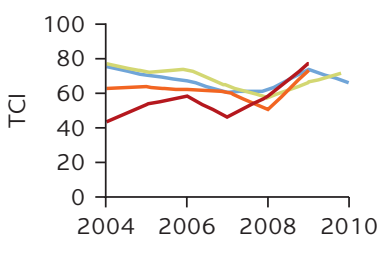

h. SYR

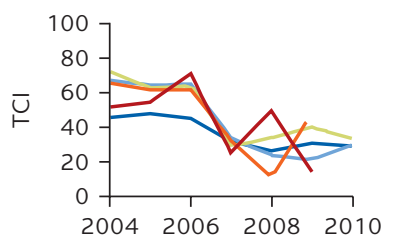

Source: World Bank Trade in Services Database.

Note: $\mathrm{TCl}=$ trade complementarity index. EGY = Egypt, Arab Rep.; IRN = Iran, Islamic Rep.; IRQ = Iraq; ISR = Israel; JOR = Jordan; LBN = Lebanon; LBY = Libya; SYR = Syrian Arab Republic; TUN = Tunisia; TUR = Turkey.

Figure 5.8 depicts the indexes of trade intensity of each bilateral pair observed in the database, averaged over 2005-09 to maximize the number of observations. It shows that the intensity of Turkey's exports to Egypt, the Islamic Republic of Iran, and Israel was extremely low. Turkey appeared to be a relatively intense export destination for Syria, Jordan, Iraq, and the Islamic Republic of Iran, although its imports from these countries represented only a small share of its total imports in 2005.

\section{Revealed comparative advantage}

Sectoral data can be used to identify sectors in which a country has a RCA. The RCA compares the share of exports of a country in world exports with the average share of exports of all countries in the world exports for a given services subsector. An RCA index above 1 indicates that a country's share of exports in a sector is higher than the global share. The higher the ratio, the more competitive the country is in a subsector.

Figure 5.9 graphs the RCA Index for the countries of interest in 2000, 2005, and 2009. Not surprisingly, the countries shown have RCAs in exports of traditional services, including transport, but particularly travel. The RCA Indexes for modern services are very low, except for Israel, which has an RCA in IT services, and Tunisia, which has an RCA in communications services. The similarity of the structures of RCAs for these countries is another indicator of the limited scope for enhanced regional integration through services trade. 
FIGURE 5.8

\section{Trade intensity index for Turkey and selected countries in the Middle East and North Africa, 2005-09}

a. Imports of Turkey

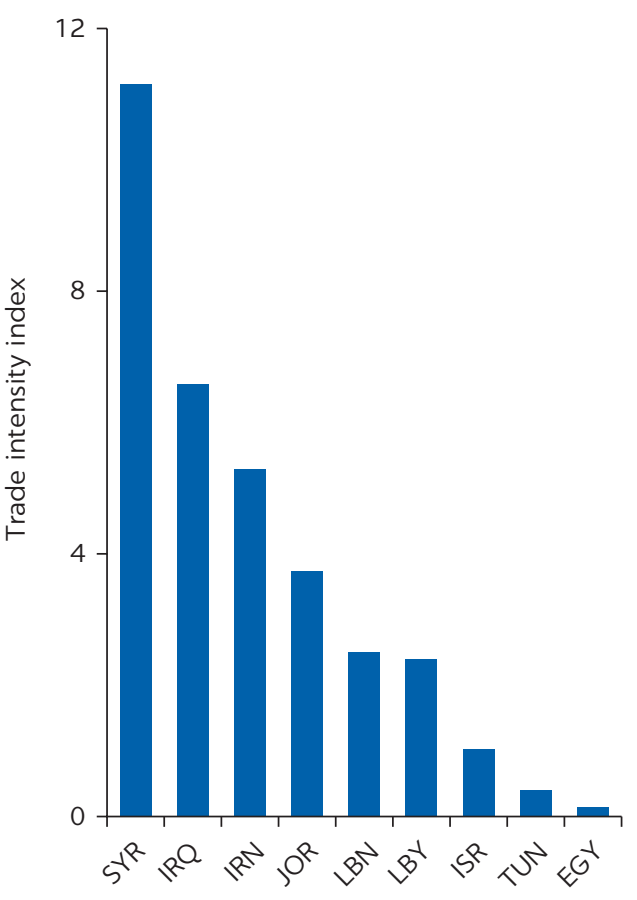

b. Exports of Turkey

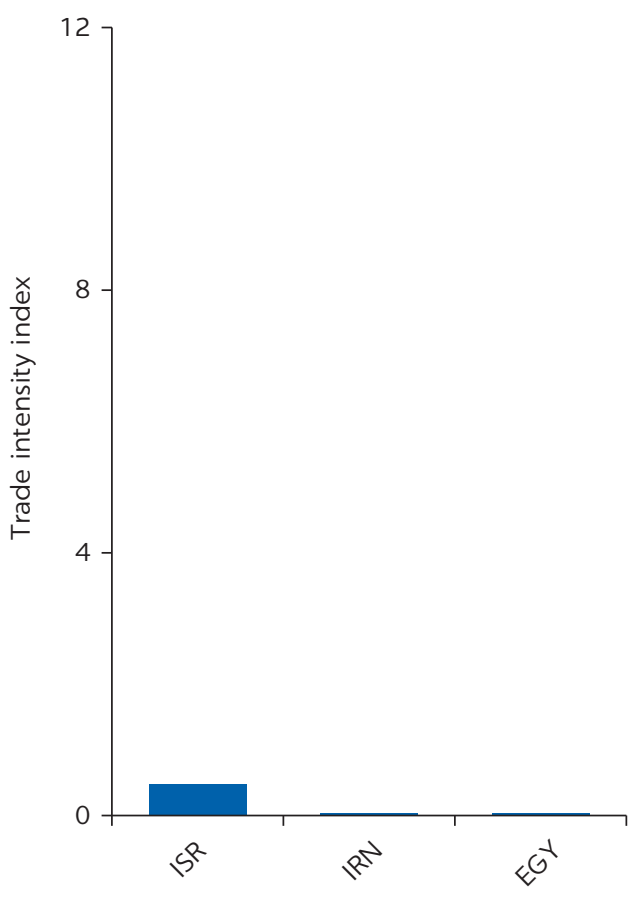

Source: World Bank Trade in Services Database. Note: $\mathrm{EGY}=$ Egypt, Arab Rep.; IRN = Iran, Islamic Rep.; IRQ = Iraq; ISR = Israel; JOR = Jordan; LBN = Lebanon; LBY = Libya; SYR = Syrian Arab Republic; TUN = Tunisia.

Comparative advantage is a dynamic process. Factors such as natural endowments, the business environment, and capabilities shape comparative advantage and therefore productivity. But policy variables, such as regulation, also play a role.

\section{Export sophistication}

Measures of sophistication reveal whether the composition of services moves in the direction of modern activities. Figure 5.10 plots the average sophistication of services exports (EXPY) against average per capita income for 2001 and 2009. EXPY is an index of services export sophistication. Any increase in a country's EXPY indicates a shift toward exports of more sophisticated products. The sophistication of a service (PRODY) is calculated as the weighted average of the GDPs of countries that export that service. In general, higher value-added products have higher PRODYs. A country's EXPY is calculated as the weighted average of the PRODYs of the services the country exports. EXPY thus captures whether a country's export basket consist primarily of services typically exported by high-income economies, which are perceived as relatively sophisticated. This measure is relevant, because 
FIGURE 5.9

\section{Revealed comparative advantage index for Turkey and selected countries in the Middle East and North Africa, 2000, 2005, and 2009}

a. EGY

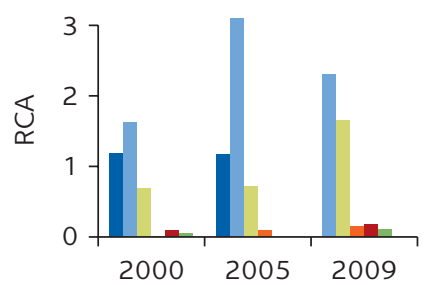

e. JOR

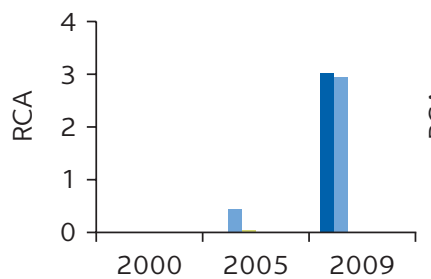

i. TUN

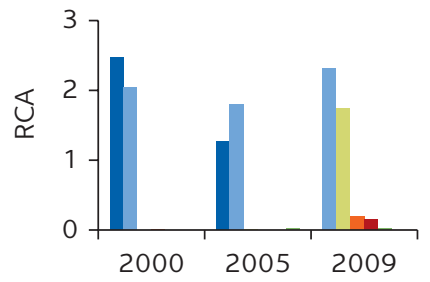

b. IRN

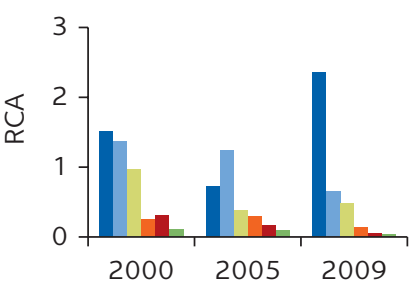

f. LBN

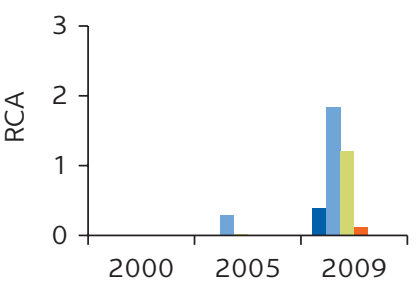

j. TUR

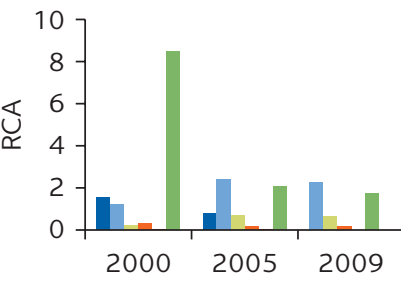

c. IRQ

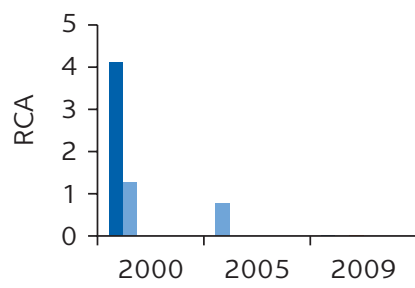

g. LBY

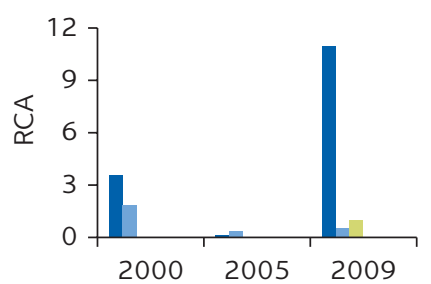

d. ISR

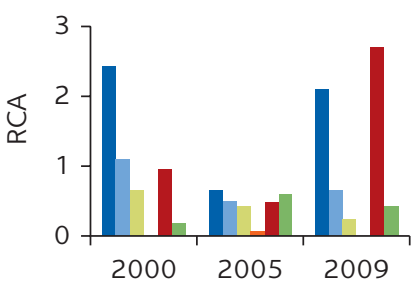

h. SYR

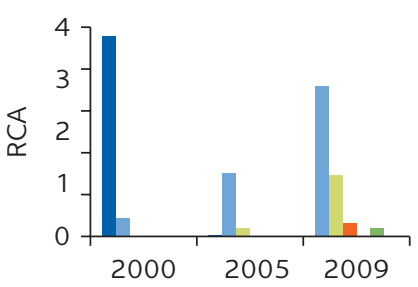

Transport $\square$ Travel $\square$ Communications

- Financial Computer $\square$ Personal

Source: World Bank Trade in Services Database.

Note: $\mathrm{RCA}=$ revealed comparative advantage. EGY = Egypt, Arab Rep.; IRN = Iran, Islamic Rep.; IRQ = Iraq; ISR = Israel; JOR = Jordan; LBN = Lebanon; LBY = Libya; SYR = Syrian Arab Republic; TUN = Tunisia; TUR = Turkey.

although emerging economies are increasingly exporting sophisticated services, sophisticated services tend to be exported by higher-income countries. An increase in EXPY indicates that the share of high-PRODY services in the export basket has increased.

In Jordan, Tunisia, and Turkey, the sophistication of services is below average given their per capita income levels. Between 2001 and 2009, Israel and more strikingly Libya increased the sophistication of their services exports. In contrast, sophistication fell in Jordan and Turkey.

Figure 5.11 presents each country's EXPY between 2001 and 2009. Sophistication appear to have increased in all countries, although the increase was less pronounced in Turkey than in the other countries of interest. This increase declined with the onset of the global financial crises in 2008.

Indexes of sophistications are relative measures. Of all the countries of interest considered in this chapter, Lebanon and Israel have export baskets that most closely resemble the baskets of rich countries. 
FIGURE 5.10

\section{Relationship between sophistication of services exports and per capita GDP in Turkey and selected countries in the Middle East and North Africa, 2001 and 2009}

a. 2001

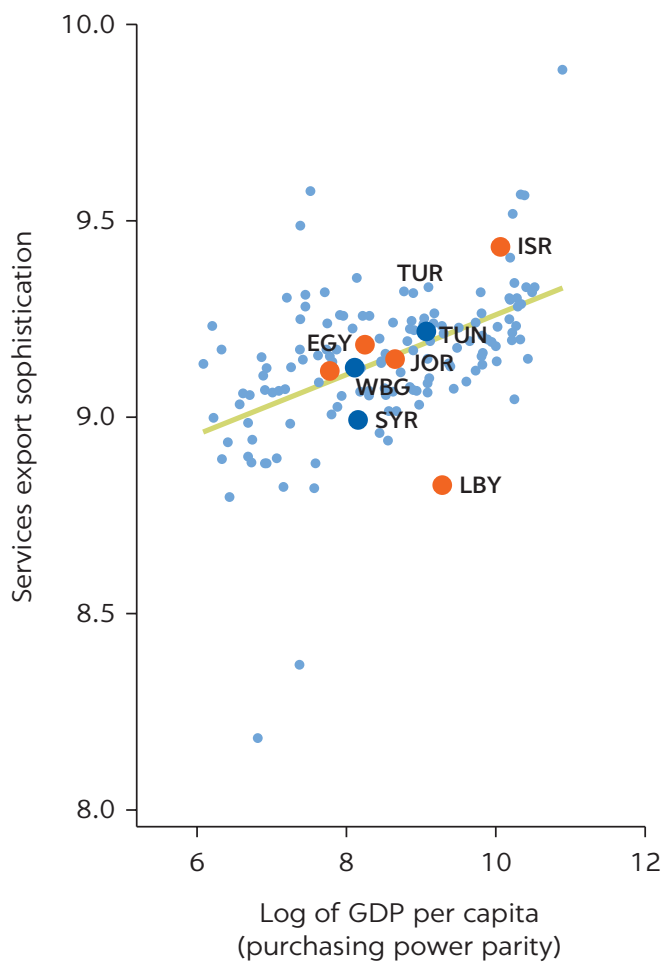

b. 2009

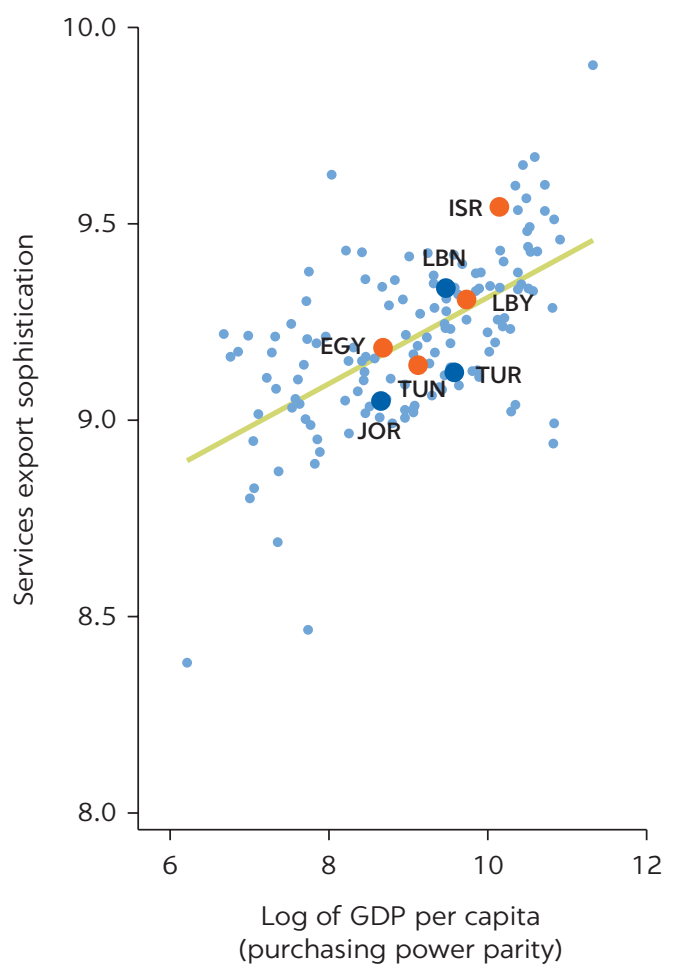

Sources: World Bank Trade in Services Database and World Bank World Development Indicators. Note: GDP = gross domestic product. Dark blue dots indicate core countries of interest; orange dots indicate other economies in the region included in the analysis: EGY = Egypt, Arab Rep.; ISR = Israel; JOR = Jordan; LBN = Lebanon; LBY = Libya; SYR = Syrian Arab Republic; TUN = Tunisia; TUR = Turkey; WBG = West Bank and Gaza.

\section{Export diversification}

In addition to transitioning toward sophisticated and modern services exports, countries need to diversity their exports. This section looks at whether exports are concentrated in a single or a handful of sectors or whether they are diversified.

To assess diversification, we measure its opposite, concentration, based on the Herfindahl-Hirschman Index. The normalized version of the index ranges from 0 to 1 , with higher values indicating higher concentration of exports of services.

Figure 5.12 reveals that some significant changes occurred between 2000 and 2010. In the Islamic Republic of Iran, Libya, and Tunisia, services subsectors became less concentrated. In Egypt, Iraq, Israel, Syria, and Turkey, exports became more concentrated-although where the starting value of services exports is low, adding just one sector can change the index dramatically (in such cases it is probably more useful to look at simple export shares, the number of sectors involved, or the absolute levels of exports).

There is limited evidence of scope for further integration of services in the region. Although some countries undertrade, most countries' current export levels to Turkey are above (the Islamic Republic of Iran, Israel, Libya, Iraq, Jordan, 
FIGURE 5.11

Sophistication of services exports of Turkey and selected countries in the Middle East and North Africa, 2001-09

a. Core countries

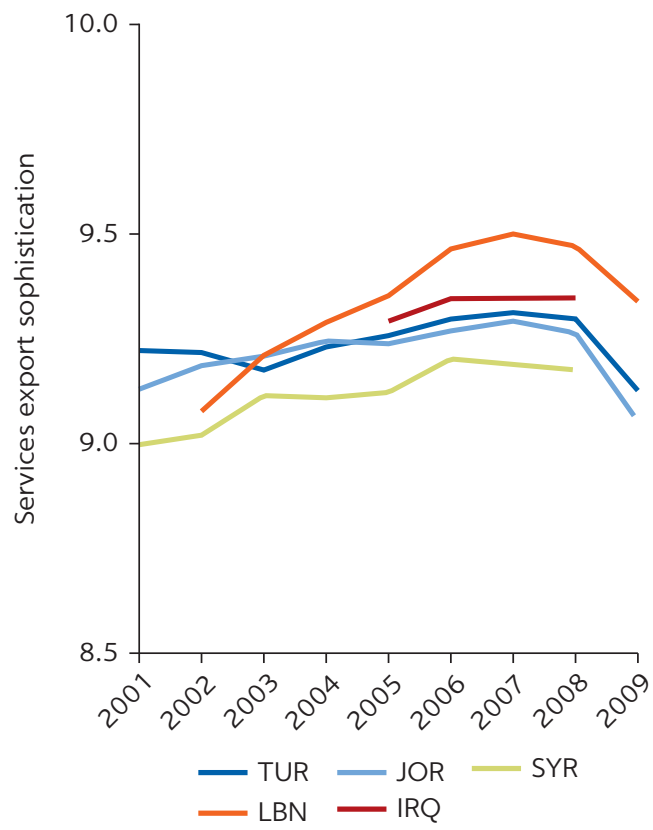

b. Outer circle countries

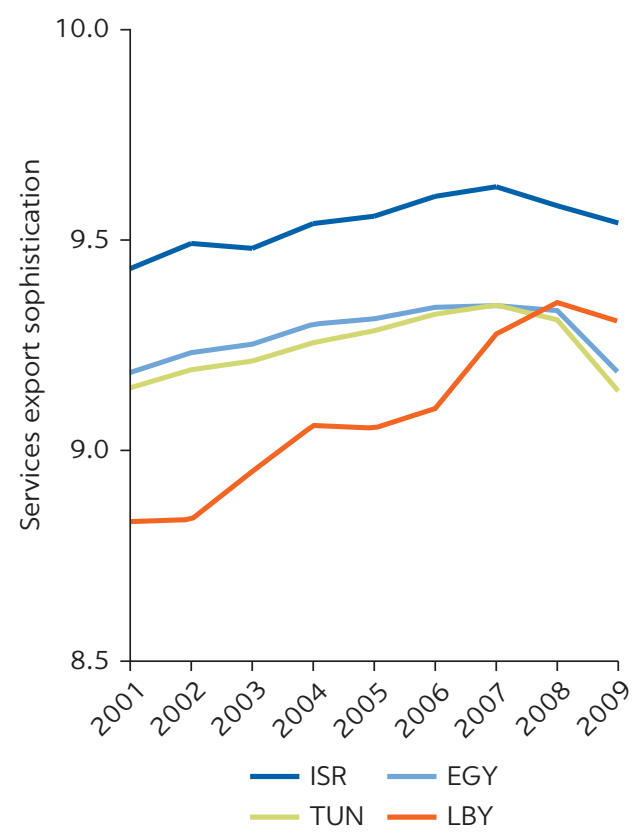

Source: World Bank Trade in Services Database.

Note: $\mathrm{EGY}=$ Egypt, Arab Rep.; IRQ = Iraq; ISR = Israel; JOR = Jordan; LBN = Lebanon; LBY = Libya;

SYR = Syrian Arab Republic; TUN = Tunisia; TUR = Turkey.

FIGURE 5.12

Herfindahl-Hirschman Index of concentration for Turkey and selected countries in the Middle East and North Africa, 2000 and 2010

a. 2000

b. 2010
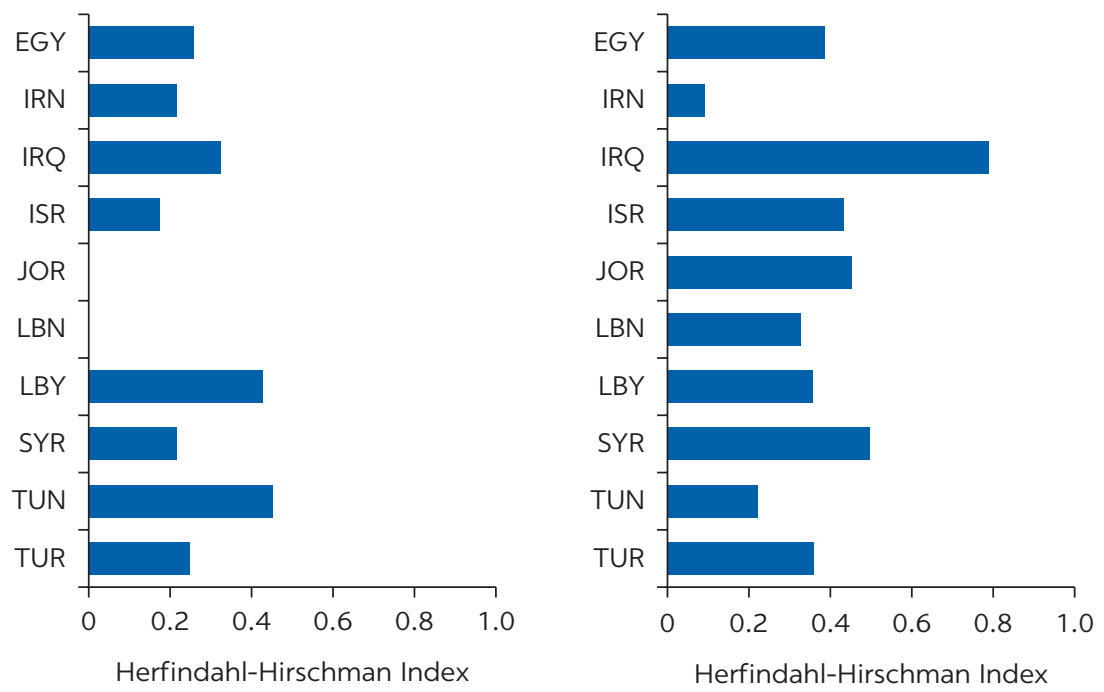

Source: World Bank Trade in Services Database.

Note: $\mathrm{EGY}=$ Egypt, Arab Rep.; IRN = Iran, Islamic Rep.; IRQ = Iraq; ISR = Israel; JOR = Jordan; LBN = Lebanon; LBY = Libya; SYR = Syrian Arab Republic; TUN = Tunisia; TUR = Turkey. 
and Syria) or close to (Tunisia and Lebanon) expected given structural trade determinants. Trade complementarities between core countries have remained steady (Turkey and Egypt) or fallen (Syria and Lebanon); only in Israel do they appear to be increasing. These patterns probably reflect the similarity in the exports of these countries.

Services exports became more concentrated between 2000 and 2010 in Egypt, Iraq, Israel, Syria, and Turkey. Although its imports from these countries represent a small share of its total imports in 2005, Turkey appears to be a relatively intense export destination for Iraq, the Islamic Republic of Iran, Jordan, and Syria.

\section{VALUE ADDED OF SERVICES}

Services can directly enhance regional integration through bilateral trade. They also constitute an important input for other export sectors. This section focuses on the importance of four subsectors-electricity, gas, and water; construction; trade and transport services; and other private services-for inputs into other domestic and export sectors of economies of interest, using the World Bank Export of Value Added Database. It presents two tables, a domestic value added table and an export value added table, which identifies the value added contribution of particular inputs to sectors that either sell the final good to the domestic market or export it.

Table 5.2 compares the total (direct and indirect considering forward linkages) value added contributions of the services subsectors to the economy as a whole as well as other sectors of the economy, including agriculture, energy extraction, and minerals; manufacturing; and other (public services and

TABLE 5.2 Direct and forward linkages of selected services in Turkey and selected countries in the Middle East and North Africa (percent)

\begin{tabular}{|c|c|c|c|c|c|c|c|c|c|c|}
\hline \multirow{2}{*}{$\begin{array}{l}\text { SECTOR/ } \\
\text { SUBSECTOR }\end{array}$} & \multicolumn{2}{|c|}{ TURKEY } & \multicolumn{2}{|c|}{ EGYPT, ARAB REP. } & \multicolumn{2}{|c|}{ TUNISIA } & \multicolumn{2}{|c|}{ IRAN, ISLAMIC REP. } & \multicolumn{2}{|c|}{ ISRAEL } \\
\hline & DOMESTIC & EXPORT & DOMESTIC & EXPORT & DOMESTIC & EXPORT & DOMESTIC & EXPORT & DOMESTIC & EXPORT \\
\hline \multicolumn{11}{|l|}{ Services } \\
\hline $\begin{array}{l}\text { Electricity, gas, } \\
\text { and water }\end{array}$ & 1.8 & 3.1 & 2.1 & 1.8 & 2.8 & 2.7 & 4.6 & 2.7 & 1.9 & 1.7 \\
\hline Construction & 6.9 & 0.5 & 6.8 & 1.6 & 4.8 & 0.6 & 4.5 & 0.3 & 6.3 & 1.7 \\
\hline $\begin{array}{l}\text { Trade and } \\
\text { transport services }\end{array}$ & 27.3 & 25.8 & 14.6 & 23.5 & 27.1 & 35.5 & 13.8 & 6.8 & 13.3 & 16 \\
\hline $\begin{array}{l}\text { Other private } \\
\text { services }\end{array}$ & 13.6 & 12.3 & 16.6 & 14.1 & 11.3 & 9.5 & 8.9 & 7.6 & 26.4 & 32.9 \\
\hline All services & 49.5 & 41.7 & 40.1 & 41.1 & 45.9 & 48.3 & 31.8 & 17.5 & 48 & 52.3 \\
\hline $\begin{array}{l}\text { Agriculture, } \\
\text { energy extraction, } \\
\text { and minerals }\end{array}$ & 9.5 & 8.7 & 27.3 & 38.9 & 21.5 & 22 & 45.4 & 78.8 & 3.3 & 6.4 \\
\hline Manufacturing & 23.4 & 48 & 20.1 & 17.5 & 16.5 & 26.8 & 7.2 & 2.9 & 18.1 & 39.5 \\
\hline $\begin{array}{l}\text { Other (public } \\
\text { services and } \\
\text { dwellings) }\end{array}$ & 17.5 & 1.7 & 12.5 & 2.5 & 16.1 & 2.9 & 15.5 & 0.8 & 30.6 & 1.8 \\
\hline
\end{tabular}


dwellings). Services represent a significant share in the value added of other export sectors of the economy, particularly manufacturing. The four services subsectors contributed 32-50 percent of total domestic value added and 18-52 percent of total export value added in 2007. These subsectors provide strong forward linkages to all other sectors of the economy, even though their direct contribution value added may not be that large.

Trade and transport services are important to the export performance of Turkey and Tunisia; other private services are important for Israel. For most countries of interest, manufacturing uses services relatively intensely; forward linkages of services accounted for between one-quarter and two-fifths of the total forward linkages in manufacturing in 2007 (closer to 10 percent for Egypt). In Israel the share of services in the forward linkages of agriculture, energy extraction, and minerals is about one-third, a much smaller contribution than in the other countries.

The analysis shows that services are an important component of regional integration, beyond their direct contribution to export value added. They contribute to each country's export competitiveness in other sectors of the economy through forward linkages. A competitive services sector is necessary for any country wanting to reach its export potential.

Although forward linkages are more important, backward linkages in services sectors are not negligible for the countries of interest. Increased services exports will have spillover effects on other sectors of the economy. Having a vibrant services sector is thus important for regional trade and integration.

\section{CONCLUSION}

The importance of services for the economies of interest varies widely. Some countries, such as Lebanon and Jordan, have large services sectors and show strong export performance in services. Other countries have less developed services sectors and less trade in services, suggesting potential for future growth through services.

Most countries in the region remain specialized in traditional servicesnamely, tourism and (in Turkey) transport. The level of sophistication is low, except in Israel and Lebanon, whose export bundles are more similar to those of high-income countries. Only three countries in the region have RCAs in modern services: Israel (IT services), Tunisia (communications services), and Lebanon (financial services). Moreover, the situation was largely stagnant, with little change in services exports between 2000 and 2010. Services are important for a vibrant export sector, particularly manufacturing, because they represent a significant share of the value added of other export sectors. Having a vibrant services sector is therefore important for regional trade and integration, above and beyond trade in services.

Services trade in the region is low, and the potential for further integration seems limited by similar specialization profiles. A more diversified and sophisticated services sector could enhance regional integration, in both services and manufacturing. A priority for policy makers should be diversification, in particular toward modern and more sophisticated services. Eliminating domestic impediments that may be holding back the development of such services could spur growth and regional integration, not only in services but also in the manufacturing sector, thanks to the forward linkages of services in most countries in the region. 


\section{NOTES}

1. Data available for the countries of interest are limited, restricting the analyses in this chapter.

2. This section relies on the bilateral flows reported in the World Bank Trade in Services Database. Data on bilateral trade in services are severely limited for these countries.

3. Manufacturing sectors include processed foods; beverages and tobacco products; textiles; wearing apparel; leather products; wood products; paper products and publishing; chemical, rubber, and plastic products; mineral products; ferrous metals; metals not elsewhere classified (n.e.c.); metal products; transport equipment; machinery and equipment; and manufactures n.e.c.

\section{REFERENCES}

CEPII (Centre d'Études Prospectives et d'Informations Internationales), Gravity (database), Paris, www.cepii.fr/cepii/en/bdd_modele/bdd.asp.

Sáez, S., D. Taglioni, E. van der Marel, C. H. Hollweg, and V. Zavacka. 2014. Valuing Services in Trade: A Toolkit for Competitiveness Diagnostics. Washington, DC: World Bank.

World Bank. 2014. Over the Horizon: A New Levant. Washington, DC: World Bank.

World Bank Export of Value Added Database, Washington, DC, https://datacatalog.worldbank .org/dataset/export-value-added-database.

World Bank Trade in Services Database, Washington, DC, https://datacatalog.worldbank.org /dataset/trade-services-database.

World Bank World Development Indicators (database), Washington, DC, http://wdi .worldbank.org. 


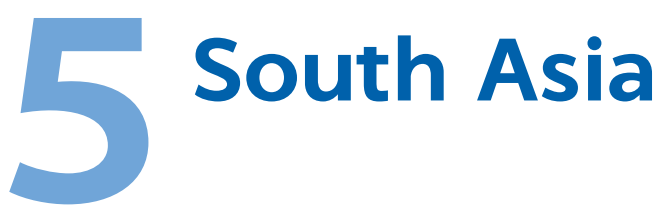





\title{
Diversifying Nepal's Economy by Creating a Dynamic Services Sector*
}

\author{
CLAIRE H. HOLLWEG
}

This chapter assesses Nepal's trade potential in services. It uses the Services Trade Competitiveness Diagnostic toolkit to identify actionable policy measures that can help Nepal achieve its potential. The objective is to support the government of Nepal in its efforts to identify strategies for greater integration in the global marketplace, as identified in the Nepal Trade Integration Strategy (NTIS) 2015 (Government of Nepal 2015a).

Three of the 12 sectors identified in the NTIS with potential to drive export growth are services related:

- tourism (leisure, business, education, and medicine)

- labor services (semi-skilled and skilled human resources)

- information technology (IT) and business process outsourcing (BPO) services.

The NTIS (a follow-up to the NTIS 2010 [Government of Nepal 2010]) charts a possible course for the development of the export sector over the following 3-5 years, suggests capacity-developing actions, and identifies short- to medium-term priorities that support inclusive growth.

This chapter uses the most recent data available for services trade from a variety of data sources, to describe Nepal's performance. The analysis was substantiated by interviews with stakeholders from the public and private sector.

The chapter is organized as follows. The first section analyzes the direct services export performance of Nepal relative to comparator countries. It takes a detailed look at the performance of Nepal's priority export potential

\footnotetext{
* The author thanks Swarnim Wagle, Jose Guilherme Reis, Celia Ortega Sotes, Gonzalo Varela, Michele Ruta, Paul Brenton, Roshan Darshan Bajracharya, Ashish Narain, Guillermo Arenas, Santosh Pandey, Ashish Rauniar, Taneem Ahad, Natalia Corral and Deepa Shakya for very useful comments. This chapter was prepared as a part of a traderelated analytical program of work carried out by the World Bank in Nepal. It is a shortened version of Policy Note 3 in the 2016 World Bank publication From Evidence to Policy: Supporting Nepal's Trade Integration Strategy (World Bank 2016).
} 
services subsectors. The second section analyzes the indirect performance of services exports, taking account services used as inputs in other sectors' exports. It identifies sources of potential for services exports and key obstacles for improved efficiency in the sector. The third section examines the policy implications of this analysis, taking both a cross-cutting and sector-specific point of view.

\section{ASSESSING THE POTENTIAL OF SERVICES EXPORTS}

Nepal's gross services exports have been extremely dynamic. Measured in gross values, total services exports reached $\$ 1.2$ billion in 2014, accounting for 54 percent of Nepal's total exports. ${ }^{1}$ Within the region, the share of services exports in total exports is highest in Nepal; larger countries (Bangladesh, China, and Vietnam) are more specialized in exports of goods.

Commercial services exports grew at an average annual rate of 17 percent between 2005 and 2014, almost quadrupling in value. ${ }^{2}$ This growth surpassed almost all comparator countries, although it fell short of growth in two other landlocked countries, Uganda (45 percent) and Rwanda (42 percent), whose export baskets also specialize in services.

Services contributed significantly to domestic growth. In 2014 the sector accounted for 51 percent of GDP, up from 45 percent in 2005. Agriculture accounted for 35 percent and industry 16 percent. All sectors experienced growth since 2005, except manufacturing, which was flat in 2008 and 2009 (figure 6.1). The leading sector was services, which accounted for more than half of GDP growth in most years, followed by agriculture. The industrial sector-in particular manufacturing-has played a less important role in growing the domestic economy.

Measuring exports by the domestic value addition they create reveals the strong reliance of Nepal's economy on services exports. A country's performance

FIGURE 6.1

Sectoral contributions to growth in Nepal, 2005-14

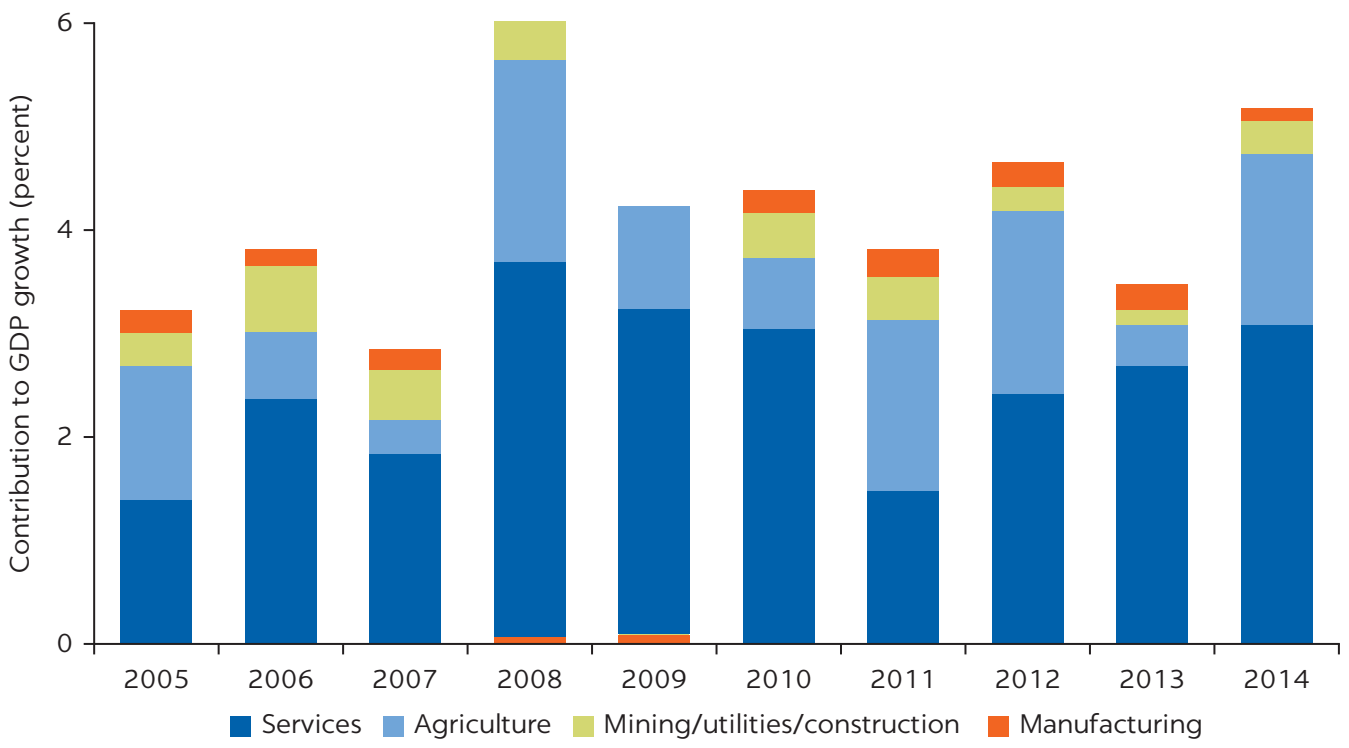

Source: World Bank World Development Indicators. Note: GDP = gross domestic product. 
FIGURE 6.2

\section{Correlation between direct value added in services exports and per capita GDP, 2011}

a. Direct

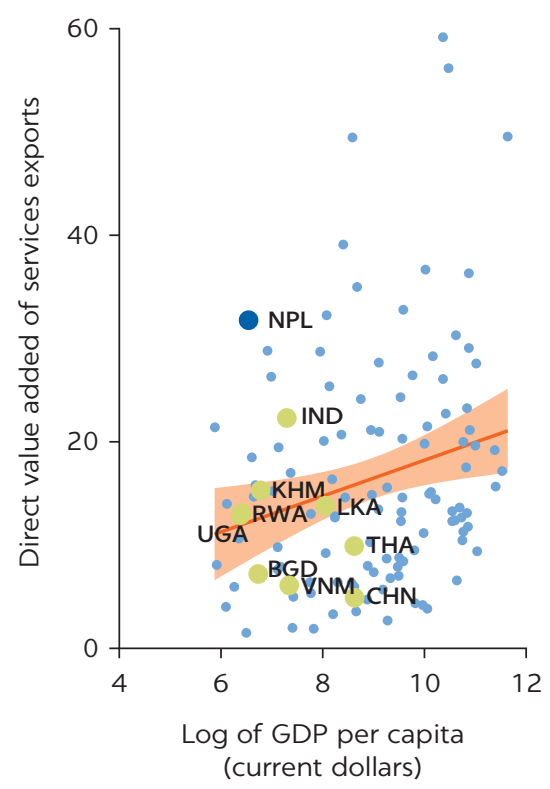

b. Total (backward)

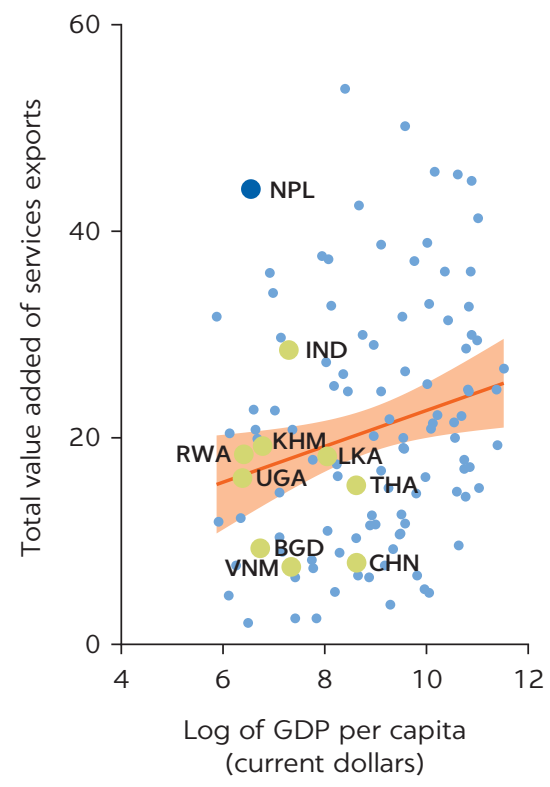

Source: World Bank Export of Value Added Database.

Note: GDP = gross domestic product. Each dot in the figure represents a country-year observation: $\mathrm{BGD}=$ Bangladesh; $\mathrm{CHN}=$ China; $\mathrm{KHM}=$ Cambodia; IND = India; LKA = Sri Lanka; $\mathrm{NPL}=$ Nepal; RWA = Rwanda; THA = Thailand; UGA = Uganda; VNM = Vietnam.

in gross services exports can distort the real contribution of a sector's exports to an economy, however, because the exports may embody heavy foreign input use.

A better measure is therefore the domestic value added created by exports. It is possible to split the contribution of a sector into direct and indirect contributions. Value added generated by total services exports is high, but nonservices exports add more value per dollar of gross exports. Direct services exports-the value added the services sector directly exports-represent 32 percent of all domestic value added exported in Nepal. This figure is significantly higher than it is in other countries at similar levels of economic development and all comparator countries, including India (figure 6.2). (Direct exports of commercial services represent 20 percent of all domestic value added exported in Nepal, a smaller share than in India; direct exports of nonservices represent 29 percent.) Adding the domestic inputs that the services sector demands for its exports (that is, the backward linkages), the services sector represents 44 percent of all domestic value added exported by Nepal. (Exports of commercial services represent 31 percent, more than even India.) The total export value added share of services (44 percent) is smaller than the gross export share of services (54 percent), suggesting that exports by other sectors add more value per dollar of gross exports.

\section{Concentration of exports}

Nepal's services exports have been most dynamic in telecommunications, growing by an average rate of 32 percent between 2005 and 2014, and travel, which increased by an average annual rate of 16 percent. Growth of Nepal's 
telecommunications exports was above both the world average and Nepal's average for commercial services. The transport sector grew slightly below the average for Nepal and at about the same rate as the world average. Nepal gained world market shares in both subsectors (figure 6.3).

The two high-growth sectors-travel (tourism) and telecommunicationsaccounted for 82 percent of Nepal's services exports in 2013. Travel services accounted for 45 percent, telecommunications 37 percent, and other business services 15 percent of total services exports.

Figure 6.4 plots the Herfindahl-Hirschman Indexes of export concentration for Nepal and comparators. It shows that China, Bangladesh, and India have more diversified services export baskets than Nepal and that Cambodia, Thailand, and Vietnam (all of which also rely heavily on tourism) had higher concentration ratios than Nepal. In most of the countries shown, the index rose between 2005 and 2013.

Focusing efforts on tourism and telecommunications services will likely continue to increase this export concentration, increasing vulnerabilities to sector-specific shocks. Scope to increase exports of other services may be limited without further action by the government.

\section{Appreciation of the exchange rate}

The real appreciation of Nepal's exchange rate affects its competitiveness. Linked to increasing remittances inflows, Nepal's real effective exchange rate

FIGURE 6.3

Growth of services exports in Nepal versus growth of world imports of services

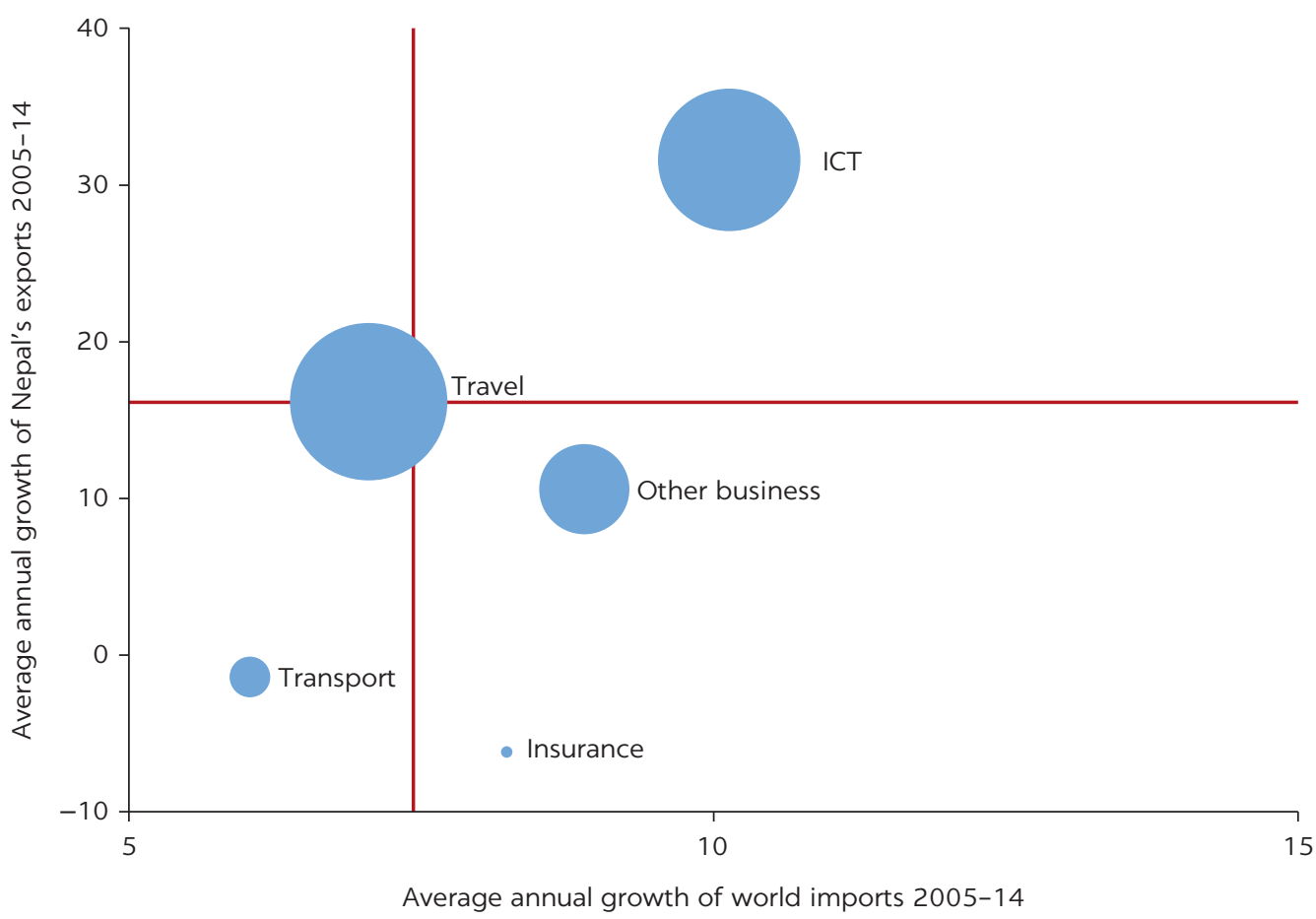

Source: UNCTADstat.

Note: The size of the circle represents the importance of the sector in Nepal's export basket. The horizontal (vertical) red line is the compounded average annual growth of Nepal's (the world's) commercial services exports between 2005 and 2014 . 
FIGURE 6.4

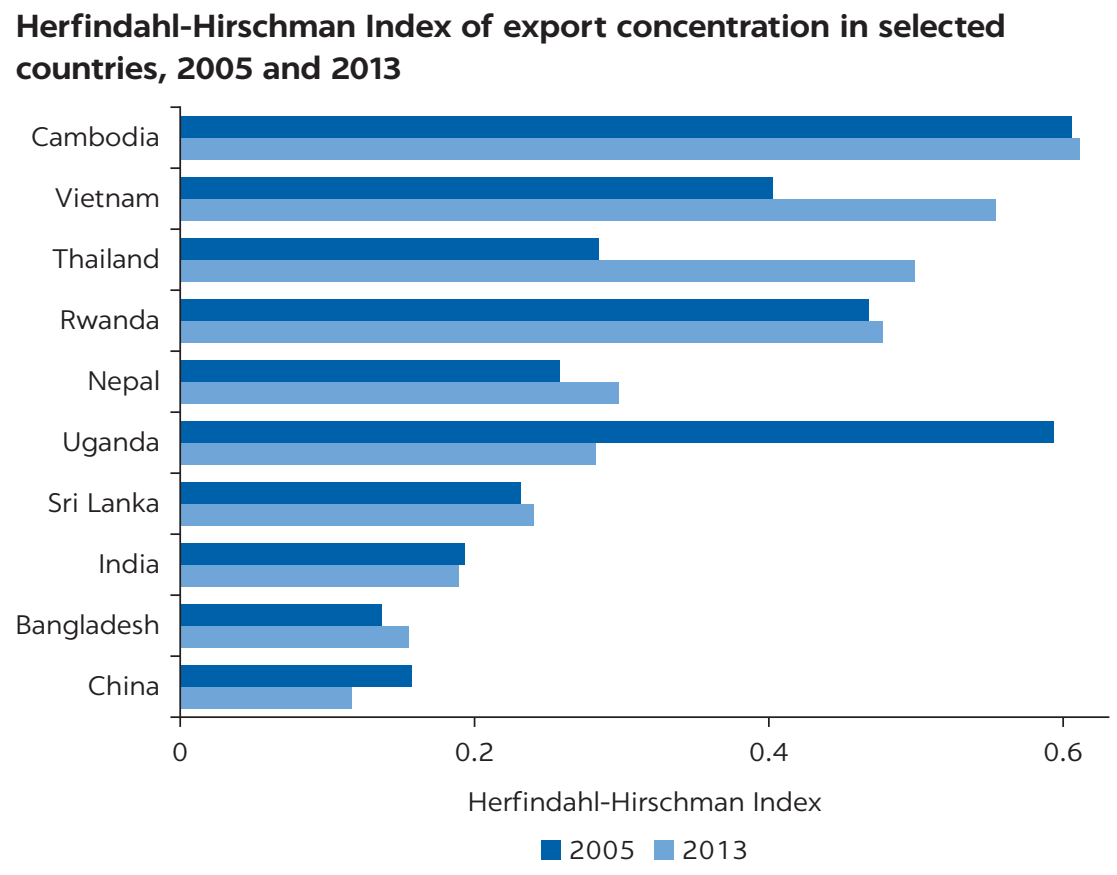

Source: UNCTADstat.

appreciated between 2008 and 2015, making exports more expensive and imports less expensive. Because services exports tend to have a lower import content than goods exports (particularly exports in global value chains), the dampening effect of continued exchange rate appreciation is less than in goods, where cheaper imported inputs help offset the loss of competitiveness of exports.

\section{Direct and indirect contributions to the value added of exports}

The most important services subsectors that export value added directly include other services, other business services and ICT, and transport services. The importance of other services increases once one considers the domestic inputs it uses to generate its exports. Finance and communications services create limited value added directly, but they also use domestic inputs.

More than 60 percent of the domestic value added of Nepal's exports is created directly within export sectors; 40 percent is generated by indirect linkages with export sectors (figure 6.5). Manufacturing exports account for almost all the backward linkages with Nepal's domestic economy; agriculture accounts for almost none.

Services are inputs in exports of manufactured and agriculture goods. After accounting for these forward linkages, the services sector accounts for 57 percent of the total value of exports.

\section{Potential to increase services exports}

Gross services exports amounted to 6.2 percent of Nepal's GDP in 2013, up from 4.7 percent in 2005 , indicating that services exports grew faster than GDP. The figure is lower than it is in other countries at similar stages of economic development. 
FIGURE 6.5

Direct and total value added of Nepal's exports, by subsector, 2011

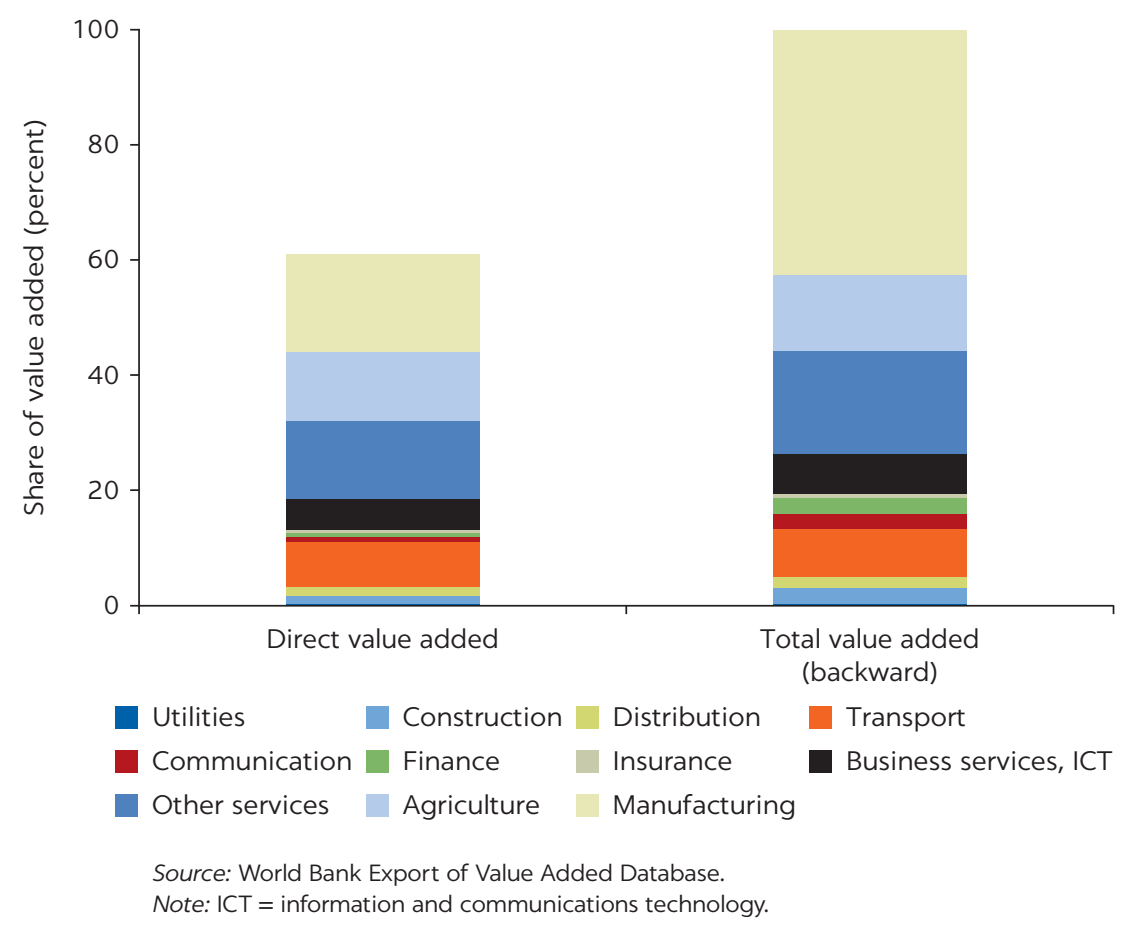

Nepal's domestic services sector is larger than expected given the country's level of economic development. The sector is large because informal, nontradable subsectors and low-value added tradables are more important in Nepal than in its peers.

Nepal outperforms comparator countries in exports of modern services but not traditional services (figure 6.6). Performance is driven by telecommunications exports, suggesting scope to increase other modern services exports. Modern services exports are not as constrained by distance or complex geography as other exports. Nepal's landlockedness should not deter its export potential in these activities.

Scope also exists to continue increasing exports in travel and transport services. Specializing in tourism can be an important development strategy for a country, and transport services are imperative to overcome connectivity challenges.

Transport services should play a more important role in a landlocked country than in a country with access to the sea. Ethiopia, for example, has an airline that serves international destinations. In Nepal the share of transport services is low, and it fell between 2005 and 2013, from 12 percent to 3 percent. The declining share was driven primarily by faster growth of other export sectors.

\section{Growth from nontraditional trade partners}

Diversifying exports to nontraditional markets can be a way to increase exports. Unlike goods exports, services exports are diversified away from India. In 2013/14 services exports to India (as reported in Nepal's balance of payments statistics) represented only 10 percent of total services exports, and were largely concentrated in travel and communication services ( 85 percent). 


\section{Correlation between services exports as share of GDP and per capita GDP, 2013}

a. Modern services exports

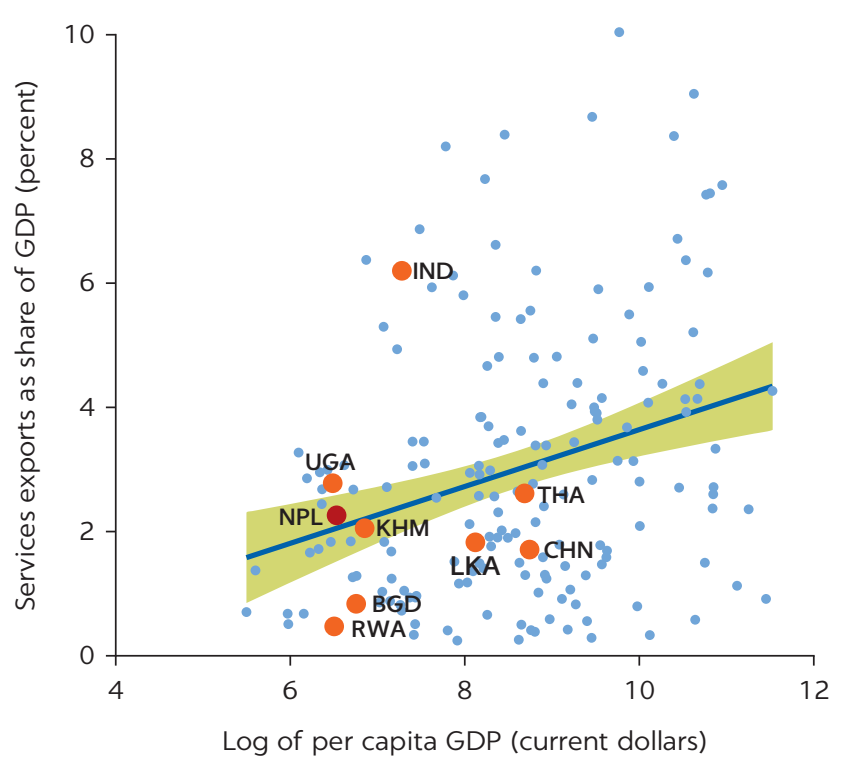

b. Traditional services exports

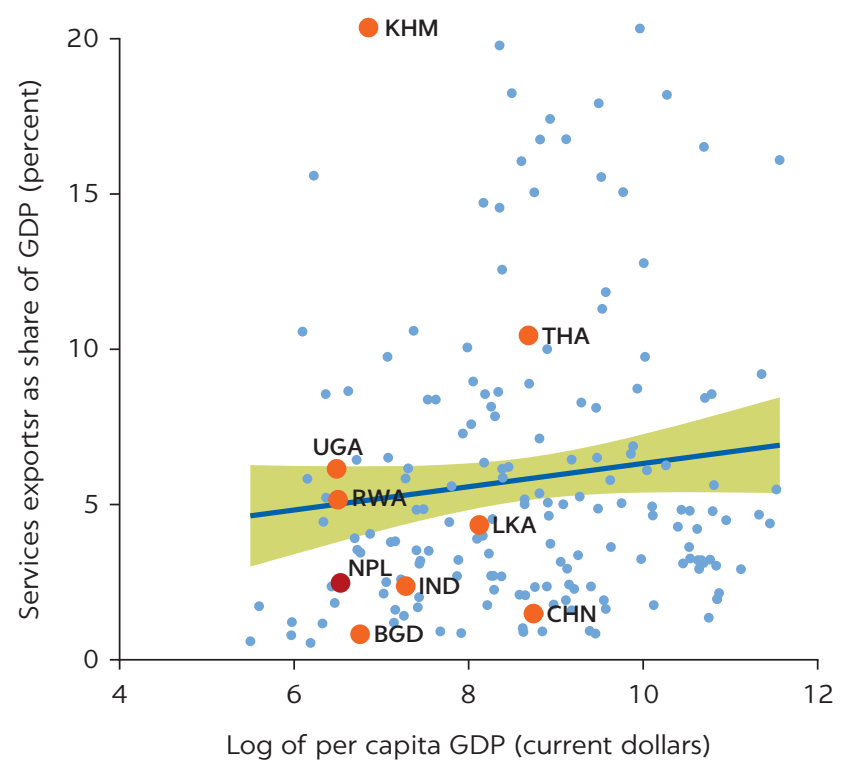

Source: World Bank World Development Indicators.

Note: $\mathrm{GDP}=$ gross domestic product. Each dot in the figure represents a country-year observation: $\mathrm{BGD}=$ Bangladesh; $\mathrm{CHN}=\mathrm{China}$; IND = India; $\mathrm{KHM}=$ Cambodia; $\mathrm{LKA}=$ Sri Lanka; NPL = Nepal; RWA = Rwanda; THA = Thailand; UGA = Uganda; VNM = Vietnam.

Here the chapter assesses scope to grow Nepal's services exports to other markets.

An analysis of export potentials using a gravity model of trade confirms that Nepal may need to look to nontraditional markets to grow its services exports..$^{3}$ Nepal's services exports to EU countries are about average, suggesting limited scope to increase these trade flows.

Trade complementarity indexes also suggest a declining potential to increase exports with major markets. A trade complementarity index can help identify markets with which a country has export potential. It reveals whether a potential importer buys services that a country exports abroad by measuring how well the export structure of one country matches the import structure of another. This index suggests that Nepal's potential to increase services exports in its current activities has been declining since 2005, because of the declining complementarity of imports and exports. In contrast, the trade potential of other countries (such as India and Uganda) in major markets has been increasing.

\section{Subsectors of revealed comparative advantages}

Nepal maintains a revealed comparative advantage (RCA) in travel and telecommunications services. It maintains an RCA in exports of travel services-as do all comparator countries except Bangladesh and India-but it lost its comparative advantage in other business services (consistent with a decline in the export share of other business services from 25 percent to 15 percent between 2005 and 2013) (figure 6.7). Anecdotal evidence suggests that travel services are concentrated in low-value market niches. 
FIGURE 6.7

Subsectors of revealed comparative advantage of selected countries, 2005 and 2013

a. 2005

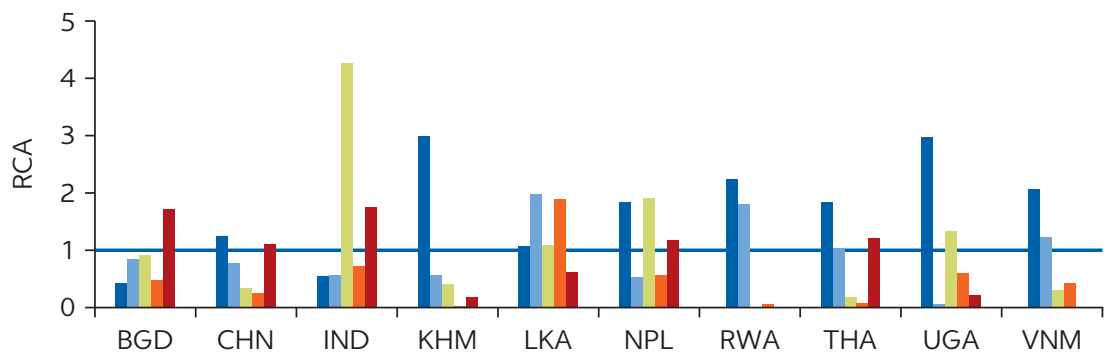

b. 2013

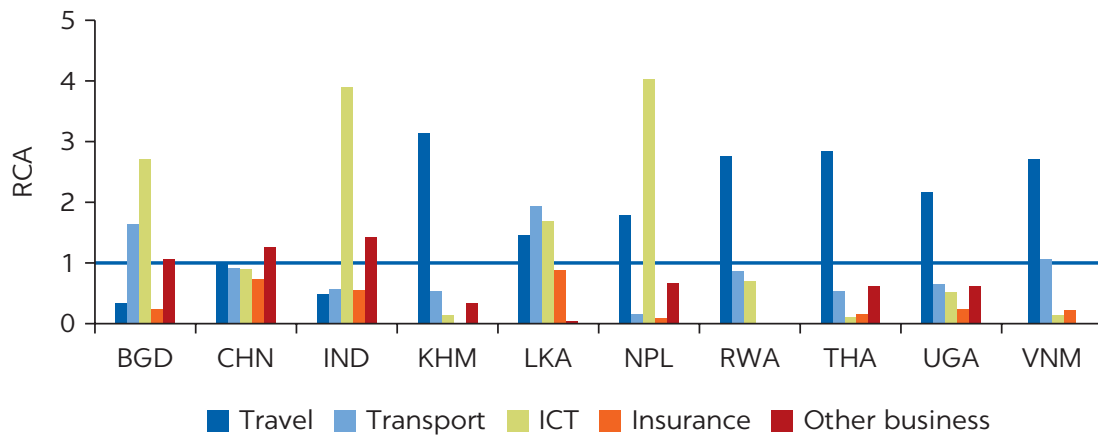

Source: UNCTADstat.

Note: ICT = information and communications technology; $\mathrm{RCA}=$ revealed comparative advantage. $\mathrm{BGD}=$ Bangladesh; $\mathrm{CHN}=$ China; IND = India; $\mathrm{KHM}=$ Cambodia; $\mathrm{LKA}=$ Sri Lanka; $\mathrm{NPL}=$ Nepal; RWA = Rwanda; $\mathrm{THA}=$ Thailand; UGA = Uganda; VNM = Vietnam .

Like Bangladesh, India, and Sri Lanka, Nepal has a strong RCA in telecommunications services. These services are not the IT and BPO services that the country targeted in the 2015 NTIS, however. These services include roaming charges of tourists visiting Nepal and incoming international calls from Nepalese living abroad.

\section{Tourism}

Traditional services exports-including tourism-should not be overlooked as important opportunities for countries to diversify and drive growth. Travel and tourism are important economic activities in many countries and have been used as a tool for economic development.

Exports of tourism are important for Nepal's economy, but they represent a smaller share of GDP than they do in peer countries. According to the World Travel and Tourism Council, the direct contribution of travel and tourism to Nepal's GDP was 3.8 percent of GDP in 2014 (table 6.1). The total contribution of the subsector, including indirect impacts, was 7.7 percent of GDP-lower than all peers except Bangladesh, Uganda, and India. In 2014 travel and tourism directly supported 3.0 percent of total employment (6.6 percent after accounting for its indirect impact and induced contribution).

Much of Nepal's tourism exports are in low value-added activities. Tourism receipts as a share of the economy are lower in Nepal than they are in Haiti and just one-sixth what they are in Cambodia. Average daily tourism expenditure 
TABLE 6.1 Contribution of tourism to GDP and employment in selected countries, 2014

Percent of total

\begin{tabular}{lcccc}
\hline CountRY & $\begin{array}{l}\text { DIRECT CONTRIBUTION } \\
\text { TO GDP }\end{array}$ & $\begin{array}{l}\text { TOTAL } \\
\text { CONTRIBUTION } \\
\text { TO GDP }\end{array}$ & $\begin{array}{c}\text { DIRECT } \\
\text { EMPLOYMENT }\end{array}$ & $\begin{array}{c}\text { TOTAL } \\
\text { EMPLOYMENT }\end{array}$ \\
\hline Bangladesh & 2.4 & 4.7 & 2.0 & 4.1 \\
\hline Cambodia & 13.2 & 29.5 & 11.5 & 26.0 \\
\hline China & 2.1 & 8.0 & 2.9 & 8.3 \\
\hline India & 2.0 & 6.2 & 5.5 & 8.7 \\
\hline Nepal & 3.8 & 7.7 & 3.0 & 6.6 \\
\hline Rwanda & 3.0 & 8.1 & 2.5 & 7.0 \\
\hline Sri Lanka & 4.3 & 10.1 & 3.9 & 9.2 \\
\hline Thailand & 8.0 & 18.1 & 5.4 & 13.2 \\
\hline Uganda & 2.6 & 7.0 & 2.2 & 6.1 \\
\hline Vietnam & 6.0 & 12.7 & 4.8 & 10.5 \\
\hline
\end{tabular}

Source: World Travel and Tourism Council.

Note: GDP = gross domestic product.

in Nepal was $\$ 38$ in 2012, according to the United Nations World Tourism Organization (according to the Nepal Tourism Strategic Plan of the government of Nepal, average daily expenditure in 2013 was \$42.80). The average length of stay for overnight tourists was 12.4 days in 2014. Group tours of the region often spend only a few nights in Nepal, partly because of the lack of diversification of Nepal's tourism spots and the low quality of its tourism infrastructure.

Five countries account for half of Nepal's overnight tourists: India (17 percent), China (16 percent), the United States (6 percent), Sri Lanka (5 percent), and the United Kingdom (5 percent). ${ }^{4}$ Three venues-national parks and wildlife reserves, the Pashupatinath Temple, and Lumbini (a Buddhist pilgrimage site)-accounted for 92 percent of total tourists. Trekking accounted for 12 percent of tourist arrivals. Adventure tourists tend to come from high-income countries; leisure tourists overwhelmingly come from China and India.

The same gravity model analysis is repeated to identify over- and undertrading for tourism exports. Rather than using total services, it uses the number of tourist arrivals. The number of tourists from high-income countries is already above or at potential levels (figure 6.8). The scope for increasing the number of tourists from high-income countries thus appears to be limited. In contrast, Nepal is attracting fewer tourists from China and India than it could. It may thus make sense to target the India and China markets. Nepal should nevertheless continue to promote tourism in the European Union and the United States, where high value can be captured.

A number of constraints prevent Nepal from achieving its potential, despite being one of the most beautiful countries in the world. Nepal ranks 102nd out of 141 countries on the World Economic Forum's Travel and Tourism Competitiveness Index (World Economic Forum 2015). It ranked 133th in environmental sustainability, 126th in ICT readiness, 119th in ground and port infrastructure, 118th in tourist services infrastructure, 113th in safety and security, 110st in business environment, 106th in air transport infrastructure, 96th in 
FIGURE 6.8

\section{Gravity model of tourism in Nepal, 2012}

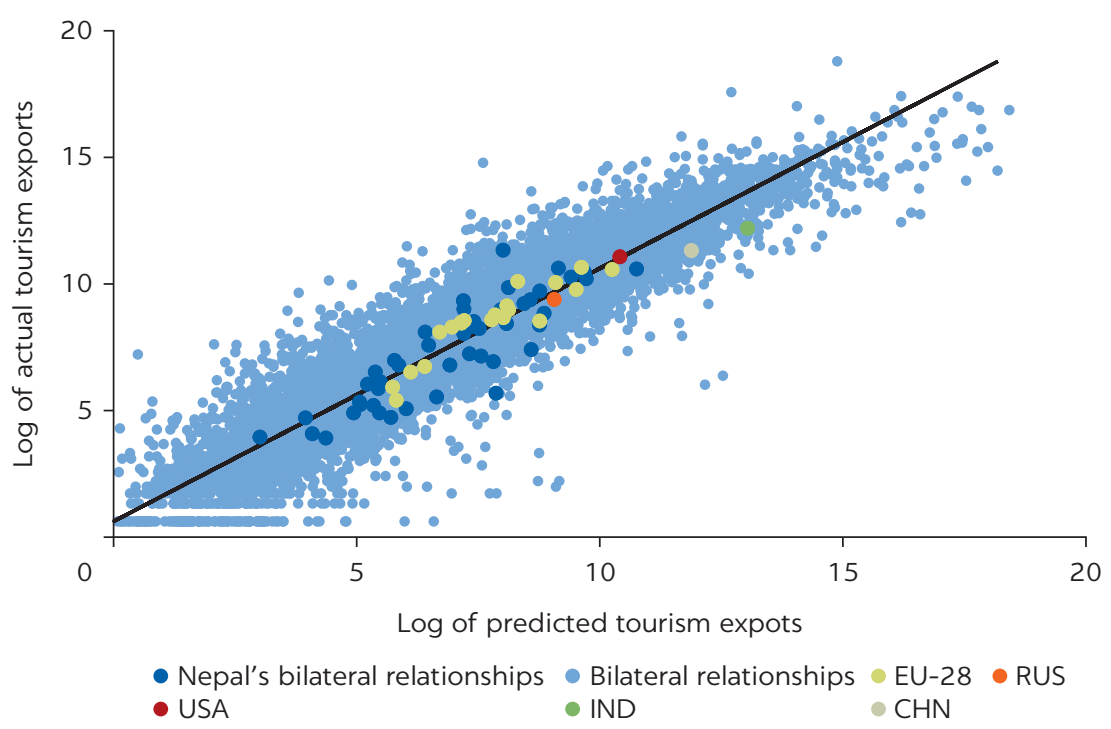

Sources: World Bank World Development Indicators, the UNWTO Tourism Statistics, the World Bank Services Trade Restrictions Database, and the Centre d'Études Prospectives et d'Informations Internationales (CEPII).

Note: $\mathrm{CHN}=$ China; $\mathrm{EU}-28=28$ member countries of the EU; IND = India; RUS = Russian Federation; USA = United States.

human resources and labor market, and 86th in health and hygiene. It ranked 25th in natural resources and 23rd in price competitiveness, suggesting potential for the sector.

The greatest constraint to the tourism sector is inadequate infrastructure, in particular airports and roads. Given that 74 percent of tourists arrive by air, addressing this constraint is critical. Half of the world's population lives within 6 hours of Nepal by plane, suggesting potential for not only Nepal's tourism sector but its aviation sector as well. Connectivity is also key for increasing trade.

Domestic flights lack adequate regulations, and aviation safety is a major concern. Roads do not reach remote areas, limiting diversification away from the top tourism spots. Infrastructure maintenance and waste management are inadequate. High duties on imports of taxis and minibuses prevent owners from replacing old units with newer and better-quality units. Kathmandu has no tourist bus terminal, forcing tourists to cue in the street when waiting for a bus, and basic amenities are lacking at tourist destinations. Domestic flights are expensive, and there are limited amenities at remote tourist destinations. Improving infrastructure would help develop the travel sector and the economy.

Inadequate tourism accommodations are also a big constraint to growth. During the high tourism season, vacancies are scarce. Only 12 of Nepal's 730 hotels have four- or five-star ratings. The lack of high-end hotels limits Nepal's ability to increase tourism expenditures per visit and expand tourism beyond the beaten track.

Other constraints pertain to the general business environment. In 2013 a World Bank mission found that markets along the tourism value chain are not fully competitive and efficient, as a result of weak competition law, inadequate enforcement of the legal framework, and market failures. Regulations restrict foreign investment in transportation services to tourists, for example, and insufficient insurance services are an issue for other sectors that require insurance for their operations. There are significant constraints to setting up and operating a hotel in Nepal (box 6.1). 


\section{BOX 6.1}

\section{Top 10 legal and regulatory issues constraining investment in hotels in Nepal}

A World Bank tourism policy note (2016) identifies legal and regulatory constraints for investment in Nepal's hotel industry. The top 10 constraints include the following:

1. Foreign investment approval: Requiring approval of all FDI is not in line with best practice, and the process lacks transparency and clarity.

2. Nonequity modes of investment/contract management: A dated regulatory regime and authorities' intervention in setting royalties and fees cause Nepal to miss out on the benefits of nonequity modes of catalyzing growth in the hotel subsector.

3. Initial Environment Examination (IEE) and Environmental Impact Analysis (EIA): The requirements for an IEE versus a more detailed EIA are not clear, and the approval criteria are not transparent.

4. Industry regulation: Regulations and practices render policies designed to promote investment in hotels ineffective. Regulation prevents new hotel projects from taking advantage of import tariff incentives, and conditions placed on tariff relief erode its benefits.

5. Land ownership: The land ownership maximum is at odds with the government's objective of attracting more FDI and larger investments in tourism. Together with the lengthy process required to gain access to land, it serves as a barrier to the diversification of hotel types and locations.

6. Hotel building permits: The building permit process is not transparent. It is difficult to access information on the approval criteria.

7. Access to electricity: Slow response times are driving hotels to bypass the Nepal Electricity Authority and install poles and transmission lines and assume the costs out of pocket. There are lengthy bureaucratic delays in receiving approval to connect, regardless of who constructs the lines.

8. Hotel standard and classification: The Department of Tourism relies on a highly subjective assessment in which the approval criteria are unclear, creating opportunities for corruption.

9. Hotel tax incentives: The tariff incentive structure fails to attract investors.

10. House and land tax exemptions: The spirit of the law is to exempt hotels from the house and land tax, but the letter of the law exempts only certain types of modern hotels. Different interpretations have created friction between hotel owners and municipalities. The definition of a hotel for the purpose of the house and land tax exemption is outdated.

Source: Ortega Sotes, Griffin, and Ahad 2016.

Other sector-specific constraints also exist. The National Tourism Board has limited capacity to promote activities. Little attention is given to safety, including food hygiene. Adventure activities, such as paragliding, mounting biking, and rafting, are largely unregulated and operators uncertified.

\section{Information technology and business process outsourcing}

Both software and BPO are promising sources of growth and competitiveness for Nepal. Remoteness is only a minor drawback for exports of modern services, making landlockedness less of a disadvantage than it is for other subsectors. There is also significant potential for youth and women to be involved in these subsectors, suppressing outward migration.

Details and internationally comparable statistics on these subsectors are scarce. There are no harmonized and internationally agreed upon definitions of what constitutes ICT-enabled services, and Nepal's central bank does not collect 
systematic data on these segments of ICT. Anecdotal evidence from firm-level interviews is therefore drawn.

Most of the large software outsourcing and BPO firms in Nepal are foreign firms serving foreign markets. These firms set up services centers in Nepal in order to take advantage of Nepal's low-cost labor. One firm based in Atlanta operates an audit center in Kathmandu, where a staff of about 135 accountants audits international corporations. Only a handful of large, export-oriented BPO firms exist. There is substantial scope to increase these and similar activities. There is limited room for upgrading, however, given the nature of the work and the scarcity of skilled personnel needed to shift into higher value-added ICT-enabled services (sometimes referred to as knowledge process outsourcing [KPO]).

Nepal's software sector includes a wide range of firms. It is home to larger, foreign-owned companies with headquarters overseas, small domestic companies, and thousands of informal freelances working from home. Many of these providers serve foreign markets.

Although the ICT subsector has potential to grow rapidly in the near future, it faces challenges and bottlenecks that will require both general improvements in Nepal's business climate and focused policy measures. The main constraints include the following:

- High turnover and brain drain: After receiving a basic set of skills, employees leave Nepal for postgraduate education or jobs overseas. Worker shortages have caused some software companies to close.

- Lack of financing: Access to capital through all growth phases is challenging. Given the nature of the industry, providing collateral is difficult. Access to venture capital is imperative for the sector to grow, but this form of capital is not available in Nepal (unlike in India where ICT firms can get loans quickly).

- Industry-specific barriers for start-ups: Start-up companies face numerous industry-specific barriers in Nepal. For example, accelerator and incubator programs are limited. Programs that exist lack business partners who understand both local and global markets.

- Profit repatriation: Foreign-owned companies set up all contracts and payments overseas in the head office (transferring funds into Nepal for running costs) rather than allowing offices in Nepal to find clients. They do partly because of the difficulty of repatriating profits from Nepal.

- Power outages: The industry relies heavily on electricity to operate. Unreliable grid power requires firms to operate back-up generators (for which diesel is sometimes unavailable), raising costs and making it difficult to compete internationally.

- Expensive Internet: Although the cost of Internet has fallen, it is still too expensive for individuals to get bandwidth at home, which lowers their ability to work remotely.

- Low levels of education and skills: The quality of IT training in Nepal is low. The government sets the curriculum, which it updates only every 6-10 yearstoo infrequently to be current with the skills demanded by the market. The curriculum does not prepare graduates for the job market. It is difficult for students to get bank loans to enhance their skills.

- High turnover: After receiving on-the-job training, many employees go overseas or freelance. 


\section{LINKAGES BETWEEN SERVICES AND MANUFACTURING}

This section explores the importance of the services sector for Nepal from the second role services play: as a source of competitive inputs into manufacturing and agriculture exports.

Good-quality, efficient, and productive inputs are important for the export competitiveness of a firm or sector. Because of the value chain linkages between sectors, the competitiveness of an upstream sector that is used as inputs to production is important for the competitiveness of downstream sectors. Examples of intermediate inputs from the services sector include a manufacturing firm hiring engineers for the design of its exports, the supply of water and electricity for crop production, and an agricultural producer hiring a trucking service to transport its crops to a market or port for export. If these inputs are supplied by domestic providers, they show up as domestically produced value added inputs in manufacturing, agriculture, or services exports (value-added linkages).

An efficient services market is essential to enhance a country's competitiveness. The weak availability of services inputs-including transport, finance, electricity, and water supply-is perceived as an obstacle to the performance of the manufacturing and agriculture sectors in Nepal. The quality of agricultural goods, for example, diminishes by the time they reach the border to export, after being trucked through the mountains of Nepal.

The importance of services for Nepal's exports increases once the inputs domestic services supply to other sectors' exports are accounted for. Twenty-five percent of the value added of Nepal's exports comes from the forward linkages services provide to other sectors' exports. Services account for 65 percent of all domestically produced inputs, compared with 21 percent for agriculture, 10 percent for manufacturing, and 5 percent for energy and minerals. ${ }^{5}$ Nepal's reliance on services inputs is greater than in all other comparator countries except Rwanda. For example, only 40 percent of domestically supplied inputs embedded in China's exports are of services.

Services exports absorb 44 percent of all domestically supplied inputs, compared with 43 percent for manufacturing, 11 percent for agriculture, and 2 percent for energy and minerals. $\underline{\underline{6}}$ The services sector's exports create strong backward linkages with the economy, larger than in all other countries, by a large margin. In most countries it is less than 20 percent. In India it is less than 30 percent.

Only a few manufacturing subsectors-textiles and clothing and to a lesser extent processed foods, beverages, and tobacco and leather-contribute significantly to export value added (figure 6.9). Little direct value addition takes place. In textiles and apparel and clothing, a significant part of the value added comes from services inputs. Other sectors, such as processed foods, beverages and tobacco, and leather products, demand much of their inputs from primary agriculture.

The structure of Nepal's services sector may be constraining higher value-added manufacturing. Distribution and transport account for 78 percent of domestic services inputs into manufacturing exports in Nepal (figure 6.10). In China and India, the figure is less than 40 percent. The share of financial and communication services used by Nepal's manufacturing sector is very low, even compared with other countries at a similar development level.

The top export sectors for Nepal appear to use more transport services than other manufacturing sectors. For example, 39 percent of the services inputs 
FIGURE 6.9

\section{Composition of manufacturing value added (backward linkages) in Nepal, 2011}

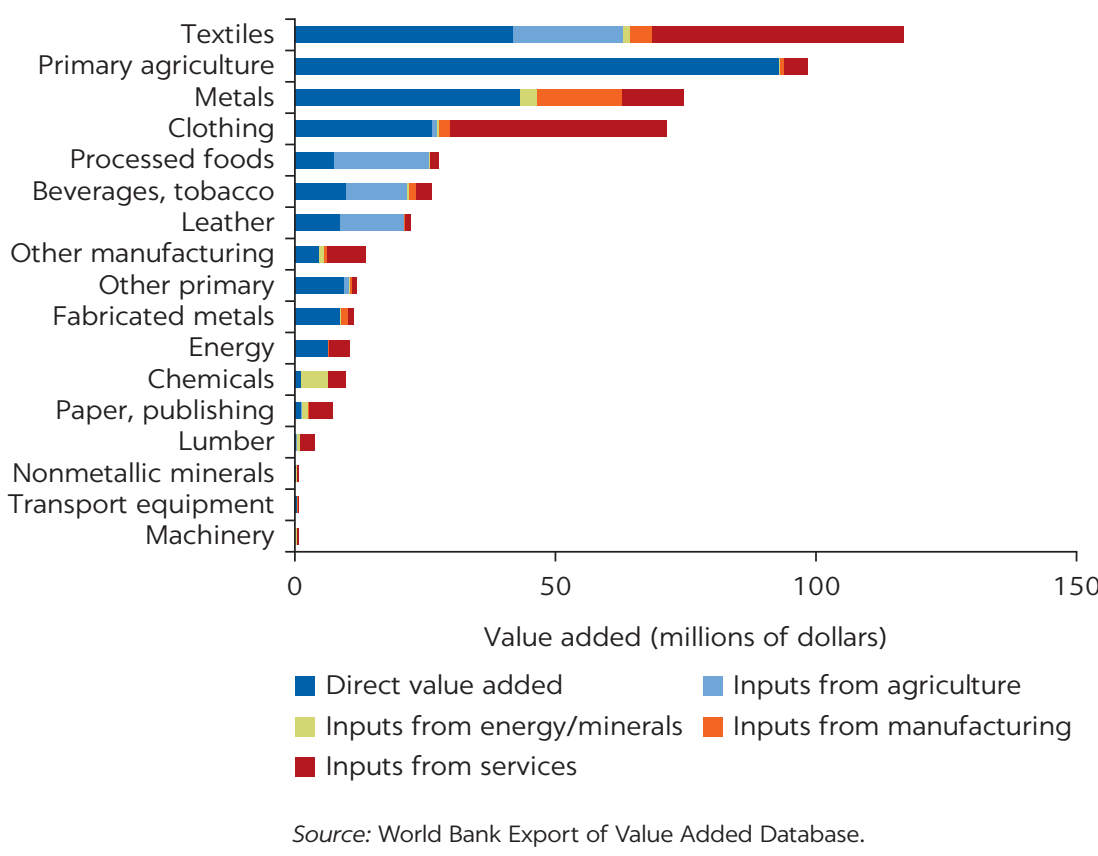

FIGURE 6.10

\section{Composition of domestic services inputs in Nepal's manufacturing} exports, 2011

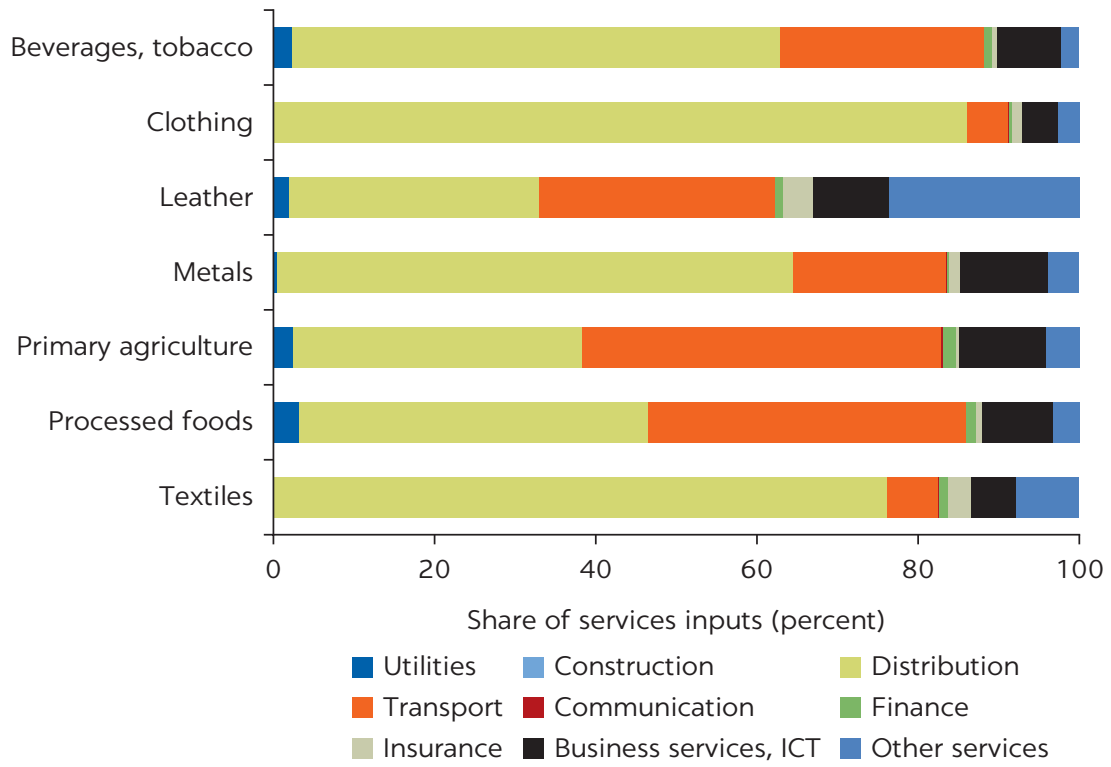

Source: World Bank Export of Value Added Database. Note: ICT = information and communications technology.

provided to processed foods exports are transport, 30 percent for leather, and 25 percent for beverages and tobacco. In contrast, it is 9 percent for total manufacturing. This highlights the importance of an efficient transport sector for Nepal's international competitiveness in its top export sectors.

Access to modern services activities is necessary for manufacturing to thrive. Communication and other modern business services are critical to promoting 
FIGURE 6.11

\section{Percent of firms identifying provision of services as major or severe obstacles}

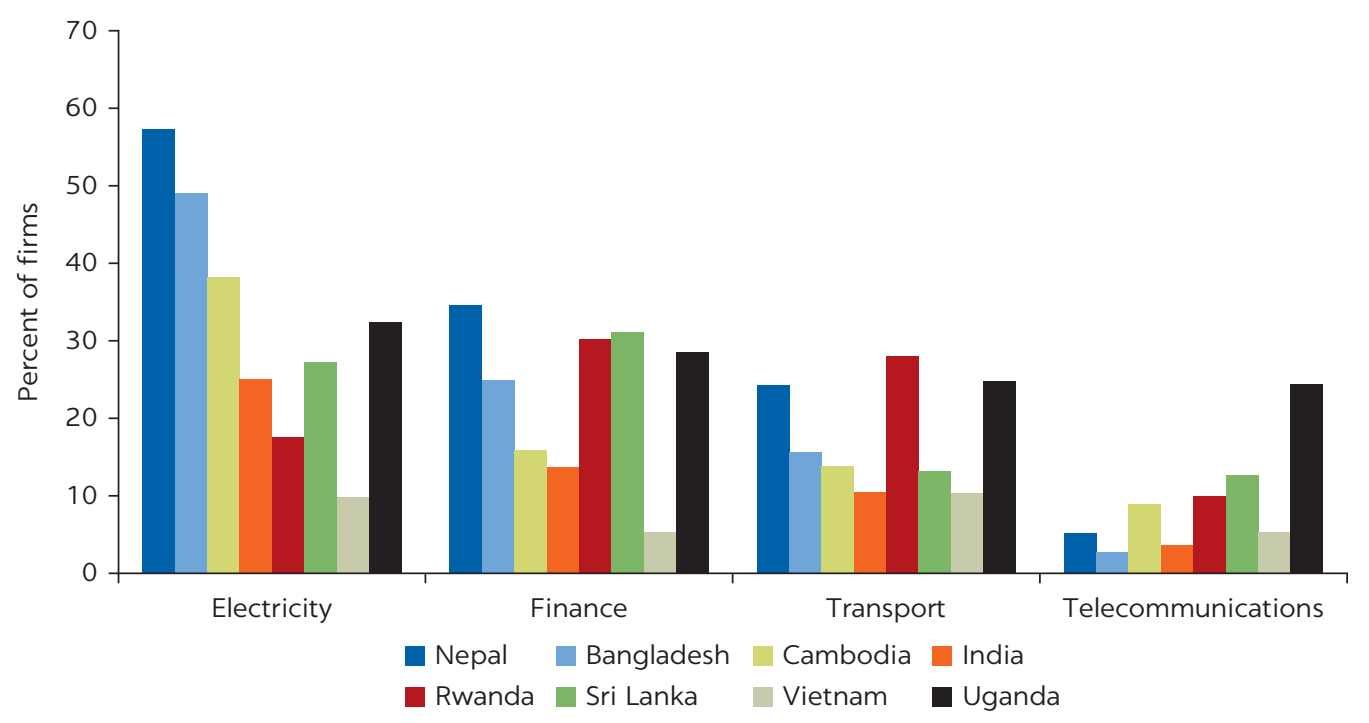

Source: World Bank Enterprise Surveys.

innovation and productivity in manufacturing, agriculture, and other sectors. For example, upgrading in the textile and apparel sector requires access to finance to purchase higher-quality inputs or design services to differentiate products on the international market.

In addition, services are where most of the value added is captured in the production of a good. Pashmina producers, for example, could increase their value added by designing more of the products they produce. Firms in Nepal identify inadequate access to finance, electricity, and transport as major or severe obstacles (figure 6.11). Transport services need to operate more efficiently in Nepal, to compensate for its landlockedness (box 6.2).

\section{THE REGULATORY ENVIRONMENT FOR SERVICES}

Inefficient supply of services inputs acts as a tax on production of goods that use these services, reducing productivity. The regulatory environment governing services providers affects both the quality of domestic services provision as well as the ability of countries to export services. This includes the actual laws, as well as how those laws are implemented in practice within a country.

High regulatory restrictiveness is associated with a lower gross (and direct value added) contribution of services to an economy's exports, though the magnitude of the negative correlation is not large (figure 6.12).

Burdensome regulations also matter for the services-manufacturing linkages, where fewer services are used as inputs to production by the manufacturing sector in countries with more burdensome regulations. This significant and negative relationship between regulatory restrictiveness and services input use holds in particular for modern services, including communications and other business and ICT services, but also for water and utilities. In fact, regulatory restrictiveness is not correlated with distribution services or transport services. 


\section{BOX 6.2}

\section{Challenges in Nepal's transport sector}

Nepal's transport sector is unionized and organized into regional cartels. At least 39 local trucking entrepreneurs associations (TEAs) dictate the rules for the country's 30,000 trucks along 429 routes, despite the fact that they have no legal authority. Three factors explain the popularity of these associations among truck owners: (a) the rise in a mass-based justice system, because of the breakdown of enforcement ability of local government; (b) the small size of truck owners and their inability to absorb economic shocks; and (c) the attraction to unionization in Nepal in the last several decades (Poudel 2015).

TEAs engage in anticompetitive practices that distort the market. After registering at the government's transportation bureau, truck owners need to join the local TEA. These associations are often the major organizations that negotiate on behalf of truck owners with the government and insurance companies. Most of the dominant TEAs offer quasi-insurance services to fulfill the void in financial services offered by insurance companies. But they also set the prices of the routes under their jurisdiction and restrict nonmembers from operating on routes they control.

Bribery is a common feature of all aspects of trucking operations. Bribes are paid to get the route permits from the government and the TEAs. They are also paid to the operatives of different agencies, which stop trucks on their way to their destinations. These cartels restrict who has control to road access. Although the government is the authority on issuing route permits, the TEAs have a say over who receives permits on most, if not all, routes. Sometimes TEAs restrict supply in the market. A World Bank survey reveals that such group formation manifests itself in the form of delayed permit issuance by TEAs on many routes (Poudel 2015).

The TEAs impose costs on the overall economy in the form of deadweight loss, which Poudel (2015) estimates at $\$ 27.6$ million a year. According to the study, in 2014 the TEAs raised the rate of inflation in the Kathmandu Valley by 11 percent, adversely affecting trade.

a. Members who are fully insured are taken care of by TEAs in case of an accident. TEAs help negotiate with the aggrieved party; they help truck owners get the insurance company to pay the agreed upon compensation to the victims, including medical costs; and free the impounded truck from the government's administrative offices. Truck operators highly value these services.

Relative to peers, Nepal imposes moderate limitations on foreign services providers. ${ }^{\underline{z}}$ According to the STRIs, restrictive regulations are placed on foreign services providers in the transport and professional services subsectors in Nepal. It is also important to note that these data are collected from surveys conducted in 2007 , and the policy environment toward transport services has changed since then (discussed more below).

Other than an open regulatory environment, there are a number of enabling factors for a country to become a competitive exporter of modern services. International evidence suggests these other enabling factors include human capital, physical infrastructure, ICT infrastructure, rule of law, and foreign investment in the services sector (Sáez and others 2014). In human capital, Nepal may have a comparative advantage in the medium term if it stimulates Nepal's workers abroad who have been trained in many services subsectors to return.

\section{CHALLENGES IN SPECIFIC SERVICES SUBSECTORS}

\section{Tourism}

The priorities identified to increase exports in the tourism sector include moving into higher value added activities, diversifying destinations, and 
FIGURE 6.12

\section{Correlation between Services Trade Restrictiveness Index (STRI) and gross services exports and services inputs, 2007}

a. Gross services exports

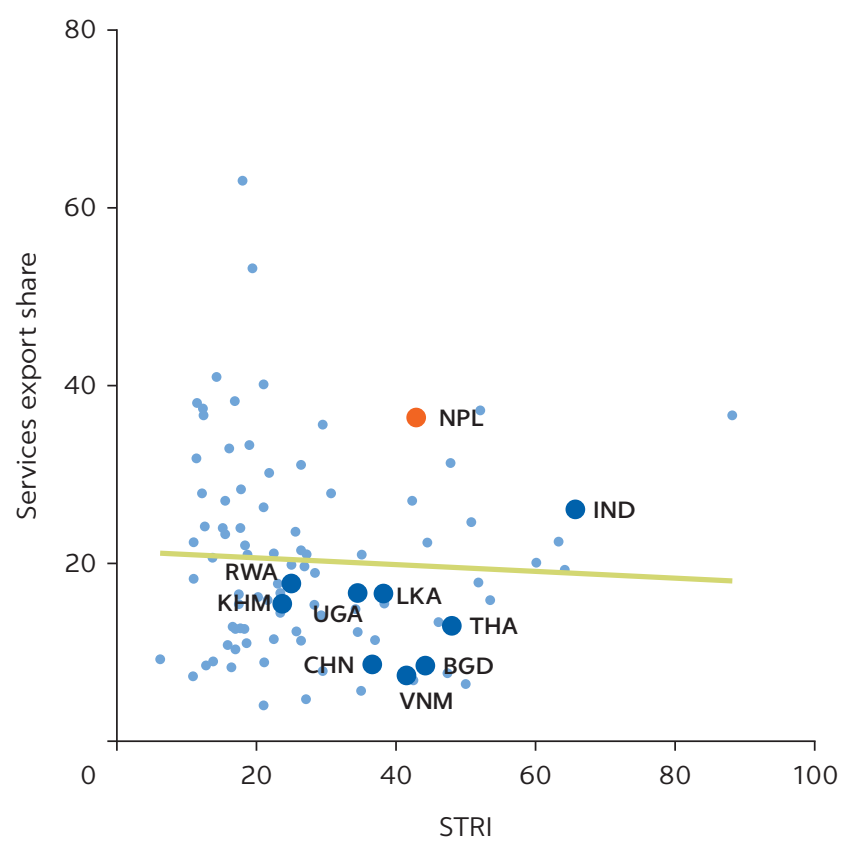

b. Services inputs

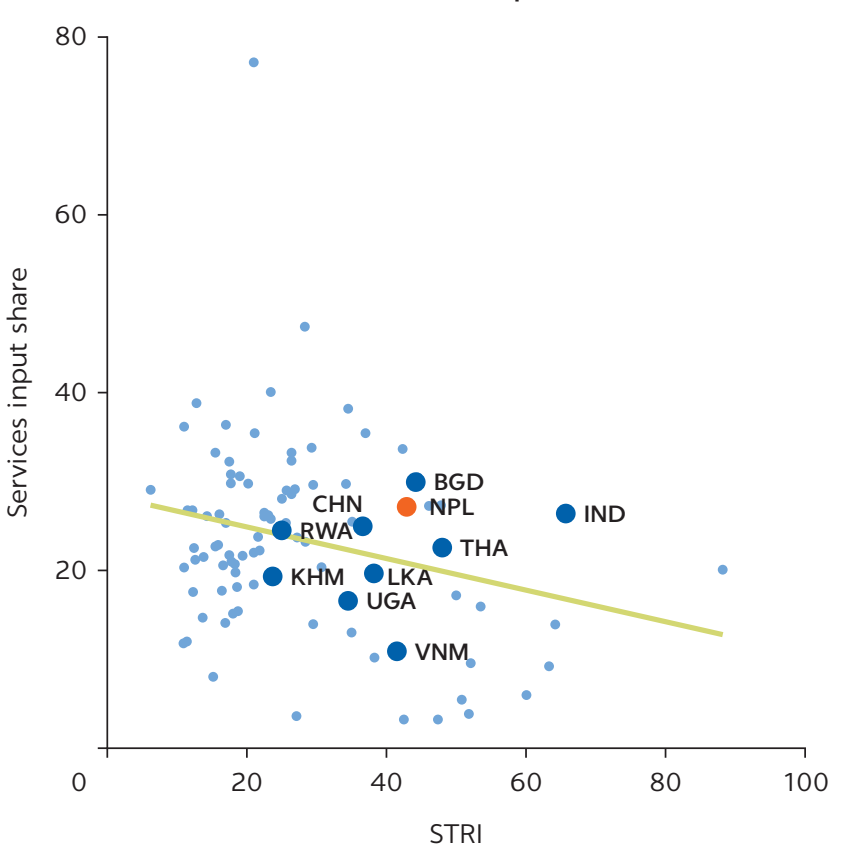

Sources: World Bank Services Trade Restrictions Database and World Bank Export of Value Added Database. Note: STRI = Services Trade Restrictiveness Index. Each dot in the figure represents a country-year observation: BGD = Bangladesh; $C H N=C h i n a ;$ IND = India; KHM = Cambodia; $\mathrm{LKA}=$ Sri Lanka; NPL = Nepal; RWA = Rwanda; THA = Thailand; UGA = Uganda; VNM = Vietnam.

connecting to other sectors. Today there exist a variety of bottlenecks that impact growth and upgrading in Nepal's tourism sector.

Upgrading into higher value added tourism activities will depend on the tourism sector having access to higher quality inputs. Although trade-related taxes are important for government revenue, large import taxes on taxies and minibuses has negative effects on the tourism sector given their importance as inputs. Enforcement of food safety standards needs to be strengthened, and there is interest in the tourism community to develop a restaurant rating system that will discourage bad food safety practices. In addition, inspections conducted by national or local institutions should be published. Hotel classification can also be improved to provide more accurate information for tourists.

Upgrading Nepal's tourism would be aided by greater foreign investment in the sector, but to date, there is lack of transparency in tourism investment policies. As heard during interviews with the private sector, there are de facto limitations to foreign investment in hotels and restaurants and tour operations (as in other sectors of the economy).

A major bottleneck to the quality of tourism in Nepal is inadequate investment in infrastructure. While not a direct mandate of the Nepal Tourism Board, the Board could emphasize the importance of infrastructure for the sector. This includes not only upgrading and maintaining airports and roads, but also auxiliary services.

Steps could also be taken to increase the number of tourists from alternative destinations and the number of tourism offerings. Today a large share of 


\section{BOX 6.3}

\section{Diaspora networks to encourage trade in services}

A sizable body of literature documents the importance of diaspora networks for promoting international trade integration (see, for example, Rauch and Trindade 2002). Studies are continuing to find diasporas important not just for trade flows but for foreign investments and knowledge diffusion. Benefits that diaspora networks offer include stronger access to information, matching and referral services that link firms together, language skills and cultural sensitivity that improve interactions, and repeated relationships that are important for creating business and trade opportunities (Ghani, Kerr, and Stanton 2014). These benefits also extend to services trade. Countries like India have taken advantage of migrants to improve exports of IT services. Ghani, Kerr, and Stanton (2014) find that overseas ethnic Indians are more likely to outsource to India than nonethnic Indians for BPO, at least for employers' initial contract placement. These initial contracts are vital because the location choices of outsourced work for company contacts are very persistent. Javorcik and others (2006) show that US FDI abroad is positively correlated with the presence of migrants from the host country, and that the existence of ethnic networks may positively affect FDI by promoting information flows across international borders and by serving as a contract enforcement mechanism.

overseas promotional events are targeted at China and India, and diversifying promotional activates is important. In addition, many activities are done through tourism fairs, in part because of financing restrictions of the Board. Other forms of tourism promotion can be beneficial. Enhancing the capacity of the National Tourism Board would be important for this process to unfold.

Linkages also exist between migration and trade in services, where overseas diaspora networks can become a vehicle to increase services exports (box 6.3). A returning diaspora community to Nepal could also impact domestic services provision, given that many Nepali migrants work in services subsectors overseas.

\section{Information technology and business process outsourcing}

Digital information and communications technologies are having a profound effect on nearly every sector. Nepal's ICT sector faces challenges and bottlenecks to sustainable growth that require both general improvement in Nepal's infrastructure and business climate and some sector-specific policy measures. Measures will involve targeted capacity building, the provision of risk capital, the expansion of partnering assistance through incubators and accelerators, and the establishment of greater business freedom.

Nepal's education system is poorly suited to the modern international business environment, and should mainstreaming soft business skills into the education system. Links between universities and the private sector are not maximized in a way that fosters product development. Doing so may involve supporting foreign investment of foreign universities in Nepal.

The lack of a clear policy for ICT was cited as a constraint, although an ICT policy has been drafted. To date no association encompasses software firms. 
The government could consider establishing a software body similar to the ones that exist in other industries, creating more public-private partnerships, and building a platform to facilitate interaction between the government and software companies on constraints.

IT infrastructure in network and computing is poor due to issues with IT backbone. Weak infrastructure limits IT companies' ability to provide and export services, including cloud-based services. Nepal has 10-12 Internet Service Providers (ISPs) with licenses, all trying to do the same thing. The lack of efficiency of this system reduces the quality of service. Licenses are granted for ISPs but not for setting up a network. The government should craft a clear policy that supports two or three backbone services providers.

\section{Finance}

There exists a "missing middle" for access to finance within SMEs. Micro-firms and large corporations are not credit constrained. SMEs face large borrowing constraints in Nepal.

The largest hurdle for SMEs to access finance is lack of collateral. The problem stems partly from banking regulations of the central bank, which are skewed toward fixed asset capital backed lending. Most SMEs are trading companies, which, by the nature of their business, do not have fixed asset collateral. They do maintain large inventories. No secure transaction registry exists in Nepal under which lending can be extended against these inventories, however.

For small entrepreneurs, inadequate business skills and financial literacy limit access to finance on the demand side. Basic business practices are not implemented. As a result, banks view these entities as nonbankable.

\section{E-commerce}

Lack of international payments infrastructure is preventing firms from exporting goods through e-commerce. The central bank (or the private sector with approval from the central bank) has to establish the payment gateway that allows for foreign payments into Nepal. To date, the only international switching is for ATMs and merchant payments. This constraint affects the handicraft sector in particular. Firms cannot sell online to overseas customers because they cannot receive foreign currency income for their goods.

There are also issues with financial infrastructure. The payment system in Nepal is not yet fully interoperable. There is a lack of a common platform that allows for direct payment transfers between people or firms with accounts in different banks (payments can be made only by check or cash).

\section{Electricity supply}

Electricity shortages and power outages are major hurdles for firms. There is immense potential in Nepal to overcome these hurdles by developing its hydropower sector. Nepal is posed to more than double its current hydropower generating capacity (Government of Nepal 2015b). The increase will eliminate severe power cuts that have reduced consumer welfare, stunted private sector competitiveness, increased the trade deficit, and contributed to severe air pollution. 


\section{POLICY IMPLICATIONS}

Horizontal and sector-specific barriers in Nepal prevent greater trade integration with the world. The scope for further trade integration may be limited unless policy reforms are implemented. Policy recommendations include:

(1) The government should continue its efforts to improve the business environment (relaxing licensing requirements, increasing transparency, reducing corruption, and so forth). The large number of informal services software contractors may stem from constraints to formally setting up or growing a business in Nepal.

(2) Policies can also support an effective start-up ecosystem, by improving access to venture capital and supporting accelerators and incubators.

(3) Capacity building should be enhanced through better linkages between industry and schools/universities. Emphasis should be placed on foreign language skills (where Nepal has a comparative advantage over other emerging markets, such as Vietnam); managerial skills; and the quality of technical training programs.

(4) Nepal has no formal project to support the business skills and financial literacy of firms. In the Lao People's Democratic Republic, a matching grant scheme funded by donors works with manufacturing firms to identify constraints to growing their business. The scheme is matching manufacturing firms with accountants to help with bookkeeping.

(5) The government should support IT infrastructure, including power supply and transport but also auxiliary services, such as systems integration..

(6) The central bank needs to establish a payments gateway or encourage a private company to do so. Allowing or payments to be received online through the gateway could increase exports of Nepal's manufacturing products via e-commerce. Financial infrastructure could be improved if the central bank regulated a common transaction platform in banks, which would allow companies or individuals to transfer funds between accounts in Nepal online.

(7) A complementary approach is through credit-rating agencies-third parties that rate a firm based on performance. Only one credit-rating agency operates in Nepal. Attempts to establish a second one faced regulatory hurdles, in particular licensing restrictions. Credit scoring should be tailored to SMEs. Nepal could learn of regional best practices from India and Bangladesh.

\section{NOTES}

1. The analysis of gross services trade focuses on transactions reported in balance of payments statistics, including cross-border trade (foreign services providers providing services in Nepal) and consumption abroad (foreigners consuming services in Nepal). Services trade that takes place through foreign direct investment (FDI) and the temporary movement of people is not covered.

2. Commercial services exports (defined as total services excluding government services) are used throughout this report (except when only total services statistics are available).

3. The analysis of export potentials using a gravity model of trade relies on observed bilateral trade flows in services. Nepal publishes bilateral trade flows in services only with India. The analysis therefore uses the World Bank Trade in Services Database, which relies on mirror flows (deducing Nepal's exports by its partner countries' reported imports). Bilateral services exports are available only until 2007 and for a few countries. The analysis compares actual services exports with potential services exports of Nepal and select partner countries. Potential services exports are predicted by GDP, distance between Nepal and 
partner countries, and whether two countries share a border or speak a common language.

4. India accounted for 15 percent of Nepal's travel exports when measured in terms of value (rather than arrivals) in 2013/14, according to balance of payments statistics, but less than 1 percent of Nepal's transport services.

5. Looking at total domestic production (not just exports), services supply 70 percent of all domestically produced inputs in the economy, compared with 22 percent for agriculture, energy, and minerals and 8 percent for manufacturing.

6. Looking at total domestic production (not just exports), services use 67 percent of all domestically supplied inputs, compared with 25 percent for manufacturing and 8 percent for agriculture, energy, and minerals.

7. The World Bank Services Trade Restrictions Database collects and makes publicly available information on services trade policy assembled in a comparable manner across 103 countries; 5 sectors (telecommunications, finance, transportation, retail, and professional services); and the key modes of service supply. The restrictiveness of the policy measures are scored and quantified into a Services Trade Restrictiveness Index (STRI). A country is considered completely closed if its STRI is 100 and completely open if its STRI is 0.

8. System integration is very challenging in delivering engineering solutions. Engineering system integration brings together component subsystems into one system and ensures that the subsystems function together as a complete system. System integration is also a process of linking different computing systems and software applications physically or functionally to work as a consolidated system.

\section{REFERENCES}

CEPII (Centre d'Études Prospectives et d'Informations Internationales), Gravity (database), Paris, www.cepii.fr/cepii/en/bdd_modele/bdd.asp.

Ghani, E., W. R. Kerr, and C. Stanton. 2014. "Diasporas and Outsourcing: Evidence from oDesk and India." Management Science 60 (7): 1677-79.

Government of Nepal. 2010. Nepal Trade Integration Strategy (NTIS). Ministry of Commerce, Kathmandu.

- 2015a. Nepal Trade Integration Strategy (NTIS). Ministry of Commerce, Kathmandu.

__. 2015b. "Vision 2030 for Nepal: Towards a Just and Lasting Prosperity." Draft Concept Note, Kathmandu.

Javorcik, B. S., C. Ozden, M. Spatareanu, and C. Neagu. 2006. "Migrant Networks and Foreign Direct Investment.” Working Paper 2006-003, Rutgers University, Newark, NJ.

Ortega Sotes, C., P. Griffin, and T. Ahad. 2016. Making Nepal's National Tourism Strategy Work: Legal Recommendations for Unlocking Investment in Tourism. Washington, DC: World Bank.

Poudel, B. 2015. "Structure of Nepal's Trucking Industry: Results from a Nationwide Survey." Kathmandu University, Dhulikhel, Nepal.

Rauch, J., and V. Trindade. 2002. "Ethnic Chinese Networks in International Trade.” The Review of Economics and Statistics 84 (1): 116-130.

Sáez, S., D. Taglioni, E. van der Marel, C. Hollweg, and V. Zavacka. 2014. Valuing Services in Trade: A Toolkit for Competitiveness Diagnostics. Washington, DC: World Bank.

UNCTADstat (database), UNCTAD (United Nations Conference on Trade and Development), Geneva, https://unctadstat.unctad.org.

UNWTO Tourism Statistics (database), The World Tourism Organization, United Nations, Geneva. http://statistics.unwto.org.

World Bank. 2016. From Evidence to Policy: Supporting Nepal's Trade Integration Strategy. Washington, DC: World Bank.

World Bank World Development Indicators (database), Washington, DC, http:// wdi.worldbank.org.

World Economic Forum. 2015. The Travel and Tourism Competitiveness Report 2015: Growth through Shocks. Geneva. 
World Bank Enterprise Surveys (database), Washington, DC, http://www.enterprisesurveys.org. World Bank Export of Value Added Database, Washington, DC, https://datacatalog.worldbank .org/dataset/export-value-added-database.

World Bank Services Trade Restrictions Database, Washington, DC, http://iresearch.worldbank .org/servicetrade/.

World Travel and Tourism Council, https://www.wttc.org/. 


\section{Services Trade Performance in Pakistan*}

ERIK VAN DER MAREL AND SEBASTIÁN SÁEZ

Services trade is limited in Pakistan. Determining the reasons behind this poor performance is critical for the country's future development. This chapter assesses that performance. It is organized as follows. The first section describes the importance of services in the domestic economy. The second section analyzes the importance of services exports and the role services play in supporting other exports. The third section studies the factors that explain the trade performance of services in Pakistan. The last section provides policy recommendations.

\section{VALUE ADDED OF SERVICES IN THE DOMESTIC ECONOMY}

The services sector was the second-largest source of employment (after agriculture) in Pakistan in 2011, accounting for about a third of all employment. The share was much smaller than in Brazil, the Philippines, or South Africa (although larger than in India) (figure 7.1). It fell from 34 percent of employment in 2000 to 33 percent in 2011 . Over this period the share of industry rose from 18 percent to 21 percent.

Pakistan's services sector is slightly smaller than expected based on its level of development, suggesting untapped potential to develop the sector (figure 7.2). It performs better than Vietnam, Indonesia, and Thailand, which have lower services value added but are more developed than Pakistan.

Pakistan's industrial sector grew between 1990 and 2013 (figure 7.3). Between 2000 and 2013, industry value added grew at a faster rate than services (figure 7.4). The average growth rate of services value added between 2000 and 2013 in Pakistan was in line with that of the Russian Federation but substantially lower than in China, Indonesia, and India (services in India and Pakistan accounted for about the same share of value added).

* The editors are grateful to the Pakistan CMU, Gabi Afram, Esperanza Lasagabaster, Muhammad Waheed, Shahzad Sharjeel and Shabnam Naz for authorization to publish. 
FIGURE 7.1

\section{Employment shares of agriculture, industry, and services in selected} countries, 2000 and 2017

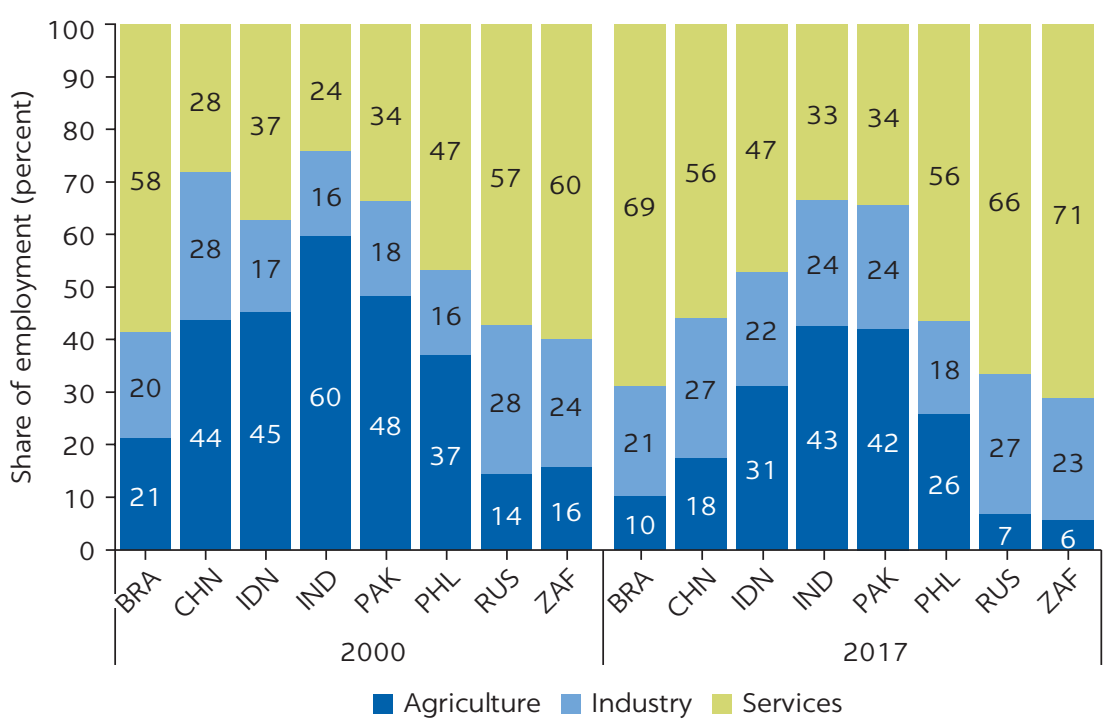

Source: World Bank World Development Indicators.

Note: $\mathrm{BRA}=$ Brazil; $\mathrm{CHN}=$ China; IDN = Indonesia; IND = India; PAK = Pakistan;

$\mathrm{PHL}=$ Philippines; RUS = Russian Federation; ZAF = South Africa

FIGURE 7.2

Cross-country correlation between value added of services and level of development, 2011-13

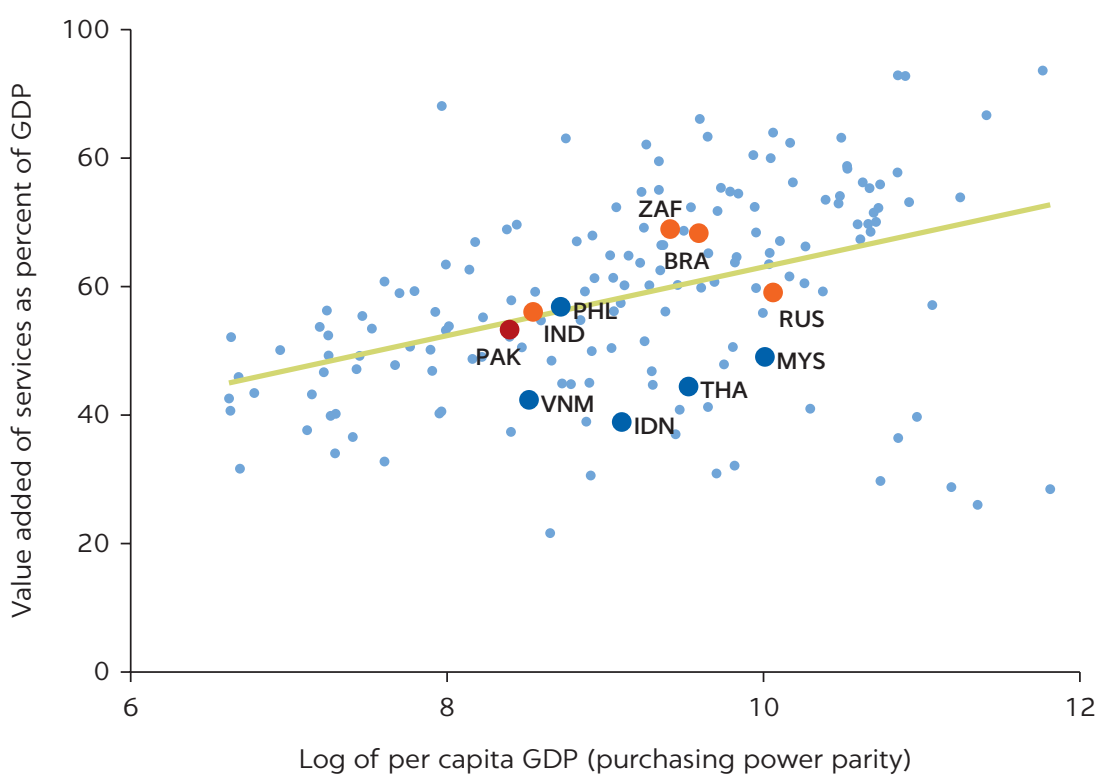

Source: World Bank World Development Indicators.

Note: GDP = gross domestic product. Dots represent countries: BRA = Brazil;

IDN = Indonesia; IND = India; $\mathrm{MYS}=$ Malaysia; $\mathrm{PAK}=$ Pakistan; $\mathrm{PHL}=$ Philippines;

RUS = Russian Federation; THA = Thailand; VNM = Vietnam; ZAF = South Africa 
FIGURE 7.3

Value added of agriculture, industry, and services in selected countries, 1990 and 2013

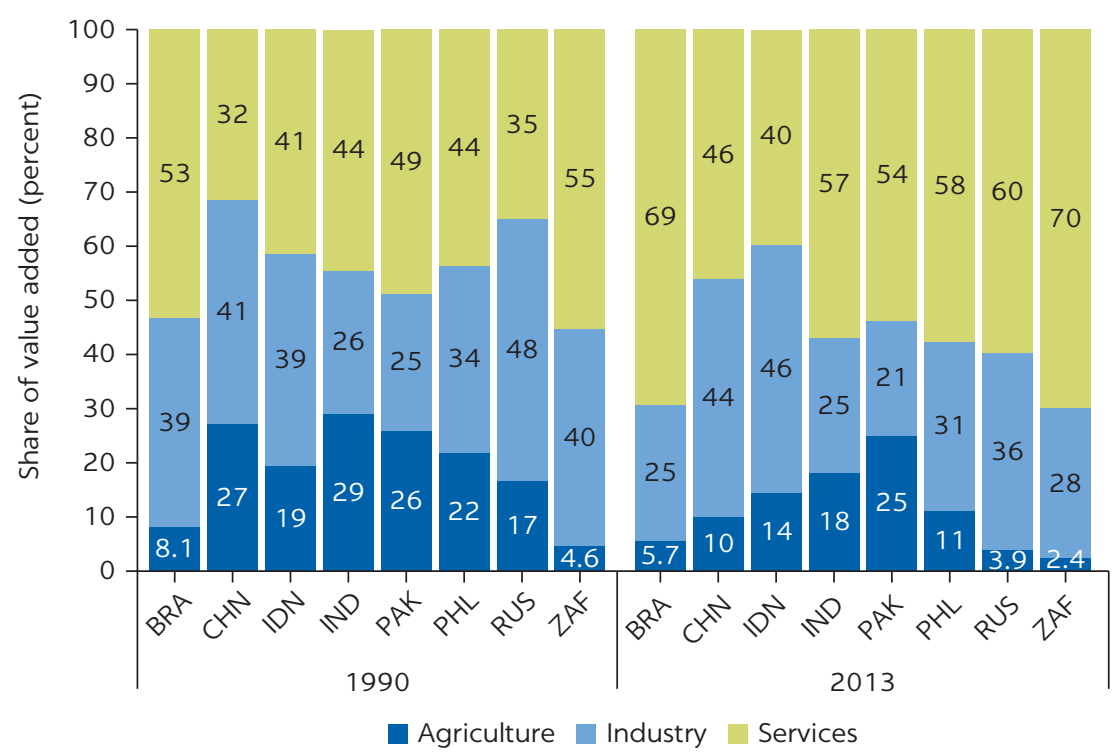

Source: World Bank World Development Indicators.

Note: $\mathrm{BRA}=$ Brazil; $\mathrm{CHN}=$ China; IDN = Indonesia; IND = India; PAK = Pakistan;

$\mathrm{PHL}=$ Philippines; RUS = Russian Federation; ZAF = South Africa.

FIGURE 7.4

Rate of growth of value added of agriculture, industry, and services in selected countries 2000-13

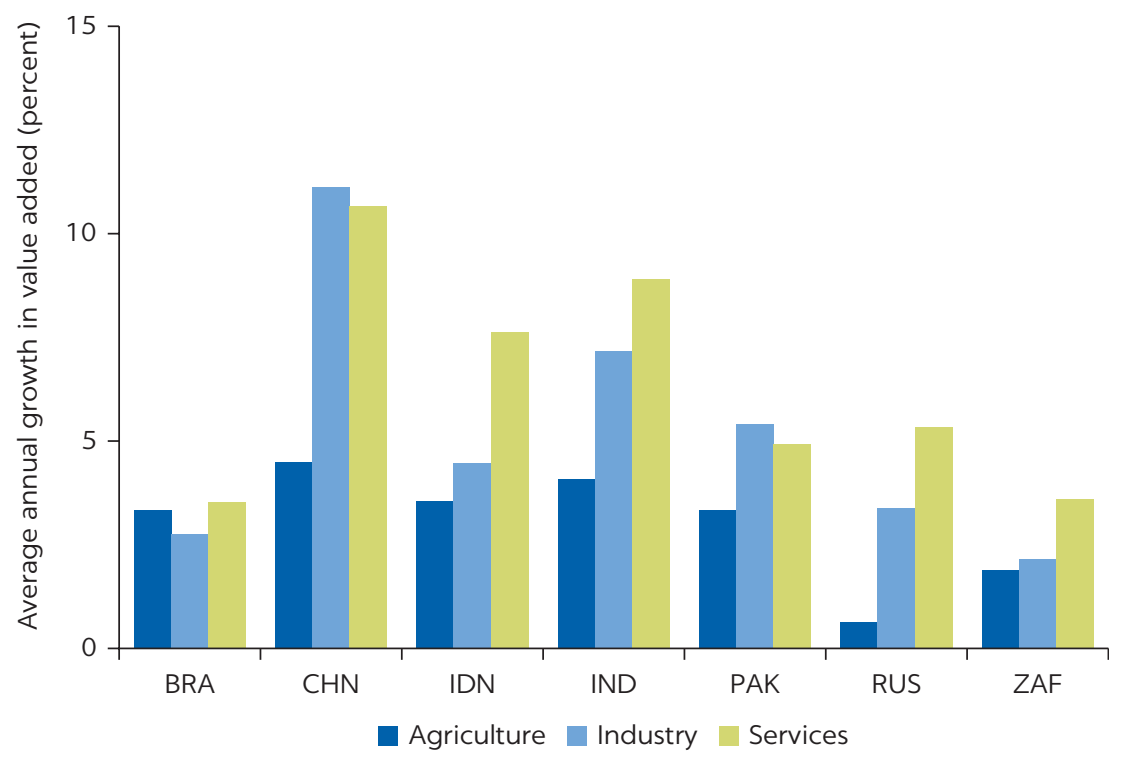

Source: World Bank World Development Indicators.

Note: $\mathrm{BRA}=$ Brazil; $\mathrm{CHN}=$ China; IDN = Indonesia; IND = India; PAK = Pakistan;

RUS = Russian Federation; ZAF = South Africa. 


\begin{tabular}{|c|c|c|c|c|c|c|c|c|c|c|c|c|c|c|c|}
\hline SECTOR & $\frac{\grave{c}}{\frac{c}{\alpha}}$ & $\begin{array}{l}\text { J } \\
\text { 嵌 } \\
\text { z }\end{array}$ & 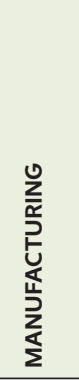 & 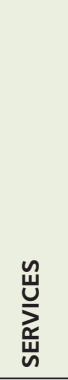 & 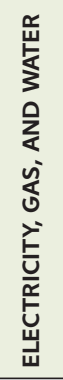 & 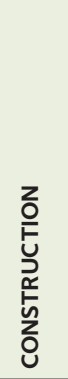 & 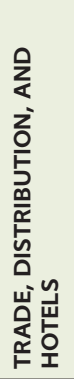 & 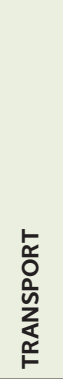 & 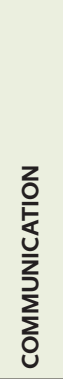 & 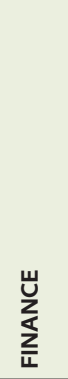 & 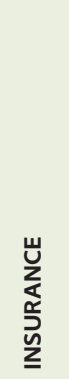 & 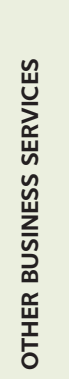 & 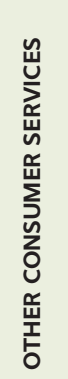 & 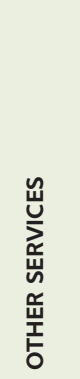 & 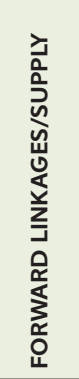 \\
\hline Primary & 3.8 & 0.3 & 8.9 & 0.5 & 0.0 & 0.2 & 0.1 & 0.0 & 0.0 & 0.0 & 0.0 & 0.0 & 0.0 & 0.1 & 13.6 \\
\hline Energy & 0.1 & 0.8 & 0.8 & 0.4 & 0.0 & 0.1 & 0.0 & 0.1 & 0.0 & 0.0 & 0.0 & 0.0 & 0.0 & 0.1 & 2.1 \\
\hline Manufacturing & 0.2 & 0.1 & 26.0 & 1.5 & 0.0 & 0.7 & 0.1 & 0.1 & 0.0 & 0.0 & 0.0 & 0.0 & 0.1 & 0.5 & 27.7 \\
\hline Services & 1.3 & 1.7 & 32.4 & 21.2 & 0.3 & 3.2 & 2.6 & 3.7 & 0.5 & 0.0 & 0.0 & 0.2 & 1.2 & 9.5 & 56.6 \\
\hline Electricity, gas, and water & 0.0 & 0.0 & 0.1 & 0.2 & 0.1 & 0.0 & 0.0 & 0.0 & 0.0 & 0.0 & 0.0 & 0.0 & 0.0 & 0.0 & 0.3 \\
\hline Construction & 0.0 & 0.0 & 0.1 & 1.6 & 0.0 & 1.5 & 0.0 & 0.0 & 0.0 & 0.0 & 0.0 & 0.0 & 0.0 & 0.1 & 1.7 \\
\hline Trade, distribution, and hotels & 0.4 & 0.5 & 9.0 & 5.3 & 0.0 & 0.4 & 2.2 & 0.1 & 0.1 & 0.0 & 0.0 & 0.0 & 0.6 & 1.8 & 15.2 \\
\hline Transport & 0.5 & 0.8 & 13.1 & 4.8 & 0.1 & 0.6 & 0.1 & 3.2 & 0.0 & 0.0 & 0.0 & 0.0 & 0.1 & 0.7 & 19.2 \\
\hline Communication & 0.0 & 0.0 & 0.0 & 0.4 & 0.0 & 0.0 & 0.0 & 0.0 & 0.4 & 0.0 & 0.0 & 0.0 & 0.0 & 0.0 & 0.4 \\
\hline Finance & 0.1 & 0.2 & 3.2 & 1.2 & 0.0 & 0.3 & 0.1 & 0.2 & 0.0 & 0.0 & 0.0 & 0.0 & 0.1 & 0.5 & 4.7 \\
\hline Insurance & 0.0 & 0.0 & 0.6 & 0.2 & 0.0 & 0.0 & 0.0 & 0.1 & 0.0 & 0.0 & 0.0 & 0.0 & 0.0 & 0.1 & 0.8 \\
\hline Other business services & 0.1 & 0.1 & 5.5 & 1.0 & 0.0 & 0.3 & 0.0 & 0.1 & 0.0 & 0.0 & 0.0 & 0.1 & 0.0 & 0.4 & 6.6 \\
\hline Other consumer services & 0.0 & 0.0 & 0.0 & 0.4 & 0.0 & 0.0 & 0.0 & 0.0 & 0.0 & 0.0 & 0.0 & 0.0 & 0.4 & 0.0 & 0.4 \\
\hline Other services & 0.1 & 0.1 & 1.0 & 6.1 & 0.0 & 0.1 & 0.1 & 0.0 & 0.0 & 0.0 & 0.0 & 0.0 & 0.1 & 5.8 & 7.4 \\
\hline Backward linkages/ demand & 5.4 & 3.0 & 68.1 & 23.5 & 0.3 & 4.2 & 2.7 & 3.9 & 0.5 & 0.0 & 0.0 & 0.2 & 1.3 & 10.2 & 100.0 \\
\hline
\end{tabular}

Source: World Bank Export of Value Added Database.

Note: "Other services" are government services. GDP = gross domestic product.

Tables 7.1 reveals the sectoral composition of Pakistan's domestic economy. It shows that services-which include utilities, transport, distribution, financial, and other business services-accounted for 57 percent of Pakistan's GDP in 2011. Trade, distribution, hotels, and transport services represent 60 percent of total value added by services (more than 34 percent of total domestic value added).

Total backward services linkages accounted for 24 percent of GDP. These linkages are mainly with other services activities; linkages to the primary, energy, and manufacturing sectors are limited. Among services activities, the most important backward linkages are in trade, distribution, and hotels; transport; and construction services. "Other services"-which include mainly government services, such as public administration, defense, health, and educationrepresent more than 7 percent of Pakistan's GDP.

\section{VALUING SERVICES IN TRADE}

Services accounted for less than 14 percent of the total value added of total exports in 2011 (table 7.2). Transport services accounted for less than 5 percent. Trade, distribution, and hotel services represented less than 2 percent. 


\begin{tabular}{|c|c|c|c|c|c|c|c|c|c|c|c|c|c|c|c|}
\hline SECTOR & $\frac{\substack{\frac{\alpha}{\alpha} \\
\frac{\alpha}{\alpha}}}{\frac{\alpha}{\alpha}}$ & 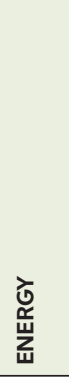 & 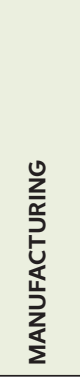 & 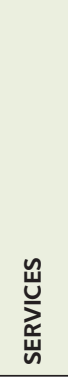 & 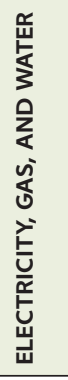 & 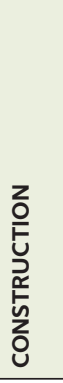 & 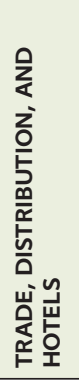 & 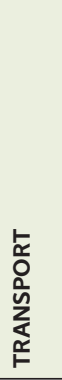 & 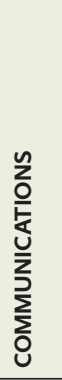 & 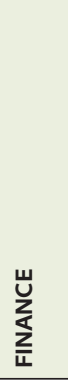 & 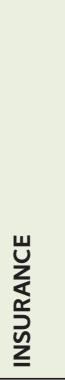 & 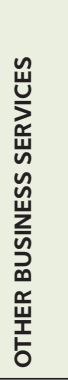 & 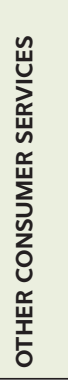 & 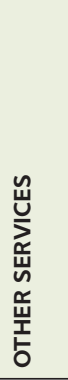 & 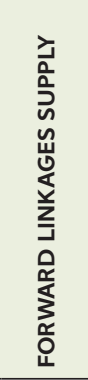 \\
\hline Primary & 6.6 & 0.2 & 10.9 & 0.2 & 0.0 & 0.0 & 0.0 & 0.0 & 0.0 & 0.0 & 0.0 & 0.0 & 0.0 & 0.1 & 17.9 \\
\hline Energy & 0.1 & 0.5 & 1.6 & 0.2 & 0.0 & 0.0 & 0.0 & 0.1 & 0.0 & 0.0 & 0.0 & 0.0 & 0.0 & 0.1 & 2.4 \\
\hline Manufacturing & 0.3 & 0.0 & 23.3 & 0.5 & 0.0 & 0.0 & 0.0 & 0.2 & 0.0 & 0.0 & 0.0 & 0.0 & 0.0 & 0.3 & 24.2 \\
\hline Services & 2.0 & 1.0 & 38.7 & 13.8 & 0.0 & 0.1 & 0.2 & 4.5 & 0.5 & 0.3 & 0.2 & 1.9 & 0.1 & 5.9 & 55.5 \\
\hline Electricity, gas, and water & 0.0 & 0.0 & 0.2 & 0.1 & 0.0 & 0.0 & 0.0 & 0.0 & 0.0 & 0.0 & 0.0 & 0.0 & 0.0 & 0.0 & 0.2 \\
\hline Construction & 0.0 & 0.0 & 0.1 & 0.1 & 0.0 & 0.1 & 0.0 & 0.0 & 0.0 & 0.0 & 0.0 & 0.0 & 0.0 & 0.0 & 0.2 \\
\hline $\begin{array}{l}\text { Trade, distribution, and } \\
\text { hotels }\end{array}$ & 0.7 & 0.3 & 9.9 & 1.9 & 0.0 & 0.0 & 0.2 & 0.2 & 0.1 & 0.0 & 0.0 & 0.3 & 0.0 & 1.1 & 12.7 \\
\hline Transport & 0.9 & 0.4 & 14.8 & 4.8 & 0.0 & 0.0 & 0.0 & 3.9 & 0.0 & 0.0 & 0.0 & 0.4 & 0.0 & 0.5 & 20.9 \\
\hline Communications & 0.0 & 0.0 & 0.0 & 0.4 & 0.0 & 0.0 & 0.0 & 0.0 & 0.3 & 0.0 & 0.0 & 0.0 & 0.0 & 0.0 & 0.4 \\
\hline Finance & 0.2 & 0.1 & 4.1 & 0.9 & 0.0 & 0.0 & 0.0 & 0.2 & 0.0 & 0.3 & 0.0 & 0.1 & 0.0 & 0.3 & 5.4 \\
\hline Insurance & 0.0 & 0.0 & 0.6 & 0.3 & 0.0 & 0.0 & 0.0 & 0.1 & 0.0 & 0.0 & 0.2 & 0.0 & 0.0 & 0.0 & 1.0 \\
\hline Other business services & 0.1 & 0.0 & 7.6 & 1.5 & 0.0 & 0.0 & 0.0 & 0.1 & 0.0 & 0.0 & 0.0 & 1.1 & 0.0 & 0.3 & 9.2 \\
\hline Other consumer services & 0.0 & 0.0 & 0.0 & 0.0 & 0.0 & 0.0 & 0.0 & 0.0 & 0.0 & 0.0 & 0.0 & 0.0 & 0.0 & 0.0 & 0.0 \\
\hline Other services & 0.2 & 0.1 & 1.4 & 3.8 & 0.0 & 0.0 & 0.0 & 0.1 & 0.0 & 0.0 & 0.0 & 0.1 & 0.0 & 3.6 & 5.4 \\
\hline Backward linkages/ demand & 9.1 & 1.7 & 74.5 & 14.7 & 0.0 & 0.2 & 0.2 & 4.8 & 0.5 & 0.3 & 0.2 & 2.0 & 0.1 & 6.4 & 100.0 \\
\hline
\end{tabular}

Source: World Bank Export of Value Added Database.

Note: "Other services" are government services.

Although direct services exports were low, services contributed heavily as inputs to other goods exports. The value-added contribution of services to total exports increases to 56 percent when forward linkages to other export activities are included, thanks to the role of services in exports of manufacturing goods, which represented 39 percent of the total contribution of services to Pakistan's total exports.

Transport services (15 percent of the total) and trade, distribution, and hotels (10 percent) are the main subsectors linked to manufacturing exports. Other activities that are highly demanded by the manufacturing sector are other business services (8 percent of the total) and finance (4 percent). Within manufacturing, textiles, clothing, and processing food use inputs from transport services. Trade and distribution services are exported mostly as inputs in textiles, clothing, and food- processing industries and somewhat in the chemical industry. Sixty percent of business services inputs are exported through the clothing industry. Business services are also exported through textiles (15 percent of total), machinery (6 percent), and other manufacturing industries (6 percent). Once Pakistan diversifies its goods manufacturing sectors and exports, other services inputs, such as business, finance, and insurance services, will be required 
FIGURE 7.5

\section{Shares of gross exports and value added of exports in goods and services in selected countries, 2011}

a. Machinery

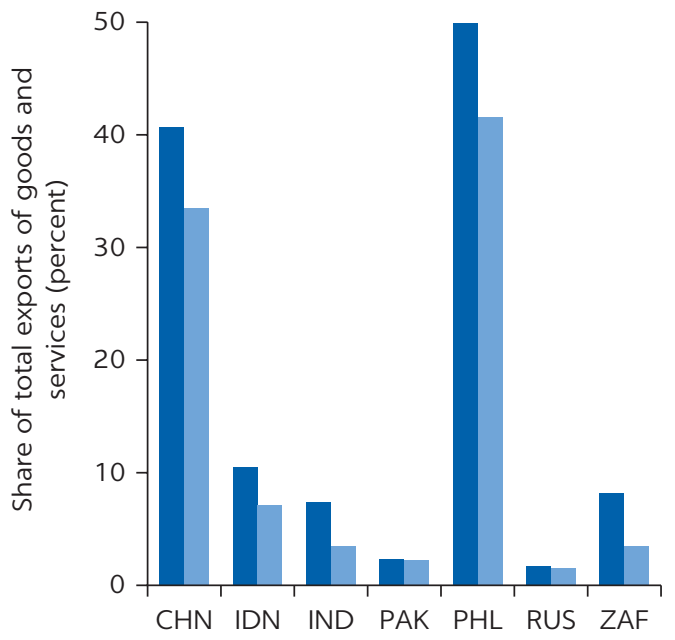

b. Other private services

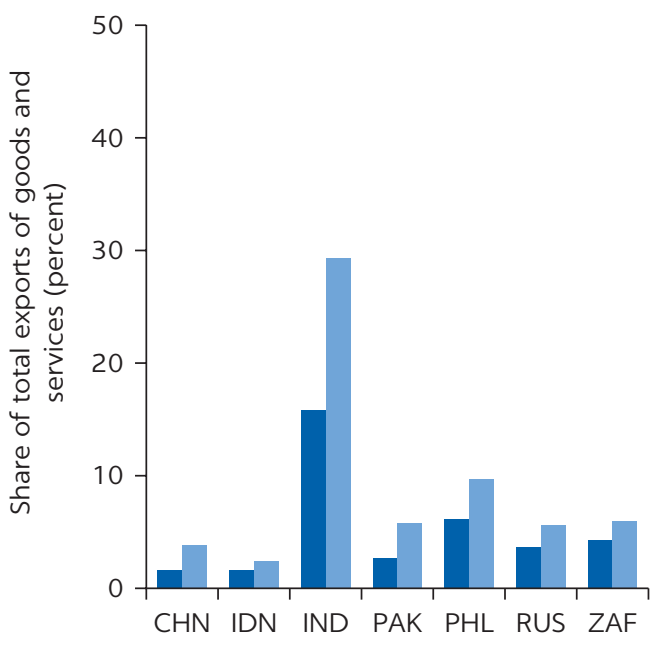

Source: World Bank Export of Value Added Database.

Note: $\mathrm{CHN}=$ China; IDN = Indonesia; IND = India; PAK = Pakistan; PHL = Philippines; RUS = Russian Federation; $\mathrm{ZAF}=$ South Africa.

and indirectly exported. Relatively little value added in telecommunications is exported through other goods exports, suggesting that this sector functions mainly as a final service to end-consumers.

Backward linkages of services exports are weak in Pakistan, representing less than 15 percent of total exports; services are mainly inputs into other export activities rather than direct exports to end-consumers. This finding has important policy implications. It means that low-cost high- quality services should be a priority for any diversification and competitiveness strategy and that assessing and understanding constraints to services development is key to increasing their contribution to economic diversification and competitiveness in goods industries.

In many countries, the share of value added is much larger for services than for goods. Gross value shares are small for Pakistan and most of the other countries in figure 7.5. The gap between gross value and value added in Pakistan is relatively small.

Table 7.3 presents the sectoral contributions to total value added. It shows that in Pakistan and most of its comparators, after considering forward linkages, services' share of total domestic value added (38 percent) is higher than its share of the value added of exports ( 33 percent). This difference was much smaller in China, the Philippines, and Indonesia. In India the pattern is reversed. The findings for Pakistan indicate that many services activities are oriented toward the domestic market and imply that activities that are important for the domestic economy (mainly manufacturing) have untapped export potential.

In Pakistan the trade, distribution, and hotels subsector ("distribution" in the table) and finance are relatively outward oriented, contributing 16.1 percent and 
TABLE 7.3 Value added of services subsectors in selected countries, 2011 (percent of total)

\begin{tabular}{|c|c|c|c|c|c|c|c|c|c|c|c|c|}
\hline \multirow[b]{2}{*}{ SECTOR/SUBSECTOR } & \multicolumn{2}{|c|}{ PAKISTAN } & \multicolumn{2}{|c|}{ RUSSIAN FEDERATION } & \multicolumn{2}{|c|}{ CHINA } & \multicolumn{2}{|c|}{ INDIA } & \multicolumn{2}{|c|}{ PHILIPPINES } & \multicolumn{2}{|c|}{ INDONESIA } \\
\hline & DOMESTIC & EXPORT & DOMESTIC & EXPORT & DOMESTIC & EXPORT & DOMESTIC & EXPORT & DOMESTIC & EXPORT & DOMESTIC & EXPORT \\
\hline \multicolumn{13}{|l|}{ Services } \\
\hline Transport & 19.2 & 20.9 & 6.7 & 7.3 & 6.4 & 7.2 & 7.8 & 9.1 & 4.7 & 5.2 & 3.4 & 3.8 \\
\hline Finance & 4.7 & 5.4 & 1.8 & 2.9 & 4.6 & 4.7 & 5.2 & 6.2 & 4.2 & 1.7 & 3.4 & 2.6 \\
\hline Communications & 0.4 & 0.4 & 1.0 & 0.6 & 2.0 & 1.4 & 1.9 & 2.6 & 2.8 & 1.9 & 1.7 & 1.7 \\
\hline Water & 0.3 & 0.2 & 1.0 & 0.3 & 0.2 & 0.2 & 0.2 & 0.1 & 0.3 & 0.2 & 0.1 & 0 \\
\hline Construction & 1.7 & 0.2 & 9.7 & 2.2 & 7.1 & 0.2 & 7.5 & 1.1 & 5.0 & 0.3 & 9.5 & 0.4 \\
\hline Distribution & 15.2 & 12.7 & 21.6 & 13.8 & 7.7 & 6.6 & 14.6 & 9.6 & 13.9 & 9.6 & 12.4 & 7 \\
\hline Insurance & 0.8 & 1.0 & 0.4 & 0.3 & 0.5 & 0.4 & 1.2 & 1.7 & 1.0 & 0.4 & 0.4 & 0.2 \\
\hline Other business & 6.6 & 9.2 & 8.0 & 6.4 & 5.2 & 4.6 & 5.1 & 15.5 & 4.5 & 6.2 & 1.0 & 0.7 \\
\hline Other services & 0.4 & 0 & 0.5 & 0.1 & 2.3 & 1.2 & 0.3 & 0.4 & 2.4 & 1.0 & 2.4 & 1.3 \\
\hline Total services & 49.2 & 50.1 & 50.8 & 33.9 & 36.1 & 26.4 & 43.8 & 46.2 & 38.9 & 26.4 & 34.4 & 17.7 \\
\hline Agriculture & 15.7 & 20.3 & 19.9 & 51.1 & 16.3 & 17.7 & 23.2 & 23.2 & 18.7 & 20.3 & 22.0 & 39.4 \\
\hline Manufacturing & 27.7 & 24.2 & 13.3 & 14.7 & 32.6 & 54.2 & 15.8 & 29.8 & 24.9 & 52.5 & 23.7 & 41.9 \\
\hline Other & 7.4 & 5.4 & 16.0 & 0.3 & 15.0 & 1.7 & 17.3 & 0.8 & 17.4 & 0.9 & 20.0 & 1.0 \\
\hline
\end{tabular}

Source: World Bank Export of Value Added Database. 
4.2 percent, respectively, to export value added. Also important for exports are transport services (for which the difference between the contribution to exports and the domestic economy is smaller). In other business services, services value-added contribution to exports is small but growing. It is lower in Pakistan than in any other country in the table except Indonesia. The contribution of distribution is higher than in all other countries examined. Finance also contributes more to exports than to the domestic economy; its contribution is more or less in line with that of the BRICS (Brazil, Russia, India, China, South Africa). The fact that the share of some of these sectors is large for export and domestic value added suggests that Pakistan shares a strong production base in these subsectors on which it can capitalize. Other sectors have relatively small shares of external value added.

Pakistan's most important forward linkages are in trade and distribution, other business services, transport, and finance. In transport linkages soared from 6.4 percent in 2007 to 20.9 percent in 2011. Domestic value added in transport more than tripled over this period, rising from 6.2 percent to 19.2 percent. In contrast, in telecommunications the absolute figures are small, there is no difference between exported and domestic value, and both figures declined, with the share of exported value added falling from 1.6 percent in 2007 to 0.4 percent in 2011.

Figure 7.6 shows the shares of nine services subsectors in total exports. In all comparator countries, transportation was an important source of forward linkages, mainly through the textile and clothing subsectors and the food and beverage subsector. In Pakistan and its comparators, forward linkages were important in trade and distribution. Other business services in Pakistan are contributing to other economic activities as inputs, particularly in other export activities. In contrast, in India and most other countries, other business services accounted

\section{FIGURE 7.6}

\section{Share of various types of services in the value added of exports in selected countries, 2011}

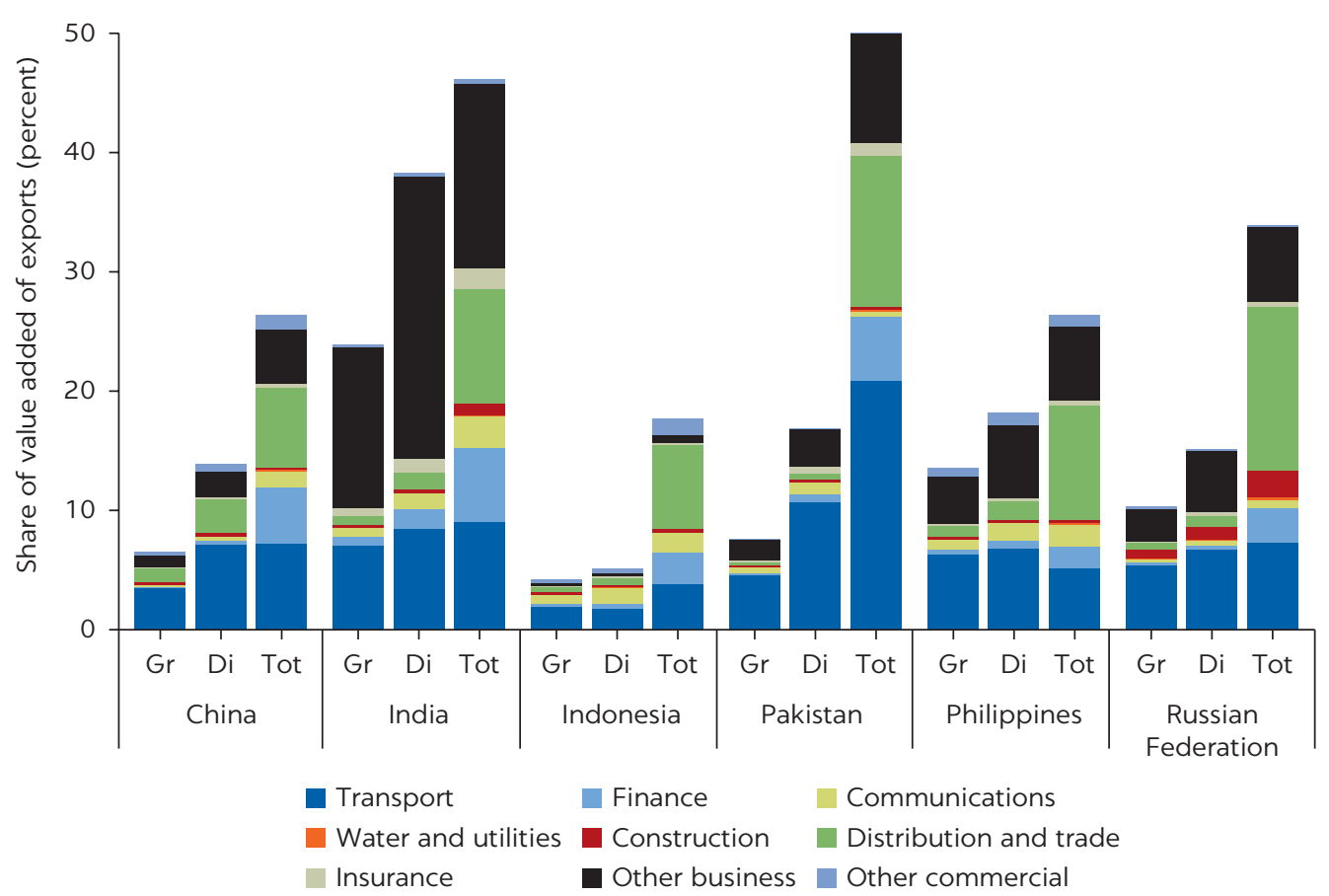


FIGURE 7.7

Cross-country correlation between the share of services exports in total exports and per capita GDP, 2011

a. Gross exports of services

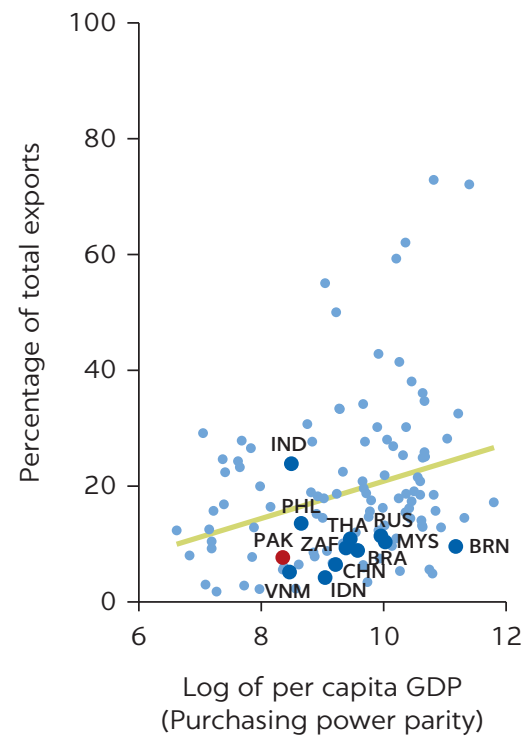

b. Direct value added of services exports

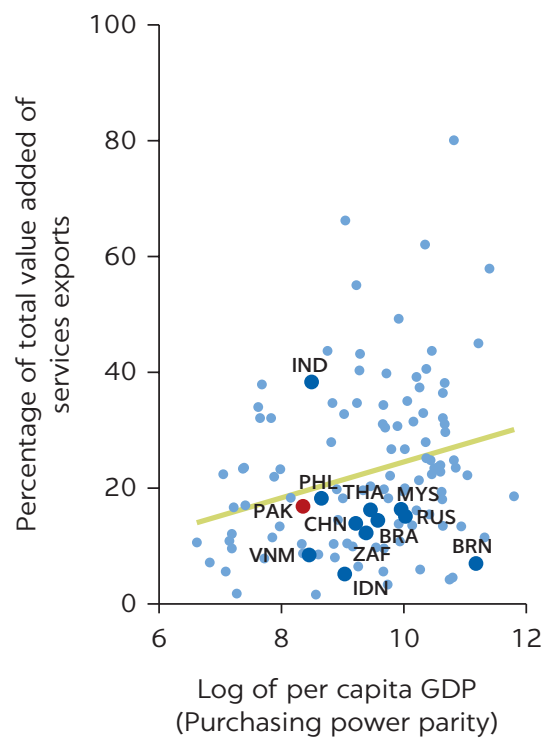

c. Total value added of services exports

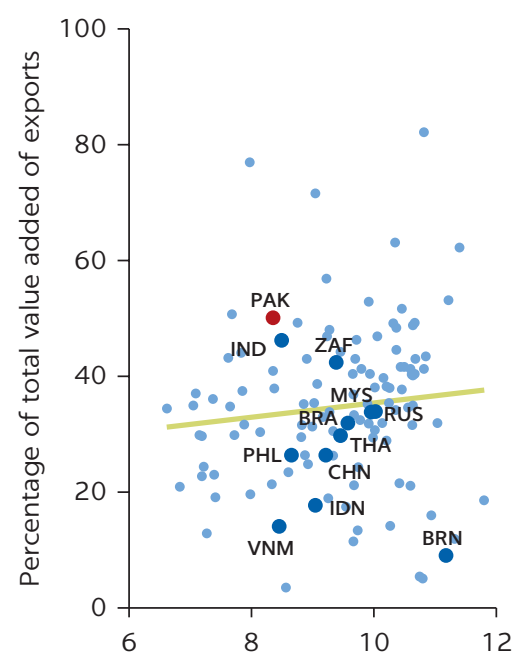

Log of per capita GDP (Purchasing power parity)

Source: World Bank Export of Value Added Database.

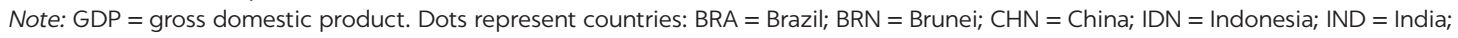
MYS = Malaysia; PAK = Pakistan; PHL = Philippines; RUS = Russian Federation; THA = Thailand; VNM = Vietnam; ZAF = South Africa.

for a larger share of direct exports than forward linkages. Finance played an important role in forward linkages in China, India, and, to a lesser extent, Russia, Indonesia, and the Philippines.

In Pakistan forward linkages play a larger role in transport, finance, distribution and trade, and insurance services than in other services. In construction and telecom services backward linkages are more important than forward linkages. That pattern is more or less similar for the countries marked in dark blue in figure 7.7. The fact that telecom services are more important for backward linkages than forward linkages is unusual.

Figure 7.7 benchmarks the performance of Pakistan, the BRICS, and Asian countries based on their level of development, proxied by per capita GDP in purchasing power parity. It shows that the share of services in total exports is above what would be expected given Pakistan's level of development when forward linkages are considered. This share is even higher than in the case of India given its level of development. In contrast, both the gross and the direct shares are below what would be expected based on Pakistan's level of development. All comparator countries except India are below the expected level.

\section{DETERMINANTS OF SERVICES TRADE}

\section{Services trade policies}

Higher-income countries tend to have fewer regulatory restrictions than lowerincome countries, as figure 7.8 shows. Regulatory restrictions in the services sector in Pakistan compare favorably with those of countries at similar income levels. 
FIGURE 7.8

\section{Cross-country correlation between Services Trade Restrictiveness Index (STRI) and per capita GDP and value added of services, 2013}
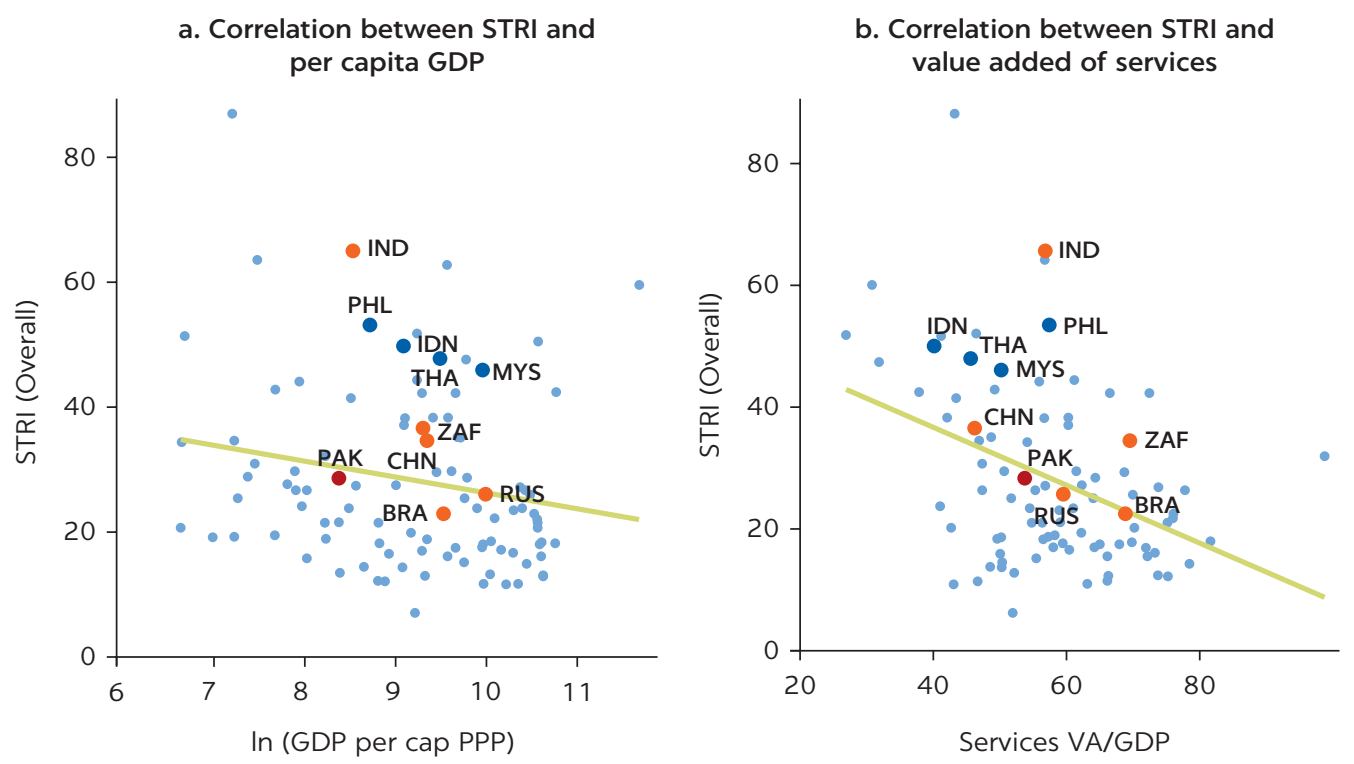

Sources: Data from the World Bank Services Trade Restrictiveness Index; World Bank World Development Indicators; and Borchert, Gootiiz, and Mattoo 2012a, 2012b.

Note: GDP = gross domestic product; PPP = purchasing power parity; STRI = Services Trade Restrictiveness Index; $\mathrm{VA}=$ value added. Dots represent countries: $\mathrm{BRA}=$ Brazil; $\mathrm{CHN}=$ China; IDN = Indonesia; IND = India; MYS = Malaysia; PAK = Pakistan; PHL = Philippines; RUS = Russian Federation; $\mathrm{THA}=$ Thailand; VNM = Vietnam; $\mathrm{ZAF}=$ South Africa.

Figure 7.9 illustrates the correlation between direct value added and total value added with the STRI for all countries. Pakistan scores below the fitted line. If indirect value-added linkages of services exports are included, Pakistan outperforms its peers, particularly peers with similar STRIs. Pakistan's relatively low STRI thus seems to be strongly associated with the transmission of indirect value added of services through other domestic downstream sectors.

Pakistan has very tight regulatory restrictions in insurance, financial, and professional services (legal and accountancy and auditing services) and somewhat tight restrictions in transport. Tight restrictions of finance and insurance services are common among Pakistan's comparator countries. Pakistan has lower restrictions on professional services than its comparators. It has no discriminatory restrictions in the retail sector (distribution).

Pakistan remains relatively closed for cross-border transactions (Mode 1) in insurance, finance, and transport services (figure 7.10). The STRI in finance exceeds 50. Transport services are heavily protected through Mode 1; they are less restricted in Mode 3 (commercial presence). Insurance and financial services are also heavily restricted through Mode 3 , making it very difficult to establish foreign affiliates in Pakistan. Professional services are relatively liberal through Mode 1, but Mode 3 restrictions are in place. Only minor Mode 3 restrictions exist in telecommunications, the most open subsector in Pakistan after retail.

Figure 7.11 illustrates the importance of the complementarity between cross-border trade and direct investment in Pakistan. Both panels show a 
FIGURE 7.9

Cross-country correlation between direct and total value added of services exports and Services Trade Restrictiveness Index (STRI), 2009
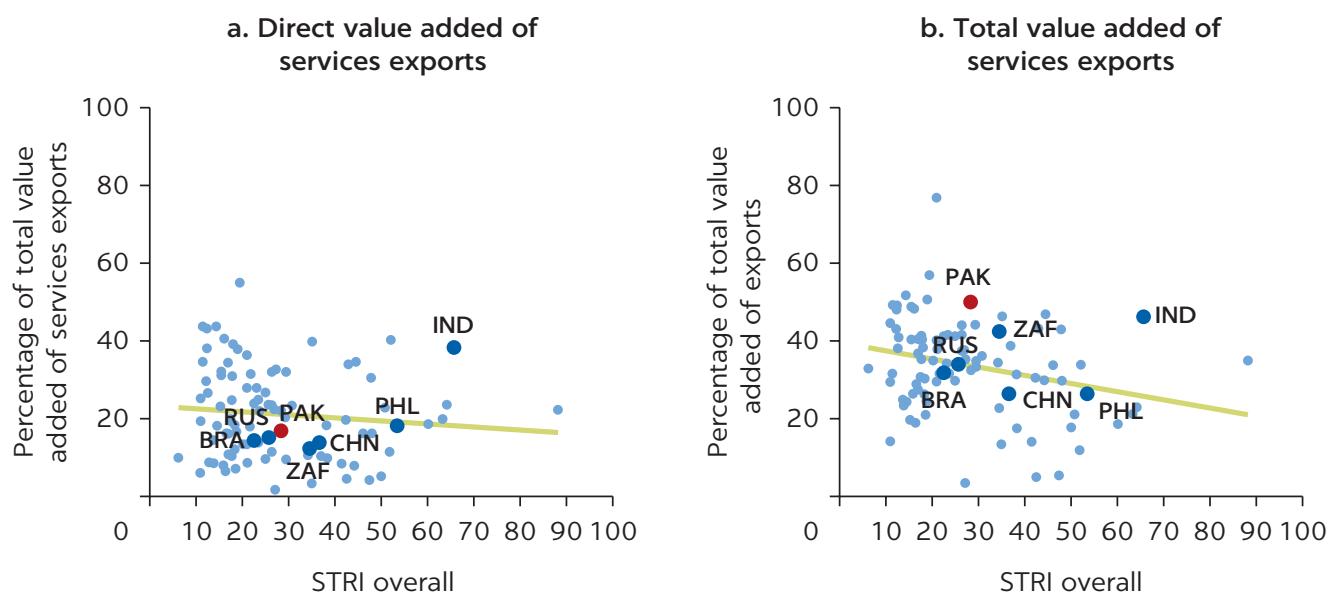

Sources: Data from World Bank Services Trade Restrictiveness Index; World Bank Exports in Value Added Database; and Borchert, Gootiiz, and Mattoo 2012a, 2012b.

Note: STRI = Services Trade Restrictiveness Index. Dots represent countries: $\mathrm{BRA}=$ Brazil; $\mathrm{CHN}=\mathrm{China}$; IND = India; PAK = Pakistan; PHL = Philippines; RUS = Russian Federation; ZAF = South Africa.

FIGURE 7.10

Services Trade Restrictiveness Index (STRI) for modes 1 and 3 in selected countries, 2009

a. Mode 1

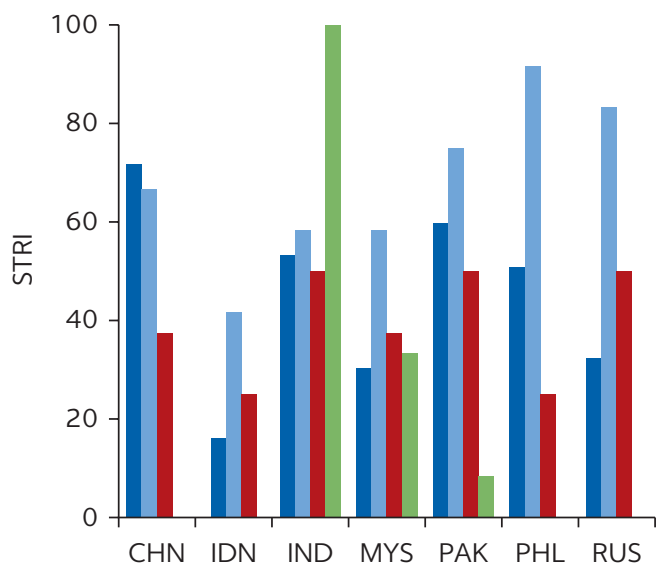

b. Mode 3

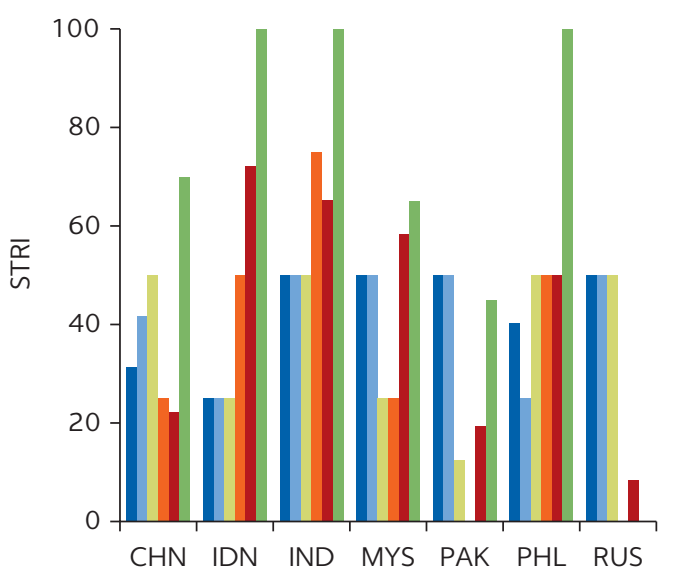

Financial $\square$ Insurance $\square$ Telecom $\square$ Retail $\square$ Transport $\square$ Professional

Sources: Data from the World Bank Services Trade Restrictiveness Index and Borchert, Gootiiz, and Mattoo 2012a, 2012b.

Note: STRI = Services Trade Restrictiveness Index. CHN = China; IDN = Indonesia; IND = India; MYS = Malaysia; PAK $=$ Pakistan; $\mathrm{PHL}=$ Philippines; RUS = Russian Federation .

negative correlation between restrictiveness and the share of services exports in GDP. For overall restrictiveness (panel a), Pakistan falls below the fitted value line, meaning that exports are below what would be expected given its level of restrictiveness. In finance (panel b), Pakistan's trade performance is as expected given its relatively tight regulatory policies (right above the fitted line). Loosening regulations in this subsector would probably increase Pakistan's export competitiveness. 
FIGURE 7.11

\section{Cross-country correlation between services exports (mode 1) as percent of GDP and Services Trade Restrictiveness Index (STRI) for mode 3, 2010}

a. Overall STRI

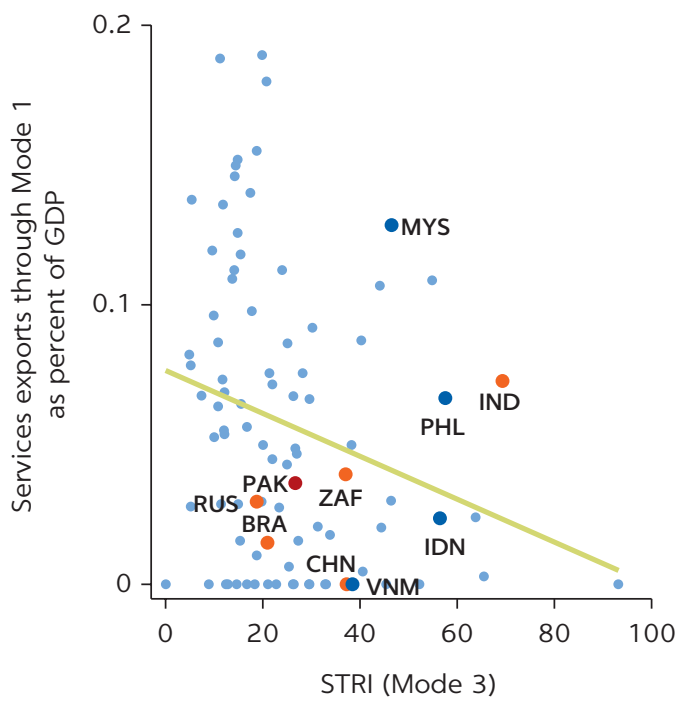

b. STRI for finance

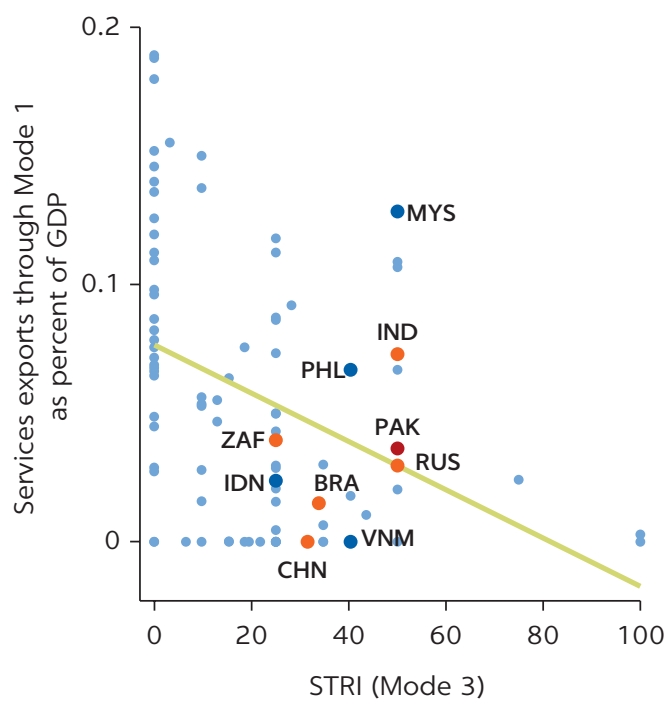

Sources: Data from World Bank Development Indicators, World Bank Services Trade Restrictiveness Index, and Borchert, Gootiiz, and Mattoo 2012a, 2012b.

Note: GDP = gross domestic product; STRI = Services Trade Restrictiveness Index. Dots represent countries: $\mathrm{BRA}=$ Brazil; $\mathrm{CHN}=$ China; IDN = Indonesia; IND = India; MYS = Malaysia; PAK = Pakistan; PHL = Philippines; RUS = Russian Federation; VNM = Vietnam; ZAF = South Africa.

Reducing trade restrictiveness in Mode 3 services has been one of the main drivers of the increase in the tradability of services. Mode 3 regulations in finance, insurance, and to a lesser extent professional services are still relatively high. Empirical studies reveal strong links between FDI and trade in Mode 3 and/or cross-border trade in services (see Lennon 2009). Outward FDI and services exports are complementary.

\section{Governance policies}

Just opening up markets to foreign entry may not be enough to spur trade in services. Because of the many market failures in the sector, governance structures are critical to keeping markets competitive once the sector is liberalized.

Three indicators-governance effectiveness, regulatory quality, and the rule of law-proxy the quality of governance. On all three measures, Pakistan has the largest gap to the frontier of good governance structures among its peers (figure 7.12).

Figure 7.13 shows that the lower the level of restrictiveness of services trade policies, the higher the regulatory quality of governments. Addressing trade restrictiveness is thus a necessary but not sufficient condition for increasing competitiveness: There is a complementary role for domestic institutions. Although Pakistan has relatively low services trade barriers, its regulatory governance structures lag those of comparator countries with similar STRIs.

\section{Endowments}

Pakistan lags its peers in many of the endowment indicators that are important for services (figure 7.14). 
FIGURE 7.12

Gap to the frontier in terms of governance effectiveness, regulatory quality, and the rule of law in selected countries

a. Gov effectiveness

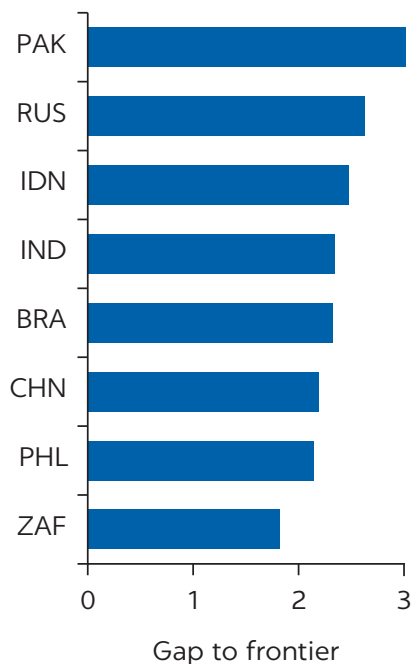

b. Req quality

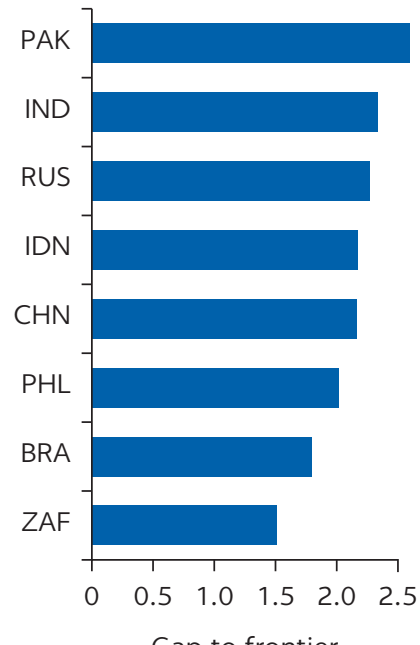

Gap to frontier c. Rule of law

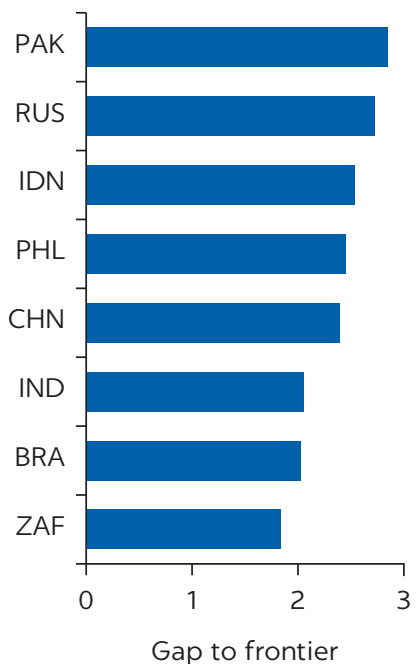

Source: World Bank Worldwide Governance Indicators.

Note: Data are for 2011-13. Gov effectiveness = governance effectiveness; Reg quality = regulatory quality. $\mathrm{BRA}=$ Brazil; $\mathrm{CHN}=$ China; IDN = Indonesia; IND = India; PAK = Pakistan; $\mathrm{PHL}=$ Philippines; RUS = Russian Federation; $\mathrm{ZAF}=$ South Africa.

FIGURE 7.13

Cross-country correlation between regulatory quality and Services Trade Restrictiveness Index (STRI), 2013

a. Overall STRI

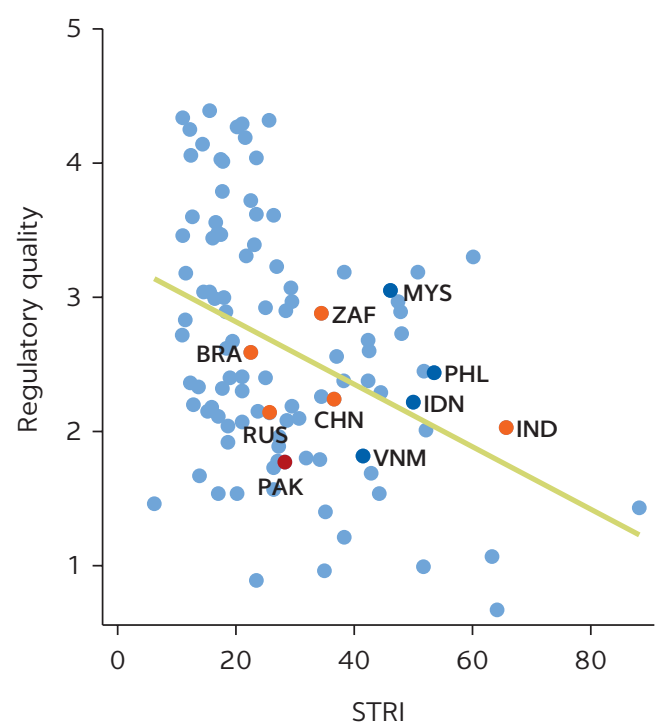

b. STRI for finance (Mode 3)

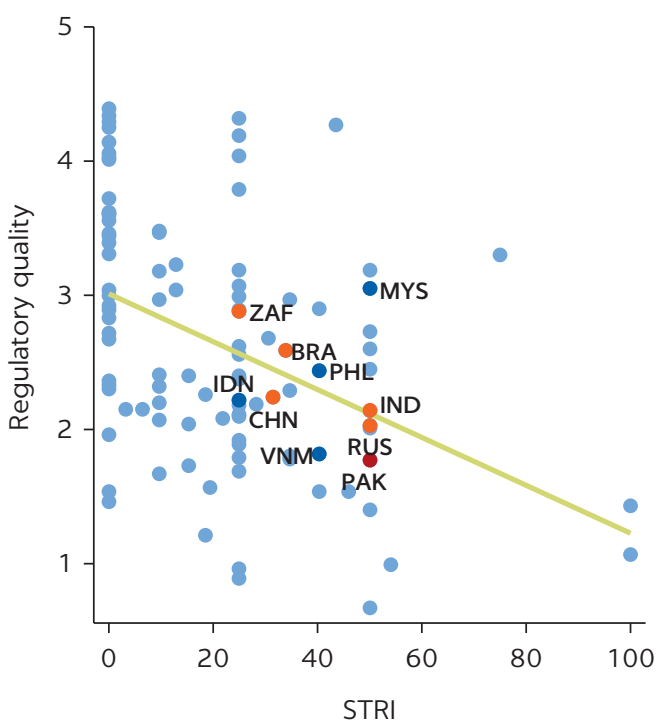

Sources: Data from World Bank Worldwide Governance Indicators, World Bank Services Trade Restrictiveness Index, and Borchert, Gootiiz, and Mattoo 2012a, 2012b.

Note: STRI = Services Trade Restrictiveness Index. Dots represent countries: BRA = Brazil; CHN = China;

IDN = Indonesia; IND = India; MYS = Malaysia; PAK = Pakistan; PHL = Philippines; RUS = Russian Federation;

$\mathrm{VNM}=$ Vietnam; $Z A F=$ South Africa. 
FIGURE 7.14

\section{Gap to the frontier in terms of number of Internet servers, number of broadband subscriptions, and human capital quality in selected countries}

a. Internet servers

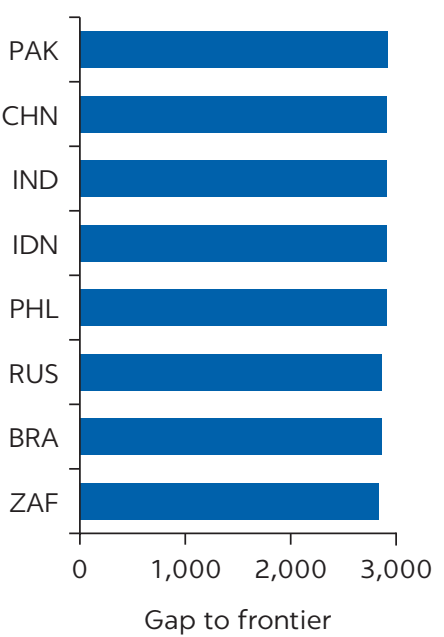

b. Broadband subscriptions

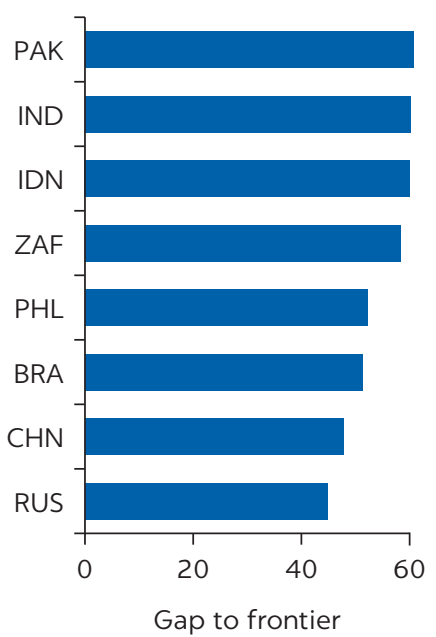

c. Human capital quality

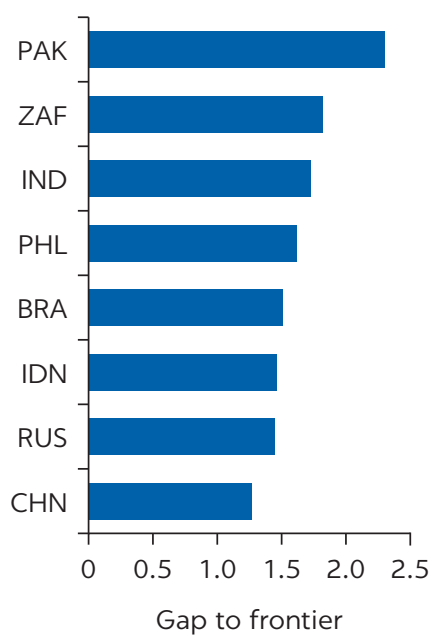

Sources: World Bank World Development Indicators and World Economic Forum 2017. Note: Data are for 2011-13. The frontier is the best performing country in each of the indicator. The first panel graphs Internet servers per 100 people. The second panel graphs broadband subscriptions per 100 people. $\mathrm{BRA}=$ Brazil; $\mathrm{CHN}=$ China; IDN = Indonesia; IND = India; PAK = Pakistan; $\mathrm{PHL}=$ Philippines; RUS = Russian Federation; ZAF = South Africa.

In addition, its services trade performance is below what one could expect based on its level of human capital and information and communications technology (ICT) endowments (figure 7.15). Policies should recognize that skills availability and upgrading are critical to success in services.

Electronic infrastructure has a positive effect on services exports (Freund and Weinhold 2000). Exporting services requires access to high-quality electronic infrastructure by firms (not necessarily the population at large). Developing country exporters may need to invest in infrastructure to ensure better-quality telecommunications if the public network is inadequate. Exporting services also requires partner countries with access to good-quality electronic infrastructure (Goswami and others 2012). Pakistan's future services trade expansion, particularly in telecom and computer services, will depend critically on the policies affecting infrastructure in these subsectors.

\section{POLICY RECOMMENDATIONS}

Services trade can make a major contribution to Pakistan's development. The findings from this analysis can orient the decisions of policy makers:

- Increasing services exports will depend to a large extent on policies on human capital, infrastructure, and governance.

- Regulatory policies in services are less restrictive than in other countries, except in some subsectors and modes of supply.

- Because of the significant role services play as inputs into other economic activities, access to high-quality low-cost services is critical for the diversification of trade in goods. 
FIGURE 7.15

\section{Cross-country correlation between services trade as percent of GDP and human capital and Internet use, 2013}
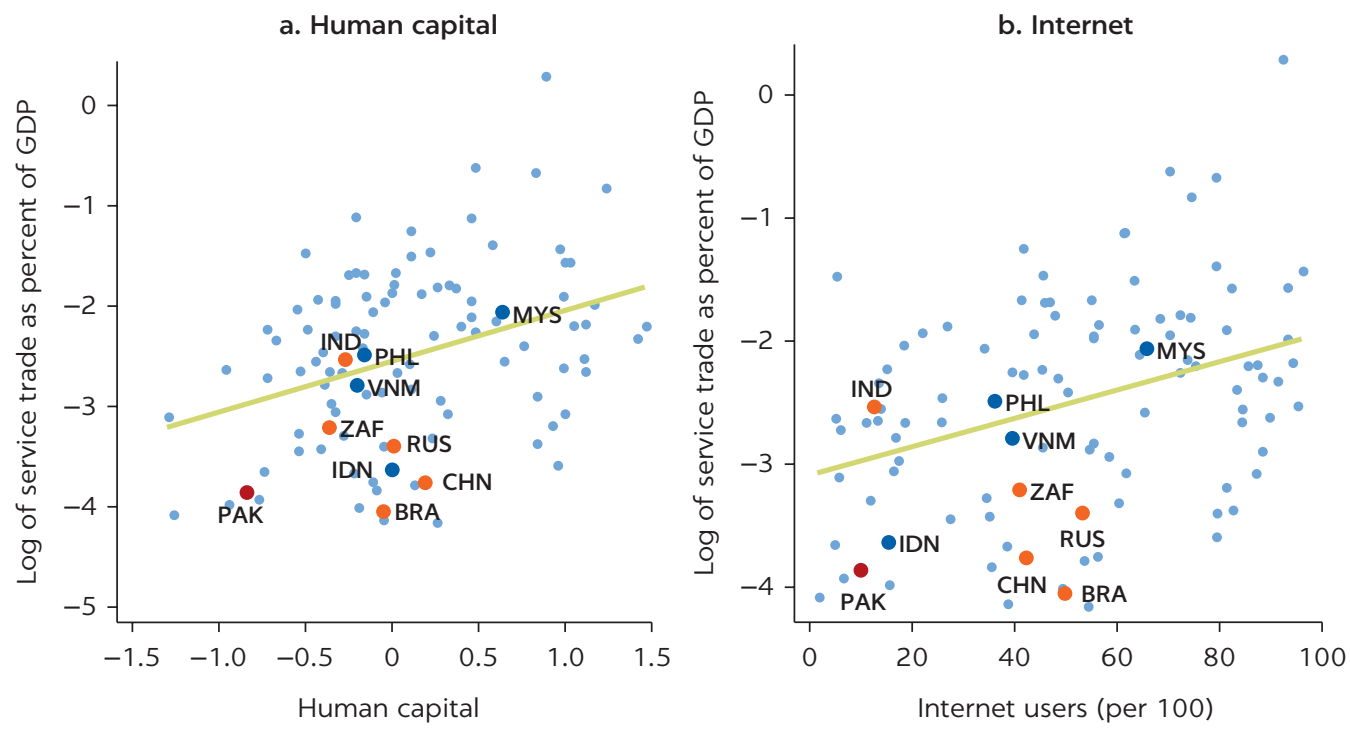

Sources: Data from the World Bank World Development Indicators and World Economic Forum 2013.

Note: The human capital measure takes into account the qualitative aspects of education across all levels and includes information on both the current and future workforce. GDP = gross domestic product. Dots represent countries: BRA = Brazil; $C H N=$ China; IND = India; IDN = Indonesia; MYS = Malaysia; PAK = Pakistan; $\mathrm{PHL}=$ Philippines; RUS = Russian Federation; VNM = Vietnam; ZAF = South Africa.

- Countries with a higher-skilled labor force and qualitatively better education export more services. Electronic infrastructure also has a positive effect on services exports. To increase the role of services trade, the government, in collaboration with the private sector, needs to invest in human capital and ICT.

- Pakistan's services trade policies are relatively open, especially compared with other countries of the region. Although there is scope for more liberalization, it should be complemented by improvement of other enabling factors that affect services: institutions, governance, the rule of law, infrastructure supportive of services, and human capital.

\section{REFERENCES}

Borchert, I., B. Gootiiz, and A. Mattoo. 2012a. "Guide to the Services Trade Restrictions Database.” Policy Research Working Paper 6108, World Bank, Washington, DC.

_. 2012b. "Policy Barriers to International Trade in Services: Evidence from a New Database." Policy Research Working Paper 6109, World Bank, Washington, DC.

Freund, C., and D. Weinhold. 2000. "On the Effect of the Internet on International Trade.” FRB International Finance Discussion Paper 693, Board of Governors, Federal Reserve System, Washington, DC.

Goswami, A. G., A. Mattoo, and S. Sáez, eds. 2012. Exporting Services: A Developing Country Perspective. Washington, DC: World Bank.

Lennon, C. 2009. "Trade in Services and Trade in Goods: Differences and Complementarities." wiiw Working Paper 53, The Vienna Institute for International Economic Studies, Vienna.

World Bank Export of Value Added Database, Washington, DC, https://datacatalog.worldbank .org/dataset/export-value-added-database. 
World Bank Services Trade Restrictiveness Index (database), Washington, DC, http://iresearch .worldbank.org/servicetrade/.

World Bank World Development Indicators (database), Washington, DC, http://wdi .worldbank.org.

World Bank Worldwide Governance Indicators (database), Washington, DC, https://datacatalog .worldbank.org/dataset/worldwide-governance-indicators.

World Economic Forum. 2013. The Human Capital Report. Geneva. http://reports.weforum.org /human-capital-index-2013/.

2017. The Global Human Capital Report: Preparing people for the future of work. Geneva. 
Sub-Saharan Africa 



\title{
Valuing Services Trade within Africa*
}

\author{
BARAK HOFFMAN, MILES MCKENNA, AND SEBASTIÁN SÁEZ
}

The increasingly important role of services across Africa is challenging longheld theories of economic development. For decades the typical first steps on the path out of poverty were increased agricultural productivity followed by growth in the manufacturing sector. A larger share of services in an economy was considered a destination far in the future, an area of comparative advantage for more advanced economies.

Over the last few years, Africa has been growing along a very different trajectory. Across the region, agriculture's share of GDP has declined, and manufacturing, rather than growing as theory may have anticipated, has stagnated. Services, by contrast, are increasing as a share of total employment and GDP, driving value addition, and providing critical inputs to boost other economic activities.

As countries have begun to seize opportunities within and through services, policy makers and economists need to question old assumptions and consider new implications. What is the role of services in structural transformation and overall competitiveness? Can they help reduce poverty? Are services a viable export sector in Africa?

For decades this sector received scant attention, especially in Africa. Data are scattered, insufficient, and difficult to collect. However, using the best available data and analytical tools, researchers can begin to seek answers to these questions.

This chapter examines the performance of services exports across Africa. It shows that measured in terms of value added services exports are much more significant for African countries than previously thought. The chapter

\footnotetext{
* The authors thank William Maloney, Cesar Calderon, Melise Jaud, and Claire H. Hollweg for their valuable inputs and suggestions and Annoula Rysova, Esteban Rojas, and Laura Juliana Higuera Ardila for research assistance. A version of this chapter was included in the Africa Competitiveness Report 2015, a joint report by the World Economic Forum, the Africa Development Fund, the World Bank, and the OECD (World Economic Forum 2015). The editors are grateful to the World Economic Forum for authorization to publish.
} 
also shows the linkages between services and other sectors of the economy. Disaggregating value-added data reveals the importance of services as inputs to other export activities, especially exports of agriculture, energy, and manufacturing.

Based on this analysis, the chapter offers some insights to inform policies that can strengthen the competitiveness and export performance of the services sector in Africa. It also identifies how certain services trade policies, such as regulations which limit competition in services markets, have a negative impact on services exports. These findings support the argument that liberalization of services can increase services trade.

\section{SERVICES GO GLOBAL}

Firms increasingly operate in a context of internationally fragmented production chains, a concept captured in the emerging literature on global value chains. Through this global value chain lens, trade is facilitated by flows of the goods, services, investment, and knowledge necessary to produce products in multiple locations, giving rise to what has been called the trade-investmentservice-intellectual property nexus (see Baldwin 2011, 2012; Feenstra 2010; Grossman and Rossi-Hansberg 2008; Helpman 2011; Jones 2000 for an analysis of defragmentation, trade in tasks, and offshoring). Trade in services is one conduit facilitating and coordinating the connections necessary to increase participation and boost competitiveness within these chains. Enhancing the competitiveness of the services sector-in effect strengthening a country's bonds with the global economy-is now imperative for Africa's continued economic development.

Over the last few decades, the falling costs of travel, improvements in information and communications technology (ICT), and the development of electronic infrastructure greatly enhanced the ability of services to be produced in one location and consumed in another. As a result, exports of services picked up for all income groups and the share of developing countries' services exports increased from 18 percent in 1990 to 30 percent in 2012. Not all countries enjoyed the same level of success, however. In particular, Africa is lagging dramatically in terms of its share of global services exports.

The shares of middle- and low-income developing countries in services exports rose dramatically between the mid-1990s and 2013, fueling much greater interest in this sector. The shares of African countries declined, however. What accounts for these patterns? Are some countries or sectors performing better than others? What can be learned from comparisons?

Productivity in services is a strategic driver of economic competitiveness. The competitiveness of most exported goods on global markets depends on access not only to raw material inputs but also to critical services inputs. These inputs include efficient, competitively priced utilities (ICT, transport); financial services (banking, insurance); and other commercial services (accounting, engineering, consulting, legal, and marketing).

Imported services can serve as a transmission channel for the transfer of new technologies, which can boost performance in skill-intensive industries and increase the value added of manufacturing exports (Francois and Woerz 2008).! As overall trade in services increases, the productivity of the services sector tends to rise, raising overall productivity and growth over time 


\section{BOX 8.1}

\section{The gender dimensions of trade in services in Africa}

Coste and Dihel (2013) combine information from existing databases, qualitative evidence, and insights from a business survey on professional services conducted in 17 Sub-Saharan African countries to capture gender participation in services trade. They show that the proportion of female employment in Africa is higher in services than in manufacturing. It is higher than in the Middle East, North Africa, or South Asia, though slightly lower than in East Asia, Latin America, and Eastern Europe.

More women work in services than in manufacturing in all regions except East Asia, where the shares are roughly equal. One possible explanation for this trend is that the predominance of small firms involved in the services sector makes it easier for women to own their own business. Across all regions, the share of full-time female employees is substantially higher in female-managed businesses than in firms managed by men. These firms are also less likely to export. Hotels and restaurants as well as wholesale and retail trade have the largest shares of female employment, female ownership, and women in top management positions. A large proportion of women are thus employed in highly tradable activities.

However, women tend to lack the same opportunities to access the full range of services occupations as men. They represent only 6 percent of top senior positions and 12 percent of the next most senior position in professional services firms in eastern and southern Africa. Equally qualified women work who in the same occupation as men also tend to have fewer responsibilities, earn less, and have lower status (ILO 2012; Staritz and Reis 2013).

Some countries are making progress in integrating women into management positions in the services sector. According to Coste and Dihel (2013), the Comoros, Madagascar, Rwanda, Swaziland, and Zambia are among the best performers in balancing gender in management positions of professional firms; women in these countries represent almost 15 percent of top managers. Women are better represented in management at accounting and legal firms; they are all but absent from management at engineering and architectural firms.

Source: Coste and Dihel 2013; see also Brenton, Gamberoni, and Sear 2013.

(van der Marel 2011). The empirical literature on these impacts in Africa also finds a significant and positive relationship between firm productivity and services performance and confirms that inadequate access to essential producer services hurts firms by undermining their productivity (see Arnold, Mattoo, and Narciso 2008; Hoekman and Kostecki 2009; Inklaar, Timmer, and Ark 2007, 2008; Triplett and Bosworth 2004; Brenton and Isik 2012).

The development of the services sector is also crucial for meeting poverty reduction and social development goals. Many of the Sustainable Development Goals (SDGs) target services, including education, health, and water and sanitation. A more competitive services sector can also improve gender equity in Africa, where a large share of small cross-border traders are women (Brenton, Gamberoni, and Sear 2013; box 8.1). For all of these reasons, increasing the competitiveness of the services sector can generate broad economic and social benefits.

\section{ASSESSING THE VALUE ADDED OF SERVICES IN TRADE}

Trade data are usually measured by transaction values-the price paid or payable for goods and services. Transaction values are gross values (inputs plus value added). 
Value added is measured as the net output of a sector after adding up all outputs and subtracting inputs. Adding up the value added of services in a sector sold directly to final consumers (in the domestic economy or as exports) provides a measure of the direct contribution of services.

This measure does not fully reflect the contribution of services' value added because services also enter as inputs in the production of products in other sectors. To account for the total value added of services in exports, one needs to measure not only direct services exports but also their forward and backward linkages to other exports.

Forward linkages are the value added contributions as inputs to all other downstream sectors. Backward linkages capture value added inputs contributed from other (upstream) sectors. These linkages represent the interdependence of sectors of an economy. By not properly accounting for the forward linkages of services embedded as inputs in downstream sectors, gross export measures undervalue services' full contribution to trade.

\section{How important are services to total exports?}

Figures 8.1 and 8.2 present three measures of the importance of services exports in Africa ${ }^{2}$ :

- gross exports of services (the transaction value of exports)

- the share of the value added of direct services exports in the value added of total exports

- both the direct and indirect (total) value added of services in all exports (including forward linkages).

These figures reveal that services exports constitute a significant share of total exports in many countries in Africa. Among Africa's low-income countries, direct services exports account for more than 20 percent of total exports in Ethiopia, Senegal, and Tanzania (figure 8.2). In some of the region's more developed countries, including Cameroon, the Arab Republic of Egypt, Kenya, Mauritius, and Tunisia, they account for more than 30 percent of total exports (figure 8.3). In other countries in the region, including Burkina Faso, Guinea, Mozambique, and Nigeria, services exports are very low.

Services are an important input to other economic activities. Except in Benin, Egypt, and Nigeria, the share of total services in overall exports (of both goods and services) is significantly larger than the direct share of services in total exports. The gap between the two indicates that services are supporting other export activities, such as manufacturing and agricultural exports. For example, services account for 83 percent of the final price of Ethiopian roses in the Netherlands.

Direct exports of services are more important than their contribution as inputs into other export activities in some countries. For example, the shares of services exports in Kenya and Mauritius are 25 and 34 percent, respectively, when trade is measured in terms of gross value. When measured in terms of direct value added, the share of services exports in total exports reaches 32 and 34 percent, respectively. When forward linkages are included, the total value added contribution of services to exports in Kenya increases only slightly, to 35 percent and 37 percent. A similar situation exists in Morocco and Zimbabwe. A small gap between the direct and total measurements suggests that services have not developed strong linkages with other export activities. This pattern is 


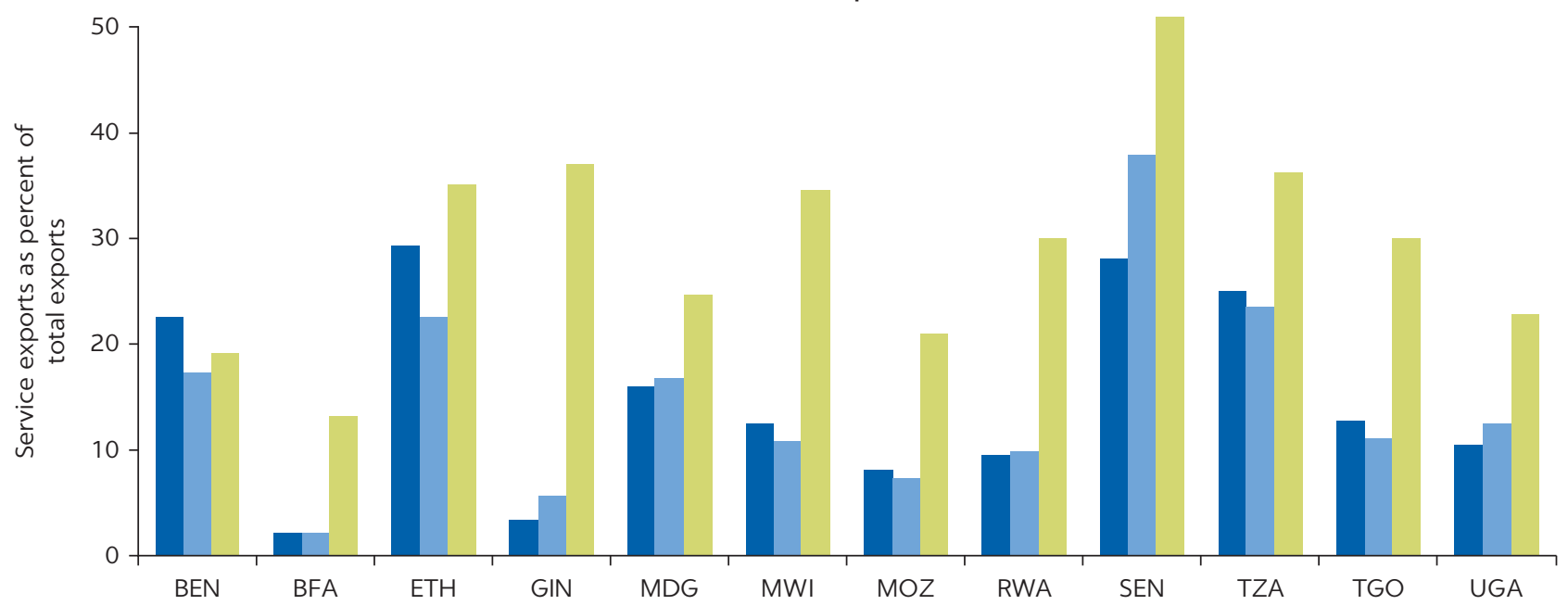

b. Other countries

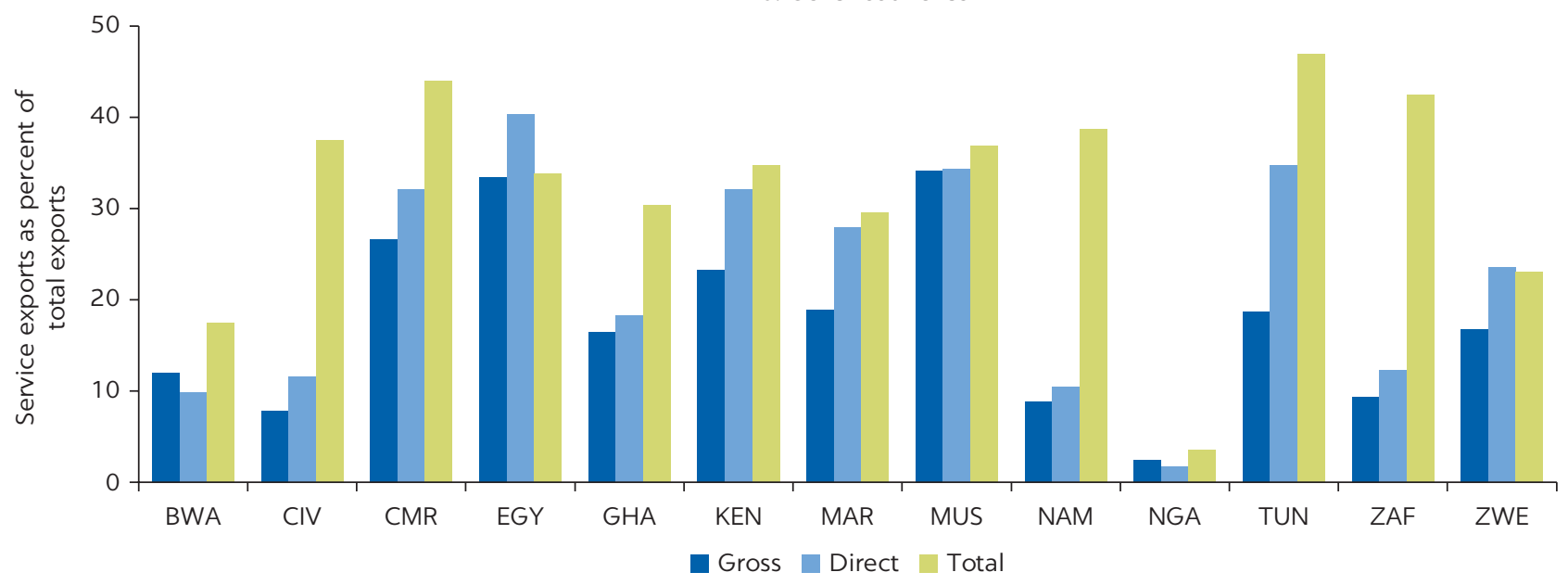

Source: World Bank Export of Value Added Database.

Note: BEN = Benin; BFA = Burkina Faso; BWA = Botswana; CIV = Côte d'Ivoire; CMR = Cameroon; EGY = Egypt, Arab Rep.; ETH = Ethiopia; GHA = Ghana; GIN = Guinea; KEN = Kenya; MAR = Morocco; MDG = Madagascar; MOZ = Mozambique; MUS = Mauritius; MWI = Malawi; NAM = Namibia; NGA = Nigeria; RWA = Rwanda; $\mathrm{SEN}=$ Senegal; $\mathrm{TGO}=$ Togo; $\mathrm{TUN}=$ Tunisia; $\mathrm{TZA}=$ Tanzania; UGA = Uganda; $Z A F=$ South Africa; $Z W E=$ Zimbabwe.

surprising, as both Kenya and Mauritius have relatively strong services subsectors. The findings suggest that most countries have the potential for increasing both direct services exports and diversifying their economies through stronger indirect linkages with downstream sectors.

\section{How important are services to other economic activities?}

The structure of services and their linkages to the domestic economy is different from the structure of services and their linkages to exports. The direct contribution of services is usually much greater for domestic value added than for exports. By contrast, the contribution of services as inputs into other activities, such as exports of primary and manufactured goods, is much greater in total exports than in domestic value added. 
Figure 8.2 illustrates this point. Services are important intermediate inputs into primary production (agriculture and energy sectors) and the manufacturing sector in all countries except Benin and Burkina Faso. In Ethiopia, Guinea, and Malawi, they account for more than half of output. The contribution of services to export value added is even more important. In Burkina Faso, Guinea, Malawi, Mozambique, Rwanda, Senegal, Togo, and Uganda, services' contribution as inputs into other export activities is greater than their contribution to domestic value added.

For some countries in the region at higher levels of development, services' contribution to manufactured exports is more important than their contribution to domestic manufacturing value added (figure 8.3). For Côte d'Ivoire, Morocco, Namibia, South Africa, and Tunisia, the role of services in manufactured exports is especially large. For Cameroon and Côte d'Ivoire, services are also an important input into exports of primary products.

\section{FIGURE 8.2}

\section{Services linkages to other economic activities and to exports in selected countries in Africa, 2011}

a. Least-developed countries

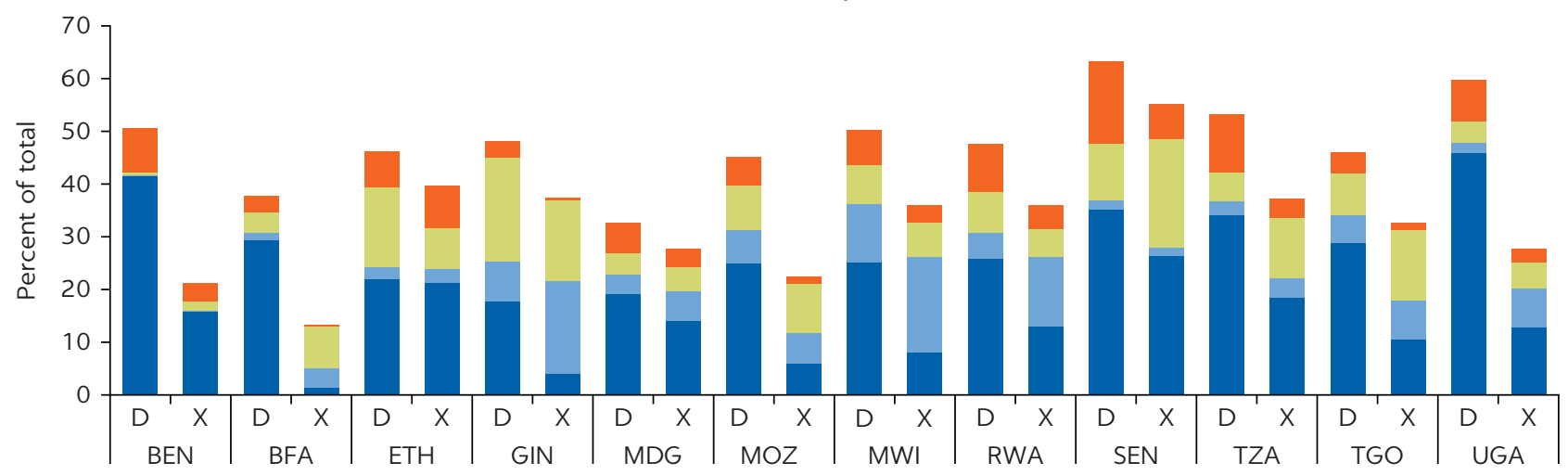

b. Other countries

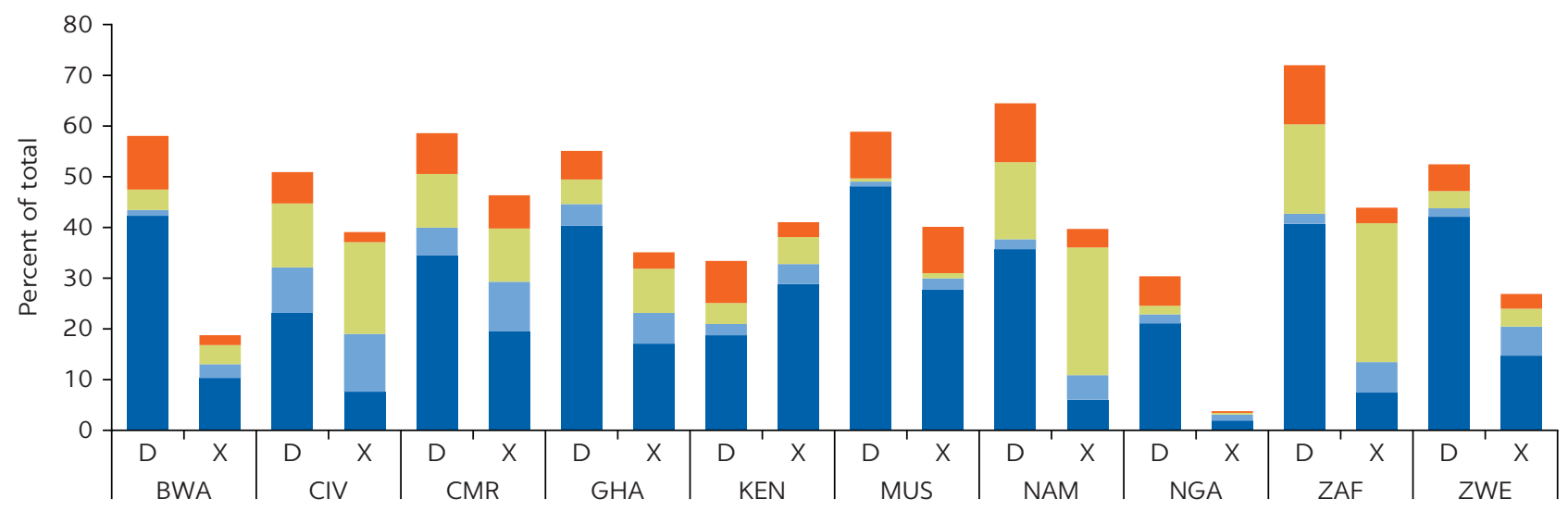

Direct value added Inputs into primary production Inputs into manufacturing Inputs into services

Source: World Bank Export of Value Added Database.

Note: $\mathrm{D}=$ domestic economy; $\mathrm{X}=$ exports. $\mathrm{BEN}=$ Benin; BFA = Burkina Faso; BWA = Botswana; CIV = Côte d'Ivoire; CMR = Cameroon; $\mathrm{ETH}=$ Ethiopia; GHA = Ghana; GIN = Guinea; KEN = Kenya; MDG = Madagascar; MOZ = Mozambique; MUS = Mauritius; MWI = Malawi; $\mathrm{NAM}=$ Namibia; NGA = Nigeria; RWA = Rwanda; SEN = Senegal; TGO= Togo; TZA = Tanzania; UGA = Uganda; ZAF = South Africa; ZWE $=$ Zimbabwe. 
FIGURE 8.3

\section{Services linkages to other economic activities and to exports in the Arabic Republic of Egypt, Morocco, and Tunisia, 2011}

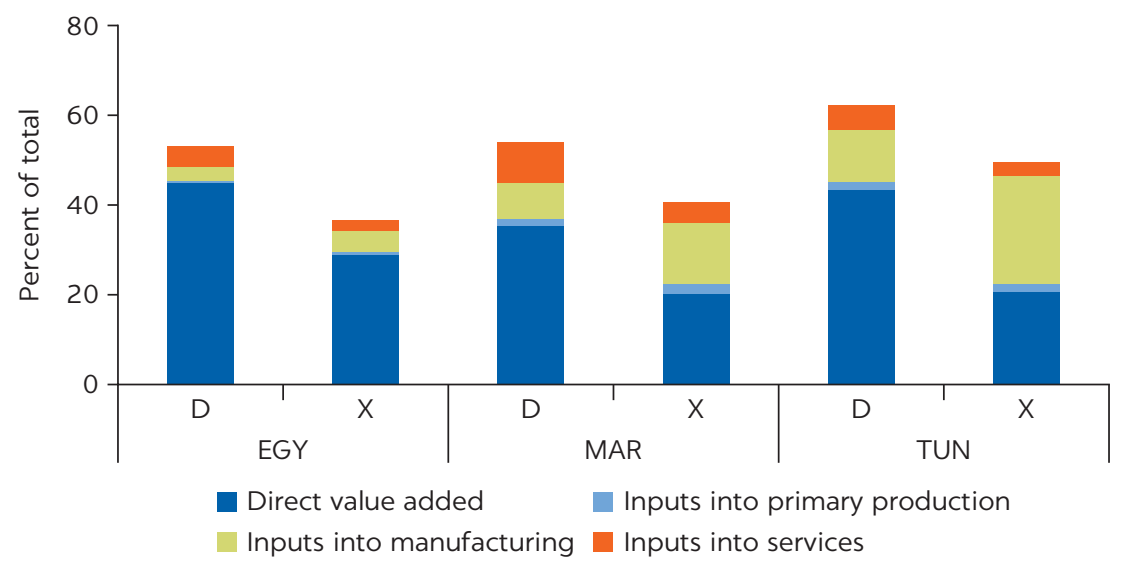

Source: World Bank Export of Value Added Database.

Note: $\mathrm{D}=$ domestic economy; $\mathrm{X}=$ exports. $\mathrm{EGY}=$ Egypt, Arab Rep.; $\mathrm{MAR}=$ Morocco; TUN = Tunisia.

\section{EXPORTS OF SERVICES FROM AFRICA}

African countries are adding their names to the growing list of developing countries that have exported services both regionally and farther abroad to major markets. Kenya, Mauritius, Senegal, and South Africa provide services as far away as Europe (Cattaneo and others 2010; Goswami, Mattoo, and Sáez 2012).

Transport, distribution, trade, and other business services are Africa's main services exports. $\frac{3}{\text { Figures }} 8.4$ and 8.5 show the contributions to total services exports for selected countries in the region. Transport services represent a significant percentage of total services exports in nearly all countries. Their importance diminishes when measured in terms of value added, indicating the weak linkages between transport and other services exports.

Distribution and trade (which include hotel and restaurants) as well as other business services (which include ICT and professional services) have stronger linkages to other export sectors. In Guinea, Senegal, and Tanzania, these shares are much larger when forward linkages are included. Exports of other commercial services-such as personal, cultural, and recreational services-are important for several of the region's lowest-income countries, such as Madagascar, Malawi, Senegal, and Uganda.

Disaggregating services export data sheds light on how services contribute to total exports in these countries (figures 8.5 and 8.6). In Kenya, for example, the direct value added provided by transport and communications services drives the performance of services exports. In Cameroon, Mauritius, and Senegal, exports of other business services account for a significant share of direct and total exports. Distribution and trade services in Cameroon, Senegal, and Tunisia are important inputs to other economic activities. In South Africa, and to a lesser extent Namibia, services are mainly an input into other export activities. 
FIGURE 8.4

\section{Structure of services exports in selected least developed countries in Africa, 2011}

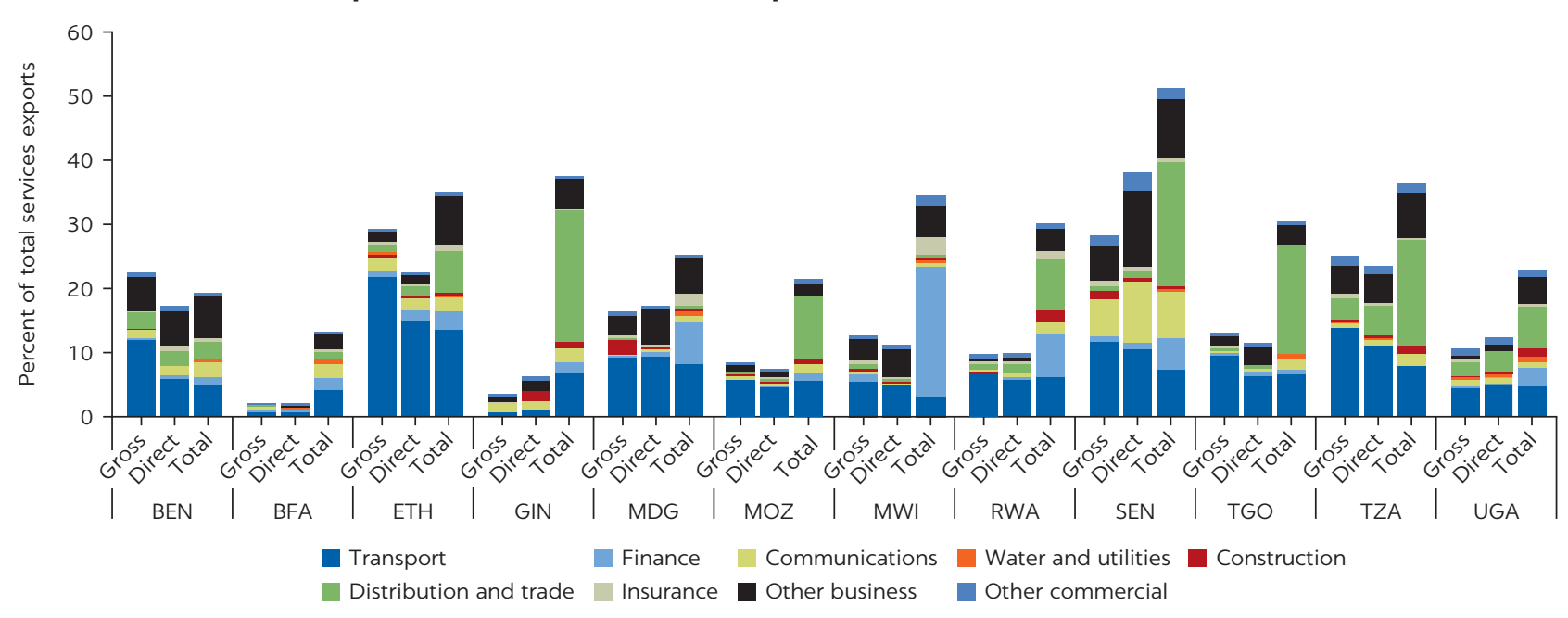

Source: World Bank Export of Value Added Database.

Note: $\mathrm{BEN}=$ Benin; BFA = Burkina Faso; $\mathrm{ETH}=$ Ethiopia; GIN = Guinea; MDG = Madagascar; $\mathrm{MWI}=\mathrm{Malawi}$; MOZ = Mozambique; RWA = Rwanda; SEN = Senegal; TGO = Togo; TZA = Tanzania; UGA = Uganda.

\section{FIGURE 8.5}

\section{Structure of services exports in selected other countries in Africa, 2011}

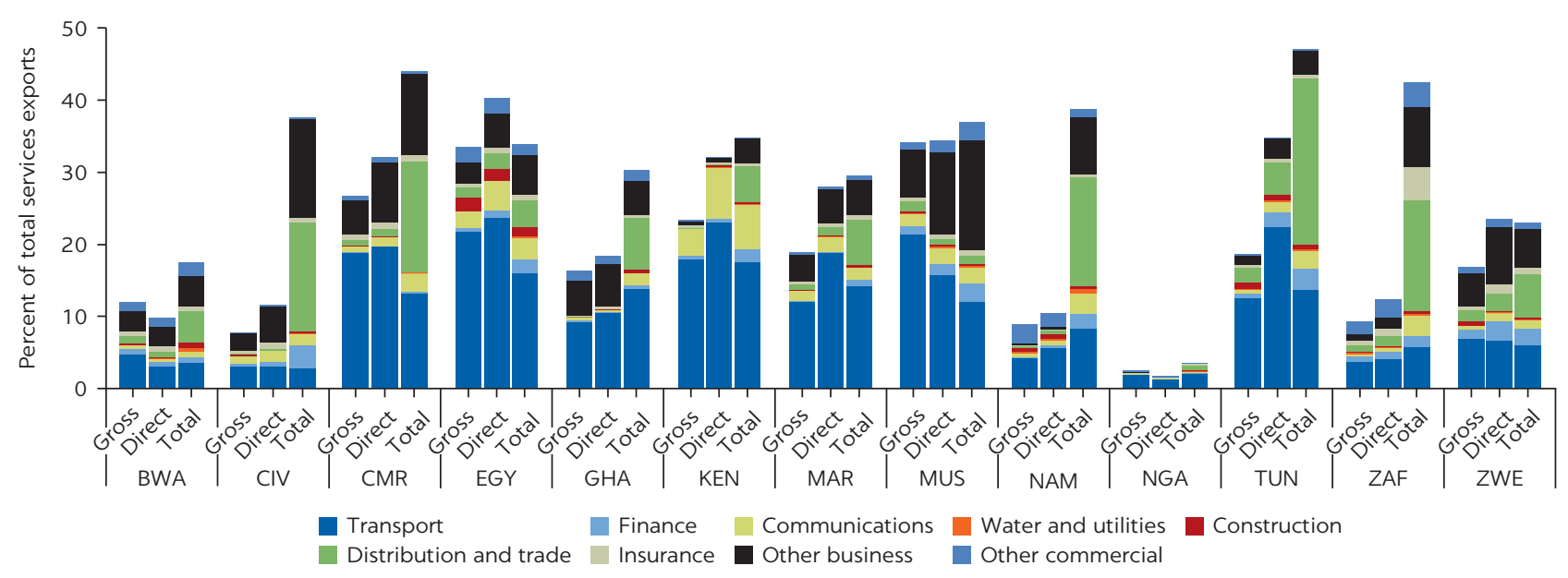

Source: World Bank Export of Value Added Database.

Note: BWA = Botswana; CIV = Côte d'Ivoire; CMR = Cameroon; EGY = Egypt, Arab Rep.; GHA = Ghana; KEN = Kenya; MAR = Morocco;

MUS = Mauritius; NAM = Namibia; NGA = Nigeria; TUN = Tunisia; ZAF = South Africa; ZWE = Zimbabwe.

\section{Services exports and economic development}

Services exports already play a significant role in many economies in the region, both as final exports and as inputs to other exports. But there is still significant potential to increase their contribution to development. A sufficiently large domestic services sector used to be a precondition for specialization in services exports; this relationship weakened in recent years suggesting that other forces have contributed to successful service exports (Sáez and others 2014). 


\section{FIGURE 8.6}

Cross-country correlation between share of services in total exports and per capita GDP, 2011

a. Gross exports of services

(as a share of total exports)

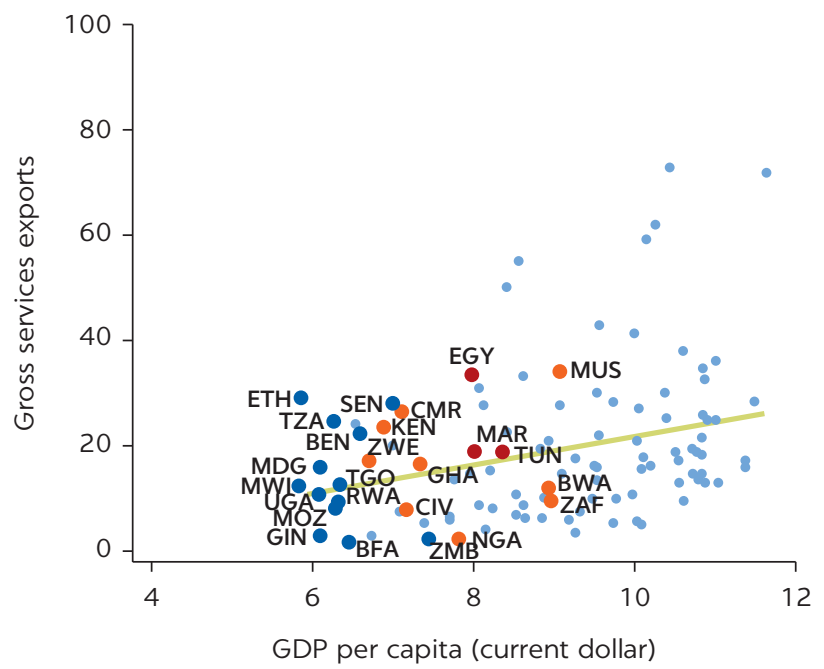

b. Direct value added of services exports (as a share of direct value added exports)

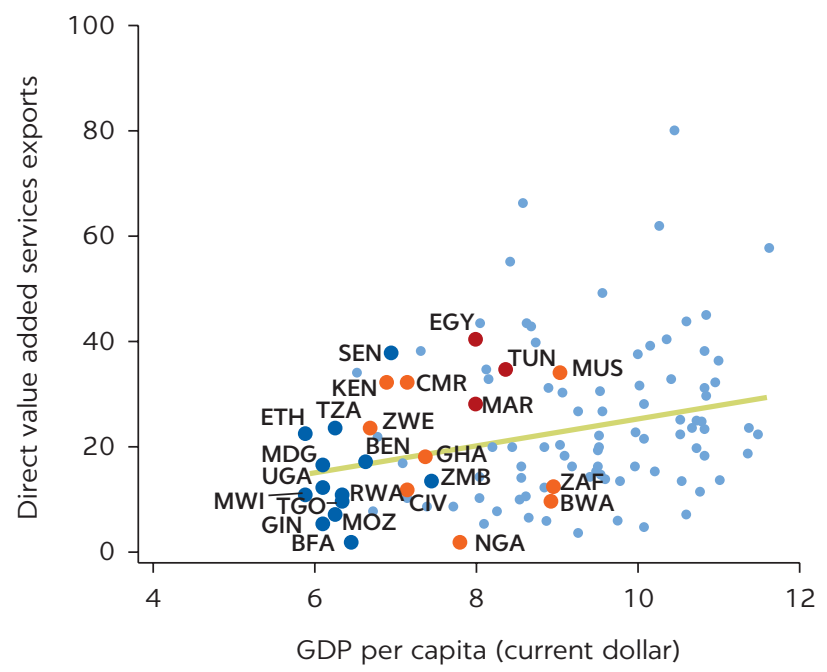

c. Total value added of services exports (as a share of total value added exports)

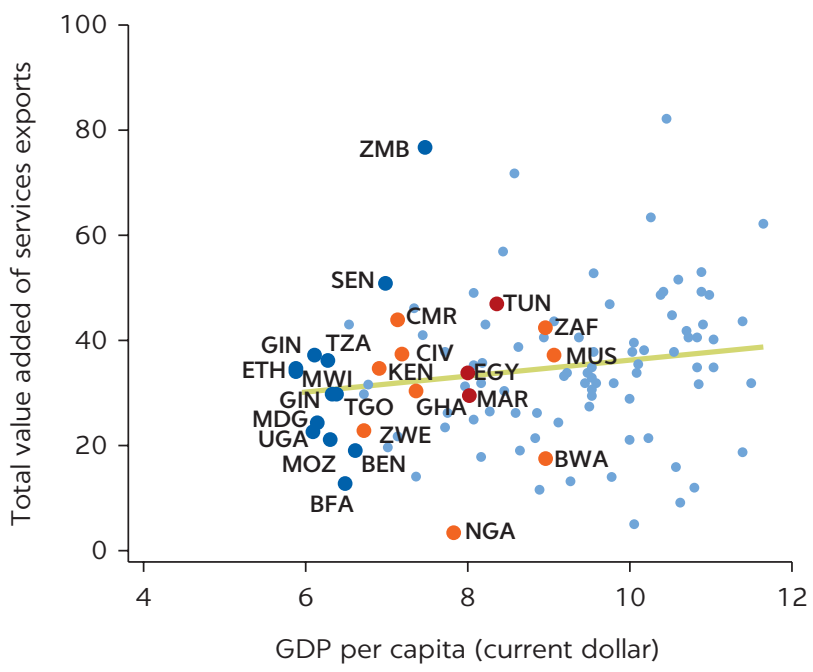

Source: World Bank Export of Value Added Database.

Note: GDP = gross domestic product. Dots represent countries. Countries labeled in purple are LDCs in Sub-Saharan Africa, in blue are other countries in Sub-Saharan Africa, and in red are countries in North Africa: BEN = Benin; BFA = Burkina Faso; BWA = Botswana; CIV = Côte d'Ivoire; CMR = Cameroon; EGY = Egypt, Arab Rep.; ETH = Ethiopia; GHA = Ghana; GIN = Guinea; KEN = Kenya; MAR = Morocco; MDG = Madagascar; MOZ = Mozambique; MUS = Mauritius; MWI = Malawi; NAM = Namibia; NGA = Nigeria; RWA = Rwanda; SEN = Senegal; TGO = Togo; TUN = Tunisia; TZA = Tanzania; UGA = Uganda; ZAF = South Africa; ZMB = Zambia; ZWE = Zimbabwe.

Goswami, Mattoo, and Sáez (2012) review the empirical literature on the determinants of services exports. They point out the importance of countries' endowments of human capital, ICT infrastructure, institutions, and geographic and cultural factors. They find that for industrial countries, the availability of ICT infrastructure and tertiary education enrollment significantly affect services exports. In developing countries, ICT infrastructure does not seem to have been critical in promoting services exports, but the effect of schooling is larger than it is in industrial countries. The ability of large services-exporting firms in developing countries to create their own ICT infrastructure or to access 
dedicated infrastructure may reduce the relevance of economywide access indicators.

Goswami, Mattoo, and Sáez (2012) also find that bilateral goods exports are positively correlated with services exports. The effect of distance, language, and colonial history is significant as well: Distance negatively affects services exports, whereas a common language or colonial history have a positive and statistically significant effect. The negative effect of distance suggests that despite the growth of electronically delivered services, proximity between suppliers and consumers still matters.

Although the evidence is not conclusive, the share of services exports appears to be positively correlated with economic development. For the least developed countries in the region, the share of direct services exports is below what would be expected based on their level of development (figure 8.6). Ethiopia, Senegal, and Tanzania are the only exceptions. Services exports in higher-income countries reveal more heterogeneity. Botswana, Côte d'Ivoire, Nigeria, and South Africa have low services exports relative to their level of development, whereas services exports from Cameroon, Egypt, Mauritius, Morocco, and Tunisia are higher than predicted. Côte d'Ivoire, South Africa, and Tunisia illustrate the importance of services when accurately accounting for forward linkages. When these linkages are included in the analysis, the share of services in total exports increases significantly in all three countries, above what would be expected based on their level of development. This finding highlights the important role services can play as inputs into other export activities and confirms that lowcost/high-quality services generate economywide benefits (Francois and Hoekman 2010; Hoekman and Mattoo 2008).

Not all services exports are equally correlated with development (figure 8.7). As a country's income level rises, some services become more important than others. Transport, distribution and trade, and utilities (water) services tend to be negatively correlated with the level of development; communications, finance, insurance, and other commercial services are positively correlated with development. Other business services have an especially strong positive correlation with the level of development. The fact that not all services are positively correlated with economic development reaffirms the importance of taking a country- and sector-specific approach when crafting policies to strengthen the competitiveness of services exports.

Most countries have uneven export services performance, suggesting comparative advantages in some subsectors and constraints in others. Kenya's shares of transport and communications services in total exports are larger than the shares of all other countries in the region and most other countries of similar per capita income. Its exports in all other subsectors are on par with or below those of comparator countries. The performance of distribution services, which are important for trade, is particularly poor. Egypt performs well only in transport, communications, and construction exports. Tunisia is strong only in trade and distribution services. South Africa performs very well in communications, distribution, insurance, and other commercial services but is average or below average in other subsectors.

\section{Export performance and trade policies}

The World Bank Group's database on applied services trade policies and regulations provides comparable information on services trade policy measures in 
FIGURE 8.7

\section{Cross-country correlation between value added of services exports (as a share of total value added of exports) and per capita GDP, by sector, 2011}

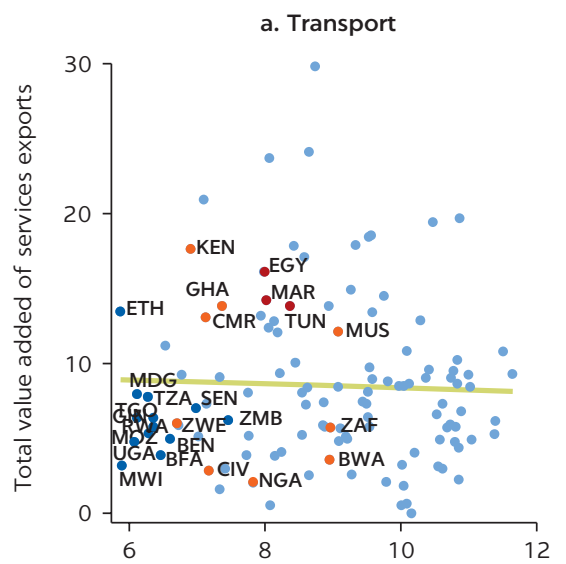

Log of per capita GDP (current dollars)

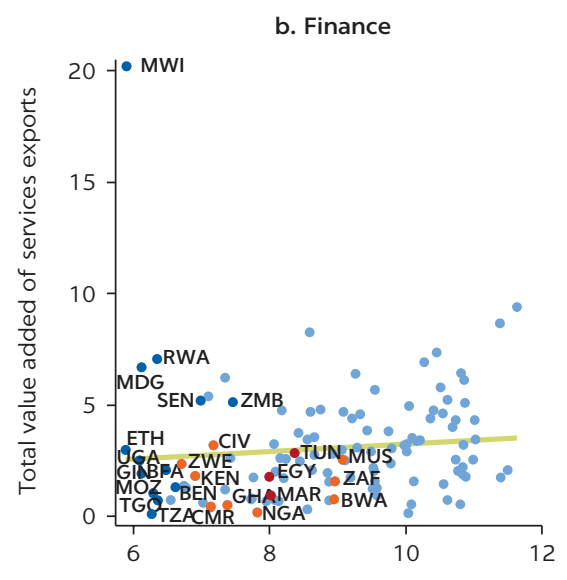

Log of per capita GDP (current dollars)

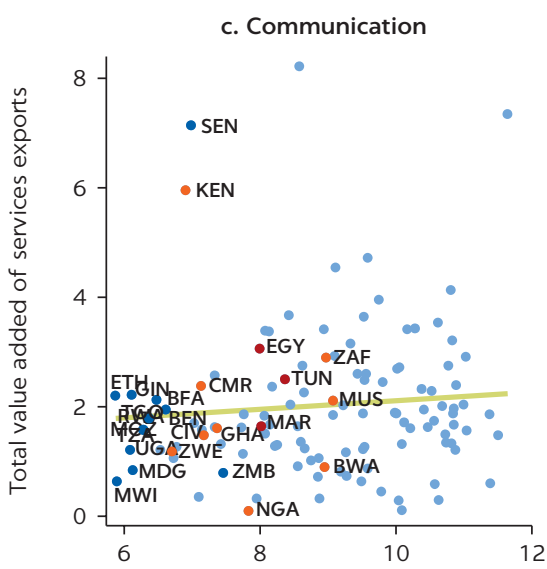

Log of per capita GDP (current dollars)

d. Insurance

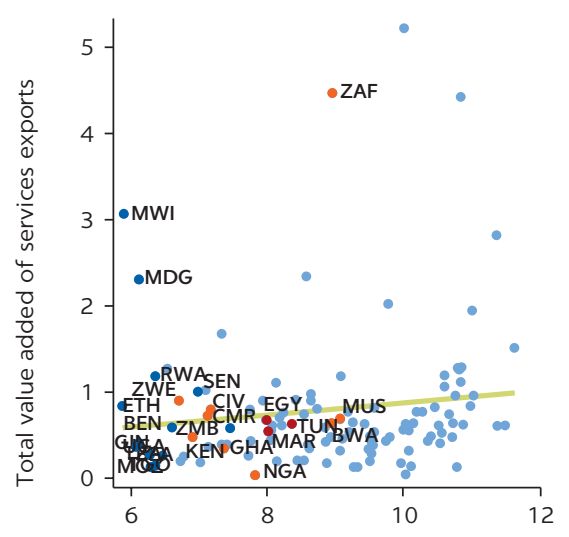

Log of per capita GDP (current dollars)

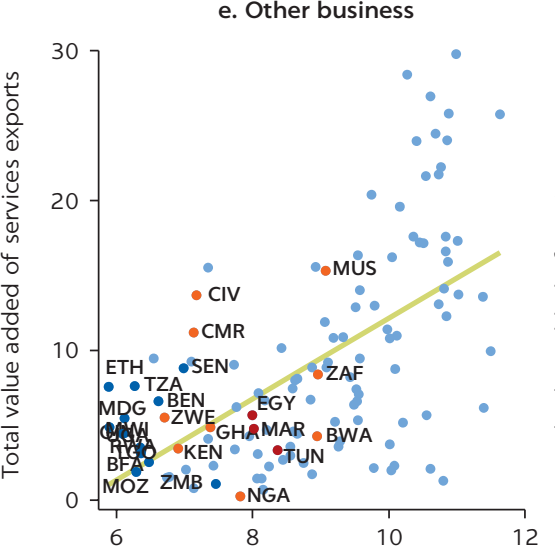

Log of per capita GDP (current dollars)

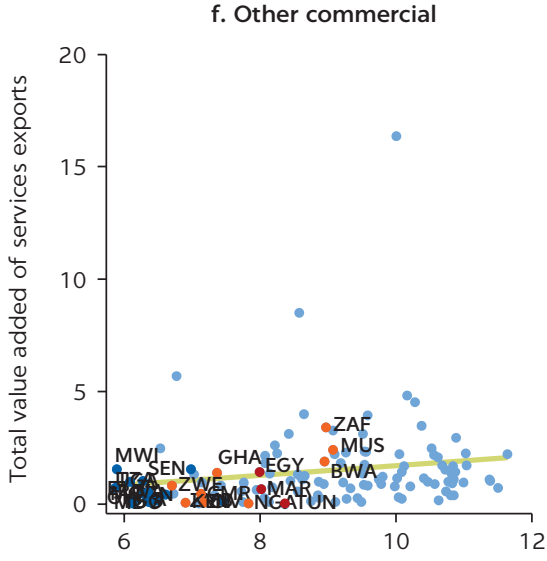

Log of per capita GDP (current dollars)

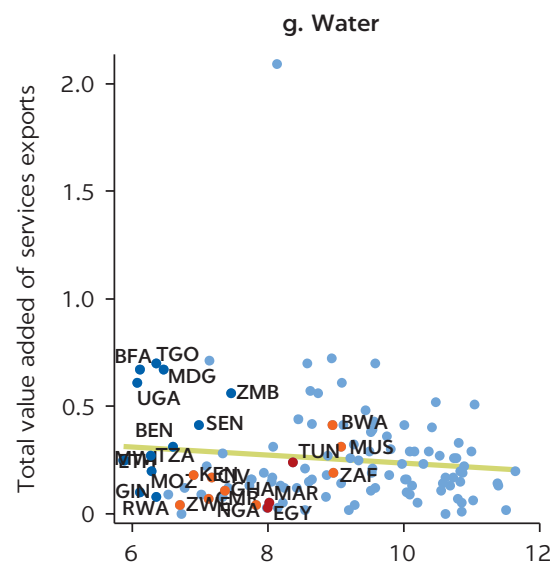

Log of per capita GDP (current dollars)

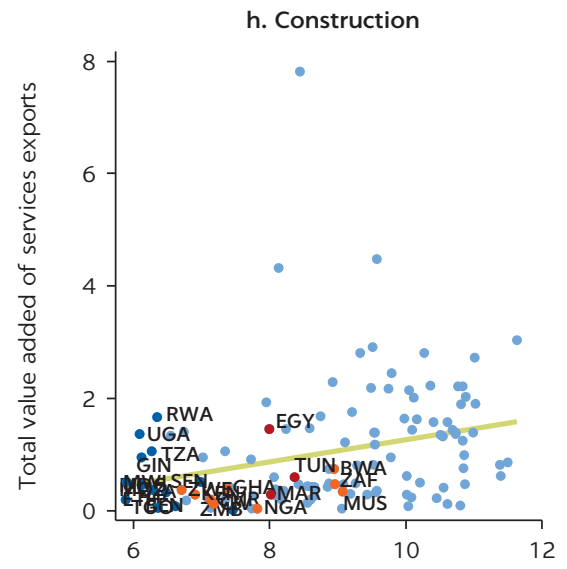

Log of per capita GDP (current dollars)

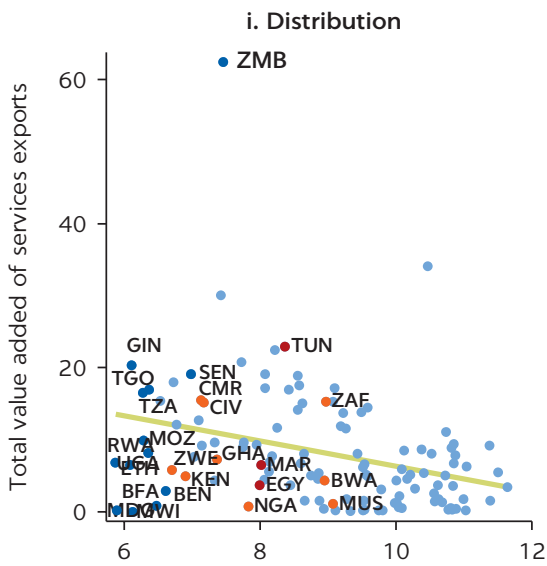

Log of per capita GDP (current dollars)

Source: World Bank Export of Value Added Database.

Note: GDP = gross domestic product. Dots represent countries: BEN = Benin; BFA = Burkina Faso; BWA = Botswana; CIV = Côte d'Ivoire; $\mathrm{CMR}=$ Cameroon; ETH = Ethiopia; GHA = Ghana; GIN = Guinea; KEN = Kenya; MAR = Morocco; $\mathrm{MDG}=$ Madagascar; $\mathrm{MOZ}=\mathrm{Mozambique}$; MUS = Mauritius; MWI = Malawi; NAM = Namibia; NGA = Nigeria; RWA = Rwanda; SEN = Senegal; TGO = Togo; TUN = Tunisia; TZA = Tanzania; $U G A=$ Uganda; ZAF = South Africa; ZMB = Zambia; ZWE = Zimbabwe 
five sectors: telecommunications, finance, transportation, retail, and professional services. It is a valuable instrument in facilitating dialogue about, and analysis of, services trade policies.

Broadly speaking, services trade confronts two types of barriers: (a) those aimed directly at limiting foreign participation in the provision of services and (b) policies aimed at correcting market failures and their potential unintended consequences. Market failures can reflect imperfect and asymmetric information, especially in knowledge-intensive sectors, lack of competition, and/or barriers to entry, particularly in sectors with significant network externalities, such as telecommunications and transport. Policies and regulations designed to correct these distortions often create their own barriers to trade.

Barriers to trade in services are more complex than barriers to trade in goods. To understand them, the World Bank used its database on applied services trade policies and regulations to build a global Services Trade Restrictions Database (STRD). It includes more than 100 economies. ${ }^{4}$ The STRD allows users to evaluate the impacts of policies and regulations. The STRD also contains a Services Trade Restrictiveness Index (STRI) for each country and service sub-sector. The scale of the STRI is 0 to 100, with higher values representing greater restrictions.

Poorly designed regulatory policies can have two potentially negative effects on trade in services: raising costs and restricting growth. The costs of services trade are higher than the costs of goods-as much as twice as high, according to Miroudot, Sauvage, and Shepherd (2013)-largely because of regulations.

The poor regulatory environment for services exports in much of Africa may be one explanation for its weak linkages within and between sectors. Countries with more restrictive regulations toward foreign services providers have lower total services exports on a value-added basis. This relationship is not as strong for gross services export shares or direct value-added services export shares, suggesting that the regulatory environment matters more for other sectors seeking to use services as inputs for their exports than for direct services exports. A restrictive regulatory framework may reduce services exports (and thus export diversification) and limit the competitiveness of other sectors of the economy (figure 8.8).

Restrictiveness in telecommunications, professional services, and transport services are high in several countries. .5 In Ethiopia, for example, telecommunications remains a monopoly. Professional services, a key input for many productive activities, tend to have the highest level of restrictiveness (above 30) of any services subsector. Scores for transport services are above 25 in most countries. Ethiopia and Zimbabwe have the highest level of restrictiveness across all sectors. Nine countries (Burundi, Ghana, Madagascar, Mauritius, Morocco, Mozambique, Rwanda, Senegal, and Zambia) fall between completely and virtually open.

Significant gains accrue from liberalization of trade in services (Francois and Hoekman 2010). Based on analysis of the STRD, Borchert, Gootiiz, and Mattoo (2012a) find that restrictions on foreign acquisitions, discrimination in licensing, restrictions on the repatriation of earnings, and inadequate legal recourse all have significant negative effects on investment inflows into services subsectors. They estimate that restrictions reduced the expected value of sectoral foreign investment by $\$ 2.2$ billion over a 7-year period.

A study in Tanzania by Jensen, Rutherford, and Tarr (2008) estimates that full reform could produce an increase in welfare (expressed in terms 
FIGURE 8.8

\section{Relationship of Services Trade Restrictiveness Index (STRI) and services exports}

a. Gross exports of services

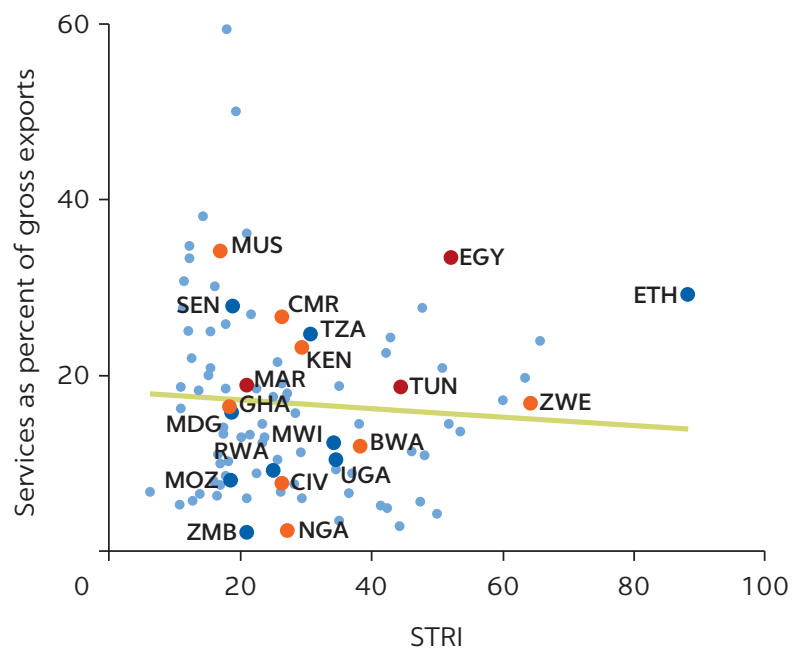

b. Direct value added of services exports

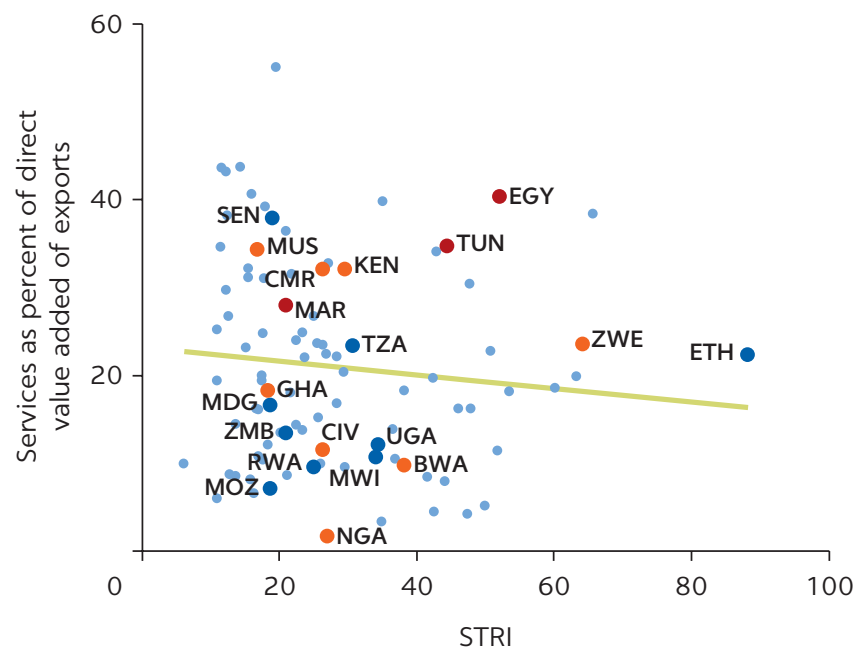

c. Total value added of services exports

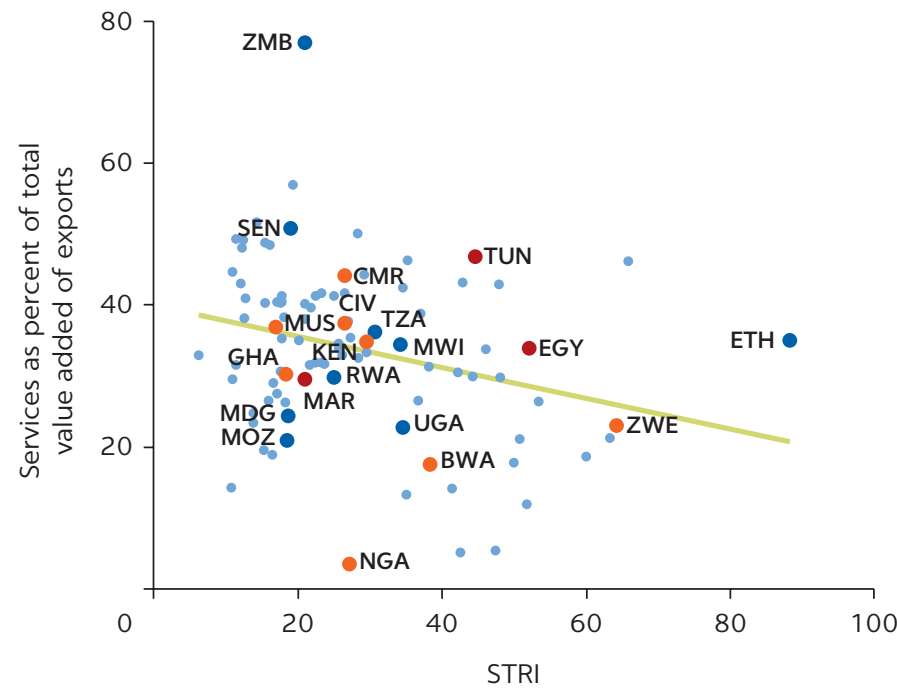

Source: World Bank Export of Value Added Database; Borchert, Gootiiz, and Mattoo 2012a.

Note: STRI = Services Trade Restrictiveness Index. Dots represent countries: BEN = Benin; BFA = Burkina Faso; BWA = Botswana; CIV = Côte d'Ivoire; $\mathrm{CMR}$ = Cameroon; $\mathrm{EGY}=$ Egypt, Arab Rep.; $\mathrm{ETH}=$ Ethiopia; GHA = Ghana; GIN = Guinea; KEN = Kenya; MAR = Morocco; MDG = Madagascar; MOZ = Mozambique; MUS = Mauritius; MWI = Malawi; NAM = Namibia; NGA = Nigeria; RWA = Rwanda; SEN = Senegal; TGO = Togo;

TUN = Tunisia; TZA = Tanzania; UGA = Uganda; ZAF = South Africa; ZMB = Zambia; ZWE = Zimbabwe.

of consumption) of 5.3 percent in the medium term and 16.0 percent in the long term. The medium-term gains derive primarily from the removal of nondiscriminatory and inefficient regulatory barriers against services providers and multinational services providers. In a similar study of Kenya, Balistreri, Rutherford, and Tarr (2009) estimate that a 50 percent reduction in nondiscriminatory services barriers and unilateral liberalization of all discriminatory services barriers would raise consumption by 10.3 percent.

Reducing barriers to trade is a necessary condition to promote low-cost and high-quality services markets, but it is not sufficient. A poorly regulated sector can also act as a de facto barrier to export competitiveness. Restrictiveness and 
indicators of regulatory quality are negatively correlated (figure 8.9). But reducing restrictiveness does not necessarily improve regulatory quality. To fully reap the benefits of liberalization, governments must address trade policies that impede services exports and improve regulatory quality (Molinuevo and Sáez 2014).

Many limitations on trade and investment in services stem from weak and ineffective governance. A poor regulatory environment may reflect a weak institutional setting (Molinuevo and Sáez 2014). Government bodies responsible for regulating services may lack an adequate mandate to enforce policies, without which they struggle to resist pressures from other government bodies or private interests that seek to block reforms in these areas. Regulatory agencies also often lack adequate resources to fully evaluate the complexity of the market and the impact of regulations.

Regulatory assessments conducted by the World Bank in several developing countries, including Burkina Faso and Liberia, confirm these findings. The lack of public access to laws and regulations, as well as their lack of clarity, is the most frequent problem identified. Many countries do not have standard rule-making guidelines that mandate the publication of a law as a requirement for entry into force or sufficient mechanisms for publicizing changes, such as an official gazette or a digital repository. Mapping regulation and making it publicly available can help bridge information gaps in the regulatory framework. Qualitative assessments can be especially useful in identifying policies needed to improve the conditions for services trade.

\section{Expanding services trade in Africa}

Policymakers across Africa are increasingly aware of the importance of services trade in their economies. As a result, the services agenda has never been higher on the list of government priorities.

Many countries, including Egypt, Ghana, Mauritius, and Rwanda, have implemented proactive policies aimed at creating a more enabling business

\section{FIGURE 8.9}

\section{Cross-country correlation between regulatory quality and Services Trade Restrictiveness Index (STRI)}

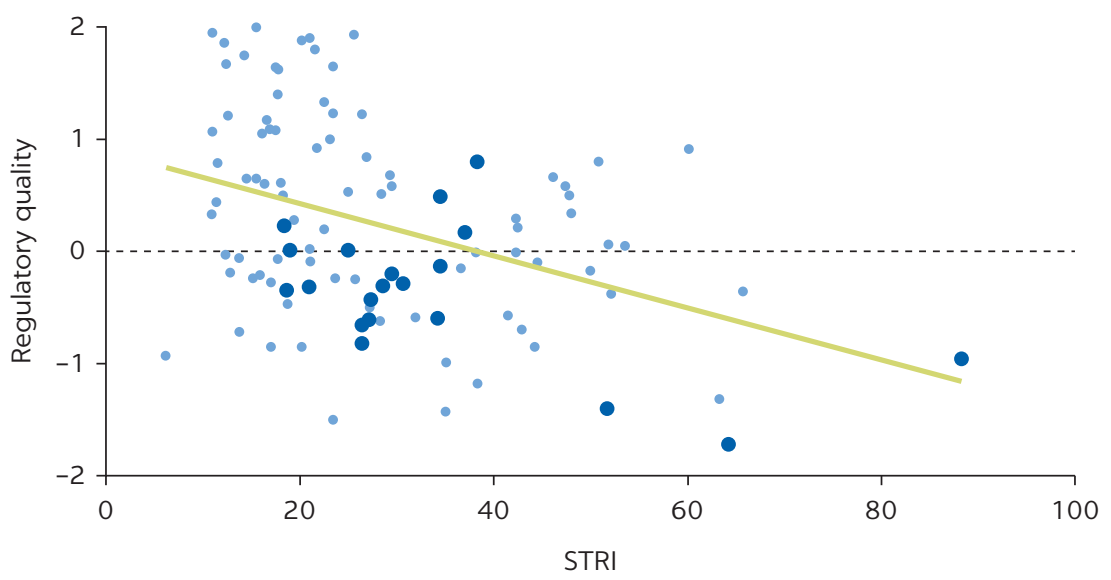

Sources: Borchert, Gootiiz, and Mattoo 2012a, 2012b; World Bank Worldwide Governance Indicators.

Note: Dark blue dots are African countries. Light blue dots are other countries. STRI = Services Trade Restrictiveness Index. 
environment for services providers. These policies usually include measures to streamline the regulatory environment, improve access to infrastructure, and provide the private sector, national or foreign, with incentives that promote services trade. Not all of these policies have been successful. Failure typically occurs because governments lack the capacity to implement them and/or stakeholders that benefit from trade barriers use their influence to keep them in place.

Development of services trade requires the adoption of policies at several levels. In many countries, liberalization of the telecommunications subsector led to the use of mobile phones and a range of services based on telecommunications infrastructure now offered by the private sector. Such liberalization required the development of a policy framework capable of encompassing new and unforeseen developments in the sector. In Kenya, for example, Safaricom's M-Pesa service became a global leader in mobile-based financial services in the span of just a few years. The rapid development of the mobile money platform expanded access to financial services to millions of people in Africa, including small traders and rural residents.

Regulatory policies that shape market integration play a significant role in the development of services trade (Brenton and Isik 2012). Despite progress on regional integration across Africa in recent years, barriers to services trade continue to limit the expansion of services, as services providers are unable to expand their activities to neighboring countries. But global markets are providing new opportunities, as services like M-Pesa (which began in Kenya but has since expanded to Afghanistan, Albania, India, Romania, and South Africa) are proving. Professional services providers in Kenya now export to as many as 40 countries. South Africans provide health services in Canada, New Zealand, and the United Kingdom (Cattaneo and others 2010; Stern 2008).

In many markets where adequate regulatory reforms were not implemented in a coordinated and complementary manner, services reforms did not produce their expected benefits (Mattoo and Payton 2007; Brenton and Isik 2012). In Zambia, the telecommunications market was liberalized, but a de facto monopoly still exists in fixed-line telephony (there is competition in mobile telephony). Important restrictions still affect international and domestic competition in transport. In Zambia's financial sector, liberalization was not complemented with the prudential regulations necessary to maintain the soundness and stability of financial markets (Mattoo and Payton 2007).

Incomplete reforms often occur as a result of the complex political economy of services reforms. Services trade policy reforms often involve a large number of government agencies and private sector representatives. The large number of actors creates enormous coordination challenges and tends to increase the power of groups opposed to reform (Brenton and Hoffman 2016). The World Bank Group's Africa trade team has been working on these issues, providing support through analytical tools, technical assistance, and focused interventions (box 8.2).

\section{CONCLUSION}

Trade in services is a critical component of countries' overall trade strategies. As technological advances have facilitated the growth of services tradability, countries are beginning to capitalize on these new opportunities. Côte d'Ivoire, Kenya, Mauritius, and Senegal have seized this opportunity. 


\section{BOX 8.2}

\section{Effects of restrictiveness on trade in professional services in East Africa}

Firm-level surveys in East Africa show that a large number of formal sector firms use professional services (Dihel and others 2010). The heterogeneity of professional endowments and the earning differentials across the region indicate substantial scope for increasing trade in such services. Yet the market remains widely underdeveloped and fragmented, because of restrictive policies and disjointed regional regulations.

Domestic regulations on entry into and operations of professional services have undermined competition and constrained growth across the region. Kenya, Tanzania, and Uganda impose tight restrictions on entry into engineering and legal services, including strict licensing and educational requirements, as well as restrictions on prices and fees, advertising, and interprofessional cooperation. These types of restrictions vary regionally-Rwanda has a less restrictive environment-but are still stricter than in emerging economies and the countries of the Organisation for Economic Co-operation and Development (OECD).

Explicit trade barriers, regulatory requirements, and policies restricting the movement of natural persons across national borders further constrain trade in professional services. Easier movement of Source: Dihel and others 2010. foreign professionals and firms could help meet demand in underdeveloped sectors across the region. In Kenya, Tanzania, and Uganda, foreign professionals represent less than 10 percent of professionals in accounting and engineering. Almost no foreign legal professionals work in East Africa. Foreign law firms are not permitted in Kenya or Tanzania. Accounting and auditing firms also face very strict prohibitions. In contrast, in Rwanda foreigners account for more than 60 percent of all professionals in these fields.

These examples are but a few of the many regulatory limitations and constraints in the region. They illustrate the need for policy reform, without which the professional services sector is unlikely to develop in a dynamic and competitive manner.

The World Bank Group's Africa trade team has been working to reduce constraints in these countries on the movement of people, the establishment of commercial presence, and the cross-border supply of professional services. Much work remains to be done in implementing the proposed regulatory changes. Regional cooperation will be important in this effort, to overcome the regulatory heterogeneity of East Africa and Sub-Saharan Africa as a whole.

The role of services goes well beyond direct exports. Access to low-cost/ high-quality services helps countries achieve social development objectives and participate in local, regional, and global value chains. As inputs into downstream activities, services also help increase the competitiveness and performance of other economic sectors, especially in agricultural, food processing, and manufacturing activities, such as textile and apparel exports.

More research needs to be conducted to better evaluate the complex roles services exports play in African economies. The services agenda must be better defined and tailored to meet the social and economic development goals of each country. Significant gaps in data must be filled and more analysis must be conducted in order to provide policy makers with the data and analysis they need to design the reforms that best position their countries to increase services trade and boost overall economic competitiveness.

\section{NOTES}

1. For the positive link between trade liberalization of the services sectors and manufacturing productivity, see Arnold, Javorcik, and Mattoo (2007) and Arnold, Mattoo, and Narciso (2008). 
2. The data come from the World Bank's Export of Value Added Database, which covers 25 countries in Africa.

3. Other business services include real estate activities; renting of transport equipment; renting of other machinery and equipment; renting of personal and household goods not elsewhere classified; computer and related activities; research and development; and other business activities.

4. The policy information to build the STRD was collected in 2008-29, from countries' legal and regulatory structures. Borchert, Gootiiz, and Mattoo (2012a) provide an in-depth description of the database.

5. For a discussion of the impact of regulations on professional services in East and Southern Africa and their impact on firms' productivity, see World Bank (2011).

\section{REFERENCES}

Arnold, J., B. S. Javorcik, A. Mattoo. 2007. "Does Services Liberalization Benefit Manufacturing Firms? Evidence from the Czech Republic.” Policy Research Working Paper 4109, World Bank, Washington, DC.

Arnold, J., A. Mattoo, and G. Narciso. 2008. "Services Inputs and Firm Productivity in Sub-Saharan Africa: Evidence from Firm-Level Data.” Journal of African Economies 17 (4): 578-99.

Baldwin, R. 2011. "Trade and Industrialisation after Globalisation's 2nd Unbundling: How Building and Joining a Supply Chain Are Different and Why It Matters.” NBER Working Paper 17716, National Bureau of Economic Research, Cambridge, MA. http://www.nber.org /papers/w17716.

—. 2012. "Global Supply Chains: Why They Emerged, Why They Matter, and Where They Are Going." Centre for Economic Policy Research Discussion Paper 9103, London.

Balistreri, E. J., T. F. Rutherford, and D. G. Tarr. 2009. "Modeling Services Liberalization: The Case of Kenya." Economic Modeling 26 (3): 668-79.

Borchert, I., B. Gootiiz, and A. Mattoo. 2012a. "Policy Barriers to International Trade in Services: Evidence from a New Database.” Policy Research Working Paper 6109, World Bank, Washington, DC.

— 2012b. "Guide to the Services Trade Restrictions Database." Policy Research Working Paper 6108, World Bank, Washington, DC.

Brenton, P., E. Gamberoni, and C. Sear. 2013. Women and Trade in Africa: Realizing the Potential. Washington, DC: World Bank. http://documents.worldbank.org/curated/en/2013 /01/18490089/women-trade-africa-realizing-potential.

Brenton, P., and B. Hoffman, eds. 2016. Political Economy of Regional Integration in Africa. Washington, DC: World Bank.

Brenton, P. and G. Isik, eds. 2012. De-Fragmenting Africa: Deepening Regional Trade Integration in Goods and Services. Washington, DC: World Bank.

Cattaneo, O., M. Engman, S. Sáez, and R. Stern, eds. 2010. International Trade in Services: New Trends and Opportunities for Developing Countries. Washington, DC: World Bank.

Coste, A., and N. Dihel. 2013. "Services Trade and Gender." In Women and Trade in Africa: Realizing the Potential, edited by P. Brenton, E. Gamberoni, and C. Sear. Washington, DC: World Bank. http://documents.worldbank.org/curated/en/2013/01/18490089/women -trade-africa-realizing-potential.

Dihel, N., A. M. Fernandes, A. Mattoo, and N. Strychacz. 2010. "Reform and Regional Integration of Professional Services in East Africa." Economic Premise No. 32, September, World Bank, Washington, DC. http://documents.worldbank.org/curated/en/2010/09/12806166/reform -regional-integration-professionalservices-east-africa.

Feenstra, R. 2010. Offshoring in the Global Economy: Microeconomic Structure and Macroeconomic Implications. Boston, MA: MIT Press.

Francois, J., and B. Hoekman. 2010. "Services Trade and Policy." Journal of Economic Literature 48 (3): 642-92.

Francois, J., and J. Woerz. 2008. "Producer Services, Manufacturing Linkages, and Trade." Journal of Industry, Competition and Trade 8 (3): 199-229. 
Goswami, A., A. Mattoo, and S. Sáez, eds. 2012. Exporting Services: A Developing Country Perspective. Washington, DC: World Bank.

Grossman, G. M., and E. Rossi-Hansberg. 2008. “Task Trade between Similar Countries.” NBER Working Paper 14554, National Bureau of Economic Research, Cambridge, MA. http:// www.nber.org/papers/w14554.

Helpman, E. 2011. Understanding Global Trade. Cambridge, MA: Belknap Press of Harvard University Press.

Hoekman, B., and M. Kostecki. 2009. The Political Economy of the World Trading System. Oxford, UK: Oxford University Press.

Hoekman, B., and A. Mattoo, A. 2008. "Services Trade and Growth.” In Opening Markets for Trade in Services: Countries and Sectors in Bilateral and WTO Negotiations, edited by A. Juan. J. Marchetti, and M. Roy, 21-58. Cambridge, UK: Cambridge University Press.

ILO (International Labour Organization). 2012. Global Employment Trends for Women 2012. Geneva: ILO.

Inklaar, R., M. P. Timmer, and B. Van Ark. 2007. "Mind the Gap! International Comparisons of Productivity in Services and Goods Production." German Economic Review 8 (5): 281-307.

— . 2008. "Market Services Productivity across Europe and the US." Economic Policy 23 (1): 141-94.

Jensen, J., T. Rutherford, and D. Tarr. 2008. "Modeling Services Liberalization: The Case of Tanzania.” Policy Research Working Paper 4801, Washington, DC: World Bank. https:// openknowledge.worldbank.org/handle/10986/6331.

Jones, R. 2000. Globalization and the Theory of Input Trade. Cambridge, MA: MIT Press.

Mattoo, A., and L. Payton. 2007. Services Trade and Development: The Experience of Zambia. Washington, DC: World Bank.

Miroudot, S., J. Sauvage, and B. Shepherd. 2013. "Measuring the Cost of International Trade in Services." World Trade Review 12: 719-35.

Molinuevo, M., and S. Sáez. 2014. Regulatory Assessment Toolkit: A Practical Methodology for Assessing Regulation on Trade and Investment in Services. Washington, DC: World Bank.

Sáez, S., D. Taglioni, E. van der Marel, C. H. Hollweg, and V. Zavacka. 2014. Valuing Services in Trade: A Toolkit for Competitiveness Diagnostics. Washington, DC: World Bank.

Staritz, C., and J. G. Reis, eds. 2013. Global Value Chains, Economic Upgrading, and Gender: Case Studies of the Horticulture, Tourism, and Call Center Industries. Washington, DC: World Bank.

Stern, M. 2008. "Moving Medics: A Case Study of South Africa." A paper prepared for the Overseas Development Institute. Development Network Africa, London.

Triplett, J., and B. Bosworth. 2004. Productivity in the U.S. Services Sector. Washington, DC: Brookings Institution.

van der Marel, E. 2011. "Determinants of Comparative Advantage in Services.” Working Paper, Groupe d'Economie Mondiale, Sciences Po, Paris.

World Bank Export of Value Added Database, Washington, DC, https://datacatalog.worldbank .org/dataset/export-value-added-database.

World Bank Worldwide Governance Indicators (database), Washington, DC, https://datacatalog .worldbank.org/dataset/worldwide-governance-indicators.

World Economic Forum. 2015. The Africa Competitiveness Report 2015. Geneva. http://reports .weforum.org/africa-competitiveness-report-2015/. 


\section{Integration of Services and
Manufacturing in Ethiopia*}

CLAIRE H. HOLLWEG, ESTEBAN ROJAS, AND GONZALO VARELA

Ethiopia's services sector has contributed considerably to economic growth and structural change. Between 2000 and 2016, Ethiopia's output more than tripled in real terms. Services contributed more than half of GDP growth between 1996 and 2016, taking over agriculture as the sector contributing most to GDP.

Ethiopia's manufacturing sector has been less impressive. Industry's share of GDP peaked at 14 percent in 2003, declining declined to 10 percent in 2012. Over the same period, services' share increased from 40 percent to 48 percent, shifting the economic structure away from agriculture and toward services. As a result, structural change in Ethiopia did not follow the traditional path through manufacturing. Instead, it moved from agriculture directly to services (box 9.1).

Ethiopia's small manufacturing sector, which has declined relative to GDP since 2003, implies that the manufacturing-led growth model of East Asia may not apply in today's world for Ethiopia's development model. In East Asia, booming manufacturing exports helped shift economic activity and workers away from low-productivity agriculture into higher-productivity manufacturing and sustain high rates of economic growth for decades. In Ethiopia both manufacturing exports and the manufacturing sector itself remain small, accounting for just 4 percent of GDP (World Bank 2014a). Concerns also exist about the competitiveness of the sector (World Bank 2014b), which has the lowest ratio of merchandise exports to GDP among populous countries in the world.

This chapter looks at the joint role of services and manufacturing in Ethiopia, providing information on the often hidden relevance of the services sector in an economy. It is organized as follows. The first section looks at the contribution of services to GDP, growth, employment, productivity, and poverty in Ethiopia relative to peer countries. 1 The second section explores the importance of services

* This chapter was prepared as a background note to the 2015 World Bank publication Ethiopia's Great Run: The Growth Acceleration and How to Pace It (World Bank 2015a). The authors thank Michael Geiger, Nicole Klingen, Lars Moller, Nataliya Mylenko, and Konstantin Wacker for value comments and Girum Abate and Federico Ganz for research assistance. The editors are grateful to Lars Moller, Carolyn Turk and Nicole Klingen for authorization to publish. 


\section{BOX 9.1}

\section{Premature deindustrialization}

One of the oldest ideas in development economics is that the route toward development involves structural change in which workers leave the agricultural sector for the higher-productivity manufacturing sector (industrialization) and later move into services (deindustrialization). Today, low- and middle-income countries are entering the deindustrialization stage much earlier than their rich predecessors, and services are playing the role that manufacturing did in the past.

In India, for example, the size of the manufacturing sector declined relatively early on, after employment in the sector reached just 13 percent of the workforce. Manufacturing employment peaked at 16 percent in Brazil and 20 percent in Mexico, according to the World Bank's World Development Indicators. In contrast, among early industrializers, employment in manufacturing reached at least 30 percent before the sector started declining. This stylized fact has become known as premature deindustrialization. Its implications for countries' development are the subject of debate.

Ghani and O'Connell (2014) argue that services have the potential to become the new growth escalator for developing countries. They show that countries farthest from the frontier of productivity exhibit the fastest productivity growth in services, converging independently of their structural characteristics (a pattern known in development economics as unconditional convergence). Manufacturing is also a growth escalator, but the convergence in services is faster than in manufacturing. Labor productivity remains low in the agriculture sector of low-income countries, unlike in services or manufacturing.

Rodrik (2014) argues that premature deindustrialization could imply a movement of labor to lowerproductivity sectors, diminishing developing countries' growth potential. He contends that services are different from manufacturing in two important ways, which make the sector unlikely to play the role of a growth escalator. First, with the rise of technology, many segments of services are themselves tradable and important in global commerce. These high-productivity, highwage, and high-skill-intensive sectors require highly trained workers, which are unlikely to be workers exiting agriculture. As manufacturing worldwide has become more capital and skill intensive, it has diminished its potential to absorb abundant labor from rural areas. As a result, the bulk of excess labor in low-income countries is absorbed in nontradable services operating at low levels of productivity.

Second, because of the nontradability of these sectors, partial productivity gains in these activities are self-limiting, as they cannot expand without inducing a negative terms of trade shock. Put differently, as demand in these sectors is constrained to within national borders, productivity improvements can result only in price reductions. Exporting manufactured goods provides an opportunity to avoid that outcome, as exporters potentially face almost infinite demand for their products.

exports for Ethiopia. The third section looks at the inputs services provide for Ethiopia's manufacturing production and exports. The fourth section assesses how the performance of services affects the productivity of manufacturing firms. The last section provides some concluding remarks.

\section{CONTRIBUTION OF SERVICES TO CHANGES IN GDP, EMPLOYMENT, AND POVERTY REDUCTION}

\section{Contribution to GDP and growth}

Growth of the services sector, in particular distribution and trade and other services, accounted for more than half of Ethiopia's GDP growth between 2000 and 2016 (figure 9.1). Services' contribution to GDP growth was 65 percent in 2000 
FIGURE 9.1

Annual contributions of agriculture, industry, and services to GDP growth in Ethiopia, 2000-16

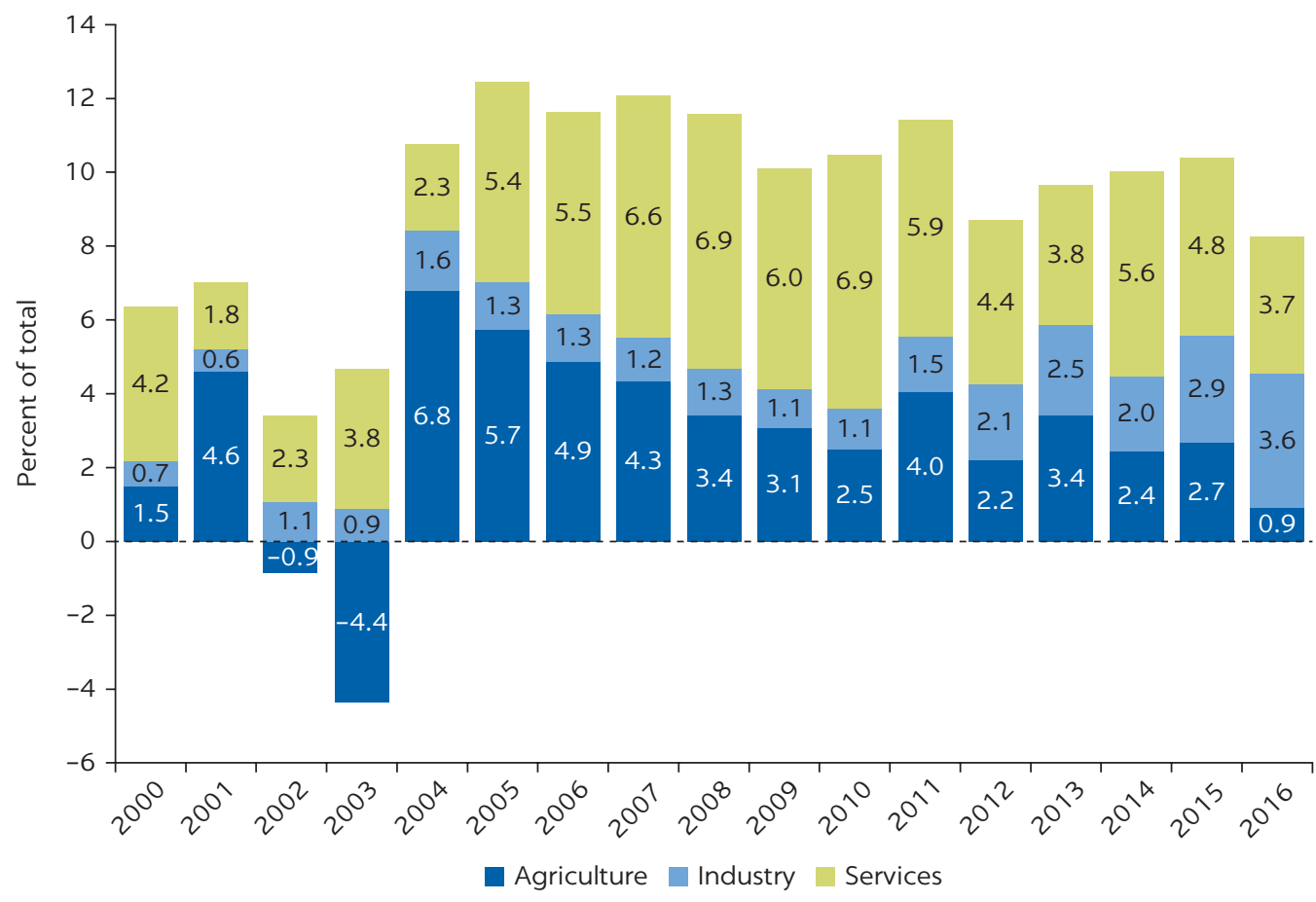

Source: World Bank World Development Indicators. Note: GDP = gross domestic product.

and 45 percent in 2016. Agriculture decreased its contribution to GDP growth from 23 percent to less than 11 percent over the same period. Services accounted for 53 percent of GDP growth between 2000 and 2016 period, growing at an average a rate of 11 percent a year. Industry accounted for 23 percent and agriculture for 24 percent of total growth.

These growth trends have resulted in a structural shift away from agriculture toward industry and services. Agriculture lost almost 15 percent in terms of value-added share between 1990 and 2016 (from 52 percent to 37 percent), industry 12 percent (from 10 percent to 21 percent), and services gained 3 percent (from 38 percent to 41 percent) (figure 9.2).

Ethiopia's economic dependency on services is similar to countries at similar stages of development. In China the share of services in value added grew 19 percentage points (from 32 percent to 52 percent) between 1990 and 2016. In Uganda it grew 23 percentage points (from 32 percent to 56 percent). In Zambia it grew 31 percentage points (from 28 percent in 1990 to 59 percent in 2015).

\section{Contribution to employment and poverty reduction}

Although the services sector is the main contributor to Ethiopia's GDP, accounting for 41 percent of total value added, its contribution to employment is low (17 percent). In high-income countries, services employ 74 percent of the workforce on average. Services account for 40 percent of employment in uppermiddle-income countries and 33 percent in lower-middle-income countries, according to World Bank World Development Indicators. 
FIGURE 9.2

Value-added of agriculture, industry, and services in selected countries, 1990, 2000, 2010, and 2016

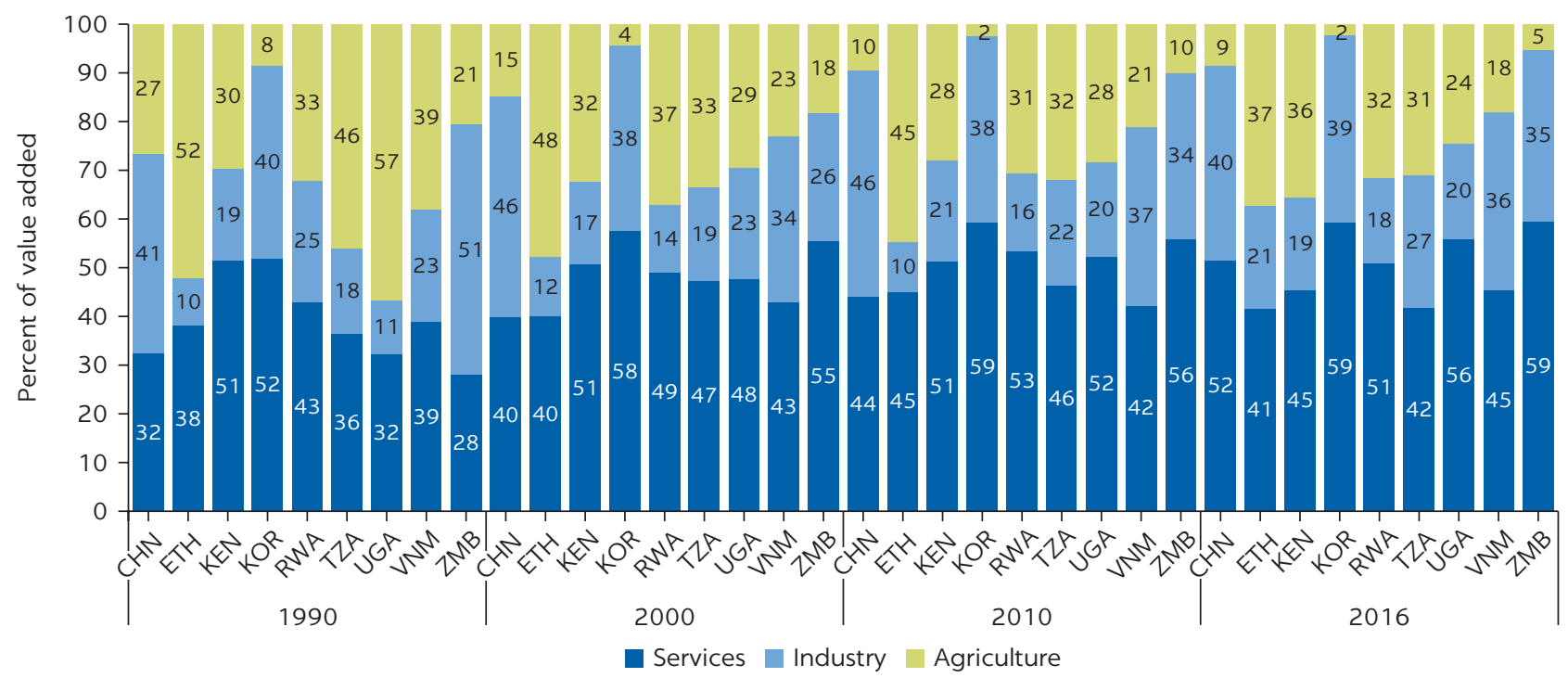

Source: World Bank World Development Indicators.

Note: $\mathrm{CHN}=$ China; $\mathrm{ETH}=$ Ethiopia; KEN = Kenya; $\mathrm{KOR}=$ Korea, Rep.; RWA = Rwanda; TZA = Tanzania; UGA = Uganda; VNM = Vietnam; ZMB = Zambia. Data for Zambia in 2016 are for 2015.

Ethiopia's share of employment in services is lower than in all comparators as well as China and the Republic of Korea. It lies significantly below the average for countries at a similar stage of development and below countries with a similar share of services in GDP.

Decomposing labor growth by sector reveals that between 1990 and 2011 the largest contribution came from the agriculture sector, with a 51 percent contribution, followed by services and industry with 23 percent and 17 percent growth contributions respectively.

Although it is still low, employment in the services sector has been growing. Average annual growth between 1991 and 2011 was 6.6 percent, more than twice the 3.1 percent growth rate for total employment. In 1990 the services sector employed 1.8 million of the 21.3 million people formally employed in Ethiopia (8.5 percent). This figure rose to 6.8 million out of 40.9 million (16.6 percent) in 2011.

The growth of trade, restaurants, and hotels explains almost all of the rapid growth of employment in the services sector. The number of people in these subsectors rose by a factor of 5.7 (8.6 percent annual average growth) between 1990 and 2011. By 2011 they accounted for 11 percent of total employment (figure 9.3).

\section{Increase in labor productivity in services}

Historically, labor productivity in the services sector in Ethiopia has been higher than in the rest of the economy, particularly the agriculture sector. 2 In 2011 the value added per worker was 2.8 times greater in the services sector than in the economy as a whole and almost 5 times greater than in the agriculture sector. Ethiopia's ratio of services labor productivity to total labor productivity is higher than all countries shown in figure 9.4 except Zambia..$^{\underline{3}}$ 


\section{FIGURE 9.3}

\section{Changes in employment in the services sector in Ethiopia, by subsector, 1990-2011}

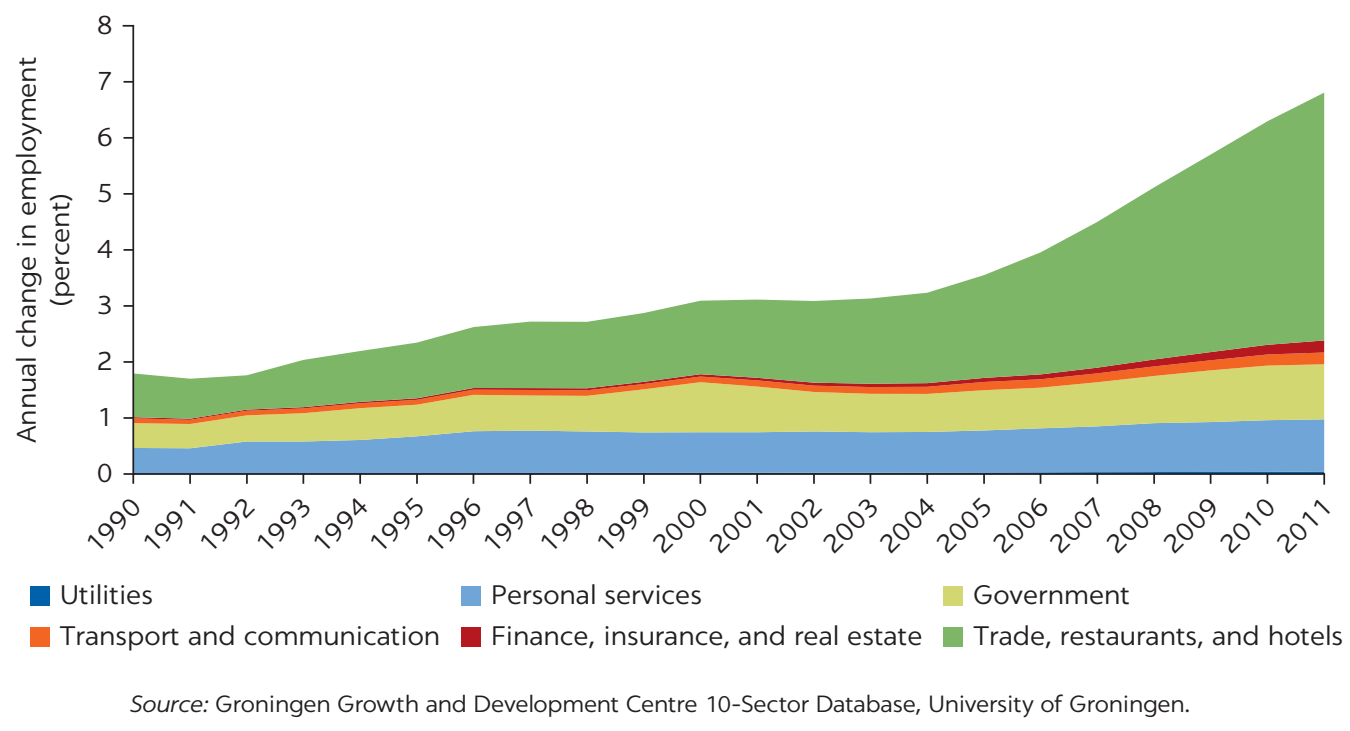

FIGURE 9.4

Ratio of labor productivity in services to average labor productivity in selected countries, 2011

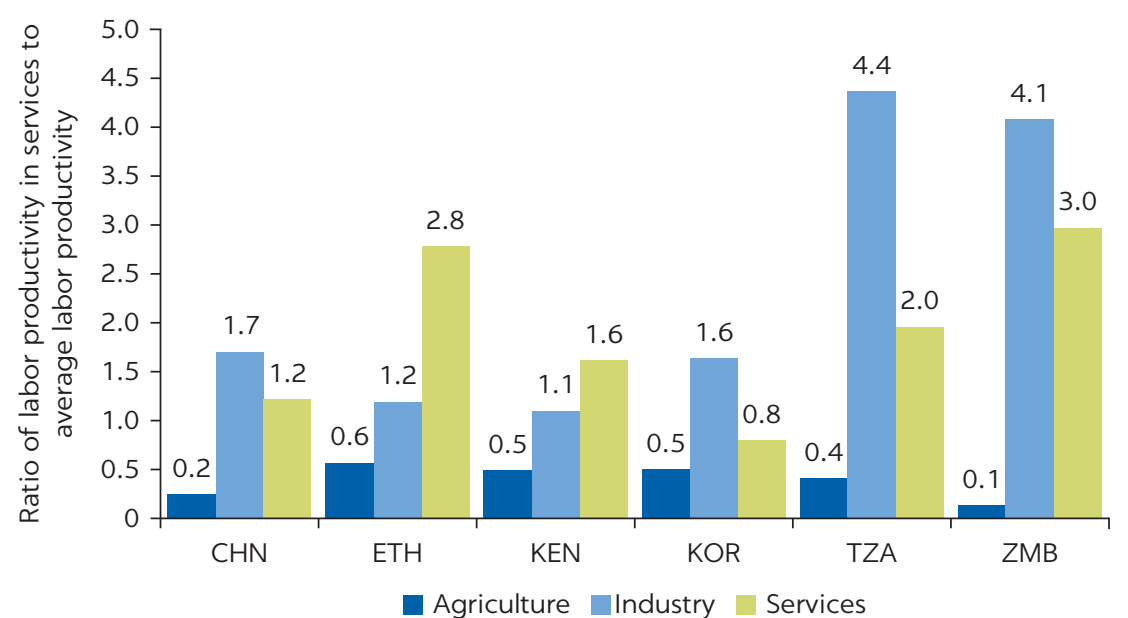

Source: Groningen Growth and Development Centre 10-Sector Database, University of Groningen.

Note: $\mathrm{CHN}=$ China; $\mathrm{ETH}=$ Ethiopia; $\mathrm{KEN}=$ Kenya; $\mathrm{KOR}=$ Korea, Rep.; TZA = Tanzania; $\mathrm{ZMB}=$ Zambia.

The labor productivity of Ethiopia's services sector increased between 1990 and 2011. The number of workers employed within the sector grew at an average annual rate of 6.6 percent; value added per worker grew at an even higher rate (8.5 percent), indicating 1.9 percent annual growth of labor productivity. ${ }^{4}$ Starting from much lower levels, labor productivity in agriculture grew at a similar annual rate (1.7 percent) over this period; labor productivity in the industry sector fell 3.1 percent a year, as employment rose 11 percent a year and value added by 7.5 percent a year. Services were therefore the main source of labor productivity growth between 1990 and 2011 (figures 9.5 and 9.6). 
FIGURE 9.5

Labor productivity in Ethiopia, by sector, 1990-2011

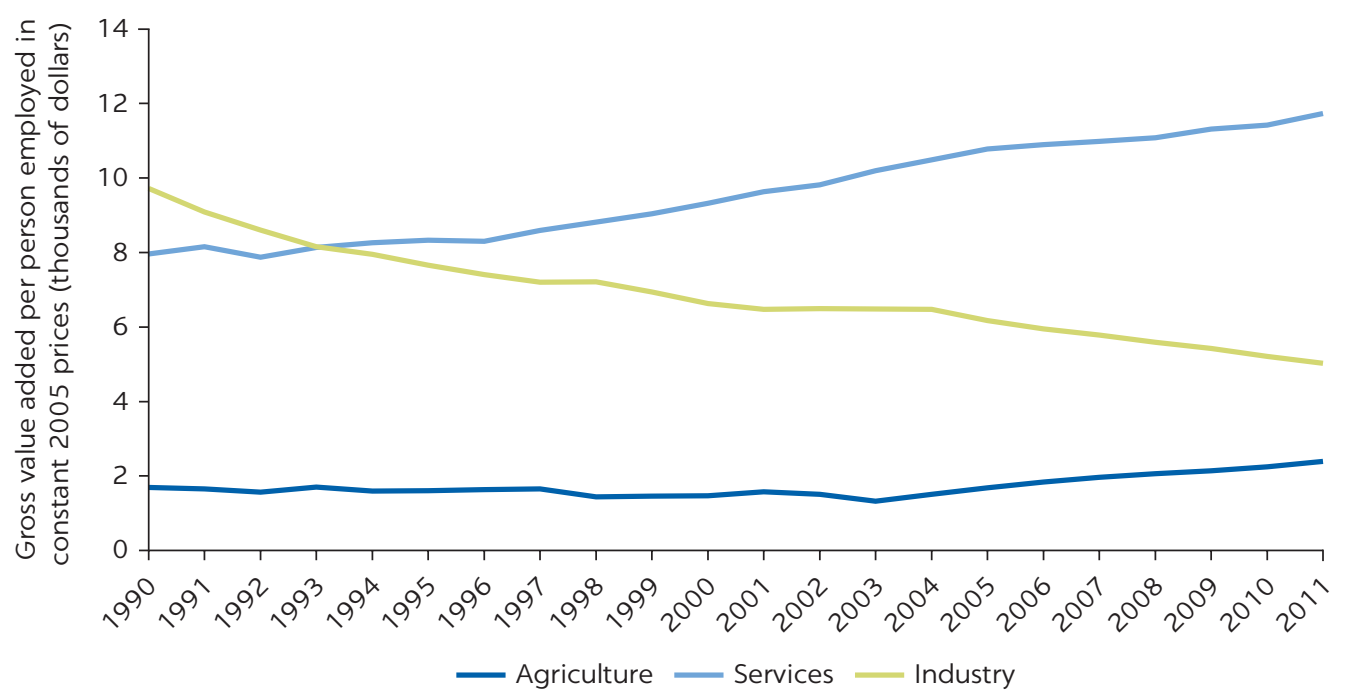

Source: Groningen Growth and Development Centre 10-Sector Database, University of Groningen.

FIGURE 9.6

Average annual growth in employment, value added, and labor productivity in Ethiopia, 1990-2011

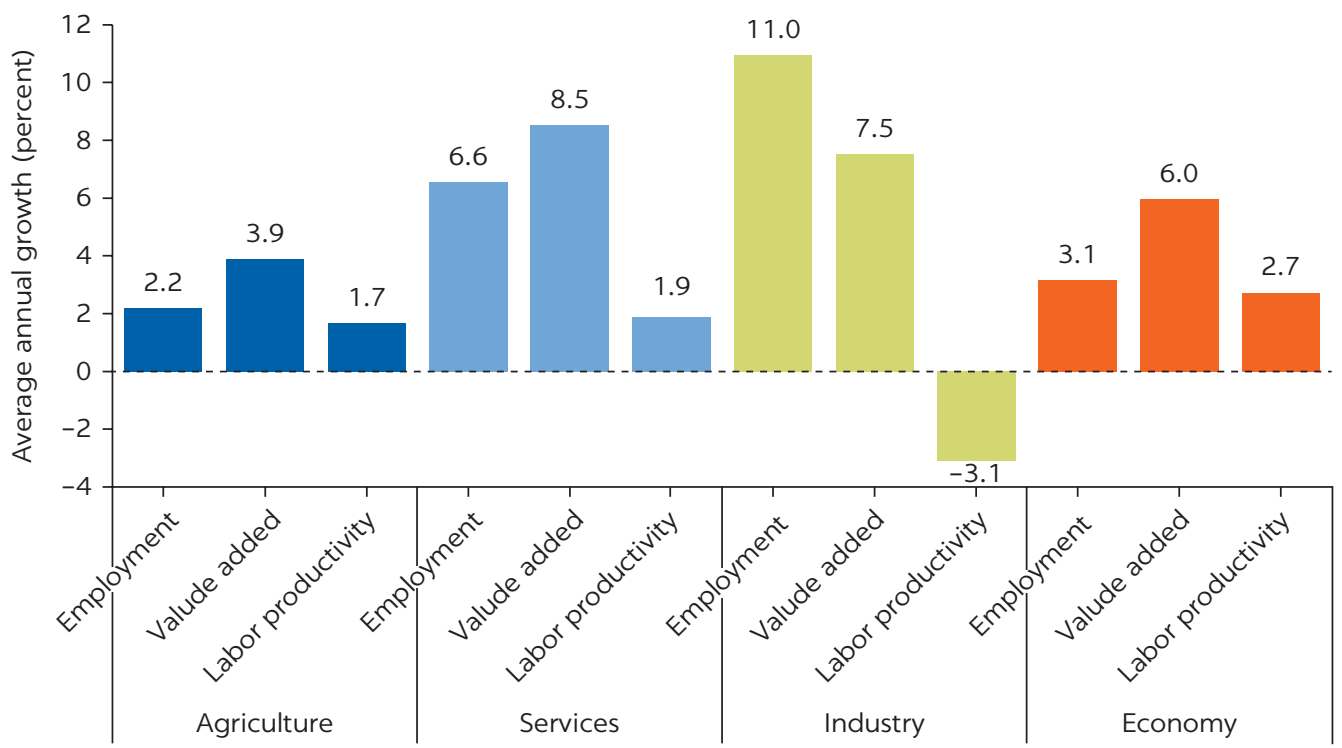

Source: Groningen Growth and Development Centre 10-Sector Database, University of Groningen.

Could Ethiopia be a case of jobless growth? Is it possible that services create much more value added than employment? If this is the case, it could rise concerns about the longer-run sustainability of a services-led growth strategy, as Rodrik (2014) notes. There is no support for the jobless growth hypothesis in Ethiopia's services sector. Although labor productivity grew substantially between 1990 and 2011, employment growth was far greater than the average for the economy (and much faster than population growth). 
Despite its effect on job growth, services' contribution to poverty reduction in Ethiopia has been small. A World Bank poverty assessment finds that the growth elasticity of poverty reduction (the percentage decline in poverty for each percentage increase in growth) of 0.15 percent is lower than the global average. ${ }^{5}$ After 2000 , growth in agriculture was particularly inclusive, contributing significantly to poverty reduction; manufacturing growth played a significant role in reducing urban poverty in Ethiopia. In contrast, services did not contribute to poverty reduction nationally, despite strong growth in value added. This finding reflects the fact that few poor households are employed in the services sector in Ethiopia. The shift to technical and professional occupations increased consumption at all consumption levels, but it contributed mainly to increasing consumption among the richest Ethiopians (World Bank 2015). $\underline{\text { }}$

\section{SERVICES EXPORTS}

\section{Services-led export growth}

Ethiopia's expanding domestic services sector has translated into an expanding services export sector. Export growth in commercial services accelerated in the years before and after the global crisis of 2008-09. Commercial services (defined as total services excluding government services) are generally used as a measure of changes in the private services sector. In Ethiopia, however, many commercial services, such as Ethiopian Airlines, are owned by the government (or other public body). They are nevertheless included as commercial services.

Exports of services in Ethiopia grew seven-fold between 2000 and 2014, surpassed only by Uganda and Rwanda. Annual growth fell from 31 percent during 2002-04 to 4.4 percent during 2012-14.

Goods exports, which outperformed services exports until 2014, slowed between 2014 and 2016. Despite Ethiopia's strong services export growth, the share of services in total exports (goods and services) fell between 2003 and 2014, thanks to stronger goods export growth, driven by the rising prices of Ethiopia's commodity exports. Those prices have since plateaued, as have Ethiopia's goods exports. The fact that services outperformed other sectors of the economy in terms of contribution to GDP suggests that nontradable services may be behind this result.

Services exports continue to be important for Ethiopia's trade, contributing to a declining trade deficit. Ethiopia's share of services in total exports (50 percent) is higher than any of the countries shown in figure 9.7. Like the other countries in the figure, Ethiopia saw its trade balance fall between 2007 and 2012. At 1.97 percent of GDP in 2012, it is similar to Uganda (1.86 percent) and Vietnam (1.87 percent). In contrast, Tanzania (0.96 percent) and Kenya (6 percent) had trade surpluses.

\section{Concentration of services exports on trade and transport activities}

Ethiopia's services exports are concentrated heavily in traditional services activities; its exports of modern services exports are lower than most of its comparators. In addition to being important inputs into production, modern 
FIGURE 9.7

Share of services in total exports in selected countries, 2003 and 2015

a. 2003

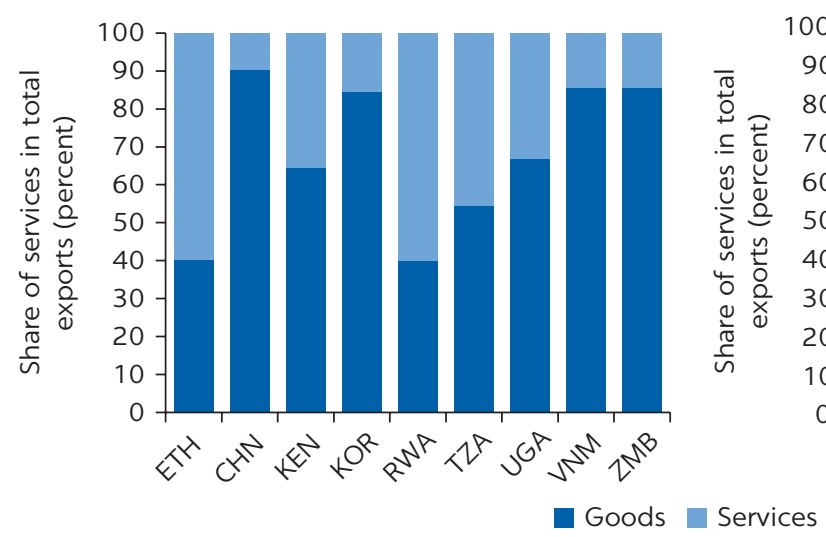

b. 2015

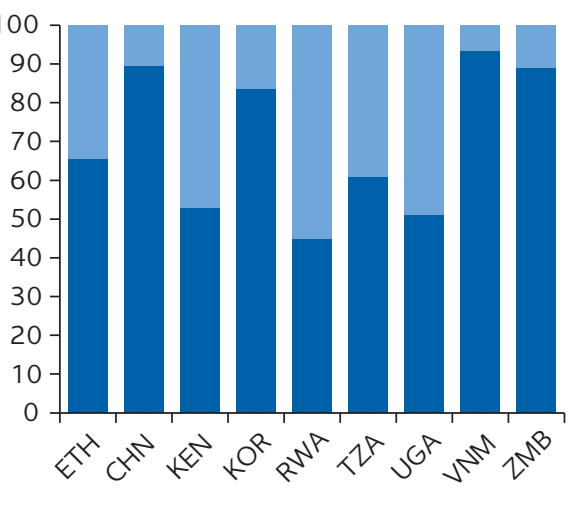

Source: UNCTADstat.

Note: In panel a, data for Kenya are for 2005. In panel b, data for Ethiopia are for 2014 and data for Kenya are for 2013. $\mathrm{CHN}=$ China; $\mathrm{ETH}=$ Ethiopia; KEN = Kenya; KOR = Korea, Rep.; RWA = Rwanda; TZA = Tanzania; UGA = Uganda; VNM = Vietnam; ZMB = Zambia.

services exhibit higher productivity and generate higher-skilled and better-paid jobs. However, many modern services subsectors have relatively low employment intensity and require higher educational levels.

Ethiopia's exports of traditional services reached 6 percent of GDP in 2010-12, significantly overperforming other comparator countries (except Tanzania and Kenya) and other countries at similar level of development. Ethiopia significantly underperformed in terms of modern services exports, which accounted for less than 2 percent of GDP (figure 9.8).

Ethiopia's services have been expanding more rapidly into traditional than modern services exports, largely as a result of Ethiopian Airlines. Transport and travel drove expansion of Ethiopia's services exports; together the two sectors accounted for 90 percent of total services exports in 2012, up from 75 percent in 2002 (figure 9.9). Ethiopian Airlines is the largest export earner (three times as important as coffee), accounting for 60 percent of Ethiopia's services sector (World Bank 2014a).

The services export structure of Ethiopia is very similar to that of Zambia and Kenya, with large shares of transport and travel. It contrasts with that of Korea, a substantially more developed economy, where, although transport is one of the largest subsectors, modern services, such as insurance, play an important role.

Exports of some modern services subsectors, including financial and other business services, have been growing more slowly and unevenly than traditional services sectors. Other business services includes merchanting and other trade-related services; operational leasing services; and miscellaneous business, professional, and technical services (legal, advertising, consulting, accounting, research and development, and so forth). China and the Republic of Korea, as well as Tanzania and Uganda, have been successful at exporting other business services.

Services trade matters for growth. The empirical literature confirms the positive relationship between trade in services and productivity, which exerts a 
FIGURE 9.8

Relationship between traditional and modern services exports and per capita GDP, 2010-12

a. Traditional Services

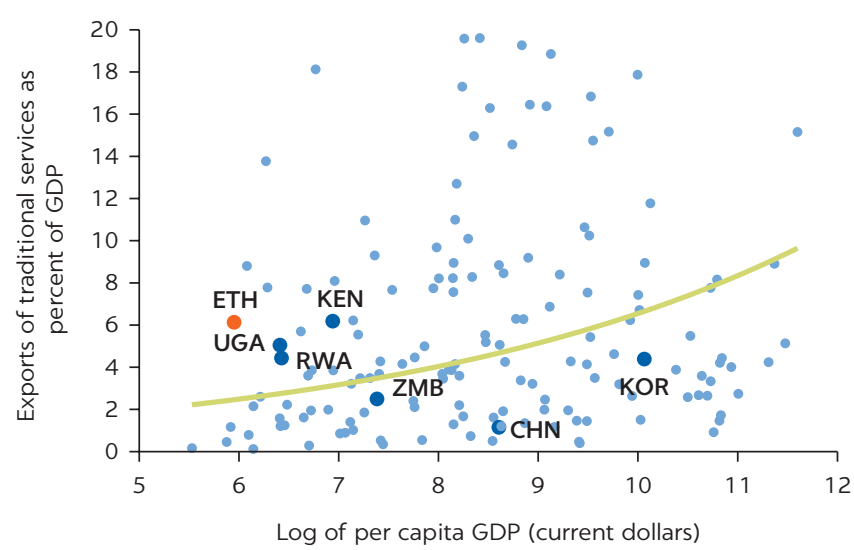

b. Modern Services

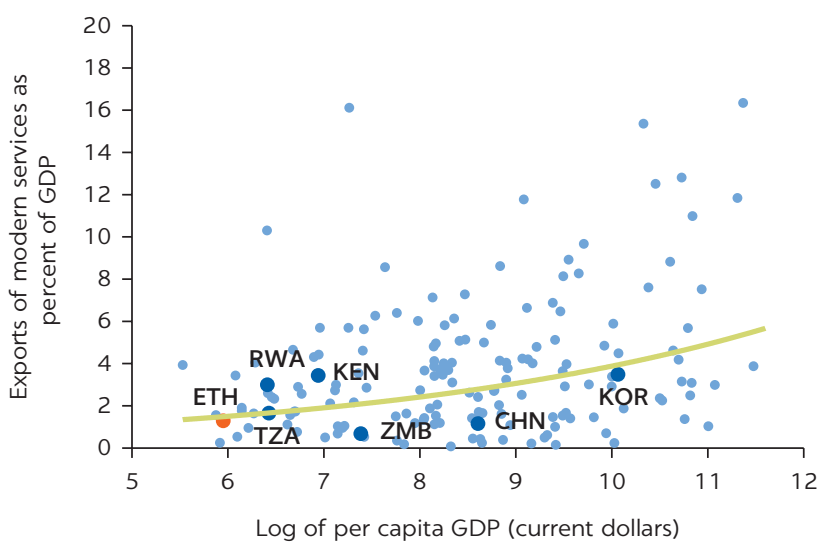

Source: World Bank World Development Indicators.

Note: $\mathrm{GDP}=$ gross domestic product. Each dot in the figure represents a country-year observation: $\mathrm{CHN}=\mathrm{China}$; $\mathrm{ETH}=\mathrm{Ethiopia;} \mathrm{KEN}=\mathrm{Kenya}$; KOR = Korea, Rep.; RWA = Rwanda; TZA = Tanzania; UGA = Uganda; ZMB = Zambia.

\section{FIGURE 9.9}

Composition of services exports by selected countries, 2013

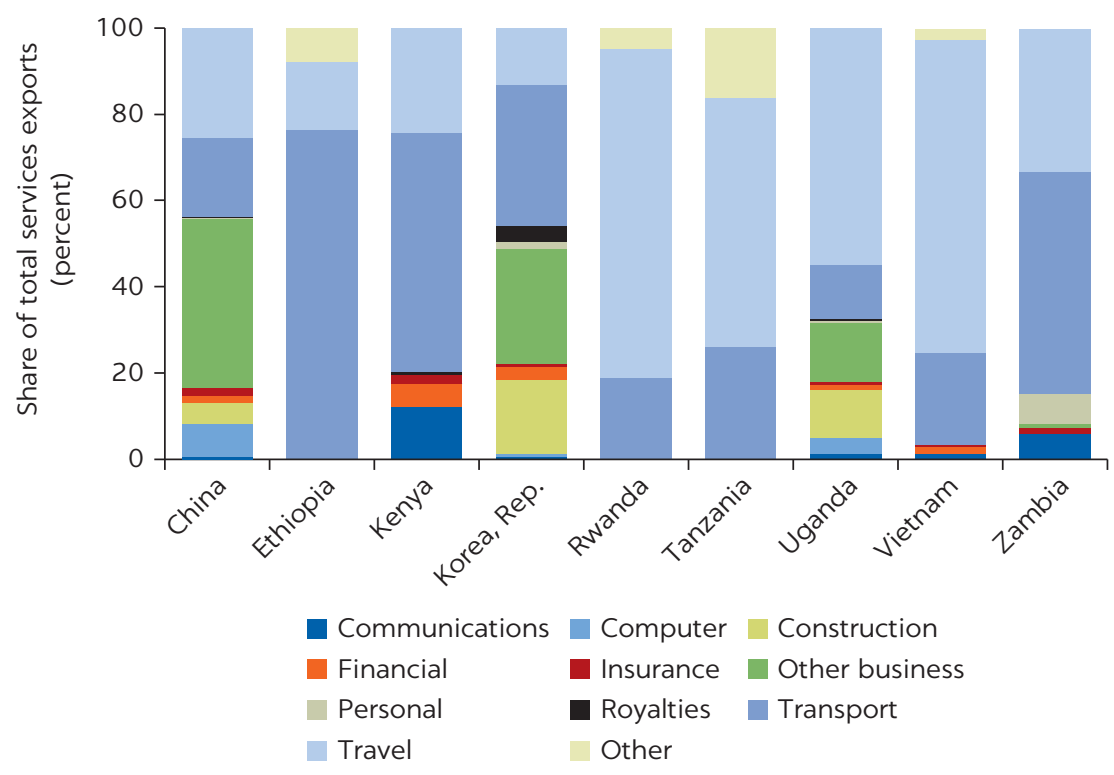

Source: UNCTADstat.

Note: Figures for Kenya and Zambia are for 2012. Figure for Ethiopia, Rwanda, and Tanzania are estimated.

large impact on growth over time (Inklaar, Timmer, and van Ark 2007, 2008; Triplett and Bosworth 2004). Trade liberalization of services subsectors is also positively linked with manufacturing productivity (Arnold, Javorcik, and Mattoo 2011; Arnold, Mattoo, and Narciso 2008; Fernandes and Paunov 2012). Services trade plays a key role in increasing the productivity of services subsectors, because services imports can serve as a transmission channel for new technologies. 


\section{LINKAGES BETWEEN SERVICES AND MANUFACTURING}

A dynamic services sector is a necessary condition for manufacturing to thrive. Lack of good-quality services as inputs can impede the emergence of a competitive manufacturing sector.

The role services can play depends in large part on the structure of the linkages between services and manufacturing. Manufacturing cannot be competitive without accessing good-quality and varied inputs from the services subsectors. Manufacturing firms in Ethiopia lack adequate access to necessary services inputs, such as finance, electricity, and water (World Bank 2014a).

The implications for growth of this structural transformation from agriculture to services will depend largely on the type of services that emerge in Ethiopia and their ability to create good-quality jobs and provide productive inputs to other sectors. Levy Yeyati and Pienknagura (2014) show that the increased importance of services in some Latin American countries did not result in a decline in skill-intensive, nontradable activities. Instead, it resulted in increased employment in more knowledge-intensive, modern sectors, such as professional services, including software development and high-end tourism. They point to the important role played by education and training in ensuring that the process of deindustrialization does not lead to a shift into lowskill-intensive employment growth.

\section{Services as both inputs into and obstacles to production}

Good-quality, efficient, and productive inputs are important to firm and sector competitiveness. Because of value chain linkages between sectors of an economy, the competitiveness of a sector that is used as an input into production is important for the competitiveness of other downstream sectors. Forward linkages from the services sector include a manufacturing firm hiring engineers to design its products, a farmer using water and electricity to raise crops, and an agricultural producer hiring a trucking service to transport its crops to a market or port for export. Agriculture may also contribute to manufacturing value added, and manufacturing may supply inputs to services or agriculture. If domestic providers supply these inputs, they show up as domestically produced value added inputs in the output of manufacturing, agriculture, or services (value-added linkages).

Concerns exist regarding the competitiveness of Ethiopia's manufacturing sector. - Between 1990 and 2016, manufacturing contributed 0.7 percentage points to annual GDP growth, compared with 3.0 percentage points by agriculture and 4.9 percentage points by services (industry as a whole contributed 2.1 percentage points). The competitiveness of Ethiopia's manufacturing is linked to that of services.

Poor availability of services inputs-including finance, electricity, and water-is perceived as an obstacle to manufacturing sector performance in Ethiopia, according to data from the 2011 World Bank Enterprise Survey. Lack of adequate electricity is considered a major obstacle by 42 percent of respondents (similar for exporters and nonexporters) (table 9.1). Electricity consumption in Ethiopia is lower than other countries at a similar level of development, and firms use a larger proportion of electricity from generators (Rosenow and others 2011), increasing costs and lowering competitiveness. Water supply is considered more of an obstacle by nonexporters (70 percent) 
TABLE 9.1 Major obstacles perceived by manufacturing firms in Ethiopia (percent of respondents, except when otherwise indicated)

\begin{tabular}{lccc}
\hline & ALL FIRMS & EXPORTERS & NON-EXPORTERS \\
\hline Electricity & $42 \%$ & $45 \%$ & $41 \%$ \\
\hline Telecommunications & $10 \%$ & $13 \%$ & $12 \%$ \\
\hline Transport & $14 \%$ & $24 \%$ & $21 \%$ \\
\hline Access to finance & $27 \%$ & $89 \%$ & $28 \%$ \\
\hline Percent of firms that experienced a power outage in fiscal 2010 & $86 \%$ & $15 \%$ & $13 \%$ \\
\hline Percent of annual sales lost in fiscal 2010 because of electrical outages & $13 \%$ & $24 \%$ & $70 \%$ \\
\hline $\begin{array}{l}\text { Percent of firms that experienced insufficient water supply for production } \\
\text { in fiscal } 2010\end{array}$ & $23 \%$ & & \\
\hline
\end{tabular}

Source: World Bank Enterprise Surveys.

Note: Sample includes 219 manufacturing firms, 38 of which export, directly or indirectly. An obstacle is considered to exist when a firm declares the provision of the input to be either a major or very serious constraint.

\section{FIGURE 9.10}

Inputs into and from productive sectors in Ethiopia, 2011
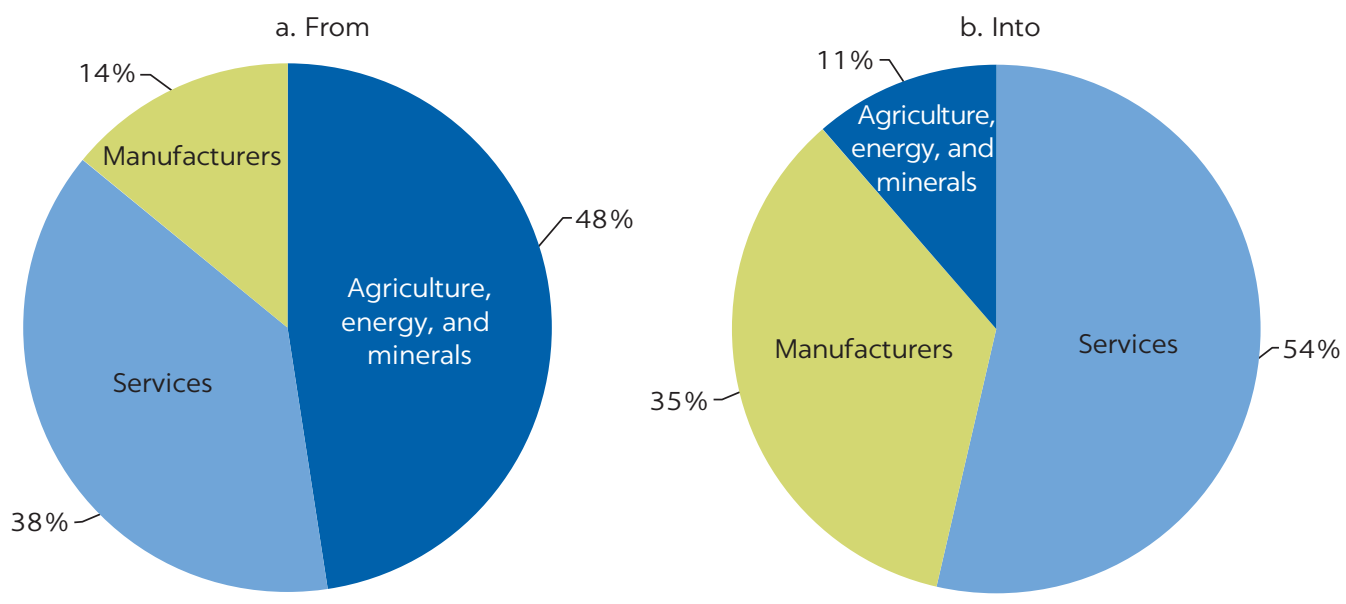

Source: Based on input-output data from the Ministry of Finance and Economic Cooperation 2011.

than exporters (24 percent). Twenty-seven percent of manufacturing firms cite lack of access to finance as a major obstacle; only 10 percent of respondents cite telecommunications and 14 percent cite transport as major obstacles.

Services are an important supplier of inputs into Ethiopia's domestic economy. They account for 38 percent of the economy's value-added linkages (excluding a sector's value added that is consumed directly rather than being used as input) (figure 9.10). In countries like China, Korea, and Vietnam, which have more diversified and established manufacturing sectors, which contribute substantially to GDP, manufacturing plays a much larger role in providing inputs to the economy.

More than a third of all the inputs measured in terms of their value added go toward manufacturing activities. In 2011 only 11 percent of all value-added inputs (from services, manufacturing, or other agricultural sectors) were provided to Ethiopia's agricultural, energy, and minerals sector; more than half were provided to the services sector. Manufacturing accounted for 35 percent of domestic input demand. This figure is below the average of Ethiopia's comparators, among which about half of total inputs go to manufacturing. 
This analysis sheds light on the disconnect between the fact that services are important inputs in the Ethiopian economy but manufacturing firms perceive services as a constraint. It first assesses the value-added linkages between services and manufacturing in Ethiopia's domestic production (and exports) at the aggregate and sectoral levels. It benchmarks these linkages for Ethiopia against peer countries and other countries at a similar level of development, to understand if this could be a possible explanation for underperformance. It also explores the structure of manufacturing to help explain the strong interconnectedness of services and manufacturing in Ethiopia. It asks whether imports of services are important for manufacturing (if they are not available domestically), and whether regulatory constraints may be preventing important linkages from forming. Given the important role that services play for a firm's or sector's competitiveness, it argues that services need to work differently for the country to succeed in manufacturing.

\section{Services inputs into manufacturing}

Services inputs into manufacturing production are an important contributor to Ethiopia's GDP. All services subsectors combined contributed about 40 percent to domestic production in 2011. Intermediate inputs into the manufacturing sector accounted for 6 percent of domestic production (when looking at the destination of services' forward linkages). These figures are similar to comparator countries except Zambia, where the share of services value added destined for manufacturing is much larger. Inputs into manufacturing represented a very small share ( 0.7 percent of total exported value added) of the value added of services sector exports (14 percent of total exported value added).

Manufacturing activities rely more heavily on inputs from services in Ethiopia than in other countries. Manufacturing contributed 13 percent to domestic production in 2011. Intermediate inputs from the services sector to manufacturing accounted for 3 percent of domestic production (when looking at the source of manufacturing's backward linkages). Inputs from primary production represented 5 percent of domestic production, a larger share than in all other countries studied except Zambia.

The services and manufacturing sectors in Ethiopia are more tightly linked than they are in most countries. The value-added share of services inputs in total manufacturing inputs (excluding manufacturing's direct value added) was 65 percent for domestic production and 63 percent for exports. Across manufacturing activities, services provided important inputs for domestic production, accounting for 17 percent of inputs in textiles and 95 percent for machinery. These figures are significantly higher than in other countries, including countries at similar income levels. Of the countries shown in figure 9.11 only Zambia has a larger share of services inputs in manufacturing. Leather, lumber, and processed foods have stronger linkages with domestic primary production (rather than imported raw materials).

\section{Differences between the structure of linkages in Ethiopia and peer countries}

Direct consumption of services is more important in Ethiopia than it is in most of the other countries shown in figure 9.12. The direct contribution of services represents 72 percent of services' total contribution to GDP in Ethiopia, 
FIGURE 9.11

\section{Composition of Ethiopia's domestic and exported manufacturing value added, by subsector, 2011}

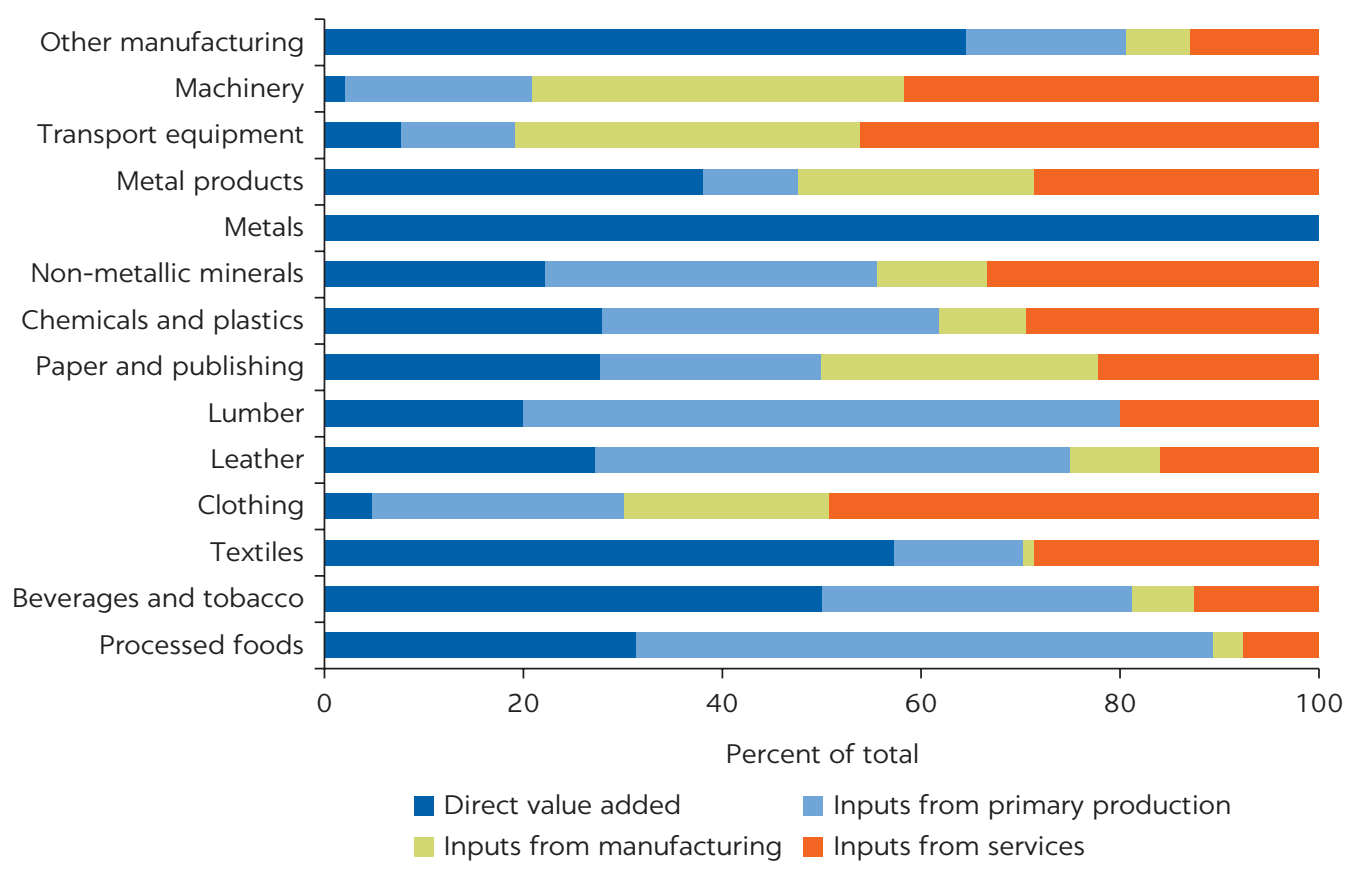

Source: Based on input-output data from the Ministry of Finance and Economic Cooperation 2011.

59 percent in China, 68 percent in Korea, and 78 percent in Vietnam. Services inputs into manufacturing exported value added are much more important in China, Korea, and Vietnam than in Ethiopia. The direct contribution of services represents 74 percent of services' total contribution to exports in Ethiopia, 17 percent in China, 36 percent in Korea, and 39 percent in Vietnam.

Most manufacturing value added in Ethiopia relies on inputs from other sectors rather than direct contributions from manufacturing (less than a third in both cases). Inputs from primary production make the largest contribution to both domestic and exported value added of manufacturing (looking at backward linkages), with services inputs accounting for less than a fourth (figure 9.13).

\section{Low value added of manufacturing in Ethiopia}

Ethiopia's manufacturing subsectors are not interconnected, that is, the share of value added created in one manufacturing subsector, and ending up being used as an input in another manufacturing subsector is low. In contrast, in China, the Republic of Korea, and Kenya, manufacturing appears to provide important inputs into other manufacturing subsectors. Inputs from other manufacturing sectors represent less than 10 percent of manufacturing's total contribution to production in Ethiopia, compared with 22 percent in China, 18 percent in Kenya, 13 percent in the Republic of Korea, and 9 percent in Vietnam. Rwanda, Tanzania, Uganda, and Zimbabwe are similar to Ethiopia, in the range of 2-3 percent.

Ethiopia's manufacturing sector adds little value directly. It is concentrated in low-value-added activities with little domestic value addition. Manufacturing's direct value added that is exported is even lower. The direct contribution of 
FIGURE 9.12

\section{Composition of services value added (forward linkages) in selected countries, 2011}

a. Composition of GDP

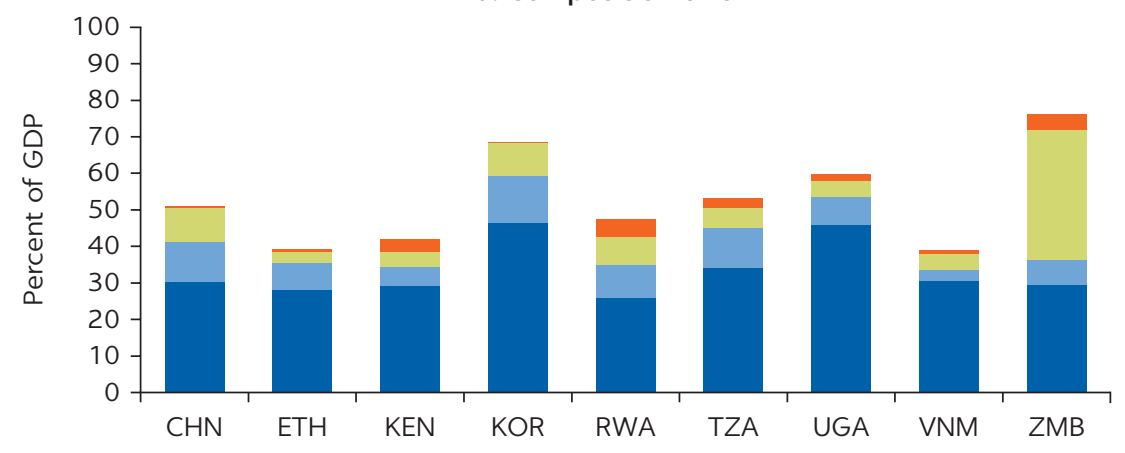

b. Composition of exports

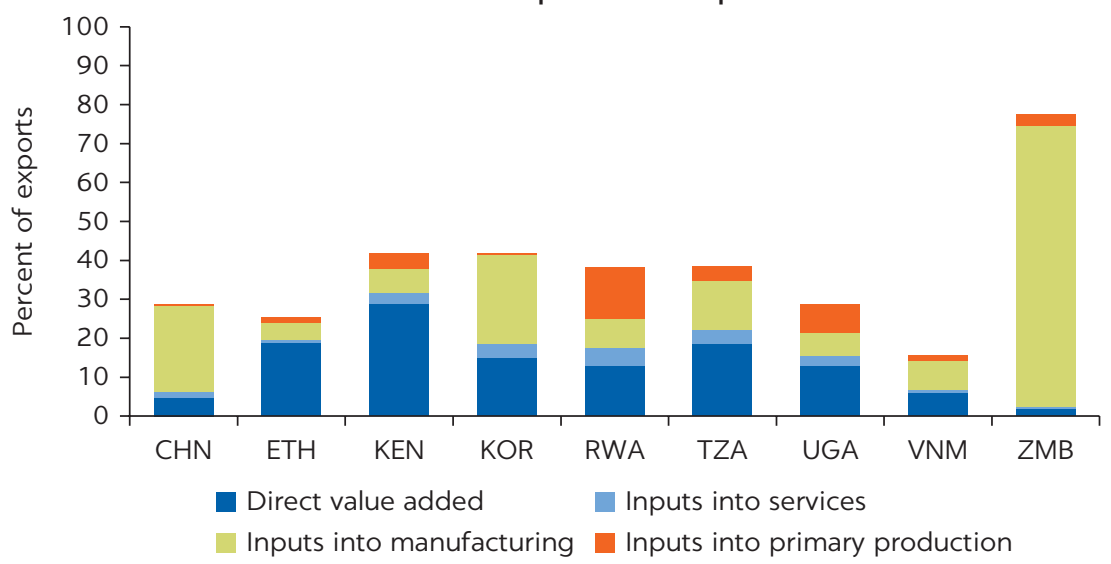

Sources: Based on input-output data from the Ministry of Finance and Economic Cooperation 2011 and World Bank Export of Value Added Database.

Note: $\mathrm{GDP}=$ gross domestic product. $\mathrm{CHN}=$ China; $\mathrm{ETH}=$ Ethiopia; $\mathrm{KEN}=$ Kenya; $\mathrm{KOR}=$ Korea, Rep.; RWA = Rwanda; TZA = Tanzania; UGA = Uganda; VNM = Vietnam; $\mathrm{ZMB}=$ Zambia.

manufacturing represents about 30 percent of manufacturing's total contribution to exports in Ethiopia, compared with 61 percent in China, 56 percent in Korea, and 52 percent in Vietnam.

Some manufacturing subsectors have been more successful at generating domestic value addition, either directly or through their input demand. Looking at levels as opposed to shares and considering backward linkages, processed foods, clothing, leather, machinery, and other manufacturing are important generators of domestic value added in Ethiopia (figure 9.14). For beverages and tobacco, paper and publishing, and textiles, more than 40 percent of value added (for either domestic production or exports) is generated within the sector. For the other manufacturing subsectors, most value addition is generated through backward linkages, in particular to services.

The structure of manufacturing helps explain the strong interconnectedness of services and manufacturing in Ethiopia. In contrast to other countries, services in Ethiopia are more important for manufacturing value added than the manufacturing sector itself. The large contribution of services to manufacturing value added is driven largely by low manufacturing value added (either directly 
FIGURE 9.13

\section{Composition of manufacturing value added (backward linkages) in selected countries, 2011}

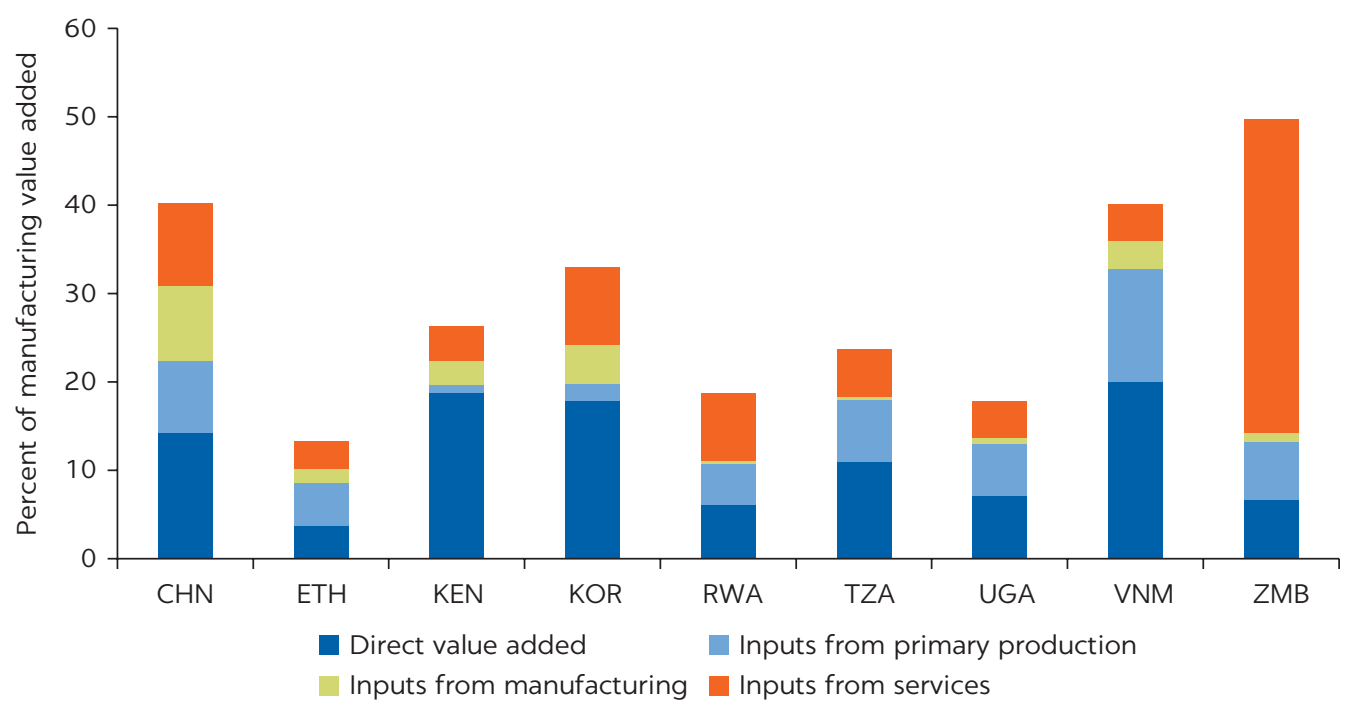

Sources: Based on input-output data from the Ministry of Finance and Economic Cooperation 2011 and World Bank Export of Value Added Database.

Note: $\mathrm{CHN}=$ China; $\mathrm{ETH}=$ Ethiopia; $\mathrm{KEN}=$ Kenya; $\mathrm{KOR}=$ Korea, Rep.; RWA = Rwanda; TZA = Tanzania; $\mathrm{UGA}=$ Uganda; VNM = Vietnam; ZMB = Zambia.

FIGURE 9.14

Composition of domestic value added in Ethiopia by manufacturing subsector, 2011

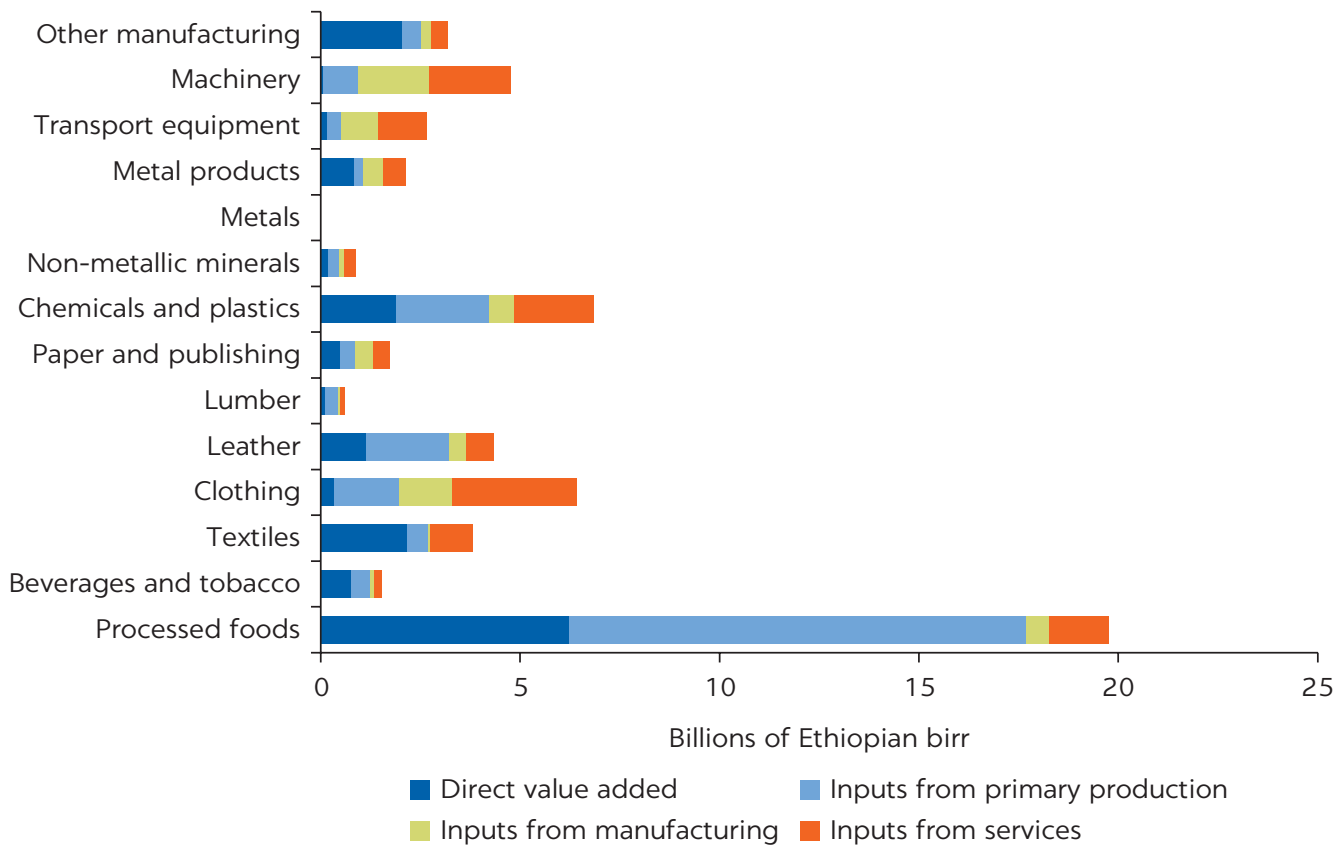


or from other manufacturing inputs). In machinery, for example, direct domestic value addition is close to zero. Production of clothing is largely in low-value added assembly activities, such as cut-make-trim, where logistics services such as transport and warehousing are relatively important. ${ }^{9}$

The structure of the services sector in Ethiopia may also be a constraining factor. Services can be important value-adding inputs. In textiles and apparel, for example, much of the value creation in the supply chain takes place in the initial stages, in research and design, and in marketing and retailing. Lack of access to such services may be preventing manufacturing in Ethiopia from moving into higher-value-added activities.

\section{Linkages of traditional rather than modern services}

The most important services inputs for manufacturing production in 2011 were distribution and trade, business and ICT, and water provision (figure 9.15), which together accounted for more than 75 percent of intermediate services inputs for manufacturing.

As countries move up the development ladder, distribution services becomes less important as an input for manufacturing. The strong linkages between distribution services and manufacturing in Ethiopia (20 percent of all services inputs) are as expected when benchmarked against other countries of similar level of development (figure 9.16). Business and ICT become increasingly important input as countries develop.

The linkages between financial services and manufacturing are particularly weak. Access to finance is a serious constraint in Ethiopia (World Bank 2014a). In 2011 financial services represented only about 3 percent of total services

\section{FIGURE 9.15}

\section{Composition of services inputs in manufacturing in selected countries, 2011}

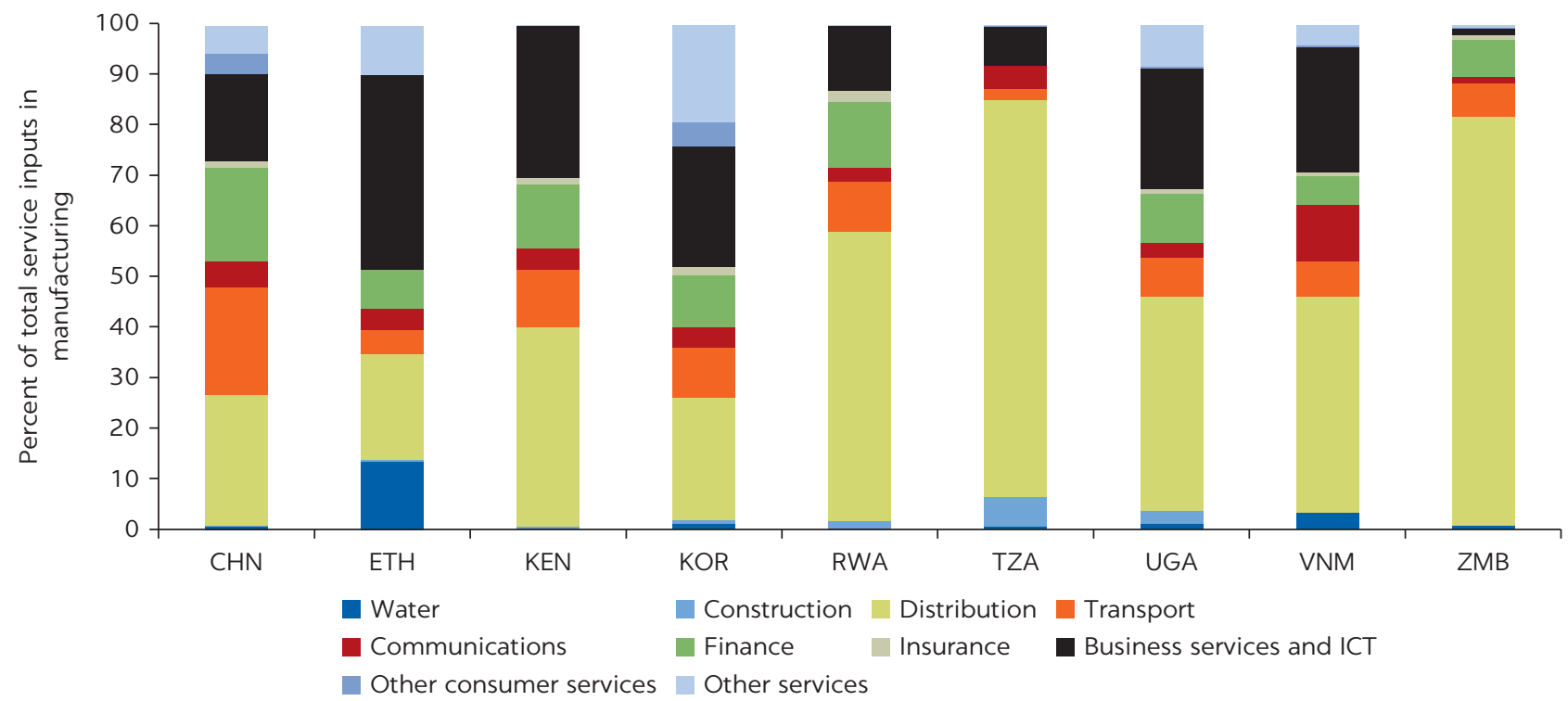

Sources: Based on input-output data from the Ministry of Finance and Economic Cooperation 2011 and World Bank Export of Value Added Database.

Note: $\mathrm{CHN}=$ China; $\mathrm{ETH}=$ Ethiopia; ICT = information and communications technology; $\mathrm{KEN}=\mathrm{Kenya}$; KOR = Korea, Rep.; RWA = Rwanda; $\mathrm{TZA}=$ Tanzania; UGA = Uganda; VNM = Vietnam; ZMB = Zambia. 
FIGURE 9.16

Relationship between services inputs in manufacturing and level of development, by subsector, 2011
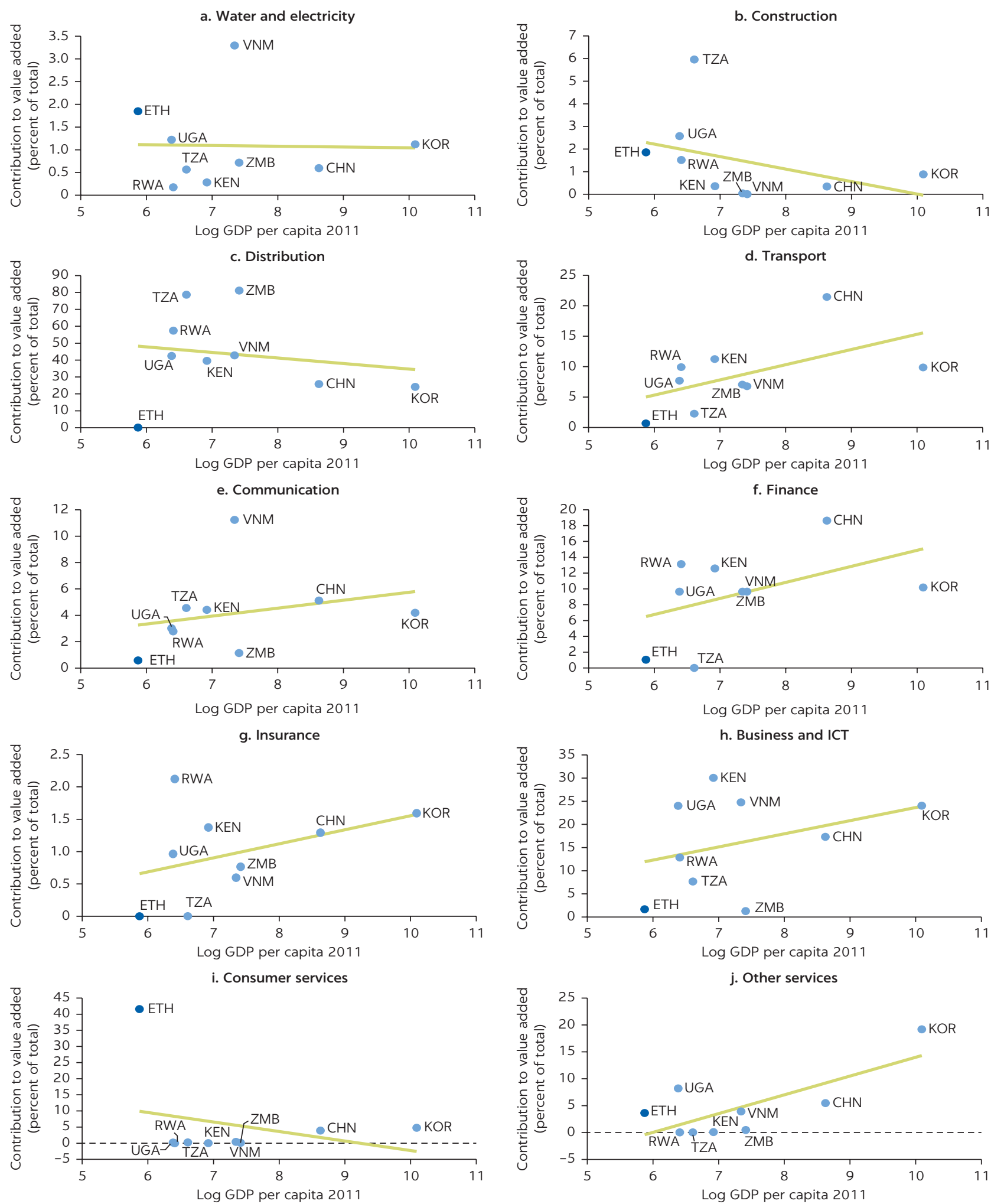

Sources: Based on input-output data from the Ministry of Finance and Economic Cooperation 2011, World Bank Export of Value Added Database, and World Bank World Development Indicators.

Note: GDP = gross domestic product. Each dot in the figure represents a country-year observation: $\mathrm{CHN}=\mathrm{China}$; $\mathrm{ETH}=\mathrm{Ethiopia}$; $\mathrm{KEN}=\mathrm{Kenya}$; $\mathrm{KOR}=$ Korea, Rep.; RWA = Rwanda; TZA = Tanzania; UGA = Uganda; VNM = Vietnam; ZMB = Zambia. 
inputs in manufacturing. A relatively small share of private investment is funded by banks, and the share of private sector lending has been declining (Rosenow and others 2011). A study on finance of small and medium-size enterprises provides evidence of a "missing middle" phenomenon, in which small enterprises are more credit constrained than either micro or medium/large enterprises. Firms that are credit constrained exhibit poorer performance and productivity (World Bank 2015b). Smaller firms' limited access to credit inhibits their ability to grow (and potentially export) and the scope of their activities.

The intensity with which Ethiopia's manufacturing sector uses financial and utility services is average. The share of financial services inputs in total services inputs for manufacturing production (6 percent) is on par with countries at similar levels of development. Insufficient access to finance is a severe constraint that affects firm productivity in Ethiopia, however. The share of investment that is financed through firms' own funds and the ratio of collateral to the total loan are very high in Ethiopia, indicating limited access to finance. The government of Ethiopia operates a rationing scheme in which credit is allocated to the greatest perceived need. The negative real interest rate leads to excess demand and rationing, cutting off many firms from credit.

The linkages between communications and transport with manufacturing are at expected levels. The structure of services inputs in manufacturing is similar for domestic production and exports. Water is an important input for paper and publishing, textiles, and beverages and tobacco. Business services and ICT are more important inputs for beverages and tobacco and paper and publishing. Distribution services are the most important services input for nearly all Ethiopia's manufacturing activities (except paper and publishing and beverages and tobacco). They are the most important input of any kind for 11 of 14 manufacturing subsectors; in 9 of them, distribution services contribute more value added than the manufacturing sector contributes itself.

Little value added takes place in Ethiopia's manufacturing sector, which may not require substantial modern services. But even in subsectors in which more domestic value added is generated, such as food processing, there seems to be insufficient use of particular services, such as finance, electricity, and water. Insufficient services may be inhibiting manufacturing from moving into higher value-added activities.

\section{Paucity of services inputs in manufacturing imports}

Across manufacturing subsectors, Ethiopia imports substantially fewer inputs than comparator countries except Rwanda. ${ }^{10}$ Services imports are highly concentrated in transport, suggesting that the weak value-added linkages with modern services activities are general, not limited to domestically supplied services subsectors. Communications, business, and ICT services are important imports for some manufacturing sectors, including chemicals and plastics, paper and publishing, textiles, beverages and tobacco, and processed foods.

\section{Effect of high restrictiveness on manufacturing sectors' use of modern services inputs}

Services trade plays a key role in increasing the productivity of services subsectors. It also serves as a transmission channel for new technologies. 
Productivity growth in services has been a driver of GDP growth in countries in the Organisation for Economic Co-operation and Development (OECD) and developing countries. In Indonesia, for example, services sector reforms implemented in the aftermath of the East Asian crisis of 1997/98 explain almost 10 percent of the productivity growth of manufacturers between 1997 and 2009 (Duggan, Rahardja, and Varela 2013). A more open services sector improved the quality of services input, increased varieties, and reduced prices. Similar studies document economywide productivity gains as a consequence of services sector reforms in Chile, the Czech Republic, India, and Indonesia (Arnold, Javorcik, and Mattoo 2011; Fernandes and Paunov 2012).

Restrictiveness toward foreign services providers may be one barrier, as it reduces the scope for competition in the sector, which in turn reduces the scope for the introduction of cheaper, newer, or better quality services inputs. Openness in the services sector is part and parcel of a comprehensive growth-enhancing trade policy. The benefits of liberalizing the services and goods markets can be mutually reinforcing; the full potential of each is not realized without adequate openness in the other.

Ethiopia maintains a restrictive regulatory environment toward foreign direct investment (FDI) in services. Many potential investments-foreign as well as domestic-fail to materialize because of entry barriers preventing investors from engaging (World Bank 2014b).

Low levels of services imports are consistent with Ethiopia's high level of regulatory restrictiveness toward foreign services providers across all modes of supply. High regulatory restrictiveness creates a reliance on domestic services. Openness toward foreign investment in services is an important determinant of services sector performance (Arnold, Javorcik, and Mattoo 2011; Fernandes and Paunov 2012).

Ethiopia is substantially more restrictive than its comparators in Mode 1 (cross-border supply), Mode 2 (consumption abroad), and Mode 3 (commercial presence/FDI); it is only slightly more restrictive than comparators in Mode 4 (movement of natural persons), traditionally the most protected mode of supply (figure 9.17). It is highly restrictive in all five services subsectors (financial, professional, retail, telecommunications, and transport services). It is completely closed to foreign investment in retail and telecommunications and almost entirely closed in transportation, professional, and financial services.

When particular services, such as financial services, are not available domestically, restricting access to imported services constrains the performance of manufacturing. The regulatory environment toward foreign services providers also affects the quality of domestically available services inputs. Regulatory restrictiveness reduces the scope for competition, which reduces the scope for the introduction of cheaper or better-quality inputs.

High regulatory restrictiveness is associated with a smaller direct value-added contribution of services to production. Considering the use of services as inputs by other sectors, including manufacturing, the relationship with the regulatory environment becomes significantly negative: Countries with burdensome regulations in services use fewer services as inputs to manufacturing sectors. The intensity of services linkages with manufacturing in Ethiopia is at expected levels given the country's level of restrictiveness. .11 
FIGURE 9.17

Services Trade Restrictiveness Index (STRI) in selected countries, by subsector and mode, 2008

a. By mode
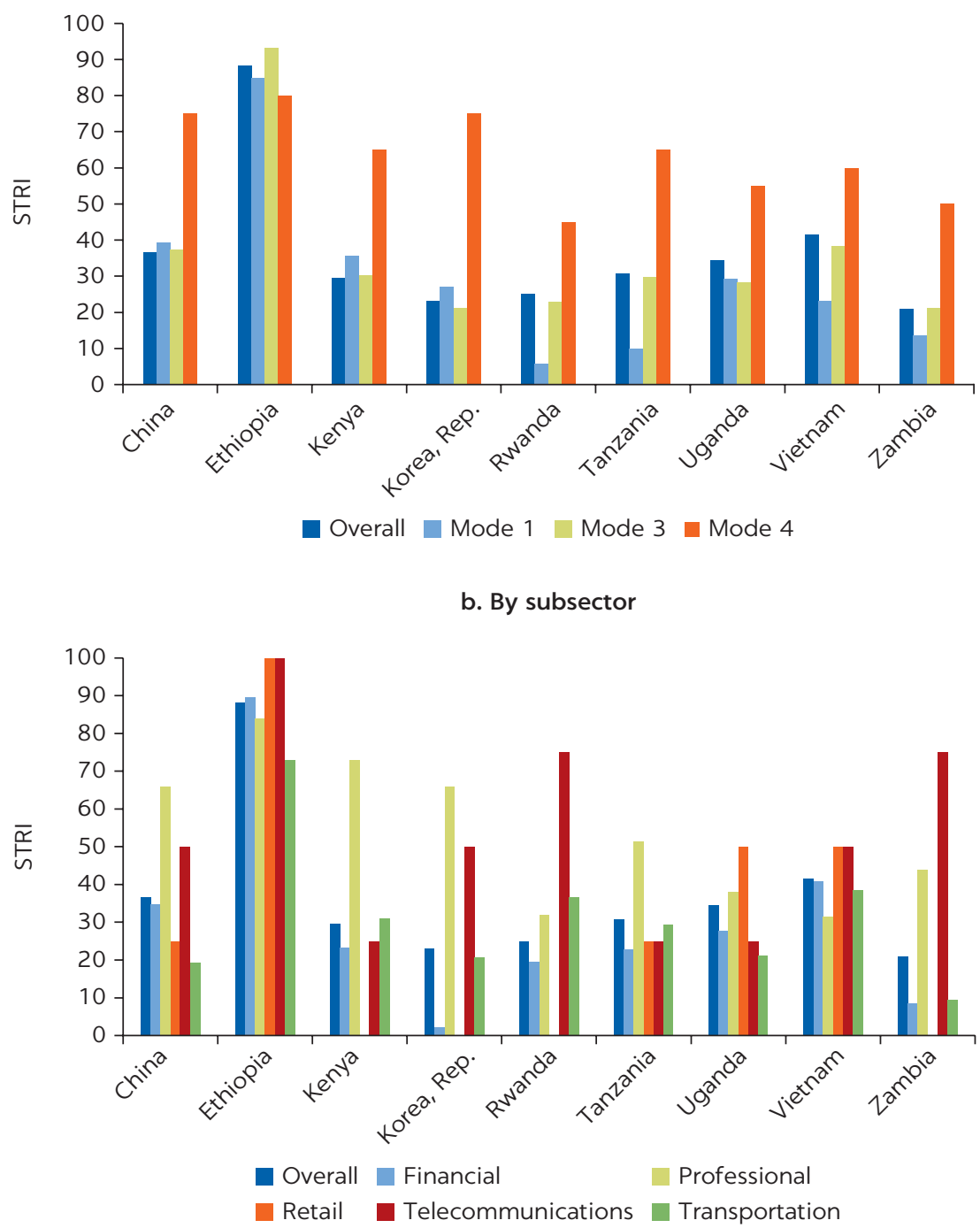

Source: World Bank Services Trade Restrictions Database.

Note: Mode 1 = cross-border trade; Mode 2 = consumption abroad; Mode 3 = commercial presence; Mode $4=$ presence of natural persons. STRI = Services Trade Restrictiveness Index.

\section{SERVICES INPUTS AND THE PRODUCTIVITY OF MANUFACTURING}

The inefficient supply of services inputs acts as a tax on production of goods that use them. An efficient and well-regulated financial sector is necessary to efficiently transform savings to investments, ensuring that resources are deployed where they yield the highest returns. Improved efficiency in telecommunications generates economywide benefits, because these services are crucial for the dissemination of knowledge. High-quality transport services contribute to the efficient distribution of goods within a country and beyond. Professional accounting services, for example, are key to reducing transactions costs. The lack of such services represents one of the most significant impediments to economic growth in Africa (Collier and Gunning 1999). 
How important is it for firm's productivity upgrading to have access to good-quality and reliable services? This question is addressed by examining cross-country and Africa-specific firm-level data to determine whether a systematic relationship exists between the perception of services inputs quality and firm's productivity.

The World Bank's Enterprise Surveys provide information on the quality of provision of key services inputs to firms in downstream sectors. These indicators are subjective (based on firms' perceptions) and objective (based on selected indicators on services provision-related incidents). Both types of information are available for the financial, telecommunications, and electricity subsectors; only subjective information is available for transport services. The surveys cover 127 countries, including 42 in Sub-Saharan Africa.

Access to finance and to electricity appear to be the most important obstacles Ethiopian firms face. ${ }^{12}$ Slightly more than 30 percent of firms identified access to finance as at least a major obstacle to their operations (major or very severe). The cross-country average was slightly more than 20 percent; the figures in other countries included less than 5 percent in China, 15 percent in Vietnam, and 20 percent in Uganda.

More than 20 percent of firms in Ethiopia identified access to electricity as at least a major obstacle, making it the second-most important obstacle in the country. This share is on par with cross-country averages (24 percent) but substantially below the average for countries in Sub-Saharan Africa (34 percent). It is still above the figures in Rwanda (15 percent), Vietnam (less than 10 percent), and China (less than 2 percent).

Ethiopian firms consider telecommunications and transport services less serious obstacles. Still, 11 percent of surveyed firms identified telecommunication services as a major or very severe obstacle, and 10 percent identified transport services as major obstacles. Relative to comparator countries, perceptions in Ethiopia appear more positive about transport services provisions and less positive about telecom services.

How does the provision of services inputs affect the productivity of downstream firms? Services are important inputs for downstream manufacturing activities. Ethiopia's policies toward all modes of services trade tend to be highly restrictive, impeding improvements in performance. This subsection exploits cross-country data on industrial dynamics (including Ethiopia) to gauge the cost of poor services provision in terms of productivity (see appendix A for the methodology and table 9.2 for the results).

The quality of financial, transport, electricity, and telecommunications services, measured through firms' perceptions, affects their performance significantly. The finding is relatively robust to alternative measures of performance (labor productivity or TFP). When focusing on African firms only, the negative effect of poor services provision on performance is less robust, likely because of the smaller sample of firms, but still negative.

Telecommunications and transport services have the greatest effects on performance. The next most important service input is access to finance. The estimated effect of electricity services is less than half the size of the average of the other services.

Combining the estimated coefficients for each service with firms' perceptions about the quality of their provision in Ethiopia and simulating the productivity impact of reforms that would raise firms' perceptions of each service to the level in comparator countries provides a sense of the economic size of the effect. For example, if access to finance in Ethiopia were as good as it is in Rwanda, 
TABLE 9.2 Determinants of labor productivity, based on perception of services' performance

\begin{tabular}{|c|c|c|c|c|c|c|c|c|}
\hline \multirow{2}{*}{$\begin{array}{l}\text { INDEPENDENT VARIABLE } \\
\text { Exporter }\end{array}$} & \multicolumn{4}{|c|}{ ALL FIRMS } & \multicolumn{4}{|c|}{ AFRICAN FIRMS } \\
\hline & $0.113^{* * *}$ & $0.113^{* * *}$ & $0.113^{* * *}$ & $0.115^{* * *}$ & $0.172^{* * *}$ & $0.169^{* * *}$ & $0.170^{* * *}$ & $0.151^{* *}$ \\
\hline & $(0.017)$ & $(0.017)$ & $(0.017)$ & $(0.017)$ & $(0.058)$ & $(0.058)$ & $(0.058)$ & $(0.066)$ \\
\hline \multirow[t]{2}{*}{ Firm size } & $0.101^{* * *}$ & $0.102^{* * *}$ & $0.102^{* * *}$ & $0.104^{* * *}$ & $0.096^{* * *}$ & $0.101^{* * *}$ & $0.100^{* * *}$ & $0.088^{* * *}$ \\
\hline & $(0.009)$ & $(0.009)$ & $(0.009)$ & $(0.009)$ & $(0.029)$ & $(0.029)$ & $(0.029)$ & $(0.032)$ \\
\hline \multirow[t]{2}{*}{ Firm age } & $-7.9 e-5$ & $-7.5 e-5$ & $-8.2 e-5$ & -0.0002 & $0.004^{* * *}$ & $0.004^{* * *}$ & $0.004^{* * *}$ & $0.005^{* * *}$ \\
\hline & $(0.0004)$ & $(0.0004)$ & $(0.0004)$ & $(0.0004)$ & $(0.001)$ & $(0.001)$ & $(0.001)$ & $(0.001)$ \\
\hline \multirow[t]{2}{*}{ Finance obstacle } & $-0.07^{* * *}$ & & & & $-0.165^{*}$ & & & \\
\hline & $(0.03)$ & & & & $(0.09)$ & & & \\
\hline \multirow[t]{2}{*}{ Transportation obstacle } & & $-0.08^{* * *}$ & & & & -0.03 & & \\
\hline & & $(0.03)$ & & & & $(0.128)$ & & \\
\hline \multirow[t]{2}{*}{ Electricity obstacle } & & & -0.036 & & & & -0.03 & \\
\hline & & & $(0.025)$ & & & & (0.09) & \\
\hline \multirow{2}{*}{$\begin{array}{l}\text { Telecommunications } \\
\text { obstacle }\end{array}$} & & & & $-0.08^{* * *}$ & & & & -0.113 \\
\hline & & & & $(0.024)$ & & & & $(0.117)$ \\
\hline \multirow[t]{2}{*}{ Constant } & $1.983^{* * *}$ & $1.985^{* * *}$ & $1.934^{* * *}$ & $1.927^{* * *}$ & $2.232^{* * *}$ & $1.939^{* * *}$ & $1.971^{* * *}$ & $2.031^{* * *}$ \\
\hline & $(0.175)$ & $(0.174)$ & $(0.180)$ & $(0.169)$ & $(0.270)$ & $(0.308)$ & $(0.324)$ & $(0.253)$ \\
\hline Sector dummies & Yes & Yes & Yes & Yes & Yes & Yes & Yes & Yes \\
\hline Country-year dummies & Yes & Yes & Yes & Yes & Yes & Yes & Yes & Yes \\
\hline Observations & 41,456 & 41,456 & 41,456 & 39,169 & 6,596 & 6,596 & 6,596 & 5,254 \\
\hline$R$-squared & 0.172 & 0.172 & 0.172 & 0.176 & 0.195 & 0.194 & 0.194 & 0.218 \\
\hline
\end{tabular}

Source: World Bank Enterprise Surveys.

Note: The dependent variable is labor productivity. Robust standard errors are in parentheses.

${ }^{* * *} p<0.01,{ }^{* *} p<0.05,{ }^{*} p<0.1$.

firms' labor productivity would increase by 4.3 percent, all else equal. If electricity conditions matched conditions in Rwanda, labor productivity gains would rise by about 2.2 percent. Matching China's transportation services would imply productivity gains of almost 4.2 percent. ${ }^{13}$

Within Ethiopia, if access to finance in the Southern Nations, Nationalities, and Peoples' Region (SNNPR) were raised to the average level in Ethiopia, firms' labor productivity there would be 8 percent higher, all else equal. If transport conditions were raised to the average level, labor productivity there would rise by 19 percent. Poor transport services reduce productivity in Tigray by an estimated 8 percent; poor telecom access reduces it by 6 percent.

\section{CONCLUDING REMARKS}

Services are an important supplier of inputs into Ethiopia's domestic economy, in which the services and manufacturing sectors are more intensely linked than in most countries in the world. But manufacturing firms report that services are obstacles to production. The structure of manufacturing helps explain the strong interconnectedness of services and manufacturing in Ethiopia, but it may also be a constraining factor for manufacturing. 
The analysis in this chapter, based on a cross-country dataset on firm dynamics, finds sizable effects of changes in the quality of services provision on firms' productivity. The largest effects are associated with transport and telecommunications, followed by access to finance. Policies that support the performance of these services, such as reducing regulations and restrictiveness to trade, would also support the performance of manufacturing exports.

\section{NOTES}

1. Eight countries were chosen as comparators: Kenya, Rwanda, Tanzania, and Uganda are low-income regional peers; Zambia is a lower-middle income country in Africa; Vietnam is a lower-middle-income country outside the region that is undergoing structural change; China is a large economy that underwent a rapid process of growth based on development of manufacturing; the Republic of Korea is a high-income aspirational country. Ethiopia's population is larger than the populations of all comparator countries except China.

2. Cross-sectoral comparisons of labor productivity should not be considered indicators of the comparative efficiency with which different sectors operate, because labor productivity does not take into account other factors of production, such as capital.

3. It is possible that differences in average capital intensity explain these differences.

4. The main contributors to growth in Ethiopia's service sector were government services (6.4 percent annual average productivity growth); community, social, and personal services (4.0 percent); and transport, storage, and communication services (3.5 percent).

5. Bourguignon (2003) reports a global average of 1.6, although with high heterogeneity across countries.

6. The fact that services do not directly employ the poor does not imply that the poor do not benefit from that growth. It is possible that they benefit through their purchases of services.

7. Because of data limitations, the analysis of services trade focuses on cross-border transaction reported in balance of payments statistics. Services trade that takes place through foreign direct investment and the temporary movement of people is not covered.

8. Manufacturing is the subsector of industry comprising International Standard Industrial Classification of All Economic Activities (ISIC) chapters 15-37.

9. A cut-make-trim (CMT) system (sometimes called cut-make-pack) is a form of contract work in which a foreign buyer pays fees to a garment factory to carry out the laborintensive task of cutting the fabric, sewing garments, and trimming or packing them. The alternative is free-on-board (FOB), in which an international garment producer places an order from more sophisticated and well-financed factories overseas, which are then responsible for the whole process of production and arrangement of the shipment.

10. This analysis draws on a different database (the Global Trade Analysis Project [GTAP]), which uses gross rather than net values (and as such is not a direct extension of the analysis presented above).

11. The regulatory environment toward foreign services providers is also negatively correlated with services exports; countries with burdensome regulations in services tend to export lower services when measured as either gross or direct value added services. In Ethiopia high levels of restrictiveness are inconsistent with the results predicted by the regression.

12. Firms were asked "How big an obstacle is the provision of access to finance, transport, telecommunications or electricity to the operations of this firm?" They were then asked to choose between five options: no obstacle, minor obstacle, moderate obstacle, major obstacle, or very severe obstacle.

13. These effects are calculated as the product of the change in the perception indicator needed to match the comparator's perception about the given service and the estimated coefficient of the effect of the perception about the given service on firms' performance. 


\section{REFERENCES}

Arnold, J., B. Javorcik, and A. Mattoo. 2011. "Does Services Liberalization Benefit Manufacturing Firms? Evidence from the Czech Republic.” Journal of International Economics 85 (1): $136-46$.

Arnold, J., A. Mattoo, and G. Narciso. 2008. "Services Inputs and Firm Productivity in SubSaharan Africa: Evidence from Firm-Level Data.” Journal of A frican Economies 17 (4): 578-99.

Bourguignon, F. 2003. "The Growth Elasticity of Poverty Reduction: Explaining Heterogeneity across Countries and Time Periods." Working Paper 28104, World Bank, Washington, DC.

Collier, P., and J. W. Gunning. 1999. "Why Has Africa Grown Slowly?” Journal of Economic Perspective 13 (3): 3-22.

Duggan, V., S. Rahardja, and G. J. Varela. 2013. "Service Sector Reform and Manufacturing Productivity: Evidence from Indonesia.” Policy Research Working Paper 6349, World Bank, Washington, DC.

Fernandes, A. M., and C. Paunov. 2012. "Foreign Direct Investment in Services and Manufacturing Productivity: Evidence for Chile.” Journal of Development Economics 97 (2): 305-21.

Ghani, E., and S. D. O'Connell. 2014. "Can Service Be a Growth Escalator in Low-Income Countries?” Policy Research Working Paper 6971, World Bank, Washington, DC.

Groningen Growth and Development Centre 10-Sector Database, University of Groningen, Netherlands, https://www.rug.nl/ggdc/productivity/10-sector.

Inklaar, R., M. Timmer, and B. van Ark. 2007. "Mind the Gap! International Comparisons of Productivity in Services and Goods Production.” German Economic Review 8 (5): 281-307.

—_. 2008. "Market Services Productivity across Europe and the US." Economic Policy 23: 141-94.

Levy Yeyati, E., and S. Pienknagura. 2014. "Who's Afraid of Tertiarisation?” VOX CEPR Policy Portal, December 10. https://voxeu.org/article/services-rise-latin-america.

Ministry of Finance and Economic Cooperation. 2011. National Accounts. Government of Ethiopia. www.mofed.gov.et.

Rodrik, D. 2014. “An African Growth Miracle?” Institute for Advanced Study, Princeton, NJ.

Rosenow, S., Q. Hasnain, F. Menses, N. O'Clery and B. Cunningham. 2011. "Ethiopia, the SingleMinded State." Presentation at the Center for International Development, Harvard University.

Triplett, J., and B. Bosworth. 2004. Productivity in the U.S. Services Sector. Washington, DC: Brookings Institution.

UNCTADstat (database), UNCTAD (United Nations Conference on Trade and Development), Geneva, https://unctadstat.unctad.org.

World Bank. 2014a. Third Ethiopia Economic Update: Strengthening Export Performance through Improved Competitiveness. Washington, DC: World Bank.

—. 2014b. Ethiopia: Investment Climate from Regional States Perspective. Policy Note, World Bank, Washington, DC.

- 2015a. Ethiopia's Great Run: The Growth Acceleration and How to Pace It. Washington, DC: World Bank.

- 2015b. SME Finance in Ethiopia: Addressing the Missing Middle Challenge. Washington, DC: World Bank.

World Bank Enterprise Surveys (database), Washington, DC, http://www.enterprisesurveys.org.

World Bank Export of Value Added Database, Washington, DC, https://datacatalog.worldbank .org/dataset/export-value-added-database.

World Bank Services Trade Restrictions Database, Washington, DC, http://iresearch.worldbank .org/servicetrade/.

World Bank World Development Indicators (database), Washington, DC, http://wdi .worldbank.org. 


\section{The Regulatory Environment for}

CLAIRE H. HOLLWEG, MARTÍN MOLINUEVO, AND SEBASTIÁN SÁEZ

The expansion of trade in services represents a major opportunity for developing countries, including Liberia, to diversify exports, improve the overall competitiveness of the economy, and promote inclusive growth. But the issue has received little attention in policy and analytical work on Liberia's trade regime. This chapter seeks to fill some of the information gaps by (a) reviewing Liberia's trade performance in services between 2004 and 2011; (b) assessing Liberia's policy and regulatory framework on services trade; (c) evaluating Liberia's governance framework, to identify administrative practices that restrict trade in services; and (d) offering policy recommendations on enhancing the regulatory environment for services trade and investment in order to help Liberia diversify its exports and boost trade competitiveness.

This chapter is organized as follows. The first section briefly reviews the performance of services trade in Liberia. The second and third sections focus on general regulatory barriers to services trade and governance related matters that affect the services performance. The fourth section studies specific sectors. The last section summarizes the chapter's main conclusion and recommendations.

Liberia has much to gain from a stronger and more efficient services sector. Sub-Saharan exporters like Liberia pay transport costs for their goods that are at least five times higher than the average tariffs they face in industrial country markets (Mattoo and Payton 2007). Liberia's transport and logistics market is among the least efficient in the Economic Community of West African States (ECOWAS); only Sierra Leone scores lower on logistics performance (World Bank 2013). Enhanced services trade can help overcome these challenges by attracting more efficient suppliers and introducing newer technologies and more efficient practices.

\footnotetext{
* This chapter highlights the key findings of a 2014 World Bank report Enhancing Regulations on Services Trade in Liberia: A Regulatory Assessment of Services Trade and Investment (World Bank 2014). The authors thank Daniel Kwabena Boakye for valuable guidance and support.
} 


\section{PERFORMANCE OF SERVICES TRADE: CONSTRAINTS AND DETERMINANTS}

\section{Services sector performance}

The undeveloped state of Liberia's services sector reduces the country's competitiveness and makes it difficult to develop exports. Telecommunications, banking, professional, and transport and logistics services are expensive and of poor quality.

The services sector is second only to agriculture in terms of employment. The size of a domestic services sector-measured, for example, by the share of value added or employment from services activity-is often a precondition to developing a robust services export sector (Sáez and others 2014).

Despite rapid growth, Liberia's services sector is still smaller than what would be expected given its level of development. The share of services in GDP tends to increase with economic development, although there are substantial variations at all levels of development (figure 10.1). Liberia's services sectors is smaller than expected in both periods considered (2005-07 and 2010-12). In contrast, the size of the services sector in other economies in the ECOWAS is above predicted levels.

Liberia's services sector is expanding; it is larger relative to the economy than the sector in Guinea and Sierra Leone. The share of services in value added rose from 26 percent in 2005 to 37 percent in 2011. This growth was at the expense of agriculture, whose share of value added declined from 67 percent in 2005 to 53 percent in 2011.

Services' share of employment in Liberia is in line with what is expected given the size of the sector. The share is similar to that of other countries with

\section{FIGURE 10.1}

\section{Cross-country correlation between share of value added of services in GDP and per capita GDP,} 2005-07 and 2010-12

a. 2005-07

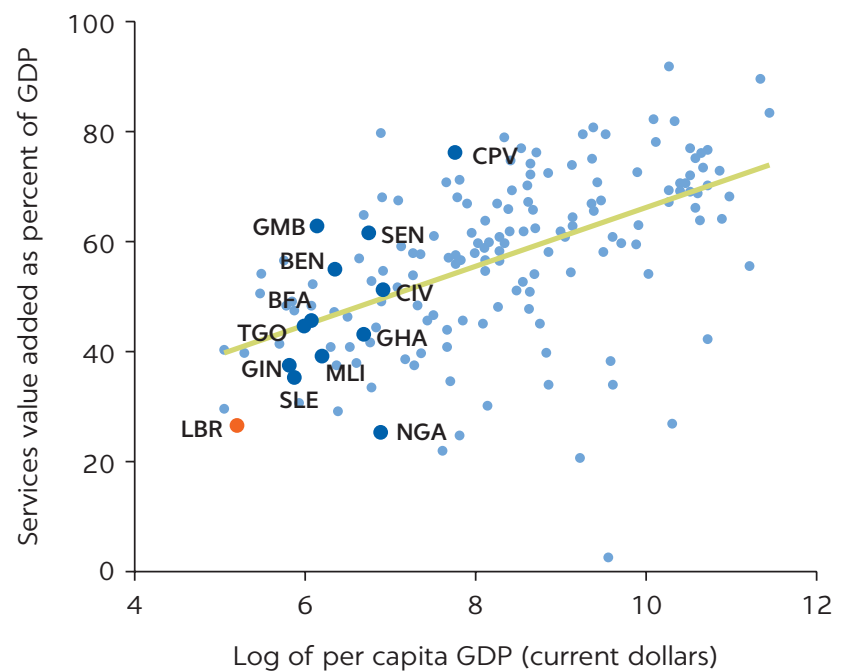

b. $2010-12$

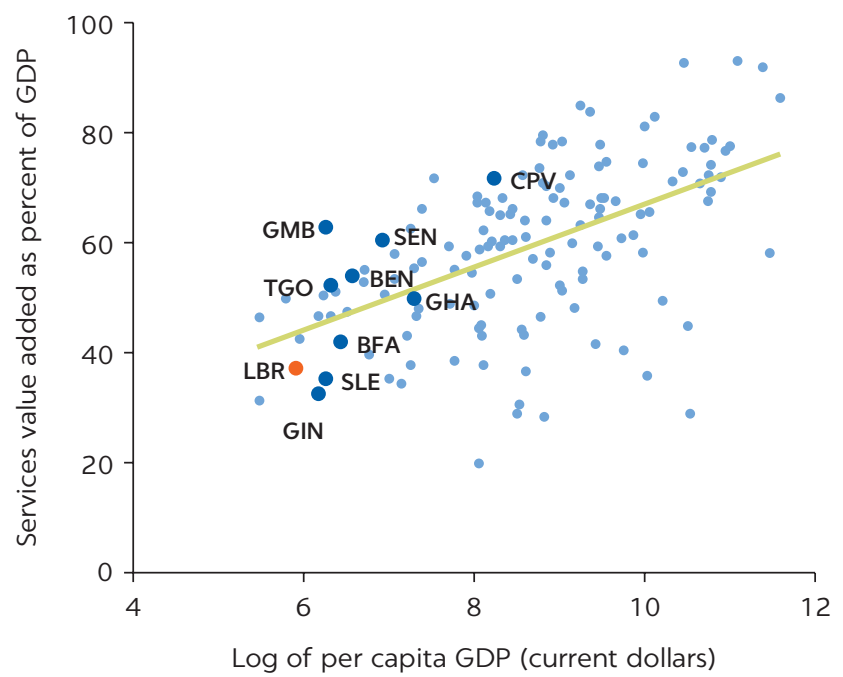

Source: World Bank World Development Indicators.

Note: GDP = gross domestic product. Dots represent countries. The countries of interest are identified by their three-digit International Organization for Standardization (ISO) codes: BEN = Benin; BFA = Burkina Faso; CIV = Côte d'Ivoire; CPV = Cabo Verde; GHA = Ghana; GIN = Guinea; GMB = Gambia, The; GNB = Guinea-Bissau; LBR = Liberia; MLI = Mali; NER = Niger; NGA = Nigeria; SEN = Senegal; SLE = Sierra Leone; $\mathrm{TGO}=$ Togo. 
similar levels of value added by the services sector. In contrast, in industry and agriculture, employment shares are lower than expected given the size of the sectors. Nearly 42 percent of Liberia's workforce was employed in the services sector in 2010, 48 percent worked in agriculture, and 9 percent worked in industry. These figures capture only employees who work for a public or private employer and receive remuneration in wages, salary, commission, tips, piece rates, or pay in kind, however. They do not include the thousands of Liberians who work informally or for themselves in agriculture. The large share of employment in services is driven by employment in the public sector, which accounts for more than a quarter of all paid employees, according to the 2010 labor force survey.

\section{Services trade performance}

Liberia's exports of services are higher than expected given the country's per capita GDP. Services imports are also high. In 2011 Liberia's commercial services exports (total services excluding government services) were 24 percent of GDP and imports were 17 percent. Many regional peers are below their predicted levels of commercial services trade, particularly for exports (figure 10.2).

FIGURE 10.2

\section{Cross-country correlation between share of exports and imports of commercial services in GDP and per capita GDP, 2005-07 and 2010-12}

\section{a. Exports, 2005-07}

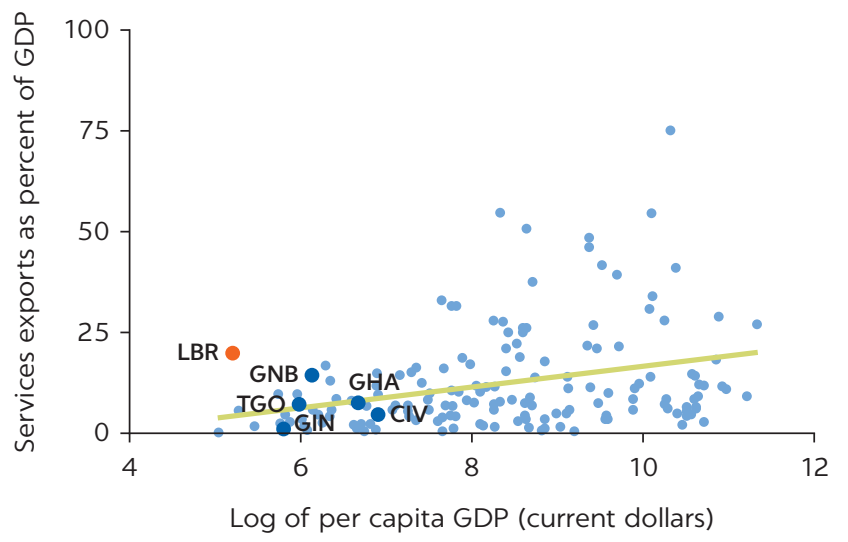

c. Imports, 2005-07

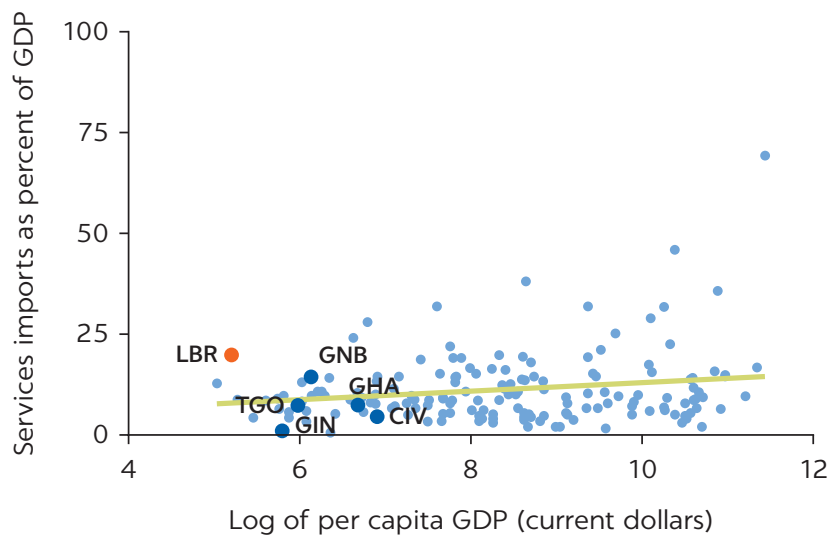

b. Exports, 2010-12

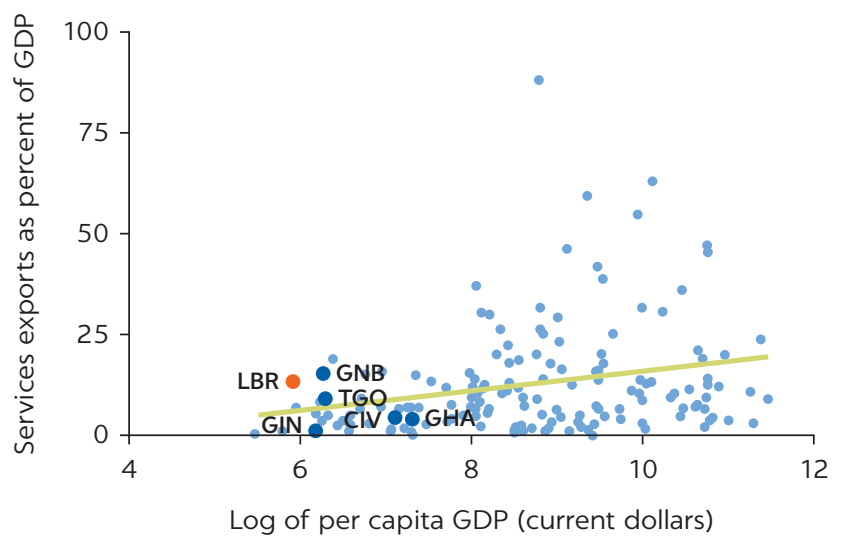

d. Imports, 2010-12

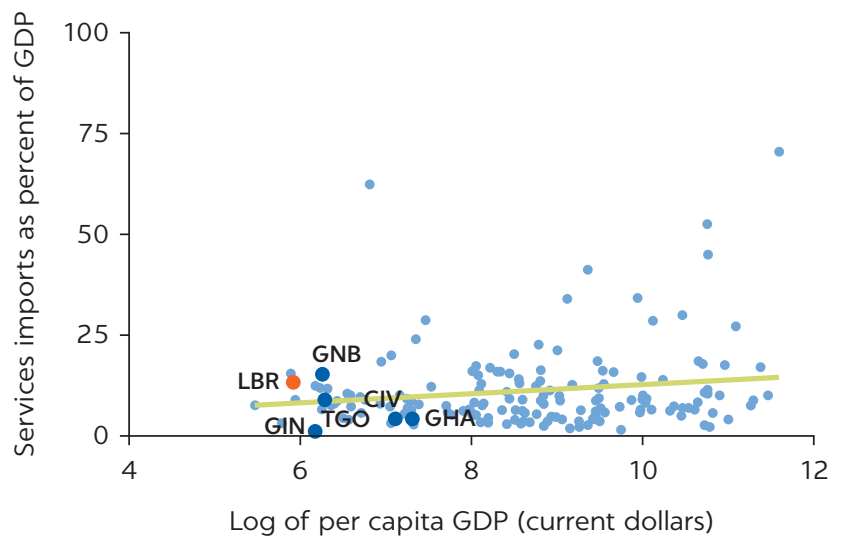

Source: World Bank World Development Indicators.

Note: GDP = gross domestic product. Dots represent countries. The countries of interest are identified by their three-digit International Organization for Standardization (ISO) codes: CIV = Côte d'Ivoire; GHA = Ghana; GIN = Guinea; GNB = Guinea-Bissau; LBR = Liberia; TGO = Togo. 
Commercial services exports and imports increased steadily between 2004 and 2008, despite falling as a share of GDP. Exports increased at an average annual rate of 28 percent during this period; imports rose by 40 percent a year. In 2009 both export and import levels dropped substantially in the wake of the financial crisis. Exports had rebounded by 2011, but imports remained below precrisis levels.

Liberia's services export sector is dependent on travel and transport services, the export shares of which are larger than expected given Liberia's level of development. This sectoral export concentration leaves the country highly vulnerability to exogenous shocks, as demonstrated during the 2008-09 global financial crisis. Between 2004 and 2008, annual exports of travel services grew from $\$ 59$ million to $\$ 158$ million. Their share in total commercial services remained constant, at about 85 percent.

Tourism is an emerging sector. Exports of other services remain modest. Liberia imports modern services, including telecommunications and financial services as well as information technology (IT)-enabled business services such as business processing outsourcing. These services accounted for 49 percent of its imports in 2011.

Travel was the only subsector that maintained a positive trade balance between 2004 and 2011 (except in 2010). Transport services also achieved a positive balance in 2011, thanks to an increase in transport services exports and decline in imports, recovering after the global trade collapse of 2008. Liberia posted a negative services trade balance in 2011, driven almost entirely by government services, which includes funds related to technical assistance and other international aid offered to Liberia as support to the post-war reconstruction. Commercial services other than travel and transport also showed an increasingly negative trade balance, from a negative $\$ 0.6$ million to $\$ 128.5$ million, as Liberia's services sector did not grow rapidly enough to accompany the countries' economic recovery. In particular, business services, which encompass IT-enabled services related to business processing outsourcing, were heavily reliant on foreign supply.

\section{Nonregulatory determinants of services}

Liberia ranked 177th out of 188 ranked economies on the United Nations Development Programme's Human Development Index, in the period 2010-12, just above landlocked Burkina Faso, The Gambia, and Sierra Leone (figure 10.3). Although its index improved steadily since the end of the war and the start of democracy, much remains to be done to catch up with other countries at its income level and the rest of Sub-Saharan Africa.

Liberia's level of education remains one of the lowest in the world. The war deprived an entire generation of education and skills, as an estimated 80 percent of the countries' schools were destroyed. Withdrawal from official education upon completion of the government-funded primary education years has resulted in a predominantly illiterate and unskilled work force that lacks basic computer skills. Adult literacy is below the average for Sub-Saharan Africa (Ministry of Education 2007).

Liberia ranks among the lowest countries in the region in the World Economic Forum's infrastructure and digital content indicator. Its telecommunications sector was severely hit by the civil war, during which copper wires were looted, leaving little infrastructure outside Monrovia. Computer and Internet usage rates are very low. In 2010 just 1 percent of the population owned a personal computer and just 7 percent had access to the Internet, according to the World Bank and the International Telecommunication Union. 


\section{FIGURE 10.3}

\section{Human Development Index in West Africa, by country, 1980-2012}

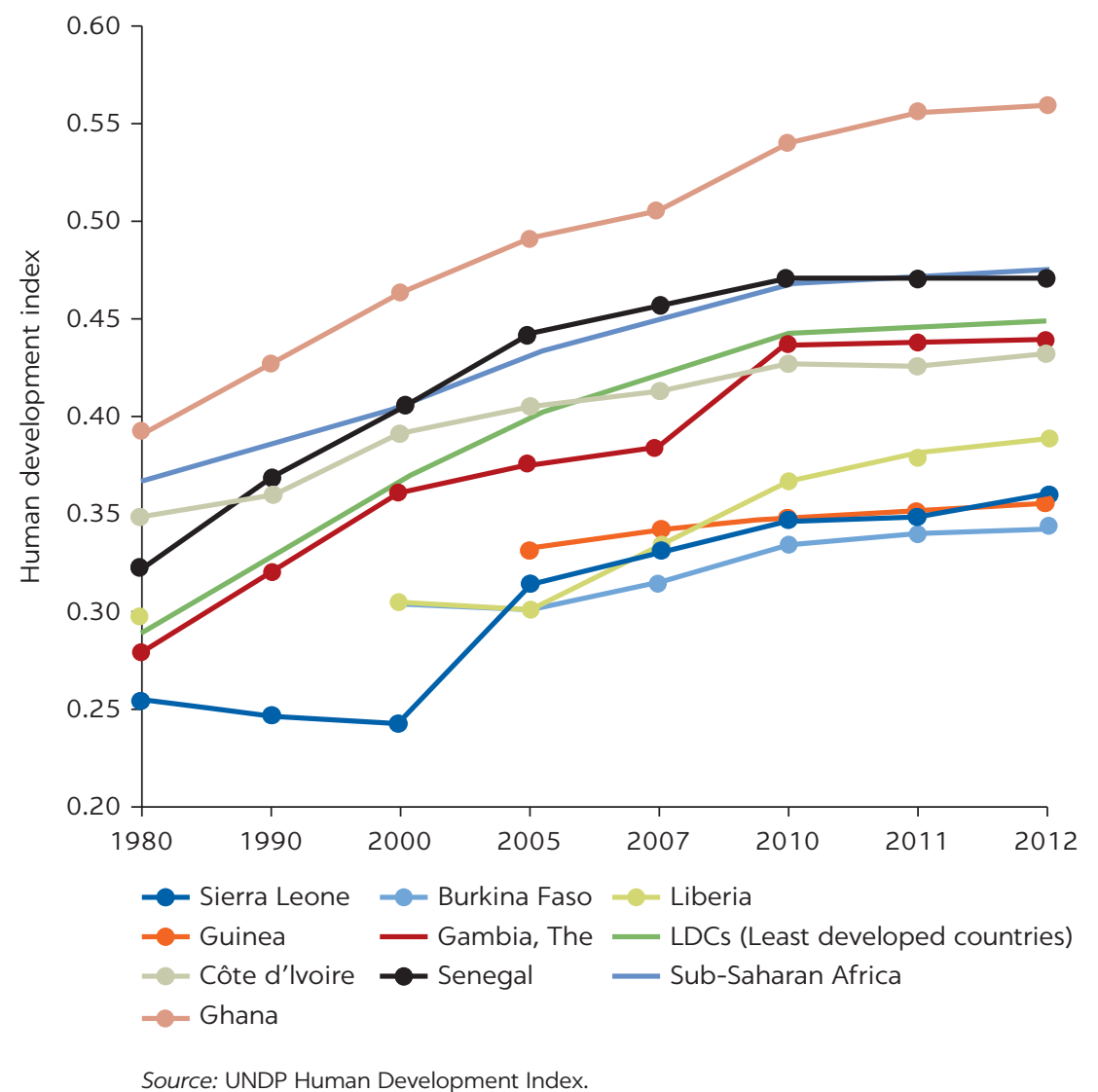

The country is striving to establish connectivity infrastructure. In 2012 it gained access to international submarine optic fiber cables for international connectivity (obviating the need to rely on satellite communications) thanks to a public-private partnership (the Cable Consortium of Liberia) formed with support from international partners, including the World Bank. Additional infrastructure is needed to reap the full benefits of the cable connection.

Governance is perceived as poor. The World Bank's Country Policy and Institutional Assessment (CPIA) rates countries based on 16 criteria grouped in four clusters: economic management, structural policies, policies for social inclusion and equity, and public sector management and institutions. 1 Liberia scores at the bottom of the region on public governance ranking (table 10.1). Its revenue collection capacity performs comparatively well, but it ranks worse than its neighbors on rule-based governance and quality of financial management and public administration.

Conditions in Liberia are not propitious for trade in services, but the country does have some advantages over its neighbors, most of which face comparable challenges in telecommunications infrastructure and skilled labor. The World Economic Forum ranks Liberia 56th position in the world in terms of quality of education. Liberia's English-speaking population, rapid economic growth, and sizable diaspora should help it develop its services sector. 
FIGURE 10.4

Liberia's Doing Business ranking, 2013

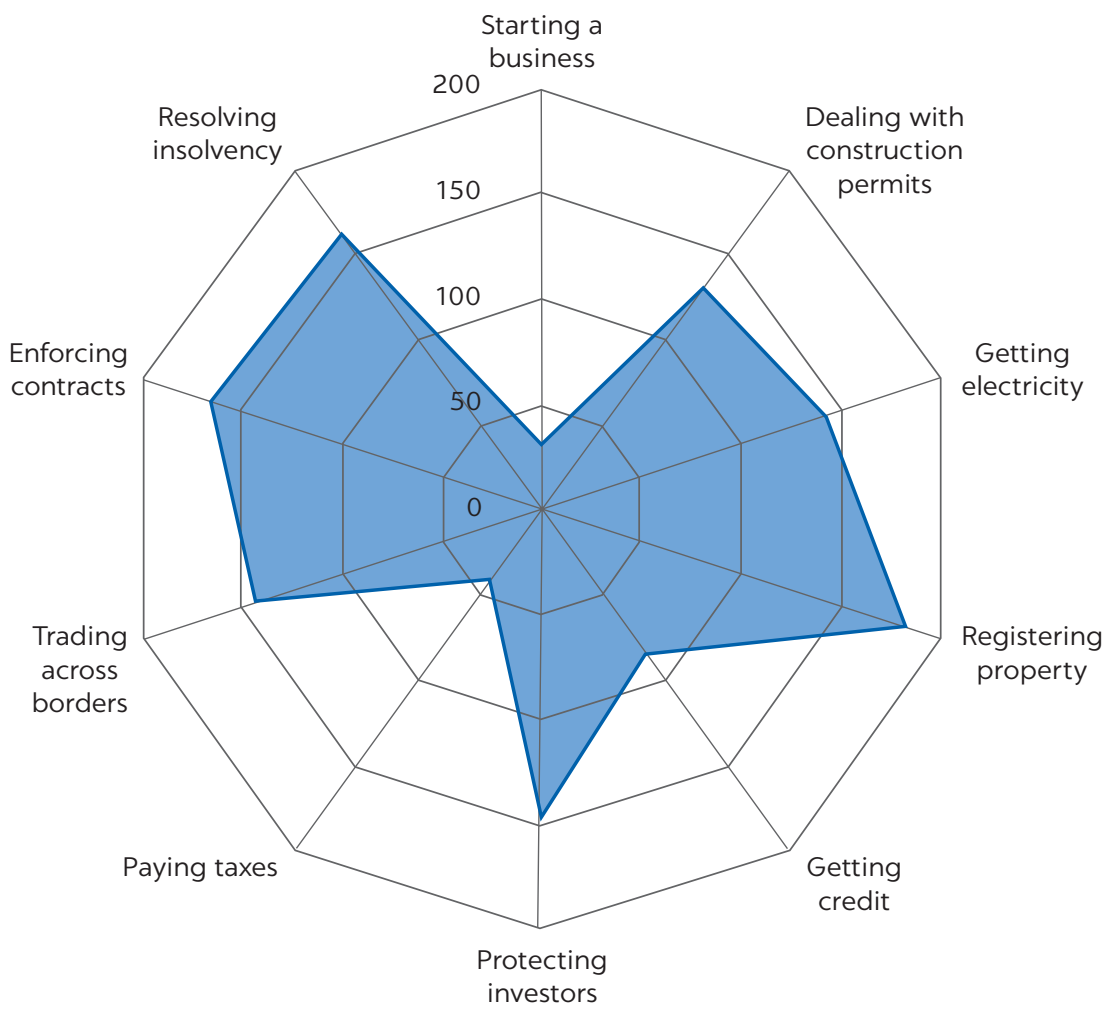

Source: World Bank Doing Business 2013.

TABLE 10.1 Governance ratings of countries of West Africa, 2012

\begin{tabular}{lccccc}
\hline & $\begin{array}{c}\text { PROPERTY RIGHTS } \\
\text { AND RULE-BASED } \\
\text { GOVERNANCE }\end{array}$ & $\begin{array}{c}\text { QUALITY OF BUDGETARY } \\
\text { AND FINANCIAL } \\
\text { MANAGEMENT }\end{array}$ & $\begin{array}{c}\text { EFFICIENCY OF } \\
\text { REVENUE } \\
\text { MOBILIZATION }\end{array}$ & $\begin{array}{c}\text { QUALITY OF PUBLIC } \\
\text { ADMINISTRATION }\end{array}$ & $\begin{array}{c}\text { TRANSPARENCY, } \\
\text { ACCOUNTABILITY, } \\
\text { AND CORRUPTION }\end{array}$ \\
\hline Burkina Faso & 3.5 & 4.5 & 3.5 & 3.5 & 3.5 \\
\hline Côte d'lvoire & 2.5 & 3 & 3.5 & 3.5 & 2.5 \\
\hline Gambia, The & 3 & 3.5 & 3.5 & 3.5 & 2 \\
\hline Ghana & 3.5 & 3.5 & 3 & 3 & 4 \\
\hline Guinea & 2 & 3.5 & 3.5 & 2.5 & 2 \\
\hline Liberia & 2.5 & 3.5 & 4 & 3.5 & 3 \\
\hline Senegal & 3.5 & 3.5 & 3 & 3 & 3.5 \\
\hline Sierra Leone & 3 & & 4.5 & 3 \\
\hline
\end{tabular}

Source: World Bank Country Policy and Institutional Assessment Database.

Note: Scale: 1 (low) to 6 (high).

\section{HORIZONTAL MEASURES AFFECTING SERVICES}

The main barrier to the development of the services sector in Liberia lies in its poor governance framework. Many barriers to trade and investment in services stem from opaque and discretionary administration of laws and regulations rather than from outright restrictions. Liberia's poor governance framework results in a number of de facto restrictions to services trade. The main weaknesses relate to the lack of transparency. Laws and regulations are not easily 
available and do not accurately reflect actual administrative practices. The costs of widespread unofficial and illicit payments are high.

The regulatory framework for services includes not only laws and regulations governing a particular sector but also measures that affect a wide range of sectors ("horizontal" measures). Regulations on tourism, for example, obviously affect services providers in the subsector, but so do other laws and regulations, such as regulations on buying and selling foreign currency, laws on entry and stay of foreigners, and procedures related to the establishment of firms.

Liberia's formal horizontal policies and regulations provide for a largely open and nondiscriminatory environment for the services sector (table 10.2). The opening up to private and foreign participation in the economy was one of the pillars of the reform process launched by the government after the end of the war. The government introduced or amended several major horizontal laws relevant to the services subsectors, with a view to creating a more conducive environment for private capital. However, part of the openness in Liberia's regulatory regime stems from of the absence of specific regulations and guidelines on some services subsectors or cross-cutting issues, which often impairs, rather than enhances, the business environment, by reducing transparency and predictability of the laws and regulations.

\section{Cross-border trade}

Liberia does not restrict cross-border trade in services, an area of regulation that is challenging because of the technical difficulties of controlling electronic

\section{TABLE 10.2 Formal horizontal restrictions/requirements to services trade in Liberia}

\begin{tabular}{|c|c|c|c|c|c|c|c|c|c|c|c|c|c|c|c|c|c|c|}
\hline & & & MAR & ET AC & CESS/ & ESTAB & LISHN & & & & & & & ERAT & & & & \\
\hline MODE OF SUPPLY & 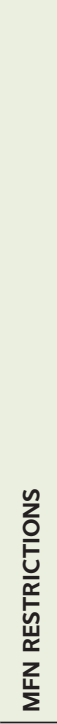 & 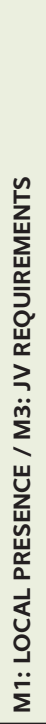 & 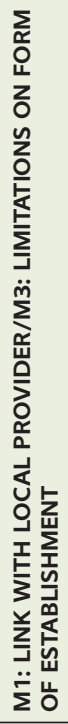 & 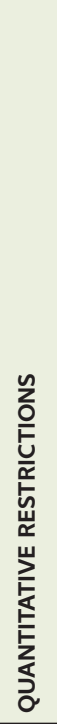 & 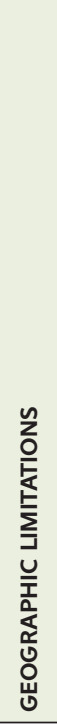 & 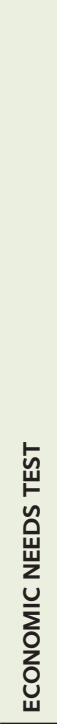 & 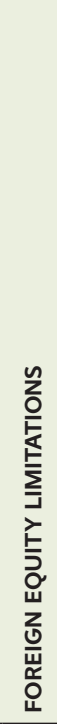 & 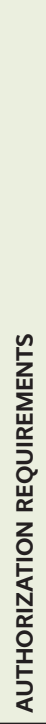 & 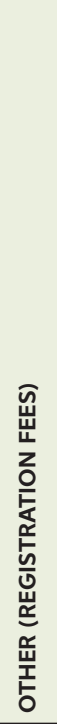 & 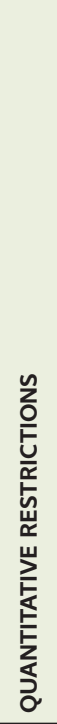 & 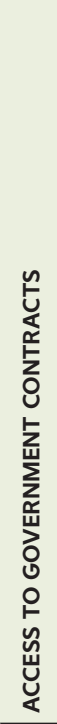 & 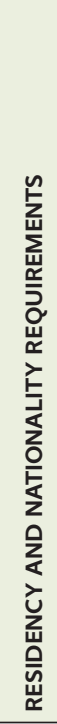 & 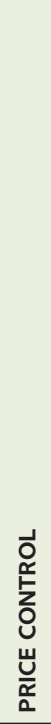 & 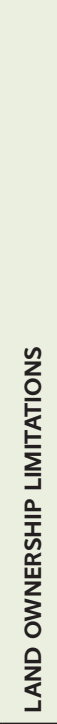 & 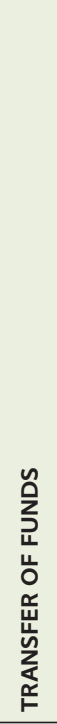 & 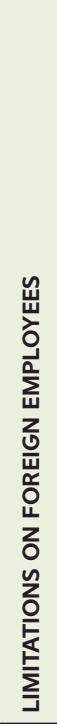 & 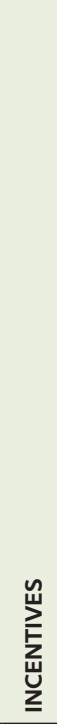 & $\begin{array}{l}\text { 塪 } \\
\text { L }\end{array}$ \\
\hline \multicolumn{19}{|l|}{ Cross-border trade } \\
\hline \multicolumn{19}{|l|}{ Consumption abroad } \\
\hline Commercial presence & & & & & & & & & • & & $\cdot$ & & & - & & • & - & \\
\hline Movement of natural persons & & & & & & - & & & & & $\cdot$ & & & - & & • & & \\
\hline
\end{tabular}

Source: World Bank 2014

Note: $\bullet=$ at least one restriction applies; JV = joint venture; $\mathrm{M} 1=$ cross-border services; $\mathrm{M} 3=$ commercial presence; $\mathrm{MFN}=$ most favored nation. 
traffic and the location of services suppliers, which by definition are outside the country's jurisdiction. It does not restrict the transfer of funds abroad. The Investment Act of 2010 guarantees foreign investors the right to make inward and outward transfers of capital, profits, dividends, and payments for foreign loans. The law does not seem to cover regular payments abroad by Liberian citizens or companies or foreign-invested enterprises acquiring other cross-border services.

\section{Commercial presence}

The Investment Act of 2010 sought to create a level playing field for foreign and domestic investors. It prohibits discrimination against foreign investors, ensuring that domestic and foreign companies have the same rights regarding licensing and permits and are subject to the same obligations, such as book-keeping requirements and taxation. It offers guarantees against expropriation, repatriation of capital, and access to courts and arbitration. The law provides that foreign investors may own or control, wholly or in partnership with Liberians, business in any sector of the economy except a few specific consumer-oriented services activities. ${ }^{2}$ It also identifies sectors in which foreign investors may participate provided that they invest a minimum of $\$ 500,000$ ( $\$ 300,000$ if at least 25 percent of the company is owned by a Liberian partner). Many of these activities are consumer-oriented services not likely to be prime sectors for foreign investment, although some restrictions may have greater effects on the economy.

\section{Employment of foreigners}

The Investment Act of 2010 states that "foreigners of any nationality may be employed in Liberia" and that investors have the right to employ any person, including foreign nationals. Both references, however, are subject to Liberia's labor and immigration laws. Foreigners wishing to be employed by a firm in Liberia must obtain a work permit issued by the Ministry of Labor. These permits are issued only after a labor market test is conducted establishing that no qualified Liberian is available to carry out the work. Independent services suppliers face fewer restrictions for short-term services, because of difficulties in monitoring short-term contracts.

The country's opaque regime on foreign employment hampers the business environment by increasing the discretionary powers of regulators and opaqueness in the regulatory framework, as companies are uncertain about the possibility of hiring foreign nationals. The use of fixed quotas of foreign employment would yield comparable results in terms of promoting domestic employment and training while providing for a more transparent and predictable regime. Greater transparency in the duration of labor permits would further enhance the business environment.

\section{Land ownership}

Land ownership in Liberia is reserved to citizens. Foreign missionary, education, and benevolent institutions are allowed to own property, provided that it is used for altruistic purposes. Foreign citizens and companies may not own land for commercial purposes. They can, however, access land through long-term leases. 
This restriction affects foreign suppliers wishing to provide services in Liberia through the establishment of a company (commercial presence) or the presence of individual suppliers.

Restrictions on land ownership are common in international trade agreements. Some countries have reserved such measures from their World Trade Organization (WTO) obligations.

\section{Incentives regime}

Liberia provides tax incentives for specific industries, including several services subsectors. Under the Consolidated Tax Amendment Act of 2010, some services may qualify for a "special tax incentive" for up to 5 years. Investment incentives are available to all parties but require a higher threshold for foreign investors.

Nationality considerations are common in subsidy and incentive policies. They are one of the most common horizontal restrictions scheduled in the General Agreement on Trade in Services (GATS) agreements.

\section{Capital requirements}

Liberia does not maintain horizontal measures on equity or capital requirements. There is generally no applicable minimum capital requirement, although an investment of $\$ 500,000$ in defined strategic sectors is required to be eligible for incentives. There are no specific restrictions on the percentage of equity foreign investor may own. However, according to the investment authorities, the government looks favorably on partnerships between foreign investors and Liberians. Foreign suppliers can participate in government procurement bids, but the Public Procurement and Concessions Act offers a margin of preference of about 15-25 percent in favor of nationals for the evaluation of both national and international bids for public contracts.

\section{Concessions regime}

The regime on concessions creates a parallel regulatory framework that applies to large foreign investments (investments of more than $\$ 10$ million). This framework allows for deviation from the general guarantees of the Investment Act of 2010. Under the concessions regime, the authorities enter into one-on-one negotiations with the investor, offering incentives or other support for investment projects deemed to have particularly strong benefits for Liberia's economy. Through these negotiations, large foreign investment can gain incentives and other benefits that are not available to smaller investors. Two foreign investments in the services sector have been established under the regime: a hotel in an historic building and the port terminal.

\section{Business registration}

The government has made important improvements to facilitate the registration of firms via the Liberian Business Registry, which operates as a one-stop shop to formalize and register enterprises and provide information services to the public. All companies established in Liberia, whether foreign or domestic, must register. Entities incorporated overseas may open branches in Liberia, for which 
they must register an office or resident agent in Liberia. This rule does not apply to companies providing services through cross-border trade.

Simplification of the registration procedures has reduced the number of steps needed to start a business. The World Bank's Doing Business indicator reflects these changes, ranking Liberia the 31st easiest place in the world to register a business in 2013 (figure 10.4). Procedures remain unclear, however, as a result of lack of access to regulation and other administrative practices.

Fees for the registration of a company are based on nationality. Liberian companies pay about $\$ 50$ for registration procedures; foreign establishments are charged more than 20 times as much. Registration has to be renewed annually, at similar costs. The regime penalizes smaller foreign investments. A regime based on objective criteria, such as the company's registered capital, would be more consistent with the nondiscrimination principle recognized in the Investment Act of 2010.

\section{GOVERNANCE AND INSTITUTIONAL SETTING}

The perception of the government's ability to implement public policies is low, even in comparison with its neighbors. Figure 10.5 depicts key elements of the governance framework in Liberia and its neighbors; figure 10.6 shows the trajectory of governance indicators in the 8 years after the end of the civil war.

Government effectiveness is perceived as particularly low. Despite the government's policies of liberalization and promotion of the private sector, regulatory quality barely improved between 2006 and 2012 .

Liberia's main deficiencies lie more in the discretionary application of general rules than in formal limitations to trade and investment. Agents perceive that rules can be applied selectively or bypassed. As a result, laws and regulations, even when well-planned and designed, do not always seem binding, undermining the perception of the regulatory quality and rule of law.

This poor governance framework results in a number of de facto restrictions to services trade. The main administrative practices and primary

FIGURE 10.5

Governance indicators in selected countries in West Africa, 2012

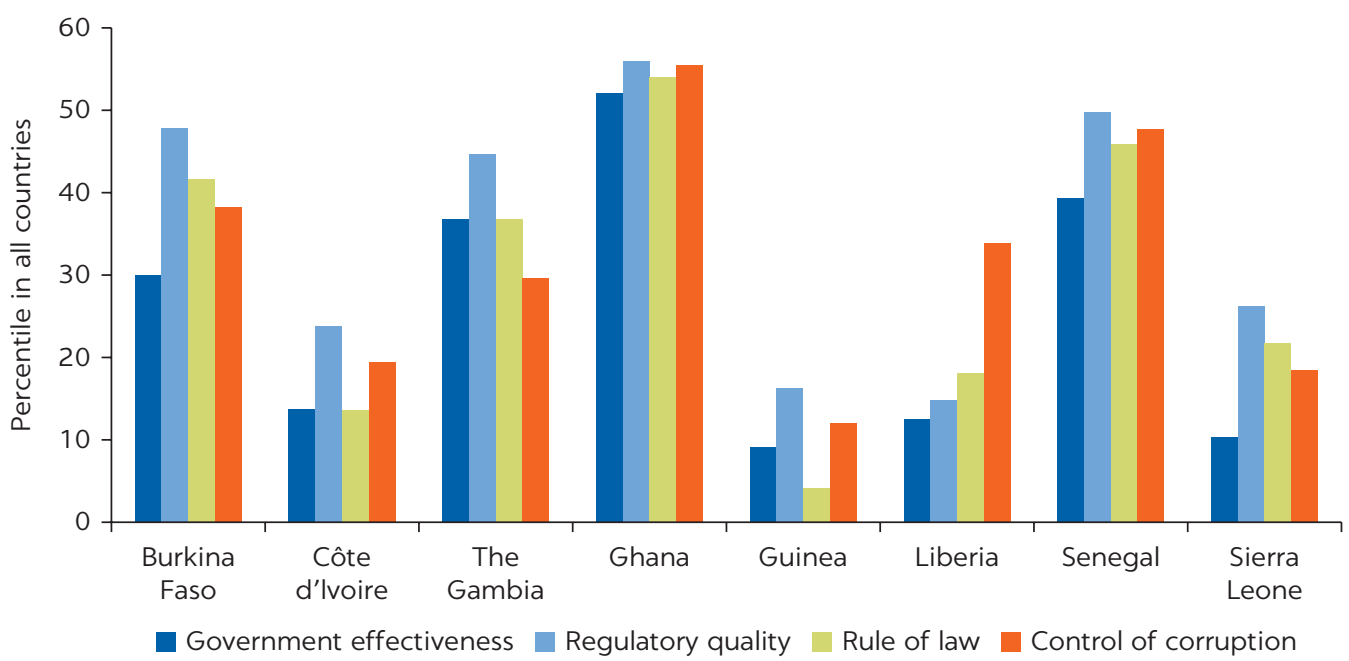

Source: Word Bank Worldwide Governance Indicators. 
FIGURE 10.6

Governance indicators in Liberia, 2003-12

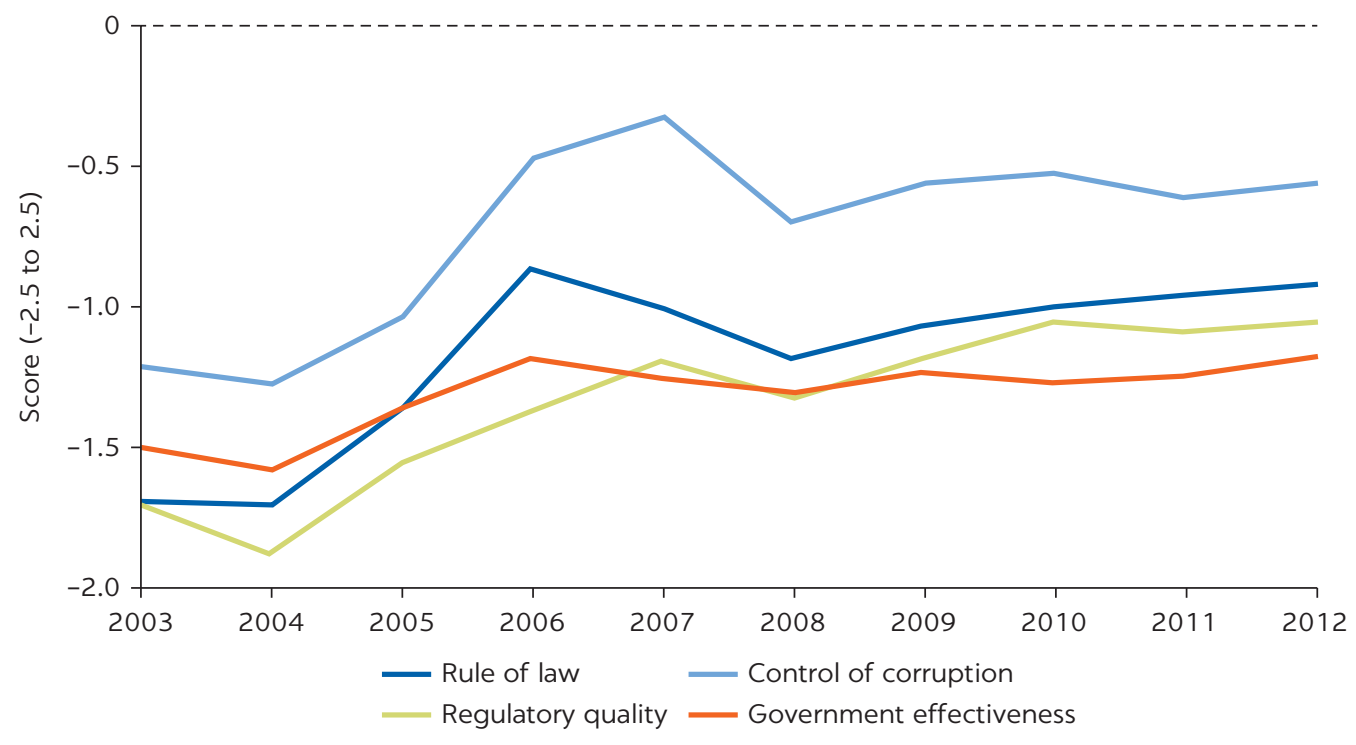

Source: World Bank Worldwide Governance Indicators.

Note: Scores range from -2.5 to 2.5 .

horizontal restrictions that restrict services trade and investment in Liberia include the following (table 10.3):

- Despite improvements in procedures for company registration, numerous practices hinder the establishment of foreign and domestic companies.

- Registration procedures are speedy but uncertain.

- The issuance of sectoral licenses is opaque and more unpredictable than company registration.

- Business operation is hindered by inconsistent or unpredictable enforcement of laws and regulations.

- The business environment remains burdened by the costs of illicit payments.

\section{Institutional framework}

As in most countries, policies related to trade and investment in services are covered by multiple institutions, such as the Ministry of Transport, the Ministry and Finance, the Ministry of Labor, the Ministry of Trade, and the National Investment Commission (NIC). The Ministry of Commerce and Industry (MOCI) has a broad mandate on trade matters, including international negotiations, but the agency suffers from shortages of human and financial resources that prevent it from fulfilling its broad functions. The NIC is the main institution governing foreign investments in Liberia.

\section{Rule-making process}

A clear and open rule-making process, including mandatory procedures or guidelines that govern the regulatory process, can improve the regulatory framework. 
TABLE 10.3 Impact of horizontal administrative practices on services trade in Liberia

\begin{tabular}{|c|c|c|c|c|c|c|c|c|c|c|c|c|c|c|c|}
\hline \multicolumn{9}{|c|}{ MARKET ACCESS/ESTABLISHMENT } & \multicolumn{7}{|c|}{ OPERATION } \\
\hline MODE OF SUPPLY & 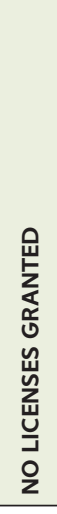 & 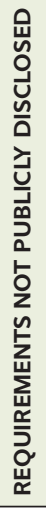 & 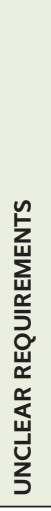 & 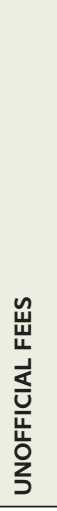 & 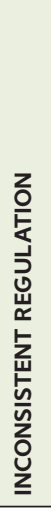 & 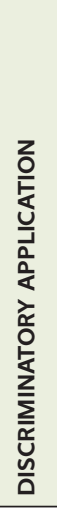 & 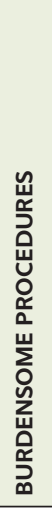 & $\begin{array}{l}\text { 㸒 } \\
\text { t }\end{array}$ & 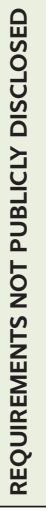 & 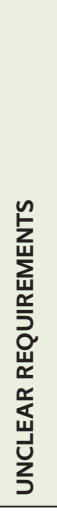 & 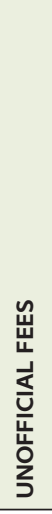 & 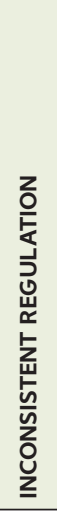 & 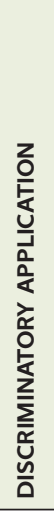 & 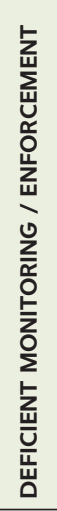 & $\begin{array}{l}\text { 続 } \\
\text { 。 }\end{array}$ \\
\hline Cross-border trade & & • & & & & & & & $\cdot$ & & & & & & \\
\hline \multicolumn{16}{|l|}{ Consumption abroad } \\
\hline Commercial presence & & • & • & • & & • & & & $\cdot$ & • & - & & • & - & \\
\hline $\begin{array}{l}\text { Movement of natural } \\
\text { persons }\end{array}$ & & • & - & & & & & & $\cdot$ & • & & & & - & \\
\hline
\end{tabular}

Source: World Bank 2014.

Note: $\cdot$ = at least one restriction applies.

Lack of governmentwide standards on rules in Liberia offers great discretion to different agencies in establishing a transparent and collaborative regulatory procedure or deviating from such standards. A standard procedure on rule-making procedures, in the form of binding guidance, would reduce discretion and promote good governance in ministries and regulatory agencies.

\section{Lack of transparency}

Lack of transparency is widely perceived as one of the main weaknesses of Liberia's legal and regulatory framework. Laws and regulations are generally inaccessible, which creates uncertainty about the requirements business have to meet.

Liberia lacks an effective official gazette that covers all laws and regulations. However, individual ministries and regulatory agencies publish information or laws and regulations relevant to their portfolio in their websites. Some private initiatives are also enhancing access to legislation.

\section{Stakeholder consultations}

Liberia made significant progress in stakeholder consultations, particularly through the Liberia Better Business Forum, a structured partnership that brings together the government and the private sector to engage in dialogue aimed at identifying, prioritizing, and resolving constraints to doing business. Consultations remain limited to specific members and detached from the regular regulatory process, however. They are not open to nonmember businesses, some regulatory bodies (such as the Ministries of Transport and Tourism), or other organizations, including nongovernmental organizations. 


\section{Interagency coordination}

Interagency coordination is particularly relevant in the wake of broad trade negotiations. For successful trade negotiations, information should flow back and forth between the trade ministry and the regulatory agency. The regulatory agencies should first provide the trade ministry with a clear picture of the regulatory status quo on their sector, including current laws and regulations, policy goals, and the regulatory plan. The MOCI should then articulate a services policy, including guidelines on potential international obligations, as part of a broader national trade policy. The Trade Ministry and other relevant ministries should have access to proposed new regulations at conception and at the draft stage, so that they can assess the impact on trade and compliance with international trade agreements.

\section{Regulatory efficiency}

Regulation is efficient if it is well targeted to address relevant problems and conducive to achieving the desired policy goal; promotes innovation and competition; and avoids erecting undesirable barriers to trade and investment. Alternatives should be considered when introducing any new regulation, in order to evaluate the different quantitative and qualitative benefits and costs each may entail. No system of assessing regulatory impacts or comparing alternative regulations exists in Liberia.

\section{SECTORAL SERVICES POLICIES AND GOVERNANCE}

Policies and governance across services subsectors differ in terms of openness and regulatory capacity. Some subsectors, such as banking, are liberalized and comparatively well regulated. Others feature tight restrictions (professional services) or lack a basic regulatory framework (distribution services) (figure 10.7).

Most subsectors remain largely open to foreign investors. Although this openness allows for a competitive environment that can promote growth and private sector development, the lack of adequate regulation may diminish the benefits of an open services regime and can create obstacles to the expansion and investment of the services sector.

Few sectors face quantitative restrictions (limits to the number of services providers that may be established in the country or a certain area). The most common measures in the services sector are qualitative restrictions, including residency requirements, restrictions on foreign employment, limits on land ownership, and knowledge transfer requirements.

Most sectoral limitations set out conditions affecting the operation (or conduct) of the businesses. Restrictions on professional services limit market access and establishment. Qualitative measures affecting establishment are imposed mostly on professional services, in the form of qualification, nationality, and residency requirements. Restrictions stemming from administrative practices in specific subsectors add to the poor governance environment affecting business in Liberia. Such de facto limitations are strictest transport and logistics services, distribution. 


\section{FIGURE 10.7}

\section{Sectoral restrictions on investment in services subsectors in Liberia}

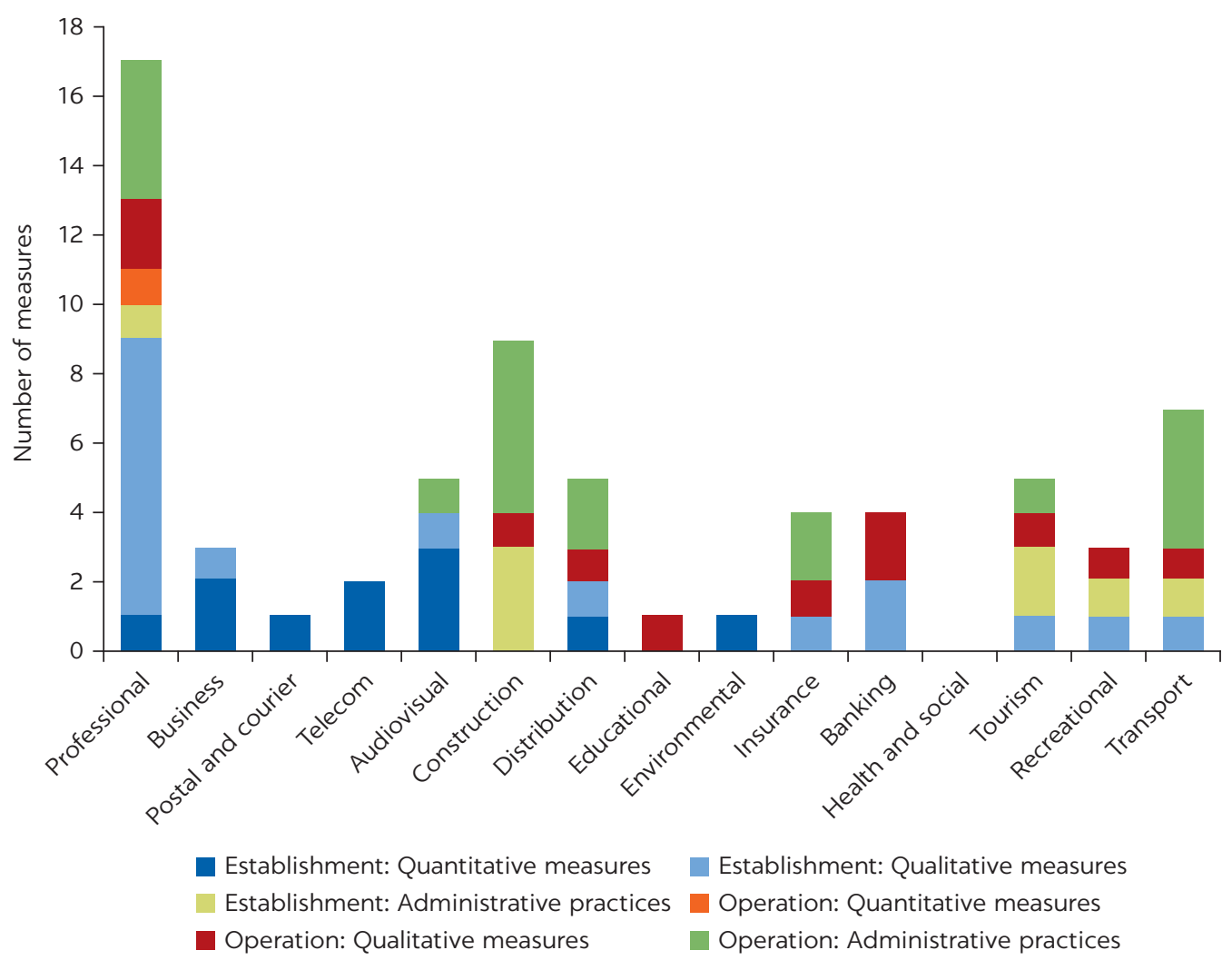

Source: World Bank 2014.

\section{Transport and logistics}

Several laws form the legal basis for regulating the establishment of business operations in the transport and logistics sectors. Regional, international, and bilateral transport and trade agreements introduce additional legal obligations.

Multiple institutions regulate Liberia's transport and logistics sectors, depending on the type of service and the statutory authority of the agency

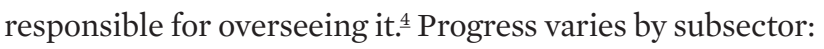

- Road transport services continues to struggle with outdated regulations and a lack of institutional backing for enforcement.

- The governance of maritime services has improved markedly since 2003, with clarified roles for the private sector and its relations with the National Port Authority.

- Rail freight services remain a small proportion of national freight services and are still governed by concessionary contracts.

- Commercial passenger services, which are supplied primarily by road and aviation services providers, have mixed legal, regulatory, and operating conditions.

- International air passenger and cargo services are open and well regulated.

- Auxiliary logistics services are less regulated than other subsectors, with lax performance quality requirements.

In line with Liberia's general laws, the legal and regulatory framework for transport and logistics features an open and generally nondiscriminatory regime 
toward foreign investment. The sectors have been liberalized, but a few formal restrictions remain in place, mostly in the form of a nationality requirement for services suppliers. Replacing the nationality requirement (with, for example, a quota for foreigners) would improve operating conditions, support Liberia's compliance with the ECOWAS Trade Liberalization Scheme (ETLS), and facilitate regional trade integration.

The main challenges in the transport and logistics subsectors are related to a weak governance framework. Low regulatory capacity results in nontransparent regulatory procedures, increased operating costs, and de facto market access restrictions. Improving the governance of regulations of carriers, vehicles, drivers, service types, and service quality is vital to ensure the efficient functioning of commercial enterprises and attract foreign direct investment.

Although few restrictions exist in law and regulation, many administrative practices and conditions continue to limit when business operations can start. Inconsistencies in licensing requirements (commercial driver licensing), opaque methods for determining financial worthiness (minimum capitalization for foreign firms), the absence of rules and policy directives (new motor carrier registration), burdensome administrative procedures (duplicative customs inspections), and the application of preferential labor market rules (labor permits for foreigners) all disadvantage foreign-owned firms.

The government has promoted regulatory reform and investment in transport and logistics. The National Transport and Policy Strategy (NTPS) directive, completed in 2009, empowers the Ministry of Transport to oversee the many governing agencies of the transport sector. Much remains to be done to improve the conditions for policy formulation and the implementation and enforcement of rules and regulatory reforms, however. Implementing the NTPS directives and fostering a governance presence that encourages regulatory compliance while providing clear requirements for market entry and operations remain challenging.

\section{Roads}

Market access to the road subsector remains fairly open for domestic firms. However, regulators have the power to limit sector capacity based on nontechnical criteria, including opaque licensing rules for foreign-owned firms. Foreign firms face differential restrictions on both entry and operations, including cabotage and in-transit shipment of intraregional trade. Weak governance results in spotty inspections and inadequate enforcement of rules. Institutional capacity to enforce carrier, vehicle, and driver standards is weak.

\section{Maritime Services}

The maritime sector is open to private sector and foreign firm participation, and the regulatory and governance framework is well structured. Public-private partnerships are allowed, but inconsistent rules on operations at major seaports and administrative practices limit participation of foreign-owned firms, particularly in domestic maritime services. Maritime services providers are restricted by nationality and residence rules, limitations on employment of foreigners, and unclear licensing requirements that discriminate against foreign firms.

\section{Aviation}

The aviation sector is very open to participation by the private sector, including foreign firms. Improvements in Liberia's economy make both the international passenger and air cargo segments attractive for foreign investments. 
Laws and regulations have provided the clarity that is essential for both market access and commercial passenger operations. There is, however, a need to strengthen the financial independence of the Civil Aviation Authority and the Airport Authority. Reassessing ownership and operational arrangements and considering a public-private partnership structure could expand the viability of secondary airports in particular.

Rail

Liberia lacks a rail transport law similar to the maritime law and the vehicle and traffic law. There is no regulatory basis for oversight of the subsector, which is instead loosely regulated through concession contracts. A rail law is needed, given the potential contributions of rail service to economic growth.

The concessionary structure of the subsector restricts market entry. Lax regulations and the absence of enforceable provisions lead to monopolistic behavior that raises trade-related costs for shippers. A major concern is how to balance future concession management to allow either competing or noncompeting private investors to leverage state-owned or concession rail tracks while ensuring returns for investors and safeguarding the public's vested interest.

\section{Logistics}

Inconsistencies in administrative practices and norms of different regulating agencies create excessive trade-related operating costs for both domestic and foreign logistics firms. Basic regulatory guidelines on safety and the quality of service are missing in some subsectors.

Customs brokerage is limited to Liberian citizens. It is affected by a discriminatory application process and deficient training, monitoring, and enforcement. With the growing complexity of trade transactions because of the intricacies of local content and origin requirements, harmonized products classifications, bilateral trade agreements, and national security concerns, the role of customs brokers/agents in facilitating trade is becoming more important.

Freight forwarding in Liberia suffers from a general lack of regulatory transparency. It is restricted by inconsistent rules; unpredictable directives; discriminatory enforcement; and barriers in customs administration, including a lack of transparency on risk assessment protocols, inefficiencies in customs inspections (duplicative inspections and long wait times), and burdensome trade document compliance requirements. Licensing and certification requirements for entry and operations are ambiguous and not publicly disclosed.

Warehousing and storage are not regulated as a specific activity. They remain open for foreign participation. Indeed, the subsector seems to be dominated by foreigners, who own large commercial warehouses in Monrovia. The subsector suffers from unclear guidelines, a culture of unofficial fees, and deficient monitoring and enforcement. Clear rules on technical standards for operation safety (including health and fire control), equipment usage, hazardous materials (for example, petroleum and gasoline), and service quality are lacking.

Multiple agencies regulate courier and parcel services, because of the range of services they provide. The primary restrictions providers face include limits on foreign employment, nationality and residency rules, missing or outdated postal regulations, and deficient monitoring and enforcement procedures. 
Improving the governance and openness of the transport and logistics sectors requires strong government support to address impediments, including ineffective regulations, inconsistencies among the NTPS implementing agencies, inadequate implementing capacity, and insufficient regulatory accountability. The government should consider the following measures:

- Review and relax the "Liberian only" rule and limits on foreign employment with mandated quotas of foreign workers that depend on the level of foreign direct investment.

- Make the improvement of transport and logistics services a national priority, by forming an Advisory Council on Transport and Logistics of nongovernment and industry experts to develop new rules for trucking and rail sectors, accountability, and governance.

- Develop a strong and effective regulator-industry partnership forum to coordinate the diverse stakeholders of the logistics subsector, in order to support open communication and dialogue to remove identified regulatory uncertainties.

- Form an interagency coordinating body of the NTPS implementing agencies to coordinate transport and logistics strategy, development, and expansion.

- Follow the recommendations of the Transport Master Plan in ensuring a multimodal approach to policy implementation that ensures a network of services capable of meeting the current and future needs of mining, agriculture, forestry, and manufacturing.

\section{Distribution}

Distribution services are Liberia's largest employer in the services sector. A 2010 labour force survey recorded more than 250,000 Liberians working in retail services-more than half the population employed in services and about a quarter of all employed (ILO 2010). The sector is dominated by self-employed and family businesses; 60 percent of retailers work alone. Retail services are mostly informal and are carried out more as a subsistence activity than a profession: at $\$ 36$ a week, wages in retail are among the lowest in Liberia.

Both wholesale and retail services are open to domestic and foreign suppliers, but restrictions apply to certain products. No specific restrictions are in place on establishing a business; establishment is open to both foreign and domestic investors on an equal footing.

Because no decree or other secondary regulation implements the Investment Act, the scope of its restrictions remains unclear, and practice differs from legal guidelines (for example, it is not clear whether a minimum investment is required to engage in wholesale or retail trade of the listed goods). Even in sectors that are more clearly defined, inconsistent practices introduce uncertainty. For example, the act refers to the retail sale of rice and cement as activities reserved for Liberian nationals, but rice is sold in supermarkets, some of which are owned by foreign nationals, and cement is sold at retail stores specializing in construction material. Some policy makers consider the limitation in nationality to apply to wholesale distribution of rice instead of retail, as set out in the law. Most of the restrictions listed in the Investment Act are either not applied or are limited to small retail stores or individual sellers. 
The distribution sector remains largely underregulated, lacks laws on competition and consumer protection, and suffers from poor monitoring. Liberia lacks a competition policy, which has raised concerns of unfair competition, especially in the distribution of key commodities such as cement. Despite measures to open the cement market-historically a monopoly-some restrictions, such as the need for import permits for cement and construction materials, remain in place.

Lack of regulation and poor monitoring of the regulations that do exist undermine the quality of goods distributed in Liberia. Better consumer protection and standards are needed. Liberia's Commercial Code sets forth general rules of liability and implied warranties for all commercial contracts, but they lack specificity with regard to the distribution sector, especially retail sales; they do not, for example, set out consumers' rights, retailers' obligations, or redress procedures. The poor regulatory framework adds to the weak capacity to develop and monitor the application of health and safety standards.

\section{Tourism}

The civil war brought an end to tourism in Liberia. Tourism remains minimal, but the subsector has strong potential for growth.

Liberia's first cruise ship of the postwar period, the National Geographic Explorer, docked in Monrovia in 2012 with 150 passengers on board, possibly the largest group of tourists to visit the country since the 1970s. Tourism services have been expanding, with investment in new and renovated hotels and the opening of travel agencies. Growth of the sector is mostly linked to expatriates based in Liberia or to Liberians living abroad who return for visits.

The regulatory and institutional framework for the tourism sector is virtually nonexistent. Despite its potential, tourism has not been a policy priority. The policy and regulatory body in charge of the sector is the Bureau of Tourism in the Ministry of Information, Cultural Affairs and Tourism, which employs about 20 people.

Tourism is governed largely by the general framework, including the law on investment and the incentives framework. A few references specific to tourism can be found in general laws. For example, the Investment Act of 2010 lists travels agencies as an industry reserved for Liberians. This restriction is not applied; some travel agencies are owned by foreigners through partnership with Liberians. The Revenue Code of 2010 lists "tourism carried out through tourist resorts, hotels and cultural sites" as eligible for the special incentives scheme.

No major regulatory restrictions affect the tourism industry, except the nationality limitation, which may operate more like a partnership requirement. Some policy makers believe adoption of a tourism policy and regulatory framework would allow for further limitations. Speculations on possible restrictions that may be applied relate mostly to nationality limitations for operators; car rental agencies; or smaller accommodation services, such as guesthouses, bed and breakfasts, and one- or two-star hotels. There is also a registration requirement for all businesses involved in tourism, although many operators are not aware of this requirement. The registration process is meant to check for compliance with industry standards, but in practice it operates mostly as a source of revenue for the ministry.

The sector suffers severely from lack of adequate regulatory standards. The main task of the Bureau of Tourism is to monitor the observance of standards, which it does through annual inspection and registration renewal (and fee 
collection). However, no national standards govern hotels or restaurants; the ministry relies on ECOWAS guidelines but lacks the capacity to enforce them. Inspectors are guided by an informal checklist, which includes the presence of a telephone and television in rooms, wall-to-wall carpeting, uniformed staff, and similar amenities to establish the category of the hotel. Inspectors are not trained to monitor hygiene and safety standards; inspections are based on their limited knowledge. Cooperation with other specialized agencies on heath standards does not take place; each agency performs its own monitoring.

\section{CONCLUSION AND RECOMMENDATIONS}

Services have been an essential component of Liberia's economic growth and should remain a priority. Growth in the sector-in particular in backbone services, such as financial services, telecoms, and transport and logistics-has the potential to support the expansion of the economy and to spur growth in other export-oriented activities, including agribusiness and mining. Development of these sectors, which are still severely underdeveloped, should remain Liberia's top policy priority regarding trade and investment in services. Liberia's growing reliance on imported modern services confirms the need to develop a strong services sector.

Liberia's legal framework supports a fairly liberal trade in services environment. In order to translate that framework into better performance, Liberia must improve the regulatory and institutional framework for services.

\section{Reducing horizontal regulatory restrictions}

The regulatory regime for trade and investment in services in Liberia is generally open and nondiscriminatory. Liberia has improved the conditions for business and removed discriminatory measures against foreign suppliers. Its legal framework is generally in line with the WTO's main obligations on services trade. The main challenge is to develop or update the regulatory framework in many services subsectors.

\section{Improving governance and administrative practices}

The government has reduced regulatory barriers to services trade and investment, but the institutional framework has not made similar progress. The role of institutions in economic development is well established (Acemoglu, Johnson, and Robinson 2000). Institutions play a particularly significant role in the development of services, for three reasons:

- Informational problems are more acute in many intermediation and knowledge-based services.

- The nature of a monopoly or oligopoly is a feature of many services activities.

- Customized services require both consumers and suppliers to make relationship-specific investments.

Liberia's institutional deficiencies increase transactions costs, limiting opportunities for the establishment and expansion of services providers. The disproportionately affect small and medium enterprises, which lack the 
human and financial resources to address barriers directly with government officials. The main governance limitations relate to the lack of access to clear regulatory guidelines. Binding governmentwide procedures for the development and adoption of regulation would support a sound regulation-making framework. Better public access to legal instruments is necessary to increase the transparency and predictability of business regulation.

Liberalization of trade in services spans multiple economic sectors and touches on the mandates of a wide range of government agencies, there is a great need to coordinate regulation-making procedures by multiple ministries and agencies.

\section{Crafting sectoral regulation}

Sector-specific regulation is underdeveloped or nonexistent, and institutional capacity is weak for most services. However, some subsectors, such as banking and accounting services, have seen regulatory progress in recent years. Professional services is the only services subsector subject to regulatory barriers, mainly in the form of nationality limitations or domestic partnership requirements. These restrictions are particularly onerous in legal and accountancy services. Administrative practices, rather than regulatory measures, are the main obstacles to the expansion of services in Liberia. The two main measures Liberia could consider to improve governance of the services sector are adoption of binding procedures for the regulation-making process and improvement of public access to business regulations, especially licensing procedures.

\section{NOTES}

1. The public sector management and institutions cluster includes property rights and rulebased governance; the quality of budgetary and financial management; the efficiency of revenue mobilization; the quality of public administration; and transparency, accountability, and corruption in the public sector.

2. Activities include supply of sand; block making; peddling; travel agencies; the making and sale of ice; tire repair shops; auto repair shops with investments of less than $\$ 550,000$; shoe repair shops; gas stations; video clubs; operation of taxis; importation or sale of secondhand or used clothing; the importation or sale of used cars (except by authorized dealerships which may deal in certified used vehicles of their make); the distribution of locally manufactured products; and the retail sale of rice, cement, timber, and planks.

3. Eligible activities include investments in tourist resorts, hotels, and cultural sites; hospitals and medical clinics; air, sea, rail, and road transport; information and communications technology (ICT); banking in specific geographical areas; and waste management.

4. The primary government institutions responsible for regulating transport and logistics are the Ministry of Transport, the Ministry of Public Works, the Ministry of Commerce and Industry, the Ministry of Finance, the Ministry of Labor, the Ministry of Justice, the Maritime Authority, the National Ports Authority, the Civil Aviation Authority, the Airport Authority, the Environmental Protection Agency, and the Postal Service. The mains laws providing legal background for the regulatory and policy framework for these sectors include the Investment Act 2010, the Consolidated Tax Amendment Act 2010, the Maritime Authority Act 2010, the Liberia Airport Authority Act 2009, the Liberia Civil Aviation Authority Act 2006, the Public Procurement and Concessions Act 2005, the Maritime Law of Liberia as Amended 2002, the Revenue Code 2000, the Labor Law 2000, and the Vehicle and Traffic Law 1972.

5. Some regulators claim that regulation-setting standards do exist. However, they were not able to produce them. 


\section{REFERENCES}

Acemoglu, D., S. Johnson, and J. A. Robinson. 2000. "The Colonial Origins of Comparative Development: An Empirical Investigation.” NBER Working Paper 7771, National Bureau of Economic Research, Cambridge, MA.

Liberia, Ministry of Education. 2007. Liberian Primary Education Recovery Program. Monrovia.

Mattoo, A., and L. Payton, eds. 2007. Services Trade and Development: The Experience of Zambia. Washington, DC: World Bank and Palgrave Macmillan.

Sáez, S., D. Taglioni, E. van der Marel, C. H. Hollweg, and V. Zavacka. 2014. Valuing Services in Trade: A Toolkit for Competitiveness Diagnostics. Washington, DC: World Bank.

UNDP Human Development Index (database), United Nations Development Programme, http://hdr.undp.org/en/data.

World Bank. 2013. Liberia DTIS Update. Leveraging Trade for Economic Diversification and Inclusive Growth Increasing. Draft Report No. ACS4910 (78504-LR), Washington, DC.

- 2014. Enhancing Regulations on Services Trade in Liberia: A Regulatory Assessment of Services Trade and Investment. Washington, DC. https://issuu.com/world.bank.publications /docs/enhancingregulationofservicestradel.

World Bank Country Policy and Institutional Assessment Database, Washington, DC, https:// datacatalog.worldbank.org/dataset/country-policy-and-institutional-assessment.

World Bank Doing Business 2013 (database), Washington, DC, http://www.doingbusiness.org.

World Bank World Development Indicators (database), Washington, DC, http://wdi .worldbank.org.

World Bank Worldwide Governance Indicators (database), Washington, DC, https:// datacatalog.worldbank.org/dataset/worldwide-governance-indicators. 



\section{Appendix A Definitions and Methodology}

\section{MODES OF SERVICES TRADE}

Services have unique characteristics, including intangibility and nonstorability, that greatly affect their tradability; they also typically require differentiation and joint production. In order to capture these aspects, the World Trade Organization (WTO) distinguished four modes of supply (table A.1).

The quality of trade data is much lower for services than for goods, because goods often face tariffs, on which data are collected with high quality and accuracy. It is particularly difficult to measure Modes 3 and 4. Revisions and refinements of the balance of payments classification are ongoing to improve the quality of the data.

\section{SECTORAL CLASSIFICATION OF SERVICES TRADE}

The gross services trade data used in this report capture primarily cross-border trade (Mode 1) and consumption abroad (Mode 2), which are measured based on countries' balance of payments statistics. Those statistics do not cover Mode 3 trade. Table A.2 defines the sectors on which data are collected (see appendix B for a more detailed breakdown).

\section{TRADITIONAL VERSUS MODERN SERVICES}

Modern services are services that can be traded across borders without the buyer and seller being in the same place. Delivery of these services is less dependent on physical infrastructure and more dependent on telecommunications and electric supply than is the supply of traditional services, which require faceto-face interaction. Examples of modern services include communications, banking, insurance, business, and remote access services; transcription of medical records; call centers; and education. Modern services tend to create higher-skilled and better-paid jobs than traditional services. Many modern services subsectors have relatively low employment intensity and require relatively high educational levels, however. 
TABLE A.1 Modes of supply of trade in services

\begin{tabular}{lll}
\hline MODE & DEFINITION & EXAMPLES \\
\hline 1 (cross-border trade) & $\begin{array}{l}\text { Services supplied from the territory of one country and } \\
\text { consumed in the territory of another }\end{array}$ & $\begin{array}{l}\text { Consultancies, market research, } \\
\text { graphic design }\end{array}$ \\
\hline 2 (consumption abroad) & $\begin{array}{l}\text { Services supplied within the territory of one country to } \\
\text { consumers from another country }\end{array}$ & Tourism, education, health services \\
\hline 3 (commercial presence) & $\begin{array}{l}\text { Services supplied by a business or professional establish- } \\
\text { ment from one country in the territory of another }\end{array}$ & Foreign direct investment \\
\hline 4 (presence of natural persons) & $\begin{array}{l}\text { Services supplied by nationals of one country in the } \\
\text { territory of another }\end{array}$ & $\begin{array}{l}\text { Consultants or health professionals } \\
\text { working abroad }\end{array}$ \\
\hline
\end{tabular}

Source: UN International Trade Statistics, https://unstats.un.org/unsd/trade/default.asp.

TABLE A.2 Balance of payments classification of services trade

\begin{tabular}{|c|c|}
\hline SECTOR & COVERAGE \\
\hline Transport & $\begin{array}{l}\text { All services that involve the carriage of passengers, the movement of goods (freight), rentals with crew, and } \\
\text { related supporting services. Excludes freight insurance, which is included under insurance services, and } \\
\text { goods procured in ports by nonresident carriers and repairs on transport equipment, which are included in } \\
\text { goods. }\end{array}$ \\
\hline Travel & Goods and services acquired by nonresidents during visits of less than a year. \\
\hline Construction & $\begin{array}{l}\text { Work performed on construction projects and installations by an enterprise outside the economy of } \\
\text { residence of that enterprise. }\end{array}$ \\
\hline Insurance & $\begin{array}{l}\text { All types of insurance, reinsurance, and related auxiliary services. Insurance services are estimated or valued } \\
\text { by the service charges included in total premiums rather than by the total value of the premiums. }\end{array}$ \\
\hline Financial & $\begin{array}{l}\text { Financial intermediation and auxiliary services, except services directly related to life insurance and pension } \\
\text { funds (covered under insurance services). }\end{array}$ \\
\hline $\begin{array}{l}\text { Computer and } \\
\text { information }\end{array}$ & $\begin{array}{l}\text { Hardware and software-related services and data-processing; provision of news, photographs, and feature } \\
\text { articles to the media; database conception, data storage, and the dissemination of data; and direct nonbulk } \\
\text { subscriptions to periodicals, regardless of means of information transmission. }\end{array}$ \\
\hline $\begin{array}{l}\text { Royalties and license } \\
\text { fees }\end{array}$ & $\begin{array}{l}\text { Franchising fees, royalties paid for the use of registered trademarks, and other fees paid for the authorized } \\
\text { use of intangible, nonproduced nonfinancial assets and proprietary rights. Excludes distributive rights with } \\
\text { limitations for audiovisual products. }\end{array}$ \\
\hline $\begin{array}{l}\text { Other business } \\
\text { services }^{\text {a }}\end{array}$ & $\begin{array}{l}\text { Merchanting and other trade-related services; operational leasing services; and miscellaneous business, } \\
\text { professional, and technical services (legal, advertising, consulting, accounting, research and development, } \\
\text { and so forth). }\end{array}$ \\
\hline $\begin{array}{l}\text { Personal, cultural and } \\
\text { recreational services }\end{array}$ & $\begin{array}{l}\text { Audiovisual and related services covering the production of motion pictures, video and radio programs, } \\
\text { musical recordings, and similar services, including fees paid to personnel involved; related limited distribu- } \\
\text { tion rights; fees paid for sporting, theatrical and similar events; services associated with museums, libraries, } \\
\text { archives, and other cultural and sporting activities; and education and health services (excluding services } \\
\text { purchase by travelers, which fall under travel services). }\end{array}$ \\
\hline
\end{tabular}

Source: UN International Trade Statistics, https://unstats.un.org/unsd/trade/default.asp.

a. Regional estimates for other business services by the United Nations Conference on Trade and Development (UNCTAD) and the WTO may be lower than the sum of data reported by individual economies. To compile relevant regional estimates for other business services (and other services items), the UNCTAD and WTO secretariats make necessary adjustments for individual economies, including other business services transactions that cannot be allocated to other specific categories. The adjustments are made only for regional and trade group aggregates.

There is no negative connotation in the definition of traditional versus modern services; some traditional services are key. Specializing in traditional services does not imply lagging in dynamism or efficiency. Specializing in tourism can be an important development strategy, and transport services are very important to overcome connectivity challenges related to landlockedness. 


\section{COMMERCIAL SERVICES}

Commercial services are defined as total services excluding government services. Government services include embassies, consulates, military units, and so forth, as well as the transactions of international organizations. In many countries, commercial services such as national airlines are owned by the government or a state-owned enterprise. In these cases, they are included in commercial services statistics.

\section{DIRECT AND INDIRECT VALUE-ADDED TRADE MEASURES}

A country's performance in gross services exports can distort the real contribution of a subsector's exports to an economy, for a variety of reasons. For example, some subsectors are intensive in the use of foreign inputs; their exports may contain little domestic value added. Some subsectors use few inputs and therefore create few linkages to other subsectors. Others use inputs from other domestic sectors; increasing these exports can have spillover effects through domestic value chains.

The direct contribution of a subsector is the value added it generates to produce its own exports directly. The indirect value-added contribution of a subsector to exports can be measured by looking at its forward and backward linkages. Backward linkages are the value added a subsector pulls from intermediateinput subsectors to produce its own exports. For example, exports of machinery comprise the direct value-added in machinery production as well as the value-added of intermediate inputs the domestic plastics industry provides to the exported machinery items.

Forward linkages are the value added a subsector generates by supplying intermediate inputs to the production of another subsectors' exports. For example, exports of food may have been produced using machinery of domestic origin. Machinery supplies part of the value added in exports of food and beverages.

Data on the value added of services exports capture cross-border trade (Mode 1) and consumption abroad (Mode 2). Services trade that takes place through foreign direct investment (FDI) and the temporary movement of people are not covered in these data. Production from inward/outward FDI and movement of natural persons shows up as GDP and is included in the statistics as domestic production (not exports).

\section{HORIZONTAL LAWS AND REGULATIONS}

Horizontal laws and regulations are measures that affect multiple services subsectors or the services sector as a whole. Regulations on tourism, for example, obviously affect services providers in the sector, but so do other laws and regulations, such as regulations on buying and selling foreign currency, laws on entry and stay of foreigners, and procedures related to the establishment of firms. 


\section{REVEALED COMPARATIVE ADVANTAGE}

Revealed comparative advantage (RCA) compares a country's share of world exports with the average share of exports of all countries for a particular subsector:

$$
R C A_{i, j}=\frac{\frac{x_{i, j}}{X_{i}}}{\frac{x_{w, j}}{X_{w}}}
$$

where $x_{i, j}$ is exports from country $i$ in sector $j, X_{i}$ is total exports of $i, x_{w, j}$ is exports from the world in sector $j$, and $X_{w}$ is total world exports. An RCA index above 1 indicates that a country's share of services exports in a subsector is larger than the average share of exports in the subsector; it is considered an indication of $\mathrm{RCA}$. The higher the ratio, the more competitive the country is in the subsector.

\section{HERFINDAHL-HIRSCHMAN INDEX}

Diversification can be assessed using its opposite, concentration, measured using the Herfindahl-Hirschman Index, which is calculated as follows:

$$
\sum_{j} \frac{x_{i, j}^{2}}{X_{i}}
$$

where $x_{i, j}$ is exports from country $i$ in sector $j$ and $X_{i}$ is total exports of $i$. The normalized version of the index ranges from 0 to 1 . Higher values indicate greater concentration.

\section{EXPORT SOPHISTICATION}

EXPY is an index of services export sophistication. PRODY is the sophistication of a particular service, it is calculated as the weighted average of the GDPs of countries that export that service. In general, higher-value-added products have higher PRODYs. A country's EXPY is calculated as the weighted average of the PRODYs of the services it exports. It captures whether a country's export basket consist primarily of services typically exported by high-income economies, which are perceived as relatively sophisticated. The EXPY for country $i$ and sector $j$ is calculated as

$$
\sum_{j} \frac{x_{i, j}}{X_{i}} P R O D Y_{j} .
$$

$P R O D Y_{j}$ is calculated as

$$
\sum_{i} \frac{\frac{x_{i, j}}{X_{i}}}{\sum_{i} \frac{x_{i, j}}{X_{i}}} Y_{i}
$$

where $x_{i, j}$ is exports from country $i$ in sector $j, X_{i}$ is total exports of $i$, and $Y_{i}$ is per capita GDP of $i$. An increase in EXPY indicates that the share of high-PRODY services in the export basket has increased. 


\section{TRADE COMPLEMENTARITY INDEX}

Computing a trade complementarity index (TCI) can help identify markets with which a country has export potential. This index assesses how well the export structure of one country matches the import structure of another. It is based on total exports and imports at the disaggregated services sectoral level, which are then aggregated into a single index for each country pair. The index ranges between 0 and 100. The higher the index, the greater the potential to export to a particular market. The TCI between exporter $i$ and importer $j$ is calculated as

$$
T C I_{i, j}=\left(1-\sum_{p} \frac{\left|\frac{x_{i, p}}{X_{i}}-\frac{m_{j, p}}{M_{j}}\right|}{2}\right) * 100
$$

where $x_{i, p}$ is exports from $i$ in product $p, X_{i}$ is total exports of $i, m_{j, p}$ is imports of $j$ in $p$, and $M_{j}$ is total imports of $j$.

\section{TRADE INTENSITY INDEX}

The trade intensity index (TII) indicate a country's relative share of exports to another country compared with the rest of the world's share of exports to that country. The TII between exporter $i$ and importer $j$ is calculated as

$$
T I I_{i, j}=\frac{\frac{x_{i, j}}{X_{i}}}{\frac{x_{w, j}}{X_{w}}}
$$

where $x_{i, j}$ is exports from country $i$ to country $j, X_{i}$ is total exports of $i, x_{w, j}$ is exports from the world to $j$, and $X_{w}$ is total world exports.

\section{INTENSIVE AND EXTENSIVE MARGIN}

The intensive margin reveals the depth of the relationship between a country and its trading partners. The extensive margin captures the number of relationships and markets.

\section{GRAVITY MODEL OF TRADE}

The gravity model of trade relates countries' bilateral trade flows to structural determinants of GDP, geographic distance, and other factors that affect trade barriers. Bilateral flows are identified from the World Bank Trade in Services Database, averaged over the period 2005-07 in order to increase the number of observations. The structural determinants of each pair of countries, together with the estimated regression coefficients, are used to compute bilateral trade potentials. The level of bilateral trade between a pair of countries is then compared with the trade potential to categorize bilateral exports as overtraded or undertraded. The regression includes a country's Services Trade Restrictiveness 
Index (STRI) (from the World Bank Services Trade Restrictions Database), to assess whether these determinants are important in explaining the level of bilateral services trade between two countries.

\section{ESTIMATING THE IMPACT OF THE QUALITY OF SERVICES INPUTS ON FIRMS' PRODUCTIVITY}

Measuring the effect of the quality of services inputs on firms' performance follows the approach of Arnold, Nicoletti, and Scarpetta (2008). The data come from the World Bank Enterprise Surveys, which are available for a cross-section of firms from 188 country-year combinations (127 countries were surveyed between 2006 and 2013).

The measure of firms' performance is productivity. Three alternative measures are used:

- labor productivity (the ratio of output to total labor costs)

- total factor productivity (TFP) estimated as a residual of a Cobb-Douglas production function in which output is a function of the capital stock, labor, and intermediate inputs

- TFP estimated as a residual from a translog specification in which output is expressed as a function of the capital stock, labor, intermediate inputs, their squared terms, and their cross-products.

The performance of services subsectors is also estimated from World Bank Enterprise Surveys, which capture firms' valuations regarding how much of a constraint they consider electricity, telecommunications, transport, and access to finance for their businesses. Firms are asked to indicate whether they consider each of dimension not an obstacle (0), a minor obstacle (1), a moderate obstacle (2), major obstacle (3), or a severe obstacle (4).

The empirical strategy consists of regressing the measure of productivity on measures of the performance of services, controlling for factors identified in the literature as relevant for firms' performance, including firm's export status, size, and age. Country-year fixed effects are controlled for, in order to eliminate potential distortions caused by changes in the relative values of the different currencies in which output, wages, intermediates, and capital stock are expressed; the effect of country-year unobservables that may affect both productivity and the perception of services' quality; and sector fixed effects (to control for timeinvariant and sector-specific unobservables).

Endogeneity may arise because poor performance may affect firms' perceptions of the obstacles poor services provision represent. If it does, it will bias the coefficient linking services performance with productivity upward, making a specification that links firm-level perceptions of services quality with firm-level productivity inappropriate. The strategy to circumvent this problem follows Arnold, Nicoletti, and Scarpetta (2008). It consists of aggregating individual firms' responses to the services-related questions at the country or regional level, which is included on the right-hand side. Doing so reduces the influence an individual firm's performance has on the regressor and better summarizes the quality provision of services in a region. 
The specification is as follows:

$$
\mu_{i}=\alpha_{c t}+\gamma_{s}+\beta \text { Serv Performance }{ }_{r}+\pi X_{i}+\varepsilon_{i}
$$

where $\mu$ is the indicator of productivity (labor productivity, residual from Cobb Douglas, or residual from translog); $\alpha$ is a country-year fixed effect; $\gamma$ is a sector fixed effect; ServPerformance is a vector of perception-based indicators of obstacles represented by access to finance, electricity, transport, and telecommunications that vary at the regional level; $X$ is a vector of controls varying at the firm level; and $\varepsilon$ is an error term, which is assumed to be orthogonal to the regressors. In order to focus on the impact on domestic firms, all regressions are estimated on a sample of domestic-owned firms or firms with less than 10 percent foreign ownership.

\section{REFERENCE}

Arnold, J., G. Nicoletti, and S. Scarpetta. 2008. "Product Market Policies, Allocative Efficiency and Productivity: Industry and Firm-Level Evidence.” OECD Economics Department Working Paper 616, Organisation for Economic Co-operation and Development, Paris. 



\title{
Appendix B Sectoral Classification of Services Trade
}

\author{
TABLE B.1 WTO sectoral classification of services trade

\begin{tabular}{|c|c|c|}
\hline \multirow[t]{5}{*}{ 1. Business services } & A. Professional services & $\begin{array}{l}\text { a. Legal services } \\
\text { b. Accounting, auditing, and bookkeeping services } \\
\text { c. Taxation services } \\
\text { d. Architectural services } \\
\text { e. Engineering services } \\
\text { f. Integrated engineering services } \\
\text { g. Urban planning and landscape architectural services } \\
\text { h. Medical and dental services } \\
\text { i. Veterinary services } \\
\text { j. Services provided by midwives, nurses, physiotherapists, } \\
\text { and paramedical personnel } \\
\text { k. Other }\end{array}$ \\
\hline & B. Computer and related services & $\begin{array}{l}\text { a. Consultancy services related to the installation of computer } \\
\text { hardware } \\
\text { b. Software implementation services } \\
\text { c. Data processing services } \\
\text { d. Database services } \\
\text { e. Other }\end{array}$ \\
\hline & $\begin{array}{l}\text { C. Research and development } \\
\text { services }\end{array}$ & $\begin{array}{l}\text { a. R\&D services on natural sciences } \\
\text { b. R\&D services on social sciences and humanities } \\
\text { c. Interdisciplinary R\&D services }\end{array}$ \\
\hline & D. Real estate services & $\begin{array}{l}\text { a. Involving own or leased property } \\
\text { b. On a fee or contract basis }\end{array}$ \\
\hline & $\begin{array}{l}\text { E. Rental/leasing services without } \\
\text { operators }\end{array}$ & $\begin{array}{l}\text { a. Relating to ships } \\
\text { b. Relating to aircraft } \\
\text { c. Relating to other transport equipment } \\
\text { d. Relating to other machinery and equipment } \\
\text { e. Other }\end{array}$ \\
\hline
\end{tabular}


F. Other business services
A. Postal services

B. Courier services

C. Telecommunication services a. Advertising services

b. Market research and public opinion polling services

c. Management consulting services

d. Services related to management consulting

e. Technical testing and analysis services

f. Services incidental to agriculture, hunting, and forestry

g. Services incidental to fishing

h. Services incidental to mining

i. Services incidental to manufacturing

j. Services incidental to energy distribution

k. Placement and supply services of personnel

I. Investigation and security

m. Related scientific and technical consulting services

n. Maintenance and repair of equipment (not including maritime vessels, aircraft, or other transport equipment)

o. Building-cleaning services

p. Photographic services

q. Packaging services

r. Printing, publishing

s. Convention services

t. Other

\section{Communication services}

a. Voice telephone services

b. Packet-switched data transmission services

c. Circuit-switched data transmission services

d. Telex services

e. Telegraph services

f. Facsimile services

g. Private leased circuit services

h. Electronic mail

i. Voice mail

j. Online information and data base retrieval

k. Electronic data interchange (EDI)

I. Enhanced/value-added facsimile services, including store and forward, store and retrieve

$\mathrm{m}$. Code and protocol conversion

$\mathrm{n}$. Online information and/or data processing (including transaction processing)

o. Other

D. Audiovisual services a. Motion picture and video tape production and distribution
services
b. Motion picture projection services
c. Radio and television services
d. Radio and television transmission services
e. Sound recording
f. Other

\begin{tabular}{ll}
\hline $\begin{array}{l}\text { 3. Construction and related } \\
\text { engineering services }\end{array}$ & $\begin{array}{l}\text { A. General construction work for } \\
\text { buildings }\end{array}$ \\
\hline $\begin{array}{l}\text { B. General construction work for civil } \\
\text { engineering }\end{array}$ \\
\hline C. Installation and assembly work \\
\hline $\begin{array}{l}\text { D. Building completion and finishing } \\
\text { work }\end{array}$ \\
\hline E. Other
\end{tabular}


TABLE B.1, continued

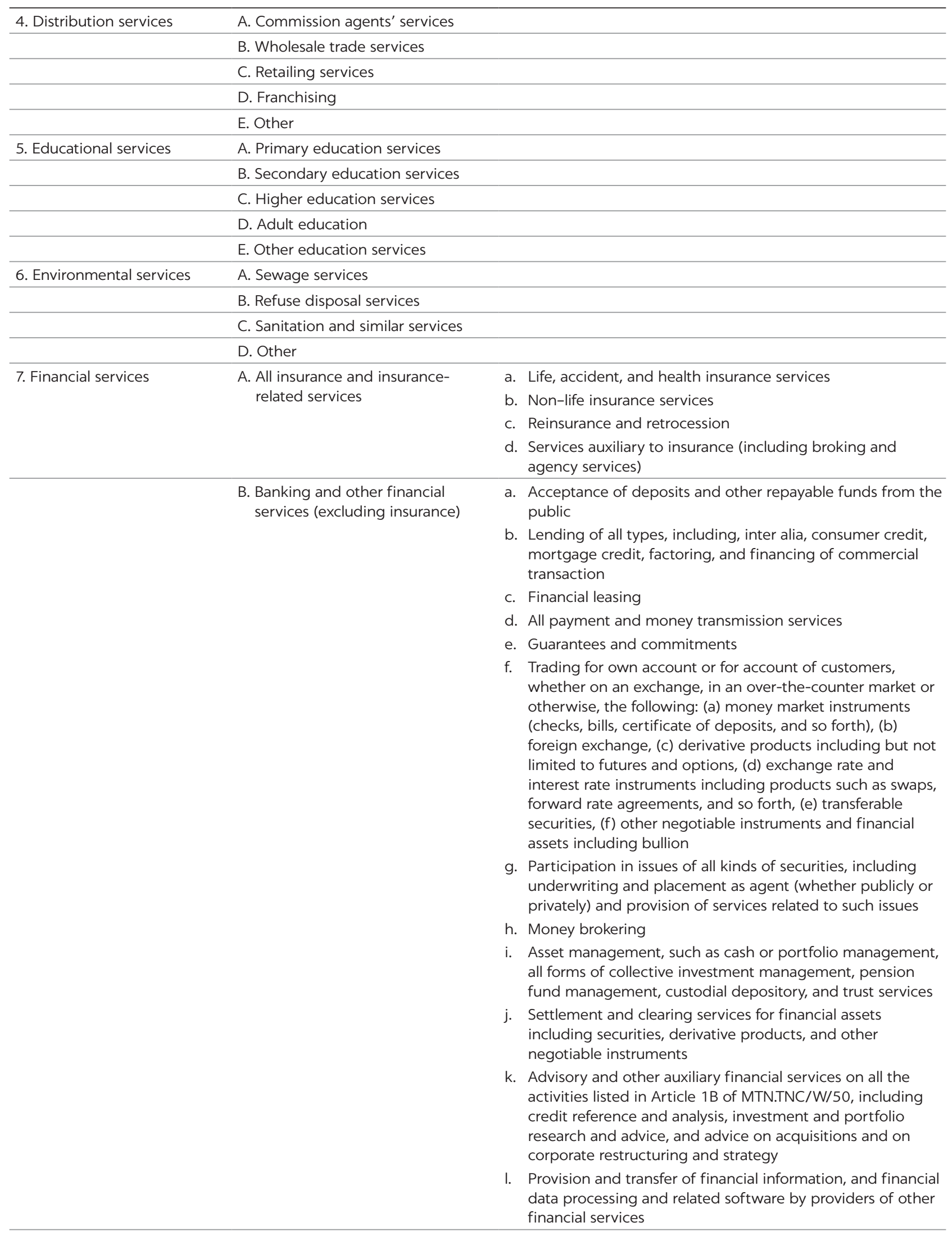


TABLE B.1, continued

\begin{tabular}{|c|c|}
\hline \multirow[t]{4}{*}{$\begin{array}{l}\text { 8. Health-related and social } \\
\text { services (other than those } \\
\text { listed under 1.A.h-j) }\end{array}$} & A. Hospital services \\
\hline & B. Other human health services \\
\hline & C. Social services \\
\hline & D. Other \\
\hline \multirow{3}{*}{$\begin{array}{l}\text { 9. Tourism and travel-related } \\
\text { services }\end{array}$} & $\begin{array}{l}\text { B. Travel agencies and tour } \\
\text { operators services }\end{array}$ \\
\hline & C. Tourist guides services \\
\hline & D. Other \\
\hline \multirow{3}{*}{$\begin{array}{l}\text { 10. Recreational, cultural and } \\
\text { sporting services (other } \\
\text { than audiovisual services) }\end{array}$} & B. News agency services \\
\hline & $\begin{array}{l}\text { C. Libraries, archives, museums, and } \\
\text { other cultural services }\end{array}$ \\
\hline & $\begin{array}{l}\text { D. Sporting and other recreational } \\
\text { services }\end{array}$ \\
\hline
\end{tabular}

\begin{tabular}{|c|c|c|}
\hline 11. Transport services & A. Maritime transport services & $\begin{array}{l}\text { a. Passenger transportation } \\
\text { b. Freight transportation } \\
\text { c. Rental of vessels with crew } \\
\text { d. Maintenance and repair of vessels } \\
\text { e. Pushing and towing services } \\
\text { f. Supporting services for maritime transport }\end{array}$ \\
\hline
\end{tabular}
B. Internal waterways transport
a. Passenger transportation
b. Freight transportation
c. Rental of vessels with crew
d. Maintenance and repair of vessels
e. Pushing and towing services
f. Supporting services for internal waterway transport

\begin{tabular}{ll}
\hline C. Air transport services & a. Passenger transportation \\
& b. Freight transportation \\
& c. Rental of aircraft with crew \\
& d. Maintenance and repair of aircraft \\
& e. Supporting services for air transport \\
\hline D. Space transport & \\
\hline E. Rail transport services & a. Passenger transportation \\
& b. Freight transportation \\
& c. Pushing and towing services \\
& d. Maintenance and repair of rail transport equipment \\
\hline
\end{tabular}




\begin{tabular}{ll}
\hline F. Road transport services & $\begin{array}{l}\text { a. Passenger transportation } \\
\text { b. Freight transportation } \\
\text { c. Rental of commercial vehicles with operator } \\
\text { d. Maintenance and repair of road transport equipment } \\
\text { e. Supporting services for road transport services }\end{array}$ \\
\hline G. Pipeline transport & $\begin{array}{l}\text { a. Transportation of fuels } \\
\text { b. Transportation of other goods }\end{array}$ \\
\hline transport & $\begin{array}{l}\text { a. Cargo-handling services } \\
\text { b. Storage and warehouse services }\end{array}$ \\
\hline I2. Other services not included elsewhere & c. Freight transport agency services \\
\hline
\end{tabular}

Source: WTO (World Trade Organization). 1991. Services Sectoral Classification List, WTO Document MTN.GNS/W/120). https://www.wto.org/english /tratop_e/serv_e/mtn_gns_w_120_e.doc.

Note: $\mathrm{EDI}=$ Electronic data interchange. 


\section{ECO-AUDIT \\ Environmental Benefits Statement}

The World Bank Group is committed to reducing its environmental footprint. In support of this commitment, we leverage electronic publishing options and printon-demand technology, which is located in regional hubs worldwide. Together, these initiatives enable print runs to be lowered and shipping distances decreased, resulting in reduced paper consumption, chemical use, greenhouse gas emissions, and waste.

We follow the recommended standards for paper use set by the Green Press Initiative. The majority of our books are printed on Forest Stewardship Council (FSC)-certified paper, with nearly all containing 50-100 percent recycled content. The recycled fiber in our book paper is either unbleached or bleached using totally chlorine-free $(\mathrm{TCF})$, processed chlorine-free $(\mathrm{PCF})$, or enhanced elemental chlorine-free (EECF) processes.

More information about the Bank's environmental philosophy can be found at http://www.worldbank.org/corporateresponsibility.

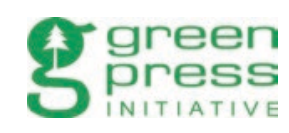


$\mathbf{R}^{\mathrm{cos}}$ ecognizing that services affect the ability of countries and their firms to compete on international markets, the World Bank's Trade and Regional Integration Unit has developed an extensive work program to promote the performance of countries' domestic services sectors, including services trade. Services for Trade Competitiveness presents selected applications of new methodologies that were developed to assess the competitiveness of countries' services sectors, discern the types of barriers to services that exist in the regulatory environment, and identify the resulting policy implications. Its assessments are designed for a wide audience, including policy makers in developing countries and development practitioners in international organizations, policy-making institutions, and academia. The purpose of this book is to help policy makers in developing countries make informed policy choices to increase their chances of benefiting from the increasing prominence of services in international trade.

This valuable volume brings together a set of country and regional studies assessing how services-related policies affect competitiveness of firms and industries in developing and transition economies. The focus is on countries that are under-researched; the analysis is based on publicly available toolkits and datasets that have been developed by the World Bank. Hopefully, this compilation will motivate others to apply and extend the approaches used in this book to additional countries and expand our knowledge of the role that trade in services can play in economic development.

Bernard Hoekman, Professor and Director,

Global Economics at the Robert Schuman Centre for Advanced Studies, European University Institute, Florence, Italy

Services trade has a direct impact on countries' opportunities to participate in the global economy and on their development aspirations. This book examines how public policies impact the performance of services in developing countries and how governments, in partnership with private sector, can increase their role in competitiveness and trade diversification. This book is a valuable contribution to policy makers, academics, and development experts interested in understanding how their countries can seize these new opportunities and enhance services contribution to development.

Ann E. Harrison, Dean, Haas School of Business, University of California, Berkeley

Services are an increasingly important feature of the economic landscape for countries at all levels of development. Their role in the global economy has also evolved substantially in recent decades, as the emergence of cross-border supply chains rests on logistics, transport, communications, finance, and technical services. While the importance of services for productivity and the organization of production in high-income countries is well studied, there is a clear need to better understand their role in helping low- and middle-income countries shift to higher value-added niches in global supply chains. This book, which brings together recent research on services and development, confronts these questions directly. It offers valuable insight into the dependence of competitiveness on the strength of the service sector, providing a needed overview across developing countries and regions.

Joseph Francois, Professor of International Economics, University of Bern, and Managing Director, World Trade Institute 